Sustenabilitatea educației doctorale în economie și afaceri

Coordonatori:

Constantin-Marius APOSTOAIE • Ana-Maria BERCU • Gabriela BOLDUREANU, Irina MANOLESCU • Adriana PRODAN • Iolanda VODA 
ALEXANDRU IOAN CUZA UNIVERSITY of IAȘI
With the support of the Erasmus+ Programme of the European Union

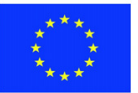

Volum publicat în cadrul proiectului

Sustainable Education through European Studies for Young Researchers (SESYR) Jean Monnet Module

587359-EPP-1-2017-1-RO-EPPJMO-MODULE

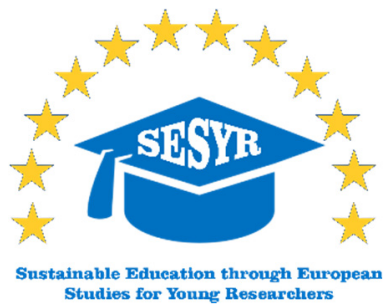

\section{Referenţi ştiinţifici:}

Prof. univ. dr. Angela Roman, Universitatea „Alexandru Ioan Cuza” din Iași Conf. univ. dr. Mihai Talmaciu, Universitatea „Alexandru Ioan Cuza” din Iași Ing. dr. Marius Atanasiu, Universitatea Tehnică „Gheorghe Asachi” din Iași

Redactor: dr. Marius Nicușor Grigore

Coperta: Manuela Oboroceanu

Tehnoredactor: Florentina Crucerescu

ISBN online 978-606-714-590-8

(c) Editura Universităţii „Alexandru Ioan Cuza” din Iaşi, 2020 700109 - Iaşi, str. Pinului, nr. 1A, tel./fax: (0232) 314947 http://www.editura.uaic.ro e-mail: editura@uaic.ro

Director: prof. univ. dr. Constantin Dram 


\title{
Sustenabilitatea educației doctorale în economie și afaceri
}

\author{
Coordonatori: \\ Constantin-Marius APOSTOAIE - Ana-Maria BERCU, \\ Gabriela BOLDUREANU • Irina MANOLESCU, \\ Adriana PRODAN • Iolanda VODĂ
}

Prefață de Adriana Prodan

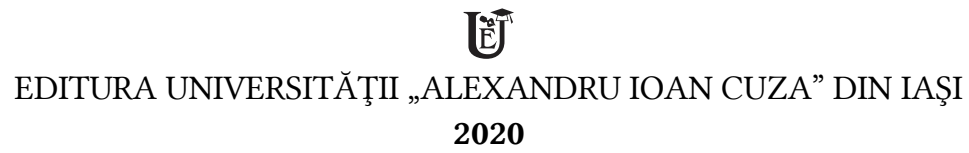


Constantin-Marius Apostoaie este lector universitar doctor în cadrul Departamentului Finanţe, Monedă şi Administraţie Publică, Facultatea de Economie şi Administrarea Afacerilor, Universitatea „Alexandru Ioan Cuza" din Iaşi. A realizat diverse stagii de documentare şi cercetare în cadrul unor instituţii precum: Universitat de Barcelona (Spania), GREThA: Groupe de Recherche en Economie Théorique et Appliquée, Universitatea din Bordeux (Franţa), Universidad de Zaragoza (Spania) etc. Totodată, a publicat, în calitate de unic autor sau în echipă, peste 60 de articole ştiinţifice în volume, reviste ori jurnale ştiinţifice (mai multe dintre acestea fiind indexate ISI sau în baze de date internaţionale recunoscute), a fost/este membru în echipă în peste 18 proiecte academice de cercetare şi/sau de predare, finanţate din surse naţionale sau europene (cu linii de finanţare precum: Horizon 2020, Erasmus+, Erasmus Mundus, COST, POSDRU, POSCCE, POCU, UEFISCDI), a participat în mai mult de 50 de conferinţe internaţionale şi naţionale.

Ana-Maria Bercu este profesor universitar habilitat la Universitatea „Alexandru Ioan Cuza” din Iaşi, Facultatea de Economie şi Administrarea Afacerilor, Departamentul de Finanțe, Monedă și Administrație publică. A absolvit un program de licență în Administrație publică (2001), cu distincția Magna cum Laude, studii postuniversitare în domeniul Gestiunii resurselor în admnistrația publică (2002) şi a finalizat studiile de doctorat în domeniul Managementului (2008). În perioada 2015-2016, a fost cercetător postdoctoral la Universitatea din Tel Aviv, Israel, în domeniul Managementului resurselor umane. A fost responsabil al Proiectului Jean Monnet „European Regional Competitiveness and Human Resource Development” (20142017), membru al Catedrei Jean Monnet EUFIRE (2016-2019), membru al echipei Proiectului Jean Monnet SESYR (2017-2020), precum și membru în numeroase alte programe europene. Are experiență în activități didactice internaționale (cu studenți în Franța, Croația, Republica Cehă, Turcia, Republica Moldova, Albania, Portugalia, Islanda, Tunisia, Camerun) și a participat la conferințe, seminarii și ateliere internaționale din străinătate. Este autor și co-autor al mai multor lucrări de specialitate: Pregătirea profesională a personalului din Administrația publică (2009), Strategii manageriale publice (2013), Funcția publică și managementul carierei funcționarului public european (2014) și a peste 80 de articole indexate în baze de date internaționale. Aria sa de interes științific vizează cercetarea problematicii performanței profesionale, a managementului relațiior de muncă, a dezvoltării resursei umane.

Gabriela Boldureanu este conferenţiar doctor la Facultatea de Economie și Administrarea Afacerilor din cadrul Universității „Alexandru Ioan Cuza” din Iași. Domeniile de cercetare sunt Management, Antreprenoriat, Comerț, iar ariile de interes științific sunt Educație antreprenorială, Inovație și performanță în IMM-uri, Administrarea afacerilor în comerț.

Irina Manolescu este conferenţiar la Facultatea de Ştiinţe Economice, Universitatea „Alexandru Ioan Cuza” din Iaşi. Activitatea de cercetare s-a materializat în publicarea unor cărţi în domeniul managementului proiectelor, amenajării turistice, managementului educaţional şi managementului intercultural, a peste 100 de articole în reviste şi volume de specialitate din ţară şi din străinătate, şi în participări la numeroase sesiuni ştiinţifice şi conferinţe naţionale şi internaţionale. A coordonat şi a fost membru al echipei în cadrul a peste 30 proiecte de cercetare sau de dezvoltare.

Adriana Prodan este profesor doctor la Facultatea de Economie şi Administrarea Afacerilor din cadrul Universității „Alexandru Ioan Cuza” din Iași. Temele de cercetare și publicare sunt cuprinse în domeniul management al resurselor umane și studii de gen.

Iolanda Vodă este cercetător ştiințific gradul II la Universitatea „Alexandru Ioan Cuza” din Iaşi, Institutul de Cercetări Interdisciplinare, Departamentul Științe Socio-Umane. A absolvit un program de licență în Economie și Relații Internaționale (2006), studii postuniversitare în Comerț internațional (2007) și a finalizat studiile de doctorat în domeniul Științe Economice (2010). În perioada 2011-2013, a fost cercetător postdoctoral în cadrul proiectului „Studii Post - Doctorale în Economie: program de formare continuă a cercetătorilor de elită - SPODE" - POSDRU/89/1.5/S/61755. Este responsabil în cadrul proiectului Jean Monnet „European Smart Cities for Sustainable Development”, SmartEU (2020-2023) și coordonator național şi membru în comitetul de management al proiectului „Transnational Collaboration on Bullying, Migration and Integration at School Level, COST Action”, CA18115 (2019-2023). Este autor și co-autor al mai multor lucrări de specialitate: 6 cărți publicate în calitate de autor/ coordonator; 7 capitole în cărți publicate în edituri naționale/internaționale; peste 50 de articole publicate, dintre care 11 indexate in Web of Scenice cu factor de impact nenul (4 Core Economics; 4 cu AIS $>0.15,1-\mathrm{Q} 1,2-\mathrm{Q} 2$ ). A participat la peste 50 de conferințe și workshop-uri, dintre care 10 în străinătate și a efectuat 6 stagii de pregătire/perfecționare în străinătate. 


\section{CUPRINS}

Prefață (Adriana Prodan) 7

Partea I. Cercetare, inovare şi educaţie

Cap. 1. ARTIFICIAL INTELLIGENCE APPLICATIONS AND TOOLS IN

HIGHER EDUCATION: AN OVERVIEW

Nicolai Romanov, Marius Iulian Cluci,

Ionuț-Daniel Anastasiei, AlexandruȚugui

Cap. 2. THE IMPACT OF INNOVATION ON RESEARCH AND DEVELOPMENT

Emmanuel Obed Dadzie, Ionela-Gabriela Matei

Cap. 3. INTERNAȚIONALIZAREA SPAȚIULUI ACADEMIC EUROPEAN

ŞI PERSPECTIVA ASUPRA STUDIILOR DE DOCTORAT

Geanina Brînză, Gina Ionela Butnaru

Cap. 4. CONSIDERAŢII ASUPRA MODULUI DE ORGANIZARE A STRUCTURILOR

DE AUDIT PUBLIC INTERN ÎN INSTITUŢIILE DE ÎNVĂŢĂMÂNT

PREUNIVERSITAR

Monica Giurgea (căs. Gherghe)

Cap. 5. STIMULAREA PROIECTELOR DE CERCETARE - INSTRUMENT

PRINCIPAL ÎN ÎMBUNĂTĂȚIREA POZIȚIONĂRII UNIVERSITĂȚILOR ÎN

CLASAMENTELE INTERNAT,IONALE

Cornelia Medeleanu, Irina Manolescu

Cap. 6. MANAGEMENTUL PROIECTELOR EUROPENE ÎN DOMENIUL

CERCETĂRII - BUNE PRACTICI PENTRU TINERII CERCETĂTORI

Adriana Prodan, Irina Manolescu, Constantin-Marius Apostoaie

Partea a II-a. Procese şi fenomene economice

Cap. 7. THE DETERRENTS OF THE FOREIGN DIRECT INVESTMENT

ATTRACTION IN ROMANIA

Sebastian Tocar

Cap. 8. DOES USING CRYPTOCURRENCY AND BLOCKCHAIN POSE NEW RISK

TO GLOBAL ORGANIZATIONS REGARD SENOR MANAGEMENT

DECISION MAKING

Levi Guy, Țugui Alexandru.

Cap. 9. THE REPUTATIONAL RISK - A QUALITATIVE RESEARCH OF THE

BANKING SECTOR IN ROMANIA

Răzvan-Ionuț Drugă

Cap. 10. ANALIZA PRACTICILOR SECTORULUI PUBLIC ÎN REPUBLICA MOLDOVA PRIN PRISMA PRINCIPIILOR GUVERNANT,EI CORPORATIVE

Domnița Grițco, Lenuța Cojocariu.

Cap. 11. STUDIUL INFLUENȚEI FENOMENULUI SUSTENABILITĂȚII ASUPRA

RAPORTĂRII ENTITĂȚILOR ECONOMICE - STUDIUL LITERATURII

ŞI ANALIZA COMPARATIVĂ A RAPOARTELOR DE SUSTENABILITATE

DIN DOMENIUL BANCAR

Mihai-Florentin Herciu. 
Cap. 12. SINTEZĂ A LITERATURII DE SPECIALITATE ÎN DOMENIUL

FRAUDEI ECONOMICE

Mădălin-Mihai Moțoc. 145

Partea a III-a. Piaţa muncii şi managementul resurselor umane

Cap. 13. VOLUNTEERISM PRACTICES - A SUSTAINABILITY FACTOR

IN COMMUNITY DEVELOPMENT PROGRAMS

Magdalena Cămănaru

Cap. 14. DOCTORAL GRADUATES IN THE LABOR MARKET IN THE CONTEXT

OF THE KNOWLEDGE ECONOMY

Alexandru Anichiti.

Cap. 15. THE INFLUENCE OF FEMALE LEADERSHIP ON ORGANISATIONAL

CULTURE

Bogdan Andrei Tiliuță, Ioana Raluca Diaconu

Cap. 16. LINK BETWEEN EMPLOYEES EMPOWERMENT AND

ORGANIZATIONAL LOYALTY: LITERATURE REVIEW

Simina Nicoleta Bohâlțeanu

Cap. 17. IMPORTANȚA ECHILIBRULUI VIAȚĂ PROFESIONALĂ-

VIAŢĂ PERSONALĂ PENTRU ANGAJAŢII ROMÂNI

Elena-Sabina Turnea, Lorena Florentina Dumitrașciuc, Adriana Prodan

Cap. 18. INFLUENŢA SATISFACŢIEI ÎN MUNCĂ ASUPRA FLUCTUAȚIEI

RESURSELOR UMANE

Mihaela Denis Gălățanu

Cap. 19. CERCETAREA PRACTICII DE COACHING:

ÎNTREBĂRI EXPLORATORII

Alina Hurubean

Cap. 20. RETENȚIA VOLUNTARILOR. O DISCUȚIE PRAGMATICĂ

DESPRE CULTIVAREA ANGAJAMENTULUI ORGANIZAŢIONAL

Paula-Simona Pădurariu

Partea a IV-a. Antreprenoriat

Cap. 21. TEHNICI CONTEMPORANE DE DEZVOLTARE A BRANDINGULUI

DE ANGAJATOR UTILE TINERILOR ANTREPRENORI

Ecaterina Chițu

Cap. 22. UTILIZAREA SOCIAL MEDIA ÎN ROMÂNIA - EVOLUȚIE

ȘI POTENȚIALI FACTORI DE INFLUENT, $\breve{A}$

Ioana Andreea Bogoslov, Anca Elena Lungu

Cap. 23. EVOLUȚIA ROMÂNIEI ANTREPRENORIALE - O ANALIZĂ

ASUPRA MEDIULUI DE AFACERI

Anca Elena Lungu, Andreea Ioana Bogoslov

Cap. 24. CARACTERISTICILE SPIRITULUI ANTREPRENORIAL DIN ROMÂNIA

Lorena Florentina Dumitrașciuc 


\section{PREFAȚĂ}

Volumul Sustenabilitatea educației doctorale în economie și afaceri valorifică ideile și cercetările doctoranzilor de la Universitatea „Alexandru Ioan Cuza” din Iași, Școala Doctorală de Economie și Administrarea Afacerilor. Lucrările au fost prezentate, prin postere sau în plen, în conferința finală a proiectului SESYR, finanțat prin programul european Jean Monnet.

Structurarea volumului în patru părți generice are ca scop valorificarea domeniilor considerate prin filosofia proiectului: managementul proiectelor, antreprenoriat și angajabilitate pentru tinerii cercetători. O colecție de 24 de articole, având 35 de autori, oferă un mediu de dezbatere științifică provocatoare pentru publicul cititor din domeniul economic.

Focalizarea subiectelor din articolele prezente pe motivațiile de cercetare ale doctoranzilor și postdoctoranzilor face ca acest volum să reprezinte un debut publicistic pentru unii autori, iar pentru alții, o consolidare a vocației. Diseminarea pasiunilor în astfel de contexte consolidează colaborarea și deschiderea spre noi subiecte investigative.

Volumul este destinat studenților, cercetătorilor și profesorilor și îl propunem ca reper bibliografic pentru dezvoltarea altor idei de cercetare și inovare în arealul nostru tematic.

Coordonator proiect SESYR, prof. dr. Adriana Prodan 



\section{Partea I. \\ Cercetare, inovare şi educaţie}





\title{
Cap. 1. ARTIFICIAL INTELLIGENCE APPLICATIONS AND TOOLS IN HIGHER EDUCATION: AN OVERVIEW
}

\author{
Nicolai Romanov ${ }^{1}$, Marius Iulian Cluci ${ }^{2}$, Ionuț-Daniel Anastasiei ${ }^{3}$, Alexandru Țugui ${ }^{4}$ \\ ${ }^{I}$ Alexandru Ioan Cuza University of Iaşi, Faculty of Economics and Business Administration, Iași, \\ Romania,nicolai.romanov@feaa.uaic.ro \\ ${ }^{2}$ Alexandru Ioan Cuza University of Iaşi, Faculty of Economics and Business Administration, Iași, \\ Romania,cluci.marius@feaa.uaic.ro \\ ${ }^{3}$ Alexandru Ioan Cuza University of Iași, Faculty of Economics and Business Administration, Iași, \\ Romania, ionut_daniel_anastasiei@yahoo.com \\ ${ }^{4}$ Alexandru Ioan Cuza University of Iaşi, Faculty of Economics and Business Administration, Iași, \\ Romania,altug@uaic.ro
}

\begin{abstract}
Purpose: The enormous interest for the Artificial Intelligence (AI) technologies can be explained by the wide area of applicability and more efficient results compared to traditional algorithm techniques. The purpose of this paper is to analyze to which extent AI technologies are integrated into higher education systems around the world and to determine the problems and solutions presented by other authors in the field. Design: We performed a systematic review using articles selected by criteria presented in the article body from two largest academic databases - Web of Science and Scopus. A total of 54 papers were selected after applying the inclusion criteria, which were analyzed and classified according to the country of origin, journal, category, algorithm and purpose.

Findings: We identified five main categories for AI usage in higher education and discussed the algorithms applied for each of them. We observed the increasing use of Artificial Neural Networks since the Deep Learning revolution started in 2010s and concluded that the field still needs further research and exploration. Originality: Unlike many other systemic reviews, we have managed to discuss the reason for choosing certain algorithms to the detriment of others and give an expert opinion.
\end{abstract}

Keywords: Artificial Intelligence, Higher Education, Dropout Prediction, Personalized Content, Automated Evaluation.

\section{Introduction}

One of the most controversial subjects from our days is Artificial Intelligence (AI) and we can all agree on that. But looking beyond all anthropological fears and bad future scenarios, AI is rapidly developing and improving the ways that industries like retail, healthcare, production or banking work. In this article our attention focuses on Machine Learning (ML) as an application area of great interest in AI. Despite all the progress that has been made in terms of AI and MLthere is one industry that has an incredible potential: education. There are incomprehensible opportunities to adopt this kind of technology into universities which could bring much more significance to higher education. Throughout this article, we will see how much knowledge we possess on the impact of $\mathrm{AI}$ and ML on higher education, with examples, content analysis and scientific contexts. There will be a meta-analysis of a several number of articles from scientists around the world which could be related to personalized learning, students' personal data, chat bots and even teacher's substitution by an AI program. As this study will show, many of the articles meta-analyzed will highlight the importance of AI as universities begin to implement it. The researches found also that there is also a great number of challenges to be resolved in the future, but the most important one is related to the way universities will adapt to these kinds of solutions as many disruptive technologies will change the way people work. 


\section{Literature review}

The first mention of AI was in the 1950s where Alan Turing's theory suggested that any machine could simulate any act of mathematical deduction only with binary data, 0 and 1 (Bedinski, 2000). Until the appearance of the Internet and first signs of AI systems, there wasn't much progress in the implementation of AI in teaching, mostly because everyone was busy with the establishment of this new technology basis. Finally, in 2016, the USAreleased the first program designed to punctually raise researches in the domain ofAI (Parker, 2018), quickly followed by China and Japan in 2017. The first program oriented to a new education system based on intelligent interactive learning was developed by China, in the „New-generation Artificial Intelligence Development Plan" (Xu \& Song, 2017). According to a group of scientists from some of the top US universities, there are six expectations from an AI system to discover the students' at risk of not graduating, as follows: using historical data, ranking students using risk estimates, interpretability of the data, early predictions, identifying risk before off-track and visualizing risk scores for each student. This is just an example of how AI can discover and solve one of the worst educational deficiencies: school dropout. The entire methodology of which this articles is consisted was developed by a German teacher from the University of Oldenburg, Olaf Zawacki-Richter. This assumes that a systematic review of articles must be done with various codes extracted from the studies "in order to synthesize findings and to shine light on their application in practice, as well as on gaps or contradictions" (Zawacki-Richter et al., 2019). Also the systematic review, which is a type of literature review that are based on systematic methods to collect secondary data, critically appraise research studies, and synthesize findings qualitatively or quantitatively (Armstrong et al., 2011).

\section{Review}

Our analysis will focus on the utility of AI and ML in higher education - we examined 54 articles that combine these fields. All of these studies speak about the real utility of AI/ML algorithms in real life situations and the advantages they obtain from using these applications in analyzing and dealing with data about students and other academic utilities (collaboration among authors, knowledge management and data mining).

\subsection{Bibliometric Analysis}

\subsubsection{Method}

The systematic review is a kind of literature review that uses systematic methods to collect secondary data, but also to answer specific questions based on the articles contents. Also, the data has to be segmented by using codes extracted from the studies, in our case, 54 studies about the use of AI and ML in higher education. Each code is basically a split of the entire number of the articles which can help us see exactly how many articles treats a specific topic and also highlights the differences between them. The main objective of this article is to have a clear picture of the present literature and the utility of AI and ML algorithms in higher education, with the help of codes and profiling, both specific to the systematic review methodology.

\subsubsection{Search Strategy}

The search strategy adopted for identifying the most relevant articles is detailed by Table $1-$ searched keywords by topic and Table 2 - inclusion or exclusion criteria. All articles were selected from Web of Science and Scopus - two most known academic databases, which grants us source credibility and integrity. Search strings were formed of two or three parts, each one referring to the topic our research is limited to: AI and ML, Education and Application. 
Table 1. Search keywords

\begin{tabular}{ll}
\hline Subject & Expression \\
\hline Artificial Intelligence & 'artificial intelligence'or 'machine learning'or 'machine intelligence' or \\
& 'deep learning' or 'artificial neural networks' or 'agent system' or 'expert \\
& system' \\
& $\&$ \\
Education & 'student' or 'university' or 'higher education' or 'college' \\
& $\&$ \\
Application & 'learning' or 'tutoring' or 'assessment' or 'evaluation' or 'prediction' or \\
& 'profiling' or 'personalized content' or 'drop-out' or 'motivation' or \\
& 'admission' or 'feedback' \\
\hline
\end{tabular}

After retrieving the search results from the queries generated by the keywords and scanning their titles, abstracts and keywords, the decision of including the paper in our analysis was made based on criteria presented in Table 2 . In order to be included, the article must simultaneously respect the following rules: the paper must treat the subject of AI technology usage or to make reference to such usage; it must be clearly specified that AI is applied to the educational domain; it must be limited to higher education level. Papers that did not satisfy the conditions (ex. there are no AI or ML methods described, there is no educational background or the work is conducted on kindergarten, primary school or secondary school students) were removed from analysis.

Table 2. Selection criteria

\begin{tabular}{ll}
\hline Select & Remove \\
\hline Artificial Intelligence usage & No Artificial Intelligence usage \\
Higher education level & Not higher education level \\
Indexed in Web of Science or Scopus & Not from selected databases \\
Usage in educational setting & Not used in educational setting \\
\hline
\end{tabular}

A total of 54 papers that were published in the period from 01.01.2003 to 31.12.2019 was identified. The number of papers increased from 7 in 2000 s to 47 in 2010 s and the number is growing from year to year. A possible explanation for this would be the deep learning revolution the technology became feasible and could be integrated into many software applications.

\subsection{Articles by category (application)}

For each of the 54 gathered studies, we have detected at least one AI application or utility that uses ML in higher education to either predict, evaluate, tutor, personalize and profile students in order to gain benefits. There were 5 studies which proposed multiple applications for their solutions (Rovira et al., 2017; McNamara et al., 2015; García-Gorrostieta et al., 2018; Duffy and Azevedo, 2015; Dodigovic, 2007) but we have taken into consideration the main approach of the article.

We have identified 20 studies that modeled AI Applications in predictions, 13 in evaluating students, 8 studies that proposed an Intelligent Tutoring System (ITS), 7 studies proposed specific personalization with the help of ML, and 6 used ML models in profiling. Each of the study selected had used at least a method related to ML to analyze its data set, which in most cases was composed out of student information, grades, assignments, feedback comments, bibliographic collaborations and others. For almost each category presented in Table 1 we have detected other subcategories, for example for the category of Predictions we have 4 sub groups: Student drop-out, Admission results (predicting whether a student will be accepted at a certain university or not), Student achievements (course performance) and Retention (keeping students in university). For the category of Evaluation we have Grading (using ML to automatically grade students), Assessment (measuring the level of teaching and knowledge), Student understanding and Instructor evaluation. For Tutoring we have detected Teaching course content, which in most cases relate to intelligent systems meant to help students, the second subgroup is Feedback which helps students and teachers 
get more insights. Personalization has 3 sub groups, Personalized content, Research and Knowledge Management which are inclined towards helping university staff in better managing its operations.

Figure 1. Application Details and subgroups

- Evaluation $=$ Personalization $=$ Predictions " Profiling - Tutoring

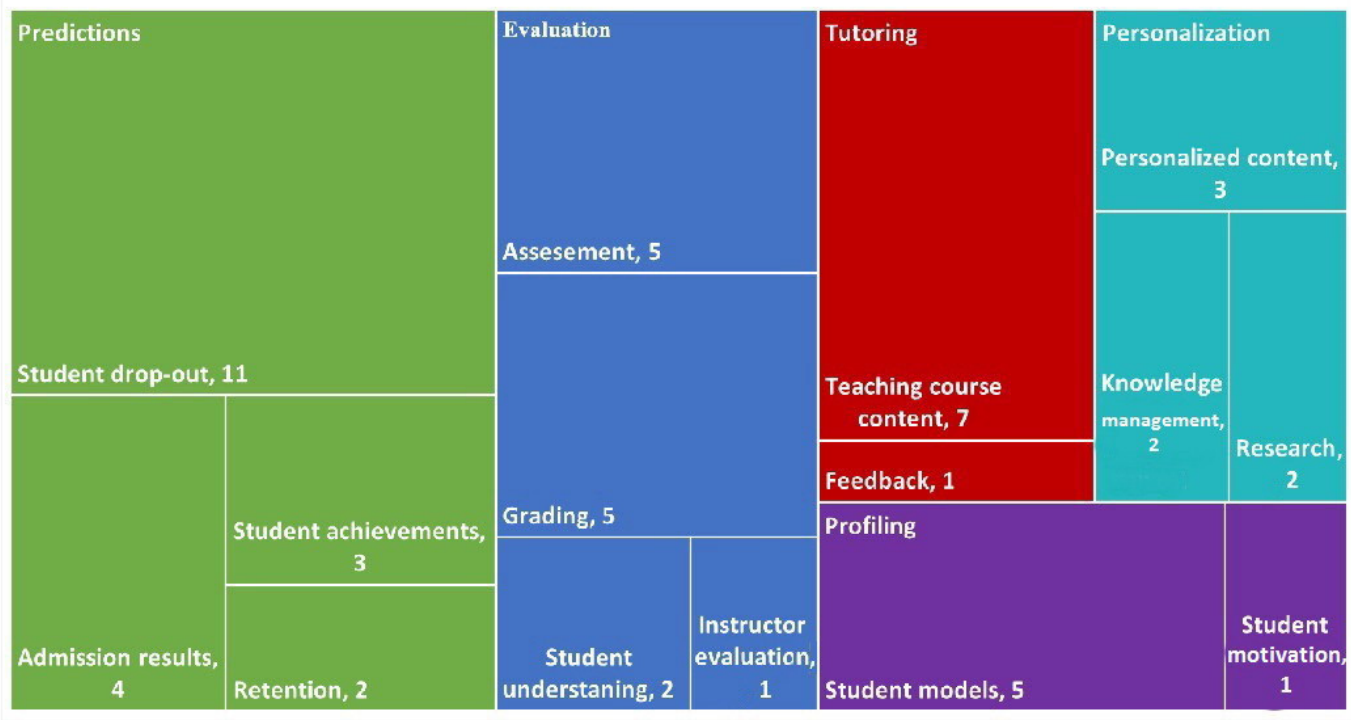

The last category is Profiling which only has two subcategories, the first and most numerous is Student Models mainly because all the articles we found with this scope try to make models that grasp the full extent of a student profile in order to achieve better understanding and data mining. The second subcategory is Student motivation. An exact number of articles used in the research for each subgroup is described in Figure 1.

\subsection{Summary of works carried out using AI/ML algorithms}

\subsubsection{Tutoring}

From all studies analyzed, seven were having as a subject the investigation of ITS by teaching course content and one researched the feedback of the students for the teachers and student's problems. The latter analyzed the positive and negative sentiment regarding the life of the students in university and the provided feedback helped the administration of the university find and solve the problematic areas. The summary of all articles can be observed in Table 3. Among the first to use ML for tutoring, Dodigovic (2007) created an application called Intelligent Tutor that aims to help students in the process of second language acquisition (SLA) by trying to identify and correct the most common errors made by them. The application was tested by 266 students from three countries and the results show that they made $83 \%$ less mistakes after interacting with the application, thus AI proves its effectiveness. 
Table 3. Applications: Tutoring

\begin{tabular}{|l|l|l|l|}
\hline Authors & Algorithms & Data & Results \\
\hline Dodigovic (2007) & Custom AI tool & $\begin{array}{l}\text { Error rate reduced by an } \\
\text { average of 83\% }\end{array}$ \\
\hline $\begin{array}{l}\text { Duffy and Azevedo } \\
\text { (2015) }\end{array}$ & Multi-agent systems & $\begin{array}{l}83 \text { undergraduate } \\
\text { students }\end{array}$ & The agent is effective \\
\hline Hooshyar et al. (2015) & $\begin{array}{l}\text { Bayesian networks, } \\
\text { multi-agent system }\end{array}$ & 1 tutor, 44 students & $\begin{array}{l}\text { Better problem-solving } \\
\text { abilities }\end{array}$ \\
\hline C. Howard et al. (2017) & Single agent systems & 26 students & $\begin{array}{l}\text { Students knowledge } \\
\text { improved }\end{array}$ \\
\hline Iglesias et al. (2009) & RL & 70 students & Better learning habits \\
\hline Liu et al. (2019) & NLP & $\begin{array}{l}\text { Two classes of 47 } \\
\text { students }\end{array}$ & $\begin{array}{l}80 \% \text { of students rated } \\
\text { as effective }\end{array}$ \\
\hline $\begin{array}{l}\text { Walkington and } \\
\text { Bernacki (2019) }\end{array}$ & $\begin{array}{l}\text { Model-tracing } \\
\text { approaches, } \\
\text { Knowledgetracing } \\
\text { approaches }\end{array}$ & $\begin{array}{l}\text { Cohen d effect is } \\
\text { between 0.38 - 0.92 }\end{array}$ \\
\hline Rani and Kumar (2017) & Sentiment analysis & $\begin{array}{l}2,200 \text { student } \\
\text { comments }\end{array}$ & $\begin{array}{l}\text { Provided feedback help } \\
\text { find problematic areas }\end{array}$ \\
\hline
\end{tabular}

Another example of intelligent tutoring application is MetaTutor - a multi-agent system developed by Duffy and Azevedo (2015), whose purpose is teaching students details about how the human circulatory system works. Authors tested their system by conducting an experiment on two groups of students $(\mathrm{N} 1=39$ and $\mathrm{N} 2=44)$. Students from the first group were given indications to use some self-regulatory learning (SRL) processes, while students from the second group were not, but still could access the module. The results show that such indications encourage learning activities, but also the fact that motivations still play an important role during learning. Also, Hooshyar et al. (2015) proposed a new approach for the learning activities by designing a Flowchart-based Intelligent Tutoring System (FITS) which is designed to help students learn programming by putting an accent on their problem-solving capacity. The proposed system makes use of Bayesian Networks and multi-agent systems for assisting students in their decisions and encourage them to adopt a programming way of thinking. Their experiment included 44 students, and concluded that the group which was using the application demonstrated better results and the task of problem solving, thus AI improved their performance.

Another research in the field of computer science was made by C. Howard et al. (2017) which attempted to create a peer dialogue agent that was meant to help students from the first steps of their learning process named KSC-PaL. The authors came to the conclusion that the interaction with a peer agent makes an impact on students' behavior and learning capacity. A distinct approach was made by Iglesias et al. (2009), as they tested a Reinforcement Learning (RL) approach to Adaptive and Intelligent educational system (AIES) on 70 students from a Computer Science program. Based on previous research, authors switched from applying RL to AIES from scratch to using an AIES with an initial value function. The results demonstrated that a RL-based system can be very useful for students in the process of learning different concepts.

Further examples of ML applications used for tutoring in higher education is also emphasized by Liu et al. (2019) research which shows how students can learn a foreign language more efficiently with the use of human-machine dialogue systems. With the help of NLP, they managed to create an application that would help students better speak foreign languages. They performed several rounds of testing on two classes of 47 students each, and the end results showed that more than $80 \%$ of the students considered the application as effective and helpful in many ways. Walkington and Bernacki (2019) also found a way to use ML in teaching, by testing an ITS meant to personalize teaching Algebra according to each students' individual interests. The tool they used 
was based on model- tracing approaches to relate problem-solving actions to a cognitive model of domain principles to give individualized feedback, and knowledge-tracing approaches to track students' progress. After applying the study on 106 volunteering students, they conclude that this method is also efficient, and boost interest and engagement in algebra. They also conclude that in depth personalization would bring even better results and efficiency in the benefit of the student.

Although different, the research made by Rani and Kumar (2017) is related to student feedback and how can universities can better find problematic areas in teaching and learning. By gathering over 2,200 feedback comments from Coursera online teaching platform and a student response system (SRS) and analyzing them using the sentiment analysis technique they managed to mine sentiment, emotion, and satisfaction parameters in student feedback to help the university and the instructors comprehend the faulty areas and find corrective actions. In the end, they emphasize that the system is as good as the data it analyzes and strongly suggest the use of better feedback tools for better understanding.

Despite the varing results of AI in tutoring, which might not be as spectacular in performance as others, it is a start and can prove insightful to a teacher that wants to adapt its methods straight to the student needs without much headache. Further research is undergoing at the moment and we should expect to see better and more customized applications in the near future.

\subsubsection{Profiling}

Some of the most important AI applications are the profiles that make the prediction algorithms possible, even if the predictions are related to opt-out rate of the students or the prediction of student's behavior during a learning process. There are three important parts of educational data mining: classification, modeling and prediction (Krishna et al., 2018). A summary of identified works in application of student profiling is shown in Table 4. What is helpful is that by using ML algorithms, teachers can profile and get insights related to their students and their wants and needs in greater details, far beyond what simple statistics or observations would bring.

Table 4. Applications: Profiling

\begin{tabular}{|c|c|c|c|}
\hline Authors & Algorithms & Data & Results \\
\hline Babić (2017) & ANN, DT, SVM & 129 students & $\begin{array}{l}\text { Academic motivation (below or } \\
\text { above average) - precision } 76.92 \%\end{array}$ \\
\hline $\begin{array}{l}\text { Hoffait and } \\
\text { Schyns (2017) }\end{array}$ & $\mathrm{RF}, \mathrm{LG}, \mathrm{ANN}$ & 6845 students & $\begin{array}{l}\text { Student failure or success } 92 \% \\
\text { accuracy }\end{array}$ \\
\hline $\begin{array}{l}\text { Hussain et al. } \\
\text { (2018) }\end{array}$ & $\begin{array}{l}\text { DT, J48 (C4.5), CART, } \\
\text { JRIPDecision Rule, } \\
\text { Gradient Boosting } \\
\text { Trees, NB }\end{array}$ & 384 students & $\begin{array}{l}\text { Predicting low-engagement students - } \\
\text { accuracy } 88.52 \%\end{array}$ \\
\hline $\begin{array}{l}\text { Hershkovitz et al. } \\
\text { (2013) }\end{array}$ & MBMLG & $\begin{array}{l}181 \\
\text { undergraduates }\end{array}$ & Better prediction \\
\hline $\begin{array}{l}\text { Toivonen et al. } \\
\text { (2019) }\end{array}$ & Neural N-Tree & $\begin{array}{l}\text { Phase 1 (64 } \\
\text { students), } \\
\text { Phase 2 (30 } \\
\text { professors) }\end{array}$ & $\begin{array}{l}\text { Better data mining and knowledge } \\
\text { discovery }\end{array}$ \\
\hline $\begin{array}{l}\text { Zhang et al. } \\
\text { (2019) }\end{array}$ & SVD, ANN, GA & 953 students & $\begin{array}{l}\text { F1-measure of } 0.8315 \text { on the final } \\
\text { model }\end{array}$ \\
\hline
\end{tabular}

As an example, Babić (2017) tried to understand students' behavior in learning management system courses and based on that build a classifier that detects students with high or low academic motivation. The work tested the performance of Artificial Neural Network (ANN), Decision Trees (DT) and Support Vector Machines (SVM) and the best results were given byANN with an accuracy of $76.93 \%$. In another case Hoffait and Schyns (2017) also tried to build a student profiling model that detects students that have a high chance to fail during their fist year at college. 
Their work indented to identify those students as early as possible so adequate measure can be taken. Three major algorithms were used: Random Forest (RF), Logistic Regression and ANN. RF show the best results achieving $92 \%$ accuracy with a confidence rate of $90 \%$.

The online activity can also be enhanced by using AI, as example Hussain et al. (2018) worked on identifying low engagement students in e-learning systems based on such variables as highest education level, final results, score on the assessment, and the number of clicks on virtual learning environment (VLE) activities. Several algorithms were tested: DT, J48 also called C4.5, Classification and Regression Tree (CART) algorithms, JRIP Decision Rule, Gradient Boosting Trees and NB (Naive Bayes). Authors were able to predict low engagement students with $88.52 \%$ accuracy. Results show that J48 (C4.5) model had the highest success rate among all models.

Other studies, such as Hershkovitz et al. (2013) manage to predict student's preparation for future learning (PFL) with relatively good results. PFL refers to what should the student learn next in the future in order to fit its needs. They used Moment-by-Moment Learning Graph (MBMLG) in order to conduct their study, the generated graph represents individual students' learning over time and is developed using a knowledge-estimation model which infers the degree of learning that occurs at specific moments rather than the student's knowledge state at those moments. In the end, the model predicted by MBMLG outperforms previous attempts to predict PFL using BKT parameters and behavioral and meta-cognitive variables. Further applications, related to profiling are the use of Educational data mining (EDM) processes with the main purpose of having more interpretable and contextual support and decision-making tools related to higher education. Such a study is made by Toivonen et al. (2019) which manages to provide a better method of knowledge discovery using Augmented intelligence (AUI) and Neural N-Tree as the main cluster analysis algorithm, in a research with multiple phases that focuses both on students and tutors. The end results show that data mining is effective and knowledge discovery is effective.

A broader study on mining and understanding student opinion is made by Zhang et al. (2019) which manages to use ML and evolutionary algorithms in order to achieve this task. They mined the opinion of 953 students, then they used singular value decomposition (SVD) to reduce multitude of dimensions and add a closed loop based on genetic algorithm (GA) in order to eliminate the over-fitting that could occur in the training process of the ANNs. The final model is efficient (F1-measure of 0.8315) and could mine student opinion on various topics with great ease.

To sum up, it is clear the there are many ML algorithms that if feed with a lot of high quality data could in return help a lot in profiling students and obtaining models. Thus, helping teachers understand what should be considered when delivering information to them, and in what manner is best suited.

\subsubsection{Personalization}

The field of personalization contains three different subgroups of works: research, personalized content and knowledge management. A short summary of articles in those three subfields is shown in Table 5. Each of this subgroup is important in better preparing the course content and the way in which the content is delivered, for better efficiency.

An example of personalization that includes tools that can be used by teachers in detecting and resolving conflicts in a learning environment was proposed by Casamayor et al. (2009). Using association rule mining authors developed a platform that had a precision of $98.7 \%$ in detecting conflicts from artificially generated text. After testing it on real data it was identified that $83 \%$ of the cases needed intervention for solving the conflict. 
Table 5. Applications: Personalization

\begin{tabular}{|c|c|c|c|}
\hline Authors & Algorithms & Data & Results \\
\hline $\begin{array}{l}\text { Ahmad and } \\
\text { Rashid (2016) }\end{array}$ & ANN, NB, SVM & $\begin{array}{l}3 \text { sub-data sets with } 313 \\
\text { cases each }\end{array}$ & $\begin{array}{l}\text { Precision for modules } \\
73.01 \%-100 \%\end{array}$ \\
\hline $\begin{array}{l}\text { Casamayor et } \\
\text { al. (2009) }\end{array}$ & Association rule mining & $\begin{array}{l}\text { Artificially generated } \\
\text { data-sets, based on real } \\
\text { use logs }\end{array}$ & $\begin{array}{l}\text { Conflict detection precision } \\
98.7 \% ; 83 \% \text { of the cases } \\
\text { need teacher's intervention }\end{array}$ \\
\hline $\begin{array}{l}\text { Chaudhri et al. } \\
\text { (2013) }\end{array}$ & $\begin{array}{l}\text { Custom - Knowledge } \\
\text { representation, NLP, } \\
\text { NLG, Knowledge } \\
\text { Machine }\end{array}$ & $\begin{array}{l}3 \text { groups of } 25,23 \text { and } \\
24 \text { students }\end{array}$ & Increased students' averages \\
\hline Chi et al. (2011) & $\mathrm{RL}$ & 3 groups of students & Significant improvements \\
\hline $\begin{array}{l}\text { Kardan and } \\
\text { Sadeghi (2013) }\end{array}$ & SVR, ANN, k-NN, DT & $\begin{array}{l}298 \text { courses (2005- } \\
\text { 2011) }\end{array}$ & $\begin{array}{l}\text { ANN MSE }=0.0014 \text { and } \\
\text { correlation }=0.929\end{array}$ \\
\hline $\begin{array}{l}\text { Srinivas and } \\
\text { Rajendran } \\
\text { (2019) }\end{array}$ & E-LDA & $\begin{array}{l}\text { Web scraper }(24,390 \\
\text { reviews) }\end{array}$ & Better efficiency \\
\hline $\begin{array}{l}\text { Benchettara et } \\
\text { al. (2010) }\end{array}$ & k-NN, Shortest Path, Katz & $\begin{array}{l}3 \text { years data from } \\
\text { DBLP, split in } 3 \text { models }\end{array}$ & $\begin{array}{l}\text { Precision: Model } 1 \text { - } 0.10 \\
\text { increase; Model } 2 \text { - } 0.3 \\
\text { increase; Model } 3 \text { - } 0.15 \\
\text { increase }\end{array}$ \\
\hline
\end{tabular}

Alternative applications can be retrieved from literature, such as the research made by Chaudhri et al. (2013) which created a intelligent book that uses knowledge representation with some techniques as NLP and natural language generation (NLG) to answer students' questions and create new similar questions that could improve their knowledge about the subject. Furthermore, Chi et al. (2011) used perhaps one of the best techniques for generating personalized content Reinforcement Learning - for a tutoring system that uses NLP in teaching physics. The chosen algorithm was Policy Iteration and the training corpus was created by interaction with students. Moreover, Kardan and Sadeghi (2013) developed a system that expand the personalization problem perfectly by identifying the elements that have an impact on student actions, creating course offering problem and creating a decision support system for administrators to help in their work with students. The target was to predict the number of registrations in the course. Several algorithms were tested, but the best one included usage of Neural Networks with a value for MSE of 0.0014. Throughout all challenges that higher education administrations have, one particular challenge stands for trying to fit the best set of courses to meet student requirements. An AI system should be able to interpret the right course for students based on his behavior, options and skills. But this is not all, the capability of a system like this should also simulate student behavior models in order to test exactly how a course can influence his grades, drop-out rate or even learning.

Knowledge management is another field related to personalization, for which we have found two studies that combine ML and knowledge. One of the two studies, conducted by Srinivas and Rajendran (2019), is related to the strengths, weaknesses, opportunities and threats (SWOT) of a university revealed by analyzing online student reviews. The method used integrates four different techniques (two of which are ML algorithms) such as topic modeling - which uses Latent Dirichlet Allocation (E-LDA), sentiment analysis, root cause and SWOT analyses in order to get better understanding. The data set was collected by web scrappers and the end results indicate that the chosen path offers efficient and economic performance summary of a university and its competitors, and can help in enrollment and retention efforts. The second study on knowledge management and ML combination is done by Benchettara et al. (2010) and focuses on academic collaboration recommendation between authors by mining the growth of co-authorship networks. At base the research focuses on supervised ML (dyadic) approach by combining different ML algorithms such as k-nearest neighbors (k-NN), Shortest Path, Katz and Commute-time on data 
from DBLP bibliographical server, split in 3 models on a 3-year span. The result of the proposed solution increased the precision from 0.1 to $0.3 \mathrm{max}$, and proves to be a good tool in linking authors, with few limitations.

One thing we would like to point out for this category is that there is no easy way to quantify the results of the works, because the end target is rather qualitative than quantitative. For example, in personalized content sub-category, the end result can be evaluated only indirectly by analyzing students' responses about their perception of content or by comparing the students test results when studying from general content and personalized content.

\subsubsection{Evaluation}

A summary of research works that appliedAI methods for student or tutor evaluation is presented in Table 6. The evaluation category refers to one of the following: evaluation of the tutors, assessment of students' written work, grading or evaluating student understanding of a certain subject. Agaoglu (2016) used four ML techniques to build a classifier that evaluates the performance of instructors. C5.0, a type of Decision Tree algorithms performed better than SVMs, ANN and DiscriminantAnalysis with an accuracy of $92.3 \%$ in determining whether the overall performance of the instructor was satisfactory. The study was based on 2850 scores from different departments from Marmara University, Turkey and demonstrated the effectiveness of applying ML models in education and teacher evaluation in particular.

One of the major challenges in assessment can be strictly related to the feedback that the automated assessments has to do and this is explained by creating a completely automated program by García-Gorrostieta et al. (2018) that can identify argumentative paragraphs and provides recommendations to improve their writing.

The SVM algorithm was also used in the work of Gierl et al. (2014) where automated essay scoring systems yield scores that consistently agree with those of human raters at a level as high, if not higher, as the level of agreement among human raters themselves. For this test were used responses for 6 English CDM-CR write-in questions from 3 years examination administrations.

Table 6. Applications: Evaluation

\begin{tabular}{|c|c|c|c|}
\hline Authors & Algorithms & Data & Results \\
\hline Agaoglu (2016) & $\begin{array}{l}\text { DT, Boosting, } \\
\text { SVM, ANN, DA }\end{array}$ & 2,850 evaluation scores & Precision $92.3 \%$ \\
\hline $\begin{array}{l}\text { Bojorque and } \\
\text { Pesántez-Avilés } \\
\text { (2019) } \\
\end{array}$ & ANN & $\begin{array}{l}20,000 \text { bibliography } \\
\text { comments }\end{array}$ & Precision $99.6 \%$ \\
\hline Amigud et al. (2017) & SVM, NB, DT & $\begin{array}{l}20 \text { written assignments } \\
\text { by } 5 \text { students }\end{array}$ & Precision $93 \%$ \\
\hline $\begin{array}{l}\text { García-Gorrostieta et } \\
\text { al. (2018) }\end{array}$ & $\begin{array}{l}\text { Custom ML } \\
\text { algorithm }\end{array}$ & $\begin{array}{l}565 \text { analyzed } \\
\text { paragraphs }\end{array}$ & $\begin{array}{l}\text { Increased proportion of } \\
\text { paragraphs with arguments } \\
\text { from } 59.66 \% \text { to } 91.48 \%\end{array}$ \\
\hline Gierl et al. (2014) & SVM & $\begin{array}{l}\text { Responses for } 6 \text { English } \\
\text { CDM-CR }\end{array}$ & $\begin{array}{l}\text { Agreement between the } \\
\text { computer classification and } \\
\text { the human raters } 94.6 \% \text { to } \\
98.2 \%\end{array}$ \\
\hline $\begin{array}{l}\text { E. Howard et al. } \\
\text { (2018) }\end{array}$ & $\begin{array}{l}\text { RF, BART, } \\
\text { xGBoost, PCR, } \\
\text { SVM, ANN, k-NN, } \\
\text { Splines }\end{array}$ & 136 participants & MAE $6.5 \%$ \\
\hline Jain et al. (2014) & $\begin{array}{l}\text { Custom - AISLE } \\
\text { (AI based tool) }\end{array}$ & 17 students & $\begin{array}{l}\text { Markov Chain Monte Carlo } \\
\text { is efficient }\end{array}$ \\
\hline $\begin{array}{l}\text { McNamara et al. } \\
(2015)\end{array}$ & DFA & $\begin{array}{l}1,243 \text { argumentative } \\
\text { essays }\end{array}$ & $\begin{array}{l}55 \% \text { exact accuracy; } 92 \% \\
\text { adjacent accuracy }\end{array}$ \\
\hline
\end{tabular}


Sustenabilitatea educației doctorale în economie și afaceri

\begin{tabular}{|l|l|l|l|}
\hline Authors & Algorithms & Data & Results \\
\hline Nehm et al. (2012) & BoW, SVM & $\begin{array}{l}2,260 \text { evolutionary } \\
\text { explanations written by } \\
565 \text { students }\end{array}$ & $\begin{array}{l}\text { Kappa inter-rater agreement } \\
\text { values }>0.80\end{array}$ \\
\hline Oztekin (2016) & DT, ANN, SVM & 1,204 records & Precision 77.61\% \\
\hline J. Chen et al. (2019) & $\begin{array}{l}\text { SVM, BP ANN, } \\
\text { RF, LR }\end{array}$ & 54 students & $\begin{array}{l}\text { The Gaussian support vector } \\
\text { machine performed the best } \\
\text { (Average Precision is 0.99) }\end{array}$ \\
\hline Dalton et al. (2018) & $\begin{array}{l}\text { LR, DT, AdaBoost, } \\
\text { ANN, NB, RF }\end{array}$ & $\begin{array}{l}\text { English data set 41,214 } \\
\text { records, Mathematics } \\
\text { data set 10,862 records }\end{array}$ & $\begin{array}{l}\text { Accuracy: English data sets } \\
\text { (RF 65.7\%), Mathematics } \\
\text { (LR 67.1\%) }\end{array}$ \\
\hline Iqbal et al. (2017) & CF, MF, RBM & $\begin{array}{l}225 \text { undergraduate } \\
\text { students }\end{array}$ & $\begin{array}{l}\text { The RBM technique is } \\
\text { better (0.3 RMSE, 0.09 } \\
\text { MSE and 0.23 MAE) }\end{array}$ \\
\hline
\end{tabular}

As shown by Jain et al. (2014), time involved in assessing a student's understanding of any domain or topic in study for the instructor can be reduce with the use of AISLE. Their experiment conducted with 17 students indicated that all of them have made an excellent score on the related course item. As for the other article with the same interest topic, Nehm et al. (2012) described in their work that Overall Summarization Integrated Development Environment (SIDE) was found to be a powerful and cost-effective tool for assessing student knowledge and performance in a complex science domain. This was possible with the study of 2,260 evolutionary explanations written by 565 students using Bow and SVM algorithms. McNamara et al. (2015) created a hierarchical model based on the principles of hierarchical classification that obtained a 55\% exact accuracy and 92\% adjacent accuracy between the predicted essay scores and the human scores based on 1243 essays written by 3 groups of students from different levels.

The work done by E. Howard et al. in 2018 concluded that the possibility of prediction of students' final mark can be done by week 6 based on mean absolute error to 6.5 percentage points. Eight algorithms used on a sample of 136 students, stated that whereby prediction models have reasonably accurate forecasts balanced with sufficient time to intervene and support at-risk students.

J. Chen et al. (2019) also conducted research in which they evaluated whether ML algorithms can predict student performance, and which method is more accurate. The Gaussian SVM, the polynomial SVM, ANN, RF and LR were employed as the classifier on a data set composed of 648 samples from 54 students enrolled in a basic course Object Oriented Programming. After comparing the accuracy and the precision-recall curve, the authors conclude that the Gaussian SVM performs the best at 0.99 average accuracy, compared to the other models. A similar research was conducted by Iqbal et al. (2017) on 225 undergraduate students, but with different techniques such as Collaborative Filtering (CF), Matrix Factorization (MF), and Restricted Boltzmann Machines (RBM) which achieved the best results with 0.3 RMSE, 0.09 MSE and 0.23 MAE. Oztekin (2016) also managed to create a model made to predict grades and ultimately graduation, with a precision of $77.61 \%$. He included multiple interesting variables, marking great originality and a deep overview over the multiple factors to account for in such a complicated model. Furthermore, Dalton et al. (2018) made a research on the same topic with the focus on Maths and English courses, with a data set of 10,862 and 41,214 records respectively. For the English course data set's best prediction model in terms or recall, precision and support values is the RF with 65.7\% accuracy, as for the Mathematics data set's Logistic Regression gives the best prediction at an accuracy of $67.1 \%$. As the study points, subject cumulative grade point average is the best predictor for the English model and without subject cumulative grade point average is the best predictor for the Mathematics model. 
From all the results of analyzed papers we can conclude that AI can be efficiently used for evaluating either students or tutors. Most papers achieved great results based on the metrics they used to validate their results.

\subsubsection{Prediction}

A short summary of studies that used AI algorithms for predicting student achievements, admission results, student drop-out or retention is shown in Table 7.

The main focus of Costa et al. (2017) was analyzing the possibility of applying ML techniques for identification of students that are likely to fail in a introductory programming class. More importantly, the study focuses on identifying those students as early as possible so that preventive measures can be taken. Four different algorithms were analyzed with two data sources that contain information about students in distance learning and on-campus learning. Results show that the SVM algorithm was the most efficient with and F-measure of 0.92 for distance learning and 0.83 for on-campus learning.

The purpose of the work done by Alkhasawneh and Hargraves (2014) was developing a model for predicting student first year retention in science, technology, engineering, and mathematics disciplines among underrepresented minority (URM) students. They used a Feed Forward back propagation neural network and features from two different data sets - data obtained from Office of Institutional Research and data obtained from focus groups. Overall the accuracy for predictions was $74 \%$, although it dropped to $60 \%$ for URM category.

In the study of Aluko et al. (2016) two algorithms (k-NN and LDA) were used to predict academic success of students enrolled in architecture courses. The target variable, academic success was defined as pass or fail, while different features such as academic grades were fed into the model. A total of 1021 samples and 13 features were collected for the study and the best of two models was k-NN with a $73.33 \%$ accuracy.

Another two studies that focuses on admission results are Andris et al. (2013) and Bahadir (2016). The first one uses SVMs for identifying students that can be favored by their geographical region. Researchers obtained an accuracy of $93 \%$ and showed that the origin region of student can influence their admission results. The second study tries to predict teachers' academic success when they enter graduate education. The study focused on two algorithms - LR and ANN and the data set contained 372 profiles and obtained precision of $90.75 \%$ and $93.02 \%$ respectively.

In their study from 2014, J.-F. Chen and Do performed a comparison between two types of ANNs (cuckoo search and gravitational search) to identify which one is the best for predicting students achievements. The data set for training contained 653 records that hold information about 8 features. The algorithms were compared by four different metrics: MAPE, RMSE, MAE and R. Results show that ANN-Cuckoo search had better results in every metric analyzed.

Table 7. Applications: Prediction

\begin{tabular}{|c|c|c|c|}
\hline Authors & Algorithms & Data & Results \\
\hline Costa et al. (2017) & $\begin{array}{l}\text { SVM, DT - J48 } \\
(\mathrm{C} 4.5), \text { ANN, NB }\end{array}$ & $\begin{array}{l}161 \text { on-campus } \\
\text { students; } 262 \\
\text { distance students } \\
\end{array}$ & $\begin{array}{l}\text { F-measure } 0.92 \text { (distance) and } \\
0.83 \text { (on-campus) }\end{array}$ \\
\hline $\begin{array}{l}\text { Acikkar and Akay } \\
\text { (2009) }\end{array}$ & SVM & $\begin{array}{l}143 \text { candidates } \\
\text { (2006); } 117 \\
\text { candidates }(2007)\end{array}$ & $\begin{array}{l}\text { Precision } 97.17 \%(2006) \text { and } \\
90.51 \%(2007)\end{array}$ \\
\hline $\begin{array}{l}\text { Alkhasawneh and } \\
\text { Hargraves (2014) }\end{array}$ & ANN & $\begin{array}{l}1,966 \\
\text { freshmen(2007- } \\
\text { 2009); focus groups } \\
-16 \text { students }\end{array}$ & $\begin{array}{l}\text { Student retention precision } \\
74 \%\end{array}$ \\
\hline Aluko et al. (2016) & LDA, k-NN & $\begin{array}{l}\text { 1,021 students } \\
(2011-2014)\end{array}$ & Precision $73.33 \%$ \\
\hline Andris et al. (2013) & LDA, SVM & 10,887 applicants & Precision 93\% \\
\hline
\end{tabular}


Sustenabilitatea educației doctorale în economie și afaceri

\begin{tabular}{|c|c|c|c|}
\hline Authors & Algorithms & Data & Results \\
\hline Bahadir (2016) & ANN, LG & 372 student profiles & $\begin{array}{l}\text { Precision ANN-93.02\%, LRA } \\
-90.75 \%\end{array}$ \\
\hline $\begin{array}{l}\text { J.-F. Chen and Do } \\
\text { (2014) }\end{array}$ & $\begin{array}{l}\text { ANN - Graviational } \\
\text { search, ANN - } \\
\text { Cuckoo Search }\end{array}$ & 653 students & $\begin{array}{l}\text { RMSE ANN/GSA - 0.76, } \\
\text { ANN/CA - } 0.73\end{array}$ \\
\hline $\begin{array}{l}\text { Raju and Schumacker } \\
(2015)\end{array}$ & DT, LG, ANN & $\begin{array}{l}\text { 22,099 students } \\
(1995-2005)\end{array}$ & $\begin{array}{l}\text { Max AUC - ROC value } 0.777 \\
\text { ANN }\end{array}$ \\
\hline $\begin{array}{l}\text { Rovira et al. (2017) - } \\
\text { out }\end{array}$ & $\begin{array}{l}\text { LR, NB, SVM, RF, } \\
\text { AdaBoost }\end{array}$ & $\begin{array}{l}\text { 4,434 students } \\
(2009-2014)\end{array}$ & $\begin{array}{l}\text { AdaBoost }(73 \% \text { F1 score, } \\
91 \% \text { recall), RF }(76 \% \text { F1 } \\
\text { score, } 82 \% \text { recall) }\end{array}$ \\
\hline Sultana et al. (2017) & DT, LG, NB, ANN & $\begin{array}{l}113 \text { students; } 650 \\
\text { instances from an } \\
\text { online repository }\end{array}$ & $\begin{array}{l}\text { Data set } 1-\text { precision } 65 \% \\
\text { (DT), Data set } 2-\text { precision } \\
84 \% \text { (NB and DT) }\end{array}$ \\
\hline Tan and Shao (2015) & RF, LR, ANN, DT & 62,375 students & $\begin{array}{l}\text { Better performance in } \\
\text { predicting drop outs }\end{array}$ \\
\hline $\operatorname{Er}(2012)$ & $\begin{array}{l}\text { Instance-based } \\
\text { learning Classifier, } \\
\text { DT, NB, K-Star } \\
\end{array}$ & $\begin{array}{l}\text { METU-Online } \\
\text { system }\end{array}$ & K-Star had $82 \%$ accuracy \\
\hline $\begin{array}{l}\text { Kotsiantis et al. } \\
\text { (2003) }\end{array}$ & $\begin{array}{l}\text { DT,ANN, NB, LR, } \\
\text { SVM }\end{array}$ & $\begin{array}{l}354 \text { distance } \\
\text { students }\end{array}$ & $\begin{array}{l}\text { NB }(82.89 \% \text { accuracy) and } \\
\text { BP }(83.89 \%) \text { had best results }\end{array}$ \\
\hline $\begin{array}{l}\text { Lakkaraju et al. } \\
\text { (2015) }\end{array}$ & $\begin{array}{l}\text { RF, AdaBoost, LR, } \\
\text { SVM, DT }\end{array}$ & $\begin{array}{l}2012-12,383 \\
\text { students, } 2013- \\
12,404 \text { students }\end{array}$ & RF best performed, AUC 0.91 \\
\hline $\begin{array}{l}\text { Lykourentzou et al. } \\
(2009)\end{array}$ & $\begin{array}{l}\text { ANN, SVM, fuzzy } \\
\text { ARMAP }\end{array}$ & 193 students & Accuracy of $75 \%-85 \%$ \\
\hline $\begin{array}{l}\text { Alban and Mauricio } \\
(2019)\end{array}$ & ANN & 2,670 students & $\begin{array}{l}\text { Multilayer Perceptron } \\
\text { prediction rate of } 96.3 \% \text {, } \\
\text { accuracy rate of the radial } \\
\text { base is } 96.8 \%\end{array}$ \\
\hline Basu et al. (2019) & $\begin{array}{l}\text { LG, NB, DT, SVM, } \\
\text { kNN, RF, GB }\end{array}$ & 11,001 students & $\begin{array}{l}\text { LR classifier performed best, } \\
\text { AUC score of } 79.6 \%\end{array}$ \\
\hline Berens et al. (2018) & AdaBoost & $\begin{array}{l}\text { 26,686 students } \\
\text { (public), 16,192 } \\
\text { students (private) }\end{array}$ & $\begin{array}{l}\text { 1st semester accuracy: } 79 \% \\
\text { (public), } 85 \% \text { (private). } 4^{\text {th }} \\
\text { semester accuracy: } 90 \% \\
\text { (public), } 95 \% \text { (private) }\end{array}$ \\
\hline Dekker et al. (2009) & $\begin{array}{l}\text { OneR, CART, J48 } \\
\text { (C4.5), NB, Logit, } \\
\text { JRip, RF }\end{array}$ & 648 students & $\mathrm{J} 48$ best accuracy at 0.79 \\
\hline $\begin{array}{l}\text { RodriguezMaya et al. } \\
(2017)\end{array}$ & $\begin{array}{l}\text { NB, J48 (C4.5), RF, } \\
\text { RT }\end{array}$ & 671 students & $\begin{array}{l}\text { RF had best results, precision } \\
\text { of } 86.14 \%\end{array}$ \\
\hline
\end{tabular}

From all twenty studies identified in the prediction model, more than half are concentrated around the prediction of the biggest problem of universities, students drop-out. Although, four of the studies also concentrated in predicting the admission results, which can help higher education experts to see where exactly should they point their attention in solving areas with issues.

A study in predicting admission results was conducted by Basu et al. (2019) in which they try to predict student college commitment decisions by using supervised ML techniques. They gathered data from 11,001 students, each with 35 associated features, admitted to a small liberal arts college in California, and assessed the predicting performance of LR, NB, DT, SVM, k-NN, $\mathrm{RF}$ and Gradient Boosting in order to find a suitable algorithm for such a task. The best model was generated by LR predicting whether a student will accept an admission offer, with an AUC score of $79.6 \%$ and thus demonstrating that institutions could use such model in improving the accuracy 
of their estimates of entering class sizes which will allow for optimal resource allocation and better economic planning.

A very popular and important subcategory is the student drop-out prediction, which is a strident issue for most universities nowadays, which has a negative social, economic and academic impact. We identified a total of 11 studies that focus on student drop-out prediction by using different ML algorithms to classify students, their reason to drop out and seek relations between different related dimensions with varying degrees of accuracy. As expected, all these studies use classification in order to label students accordingly to the perceived risk of dropping out. As result, there is no surprise that DT, J48 (C4.5) and RF appear in most of the studies with relatively good results, closely followed by more complex ML algorithms such as AdaBoost, ANN, SVM and others.

Although it is unclear which ML algorithm is the best in classifying and predicting student drop-out, the current trend is on using RF, as also concluded from the studies of Rodriguez-Maya et al. (2017), Lakkaraju et al. (2015), Tan and Shao (2015) and Rovira et al. (2017).

Rodriguez-Maya et al. (2017) tried to predict student drop-out based on the student selfreported information and scores on the university entrance exam. With a data set containing responses from 671 students, they seek the best classifier among NB, J48 (C4.5), RF, Regression Trees (RT) and Multilayer Perceptron in order to create an efficient model. RF has performed the best with a precision of $86.14 \%$. Lakkaraju et al. (2015) performed a similar study, only with a larger data set (12,383 students for 2012, and 12,404 students for 2013) and more diverse ML algorithms, which include AdaBoost, SVM, LR and others. Surprisingly, RF performed the best with slightly better results than AdaBoost with a 0.91 AUC. A similar study is conducted by Tan and Shao (2015) on 62,375 students where they compare different ML algorithms to see which gets a better accuracy, precision, recall and F-measure. The results show that RF algorithms are better, with the highest F-measure of $71.91 \%$ and overall better results and malleability. Rovira et al. (2017) applied AI techniques for three different tasks: drop-out prediction, grade prediction and personalized recommendations. The study analyzed a data set if 4434 students enrolled in Law, Computer Science and Mathematics courses of the Universitat de Barcelona. Regarding dropout results - two algorithms showed good results: AdaBoost (73\% F1 score, 91\% recall) and RF (76\% F1 score, $82 \%$ recall).

A similar decision tree called J48 (C4.5) has the best performance in Dekker et al. (2009) work with an accuracy of 0.79 on a smaller sample of just 648 students and by combining cost-sensitive learning. Also, Sultana et al. (2017) had used DT, Logistic Regression, NB and Neural Networks for predicting dropout among electrical engineering students. The study had two data sets: the first one had 113 students and DT had the best accuracy with $65 \%$, the second one had 650 instances and the best accuracy in classification was shown by DT and NB - 84\%.

Other studies focused on using ANN for prediction and reached very high accuracies, such as the one made by Alban and Mauricio (2019) on 2,670 students from a public university with Multilayer Perceptron prediction rate of $96.3 \%$, and $96.8 \%$ for radial basis function. Kotsiantis et al. (2003) and had similar results with ANN, but with a lower accuracy of $83.89 \%$ and on a smaller sample of online students. Also, on distance students, $\operatorname{Er}$ (2012) manages to predict students dropout for an online course with the highest accuracy for a single ML algorithm of $82 \%$. Lykourentzou et al. (2009) was among the first to combine multiple ML algorithms in schemas, but the sample was small and the accuracy varied between $75-85 \%$ for all the proposed models.

Last, but not least the most efficient research focused on a more complex approach, Berens et al. (2018) used AdaBoost that combined regression analysis, ANN and DT to predict drop-out for students from public and private universities. The initial result was modest, as for the first semester the accuracy of the model was 79\% (public) and $85 \%$ (private), but it drastically increased and become better by the fourth semester with $90 \%$ (public) $95 \%$ (private) on a huge data set of 42878 students from a German university. As a conclusion, most of the studies that focus on predicting student drop-out look alike in the strategy they take, the variables they consider as drop-out reasons 
and the dimensions used, but vary greatly in the ML algorithms that work the best and the data collection leading to various approaches that we just described.

\subsection{Summary of AI/ML algorithms applied}

In Table 8 we systematize the distribution of all applied ML algorithms in analyzed articles.

Table 8. Summary of AI/ML algorithms applied

\begin{tabular}{|l|l|l|l|l|l|l|}
\hline Algorithm & Predictions & Evaluation & Tutoring & Personalization & Profiling & Total \\
\hline ANN & 11 & 6 & - & 2 & 3 & 22 \\
\hline SVM & 8 & 8 & - & 1 & 1 & 18 \\
\hline DT & 10 & 4 & - & 1 & 2 & 17 \\
\hline NB & 7 & 2 & - & 1 & 1 & 11 \\
\hline RF & 6 & 3 & - & - & 1 & 10 \\
\hline LG & 5 & - & - & - & 1 & 6 \\
\hline LR & 4 & 2 & - & - & - & 6 \\
\hline k-NN & 2 & 1 & - & 1 & - & 4 \\
\hline AdaBoost & 3 & 1 & - & - & - & 4 \\
\hline Agent systems & - & - & 3 & - & - & 3 \\
\hline RL & - & - & 1 & 1 & - & 2 \\
\hline LDA & 2 & - & - & - & - & 2 \\
\hline Others & 9 & 14 & 6 & 7 & 9 & 45 \\
\hline
\end{tabular}

Given the fact that deep learning revolution started in early 2010s and that, overall, ANN's have been identified as the most used method with 22 cases it can be concluded thatANN provide a very efficient way of solving problems and making predictions. ANN's have been applied in 11, 5, 3 and 3 articles from Predictions, Evaluation, Personalization and Profiling subjects respectively and it has the highest number in four of them - all except Evaluation. The leading algorithm on Evaluation topic is SVM with 7 identified usages. SVM is also the second most used algorithm with a total number of 18 uses: 8 for Predictions, 2 for Personalization and 1 for Profiling. The third algorithm in top is DT which was used in 17 research works: 10 for Predictions, 3 for Evaluation and 2 for Personalization and Profiling. Another two classic ML algorithms were used 10 or more times - RF and NB.At the bottom of the table there are RL and LDAwith only 2 identified research papers. Two algorithms were used only for a single type of work - LDA for Predictions and Agent Systems for Tutoring.

\section{Conclusions}

In this paper we reviewed 54 papers that researched the possibility of applying ML techniques to different applications in higher education: prediction of student drop-out or retention, generation of personalized content for students, creation of tutoring systems, student profiling and automated evaluation of students or tutors. Three main conclusions result from our work:

The first conclusion is that AI field has a great potential to be applied in higher education to help students, professors and other members of faculty stuff. With the help of AI universities can predict whether a student is likely to quit the program early enough to be able to take efficient measures. AI can create individual learning paths for each student based on his or her capability of learning and remembering things. Automated evaluation of students' works is yet another example of jobs that can be done by AI and will save a lot of time for professors.

Our second conclusion is thatAI algorithms perform well on different tasks, ANN being the most recent and most efficient one in many of them. The dominance of ANN can be explained by technological progress made in recent years and more computer power being affordable to everyone. The number of research papers started to increase in 2010, the year of deep learning revolution, and had an ascendent trend till 2019. Last years were also marked by the appearance of 
more and more model architectures that have better results and use fewer resources in the process of training. We expect the trend to continue its ascendent evolution, which means the number of research papers that apply AI in higher education will increase.

Finally, third conclusion states that there is still little research in this direction compared to its potential. Existing research can be improved by exploring the possibility of adding more diverse data or applying different algorithms and neural network architectures for each possible application. The data that is fed to model training can be improved both in a quantitative and qualitative way. Choosing different architectures and applying hyperparameter tuning for ANN's can also lead to substantial improvements.

\section{Limitations and Further Research}

Although we tried as much to avoid limitations, it must be considered that we have included only articles written in English, meaning that we have left aside those written in other foreign languages. Second, the keywords used were also in English, thus we have possibly missed some articles that could have tags and titles in different languages. Furthermore, we only used two academic databases in our research and also there could be some subjectivity in searching, discriminating and choosing the studies, not to mention that we only found 54 suitable articles. Besides, the chosen scientific articles rely on their authors selfproclaimed research design and results, that might be another source of bias. Additionally, we only included academic studies in our review, but not all the AI applications with ML algorithms used in education have a special scientific article written for them, as there are many practical applications that have simply practical usage. Thus, we definitely have a blind spot in this area, and we suggest further research in this field and a better method of collecting information, that goes beyond a systematic review.

As a further research, we suggest that the PRISMA diagram could also be included, as it shows exactly how many exclusions were done in the search of studies and how the minimum requirements of the studies influenced the final number of reviews. More articles should also be considered, in different languages (not just English) and from multiple academic databases. There is also a possibility to extend the systematic review to other subjects as well, referring to AI in primary school, secondary school or even kindergartens. This may be a comparison between how much society expects AI to help higher education compared to first steps in child education.

\section{References}

- Acikkar, M., \& Akay, M. F. (2009). Support vector machines for predicting the admission decision of a candidate to the school of physical education and sports at Cukurova University. Expert Systems with Applications, 36(3), 7228-7233.

- Agaoglu, M. (2016). Predicting instructor performance using data mining techniques in higher education. IEEE Access, 4, 2379-2387.

- Ahmad, H. A., \& Rashid, T. A. (2016). Lecturer performance analysis using multiple classifiers. JCS, 12(5), 255-264.

- Alban, M., \& Mauricio, D. (2019). Neural networks to predict dropout at the universities. International Journal of Machine Learning and Computing, 9(2), 149-153.

- $\quad$ Alkhasawneh, R., \& Hargraves, R. H. (2014). Developing a hybrid model to predict student first year retention in stem disciplines using machine learning techniques. Journal of STEM Education: Innovations and Research, 15(3), https://www.jstem.org/jstem/index.php/ JSTEM/article/view/1805/1627.

- $\quad$ Aluko, R. O.,Adenuga, O.A., Kukoyi, P. O., Soyingbe,A.A., Oyedeji, J. O., et al. (2016). Predicting the academic success of architecture students by pre-enrolment requirement: Using machine-learning techniques. Construction Economics and Building, 16(4), 86-98. 
- Amigud, A., Arnedo-Moreno, J., Daradoumis, T., \& Guerrero-Roldan, A.-E. (2017). Using learning analytics for preserving academic integrity. International Review of Research in Open and Distributed Learning: IRRODL, 18(5), 192-210.

- Andris, C., Cowen, D., \& Wittenbach, J. (2013). Support vector machine for spatial variation. Transactions in GIS, 17(1), 41-61.

- Armstrong, R., Hall, B. J., Doyle, J., \& Waters, E. (2011). "Scoping the scope" of a cochrane review. Journal of public health, 33(1), 147-150.

- Babić, I. Đ. (2017). Machine learning methods in predicting the student academic motivation. Croatian Operational Research Review, 443-461.

- Bahadir, E. (2016). Using neural network and logistic regression analysis to predict prospective mathematics teachers'academic success upon entering graduate education. Educational Sciences: Theory and Practice, 16(3), 943-964.

- Basu, K., Basu, T., Buckmire, R., \& Lal, N. (2019). Predictive models of student college commitment decisions using machine learning. Data, 4(2), 65-83.

- Benchettara, N., Kanawati, R., \& Rouveirol, C. (2010). A supervised machine learning link prediction approach for academic collaboration recommendation. In Proceedings of the fourth acm conference on recommender systems, 253-256.

- Berens, J., Schneider, K., Görtz, S., Oster, S., \& Burghoff, J. (2018). Early detection of students at risk-predicting student dropouts using administrative student data and machine learning methods (CESifo Working Paper Series). CESifo. https://ideas.repec.org/p/ces/ceswps/_7259.html.

- Berlinski, D. (2000). The advent of the algorithm: The idea that rules the world. Harcourt

- Bojorque, R., \& Pesántez-Avilés, F. (2019). Academic quality management system audit using artificial intelligence techniques. In International conference on applied human factors and ergonomics. Springer, 275-283

- Casamayor, A., Amandi, A., \& Campo, M. (2009). Intelligent assistance for teachers in collaborative e-learning environments. Computers \& Education, 53(4), 1147-1154.

- Chaudhri, V. K., Cheng, B., Overtholtzer, A., Roschelle, J., Spaulding, A., Clark, P., Greaves, M., \& Gunning, D. (2013). Inquire biology: A textbook that answers questions. AI Magazine, 34(3), 55-72.

- Chen, J.-F., \& Do, Q. H. (2014). Training neural networks to predict student academic performance: A comparison of cuckoo search and gravitational search algorithms. International Journal of Computational Intelligence and Applications, 13(01), 1450005.

- Chen, J., Luo, L., \& Song, J. (2019). Course performance prediction for basic courses of universities based on support vector machine. In Journal of physics: Conference series. IOP Publishing, 1168(3), 032066

- Chi, M., VanLehn, K., Litman, D., \& Jordan, P. (2011). Empirically evaluating the application of reinforcement learning to the induction of effective and adaptive pedagogical strategies. User Modeling and UserAdapted Interaction, 21(1-2), 137-180.

- Costa, E. B., Fonseca, B., Santana, M. A., de Araújo, F. F., \& Rego, J. (2017). Evaluating the effectiveness of educational data mining techniques for early prediction of students' academic failure in introductory programming courses. Computers in Human Behavior, 73, 247-256.

- Dalton, A. R., Beer, J., Kommanapalli, S., \& Lanich Ph D, J. S. (2018). Machine learning to predict college course success. SMU Data Science Review, 1(2), 1-14.

- $\quad$ Dekker, G. W., Pechenizkiy, M., \& Vleeshouwers, J. M. (2009). Predicting students drop out: A case study. International Working Group on Educational Data Mining, 41-50.

- Dodigovic, M. (2007). Artificial intelligence and second language learning: An efficient approach to error remediation. Language Awareness, 16(2), 99-113. 
- Duffy, M. C., \& Azevedo, R. (2015). Motivation matters: Interactions between achievement goals and agent scaffolding for self-regulated learning within an intelligent tutoring system. Computers in Human Behavior, 52, 338-348.

- Er, E. (2012). Identifying at-risk students using machine learning techniques: A case study with is 100. International Journal of Machine Learning and Computing, 2(4), 476-480.

- García-Gorrostieta, J. M., López-López, A., \& González-López, S. (2018). Automatic argument assessment of final project reports of computer engineering students. Computer Applications in Engineering Education, 26(5), 1217-1226.

- Gierl, M. J., Latifi, S., Lai, H., Boulais,A.-P., \& De Champlain,A. (2014).Automated essay scoring and the future of educational assessment in medical education. Medical education, 48(10), 950-962.

- Hershkovitz, A., Baker, R., Gowda, S. M., \& Corbett, A. T. (2013). Predicting future learning better using quantitative analysis of moment-by-moment learning. In Educational data mining 2013, 74-82.

- Hoffait, A.-S., \& Schyns, M. (2017). Early detection of university students with potential difficulties. Decision Support Systems, 101, 1-11.

- Hooshyar, D., Ahmad, R. B., Yousefi, M., Yusop, F., \& Horng, S.-J. (2015). A flowchartbased intelligent tutoring system for improving problem-solving skills of novice programmers. Journal of Computer Assisted Learning, 31(4), 345-361.

- Howard, C., Jordan, P., Di Eugenio, B., \& Katz, S. (2017). Shifting the load: A peer dialogue agent that encourages its human collaborator to contribute more to problem solving. International Journal of Artificial Intelligence in Education, 27(1), 101-129.

- Howard, E., Meehan, M., \& Parnell, A. (2018). Contrasting prediction methods for early warning systems at undergraduate level. The Internet and Higher Education, 37, 66-75.

- Hussain, M., Zhu, W., Zhang, W., \& Abidi, S. M. R. (2018). Student engagement predictions in an e-learning system and their impact on student course assessment scores. Computational intelligence and neuroscience, 2018, 1-21. http:/downloads.hindawi.com/journals/ cin/2018/6347186.pdf

- Iglesias, A., Martínez, P., Aler, R., \& Fernández, F. (2009). Reinforcement learning of pedagogical policies in adaptive and intelligent educational systems. Knowledge-Based Systems, 22(4), 266-270.

- $\quad$ Iqbal, Z., Qadir, J., Mian, A. N., \& Kamiran, F. (2017). Machine learning based student grade prediction: A case study. arXiv preprint arXiv:1708.08744, 1-22. https://arxiv.org/pdf/ 1708.08744.pdf

- Jain, G. P., Gurupur, V. P., Schroeder, J. L., \& Faulkenberry, E. D. (2014). Artificial intelligencebased student learning evaluation: A concept map-based approach for analyzing a student's understanding of a topic. IEEE Transactions on Learning Technologies, 7(3), 267-279.

- Kardan, A. A., \& Sadeghi, H. (2013). A decision support system for course offering in online higher education institutes. International Journal of Computational Intelligence Systems, 6(5), 928-942.

- Kotsiantis, S. B., Pierrakeas, C., \& Pintelas, P. E. (2003). Preventing student dropout in distance learning using machine learning techniques. In International conference on knowledge-based and intelligent information and engineering systems, Springer, 267-274

- Krishna, K. P., Kumar, M. M., \& Sri, P. A. (2018). Student information system and performance retrieval through dashboard. International Journal of Engineering \& Technology, 7(2.7), 682-685.

- $\quad$ Lakkaraju, H., Aguiar, E., Shan, C., Miller, D., Bhanpuri, N., Ghani, R., \& Addison, K. L. (2015). A machine learning framework to identify students at risk of adverse academic outcomes. In Proceedings of the 21th acm sigkdd international conference on knowledge discovery and data mining, 1909-1918. 
- Liu, T., Yuizono, T., Lu, Y., \& Wang, Z. (2019). Application of human-machine dialogue in foreign language teaching at universities. In Iop conference series: Materials science and engineering, 573(1), IOP Publishing, 012047.

- Lykourentzou, I., Giannoukos, I., Nikolopoulos, V., Mpardis, G., \& Loumos, V. (2009). Dropout prediction in e-learning courses through the combination of machine learning techniques. Computers \& Education, 53(3), 950-965.

- McNamara, D. S., Crossley, S. A., Roscoe, R. D., Allen, L. K., \& Dai, J. (2015). A hierarchical classification approach to automated essay scoring. Assessing Writing, 23, 35-59.

- $\quad$ Nehm, R. H., Ha, M., \& Mayfield, E. (2012). Transforming biology assessment with machine learning: Automated scoring of written evolutionary explanations. Journal of Science Education and Technology, 21(1), 183-196.

- Oztekin, A. (2016). A hybrid data analytic approach to predict college graduation status and its determinative factors. Industrial Management \& Data Systems, 1678-1699.

- $\quad$ Parker, L. E. (2018). Creation of the national artificial intelligence research and development strategic plan. AI Magazine, 39(2), 25-31.

- Raju, D., \& Schumacker, R. (2015). Exploring student characteristics of retention that lead to graduation in higher education using data mining models. Journal of College Student Retention: Research, Theory \& Practice, 16(4), 563-591.

- $\quad$ Rani, S., \& Kumar, P. (2017). A sentiment analysis system to improve teaching and learning. Computer, 50(5), 36-43.

- Rodrıguez-Maya, N. E., Lara-Álvarez, C., May-Tzuc, O., \& Suárez-Carranza, B. A. (2017). Modeling students' dropout in Mexican universities, Research in Computing Science, 139, 163-175

- $\quad$ Rovira, S., Puertas, E., \& Igual, L. (2017). Data-driven system to predict academic grades and dropout. PLoS one, 12(2), 1-21. https://doi.org/10.1371/journal.pone.0171207.

- Srinivas, S., \& Rajendran, S. (2019). Topic-based knowledge mining of online student reviews for strategic planning in universities. Computers \& Industrial Engineering, 128, 974-984.

- Sultana, S., Khan, S., \& Abbas, M. A. (2017). Predicting performance of electrical engineering students using cognitive and non-cognitive features for identification of potential dropouts. International Journal of Electrical Engineering Education, 54(2), 105-118.

- $\quad$ Tan, M., \& Shao, P. (2015). Prediction of student dropout in e-learning program through the use of machine learning method. International Journal of Emerging Technologies in Learning, 10(1), 1117.

- $\quad$ Toivonen, T., Jormanainen, I., \& Tukiainen, M. (2019).Augmented intelligence in educational data mining. Smart Learning Environments, 6(1), 1-25. https://slejournal.springeropen. com/track/pdf/10.1186/s40561-019-0086-1

- Walkington, C., \& Bernacki, M. L. (2019). Personalizing algebra to students' individual interests in an intelligent tutoring system: Moderators of impact. International Journal of Artificial Intelligence in Education, 29(1), 58-88.

- Xu, F., \& Song, X. (2017). Research on the acceptability of oral English test based on humanmachine dialogue for junior high school. Science \& Technology Vision, 11, 29-30.

- Zawacki-Richter, O., Marín, V. I., Bond, M., \& Gouverneur, F. (2019). Systematic review of research on artificial intelligence applications in higher education-where are the educators? International Journal of Educational Technology in Higher Education, 16(1), 1-27. https://educationaltechnologyjournal.springeropen.com/track/pdf/10.1186/s41239-019-0171-0 .

- Zhang, J., Zhang, P., \& Xu, B. (2019). Analysis of college students' public opinion based on machine learning and evolutionary algorithm. Complexity, 2019, 1-10. https://doi.org/10.1155/2019/1712569 


\title{
Cap. 2. THE IMPACT OF INNOVATION ON RESEARCH AND DEVELOPMENT
}

\author{
Emmanuel Obed Dadzie ${ }^{1}$, Ionela-Gabriela Matei ${ }^{2}$ \\ ${ }^{I}$ Alexandru Ioan Cuza University of Iaşi, Faculty of Economics and Business Administration, Iasi, \\ Romania, emmaobeddadzie@gmail.com \\ ${ }^{2}$ Alexandru Ioan Cuza University of Iaşi, Faculty of Economics and Business Administration, Iasi, \\ Romania,matei.ionelagabriela@gmail.com
}

\begin{abstract}
Innovation is seen as a growth catalyst for productivity, market competitiveness, quality of products and services and business efficiency. Innovation can be measured at various levels including organizational and political levels. Research and development is a vital field that has consistently attracted global interest. Research and development is closely linked to innovation since they both trend on the same path, such as, developing new products/services or finding solutions to improve/ update old ones. In this research, we analyze the extent to which innovation (in a global context) affects research and development (R\&D). Partial least squares - structural equation models (PLS-SEM) are used in our analysis. We also analyze the relationship between innovation and $\mathrm{R} \& \mathrm{D}$. We anticipate that innovation has a positive impact on R\&D. Also, we anticipate a positive relationship between innovation and R\&D.
\end{abstract}

Keywords: innovation, research, development.

JEL Classification: I23, O19, O32

\section{Introduction}

Innovation as a process (Dziallasa \& Blind, 2019) requires knowing the needs, presenting itself in the form of a creative idea that comes along with it more value and novelty thereby fulfilling its full characteristics.

The innovation activity represents the transformation of the results of scientific research and practical elaborations into new knowledge, products and services (Leonard \& Swap, 1999) that correspond to the needs and requirements of the markets and that are subsequently subjected to the technological or commercial process.

As a result, research and development activities (although different from one institution/company to another) are keen in acquiring a larger market share despite the risk associated with investment as well as the risk of researchers' inability to pre-predict the desired result.

The revolutionary way in which science is currently evolving leads to the emergence of fundamental changes, imprinting a more open, collaborative and international character of innovation. Thus, the innovation process involves many actors, creating a regulatory environment (OECD, 2007) that favors the creation of new ones and facilitates the access of innovative enterprises to national public or private investments and venture capital.

Research at EU level is multidisciplinary, contributing to addressing existing challenges by exploring new forms of innovation and consolidating knowledge for EU and national policy actions (European Commission, 2018).

In terms of supporting emerging technologies, researchers can transform the results of scientific research into technologies that can be taken over by industry and enterprises.

\section{Literature review}

Understanding the challenges facing society today requires effective cooperation between science and society in order to associate scientific excellence with awareness and social 
responsibility. In this case, the European Union focuses more on societal challenges (European Commission, 2011) and less on disciplinary research. Thus, the EU promotes coherent and efficient cooperation between EU and non-EU member states.

\subsection{European Union - a major player in global research and development ac}

Research and innovation directly contribute to the prosperity of all economies, stimulating economic growth and investment by providing the knowledge and solutions needed for various problems.

The European Union is considered the world's leading "knowledge factory" due to the fact that it accounts for almost a third of the world's scientific and technological production. As a major player in the scientific and technological landscape, the EU is one of the undisputed leaders in many fields, with its strengths being openness, diversity and excellence in business and institutions.

At the same time, the European Union is facing increasingly fierce international competition in the fields of research and technological production and is creating various multi-annual framework programs to support innovation through collaboration (European Commission, 2018).

By consolidating and interconnecting existing research infrastructure, the EU seeks to provide high-quality researchers and professionals to facilitate the exchange and use of data between countries, industries, disciplines, etc. That said, due to global challenges, the EU is trying to strengthen the idea of international collaboration between researchers and innovators by creating different partnerships between them, as well as an internal market (European Commission, 2019).

Therefore, stimulating innovation (European Commission, 2018) encourages businesses to invest more in research and collaborate with the public sector to bring and distribute concrete benefits to citizens, to harness existing scientific potential, to create new jobs, to improve living standards and to stimulate industrial competitiveness on the market that is based on advanced technological products and processes in the global value chain.

At the base of innovation and technological progress are often investments and scientific excellence (Abbott, 2013), they develop new industries and markets.

The training (Anjum, 2020) of top researchers is created through the support given to young and experienced researchers to consolidate their professional careers and gain new knowledge and experiences that capitalize on their full potential through various courses and internships abroad or in the private sector.

The European Union is constantly trying to develop new sources of economic growth through advanced production that is supported by a modern and dynamic business environment.

The reason behind the promotion of a policy in the field of innovation, research and development (OECD, 2007) lies in the need to increase efficiency and reduce the costs of production processes, while strengthening the competitiveness of the national and international economy. At the same time, through research and development, the economy is experiencing a sharper development, and through technological innovation, certain societal problems are combated and / or diminished.

\subsection{Innovation - the pillar of creativity}

Innovation has become the most important key, both in terms of development, but also of what drives economies towards efficiency, the countries being currently categorized according to the degree of existing competitiveness.

Organizational culture can be structured in different ways, but what is the basis of it is the registered performance in order to stimulate the creation of new innovative ideas for success. In other words, innovation must be accepted by individuals and transform all aspects (resources, behaviors, mechanisms, management, leadership, etc.) that embody it in a real success that will help the development of society (Aziz \& Marcos, 2013). 
An innovative culture is characterized by opportunities, freedom to create, successive changes, openness to new, flexibility, risk-taking, people with immeasurable creative capacity, high potential debates and conflicts of interest (Sharman \& Johnson, 1997) (Dobni, 2008).

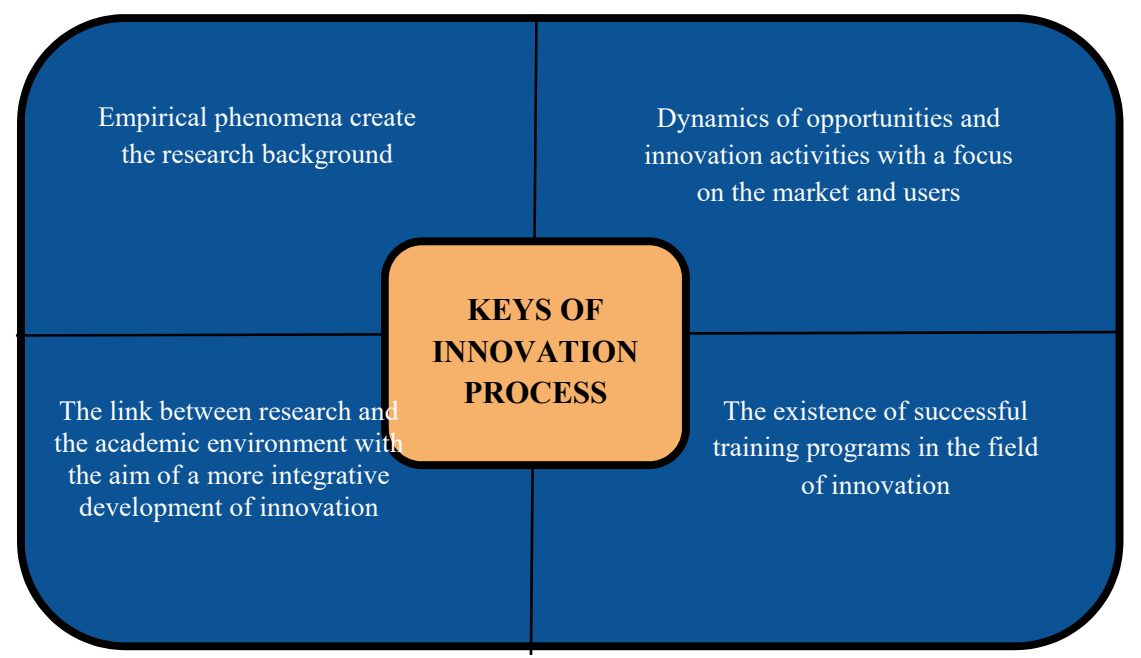

Fig. 1. Key aspects of the innovation process

Source: Own estimation

The innovation is based on a clear mission, a vision of success and well-defined strategies, which together promote the development and implementation of new products, services, businesses and processes that offer sustainable and lasting growth opportunities. Moreover, innovation does not follow the same rules and principles as imitation, the latter one following an idea that was the basis of that innovation.

In the doctoral programs, the innovation resides in the research and the models that the doctoral students carry out in order to help the research reach certain heights, but also to support the university educational environment in a continuous dynamic towards an increase of the quality performance of this.

Unlike science and technology development, practice-based innovation (Melkas \& Harmaakorpi, 2012) is a concept that has its roots in the differences between the methods of researching knowledge innovation, for which why the first step is to identify the practical problem and then it is resorted to by learning, using and interacting.

\section{Data and methodology}

Many experts have analyzed the impact of research and development on innovation and not the other way around. Therefore, Burcay Yasar Akcali and Elcin Sismanoglu (2015) analyzed the effect of innovation, research and development (R\&D) and their costs on growth in developed and developing countries. Mesut Savrula and Ahmet Incekarab (2015)analyzed the effect that research and development have on innovation performance, making a country-wide assessment to see what differences and aspects influence / affect more or less, while Streimikiene Dalia (2014) made a analysis of the impact of research and development of innovations on Lithuanian business. Finally, Pegkas Panagiotis, Staikouras Christos and Tsamadias Constantinos (2019) talk about how research and development spending impacts innovation in EU member states.

The research question is centered on: "To what extent does innovation affect R\&D?" Also, the main hypotheses are elaborated below.

H1: Innovation has a positive effect on R\&D. 
$\mathrm{H} 2$ : There is a relationship between innovation and R\&D.

The data is ascertained for 28 countries which form the European Union (EU). The source of the data is the Global Innovation Index (GII) of the World Intellectual Property Organization (WIPO) which was recently created.

Table 1. Variable description

\begin{tabular}{|l|l|l|}
\hline $\begin{array}{l}\text { Variable } \\
\text { abbreviation }\end{array}$ & Variable name & Variable description \\
\hline ICT & $\begin{array}{l}\text { Information and } \\
\text { Communication } \\
\text { Technology }\end{array}$ & $\begin{array}{l}\text { Kind of education that uses ICT to support, improve and } \\
\text { optimize the delivery of information. }\end{array}$ \\
\hline KNWIMP & Knowledge impact & $\begin{array}{l}\text { The level at which knowledge and concepts are understood } \\
\text { and developed, being subsequently shared with others. }\end{array}$ \\
\hline ONLINECR & Online creativity & $\begin{array}{l}\text { The ability to produce unusual ideas or new ideas based on } \\
\text { originality / innovation in online environment. }\end{array}$ \\
\hline INNLINKS & Innovation linkages & $\begin{array}{l}\text { The link between academia or researchers and the business } \\
\text { environment by providing information that leads to } \\
\text { innovation. }\end{array}$ \\
\hline TERTEDU & Tertiary education & $\begin{array}{l}\text { Post-secondary education represents any level of } \\
\text { education after high school, including bachelor, master } \\
\text { and doctorate degrees. }\end{array}$ \\
\hline
\end{tabular}

The analysis used Ordinary Least Square (OLS) model for panel data and time series based on the equation below:

$I C T=\propto+\beta_{1}(\text { KNWIMP })_{i, t}+\beta_{2}(\text { ONLINECR })_{i, t}+\beta_{3}(\text { INNLINKS })_{i, t}+\beta_{4}(\text { TERTEDU })_{i, t}+$ $\theta_{i, t}+\varepsilon_{i, t}(1)$

where:

ICT- information and communication technology

KNWIMP - knowledge impact

ONLINECR - online creativity

INNLINKS - innovation linkages

TERTEDU- tertiary education

$\theta$ - random year-effect/ random country-effect

$\varepsilon-$ residuals

In Appendix A1 we can see a high correlation between lag ICT and log ICT as well as between innovation linkages and online creativity.

Table 2. Summary statistics of the variables

\begin{tabular}{llllll}
\hline Variable & Min & Max & Mean & Std. Dev. & Obs. \\
\hline LOG_knwimp & 0.00 & 4.63 & 3.05 & 0.92 & 177 \\
LOG_ict & 0.69 & 4.32 & 3.06 & 0.73 & 177 \\
LOG_onlinecr & 0.00 & 3.91 & 2.87 & 0.83 & 177 \\
LOG_innvli $\sim$ s & 0.69 & 4.68 & 3.42 & 0.90 & 177 \\
LOG_tertedu & 0.69 & 4.39 & 3.31 & 0.79 & 177 \\
L_LOG_ict & 0.69 & 4.32 & 3.07 & 0.72 & 155 \\
\hline
\end{tabular}


As we can see in table no. 2, the knowledge impact and online creativity has the same minimum (0.00) but different maximum levels (4.63 and 3.91), which leads us to consider that the knowledge has a higher impact than online creativity. The second situation when the minimum recorded the same value (0.69) is represented by ICT, innovation linkages, tertiary education and lag of ICT which leads us to the fact that these indicators have a higher impact than the previous ones. Also, the mean of all of them register lower values than how we expected, which tells us that is not a strong development and all the countries from EU should invest more on this side.

Table 3. Summary statistics of the mean of variables (mean by year)

\begin{tabular}{llllll}
\hline Variable & Min & Max & Mean & Std. Dev. & Obs. \\
\hline MY_LOG_knw p & 2.92 & 3.25 & 3.05 & 0.10 & 189 \\
MY_LOG_ict & 2.95 & 3.16 & 3.06 & 0.08 & 189 \\
MY_L_LOG_ict & 2.95 & 3.16 & 3.07 & 0.08 & 162 \\
MY_LOG_onl $\sim r$ & 2.80 & 2.93 & 2.87 & 0.04 & 189 \\
MY_LOG_inn $\sim$ S & 3.16 & 3.70 & 3.42 & 0.20 & 189 \\
MY_LOG_ter u & 3.21 & 3.41 & 3.31 & 0.08 & 189 \\
\hline
\end{tabular}

Source: Own estimation

Looking on the situation by year (table 3 ) we can see different results with higher values of minimum. Thus, the innovation linkages and tertiary education registered high values, respectively 3.16-3.70 and 3.21-3.41 which leads us to consider them important for research and development.

Table 4. Summary statistics of the mean of variables (mean by county)

\begin{tabular}{llllll}
\hline Variable & Min & Max & Mean & Std. Dev. & Obs. \\
\hline MC_LOG_knw p & 1.17 & 4.25 & 3.05 & 0.77 & 189 \\
MC_LOG_ict & 1.22 & 4.03 & 3.08 & 0.67 & 189 \\
MC_L_LOG_ict & 1.31 & 4.11 & 3.10 & 0.66 & 189 \\
MC_LOG_onl $\sim r$ & 0.58 & 3.85 & 2.88 & 0.81 & 189 \\
MC_LOG_inn $\sim S$ & 1.53 & 4.53 & 3.47 & 0.83 & 189 \\
MC_LOG_ter $\sim u$ & 1.24 & 4.23 & 3.34 & 0.70 & 189 \\
\hline & \multicolumn{5}{c}{ Source: Own estimation }
\end{tabular}

Looking on the situation by country (table 4) we can see different results with lower values of minimum and "high" values for maximum. Being this big difference we can tell that every country that register low values for research and development process should invest more for them to achieve a high economic and developed performance.

Hausman test result shows a chi-square value of 0.28 . Hence, random effect is used in the estimation.

Table 5. The impact of innovation on research and development

\begin{tabular}{lllll}
\hline VARIABLES & $(\mathbf{1})$ & $\mathbf{( 2 )}$ & $\mathbf{( 3 )}$ mean by county & (4) mean by year \\
\hline LOG_ict & 0.113 & 0.322 & $-13.957^{* * *}$ & $5.429 * * *$ \\
& $(0.120)$ & $(0.266)$ & $(0.000)$ & $(1.036)$
\end{tabular}




\begin{tabular}{lllll}
\hline VARIABLES & $(\mathbf{1})$ & $\mathbf{( 2 )}$ & $\mathbf{( 3 )}$ mean by county & (4) mean by year \\
\hline L_LOG_ict & & -0.327 & $6.172^{* * * *}$ & $-4.931^{* * *}$ \\
& & $(0.435)$ & $(0.000)$ & $(1.048)$ \\
LOG_onlinecr & -0.196 & -0.232 & $10.750^{* * * *}$ & $-0.369^{* * *}$ \\
& $(0.161)$ & $(0.160)$ & $(0.000)$ & $(0.091)$ \\
LOG_innvlinks & 0.100 & 0.069 & $3.805^{* * * *}$ & $0.194 *$ \\
& $(0.169)$ & $(0.175)$ & $(0.000)$ & $(0.109)$ \\
LOG_tertedu & 0.029 & -0.147 & - & $-0.430^{* * *}$ \\
Constant & $(0.109)$ & $(0.187)$ & - & $(0.074)$ \\
& $3.636^{* * *}$ & $4.370^{* * *}$ & $-16.815^{* * *}$ & $3.437^{* * *}$ \\
Observations & $(0.625)$ & $(0.963)$ & $(0.000)$ & $(0.401)$ \\
R-squared & 177 & 149 & 162 & 189 \\
Number of countries & 27 & 27 & 27 & 0.313 \\
\hline
\end{tabular}

Note: Robust standard errors in parentheses

$* * * \mathrm{p}<0.01, * * \mathrm{p}<0.05, * \mathrm{p}<0.1$

Source: Own estimation

Table no. 5 shows the results for the regression of impact of innovation on research and development using OLS method. In models (1) and (2), ICT is not significant and this means that the innovation process has no impact on research and development whilst in models (3) and (4) innovation process is significant at $10 \%$ and $0.10 \%$ respectively. As we can see, in the model 4 , the innovation by country was negatively influenced by the ICT $(-13.957)$ and by the constant (16.815) and positively by lag of ICT (6.172), online creativity (10.750) and innovation linkages (3.805). In model 5 , the innovation by year was negatively influenced by lag of ICT (-4.931), online creativity $(-0.369)$ and tertiary education $(-0.430)$ and positively by ICT (5.429) and constant (3.437), being the opposite situation of model 4.

\section{Conclusions}

Investments in research and technology are the main way to support the efficient use of resources and diversity, aiming to create a prosperous society.

The research and development activity is in continuous development in the EU member states. The connection between the scientific community and the business environment is constantly growing. As a result, the research results have a low degree of implementation at present, and the new technologies do not end up being fully integrated in the economic processes of private companies.

The lack of dialogue and collaboration between business representatives and researchers is a vulnerability of the research and development and innovation sector. Thus, a series of solutions would be: promoting the interest for science and innovation in pre-university education, by including in textbooks and electronic teaching materials recent discoveries, by including in the curriculum elements of education on entrepreneurship based on innovation, by collaborating with 
technical journals addressed to students and with science popularization publications; diversification of funding sources by promoting venture capital funds, which could have a beneficial influence on the development of the financing process of innovation activity and improving the availability of statistical data on research and development and innovation in the ICT sector (defined according to OECD) disaggregated by gender, removing existing methodological limitations, producing them systematically and ensuring user access to them.

\section{References}

- Abbott, L. (2013). Theories of Industrial Modernization \& Development: A Review, Manchester, England: Industrial Systems Research.

- Anjum, S. (2020). Impact of internship programs on professional and personal development of business students: a case study from Pakistan. Future Business Journal, 6(2), 1-13.

- Aziz, H. A. \& Marcos, S. (2013). The Proceedings of the 8th European Conference on Innovation and Entrepreneurship. Brussels, Hogeschool - Universiteit Brussel (HUBrussel).

- Dobni, C. (2008). Measuring innovation culture in organizations. European Journal of Innovation Management, 11(4), 539-555.

- Dziallasa, M. \& Blind, K. (2019). Innovation indicators throughout the innovation process: An extensive literature analysis. Technovation, February-March, 80-81, 3-29.

- European Commission (2011). Europe 2020 Flagship Initiative Innovation Union, Luxembourg: Publications Office of the European Union.

- European Commission (2018). A renewed European Agenda for Research and InnovationEurope's chance to shape, Brussels: European Commission.

- European Commission (2018). Decision of the European Parliament and of the Council on establishing the specific programme implementing Horizon Europe - the Framework Programme for Research and Innovation, Brussels: s.n.

- European Commission (2018). Driving Progress for Research and Innovation in Europe - The potential of R\&I foundations, Brussels.

- European Commission (2019). European Research Infrastructures. [Online] Available at: https://ec.europa.eu/info/research-and-innovation/strategy/european-researchinfrastructures en

- Leonard, D. \& Swap, W. (1999). When Sparks Fly: Igniting Creativity in Groups. Boston, Massachusetts: Harvard Business School Press.

- Melkas, H. \& Harmaakorpi, V. (2012). Melkas, H., \& Harmaakorpi, V. (2012). Epilogue: Two Modes of Practice-Based Innovation. In H. Melkas, V. Harmaakorpi, H. Melkas, \& V. Harmaakorpi (Eds.), Practice-Based Innovation: Insights, Applications and Policy Implications. 1 ed. s.1.:Springer-Verlag Berlin Heidelberg.

- OECD (2007). Innovation and Growth - Rationale for an innovation strategy, s.1.: OECD Publishing.

- Panagiotis, P., Christos, S. \& Constantinos, T. (2019). Does research and development expenditure impact innovation? Evidence from the European Union countries. Journal of Policy Modeling, September-October, 41(5), 1005-1025.

- Savrula, M. \& Incekarab, A. (2015). The Effect of R\&D Intensity on Innovation Performance: A Country. Procedia - Social and Behavioral Science, 210, 388-396.

- Sharman, D. \& Johnson, A. (1997). Innovation in all things! Developing creativity in the workplace. Industrial and Commercial Training, 29(3), 85-87.

- Streimikiene, D. (2014). The Impact of Research and Development for Business Innovations in Lithuania. Amfiteatru Economic Journal, 16(37), 965-979. 
- Yasar Akcali, B. \& Sismanoglu, E. (2015). Innovation and the Effect of Research and Development (R\&D) Expenditure on Growth in Some Developing and Developed Countries. Procedia - Social and Behavioral Sciences, July , 195, 768 - 775.

\section{APPENDIX}

A1. Correlation matrix

\begin{tabular}{lllllll}
\hline & LOG_kn p & LOG_ict & L_LOG_ $\sim$ t & LOG_on $\sim r$ & LOG_in s & LOG_te $u$ \\
LOG_knwimp & 1 & & & & \\
LOG_ict & 0.3052 & 1 & & & \\
L_LOG_ict & 0.2148 & 0.8968 & 1 & 1 & 1 \\
LOG_onlinecr & 0.0319 & 0.5037 & 0.5108 & & \\
LOG_innvli s & 0.1022 & 0.5429 & 0.4912 & 0.7397 & 1 \\
LOG_tertedu & -0.16 & 0.2463 & 0.231 & 0.1367 & 0 & 1 \\
\hline
\end{tabular}




\title{
Cap. 3. INTERNAȚIONALIZAREA SPAȚIULUI ACADEMIC EUROPEAN ȘI PERSPECTIVA ASUPRA STUDIILOR DE DOCTORAT
}

\author{
Geanina Brînză', Gina Ionela Butnaru ${ }^{2}$ \\ ${ }^{1}$ Universitatea Ștefan cel Mare, Facultatea de Științe Economice și Administrație Publică, Suceava, \\ România,brinza.geanina@gmail.com \\ ${ }^{2}$ Universitatea ,Alexandru Ioan Cuza” din Iaşi, Facultatea de Economie și Administrarea Afacerilor, Iași, \\ România,gina.butnaru@uaic.ro
}

\begin{abstract}
This paper is treating the subject of internationalisation in the academic space through a literature analysis. We follow the perspective of an internationalisation of doctoral studies, creating a picture of internationalisation components in the European context. Internationalisation of the academic space is an inevitable result of globalisation and knowledge-based economy of $21^{\text {st }}$ century. Consequently, it is necessary to identify the main ways considered by European universities, while they reconsider their international programs and strategies of doctoral preparation to face the new tendencies, the demand in education, as well as the pressure of the labour market. Aspects of the alignment of internal culture with internationalisation objectives will be approached to get more efficient results. The framework helps understanding different internationalisation approaches, and can be useful from both managerial and research perspective.
\end{abstract}

Keywords: internationalisation, academic space, doctoral studies, Erasmus + .

\section{Introducere}

Instituțiile de învățământ superior din cadrul Uniunii Europene (UE) joacă un rol esențial în societate, prin încurajarea inovației, a dezvoltării și creșterii economice și îmbunătățirea generală a bunăstării cetățenilor. Unele universități europene sunt printre cele mai prestigioase din lume, ceea ce le face să fie foarte atractive în rândul tinerilor.

Globalizarea transformă atât procesele de producție de cunoștințe, cât și universităţile și profesia academică (Eurydice, 2019). Centrul de greutate al cercetării și dezvoltării științifice se schimbă subtil în Europa (Cummings, 2009). Mai mult, țările dezvoltate și în curs de dezvoltare de pe tot globul investesc în sistemele lor naționale de învățământ superior ca motoare cheie ale dezvoltării resurselor umane şi, în final, contribuie la competitivitatea economică viitoare. Întrucât producția de cunoștințe devine o industrie globală, mai degrabă decât una naţională, naţiunile au o miză imensă în a se asigura că universitățile lor (și academicienii din ele) sunt participanți activi și lideri în această nouă ,industrie” globalizată. În măsura în care universitățile unei națiuni și forța sa de muncă academică formează următoarea generație, apare o miză foarte ridicată: cea a dezvoltării capacității studenților, care reprezintă următoarea generație de lideri. Profesorii au o miză mare, deoarece în rolul lor de a forma oamenii, au datoria de a oferi o perspectivă internațională studiilor academice și de a dezvolta abilităţile doctoranzilor din perspectiva viitoarei generaţii de lideri.

Universitățile din țările în curs de dezvoltare încearcă să egaleze evoluția pozitivă istorică de care au beneficiat Statele Unite și alte economii occidentale, intenționând de asemenea să devină universități recunoscute pe plan internațional și, prin urmare, să ofere o profesie şi o forță de muncă indigene de talie mondială - ceea ce prin definiție implică dezvoltarea unei profesii academice care face parte din comunitatea din ce în ce mai globală de cercetare. Un instrument cheie al acestor inițiative economice naționale este internaționalizarea sistemelor de învățământ superior și constituirea resurselor umane ale acestora, respectiv a profesiei academice. 
În ultimele decenii, universitățile au suferit o serie de schimbări care afectează atât populația studenților, cât și condițiile pe care un tânăr trebuie să le îndeplinească pentru a fi doctorand în secolul XXI (UEFISCDI, 2015). Universitățile și-au transformat rolul în societate de la pregătirea unei elite până la oferirea de educație de masă, ceea ce înseamnă că mai mulți studenţi anual finalizează studiile doctorale. Populaţia studenților nu este doar mai mare, ci și mai eterogenă în ceea ce privește mediul academic, lingvistic și cultural. Mai mult, universitățile sunt structurate din ce în ce mai mult pentru a răspunde rapid așteptărilor în schimbare ale pieței muncii, ceea ce duce la o dezbatere cu privire la ce tip de instituție sunt și ce ar trebui să devină. Schimbarea către o ideologie politică și economică, bazată pe comerțul liber și generarea de profituri, au pus bazele internaționalizării pe agenda mai multor universități europene.

Există o preocupare tot mai mare pentru abordarea dezvoltării academice din perspectiva competenţelor studenților, profesorilor și cercetătorilor. În consecință, obiectivul principal al internaționalizării este dezvoltarea cunoștințelor, aptitudinilor, atitudinilor și valorilor recunoscute la nivel internațional. Interesul acestei abordări constă în faptul că răspunde cerințelor pieței muncii.

Această cercetare se bazează pe obiective precum: O1. conceptualizarea ideilor relevante specifice internaționalizării în mediul academic; O2. analiza privind adaptarea componentelor specifice internaționalizării în sistemul doctoral european.

\section{Internaționalizarea spațiului academic european reflectată în literatura științifică}

\subsection{Internaționalizarea învățământului superior la nivel global}

Globalizarea a determinat o transformare a procesului de educaţie, atât pentru mediile academice cât și pentru profesia academică. Dezvoltarea sistemului de învățământ presupune investiții la nivel național și internațional deoarece învăţământul este considerat motorul de creștere a resurselor umane și a competitivității economice. Forța de muncă din mediul educaţional este supusă acestei transformări permanente determinate de procesul de globalizare, motiv pentru care este necesară formarea acestora pentru conturarea unui profil al cadrului didactic cu o perspectivă internațională capabilă să pregătească următoarele generații de lideri pentru societate (Huang și colab., 2014).

Internaţionalizarea învăţământului superior la nivel național, sectorial şi instituţional reprezintă procesul de integrare a unei dimensiuni internaţionale, interculturale sau globale ce are ca scop colaborarea internațională (Knight, 2003). În acest context, Teichler (2009), a identificat două aspecte ale internaţionalizării învăţământului superior: a) o creștere a operațiunilor specifice de trecere a frontierei internaționale (exemplu: mobilitatea studenților și a personalului, predarea limbilor străine și învățarea, activități de cercetare în cooperare, studii în zonă); b) o tendință spre universalizare, globalizare, internaţionalizare și regionalizare a substanței și funcțiilor învăţământului superior care ar putea depăși mobilitatea și cooperarea transfrontalieră. Acest ultim aspect se referă la internaționalizarea în centrul învățământului superior, punându-se accent pe dimensiunea internațională atât în predarea, cât și în învățarea obișnuită, precum și în activitățile de cercetare, și politicile care consolidează dimensiunea internațională a acestor activități de bază.

Internaționalizarea învățământului superior se caracterizează nu numai printr-o tendință treptată de creștere a activităţilor internaționale sau printr-o dimensiune internațională mai puternică pentru activitățile de bază ale învățământului superior, ci și prin modificări calitative substanţiale. Aceste modificări se referă la trei schimbări sau tendințe: a) de la un model vertical sau ierarhic de cooperare și mobilitate către relații internaționale în condiții egale; b) de la acțiuni cazuistice către politici sistematice de internaţionalizare; c) de la deconectarea activităţii internaţionale specifice și internaționalizarea activităţilor de bază spre o internaționalizare integrată a învățământului superior.

Analizând literatura despre internaționalizarea învățământului superior, se constată faptul că analiza dimensiunii internaționale a învățământului superior a devenit mai complexă, deoarece se 
concentrează pe legături între diverse activități orientate la nivel internaţional, cum ar fi mobilitatea, transferul de cunoștințe, cooperarea și educația internațională (Kehm și Teichler, 2007). În consecință, nucleul internaționalizării în învățământul superior este format dỉn instituții, oameni - inclusiv academicieni - și cunoștințe. În acest context, au fost identificate șapte teme largi despre internaţionalizarea învățământului superior (Kehm și Teichler, 2007) referitoare la: 1) mobilitatea studenților și a personalului; 2) influențele reciproce ale sistemelor de învățământ superior; 3) internaționalizarea conţinutului predării, învățării și cercetării; 4) strategii instituționale de internaționalizare; 5) transfer de cunoștințe; 6) cooperare și concurență; 7) politici naționale și supranaționale în ceea ce privește dimensiunea internațională din învățământul superior.

Mai mult, internaţionalizarea actuală a învățământului superior cuprinde în principal trei componente (Huang și colab., 2014): a) schimbul de oameni și mobilitatea personală peste granițe, în principal studenți, profesori și cercetători; b) schimbul și acreditarea programelor, cursurilor și gradelor, inclusiv împărtășirea programelor de învățământ și, în special, dezvoltarea programelor transnaționale; c) activitățile proiectelor de cercetare, inclusiv organizarea de conferințe internaționale și cercetare comună, în principal pentru prezentarea rezultatelor cercetării și a schimburilor academice.

Așadar, importanța internaționalizării este determinată de transformarea pe care o aduce mediului academic la nivel naţional și instituțional, dar și de extinderea și diversitatea modului prin care se face implementarea programelor educaționale la nivel internațional (UEFISCDI, 2015).

\subsection{Scopul internaționalizării în mediul academic}

În țările în care limba engleză este una dintre limbile oficiale, printre altele, este favorizată atât circulația, cât și migrația pentru studiu (Petcu și colab., 2015). Atât circulația, cât și migrația pentru studiu par a fi fenomene înglobate istoric, deoarece academicienii generațiilor mai vechi par a fi mai mobili, în scopuri de studiu și de formare.

Termenul utilizat pe scară largă, cel de internaționalizare, ne arată că organizațiile de învățământ au cunoscut o tendință de creștere a caracteristicilor internaționale a învățământului superior în ultimele decenii (Knight 2003; Teichler 2011). În multe privințe, universitățile sunt deja internaționale (Kerr, 1990), dar în ultimii ani, influența diminuată a reglementărilor naționale a ajutat la creșterea enormă a activităților internaționale vizibile în învățământul superior. În acest context, indivizii tind să analizeze modul în care profesiunea academică este încorporată în internaționalizarea învățământului superior (Musselin 2004; Teichler 2004, 2009, 2011): viteză mai rapidă și o răspândire mai largă a transferului de cunoștințe în întreaga lume; un accent mai mare acordat capitalului global al cunoștințelor și analizei comparative ulterioare; o creștere a comunicării și colaborării transfrontaliere din partea instituțiilor, a subunităților acestora și a persoanelor; creșterea mobilității studenților; creșterea mobilității profesioniștilor înșiși.

În concluzie, importanța internaționalizării a cunoscut un trend ascendent pentru totalitatea tipurilor de instituții de învăţământ superior, dar și pentru guverne, și nu în ultimul rând, este cunoscut faptul că procesul de internaționalizare se află într-o continuă expansiune la nivel internațional (UEFISCDI, 2013).

\subsection{Factorii care modelează internaționalizarea academică}

Internaţionalizarea profesiei academice este modelată de diferențe și de disparităţi (Rostan, 2011). Pe de o parte, internaționalizarea academiei se concretizează prin disparităţi derivând din distribuția inegală a resurselor economice, politice și culturale în regiuni, țări, sisteme de învățământ superior, instituții de învățământ superior, familii și persoane fizice. Pe de altă parte, diferențele de internaționalizare academică s-ar putea să nu depindă de distribuția inegală a oportunităților și resurselor, ci de alți factori, cum ar fi: natura disciplinelor academice, tipul de universitate de cercetare efectuată, gradul de încorporare a acestora în setările naționale sau locale și diferitele misiuni sau structuri organizaționale ale instituției în care lucrează. Mai mult, 
academicienii care au studiat în străinătate pot fi mai internaționali doar pentru că experiența lor în străinătate le-a oferit rețele internaționale, o mai bună competență a limbilor străine, competențe interculturale mai bune și o mai bună cunoaștere a țărilor străine.

Există caracteristici individuale, atât atribuite, cât și dobândite, personale și profesionale, cum ar fi: vârsta, genul, mediul familial, realizările educaţionale, preferințele și sarcinile, însă există și factorii instituționali, cum ar fi disciplina academică și tipul de instituție în care lucrează academicienii care conturează internaționalizarea academică. Există contextele naționale și regionale în care funcționează mediul academic, cum ar fi dimensiunea țării, limba, tradiția culturală și situația economică și politică (UEFISCDI, 2015). Proiectele internaționale urmăresc diminuarea și eliminarea disparităţilor existente în mediul academic mondial. Înglobarea dimensiunii internaționale în misiunea, funcțiile și metoda de furnizare a serviciilor educaționale are ca obiectiv creșterea calității educației și cercetării pentru personalul academic și studenți (Petcu și colab., 2015). Implicarea în proiecte internaţionale oferă posibilitatea participanților să își formeze competențele și abilitățile necesare care permit contribuirea ulterioară la adaptarea mediului academic la nivel regional, național și global (ANPCDEFP, MECȘ, 2015).

\subsection{Dimensiunile internaționalizării în mediul academic}

Pornind de la noțiunea de internaţionalizare au fost dezvoltate şapte dimensiuni pentru domeniul academic (Eurydice, 2018). Fiecare dimensiune reunește unele activităţi axate pe plan internațional care se corelează între ele, fiind în același timp relativ independente de dimensiunile rămase. Fiecare dimensiune explică o cantitate semnificativă a variabilității în datele disponibile și toate cele șapte dimensiuni reprezintă aproape două treimi din variabilitatea activităţii academice internaționale. Dimensiunile internaționalizării academice includ (Huang și colab., 2014): 1) colaborarea în procesul de cercetare cu colegii străini (se referă la cercetarea, colaborarea, coordonarea internațională și la studii postdoctorale, prin trecerea granițelor în altă țară în care academicienii și-au câștigat diplomele postdoctorale); 2) mobilitatea fizică pentru studiu (se referă atât la studii universitare, cât și la studii postuniversitare, luând din nou în considerare țările în care cadrele universitare au obținut diferite diplome care au fost aceleași sau diferite din țara de angajare actuală); 3) publicarea și diseminarea în afara țării de origine sau în altă limbă (se referă la proactivitatea de a publica lucrări într-o țară străină, într-o limbă de circulație internațională şi în format electronic); 4) deschiderea la mobilitatea locurilor de muncă în afara granițelor naționale (se concentrează pe disponibilitatea și acțiunile concrete întreprinse pentru a se muta într-o poziție academică într-o altă țară); 5) orientarea generală către internaționalizare atât a predării, cât și a cercetării (se referă la o orientare generală care vizează aducerea perspectivelor și conținutului internaţional, fie în predare și/sau în cercetare, deși rămânând în propria țară); 6) predarea în străinătate și/sau într-o limbă internațională; 7) mobilitatea internaţională a studenților.

Internaţionalizarea actuală a învățământului superior cuprinde în principal trei componente: prima este schimbul de oameni și mobilitatea personală peste granițe, în principal studenți, profesori și cercetători; a doua este schimbul și acreditarea programelor, cursurilor și gradelor, inclusiv împărtăşirea programelor de învățământ și, în special, dezvoltarea programelor transnaționale; iar a treia este reprezentată de activitățile proiectelor de cercetare, inclusiv organizarea de conferințe internaționale și cercetare comună, în principal pentru prezentarea rezultatelor cercetării și a schimburilor academice (Huang și colab., 2014).

În consecință, este posibil să concepem internaționalizarea academică precum o construcție multidimensională formată dintr-un set comun de componente sau dimensiuni şi să o studiem fie la nivel global, fie în contexte naționale sau regionale mai limitate (Cotelnic, 2017).

\subsection{Internaționalizarea profesiei academice}

În decursul timpului, s-au identificat trei aspecte distinctive ale internaţionalizării profesiei academice: mobilitatea transfrontalieră, atât în scop de studii, cât și pentru angajare; participarea sau implicarea în activități internaționale de predare și/sau cercetare; și în al treilea rând prin 
atitudini față de valoarea conexiunilor internaționale și a relațiilor interculturale (Welch, 1997). Pe baza acestora, au fost elaborate trei seturi de indicatori de internaționalizare desprinși din studiul Carnegie: 1) proporția personalului academic care a obținut cel mai înalt titlul academic într-o altă țară; 2) întinderea conexiunilor internaționale ale universităţilor; 3) percepțiile personalului universitar asupra importanței asupra acestei legături.

Analiza lui Welch (1997) a internaționalizării profesiei academice se realizează atât la nivel de sistem, cât și la nivel individual. El abordează atât diferențele în ceea ce privește gradul de internaționalizare între sisteme, cât și în impactul deținerii unui grad superior străin pe mai multe aspecte ale vieții academice. Problemele examinate în legătură cu mobilitatea includ diferențele de gen, distribuția pe discipline, tiparele de angajare (contracte full-time sau part-time), participarea la activități internaţionale legate de educație, satisfacția locului de muncă și preferințele pentru predare vs. cercetare.

Contribuția lui El-Khawas (2002) se concentrează pe două aspecte: 1) mecanismele prin care academicienii includ o dimensiune internațională în activitatea lor; 2) oportunitățile și constrângerile cu care se confruntă noii academicieni în construirea carierei care includ componente internaționale.

Sunt luate în considerare mai multe forme de mecanisme internaţionale de sprijin investigate de studiul Carnegie. Călătoria internaţională pentru cercetare și studiu - inclusiv călătorii în străinătate pentru studii sau cercetări și pentru activităţi de predare la o facultate într-o altă țară este considerată una dintre formele majore de implicare internațională. Alți doi indicatori bine recunoscuți ai implicării internaționale sunt publicarea cercetării într-o altă țară și efectuarea de cercetări cu cadre didactice din alte țări. În cele din urmă, este luată în considerare influența academicienilor asupra conținutului curriculumului din universitatea sau departamentul lor incluzând perspective transnaționale în predarea și furnizarea de surse internaționale de materiale didactice. Acești indicatori de implicare internaţională sunt completaţi de diverşi indivizi și se referă la orientările de valoare ale universitarilor care susțin idealul de a avea o perspectivă internaţională, precum și importanța de a avea contacte internaționale și de a ține pasul cu cercetările publicate în alte țări.

Internaționalizarea profesiei academice se referă la deschiderea granițelor pentru cercetare şi predare determinând creșterea mobilității studenților și a personalului universitar peste granițe. Două aspecte largi ale internaționalizării facultăților sunt luate în considerare (Finkelstein și colab., 2009): 1) măsura în care facultatea internaționalizează conținutul activităților academice, așa cum se reflectă în măsura în care acestea integrează perspective internaționale în conținutul cursului lor și în măsura în care cercetarea lor are un scop internațional; 2) măsura în care facultatea internaționalizează rețelele de cercetare în cadrul cărora lucrează, așa cum se reflectă în colaborarea pentru proiecte de cercetare cu colegii internaționali, colaborarea în cadrul publicaţiilor academice cu colegi străini și publicarea articolelor la nivel internaţional. Aceste aspecte sunt alese deoarece constrâng dimensiunile de bază ale activităților facultăților și pentru că permit o largă comparabilitate cu sondajul Carnegie.

În consecință, accentul este pus pe măsura în care perspectivele internaționale modelează conținutul predării sau al cercetării și pe măsura în care limitele naționale restricționează rețelele profesionale ale facultăţilor.

\section{Analiza privind internaționalizarea spațiului academic superior european}

\subsection{Internaționalizarea studiilor doctorale prin proiectele Erasmus+}

Globalizarea reprezintă catalizatorul internaționalizării ca răspuns la promovarea dezvoltării învăţământului superior în multe state. Creșterea progresivă și mișcarea intensă a numărului de persoane în cadrul UE a determinat evoluția studiilor universitare de doctorat. Internaționalizarea implică activităţi de recrutare a studenților internaţionali. Schimbul de studenți și de cadre universitare implică construirea competențelor interculturale și internaționalizarea curriculumului 
(Eri și colab., 2019). În cadrul UE există un program prin intermediul căruia se desfășoară activități de internaționalizare studiilor universitare de doctorat - Erasmus + .

Erasmus+ este programul UE care are scopul de a moderniza și internaţionaliza educaţia, formarea profesională și cercetarea în rândul tinerilor (ANPCDEFP și Erasmus+, 2020).

Erasmus+ contribuie la constituirea schimburilor de studenți şi doctoranzi între statele participante la program și între acestea și țările partenere. Studiind în străinătate cu ajutorul programului Erasmus + , pot fi dobândite noi competențe lingvistice, comunicaţionale, interculturale și non-tehnice care aduc reale avantaje în cariera profesională. Pot fi îmbinate perioada de studii în străinătate cu stagii, pentru dobândirea imediată a experienței profesionale o cerință de o reală importanță pe piața muncii. Oportunitățile de a studia în străinătate prin programele Erasmus+ sunt disponibile pentru studenți, masteranzi și doctoranzi (Comisia Europeană, 2020).

În cadrul programelor Erasmus + nu există nicio diferență între mobilitatea studiilor universitare cu licență, nivel de master sau de doctorat. Asemănările proiectelor Erasmus+ în cadrul studiilor universitare (Montaldo și colab., 2019) se referă la: 1) mobilitatea pentru studii durează între 3 și 12 luni și între 2 și 12 luni pentru mobilitate stagiară; 2) studenții trebuie să semneze un acord de învățare, bazat pe un șablon furnizat de agenția națională (care necesită validarea a 30 ECTS pe semestru); 3) bursele sunt egale pentru cele trei cicluri de studiu; 4) la sfârșitul mobilității studenții vor beneficia de contract de studii și foaie matricolă, iar mobilitatea ar putea fi inclusă în suplimentul de diplomă.

Apar adesea unele dificultăți comune pentru implementarea mobilităților la nivel de studii doctorale (Montaldo și colab., 2019): validarea a 30 ECTS pe semestru este dificilă pentru ciclul III de studiu; mobilitatea doctorală se face pe termen scurt; mobilității în co-tutelă îi este necesară o perioadă mai mare de 12 luni de mobilitate; apar dificultăți cu documentele (contractul de studii și foaia matricolă) aferente mobilității bazate pe cercetare; Franța nu poate beneficia de mobilitatea stagiară pentru doctoranzi; situația familială și financiară reprezintă probleme complexe pentru proiectele de mobilitate Erasmus+.

\subsection{Internaționalizarea implementată prin proiectele Erasmus+ în învățământul superior}

Există o preocupare crescândă pentru abordarea dezvoltării academice din perspectiva competenţelor studenţilor, cadrelor didactice şi cercetătorilor. Astfel, obiectivul principal al internaţionalizării este dezvoltarea cunoştinţelor, aptitudinilor, atitudinilor şi valorilor care să fie recunoscute la nivel internaţional (Jackson, 2003).

În anul 2017 s-au împlinit 30 de ani de existență Erasmus+. În anul 2018 a fost luată o inițiativă ambițioasă - construirea unei căi prin care mobilitățile să devină o realitate pentru toți cetățenii din spațiul european educațional, cu finalitate în anul 2025. Se urmărește excluderea barierelor ce apar în cadrul mobilităților - cu scop în învăţarea, predarea și participarea la traininguri pentru tinerii din învățământul superior. Finalitatea acestui proiect este includerea socială, inovația, cooperarea transdisciplinară și consolidarea competențelor tinerilor din spațiul educațional european superior (Comisia Europeană, 2019). În figura 1 redăm comparativ situaţia proiectelor Erasmus + aprobate în perioada 2014-2018: 


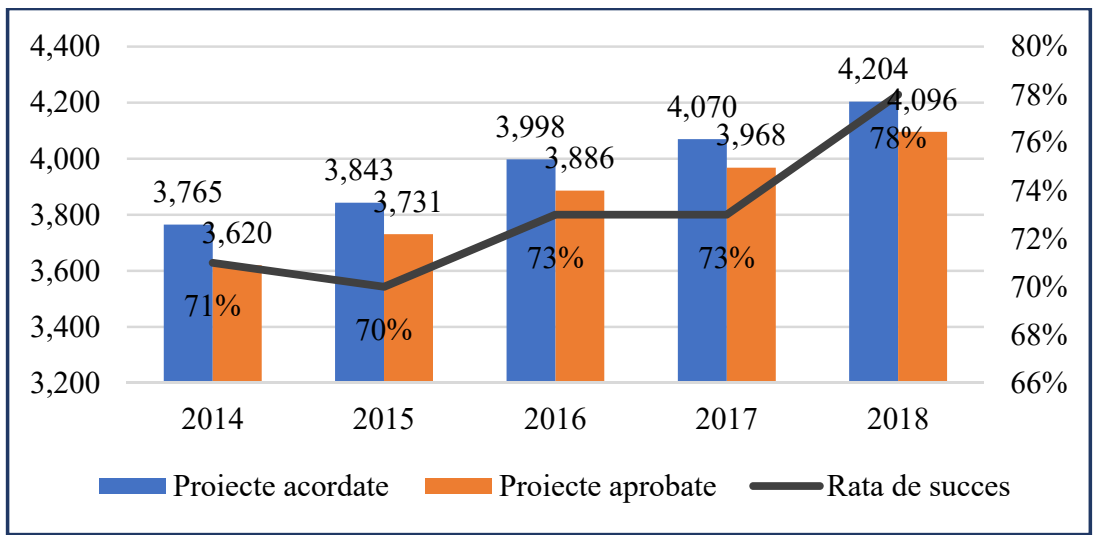

Fig. 1. Evoluția proiectelor Erasmus+ din învăţământul superior (2014-2018) Sursa: Comisia Europeană (2019) Erasmus+ annual report, pag. 34. DOI: 10.2766/989852

Proiectele europene au avut o rată ridicată de succes în rândul tinerilor din învăţământul superior. Proiectele acordate în anul 2018 s-a ridicat la un număr de 4204, în comparație cu 3765 de proiecte aprobate în anul 2014, rată de succes a urcat de la 71\%, în 2014 la 78\% în anul 2018. Proiectele Erasmus + aprobate au crescut concomitent cu numărul de proiecte acordate, de la 3620 în anul 2014, la 4096 în anul 2018.

Participanții proiectelor Easmus+ contribuie la împărtășirea identității europene și la deschiderea spre integrarea în piaţa muncii din străinătate, favorizând coeziunea socială și toleranța. În figura 2, redăm comparativ numărul de participanți în proiectele Erasmus+ și sumele alocate pentru învățământul universitar:

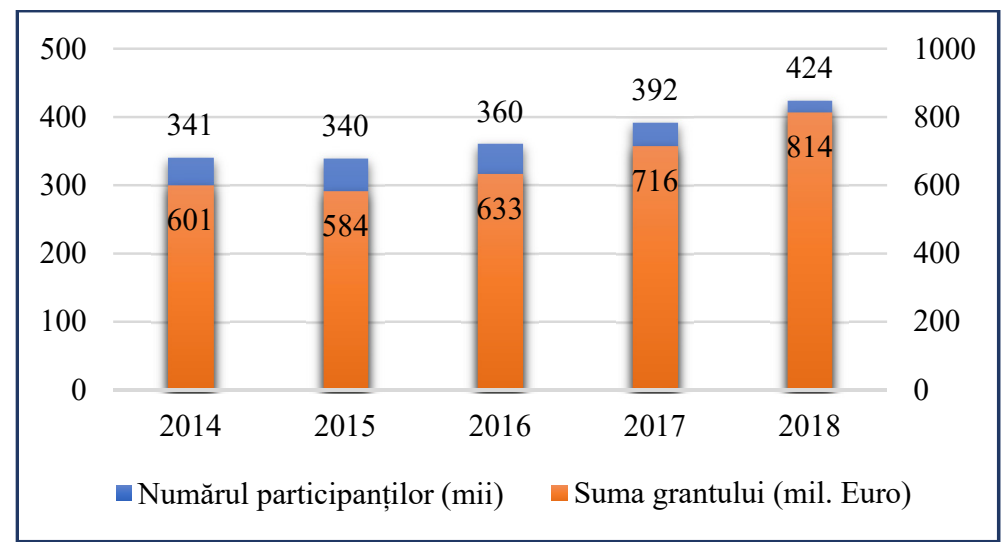

Fig. 2. Evoluția numărului de participanți în proiecte Erasmus+ și suma grantului oferit pentru învățământul superior

Sursa: Comisia Europeană (2019) Erasmus+ annual report, pag. 34. DOI: 10.2766/989852

Evoluția numărului de proiectelor europene Erasmus+ a fost ascendentă: în anul 2018 numărul proiectelor acordate au ajuns la valoare de 814 mil. Euro și 424 mii de participanți de la o valoare a granturilor oferite de 601 mil. Euro, cu un număr de 341 mii de participanți în anul 2014.

Programul european, Erasmus Without Paper Network, a fost iniţiat în anul 2018, pentru conectarea informațiilor din sistem, o modalitate simplificată, digitală, prin care este facilitată mobilitatea studenților și conectarea cu Erasmus Without Paper. Există peste 1300 de instituții 
universitare implicate din Europa. Scopul este determinat de dorința de adaptare și modernizare, respectiv înlocuirea completă a hârtiilor cu documente în format digital, cu acces facil și ușor de prelucrat (Erasmus Without Paper, 2018).

Programul Digital Opportunity Traineeship reprezintă un alt program prin care a fost urmărită îmbunătățirea abilităților digitale pentru un număr de 5000 de studenți din universitățile europene, indiferent de specializare. Acest proiect este finanţat de Horizon 2020 şi implementat prin Erasmus+ (Comisia Europeană, 2019).

Erasmus + sprijină instrumentele UE de transparență și recunoaștere a competențelor și calificărilor - în special Europass, Youthpass, Cadrul european al calificărilor (CEC), Sistemul european de credite transferabile (ECTS), Registrul european pentru asigurarea calității în învățământul superior (EQAR), Asociația europeană pentru asigurarea calității în învățământul superior (ENQA) precum și rețelele la nivelul UE în domeniul educaţiei și formării care sprijină aceste instrumente, prin centrele naționale de informare cu privire la recunoașterea academică a diplomelor (NARIC), rețelele Euroguidance, centrele naționale Europass și punctele naționale de coordonare CEC.

Toate aceste instrumente își propun să faciliteze recunoașterea și înțelegerea competențelor și calificărilor, în interiorul și în afara frontierelor naţionale, în toate subsistemele de educație și formare, precum și la nivelul pieței muncii, chiar dacă acestea au fost dobândite prin educaţie și formare formală sau prin alte experiențe de învățare. Instrumentele vizează, de asemenea, să asigure faptul că educaţia, formarea şi politicile pentru tineret contribuie la realizarea obiectivelor Strategiei Europa 2020 pentru o creștere inteligentă, durabilă și favorabilă incluziunii, precum și la realizarea obiectivelor principale în domeniul educației și ocupării forței de muncă printr-o mai bună integrare pe piaţa muncii și o mobilitate sporită (Comisia Europeană, 2019).

\subsection{Efectele pandemiei SARS-CoV2 asupra internaționalizării prin proiectele Erasmus+}

Pandemia SARS-CoV2 a prezentat un impact negativ asupra activităţilor aflate în derulare sau planificate în cadrul programului Erasmus+. Obiectivul principal al Comisiei Europene (2020) a vizat protecția și siguranța participanților în proiectele europene, respectarea măsurilor de limitare a răspândirii virusului pe plan naţional și/sau european.

Internaționalizarea prin proiectele Erasmus + implica mobilitatea persoanelor, acest aspect ar fi crescut riscul de infectare cu virusul SARS-CoV2 al studenţilor doctoranzi și al persoanelor care ar fi intrat în contact cu aceștia. În situațiile de repatriere a studenților doctoranzi, consorțiile au fost sprijinite pentru a facilita contactele cu ambasadele și autoritățile din țara de origine. Instituțiile de învățământ superior au primit solicitare să prezinte flexibilitate și pragmatism, în scopul atingerii rezultatelor indicate în acordurile semnate, fără a ține cont de locația geografică a studenților doctoranzi. Metodele adoptate au permis abordarea studiului la distanță prin utilizarea instrumentelor digitale, această flexibilitate a permis, în mod special, sprijinirea studenților doctoranzi întorși în țările lor să îşi finalizeze cursurile la instituţia gazdă. Comisia Europeană colaborează cu Uniunea Europeană a Studenților și rețeaua de studenți Erasmus+ pentru a oferi sprijin studenților aflați în nevoie și pentru a oferi egalitate de șanse tuturor studenților aflați în programele Erasmus+ (Comisia Europeană, 2020).

Studenții doctoranzi care urmau să participe în proiecte de mobilitate Erasmus + au fost anunțaţi că nu va fi necesar să își amâne stagiile planificate în străinătate, aceștia vor primi autorizare să reia cursurile în termen de maximum 18 luni de la absolvire, comparativ cu intervalului practicat anterior pandemiei de 12 luni (Comisia Europeană, 2020).

\section{Concluzii}

Perspectiva integrării în spaţiul european al învăţământului superior şi cercetării şi pe piaţa mondială a serviciilor educaţionale şi de cercetare presează universităţile să se orienteze spre internaţionalizare, ca sursă de competitivitate şi atractivitate. Astfel, mobilitatea internaţională şi 
dimensiunea interculturală devin axe principale în oferta instituţiilor de învăţământ şi de cercetare (ANPCDEFP, 2020).

Deoarece majoritatea universităţilor româneşti se află încă în faza de demaraj sau dezvoltare timpurie a cooperării internaţionale, se impune, încă de la început, adoptarea unor mecanisme adecvate managementului strategic al relaţiilor internaţionale. Pe plan intern, este necesar ca universitatea să aibă capacitatea de elaborare şi implementare a unor strategii şi politici de internaţionalizare adecvate structurii şi necesităţilor sale, adaptate mediului înconjurător. Un factor important în acest proces este flexibilitatea organizaţională şi capacitatea de adaptare la schimbare a partenerilor interni şi externi.

În mod ideal, activitatea de relaţii internaţionale de la nivelul instituţiilor de învăţământ superior se concentrează pe trei axe strategice: expertiză geografică şi gestionarea cooperării internaţionale (organizare administrativă în funcţie de spaţii lingvistice/ geografice/ culturale), managementul proiectelor internaţionale (prospectare, lobby, contractare, monitorizare, diseminare), evaluare globală a activităţilor internaţionale desfăşurate în toate structurile organizaţionale (Comisia Europeană, 2019).

Mai mult, pandemia SARS-CoV2 a generat păreri contradictorii cu privire la evoluția internaționalizării academice ulterior pandemiei. Există voci care consideră că fondurile pentru proiectele europene vor fi dublate sau triplate pentru perioada 2021-2027, indiferent de criză. Alți specialiști consideră că mobilitățile pentru studii vor determina potențialii participanţi să considere că nu este esențială participarea în proiecte, ba mai mult, va fi considerat un lux pe care nu ni-l mai putem permite. Aceste timpuri se consideră că ne îndreaptă către naționalism (Strauss, 2020).

\section{Bibliografie}

- ANPCDEFP (2020). Mobilitate de studiu (pentru studenți), Proiecte de mobilitate Invățământ universitar. Disponibil la https://www.erasmusplus.ro/invatamant-universitarmobilitati

- $\quad$ ANPCDEFP, Erasmus+ (2020). Cel mai mare program al UE pentru educație, formare profesională și tineret. Disponibil la https://www.erasmusplus.ro/erasmusplus

- ANPCDEFP, MECȘ, (2015) Internaționalizarea universităților din România prin programele Uniunii Europene pentru educație și formare. Analiză de impact. Disponibil la http://www.presidency.ro/files/userfiles/Studiu-impactul_programelor_UE.pdf

- Comisia Europeană (2019). Erasmus + annual report. Disponibil de la DOI: 10.2766/989852

- Comisia Europeană (2019). Erasmus + Ghidul programului. Versiunea 2(2019). Disponibil la https://ec.europa.eu/programmes/erasmus-plus/sites/erasmusplus2/files/erasmus-plusprogramme-guide-2019_ro.pdf

- Comisia Europeană (2019). Shaping Europe s digital future, Digital Opportunity Traineeships initiative exceeds original targets. Disponibil la https://ec.europa.eu/digital-singlemarket/en/news/digital-opportunity-traineeships-initiative-exceeds-original-targets

- Comisia Europeană (2020). EACEA, Coronavirus: Consequences for Erasmus Mundus Projects. Disponibil la https:/eacea.ec.europa.eu/erasmus-plus/news/coronavirusconsequences-for-erasmus-mundus-projects_en

- Comisia Europeană (2020). Erasmus+, COVVID-19 - Întrebări adresate de participanţii la programul Erasmus + și la Corpul european de solidaritate. Disponibil la https://ec.europa.eu/programmes/erasmus-plus/resources/coronavirus-faq-participants_ro

- Comisia Europeană (2020). Erasmus+ Studii în străinătate. Disponibil la https://ec.europa.eu/programmes/erasmus-plus/opportunities/individuals/students/studyingabroad_ro

- Comisia Europeană (2020). Impactul pandemiei de COVID-19, Erasmus+. Disponibil la https://ec.europa.eu/programmes/erasmus-plus/resources/coronavirus-impact_ro 
- Cotelnic, A. (2017). Dimensions of Higher Education Internalization, Academy of Economic Studies of Moldova, Centre for Studies in European Integration, EconPapers Economics at your fingertips. Disponibil la https://EconPapers.repec.org/RePEc:tkp:fktm17:24-28.

- Cummings, W. K. (2009). Teaching versus research in the contemporary academy. In RIHE (Ed.), The changing academic profession over 1992-2007: International comparative and quantita- tive perspectives, RIHE international seminar report 13, Hiroshima: RIHE Hiroshima University, 39-56.

- El-Khawas, E. (2002). Developing an academic career in a globalising world, in J. Enders \& O. Fulton (Eds.), Higher education in a globalising world. International trends and mutual observations, Dordrecht: Kluwer Academic Publishers, 241-254.

- Erasmus without paper (2018). EWP Network. Disponibil la https://www. erasmuswithoutpaper.eu/ewp-network

- Eri, R., Gudimetla, P. Vemuri, R. (2019) Beyond the Technical Skills: A Case for Internationalization of Graduate Attributes in $\mathrm{PhD}$ Programs, Universal Journal of Educational Research 7(3). Disponibil la DOI: 10.13189/ujer.2019.070316

- Eurydice (2018). Ireland, Other Dimensions of Internationalisation in Higher Education. Disponibil la https:/eacea.ec.europa.eu/national-policies/eurydice/content/other-dimensionsinternationalisation-higher-education-31_en

- Eurydice (2019). România, Mobilități în învățământul superior. Disponibil la https:/eacea.ec.europa.eu/national-policies/eurydice/content/mobility-higher-education56 ro

- Finkelstein, M. J., Walker, E., \& Chen, R. (2009). The internationalization of the American Faculty: Where are we, what drives or deters us? In R. Chen \& RIHE (Eds.), The changing academic profession over 1992-2007: International comparative and quantitative perspectives, RIHE international seminar report 13, Hiroshima: RIHE Hiroshima University, 113-144.

- Huang, F., Finkelstein, M., Rostan, M. (2014). The Internationalization of the Academy Changes, Realities and Prospects, Springer, New York, London.

- Jackson, M.G. (2003). Internationalizing the University Curriculum, Journal of geography in Higher Education, 27(3), November, 325-340.

- Kehm, B. M., \& Teichler, U. (2007). Research on internationalisation in higher education. Journal of Studies in International Education, 11(3/4), 260-273.

- Kerr, C. (1990). The Internationalisation of learning and the nationalisation of the purposes of higher education: Two 'Laws in Motion' in conflict? European Journal of Education, 25(1), 5-22.

- Knight, J. (2003). Updated internationalization definition. International Higher Education, 33, 23.

- Montaldo, M., Arnarsdottir, H., Lorubio, D. (2019). Erasmus+ and the internationalisation of $\mathrm{PhD}$ studies, European Commission | Initiatives and policy instruments, Disponibil la https://uni-

foundation.eu/uploads/EAIE_Erasmus $\% 20 \mathrm{and} \% 20$ the $\% 20$ internationalisation $\% 20 \mathrm{of} \% 20 \mathrm{Ph}$ D\%20studies_EAIE2019.pdf

- Musselin, C. (2004). Towards a European academic labour market? Some lessons drawn from empirical studies on academic mobility. Higher Education, 48, 55-78.

- Petcu, V., Petcu, A., Hâj, C., Santa, R., Fiţ, C.R. (2015). Ghid practic privind internaționalizarea învățământului superior românesc, București, 13-16.

- Rostan, M. (2011). English as "lingua franca" and the internationalization of academe. International Higher Education, 63 (Spring), 11-13. 
- Strauss, M. (2020). Coronavirus: Is the EU's Erasmus program under threat?, Deutsche Welle $(D W)$, Europe. Disponibil la https://www.dw.com/en/coronavirus-is-the-eus-erasmusprogram-under-threat/a-53019986

- Teichler, U. (2004). The changing debate on internationalisation of higher education. Higher Education, 48(1), 5-26.

- Teichler, U. (2009). Internationalisation of higher education: European experiences. Asia Pacific Education Review, 10(1), 93-106.

- Teichler, U. (2011). Academic staff mobility. In U. Teichler, I. Ferencz, \& B. Wächter (Eds.), Mapping mobility in European higher education. Vol. I: Overview and trends. Brussels, European Commission, Directorate General for Education and Culture, 111-146.

- UEFISCDI (2013). Internaționalizarea Învățământului Superior în România, Analiza profilurilor universităților din România pe mai multe dimensiuni: Internaționalizarea și echitatea Învățământului Superior în România Disponibil la. http://www.politiciedu.uefiscdi.ro/wp-content/uploads/2013/04/Analiza-profilurilor-univ-din-Romania-pe-mmdimensiuni-Internationalizarea-si-echitatea.pdf

- UEFISCDI (2015). Cadrul strategic pentru internaționalizarea Învățământului Superior din România Analiză și recomandări, Higher Education Policy Series No. 12. Disponibil la http://old.uefiscdi.ro/Upload/370bd06a-979b-4b40-8632-fa65781e50d4.pdf

- Welch, R. (1997). The peripatetic professor: The internationalization of the academic profession. Higher Education, 34, 323-345. 



\title{
Cap. 4. CONSIDERAŢII ASUPRA MODULUI DE ORGANIZARE A STRUCTURILOR DE AUDIT PUBLIC INTERN ÎN INSTITUŢIILE DE ÎNVĂŢĂMÂNT PREUNIVERSITAR
}

\author{
Monica Giurgea (căs. Gherghe) \\ Universitatea „Alexandru Ioan Cuza” din Iaşi, Şcoala Doctorală de Economie şi Administrarea Afacerilor \\ Iaşi,România,gherghe.monica@yahoo.com
}

\begin{abstract}
In the decision-making process that takes place in any organization, managers base their decisions on the knowledge and information they possess, but also on the advice provided by specialists. One of these specialists is the public auditor. The pre-university education institutions wish to participate and align themselves with the European context through the support provided by European funding programs. Having this goal, they are forced to constantly improve their resource management system. The auditors' duty is to provide for this purpose a response as concrete as possible to the needs of management and to ensure reports that offer a level of confidence as high as possible. The purpose of this analysis is to highlight the current position of the public internal audit function in the public pre-university education system using the content analysis method performed on a number of 20 annual activity reports from different Romanian counties.
\end{abstract}

Keywords: internal public audit, educational management.

\section{Introducere}

În sistemul administraţiei publice, în general, dar şi în sistemul de învăţământ, auditorul este format, dar şi determinat de prevederile cadrului normativ, să evalueze în permanenţă "legalitatea, economicitatea, eficienţa şi eficacitatea" utilizării resurselor. Acest demers este într-o conexiune directă cu viziunea pe care trebuie să şi-o construiască nu numai managerii din sistemul de învăţământ, ci şi auditorii asupra sistemului managerial. Problematica organizării şi a dimensionării compartimentelor de audit este una încă de actualitate în sistemul public. Chiar dacă încă din anul 1999, odată cu publicarea Ordonanţei Guvernului nr. 119 privind controlul intern şi controlul financiar preventiv, s-a încercat reglementarea domeniului, încă ne aflăm în etapa de tranziţie de la managementul şi controlul realizate în mod standardizat, prin prevederi ale cadrului normativ de reglementare, la un control realizat prin complementaritatea celui managerial $\mathrm{cu}$ evaluările efectuate în mod independent, de structuri independente cum sunt auditul public extern sau, mai frecvent, auditul public intern. Această formă de management bazat pe obiective este, în mod cert, un model compatibil cu sistemul de învăţământ, dat fiind faptul că se adresează unor nevoi certe ale societăţii şi chiar ale unor grupuri ţintă. Sub acest aspect, modul de repartizare a resurselor (umane, materiale, informaţionale, financiare), precum şi modelul de management adoptat, conduc la obţinerea unor rezultate diferite, în funcţie de mecanismul de răspundere managerială implementat.

Contextul în care a luat naştere acest demers ştiinţific a fost unul strict practic - o concluzie obţinută exclusiv pe baza propriului raţionament profesional şi a experienţei dobândite în sectorul public: oricâte calităţi profesionale ar avea un salariat, oricât de bine pregătit ar fi în domeniul său de activitate, nu poate deveni şi manager, indiferent de context. Dacă totuşi contextul înlesneşte ca acesta să ajungă să deţină o funcţie de conducere, acest fapt nu implică obligatoriu şi obţinerea unor rezultate, a performanţei.

În procesul de luare a deciziilor care are loc în orice organizaţie managerii îşi fundamentează deciziile pe baza cunoştinţelor şi informaţiilor pe care le deţin, dar şi pe baza consultanţei acordate de către specialişti. Unul dintre aceşti specialişti este auditorul. În unităţile de învăţământ 
preuniversitar exercitarea funcţiei de audit public intern nu are loc prin intermediul unei structuri proprii, ci este asigurată de către ordonatorul secundar de credite, respectiv de inspectoratele şcolare județene şi de primării sau, după caz, consilii județene în subordinea cărora acestea funcţionează. În contextul în care cadrul legislativ impune exercitarea funcţiei de audit, dar şi în împrejurările în care unităţile de învăţământ îşi doresc să participe şi să se alinieze contextului european prin intermediul sprijinului oferit de diverse programe de finanţare, aceste entităţi se văd nevoite să-şi perfecţioneze în permanenţă sistemul de gestionare a resurselor. Auditorii publici au datoria să ofere în acest scop un răspuns cât mai concret şi să asigure utilizatorilor furnizarea unor rapoarte care să ofere, în primul rând managerilor, un nivel de încredere cât mai ridicat. Ca parte a unui studiu mai amplu, în care urmărim identificarea modului în care auditul intern poate oferi suport în realizarea unei gestiuni cât mai riguroase a riscurilor care se manifestă în cadrul unităţilor de învăţământ preuniversitar, prin analiza de faţă se doreşte conturarea poziţiei auditului public intern, în linii mari, în unităţile de învăţământ preuniversitar.

\section{Studiu empiric}

\subsection{Contextul realizării studiului}

Controlul financiar în sistemul administraţiei publice din România urmăreşte dezvoltarea unor mecanisme care să asigure gestiunea riguroasă a fondurilor publice conform criteriilor şi conceptelor stabilite la nivel internaţional. Auditul public intern este o componentă a sistemului de control intern managerial, este organizat în mod distinct în subordinea directă a managerului şi urmăreşte, în mod prioritar, limitarea erorilor şi a fraudei.

\subsection{Scopul analizei}

Sistemul de învăţământ oferă programe de formare pentru directori, inclusiv pe linia consilierii asigurate de structura de audit public intern, însă până la formarea profesională în domeniu noii directori se familiarizează mai curând cu noţiunea de self-management. În acest context, se pune întrebarea "Cum poate auditul public intern să susţină creşterea calităţii managementului într-o unitate de învăţământ preuniversitar?". Acesteia i se subsumează o serie de alte întrebări determinate de contextul actual: "Este auditul intern desfăşurat în sectorul de învăţământ un instrument util managerilor?", "Prin felul în care se desfăşoară în prezent, auditul intern este performant?", "Există posibilităţi de adaptare a acestei funcţii, prin raportare la modul în care ea se desfăşoară practic, la contextul actual: legislativ, informaţional, tehnic etc.", "Poate funcţia de audit să furnizeze un răspuns util şi, mai ales, în timp real managementului?’.

Scopul prezentei analize are în vedere cunoaşterea poziţiei actuale a funcţiei de audit public intern în sistemul de învăţământ preuniversitar de stat. Obţinerea unei astfel de informaţii o găsim utilă atât managerilor, cât şi auditorilor, dar mai ales pentru conturarea ulterioară a posibilităţilor de adaptare ale auditului la noile condiţii date de dezvoltarea socială, economică şi tehnică de care beneficiază acestea. Acestea ar putea sta la baza conturării ulterioare a posibilităţilor de care dispune auditul public intern exercitat prin intermediul structurilor din cadrul inspectoratelor şcolare, precum şi maniera în care contribuie la consolidarea funcţiei de asigurare a managementului, de gestionare eficientă a riscurilor şi a resurselor entităţilor supuse analizei.

\subsection{Eşantion şi obiective}

Aria de cercetare la care s-a raportat prezentul demers ştiinţific o constituie entităţile publice din învăţământul preuniversitar care au constituite structuri proprii de audit intern. Eşantionul ales pentru efectuarea analizei de faţă include un număr de 20 de inspectorate şcolare judeţene din cele 47 existente, respectiv: Arad, Bacău, Bihor, Botoşani, Braşov, Brăila, Buzău, Cluj, Constanţa, Dolj, Galaţi, Giurgiu, Hunedoara, Iaşi, Ilfov, Neamţ, Prahova, Suceava, Sibiu, Vaslui. Pentru aceste cazuri s-a procedat la efectuarea unei analize de conţinut a unor date secundare, respectiv a datelor centralizate în rapoartele anuale de activitate ale anului 2018. Prelucrarea datelor s-a făcut manual, 
centralizate cu ajutorul unei aplicaţii de calcul tabelar. Aceste rapoarte anuale au ca bază documentară rapoartele misiunilor desfăşurate şi privesc activitatea desfăşurată în cadrul structurilor de audit din sistemul de învăţământ preuniversitar de stat, respectiv la nivelul inspectoratelor şcolare județene, precum şi în cadrul entităţilor publice subordonate, aflate în coordonarea sau sub autoritatea acestora. Ele sunt instrumente destinate atât top managerilor care pot aprecia astfel rezultatele activităţii desfăşurate pe parcursul unui an bugetar de către personalul de specialitate, cât şi instituţiilor cu atribuţii de evaluare externă cum sunt Ministerul Educaţiei şi Cercetării, Curtea de Conturi a României sau Unitatea Centrală de Armonizare pentru Auditul Public Intern din România, instituţie aflată în subordinea direct a Ministerului Finanţelor Publice.

Obiectivele prezentului studiu urmăresc crearea unui profil al structurii de audit, respectiv al auditorului la nivelul eşantionului ales şi anume:

1. stabilirea modului de înfiinţare a structurii de audit public intern;

2. identificarea modurilor de organizare şi de funcţionare a structurilor de audit;

3. stabilirea independenţei structurii de audit public intern;

4. urmărirea obiectivităţii auditorilor;

5. stabilirea gradului de ocupare a posturilor de auditori interni la nivelul celor 20 de inspectorate şcolare judeţene.

\subsection{Metodologia de cercetare}

Metodologia de cercetare utilizată a implicat realizarea unei analize de conţinut pe baza unei cercetări documentare. S-au studiat rapoartele anuale de audit public intern elaborate de 20 de compartimente de audit din cadrul inspectoratelor şcolare judeţene care au fost incluse în eşantion, iar dacă textul unor rapoarte nu a fost suficient de edificator ca şi conţinut informaţional, acesta a fost completat prin studiul organigramelor, regulamentelor de organizare şi funcţionare, a altor rapoarte şi informaţii privind activitatea de audit public intern desfăşurată de entităţile incluse în eşantion care, potrivit normelor legale, sunt publice. Evident, din acest punct de vedere, limitarea studiului a fost impusă de existenţa/publicarea documentelor necesar a fi studiate.

Inspectoratele şcolare judeţene din România sunt instituţii publice organizate sub forma unor servicii publice deconcentrate care îşi desfăşoară activitatea ca ordonatori secundari de credite, în subordinea Ministerului Educaţiei şi Cercetării. Acestea funcţionează potrivit prevederilor OMECTS nr. 5530/2011 privind aprobarea Regulamentului-cadru de organizare şi funcţionare a inspectoratelor şcolare, cu modificările şi completările ulterioare. În cadrul tuturor inspectoratelor şcolare activitatea de audit se desfăşoară prin intermediul structurilor de specialitate, aflate în subordonarea directă a top managerilor, respectiv a inspectorilor şcolari generali. Rolul de bază al acestora este acela de a oferi managerilor servicii de consiliere şi de asigurare cu privire la activitatea desfăşurată în cadrul instituţiilor pe care aceştia le conduc. Aceste rapoarte anuale sunt elaborate de toate structurile de audit public intern din România şi au rolul de a oferi administraţiei publice centrale o imagine de ansamblu asupra acestei activităţi astfel încât să contribuie la dezvoltarea unor viitoare direcţii de acţiune elaborate de diferite instituţii cărora le revin astfel de atribuţii.

În privinţa apariţiei structurilor de audit public intern este necesar a fi subliniat faptul că responsabilitatea pentru crearea acestora revine conducătorului instituţiei publice, cel care va stabili cât din resursele organizaţiei sale se vor aloca acestui compartiment. Înfiinţarea auditului public intern, ca funcţie, se poate realiza, după cum reflectă datele centralizate în tabelul nr. 1, fie ca structură proprie, fie prin accesul la funcţia care este asigurată, conform legii, de organul ierarhic superior. Din analiza efectuată a rezultat faptul că toate cele 20 de inspectorate şcolare au înfiinţat auditul intern ca structură proprie, în toate cazurile sub formă de compartiment, iar dintre acestea 17 sunt funcţionale întrucât respectă normele legale de funcţionare, iar 3 nu sunt funcţionale determinat de faptul că au posturile din organigramă neocupate. S-a constatat că pentru cele trei județe această funcţie nu a fost asigurată nici de organul ierarhic superior. 
Tabel 1. Situaţia privind înființarea și funcționarea activităţii de audit intern în cadrul Inspectoratelor Şcolare Judeţene la data de 31 decembrie 2018

\begin{tabular}{|c|c|c|c|c|c|c|c|c|c|c|c|c|c|c|}
\hline \multirow{3}{*}{$\begin{array}{l}\text { Categorii de } \\
\text { entităłpi }\end{array}$} & \multirow{3}{*}{$\begin{array}{l}\text { Denumire } \\
\text { entitate } \\
\text { publică }\end{array}$} & \multicolumn{8}{|c|}{ Infiinfarea avditulvi public intern } & \multicolumn{5}{|c|}{ Funcfionarea avditulvi public intern } \\
\hline & & \multicolumn{3}{|c|}{$\begin{array}{l}\text { Entitatea a infiinfat avditul } \\
\text { public intern prin: }\end{array}$} & \multicolumn{5}{|c|}{$\begin{array}{l}\text { Structurile proprii de avdit intern sunt organizate sub } \\
\text { formă de: }\end{array}$} & \multicolumn{2}{|c|}{$\begin{array}{l}\text { Structură proprie înfiintată } \\
\text { care: }\end{array}$} & \multicolumn{2}{|c|}{$\begin{array}{l}\text { Functia de avdit intern furnizată } \\
\text { de organul ierarhic superior: }\end{array}$} & \multirow{2}{*}{$\begin{array}{l}\text { Nefunctională } \\
\text { din cauzza } \\
\text { neînființării }\end{array}$} \\
\hline & & $\begin{array}{l}\text { Structură } \\
\text { proprie }\end{array}$ & ierarhic & $\begin{array}{l}\text { Avoitul } \\
\text { nu este } \\
\text { infiinfat }\end{array}$ & $\begin{array}{l}\text { Directie } \\
\text { Generală }\end{array}$ & Directie & Serviciv & Birov & Compartiment & Funç̧ionează & Nv functionează & Functionează & Nv functionează & \\
\hline 1 & 2 & 3 & 4 & 5 & 6 & 7 & 8 & 9 & 10 & 11 & 12 & 13 & 14 & 15 \\
\hline $\begin{array}{c}\text { Ordonator } \\
\text { principal de } \\
\text { credite }\end{array}$ & $\begin{array}{c}\text { Ministerul } \\
\text { Educatiei și } \\
\text { Cercetării }\end{array}$ & 20 & 0 & 0 & 0 & 0 & 0 & 0 & 20 & 17 & 3 & 0 & 0 & 0 \\
\hline
\end{tabular}

Sursa: Rapoartele anuale privind activitatea de audit public intern publicate în anul 2019 de cele 20 de entităţi cuprinse în eşantion

Potrivit Raportului privind activitatea de audit intern din sectorul public din România, pentru anul 2018, ordonatorii de credite din întregul sector public au organizat funcţia de audit sub formă de compartiment în proporţie de $87 \%$ din numărul total al structurilor (1762 de structuri de audit public intern existent la nivel naţional). Această formă de organizare este caracteristică şi sistemului de învăţământ unde, cu excepţia Ministerului Educaţiei şi Cercetării - organizat sub formă de serviciu, respectiv a Inspectoratului Şcolar al Municipiului București - organizat sub formă de birou, toate celelalte structuri din ţară sunt organizate sub formă de compartimente. Cea mai mare deficienţă a acestei forme de organizare este dată de faptul că nu este reglementată de cadrul normativ şi, din acest motiv, nu se pot înfiinţa posturi cu atribuţii de conducere la nivel de compartiment. În mod implicit, apar deficienţe în exercitarea funcţiei, precum şi dificultăţi în derularea propriu-zisă a misiunilor. Un alt aspect rezidă în faptul că, dacă se realizează totuşi nominalizarea unor persoane ca şi coordonatori ai compartimentelor, nu există posibilitatea legală de remunerare a acestor salariaţi corespunzător atribuţiilor care le revin. Acest fapt care fără îndoială determină apariţia unor insatisfacţii şi, cu certitudine, afectează calitatea activităţii pe care aceştia o desfăşoară. Cu privire la înfiinţarea şi funcţionarea activităţii de audit public intern se impune şi precizarea faptului că începând cu anul 2012, o dată cu apariţia OUG nr. 26, cadrul normativ a exclus modalitatea de asigurare a acestei funcţii prin intermediul contractelor de prestări servicii, modalitate reglementată anterior de Legea nr. 672/2002 prin art. 11 lit. c).

Cele trei cazuri de structuri nefuncţionale de audit reliefate în tabelul nr. 1 se pot explica prin resursele financiare insuficiente, salarizarea demotivantă a postului de auditor public intern în învăţământ. Din acelaşi motiv, în unele cazuri aceste posturi au fost redistribuite către alte structuri din cadrul entităţii şi au fost transformate în posturi de consilier de către ordonatorul principal de credite. De asemenea, se impune a fi subliniat un aspect particular al funcţionării unei structuri de audit intern în sectorul public în general, nu doar în învăţământ: în situaţia în care auditul intern este asigurat de ordonatorul superior de credite, acesta are obligaţia auditării cel puţin o dată la trei ani a entităţii respective. Dacă în acest interval de trei ani nu s-a efectuat nicio misiune de audit intern la entitatea subordonată, atunci funcţia este considerată înfiinţată, dar nefuncţională. Gradul de funcţionare se determină ca raport între numărul de entităţi în care auditul funcţionează şi numărul de entităţi care aveau obligaţia legală de a avea constituită o structură de audit public intern care să fie funcţională. Interesul scăzut al conducătorilor de instituţii publice, dar şi politicile publice care nu au urmărit consolidarea acestei funcţii, au făcut ca până la nivelul anului 2019 aceste compartimente să dispună de un singur post. În plus, practicienii din domeniu subliniază faptul că problema subdimensionării compartimentelor de audit este o constant la nivelul întregului sistem public care afectează în primul rând independenţa auditorilor (Dascălu, 2016). 
Tabel 2. Comunicarea raportului anual de activitate în cadrul structurilor de audit cuprinse în eşantion la 31.12.2018

\begin{tabular}{|c|c|c|c|c|c|c|c|}
\hline $\begin{array}{c}\text { Categorii } \\
\text { de entități }\end{array}$ & $\begin{array}{c}\text { Denumire } \\
\text { entitate } \\
\text { publică }\end{array}$ & \multicolumn{2}{|c|}{$\begin{array}{c}\text { Entitatea are structură proprie de } \\
\text { audit intern care functionează? }\end{array}$} & $\begin{array}{c}\text { Entitatea a înființat auditul } \\
\text { intern prin OIS (organul } \\
\text { ierarhic superior) }\end{array}$ & $\begin{array}{c}\text { Entitatea nu } \\
\text { a înființat } \\
\text { audit intern }\end{array}$ & $\begin{array}{c}\text { Structura proprie de audit intern, care } \\
\text { funcționează, a emis raport anual? }\end{array}$ \\
\hline $\mathbf{l}$ & $\mathbf{2}$ & $\mathbf{3}$ & $\mathbf{N U}$ & $\mathbf{4}$ & $\mathbf{5}$ & $\mathbf{6}$ & $\mathbf{7}$ \\
\hline $\begin{array}{c}\text { Ordonator } \\
\text { principal de } \\
\text { credite }\end{array}$ & $\begin{array}{c}\text { Ministerul } \\
\text { Educației și }\end{array}$ & 20 & 0 & 0 & & & $\mathbf{7}$ \\
\hline
\end{tabular}

Sursa: Rapoartele anuale privind activitatea de audit public intern publicate în anul 2019 de cele 20 de entităţi cuprinse în eşantion

Conform datelor analizate, din cele 20 de entităţi numai 17 au comunicat un raport anual către ordonatorul de credite, aspect uşor de intuit având în vedere că pentru 3 unităţi compartimentul nu este funcţional. Între consecinţele neorganizării auditului public intern este şi faptul că nu se elaborează un raport anual care să ofere ordonatorului superior de credite şi administraţiei publice centrale o imagine de ansamblu asupra modului şi măsurii în care a fost exercitată această funcţie. Important de subliniat este faptul că, deşi Legea nr. 672/2002 care reglementează organizarea acestei activităţi prevede sancţiuni pentru neorganizarea auditului (este contravenţie sancţionată cu amendă între 3000 şi 5000 de lei), în fapt acestea nu sunt în general puse în aplicare.

Tabel 3. Independenţa structurilor de audit public intern cuprinse în eşantion la data de 31 decembrie a anului 2018

\begin{tabular}{|c|c|c|c|c|c|c|c|c|c|c|c|c|c|c|c|}
\hline \multirow[t]{2}{*}{$\begin{array}{l}\text { Categorii } \\
\text { de entități }\end{array}$} & \multirow[t]{2}{*}{$\begin{array}{l}\text { Denumire } \\
\text { entitate } \\
\text { publică }\end{array}$} & \multicolumn{4}{|c|}{$\begin{array}{l}\text { Funcția de audit intern } \\
\text { raportează direct } \\
\text { managementului superior al } \\
\text { organizației? }\end{array}$} & \multicolumn{5}{|c|}{$\begin{array}{l}\text { Numirea/destituirea managementului funcției de } \\
\text { audit intern în anul de raportare s-a realizat cu } \\
\text { respectarea procesului de avizare? }\end{array}$} & \multicolumn{5}{|c|}{$\begin{array}{l}\text { Numirea/destituirea auditorilor interni în anul de } \\
\text { raportare s-a realizat cu respectarea procesului de } \\
\text { avizare? }\end{array}$} \\
\hline & & DA & NU & $\begin{array}{c}\text { Fără } \\
\text { informatii }\end{array}$ & Observații & DA & NU & $\begin{array}{l}\text { Nu a fost cazul în } \\
\text { anul de raportare }\end{array}$ & $\begin{array}{c}\text { Fără } \\
\text { informatii }\end{array}$ & Observații & DA & NU & $\begin{array}{l}\text { Nu a fost cazul în } \\
\text { anul de raportare }\end{array}$ & $\begin{array}{c}\text { Fără } \\
\text { informații }\end{array}$ & Observațil \\
\hline 1 & 2 & 3 & 4 & 5 & 6 & 7 & 8 & 9 & 10 & 11 & 12 & 13 & 14 & 15 & 16 \\
\hline $\begin{array}{l}\text { Ordonator } \\
\text { principal } \\
\text { de credite }\end{array}$ & $\begin{array}{c}\text { Ministerul } \\
\text { Educației și } \\
\text { Cercetăriii }\end{array}$ & 17 & 3 & 0 & 0 & & & $\mathrm{x}$ & & & 14 & 3 & 3 & & \\
\hline
\end{tabular}

Sursa: Rapoartele anuale privind activitatea de audit public intern publicate în anul 2019 de cele 20 de entităţi cuprinse în eşantion

Independenţa este o caracteristică a funcţiei de audit public intern, în timp ce obiectivitatea este atributul auditorilor. Pentru existenţa independenţei funcţiei în oricare entitate public, aceasta trebuie, în primul rând, să fie subordonată direct managementului superior (în cazul învăţământului preuniversitar, respectiv a inspectoratelor şcolare, auditorul se subordonează inspectorului şcolar general). Din acest motiv cadrul normativ de reglementare prevede faptul că numirea şi destituirea managerilor structurilor de audit intern, dar şi a auditorilor, se supun avizării. În scopul confirmării independenţei, auditorii publici interni au obligaţia de a declara la începerea fiecărei misiuni poziţia lor faţă de structurile ce urmează a fi auditate, respectiv independenţa faţă de aceste entităţi.

În ceea ce priveşte independenţa structurilor de audit public intern, pe baza analizei s-a concluzionat că în cele 17 cazuri în care funcţia este exercitată, auditorii raportează direct top managerilor din organizaţie, în timp ce 3 judeţe nu sunt în această situaţie, neavând posturile ocupate. Din cele 17 cazuri, în 14 unităţi numirea auditorilor s-a făcut cu respectarea procesului de avizare de către Ministerul Educaţiei şi Cercetării, în timp ce în alte trei județe acest aspect nu a fost posibil determinat de faptul că funcţia este exercitată de salariaţi ocupând alte posturi (de exemplu de consilieri - ocupă, în consecinţă alte funcţii însă exercită atribuţii specifice postului de auditor). În alte trei unităţi nu s-a pus problema respectării procedurii, având în vedere că posturile au rămas vacante. 
Tabel 4. Stadiul emiterii normelor proprii în cadrul structurilor de audit public intern cuprinse în eşantion la data de 31 decembrie a anului 2018

\begin{tabular}{|c|c|c|c|c|c|c|c|c|c|c|c|c|c|c|c|}
\hline \multirow{3}{*}{$\begin{array}{l}\text { Categonii de } \\
\text { entități }\end{array}$} & \multirow{3}{*}{$\begin{array}{c}\text { Denumire } \\
\text { entitate publică }\end{array}$} & \multicolumn{2}{|c|}{$\begin{array}{c}\text { Structura de audit } \\
\text { intem funcțională } \\
\text { a emis raport anual } \\
\text { de activitate? }\end{array}$} & \multicolumn{3}{|c|}{$\begin{array}{l}\text { OIS și-a dat acordul ca } \\
\text { entitatea subordonată să- } \\
\text { și emită norme proprii? }\end{array}$} & \multicolumn{8}{|c|}{ Stadiul normelor proprii specifice } & \multirow{3}{*}{ Observații } \\
\hline & & \multirow{2}{*}{$\mathrm{DA}$} & \multirow{2}{*}{$\mathrm{NU}$} & \multirow{2}{*}{ DA } & \multirow{2}{*}{$\begin{array}{l}\text { Data șinr. } \\
\text { acordului }\end{array}$} & \multirow{2}{*}{$\mathrm{NU}$} & \multirow{2}{*}{ Neintocmite } & \multirow{2}{*}{$\begin{array}{l}\text { Întocmite dar } \\
\text { netransmise la } \\
\text { UCAAAPI / OIS }\end{array}$} & \multicolumn{2}{|c|}{$\begin{array}{l}\text { Intocmite și transmise la UCAAPI/ } \\
\text { OIS în vederea avizănii dar neavizate } \\
\text { până la data de } 31 \text { decembrie }\end{array}$} & \multirow{2}{*}{$\begin{array}{c}\text { Restituite de } \\
\text { UCAAPI/OIS } \\
\text { cu observatịi } \\
\text { pentru } \\
\text { modificăn' } \\
\text { completări }\end{array}$} & \multicolumn{2}{|c|}{$\begin{array}{l}\text { Avizate de către UCAAPI / OIS } \\
\text { până la data de } 31 \text { decembrie }\end{array}$} & \multirow{2}{*}{$\begin{array}{c}\text { Färă } \\
\text { informații }\end{array}$} & \\
\hline & & & & & & & & & $\mathrm{DANU}$ & $\begin{array}{c}\text { Data șint. } \\
\text { documentului de } \\
\text { transmitere }\end{array}$ & & DANU & $\begin{array}{c}\text { Data șinr. } \\
\text { avizului }\end{array}$ & & \\
\hline 1 & 2 & 3 & 4 & 5 & 6 & 7 & 8 & 9 & 10 & 11 & 11.1 & 12 & 13 & 14 & 15 \\
\hline $\begin{array}{l}\text { Ordonator } \\
\text { principal de } \\
\text { credite }\end{array}$ & $\begin{array}{c}\text { Ministerul } \\
\text { Educatiei iși } \\
\text { Cercetării }\end{array}$ & 17 & 3 & ' & I & 1 & ' & ' & l & 1 & ' & 1 & l & I & $\begin{array}{l}\text { Fara obligatia intocmirii } \\
\text { de nome proprii (OMEN } \\
5509 / 2017) \\
\end{array}$ \\
\hline
\end{tabular}

Prin raportare la activitatea derulată de auditori, un punct de sprijin extrem de important îl constituie normele metodologice referitoare la exercitarea acestei activităţi. Dat fiind caracterul extrem de unitar în care activităţile se desfăşoară la nivelul întregului sistem de învăţământ preuniversitar, aceste norme sunt elaborate de ordonatorul principal de credite, Ministerul Educaţiei şi Cercetării, entitate căreia îi revin obligaţii privind raportarea către UCAAPI. Astfel, niciuna dintre cele 20 de unităţi din eşantion nu a raportat obligaţii de emitere a unor astfel de norme, după cum s-a reflectat în tabelul nr. 4 dar fiind faptul că această obligaţie îi revine exclusive Serviciului Audit din cadrul ministerului coordonator.

Tabel 5. Obiectivitatea auditorilor din cadrul structurilor de audit public intern cuprinse în eşantion la data de 31 decembrie a anului 2018

\begin{tabular}{|c|c|c|c|c|c|c|c|c|c|c|c|c|c|c|c|}
\hline \multirow[t]{2}{*}{$\begin{array}{l}\text { Categorii } \\
\text { de entități }\end{array}$} & \multirow[t]{2}{*}{$\begin{array}{l}\text { Denumire } \\
\text { entitate } \\
\text { publică }\end{array}$} & \multicolumn{4}{|c|}{$\begin{array}{l}\text { Funcția de audit intern } \\
\text { raportează direct } \\
\text { managementului superior al } \\
\text { organizației? }\end{array}$} & \multicolumn{5}{|c|}{$\begin{array}{l}\text { Numirea/destituirea managementului funcției de } \\
\text { audit intern în anul de raportare } s \text {-a realizat cu } \\
\text { respectarea procesului de avizare? }\end{array}$} & \multicolumn{5}{|c|}{$\begin{array}{l}\text { Numirea/destituirea auditorilor interni în anul de } \\
\text { raportare s-a realizat cu respectarea procesului de } \\
\text { avizare? }\end{array}$} \\
\hline & & DA & NU & $\begin{array}{c}\text { Fără } \\
\text { informații }\end{array}$ & Observații & DA & NU & $\begin{array}{l}\text { Nu a fost cazul în } \\
\text { anul de raportare }\end{array}$ & $\begin{array}{c}\text { Fără } \\
\text { informații }\end{array}$ & Observații & DA & NU & $\begin{array}{l}\text { Nu a fost cazul în } \\
\text { anul de raportare }\end{array}$ & $\begin{array}{c}\text { Fără } \\
\text { informații }\end{array}$ & Observații \\
\hline 1 & 2 & 3 & 4 & 5 & 6 & 7 & 8 & 9 & 10 & 11 & 12 & 13 & 14 & 15 & 16 \\
\hline $\begin{array}{l}\text { Ordonator } \\
\text { principal } \\
\text { de credite }\end{array}$ & $\begin{array}{c}\text { Ministerul } \\
\text { Educației și } \\
\text { Cercetării }\end{array}$ & 17 & 3 & 0 & 0 & & & $x$ & & & 14 & 3 & 3 & & \\
\hline
\end{tabular}

Sursa: Rapoartele anuale privind activitatea de audit public intern publicate în anul 2019 de cele 20 de entităţi cuprinse în eşantion

În scopul păstrării obiectivităţii, auditorii publici interni au obligaţia de a nu fi implicaţi în activităţile pe care, în mod potenţial, le pot audita. Conform datelor structurate în tabelul nr. 517 compartimente de audit sunt funcţionale şi tot 17 din cele 20 au avut activitate; pentru aceste 17 unităţi putem vorbi de neimplicarea în derularea activităţilor auditabile, entităţi pentru care, în acest scop, s-a şi completat de către auditori declaraţia de independenţă. Din păcate, la nivelul întregului sistem public, de la an la an sunt raportate din ce în ce mai multe situaţii în care obiectivitatea auditorilor este afectată de faptul că aceştia sunt implicaţi în derularea activităţilor auditabile sau desfăşoară misiuni fără completarea declaraţiei de independenţă.

În perioada în care ne regăsim se pune accent în mod deosebit pe responsabilitatea organizaţională, pe exercitarea unui control intern responsabil, pe guvernanţa corporativă şi managementul riscurilor. Ori structurile de audit intern sunt cele care pot oferi o confirmare managerilor asupra faptului că aceste procese se derulează în mod eficient, urmărind în fond îndeplinirea obiectivelor manageriale. Deci structurile de audit intern trebuie să existe, să fie funcţionale şi să aibă în aceeaşi măsură acces la resurse, mai ales umane, care să şi posede abilităţile necesare în îndeplinirea obiectivelor organizaţiei. Fără îndoială, deficitul de resurse umane conduce la imposibilitatea exrcitării funcţie de audit şi a îndeplinirii atribuțiilor legale 
Tabel 6. Situaţia privind ocuparea posturilor de auditori interni din cadrul Inspectoratelor Şcolare Judeţene incluse în eşantion la 31.12.2018

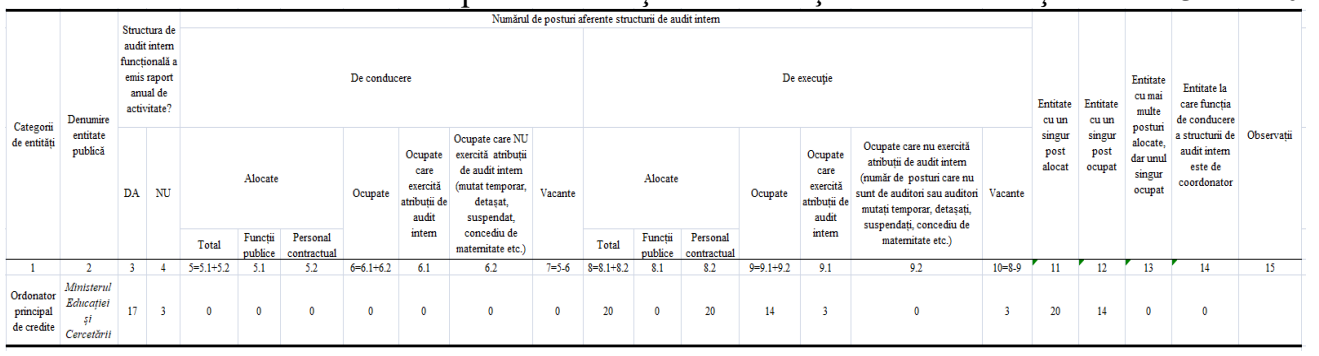

Sursa: Rapoartele anuale privind activitatea de audit public intern publicate în anul 2019 de cele 20 de entităţi cuprinse în eşantion

\section{Concluzii}

Funcţiile aparatului administrativ din învăţământul preuniversitar de stat se împart în acest moment la nivel local, judeţean şi regional, dar şi naţional, după două criterii distincte: politicile publice prin care are loc implementarea programelor educaţionale - au în vedere strict modul de organizare a sistemului de învăţământ preuniversitar, precum şi strategiile prin care se urmăreşte finanţarea şi administrarea fondurilor necesare funcţionării şi dezvoltării sistemului de educaţiei preuniversitară. Se includ aici, inspectoratele şcolare judeţene împreună cu unităţile de învăţământ preuniversitar aflate în coordonare, subordonare sau sub autoritate (unităţile de învăţământ preuniversitar de stat - grădiniţe cu program scurt sau prelungit, şcoli, licee, şcoli profesionale, palate ale copiilor, case ale corpului didactic, cluburi sportive), precum şi entităţi ale administraţiei publice locale (primării, consilii judeţene, structuri asociative la care acestea au aderat şi care asigură exercitarea funcţiei de audit). Participarea managerilor şi salariaţilor din entităţile mai sus menţionate: directori (primi şi adjuncţi), inspectori (şcolari, generali, generali-adjuncţi), administratori financiari/contabili sau de patrimoniu, responsabili cu resursele umane (secretari de şcoală cu şi fără funcţie de conducere), manageri din administraţia publică locală, auditori publici interni sau externi, influenţează fiecare, într-o măsură mai mare sau mai redusă, rezultatele obţinute în procesul administrativ.

La acest moment, modul de funcţionare a administraţiei locale şi judeţene pare a fi orientat în mod deosebit pe finanţarea şi administrarea fondurilor repartizate acestor entităţi publice, dar mai puţin direcţionat spre formularea unor strategii, pe stabilirea unor priorităţi şi a unor politici publice coerente. Cadrul legal, atât cel din sistemul public, în general, cât şi cel specific educaţiei este întro neîntreruptă transformare, fapt care pentru toate aceste entităţi publice şi pentru toate nivelurile decizionale implică o modificare permanentă a măsurilor: administrative, financiare, de politică educaţ̧ională. Ori toate politicile, strategiile şi măsurile care se tot aplică necesită a apreciere a coerenţei şi mai ales a ciclului scop-mijloace-rezultate.

Analizând relaţia existentă între funcţia de management şi exercitarea funcţiei de audit public intern putem sublinia faptul că majoritatea managerilor implicaţi în funcţionarea şi finanţarea instituţiilor de învăţământ nu percep auditul ca pe o resursă importantă pentru performanţa managerială, ci mai degrabă ca pe o structură faţă de care trebuie îndeplinite noi şi noi obligaţii de raportare. Se impune, din acest punct de vedere, evidenţierea clară a diferenţelor între ceea ce înseamnă pentru manageri auditul public intern şi cel extern. Prezenţa unor specialişti în organizaţie în domeniul auditului este preferabilă, având în vedere faptul că existenţa lor asigură o cunoaştere mai detaliată a domeniului, chiar dacă există riscul de a le fi afectată obiectivitatea de faptul că participă la o parte dintre activităţile asupra cărora intervin deciziile managerilor. Auditorii externi sunt fără îndoială mult mai obiectivi, însă intervine dezavantajul necunoaşterii în profunzime a culturii organizaţionale, ca element fundamental ce influenţează deciziile managerilor. 
Pe de o parte, este evident faptul că organizaţiile implicate în procesul de învăţământ se confruntă cu dificultăţi în activarea funcţiei de audit public intern. În mod deosebit entităţile care funcţionează în mediul rural întâmpină mari dificultăţi. Şi mediul urban s-a confruntat şi încă se confruntă cu o schemă de personal insuficientă. Ne propunem însă să alocăm un "spaţiu distinct" evidenţierii măsurii în care s-a reuşit implementarea practicii internaţionale de asociere a mai multor unităţi administrativ-teritoriale pentru a beneficia în comun de o structură bine organizată care să asigure funcţionarea auditului public intern.

Raportul privind activitatea de audit intern din sectorul public din România, pentru anul 2018, indică pe de altă parte clar faptul că deşi Legea nr. 672/2002 prevede obligativitatea aplicării de sancţiuni în cazul neorganizării auditului, această faptă constituind contravenţie care determină aplicarea de amenzi cuprinse între 3.000 şi 5.000 de lei, aceste sancţiuni nu au fost aplicate timp de 16 ani care au trecut de la adoptarea acestei legi. Principalii factori de influenţă sunt, din acest punct de vedere, preponderent subiectivi cum sunt, de exemplu, percepţia managerilor sau dorinţa/capacitatea auditorilor de a-şi face simţită prezenţa, de a le explica managerilor măsura în care activitatea lor poate deveni suport în fundamentarea deciziilor manageriale. În acest context, misiunea de bază a auditului rezidă în funcţia sa de consiliere. Consilierea reprezintă activitatea desfăşurată de auditorii interni căreia îi revine sarcina de a adăuga valoare, de a îmbunătăţi procesele guvernanței în cadrul entității publice, fără ca auditorii interni să-și asume în acest context răspunderi manageriale. Consilierea acordată ordonatorilor de credite pentru desfășurarea unor activități complexe, mari consumatoare de resurse financiare, materiale și umane, a permis îmbunătățirea performanței acestor activități și mai buna gestionare a riscurilor asociate.

Majoritatea studiilor abordează problema performanţei manageriale din perspectiva asigurării calităţii serviciilor educaţionale (a relaţiilor managerilor cu personalul didactic, a misiunii şcolii şi a relaţiilor pe care aceasta o dezvoltă cu comunitatea, a reformelor pe care sistemul de învăţământ preuniversitar le-a traversat: din punct de vedere a curriculei şcolare, a resurselor materiale, a relaţiilor comunitare, din punct de vedere managerial - $\mathrm{cu}$ sublinieri aproape nesemnificative asupra a ceea ce înseamnă procesele administrative pentru şcoală) - prin raportare sau nu la contextul european. Există studii care abordează relaţia dintre auditul public intern şi managementul sistemului de învăţământ, abordarea existentă (exclusiv din prisma finanţării de la bugetul de stat şi, implicit, prin raportare la o singură categorie de manageri), din punctul nostru de vedere, nu oferă o imagine completă.

Problematica auditului public intern este extrem de vastă. Stabilirea nivelului la care ea se află în acest moment în România are în vedere în mod deosebit problematici specifice controlului intern şi auditului public intern în general. În ceea ce priveşte auditul public intern în învăţământul din România trebuie menţionate o serie de studii de caz privind analiza dintre domeniile auditate şi nivelul riscurilor (Dumbravă\&Sfetcu, 2013) sau impactul deprecierii profesionale a auditorilor publici interni asupra performanţei auditului (Bush, 2015). Autorii au analizat influenţa resurselor financiare asupra deprecierii profesionale a auditorilor, ca efect al constrângerilor economice asupra pregătirii profesionale a auditorilor şi impactul acestei deprecieri asupra performanţei auditului.

Contextul actual a adus în atenţie educaţia ca unul dintre domeniile care necesită să dispună de o capacitate de adaptabilitate deosebită. Managerii din sistemul educaţional trebuie să fie extrem de atenţi la modul în care toţi partenerii şi participanţii la acest proces resimt nevoia de adaptare la cerinţele şi contextul european prin: descentralizarea sistemului, depolitizare şi profesionalizare, adaptare la realităţile economice şi sociale. În acest context, managerii trebuie să dispună de repere cât mai valide care să le ofere suport în fiecare dintre domeniile în care se desfăşoară procesul decizional.

\section{Referințe}

- Arnove, R., Torres, C.A., Franz, S. (2012). Comparative Education: The Dialectic of the Global and the Local, Rowman\&Littlefield Publishers INC, Plymouth, United Kingdom. 
- $\quad$ Bush, T. (2015). Leadership şi management educaţional. Teorii şi practici actuale, Editura Polirom, Iaşi.

- Chelcea, S. (2001). Metodologia cercetării sociologice: metode cantitative şi calitative, Editura Economică, Bucureşti.

- Cristea, S. 2004). Managementul organizaţiei şcolare, Editura Didactică şi Pedagogică, București.

- Dascălu, E. D. (2016). Factori pentru dimensionarea adecvată a compartimentelor de audit intern din sectorul public. Audit Financiar, 14, Iunie, 585-593.

- Dătculescu, P.(2006). Cercetarea de marketing, Editura Brandbuilders, Otopeni.

- Dumbravă, P., Sfetcu, M. (2013). Analiza legăturii dintre domeniile auditate şi nivelul riscurilor, Audit Financiar, 6 Bucureşti.

- Flonder, D. (2012). Management educaţional: motivarea angajaţilor, Editura PIM, Iaşi.

- Ghiţă, E. (2009). Control intern şi audit public intern, Editura Sitech, Craiova.

- Ghiţă, M. (2005). Audit public intern - concepte şi metodologie, Editura Mirton, Timişoara.

- Ghiţă, M. (2006). Auditul intern în sistemul public, Editura Tribuna Economică, Bucureşti.

- Jinga, I. (2001). Managementul învăţământului, Editura Aldin Press, Bucureşti.

- Macarie, F. (2008). Auditul public intern - suport în procesul decizional, Revista Transilvană de Ştiinţe Administrative, 2(22), Cluj-Napoca, 34-43.

- Marinescu, G. (2007). Management public modern, Editura Tehnopress, Iaşi.

- Mitea, A. (2005). Auditul public intern, de la funcţia de control la funcţia de consiliere în cadrul asistenţei manageriale, Editura Ministerului Administraţiei şi Internelor, Bucureşti.

- Morariu, A., Suciu, G., Stoian, F. (2008). Auditul intern şi guvernanţa corporativă, Editura Universitară, Bucureşti.

- $\quad$ Mureşan, D. (2012). Managementul public, Editura Institutului European, Iaşi.

- $\quad$ Nicolescu, O., Verboncu, I. (2008). Fundamentele managementului organizaţiei, Editura Universitară, Bucureşti.

- $\quad$ Penninckx, M., Vandhoof, J., De Maeyer, S., Van Petegem, P. (2002). Auditing failure: moral competence and school effectiveness, British Educational Research Journal, 28(6), 789-804.

- $\quad$ Sfetcu, M. (2016). Valenţe ale performanţei auditului public intern în învăţământul de stat din România - Teză de doctorat, Cluj-Napoca.

- Tourish, D., Harnegie, O. (1998). Auditing staff-management communications in schools: a framework for evaluating performance, International Journal of Education Management, 12(4), 176-182.

- Țoca, I. (2007). Management educaţional, Editura Didactică şi Pedagogică, Bucureşti.

- Zaiţ, D., Spalanzani, A., Zaiţ, A. (2015). Construcţia strategică a cercetării. Opţiuni metodologice - între logic şi euristic, Editura Sedcom Libris, Iaşi.

- $\quad$ www.acor.ro - site-ul Asociaţiei Comunelor din România - accesat în data de 23.03.2020.

- $\quad$ www.mfp.ro/Audit Public Intern - MFP - site-ul Ministerului Finanţelor Publice care asigură publicitatea tuturor informaţiilor (cadru normativ, ghiduri, manual utile) în materie de audit public intern - ultima dată accesat pe data de 05.04.2020.

- $\quad$ www.mfp.ro/UCAAPI - site-ul Unităţii Centrale de Armonizare pentru Auditul Public Intern - accesat în data de 16.03.2020.

- Legea nr. 672/2002 privind auditul public intern, republicată, cu modificările şi completările ulterioare.

- H.G. nr. 1086/2013 pentru aprobarea Normelor generale privind exercitarea activităţii de audit public intern, cu modificările şi completările ulterioare.

- O.G. nr. 119/1999 privind controlul intern şi controlul financiar preventiv, republicată, cu modificările şi completările ulterioare. 
- $\quad$ O.M.E.N. nr. 5509/2017 privind aprobarea Normelor metodologice privind organizarea şi exercitarea activităţii de audit public intern la nivelul Ministerului Educaţiei Naţionale şi în entităţile publice aflate în subordinea, coordonarea sau sub autoritatea Ministerului Educaţiei Naţionale la nivelul cărora nu există norme specifice de audit public intern, întocmite conform prevederilor Hotărârii Guvernului nr. 1.086/2013, şi a Cartei Auditului Intern aplicabile Compartimentului de audit intern al Ministerului Educaţiei Naţionale.

- OMECTS nr. 5530/2011 privind aprobarea Regulamentului-cadru de organizare şi funcţionare a inspectoratelor şcolare;

- OUG nr. 26/06.06.2012 privind unele măsuri de reducere a cheltuielilor publice şi întărirea disciplinei financiare şi de modificare şi completare a unor acte normative;

- Legea nr. 1 din 5 ianuarie 2011 a Educaţiei naţionale, cu modificările şi completările ulterioare;

- Strategia dezvoltării auditului public intern pentru 2018-2020 - UCAAPI (Ministerul Finanţelor Publice), Bucureşti, 2017;

- Sisteme de responsabilitate publică în administrarea învăţământului preuniversitar, Bucureşti, decembrie - 2007 - Institutul de Ştiinţe ale Educaţiei - Laboratorul management educaţional. 


\title{
Cap. 5. STIMULAREA PROIECTELOR DE CERCETARE - INSTRUMENT PRINCIPAL ÎN ÎMBUNĂTĂȚIREA POZIȚIONĂRII UNIVERSITĂȚILOR ÎN CLASAMENTELE INTERNAȚIONALE
}

\author{
Cornelia Medeleanu ${ }^{1}$, Irina Manolescu ${ }^{2}$ \\ ${ }^{1}$ Universitatea ,Alexandru Ioan Cuza” din Iaşi, Facultatea de Economie şi Administrarea Afacerilor, Iaşi, \\ România,mirela.medeleanu@gmail.com \\ ${ }^{2}$ Universitatea ,Alexandru Ioan Cuza” din Iaşi, Facultatea de Economie şi Administrarea Afacerilor, Iaşi, \\ România,irina.manolescu@gmail.com
}

\begin{abstract}
In a world of quantifications and rankings, the universities have not escaped by hierarchies. The advantages of universities rankings are evaluation of their current world performance, given that internationalization is an essential feature of academic system, and diagnosis of differences between the universities, by different indicators, to provide support for strategies to consolidate their progress. One of the main functions of these rankings can be ensuring prestige and international visibility in education and research area to attract competitive human and financial resources by universities. Research is one of the areas with high impact in the universities rankings, forcing them to allocate important resources to cover specific indicators. The paper reviews the most important universities rankings and highlights the correlations between the allocation of financial resources ( $\& \& D$ expenditure) for research projects at national level and the positions occupied by universities of different countries in international rankings.
\end{abstract}

Keywords: universities ranking, internationalization, research projects, R\&D expenditure.

\section{Introducere}

Într-o lume dominată de cuantificări şi clasamente, universităţile, deşi tradiţional considerate instituţii de o complexitate şi un rol extrem de special în societate, nu au scăpat de ierarhizări. În contextul internaţionalizării accentuate a educaţiei şi cercetării, ca factor esenţial în asigurarea calităţii, clasamentele globale academice oferă universităţilor posibilitatea evaluării şi identificării performanţelor actuale în context mondial sau regional şi asigură suport pentru crearea de strategii prin care să îşi susţină şi să îşi consolideze progresul.

Având ca premise preocupări privind ierarhizarea naţională a universităţilor (de exemplu topul universităţilor americane realizat de U.S. News and World Reports), publicarea, în 2003, a Academic Ranking of Word Universities (ARWU), cunoscut ca Shanghai Ranking, ca rezultat al unui proiect, demarat în 1998, de analiză comparativă a universităţilor de top din China faţă de patru grupuri de universităţi din Statele Unite ale Americii (Liu, 2009), a avut un impact remarcabil atât asupra sistemelor de învăţământ superior din lume, cât şi asupra diferitelor categorii de stakeholderi. Astfel, în următorii ani, au fost elaborate mai multe metodologii de clasificare a universităţilor şi au fost publicate zeci de mii de studii şi materiale despre topurile academice mondiale şi „drumul către excelenţa academică” (Altbach şi Salmi, 2011). Shin şi Toutkoushian (2011) asociază dezvoltarea rapidă a clasamentelor universitare cu creșterea interesului pentru egalitarism în învăţământul superior. Pentru universităţi şi responsabili politici din sistemul de învăţământ superior, ,în căutarea excelenţei” (Peters şi Waterman, 1982) pare a se fi transformat într-o vânătoare a unui loc în topurile universităţilor de clasă mondială, generatoare de confruntare şi nu de competiţie.

O căutare simplă în baze de date, limitată doar la limba engleză, listează zeci de mii de articole care au ca subiect clasamente ale instituţiilor de învăţământ superior sau analize privind universităţi de talie mondială. Spre exemplu, prin interogarea Google Scholar (iulie 2020), s-au obţinut 
următoarele rezultate: "top universities" - cca. 30.800 de înregistrări, "world-class university" cca. 25.900, "world-class universities" - cca. 15.900, "universities ranking" - cca. 2.640, "academic ranking" - cca. 16.100. Analizând distribuţia temporală a documentelor, s-a observat creşterea interesului cercetătorilor pentru studierea diferitelor interferenţe ale clasamentelor universităţilor, peste $65 \%$ dintre studii fiind publicate în ultimii 10 ani. De asemenea, s-a observat spontan preponderenţa autorilor afiliaţi la universităţi din sisteme de învăţământ superior și cercetare fără tradiție recunoscută la nivel mondial, cum ar fi estul și sudul Asiei, Orientul Mijlociu, America Latină, Africa şi a studiilor privind calitatea învăţământului superior şi accederea universităților din aceste regiuni în elita mondială.

Dezvoltarea clasamentelor internaţionale se derulează având în vedere şi principalele funcţii ale acestora, acestea fiind (Andronesi et.al., 2016): asigurarea prestigiului, a vizibilităţii internaţionale, avantaj în atragerea de resurse umane şi financiare competitive pentru universitate, precum şi diagnosticarea decalajelor universităţii pe baza criteriilor considerate esenţiale.

În 2020, IREG Observatory on Academic Ranking and Excellence (IREG Observatory) inventariază 23 de clasamente mondiale ale universităţilor, propuse de diverse organisme independente (centre de cercetare, companii media, agenţii, consultanţi ş.a.). Analizând metodologiile, se observă că mai multe dintre acestea sunt specifice unor domenii de educaţie (ex. economie şi administrarea afacerilor, artă) sau sunt instrumente de comparare în principal între programe de studii. Se constată că doar 11 clasamente îndeplinesc simultan condiţiile: sistem multifactorial de indicatori de evaluare, evaluarea cercetării academice, listarea ierarhizată şi publicarea fără întrerupere a rezultatelor.

Cercetarea academică reprezintă unul dintre domeniile cu impact covârşitor în evaluarea universităţilor, obligând alocarea de către acestea (inclusiv a celor tradiţional orientate către predare) a unor resurse importante pentru acoperirea indicatorilor specifici. Majoritatea clasamentelor internaţionale ale universităţilor iau în considerare acest domeniu, chiar dacă ponderea rezultatelor cercetării în totalul punctelor este foarte variată (de la 3\% în UI GreenMetric Ranking of World Universities, până la 100\% în Nature Index, NTU Ranking şi US News Best Global Universities Rankings).

Analizând, printr-o cercetare sistematică, 13 metodologii de clasificare academică (mondiale şi naţionale), Vernon, Balas şi Momani (2018), evidenţiază importanţa rezultatelor cantitative măsurate prin indicatorii clasamentelor, în contrast cu importanţa redusă a calităţii cercetării, reflectată mai curând prin evaluarea colegială (peer review), deşi aceasta aduce valoare societăţii, prin „descoperiri științifice, rezultate economice și impactul asupra sănătății publice” (Vernon, Balas şi Momani, 2018).

Unul dintre factorii cu impact asupra cercetării (Zare et.al., 2016, Nguyen, 2015, Henry et.al., 2020) este finanţarea cercetării.

Printr-o serie de studii (Meo et.al., 2013a, Meo et.al., 2013b, Meo\&Usmani, 2014) s-au verificat corelaţiile între diverşi indicator privind cercetarea, concluzionându-se că există corelaţii puternice între cheltuielile de cercetare şi dezvoltare şi rezultate ale cercetărilor (documente, patente), h-index, numărul articolelor indexate ISI. O altă concluzie a fost că nu există nicio legătură între PIB/locuitor şi rezultatele cercetării.

Într-un al studiu, Jamjoom şi Jamjoom (2016) identifică slabe corelaţii între PIB/cap de locuitor şi cheltuielile pentru cercetare şi dezvoltare şi rezultate sau indicatori ai cercetării (numărul articolelor, numărul citărilor, h-index ş.a).

Accederea în clasificările mondiale ale universităţilor a devenit un scop pentru unele guverne din lume, care au elaborat şi implementat strategii în acest sens. Sunt identificate două exemple, relativ similare, dar care au avut rezultate diferite: Proiectul 211/935 al Chinei şi Proiectul 5-100 al Rusiei.

Cercetătorii Liu (2009), Zhang, Patton şi Kenney (2013) recunosc contribuţia proiectului 211/935 la expansiunea remarcabilă a învăţământului superior chinez. Guvernul Chinei a investit 
echivalentul a aproximativ echivalentul a 34 mld.USD (Ying, 2011), în două etape (1999-2001 și 2004-2007), pentru a creşte competitivitatea internaţională a 39 de universităţi.

În mai 2013, Guvernul Rusiei a lansat proiectul 5-100, cu scopul de a maximiza poziţia concurenţială a unui grup de universităţi ruse pe piaţa mondială de cercetare și educaţie şi de a lista în 2020 cinci universităţi în top 100. Au fost selectate 21 de universităţi de vârf, în afara celor două care se aflau deja în topuri, una în top 100 şi una în top 500, care au beneficiat de programe individuale de dezvoltare. Iniţial, programul a avut o finanţare de cca. echivalentul a 0,8 mld. USD (site-ul proiectului) pentru perioada 2013-2017, pentru subvenții suplimentare, susținerea dezvoltării în vederea accederii în topurile mondiale, prin creșterea potențialului de cercetare și integrarea inovării în învăţământul superior.

Scopul prezentei cercetări este ca, printr-o trecere în revistă a celor mai importante clasamente universitare globale şi prin analiză cantitativă comparativă, să se pună evidenţă corelaţii între alocările de resurse pentru proiectele de cercetare la nivel naţional şi poziţiile ocupate de universităţile din diferite ţări în clasamentele internaţionale.

\section{Colectarea datelor şi metode de cercetare}

Pentru identificarea reperelor ştiinţifice reprezentative pentru această cercetare, s-a interogat bazele de date prin Google Scholar, utilizând combinarea termenilor cheie, căutarea după expresii şi operatorii booleeni pentru rafinarea rezultatelor. Informaţii despre metodologiile clasamentelor mondiale ale universităţilor au fost preluate de pe site-ul IREG Observatory şi de pe cele ale acestora, de pe care au fost culese şi rezultatelor evaluărilor, în vederea prelucrării statistice.

Datele referitoare la produsul intern brut (PIB) şi la procentul privind cheltuielile de cercetare dezvoltare, pe ţări, au fost preluate din baza de date statistice a Băncii Mondiale. Prelucrarea statistică s-a realizat în Excel şi IBM SPSS Statistics, pentru analiza corelaţiilor dintre cheltuielile pentru cercetare dezvoltare şi numărul universităţilor listate în primele 500 de universităţi ale lumii. Au fost incluse în analiză doar ţările care au cel puţin o universitate clasificată în topul de referinţă.

\section{Rezultate şi discuţii}

Cercetarea academică, sub toate formele (fundamentală, aplicată, pentru inovare şi dezvoltare), este un proces ale cărui rezultate contribuie la performanţa universităţii imediată a universităţii, cu un impact major asupra potenţialului şi capacităţii viitoare ale organizaţiei şi societăţii. Importanţa acesteia este reflectată în majoritatea clasamentelor globale ale universităților (Tabelul 1).

Tabelul 1. Ponderea indicatorilor privind cercetarea în clasamente academice

\begin{tabular}{lcc}
\hline Clasamentul & $\begin{array}{l}\text { Prima } \\
\text { ediţie }\end{array}$ & $\begin{array}{c}\text { Ponderea rezultatelor } \\
\text { cercetării, 2019/2020 }\end{array}$ \\
\hline ShanghaiRanking's Academic Ranking of World Universities & 2003 & $60 \%$ \\
(ARWU) & 2004 & $20 \%$ \\
QS World University Rankings & 2004 & $45 \%$ \\
Ranking Web of Universities (Webometrics) & 2004 & $60 \%$ \\
THE World University Rankings & 2007 & $100 \%$ \\
NTU Ranking & 2008 & $*$ \\
CWTS Leiden Ranking & 2009 & $80 \%$ \\
SCImago Institutions Ranking & 2010 & $40 \%$ \\
RUR Round University Ranking & 2010 & $3 \%$ \\
UI GreenMetric Ranking of World Universities &
\end{tabular}




\begin{tabular}{lcc}
\hline Clasamentul & $\begin{array}{l}\text { Prima } \\
\text { ediţie }\end{array}$ & $\begin{array}{c}\text { Ponderea rezultatelor } \\
\text { cercetării, 2019/2020 }\end{array}$ \\
\hline URAP University Ranking by Academic Performance & 2010 & $85 \%$ \\
CWUR World University Rankings & 2012 & $40 \%$ \\
Nature Index & 2014 & $100 \%$ \\
U-Multirank & 2014 & $*$ \\
US News Best Global Universities Rankings & 2014 & $100 \%$ \\
Reuters Top 100: The World's Most Innovative Universities & 2015 & $*$ \\
Three University Missions Moscow International University & 2017 & $25 \%$ \\
Ranking & * Informaţii indisponibile. \\
\hline \multicolumn{2}{c}{ Sursa: Metodologiile clasamentelor }
\end{tabular}

Trei dintre clasamentele globale universitare, respectiv NTU Ranking, Nature Index, US News Best Global Universities Rankingsn evaluează exclusiv cercetarea. ShanghaiRanking's Academic Ranking of World Universities (ARWU) acordă o pondere de $60 \%$ indicatorilor de calitate ai cercetării, similar cu THE World University Rankings.

Interesul manifestat de către cercetătorii din zone fără tradiţie în învăţământul superior şi în cercetare avansată se poate corela cu tendinţa sistemelor de a-şi transforma universităţile în şcoli de elită mondială. În Fig. 1 este prezentată o proiecţie grafică a evoluţiei numărului de universităţi de top situate în primele 100, respectiv 500 de locuri ale clasamentului, pe regiuni.

Clasificarea pe regiuni şi repartizarea ţărilor a fost realizată în funcţie de criterii geografice, tradiţie, afinităţi culturale. Prezentarea regiunilor în grafic este realizată în ordinea alfabetică. În regiunea „Asia de Est” a fost inclusă o singură ţară, Japonia, având în vedere că prezintă caracteristici diferite faţă de celelalte sisteme naţionale din regiune. Au fost utilizate datele din clasamentul Shanghai Ranking's Academic Ranking of World Universities (ARWU), deoarece vechimea acestuia asigură cea mai bună acoperire temporală.

Se observă tendinţe importante de creştere a numărului de universităţi care au intrat în primele 500 de locuri ale clasamentului mondial pentru regiunea Asia de Sud Est, adevăraţi „tigri asiatici” academici şi Australia şi Oceania. Tendinţe în creştere se pot vizualiza şi pentru Orientul Mijlociu, America Latină şi Africa, dar acestea au un număr total redus de universităţi în topuri. De remarcat este creşterea numărului de universităţi clasate în primele 100 locuri din Australia şi Oceania, Asia de Sud-Est şi Orientul Mijlociu.

În acest context al accederii ,tigrilor” în elita internaţională academică, se înregistrează declasarea universităţilor din America de Nord (în principal, din Statele Unite ale Americii), Asia de Est (respectiv, Japonia) şi Europa.

În Fig. 2, este evidenţiată relația dintre numărul universităților și cheltuielile naţionale de cercetare-dezvoltare, utilizând informaţiile din ARWU, ediţia 2016 şi cheltuielile de cercetare dezvoltare din 2015. Alegerea anului 2015 pentru exemplificare a fost determinată de faptul că în baza de date sunt mai puţine înregistrări lipsă faţă de anii următori. Trebuie menţionat că indicatorul include toate cheltuielile destinate cercetării şi dezvoltării, chiar dacă fondurile nu sunt consumate în totalitate în universităţi. 


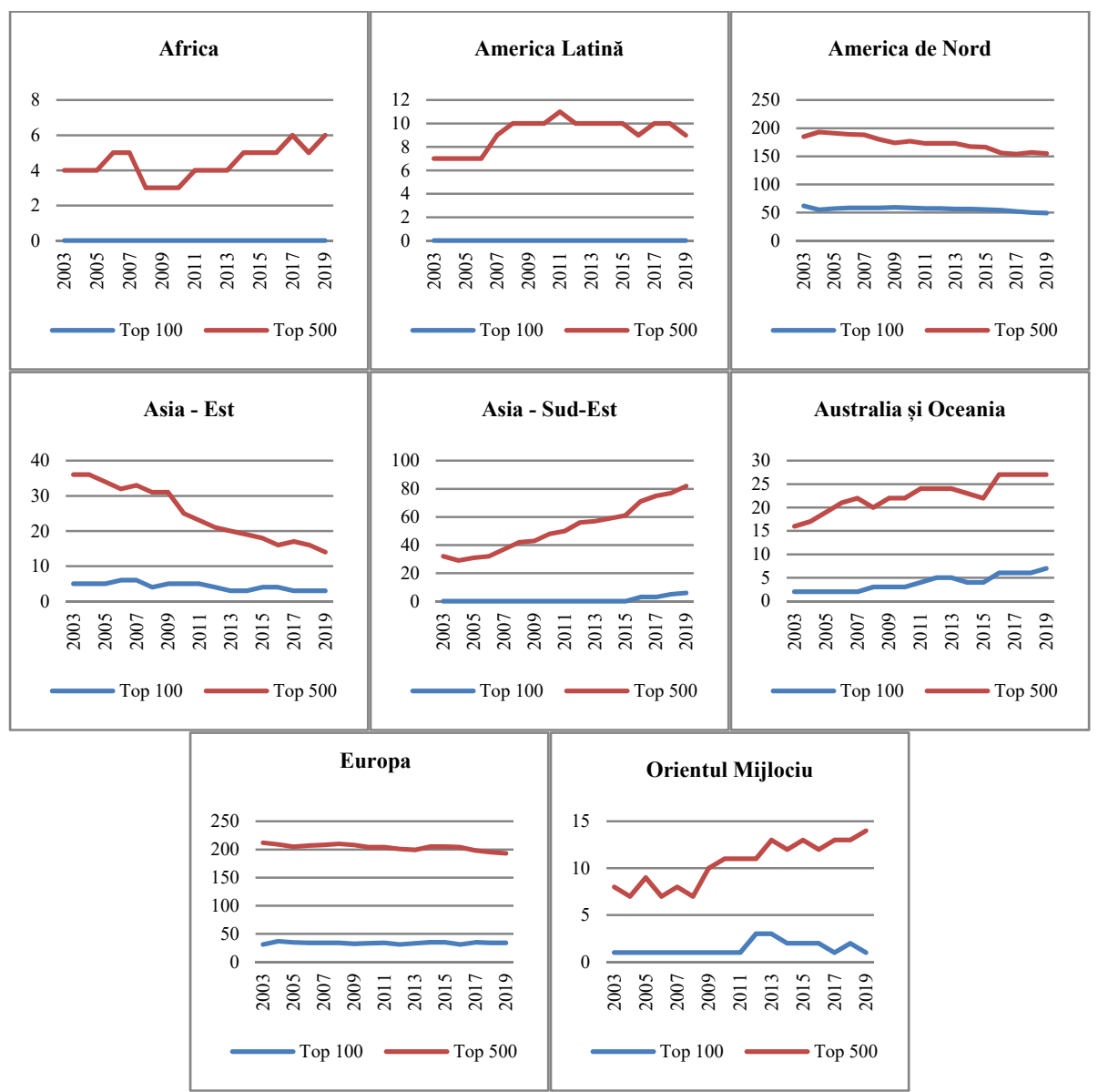

Fig. 1. Evoluţia numărului de universităţi în top 100, respectiv 500, pe regiuni Sursa: Datele primare din clasamentele ARWU 2003-2019, prelucrate de autori

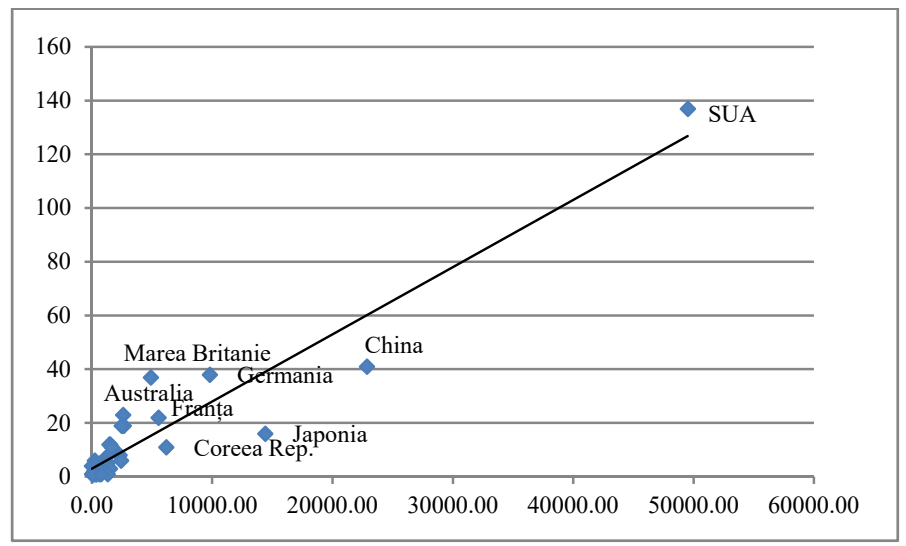

Fig. 2. Relația dintre numărul universităţilor și cheltuielile naționale de cercetare-dezvoltare: ARWU 500_2016/CCD_2015

Sursa: Date primare preluate din clasamentele ARWU şi din baza de date a Băncii Mondiale şi prelucrate de autori 
Calculând mediile cheltuielilor realizate pentru cercetare şi dezvoltare şi valorile minime (Tabelul 2) pentru prezenţa în clasamentul ARWU, din anii 2015 şi 2017, se poate observa că media cheltuielilor pentru cercetare şi dezvoltare este de aproximativ două ori mai mare în ţările care au cel puţin o universitate în primele 100, faţă de cele care au cel puțin o universitate în top 500, respectiv 2,05 (2015) şi 1,91 (2017). Analizând cele două valori, reiese o ipoteză de cercetat: pe măsura dezvoltării sistemului sau universităţii, se îmbunătăţeşte capacitatea de a genera performanţe, prin acumularea bogăţiei (materiale, de cunoaştere / de cunoştinţe, de procese ş.a.), într-un ,efect de scară”. Extinzând clasamentul către 1000 de locuri (în 2017, doar 800), se constată scăderea mediei cheltuielilor cu cercetarea şi dezvoltarea. Creşterea volumului cheltuielilor în timp (2017 faţă de 2015), poate fi generată de: creşterea PIB sau creșterea procentului din PIB pentru cheltuieli de cercetare şi dezvoltare.

Tabelul 2. Media și valoarea minimă a cheltuielilor naționale pentru cercetare-dezvoltare şi prezenţa în clasamentele ARWU

\begin{tabular}{lllll}
\hline Clasament & Media (mld. USD) & \multicolumn{2}{c}{ Valoarea minimă (mld. USD) } \\
& 2015 & 2017 & 2015 & 2017 \\
\hline 100 & 6923,00 & 8722,80 & 677,90 & 703,35 \\
500 & 3366,53 & 4555,50 & 32,16 & 34,61 \\
800 & & 3226,31 & & 8,70 \\
\hline
\end{tabular}

Sursa: Date primare preluate din baza de date a Băncii Mondiale şi prelucrate de autori

Valorile minime identificate nu echivalează cu nişte condiţionări de genul ,suma X asigură un loc" în clasamentul vizat, având în vedere că există țări care avut cheltuieli mai mari pentru cercetare şi dezvoltare, fără a avea o universitate de talie mondială, dar pot constitui repere pentru planificarea unor resurse.

Pentru a verifica puterea asocierii între variabilele analizate, s-au calculat coeficientul de corelaţie Pearson (Tabelul 3).

Având în vedere rezultatele coeficientului Pearson, $\mathrm{r}_{100}=0.888, \mathrm{p} \rightarrow 0$, pentru perechea CCD_2015 şi Nr. univ. ARWU 100_2016 şi $\mathrm{r}_{500}=0.844, \mathrm{p} \rightarrow 0$, pentru perechea CCD_2015 şi Nr. univ. ARWU 500_2016, se constată că există o corelaţie pozitivă şi puternică între cheltuielile naţionale pentru cercetare şi dezvoltare şi numărul universităţilor clasate în primele 100, respectiv 500 ale lumii, în clasamentul ARWU. Rezultatele obţinute sunt semnificative pentru un prag de încredere de $\mathrm{p}=0,01$.

Tabelul 3. Coeficientul de corelaţie Pearson

\begin{tabular}{llll}
\hline & & Nr. univ. ARWU & Nr. univ. ARWU \\
& $100 \_2016$ & $500 \_2016$ \\
\hline CCD_2015 & Coeficientul de corelaţie Pearson &, $888^{* *}$ &, $844^{* *}$ \\
(mld. USD) &, 000 &, 000 \\
& Sig. (2-tailed) & 67 & 67 \\
& $\mathrm{~N} \quad{ }^{* *}$. Corelaţia este semnificativă la nivelul 0.01 (2-tailed)
\end{tabular}

Pentru un aport suplimentar de informaţie, s-au generat grafice comparative (Fig. 3 - Fig. 6), pentru patru ţări: China (Fig. 3), care a implementat proiectul 985 pentru promovarea şi dezvoltarea sistemului de învăţământ superior, Rusia (Fig. 4), care finanţat Proiectul 5-100 şi pentru Statele Unite (Fig. 5) şi Marea Britanie (Fig. 6), care domină primele locuri ale clasamentelor globale mondiale. 
China

Cheltuieli pentru cercetare şi dezvoltare (US\$)

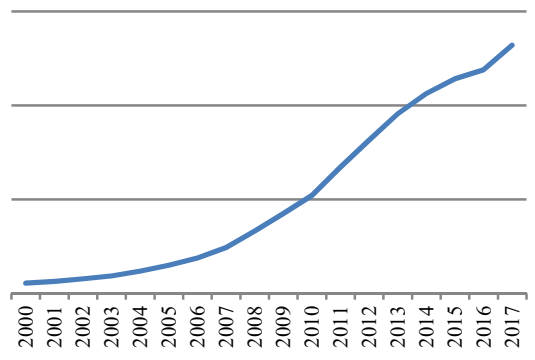

China

Numărul universităţilor în Top 100 şi Top 500

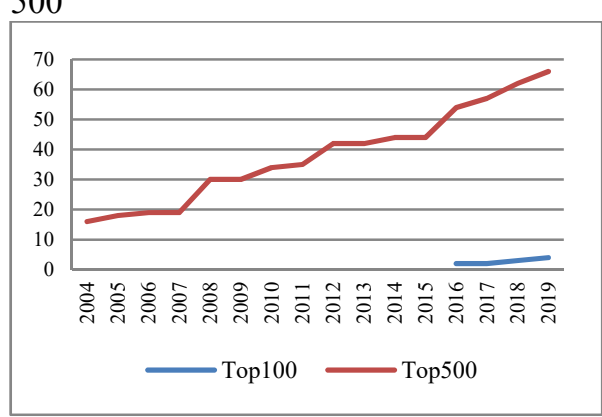

Fig. 3. Cheltuielile pentru cercetare şi dezvoltare vs. Evoluţia numărului universităţilor în ARWU pentru China

Sursa: Date primare preluate din clasamentele ARWU şi din baza de date a Băncii Mondiale şi prelucrate de autori

Observând cele două imagini, am putea deduce că politicile, strategiile şi proiectele adoptate şi implementate în China, susţinute de o finanţare într-o creştere aproape logaritmică a activităţilor de cercetare şi dezvoltare, sunt eficiente.

Rusia

Cheltuieli pentru cercetare şi dezvoltare (US\$)

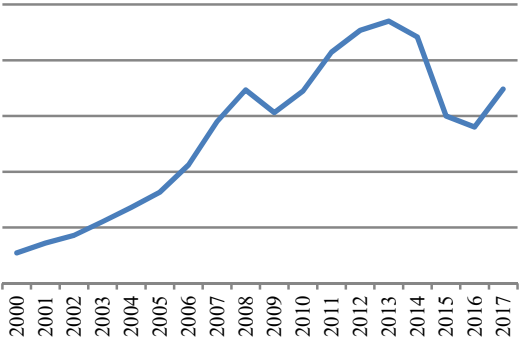

Rusia

Numărul universităţilor în Top 100 şi Top 500

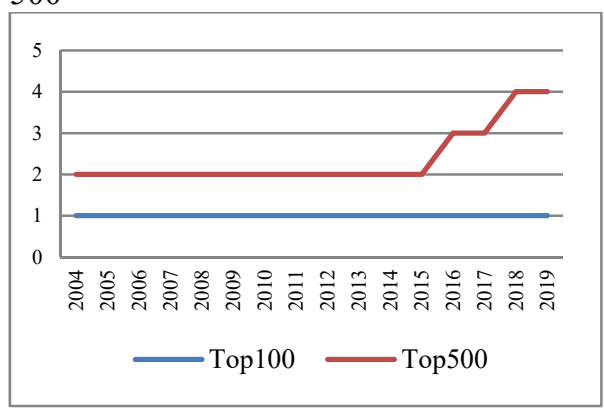

Fig. 4. Cheltuielile pentru cercetare şi dezvoltare vs. Evoluţia numărului universităţilor în ARWU pentru Rusia

Sursa: Date primare preluate din clasamentele ARWU şi din baza de date a Băncii Mondiale şi prelucrate de autori

$\mathrm{Cu}$ scopuri precise, finanţare suplimentară şi proiecte de dezvoltare a universităţilor integrate naţional, Rusia nu a reuşit, până în 2020, să atingă obiectivul stabilit prin Proiectul 5-100. În 2019, în ARWU a fost clasificată în top 100 o singura universitate care era şi la începutul perioadei de referinţă. 
SUA

Cheltuieli pentru cercetare şi dezvoltare (US\$)

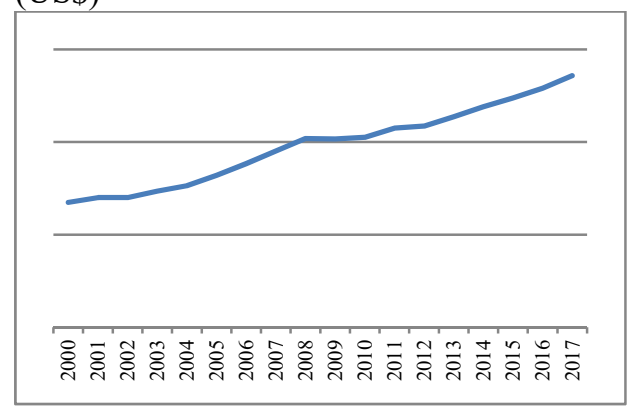

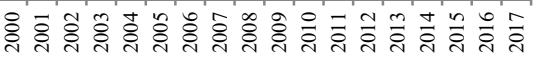

SUA

Numărul universităţilor în ARWU

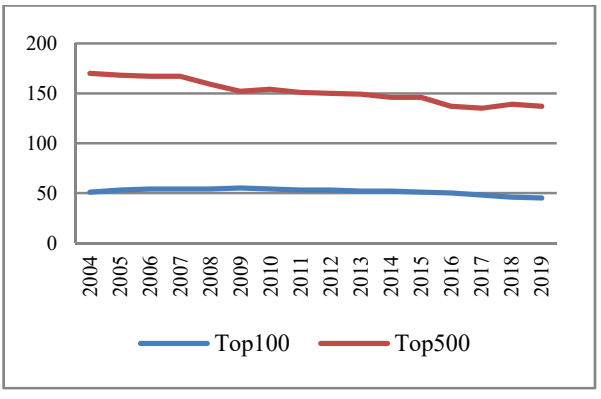

Fig. 4. Cheltuielile pentru cercetare şi dezvoltare vs. Evoluţia numărului universităţilor în ARWU pentru SUA

Sursa: Date primare preluate din clasamentele ARWU şi din baza de date a Băncii Mondiale şi prelucrate de autori

Marea Britanie

Cheltuieli pentru cercetare şi dezvoltare (US\$)

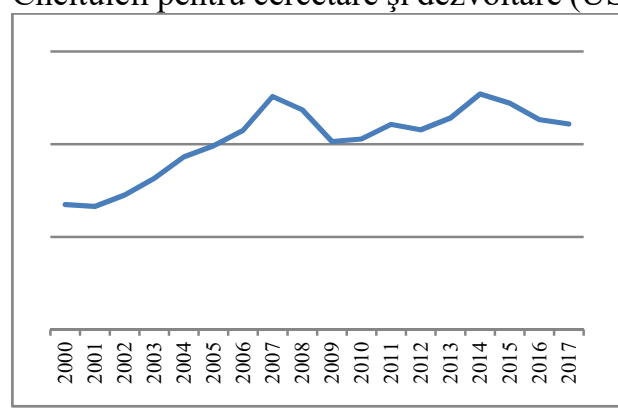

Marea Britanie

Numărul universităţilor în ARWU

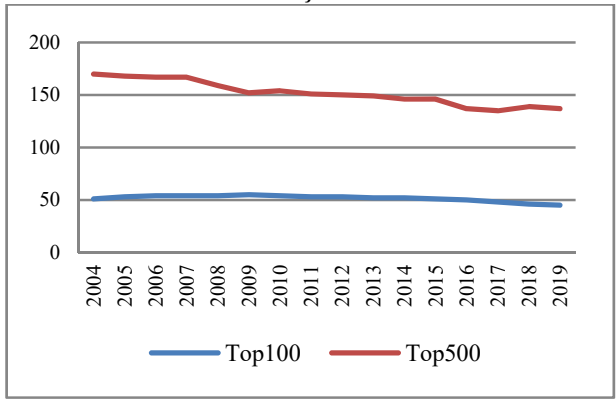

Fig. 5. Cheltuielile pentru cercetare şi dezvoltare vs. Evoluţia numărului universităţilor în ARWU pentru Marea Britanie

Sursa: Date primare preluate din clasamentele ARWU şi din baza de date a Băncii Mondiale şi prelucrate de autori

Statele Unite şi Marea Britanie înregistrează declasări ale universităţilor, mai ales în intervalul 100-500, în ciuda finanţării mari a cercetării şi dezvoltării, mai ales de către Statele Unite.

Rezultatele obţinute sunt limitate de corectitudinea datelor introduse în bazele de date sau prezentate pe site-uri, chiar dacă, în măsura capacităţilor tehnice şi informaţionale, autorii au corectat erori identificate. De asemenea, informaţiile au fost limitate la documente în limba engleză, cu excepţia studiului colectivului de cercetători (Andronesi şi colegii), care au elaborat Metaranking-ul pentru universităţile din România.

\section{Concluzii}

Studiul propus prezintă doar un singur factor, respectiv efortul financiar naţional pentru dezvoltare şi inovare, reprezentat prin cheltuielile pentru cercetare şi dezvoltare şi analizează, prin modele diferite, influenţa acestuia asupra capacităţii sistemului de educaţie şi cercetare, definită prin numărul de universităţi de ligă mondială, listate în primele 100 sau primele 500 ale lumii, fără a realiza corelaţii directe cu performanţele universităţilor.

S-a constatat că există o corelaţie directă şi puternică între stimularea financiară a cercetării (cheltuieli pentru cercetare şi dezvoltare) şi performanţa academică naţională a universităţilor (numărul universităţilor de clasă mondială). 
Noi studii vor fi abordate în viitor, în continuarea acestuia, introducând în cercetare date din mai multe clasamente internaţionale, în vederea definirii unor modele culturale de dezvoltare (ex. Asia Vs. Statele Unite / Europa).

\section{Bibliografie}

- 5-100 Russian Academic Excelence Project, https://www.5top100.ru/en/about/more-about/, ultima accesare 21 iunie 2020.

- $\quad$ Altbach, P.G. [Editor]; Salmi, J. [Editor]. (2011). The road to academic excellence: the making of world-class research universities (English). Directions in development; human development Washington, D.C.: World Bank Group.

- Andronesi, O., Banabic, D., Buzea, C., David, D., Florian, B., Miroiu, A., Murgescu, B., Prisăcariu, A. și Vlăsceanu, L (2016). Raport asupra exercițiului național de Metaranking Universitar-2016 al Ministerului Educaţiei Naționale și Cercetării Științifice, în Revista de Politica Știinţei și Scientometrie - serie nouă, 5(4), 267-277.

- Henry, C., Ghani, N. A. M., Hamid, U. M. A., \& Bakar, A. N. (2020). Factors Contributing towards Research Productivity in Higher Education. International Journal of Evaluation and Research in Education, 9(1), 203-211.

- IREG Observatory on Academic Ranking of Excellence, https://ireg-observatory.org/, ultima accesare 09.06.2020.

- Jamjoom, B. A., \& Jamjoom, A. B. (2016). Impact of country-specific characteristics on scientific productivity in clinical neurology research. Eneurologicalsci, 4, 1-3.

- Liu, N. C. (2009). The story of academic ranking of world universities. International Higher Education, (54).

- Meo, S. A., \& Usmani, A. M. (2014). Impact of R\&D expenditures on research publications, patents and high-tech exports among European countries. European Review for Medical and Pharmacological Sciences, 18(1), 1-9.

- Meo, S. A., Al Masri, A. A., Usmani, A. M., Memon, A. N., \& Zaidi, S. Z. (2013b). Impact of GDP, spending on R\&D, number of universities and scientific journals on research publications among Asian countries. PloS one, 8(6), e66449.

- Meo, S. A., Usmani, A. M., Vohra, M. S., \& Bukhari, I. A. (2013a). Impact of GDP, spending on $\mathrm{R} \& \mathrm{D}$, number of universities and scientific journals on research publications in pharmacological sciences in Middle East. Eur Rev Med Pharmacol Sci, 17(20), 2697-705.

- Nguyen, Q. H. (2015). Factors Influencing the research productivity of academics at the research-oriented university in Vietnam. Theses submitted to the School of Education \& Professional Studies in Fulfilment of the requirements for the degree of doctor of education.

- $\quad$ Peters, T. J., \& Waterman Jr, R. H. (1982). In Search of Excellence-Lessons from America's Best-Run Companies New York. Peters, T./Waterman.

- Salmi, J. (2009). The challenge of establishing world class universities. The World Bank Group.

- ShanghaiRanking's Academic Ranking of World Universities (ARWU), www.shanghairanking.com

- Shin, J. C., \& Toutkoushian, R. K. (2011). The past, present, and future of university rankings. In University rankings (pp. 1-16). Springer, Dordrecht.

- Vernon, M. M., Balas, E. A., \& Momani, S. (2018). Are university rankings useful to improve research? A systematic review. PloS one, 13(3), e0193762.

- Ying, C. (2011). A Reflection on the Effects of the 985 Project. Chinese Education \& Society, 44(5), 19-30. 
- Zare, M. N., Pourkarimi, J., Salehi, G. Z., \& Rezaeian, S. (2016). In search of a world-class university in Iran. Journal of Applied Research in Higher Education, Vol. 8 Iss 4 pp. 522 - 539

- Zhang, H., Patton, D., \& Kenney, M. (2013). Building global-class universities: Assessing the impact of the 985 Project. Research Policy, 42(3), 765-775.

- $\quad$ Ranking Web of Universities (Webometrics), www.webometrics.info

- CWTS Leiden Ranking, www.leidenranking.com

- CWUR World University Rankings / Center for World University Rankings, www.cwur.org

- Emerging/Trendence Global University Employability Ranking, www.emerging.fr

- Nature Index, www.natureindex.com

- NTU Ranking, www.nturanking.lis.ntu.edu.tw/

- QS World University Rankings, www.topuniversities.com

- Reuters Top 100: The World's Most Innovative Universities, www.reuters.com

- $\quad$ RUR Round University Ranking, www.roundranking.com

- SCImago Institutions Ranking, www.scimagolab.com

- $\quad$ THE World University Rankings, www.timeshighereducation.com

- U-Multirank, www.umultirank.org

- UI GreenMetric Ranking of World Universities, www.greenmetric.ui.ac.id/what-isgreenmetric/

- $\quad$ uniRank University Ranking ${ }^{\mathrm{TM}}$, www.4icu.org

- URAP University Ranking by Academic Performance, www.urapcenter.org

- US News Best Global Universities Rankings, www.usnews.com

- Youth Incorporated Global University Rankings, www.youthincmag.com

- Forbes The Best Business Schools Ranking, www.forbes.com

- BoF Global Graduate Business Ranking, www.businessoffashion.com

- Three University Missions Moscow International University Ranking, www.mosiur.org 


\title{
Cap. 6. MANAGEMENTUL PROIECTELOR EUROPENE ÎN DOMENIUL CERCETĂRII - BUNE PRACTICI PENTRU TINERII CERCETĂTORI
}

\author{
Adriana Prodan ${ }^{1}$, Irina Manolescu ${ }^{2}$, Constantin-Marius Apostoaie ${ }^{3}$ \\ ${ }^{1}$ Universitatea ,Alexandru Ioan Cuza” din Iaşi, Facultatea de Economie şi Administrarea Afacerilor, Iaşi, \\ România,pada@uaic.ro \\ ${ }^{2}$ Universitatea „Alexandru Ioan Cuza” din Iași, Facultatea de Economie și Administrarea Afacerilor, Iași, \\ România,irina.manolescu@gmail.com \\ ${ }^{3}$ Universitatea „,Alexandru Ioan Cuza” din Iaşi, Facultatea de Economie şi Administrarea Afacerilor, Iaşi, \\ România,marius.apostoaie@uaic.ro
}

\begin{abstract}
This paper focuses on the team's research activity in the field of European Project Management and follows the main themes proposed to the $\mathrm{PhD}$ students. The study will be focus on principles and practices specific to EU research project management, EU-funded research projects, opportunities regarding EU research projects and the Horizon 2020 program, Project Cycle Management and Project Sustainability and good practices from other countries. The research activity aims to provide support to young researchers, holding a $\mathrm{PhD}$, starting or consolidating a research team, after they have setup an independent research program and that have obtained significant results in their field. The results will also be available to researchers working abroad and who wish to run research projects in research institutions in Romania. As a starting point, two strategies will be analyzed; SNCDI 2020 and Horizon 2020, then the literature will be reviewed to identify reports, articles on trends/evolutions in Romanian research. After conducting a critical and comprehensive literature review and identifying the current state of research, we will carry out a qualitative analysis of main research projects (title, key words, field, researcher affiliation, funded/non-funded project, etc.) funded by a Romanian lines of funding that are representative for top researchers. We will take into account the main research topics submitted in competitions launched by UEFISCDI and analyze, namely, the „Research Projects for stimulating the setting-up of young independent research teams - type TE”. The case study will also include the application of questionnaires to $\mathrm{PhD}$ advisers, researchers and doctoral students in order to identify their main lines of research and establish that these are in accordance with SNCDI 2020 and Horizon 2020 strategies. The research impact will be of great importance not only for the university and local community but for the entire academic community of Romania. We hope that this research, we will motivate our $\mathrm{PhD}$ students to get involved in attracting more financing opportunities.
\end{abstract}

Keywords: research projects, Project Cycle Management, Project Sustainability.

\section{Context}

Acest studiu are ca punct de plecare experienţa autorilor din cadrul proiectului Jean Monnet Sustainable Education through European Studies for Young Researchers (SESYR), derulat la Universitatea Alexandru Ioan Cuza din Iaşi, în perioada 2017-2020. O activitate distinctă în cadrul acestui proiect a constituit-o derularea modulului Managementul proiectelor europene pentru tinerii cercetători, având ca lectori cei trei autori iar ca grup ţintă doctoranzii Şcolii doctorale a Facultăţii de Economie şi Administrarea Afacerilor ai Universităţii Alexandru Ioan Cuza din Iaşi. Propunerea acestei activităţi a fost motivată de importanţa competenţelor de management de proiect pentru tinerii cercetători, competențe care le pot asigura finanţarea cercetărilor proprii, o mai bună vizibilitate şi pot conduce la stimularea carierei lor.

Conţinutul modulului a inclus aspecte generale - Principii şi practici specifice proiectelor de cercetare la nivelul UE, tehnice - Documentaţia pentru finanţarea proiectelor de cercetare din fondurile programelor UE, Managementul ciclului de proiect (PCM) - planificare, organizare, implementare, monitorizare şi evaluare, informative - Oportunităţi de finanţare a proiectelor de 
cercetare în UE şi programul Orizont 2020, precum şi de bune practici - Capitalizarea rezultatelor cercetării şi sustenabilitatea proiectelor.

Discuţiile avute în cadrul întâlnirilor realizate la acest modul (56 de ore în fiecare din cei 3 ani de implementare ai proiectului) au inclus şi aplicarea unor instrumente de învăţare sub forma unor chestionare, precum şi problematizarea unor aspecte specifice managementului proiectelor de cercetare, sub forma unor şedinţe de tip focus-grup. Rezultatele obţinute în urma acestor metode şi instrumentele sunt prezentate selectiv în acest articol.

\section{Importanța managementului proiectelor în domeniul cercetării}

Proiectele şi finanţările diferă în funcţie de organizaţie. Universităţile sunt considerate organizaţii tipice pentru implementarea proiectelor şi obţinerea finanţărilor nerambursabile, de multe ori acestea dezvoltând o structură organizatorică matricială. Activitatea de cercetare se pretează la organizarea pe proiecte (atât în universităţi, instituţii de cercetare, cât şi în firme departamentul de cercetare-dezvoltare), fiind finanţată prin programe specifice, necesitând resursă umană înalt calificată şi o monitorizare atentă a rezultatelor.

Competenţele de management al proiectelor devin în acest context esenţiale, în special pentru persoanele implicate direct în cercetare. Interesant este că începuturile acestui domeniu au fost fragmentate, orientate spre cazuri particulare şi puţin formalizate, dar în prezent s-a ajuns la un nivel de standardizare şi instituţionalizare remarcabil. Treptat, în fiecare profesie şi sector, o identitate specifică a fost construită pentru managerii de proiecte (Garel, 2013). Cultura organizaţională are impact major asupra implicării în proiecte, aceasta devenind un factor cu o influenţă din ce în ce mai mare în domeniul managementului de proiect (Uchitpe, Uddin \& Crawford, 2016).

Universităţile au anumite caracteristici - inerţie, structuri de management colegiale, abordare de tip "turn de fildeş". Acestea îşi lasă amprenta asupra modelelor de implementare a proiectelor. Astfel, universitatea de tip corporativ devine un instrument important în cadrul modelului de dezvoltare durabilă şi de orientare a culturii proiectelor ținând cont de interesele diferitelor părți interesate interne și externe (Tsipesa et al., 2016).

În managementul proiectelor de cercetare, abordarea poate fi realizată la nivel strategic (de sistem sau organizaţional) şi la nivel operaţional (parametrii proiectului).

Pentru ca universităţile să obţină avantaje nete din investiţia lor în proiecte, trebuie să existe o legătură clară între rezultatele create de proiecte și cerințele strategice ale organizației. Universităţile care au pus la punct structuri şi instrumente prin care să se realizeze o concordanţă între rezultatele proiectelor şi obiectivele lor organizaţionale vor fi mai bine plasate strategic. S-au pus în evidenţă patru elemente cheie pentru îmbunătățirea performanței proiectelor și, prin urmare, crearea de valoare pentru organizații: (1) gestionarea portofoliului, axată pe selectarea proiectelor şi programelor potrivite pentru a sprijini strategia organizației; (2) supervizarea proiectului, prin furnizarea unei legături directe între managementul superior şi managerul de proiect sau de program, pe întreg ciclul de viaţă al proiectului; (3) înfiinţarea unităţii funcţionale de mangement al proiectelor; (4) orientarea întregii culturi organizaţionale spre proiecte și programe (Too \& Weaver, 2014).

La nivel strategic, universitatea poate decide poziţionarea şi, implicit, proiectele aferente în funcţie de gradul său de conectivitate cu mediul de afaceri şi social (scăzut sau ridicat), caracterul internaţional al activităţilor sale (activ sau pasiv) sau în funcţie de rolul pe care îl atribuie cercetării (prioritar sau secundar). Abordarea strategică necesită aşadar manifestarea unei poziţionări conştiente în ceea ce priveşte nivelul dorit de relevanţă a proiectelor - regional, naţional sau internaţional, integrat sau specific, strict de cercetare sau de dezvoltare. Pe fiecare dintre aceste paliere, există stakeholderi relevanţi (Marić, 2013), iar universitatea are rolul de a-i identifica şi de a-i implica în stabilirea priorităţilor de cercetare şi în valorificarea rezultatelor ei. Categoriile de stakeholderi specifici universităţilor sunt entităţile guvernamentale, managementul (rectoratul), angajaţii, clienţii / beneficiarii direcţi, furnizorii, concurenţii, comunităţi, entităţi / agenţii de 
reglementare. Din analiza priorităţilor şi posibilităţilor de parteneriat cu aceşti stakeholderi, pot rezulta proiecte strategice aliniate la cele 8 Obiective de Dezvoltare ale Mileniului (ODM) sau, mai nou, la cele 17 Obiective de Dezvoltare Durabilă (ODD), ce corespund ambiţiilor societăţii de realizare a unui climat de prosperitate, echitate, libertate, demnitate și pace (Nelsona, Cropper, 2016) sau proiecte mult mai pragmatice, de lansare a unei noi linii de studii. Instituțiile de învățământ superior sunt actorii tipici pentru a ilustra mediul extrem de complex al managementului proiectelor - iniţiative multiple, finanţate de diferiţi sponsori, executate în parteneriat cu clienți diferiți, implementate simultan și care solicită acces la aceleași resurse limitate (Baumanna et al., 2016).

La nivel operațional, accentul cade pe setarea adecvată a parametrilor proiectului, organizarea echipei de proiect şi competenţele managerului de proiect. $\mathrm{O}$ abordare interesantă derivă din teoria managementului talentelor, sub toate aspectele implicate (Tamaş \& Abrudan, 2018):

- existenţa unui set integrat de procese și proceduri pentru identificarea, atragerea, integrarea, antrenarea, reținerea, dezvoltarea și pregătirea unei succesiuni de lideri, în vederea îndeplinirii obiectivelor strategice;

- $\quad$ abilitatea universităţilor de a atrage și cultiva talente-cheie pentru a satisface nevoi curente şi viitoare ale organizaţiei;

- iniţiativele individuale care au potenţialul de a îmbunătăţi semnificativ performanţa curentă și cea viitoare a universităţii.

Orientarea universităţilor în contextul abordării specifice managementul talentelor poate fi de tip elitist, spre identificarea performerilor de calibru sau de tip incluziv, de recunoaștere a punctelor forte și a ariilor de îmbunătățit în contextul rolului fiecărui membru al echipei.

În mediul universitar, talentul este un element esenţial; tradiţional, elita societăţii urma o carieră academică. Performanţa ca manager de proiect în cadru academic este însă intrinsec legată de constrângerile instituţionale şi de capacitatea de a valorifica oportunităţile de schimbare (Bresnen, 2016). O analiză a profilurilor actorilor relevanţi în managementul proiectelor de cercetare (de exemplu tânărul aspirant, cercetătorul junior performant, specialistul, relaționistul, seniorul realizat), precum şi conştientizarea problemelor de management al resurselor umane (evaluare de tip centralizat, deficit de personal didactic / de cercetare, plecarea din sistem a personalului-suport demotivat, niveluri extrem de diferite de satisfacție a angajaţilor) pot duce la o conturare a măsurilor adecvate de îmbunătăţire a organizării şi coordonării proiectelor.

Mediul universitar reprezintă terenul propice iniţiativelor individuale de cercetare, fără a ţine cont de priorităţile organizaţionale. Perspectiva individualistă în cadrul proiectelor de cercetare va presupune faptul că managerul de proiect se concentrează pe furnizarea livrabilelor la timp, în limita bugetului și cu o calitate specificată. Perspectiva organizațională presupune faptul că managerul de proiect va pune accentul pe sprijinirea creării de valori în organizația sa, proiectul fiind privit ca o entitate temporară, înființată de organizația sa de bază pentru a efectua o anumită misiune în numele acesteia (Andersen, 2016). Omiterea viziunii organizaţionale va conduce la o lipsă de corelaţie între fezabilitatea și relevanța proiectului (Schjetleina, Haavaldsena \& Lohne, 2016).

Rezultatele proiectelor de cercetare vor depinde aşadar de: potenţialul instituţional (reputaţia instituţiei, tradiţia în anumite domenii de cercetare, condiţiile de lucru, echipamente, baze de date, suport de publicare - recenzare, traducere, finanţare, networking), potenţialul individual (selecţia cercetătorilor joacă un rol esenţial), efortul individual (determinat de auto-motivație şi stimulii organizaţionali), precum şi de anumiţi factori externi (noi provocări societale majore, schimbări legislative, deficienţe ale sistemelor externe de reglementare / evaluare).

Pentru a se orienta spre proiecte, universităţile vor sprijini selecţia personalului cu competenţe specifice managementului de proiect şi / sau vor sprijini formarea şi dezvoltarea acestor competențe. Se consideră însă că există un decalaj între ceea ce oferă furnizorii de educaţie și ceea ce este necesar pentru a face față proiectelor din mediul complex din prezent. Au fost formulate trei domenii principale pe care instituțiile de învățământ ar trebui să le considere în dezvoltarea 
managerilor de proiect: 1) dezvoltarea gândirii critice pentru a face față complexității, 2) dezvoltarea abilităților interpersonale și leadership, nu doar a abilităților tehnice și 3) rezistenţa la vicisitudinile inerente contextului realităţii, nu doar a condiţiilor „de laborator” (Ramazani \& Jergeas, 2015).

O cerinţă specială este a orientării mai susţinute către inovare. Strategia inovativă este potenţată de teoria "oceanului albastru" (http://www.blueoceanstrategy.com), care presupune crearea unei piețe încă nedescoperite, considerarea competiției drept nerelevante, imaginarea și crearea unei noi cereri. Strategiile pentru originalitate presupun încercări pentru eșuare, experimentare, progrese treptate, învățarea necalificată.

De altfel, progresele în teoria managementului de proiect sunt susţinute structural de elementele specifice culturii academice şi domeniului cercetării.

Astfel, teoria agilităţii în managementul proiectelor a venit să înlocuiască viziunea deterministă, cea a planificării şi implementării riguroase a proiectelor. Această teorie vizează următoarele aspecte: agilitatea ar trebui considerată performanța unei echipe, mai degrabă decât un simplu adjectiv pentru practici și metode; agilitatea, ca performanță, poate depinde de o combinație de factori (organizație, echipă și proiect); nivelul de performanță poate fi măsurat prin intermediul a doi factori principali: schimbarea rapidă a planificării proiectului și implicarea activă a beneficiarilor (Conforto et al., 2016). Managementul proiectelor devine extrem de complex și, prin urmare, un teren adecvat pentru implementarea aplicaţiilor creative, spontane și intuitive, pentru obiective declarate într-un mediu în continuă schimbare. Această abordare pragmatică a aplicării teoriilor existente defineşte moduri noi de a realiza un proiect de succes (Klein, Biesenthal \& Dehlin, 2015).

Proiectele sunt dominate de tensiuni greu gestionabile, dilematice - teorie vs. practică, rigoare vs. relevanță, tensiuni între valori (ceea ce ,,ar trebui să fie” sau ,ar trebui să facă”) în abordarea bazată pe atribute și între fapte (ceea ce „este”, sau „face”) în abordarea bazată pe performanță (Bredillet, Tywoniak \& Dwivedula, 2015).

Plecând de la o analiză complexă a cercetărilor din ultima perioadă, s-a pus în evidenţă un model (Winter et al., 2006) bazat pe cinci direcții care guvernează dezvoltarea domeniului managementului proiectelor, care vizează complexitatea proiectului, procesul social, crearea valorilor, conceptualizarea proiectului și dezvoltarea practicienilor:

- de la modelul ciclului de viaţă al proiectelor la teorii despre complexitatea proiectelor;

- de la proiecte văzute ca procese instrumentale la proiecte ca procesele sociale;

- de la crearea de produse ca obiectiv principal la crearea de valoare;

- de la conceptualizare îngustă a proiectelor la conceptualizare mai largă

- de la practicieni de formaţie tehnică la practicieni analitici.

Un alt studiu evidenţiază 6 categorii generale care capătă importanţa crescută în abordările specifice managementului de proiect: contextualizare, aspecte sociale și politice, regândirea practicilor, complexitatea și incertitudinea, actualitatea proiectelor și mai larg conceptualizare. Aceste categorii acoperă o gamă largă de contribuții diferite, cu perspective diverse și alternative asupra proiectului de management (Svejvig \& Andersen, 2015).

Evoluţia interesului pentru subiecte care conturează complexitatea crescândă a domeniului este ilustrată şi prin creşterea frecvenţei unor teme integrate - management de cunoștințe, managementul performanţei, strategia proiectului, guvernare şi control - în defavoarea celor tehnice - achiziții, comunicare, gestiunea calităţii - în cadrul studiilor ce vizează managementul de proiect (Padalkar \& Gopinath, 2016)

Toate aceste noi direcţii de dezvoltare a domeniului managementului proiectelor complexitate, dileme etice, agilitate - ilustrează explicit elementele care guvernează managementul cercetării. 


\section{Metodologia cercetării}

Obiectivul cercetării îl constituie identificarea bunelor practici la nivelul studiilor doctorale care ar atenua problemele pe care le întâmpină doctoranzii din domeniul ştiinţelor economice în creşterea vizibilităţii cercetărilor lor prin implicarea în proiecte.

Abordarea a fost atât cantitativă cât şi calitativă. Au fost identificate, prin documentare, principalele tipuri de proiecte şi oportunităţi de finanţare accesibile tinerilor cercetători, determinându-se totodată caracteristicile principale ale acestor tipuri de proiecte şi linii de finanţare, pentru o mai bună înţelegere a cerinţelor finanţatorilor şi adaptare a propunerilor de proiect la aceste cerinţe. Pentru identificarea percepţiei tinerilor cercetători asupra principalelor aspecte care ţin de implicarea lor în proiecte, au fost aplicate 3 instrumente de învăţare, sub forma unor chestionare cu răspuns deschis. Aceste instrumente au fost aplicate pe parcursul întâlnirilor din cadrul modulelor SESYR derulate în cei 3 ani de implementare a proiectului, numărul de respondenţi variind - dintre cei 127 de cursanţi înscrişi la modulele SESYR au participat efectiv la chestionare între 57 şi 92 de respondenţi. La chestionarul numărul 1, care a vizat ierarhizarea argumentelor privind relevanţa cercetării, răspunsurile au fost clasificate şi s-au acordat punctaje (5 puncte - pentru argumentul nominalizat pe locul 1, 1 punct - pentru argumentul nominalizat pe locul 5), pentru a se determina tipul argumentelor considerate importante de către doctoranzi atunci când vizează implicarea lor într-un proiect de cercetare. La celelalte două chestionare, s-a calculat proporţia răspunsurilor dintr-o anumită categorie, pentru identificarea nevoilor de formare ale doctoranzilor. În cele din urmă, în analiza calitativă, s-au realizat problematizări de tip focus-grup, pentru identificarea problemelor percepute de către doctoranzi în creşterea implicării lor şi a vizibilităţii cercetărilor lor, precum şi a măsurilor ce ar putea fi luate la nivel personal şi instituţional pentru ameliorarea acestor probleme.

\section{Oportunităţi şi bariere în finanţarea proiectelor pentru tinerii cercetători din România}

Un punct cheie în derularea cercetărilor relevante este asigurarea finanţării activităţilor specifice. De cele mai multe ori, cercetările doctorale sunt finanţate printr-un parteneriat şcoală doctorală - doctorand. După 2007 au apărut şi bursele doctorale acordate prin programe nerambursabila în cadrul POSDRU şi POCU. Pe lângă acestea, tinerii cercetători au posibilitatea accesării diferitelor finanţări pentru proiecte de cercetare, fie la nivel individual, fie în echipe.

Proiectele de cercetare / dezvoltare la nivel individual apar ca o particularitate pentru domeniul cercetării - de obicei, proiectele sunt realizate în echipă. Pot fi setate şi fără o încadrare într-un proiect cu finanţare nerambursabilă, ca un element de dezvoltare personală (fiind de fapt un set de activităţi şi subactivităţi dintr-un proiect propriu-zis). În varianta cea mai simplă, sunt proiecte personale, setate ca etape în construirea carierei - de exemplu pentru cooperarea cu mediul de cercetare / academic sau pentru dezvoltarea unor abilităţi / competenţe necesare parcursului lor de cercetător. La un nivel superior, putem considera implicarea în proiecte a tânărului cercetător statutul de beneficiar al unui program / proiect organizaţional (de exemplu, în proiectele universităţii finanţate prin Erasmus +, POSDRU sau POCU). În această situaţie, tânărul cercetător are calitatea de beneficiar al unui proiect cu finanţare nerambursabilă câştigat de o anumită organizaţie şi de manager de proiect în acelaşi timp. Recunoaşterea calităţii de manager de proiect diferă însă de la o organizaţie la alta (de exemplu, în procesul de selecţie pentru un post didactic în universitate). Proiectele individuale propriu-zise de cercetare sunt cele în care tânărul cercetător este aplicant direct într-un program de finanţare - de exemplu NEC Fellowships, oferit de New Europe College, Institute for Advanced Study (http://www.nec.ro/), granturi interne UAIC (http://www.uaic.ro/cercetare/competitii-de-finantare/alte-finantari/) sau granturi Utrecht Network pentru tineri cercetători (http://www.utrecht-network.org/activities/young-researchers-grant/).

La nivel naţional, aceste proiecte individuale destinate tinerilor cercetători se regăsesc ca măsuri distincte în Planul Naţional de Cercetare-Dezvoltare şi Inovare pentru perioada 2015 - 2020 (PNCDI III), P1 - Dezvoltarea sistemului național de CD, subprogramul 1.1. Resurse umane (https://uefiscdi.gov.ro/programe-pncdi-iii-coordonate-de-uefiscdi), şi care vizează cercetarea 
postdoctorală, bursa tânărului cercetător, Premierea rezultatelor cercetării - articole, brevete, mobilitate, precum şi burse de cercetare în parteneriat cu diferite fundaţii - de exemplu ,Ştefan Odobleja” sau „Spiru Haret”.

Caracteristicile acestor proiecte la nivel individual sunt:

- documentație minimală - CV, listă de lucrări, scrisoare de intenție, proiect de cercetare simplificat (5-10 pagini), scrisori de acceptare, scrisori de recomandare;

- condițiile de eligibilitate sunt stricte - de exemplu contract de studii / angajare, ceea ce îngustează posibilităţile de aplicare pentru doctoranzi sau postdoctoranzi, excluşi din grupul ţintă al granturilor interne (cerinţa fiind pentru candidaţi de a fi beneficiarii unui contract de muncă valid pe o perioadă de minim trei ani).

- concurență - diversă, însă în general înaltă, pentru majoritatea programelor acordându-se relativ puţine finanţări (excepţie făcând premierea rezultatelor cercetării, pentru care condiţiile sunt clare, precum şi mobilităţile pentru tinerii cercetători).

- implementarea acestor proiecte poate fi considerată facilă, apărând uneori probleme cum ar fi întârzierea plăţilor, colaborare dificilă cu personalul suport din universităţi sau neîndeplinirea rezultatelor setate (pentru publicare se acordă de obicei o perioadă de grație).

Un aspect discutat în acordarea acestor finanţări a fost noţiunea de „tânăr cercetător”. Deşi vârsta este considerată un criteriu discriminatoriu (existând tendinţa la nivelul UE să fie înlocuită cu numărul de ani de experienţă în cercetare sau de la obţinerea titlului de doctor), în majoritatea finanţărilor (precum şi în indicatorii utilizaţi în evaluarea performanței cercetării / inovării la diferite niveluri) este precizat drept criteriu de eligibilitate vârsta maximă de 35 de ani (pentru asigurarea unei perioade de sustenabilitate adecvate). Pentru doctoranzii care au depăşit această vârstă este însă frustrant faptul că nu pot accesa finanţările specifice derulării cercetărilor lor.

De asemenea, nu sunt recunoscute în majoritatea candidaturilor rezultatele obţinute de cercetător în domeniul său profesional, ca specialist, chiar dacă aceste elemente ar constitui o bună premisă pentru implementarea unor proiecte de cercetare la nivelul firmelor, ci doar în candidaturile depuse ca beneficiari ai unor proiecte derulate la nivel organizaţional. Elementele care sunt punctate în cadrul selecţiei granturilor la nivel intern sau la nivel naţional, în competiţiile majore, adesea în calitate de criterii de eligibilitate, sunt determinate de nivelul publicaţiilor aplicantului.

Analizând aceste finanţări, se poate observa o discrepanţă între nivelul de excelenţă al cercetătorului cerut în candidatură (de exemplu, candidatul trebuie să fie autor principal al unui număr de articole științifice cu impact științific ridicat, publicate în reviste din cvartilele Q1 şi/sau Q2, cărți sau capitole de cărți în edituri științifice recunoscute, indexate WorldCat, citări în Scopus, Thomson-Reuters sau similare) şi nivelul modest al rezultatelor raportate în urma anumitor finanţări. De exemplu, nu sunt raportate articole ISI în rapoartele PNCDI din anii 2017 şi 2018 pentru bursele acordate tinerilor cercetători - doctoranzi şi postdoctoranzi (UEFISCDI, 2018), (UEFISCDI 2019).

O oportunitate consistentă pentru dezvoltarea competenţelor şi pentru finanţarea cercetărilor o constituie pentru tinerii cercetători cooptarea lor în echipe de cercetare. Atuul lor ca membri de echipă îl constituie faptul că grila de evaluare a majorităţii propunerilor de proiecte acorda punctaje sporite pentru echipe diverse, care au o anumită proporţie între cercetătorii tineri şi cei seniori. Dificultatea cooptării lor rezidă în găsirea unei concordanţe între domeniul cercetării din cadrul proiectului şi al temei de doctorat / postdoctorat a tânărului cercetător. Pentru o mai bună concordanţă între aceste domenii, ar trebui ca temele de cercetare doctorală să fie orientate strategic către domeniile din planul de cercetare al departamentelor / facultăţilor şi corelate cu temele prioritizate de către finanţatorii vizaţi.

Pentru reuşita finanţării unei propuneri de proiect, la nivel de relevanţă trebuie ţinut cont de viziunea finanţatorului - priorităţile proprii (scop, obiective, indicatori specifici), măsuri specifice finanţate (tipuri de activităţi), constrângerile impuse (definite în cadrul criteriilor de eligibilitate). 
Relevanţa proiectului trebuie încadrată în logica verticală, pe domenii (să ţină cont de obiectivele stipulate în programele de dezvoltare a cercetării şi inovării), precum şi în logica orizontală - regională, locală sau pe elemente comune (obiective comunitare).

Urmând logica verticală, trebuie ţinut cont de orientările programatice, strategice la nivelul naţional sau la nivelul organizaţiei - de exemplu, de obiectivele specifice din cadrul Strategiei naționale de cercetare, dezvoltare şi inovare 2014 - 2020 (Guvernul României, 2014): OS1. Crearea unui mediu stimulativ pentru iniţiativa sectorului privat, OS2. Susţinerea specializării inteligente, OS3. Concentrarea unei părţi importante a activităţilor CDI pe probleme societale, OS4. Susţinerea aspiraţiei către excelenţă în cercetarea la frontiera cunoaşterii şi mai ales de indicatorii vizaţi de finanţator (de exemplu - co-publicaţii ştiinţifice internaţionale, co-publicaţii public-privat, publicaţii ştiinţifice în topul $10 \%$ dintre cele mai citate publicaţii din lume, număr cercetători în sectorul privat etc.).

Logica orizontală presupune identificarea avantajelor şi oportunităţilor regionale / locale, de exemplu la nivelul Regiunii de Dezvoltare Nord -Est.

Priorităţile de cercetare pot fi identificate integrat în sistem matrice, la intersecţia provocărilor societale majore (îmbătrânire sănătoasă, demografie şi bunăstare, securitate alimentară, agricultură durabilă şi bioeconomie, energie curată, eficientă şi sigură, apă curată şi sigură) şi domeniilor de specializare inteligentă selectate la nivel regional (agro-alimentar, textile şi noi materiale, TIC, biotehnologii, turism şi stil de viaţă sănătos, energie şi mediu).

Analizând finanţările proiectelor de cercetare în echipă, dedicate tinerilor cercetători, prin instrumentul „Proiecte de cercetare pentru stimularea tinerelor echipe independente (TE)”, se pot desprinde următoarele caracteristici:

- rata de finanţare este una redusă (în jurul valorii de 10\%), factor inhibitor pentru propunerile de proiect în această etapă, documentaţia de finanţare necesitând o muncă intensă; din cele $90 \%$ de proiecte nefinanţate, pentru cele care depășesc un anumit punctaj (de exemplu 70 de puncte) ar putea fi gândită o schemă suplimentară de finanţare în parteneriate cu alte instituţii, inclusiv cu universităţile, prin instrumente de tip granturi interne;

- salarizarea este insuficientă, departe de nivelurile maximale prevăzute de legislaţia în vigoare pentru valorile brute medii pe oră de activitate; motivarea cercetătorilor este asigurată de punctajele obţinute în evaluarea profesională şi din finanţarea activităţilor specifice cercetării pe care doresc să o realizeze;

- există o strânsă corelaţie între apartenenţa la o universitate / institut de cercetare de prestigiu şi punctajul obţinut de propunerea de proiect - astfel, 29 dintre cele 37 (78\%) de proiecte cu punctaj peste 70 de puncte din competiţia TE în domeniul ştiinţelor economice din anul 2019 sunt ale cercetătorilor din cele 4 universităţi majore (Universitatea Babeş Bolyai - 12, ASE 8, UAIC - 5, Universitatea de Vest Timişoara - 4), iar 5 dintre primele 10 proiecte ca punctaj sunt propuse de cercetători provenind de la Universitatea Babeş Bolyai, universitatea cel mai bine cotată din România în clasamentele internaţionale;

- există o strânsă corelaţie între abordarea temelor de prioritate absolută în politica de cercetare naţională şi a temelor nişate şi obţinerea punctajelor ridicate (de exemplu, 19 din cele 37 proiecte cu punctaj peste 70 de puncte abordează temele prioritare în mod explicit - dezvoltare durabilă, energie regenerabilă, migraţie, înaltă tehnologie şi inovare, iar 15 proiecte sunt orientate spre aspecte tehnice - logică fuzzy, entropie, teoria jocurilor etc. sau a celor nişate alfabetizare financiară, plăţi informale etc.).

Aceste proiecte reprezintă o reală oportunitate pentru doctoranzi şi postdoctoranzi (aceştia sunt implicaţi în procent de $24 \%$ pentru fiecare categorie din totalul personalului angajat pentru competiţia TE din anul 2017) (UEFISCDI, 2019) atât pentru realizarea cercetărilor lor, cât şi pentru îmbunătăţirea competenţelor de a lucra în echipă.

Oportunităţile de finanţare la nivelul UE, în special prin programul Orizont 2020, sunt puţin valorificate de către România şi nu sunt specifice domeniului economic în mod direct (cele mai multe proiecte fiind în domeniile ştiinţelor inginereşti). 


\section{Percepţii ale tinerilor cercetători legate de implicarea lor în proiecte}

Implicarea doctoranzilor în proiecte de cercetare depinde în mod esenţial de informarea acestora în legătură cu oportunităţile existente, precum şi de percepţia acestora asupra uşurinţei în accesarea finanţărilor şi a avantajelor obţinute.

Întrebarea cheie a instrumentelor de învăţare sub forma chestionarelor şi problematizărilor de tip focus-grup a fost legată de posibilitatea valorificării expertizei doctoranzilor în cadrul proiectelor de cercetare şi dezvoltare, la nivel individual sau în echipă.

În legătură cu percepţia doctoranzilor asupra atuurilor principale ale cercetării lor doctorale, rezultatele aplicării chestionarului nr. 1, constând dintr-o singură întrebare („Care sunt atuurile principale ale cercetării dvs. doctorale, pe care le-aţi utiliza pentru a obţine o finanţare a activităţilor specifice? - maxim 5 argumente, în ordinea importanţei”) cu răspuns deschis, se regăsesc în tabelul nr. 1 .

Tabel nr. 1. Argumente privind relevanţa cercetărilor pentru obţinerea finanţării

\begin{tabular}{|c|c|c|c|c|}
\hline $\begin{array}{l}\text { Nr. } \\
\text { crt. }\end{array}$ & $\begin{array}{l}\text { Categoria } \\
\text { argumentului }\end{array}$ & Exemple de argumente & Punctaj & Loc \\
\hline 1. & $\begin{array}{l}\text { Actualitatea şi } \\
\text { unicitatea temei }\end{array}$ & 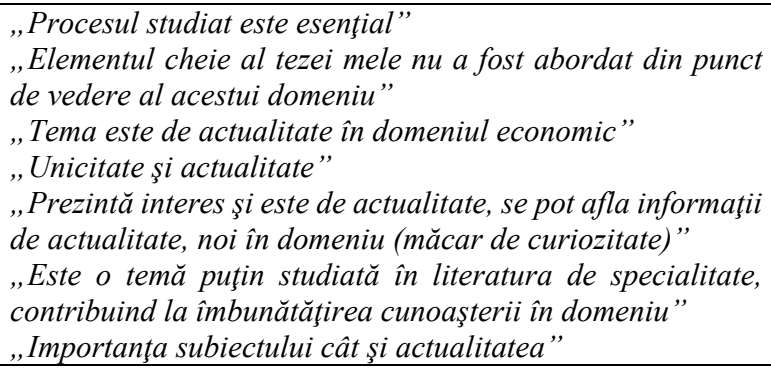 & 386 & 1 \\
\hline 2. & $\begin{array}{l}\text { Progrese } \\
\text { metodologice }\end{array}$ & $\begin{array}{l}\text { „Cercetarea conţine rezultate din analize statistice } \\
\text { avansate” } \\
\text { „Cercetarea este calitativă" } \\
\text { „Are deja rezultate conturate" }\end{array}$ & 207 & 2 \\
\hline 3. & $\begin{array}{l}\text { Aplicabilitate în } \\
\text { domeniul } \\
\text { universitar }\end{array}$ & $\begin{array}{l}\text { „Rezultatele cercetării ajută la clarificarea unor concept, } \\
\text { găsirea de soluţii” } \\
\text { „Cercetarea dă naştere unei noi discipline de studiu în } \\
\text { cadrul FEAA, având în vedere poziţia şi lipsurile } \\
\text { identificate” } \\
\text { „Dezvoltare a literaturii de specialitate” } \\
\text { „Deschide noi direcţii de cercetare” }\end{array}$ & 66 & 3 \\
\hline 4. & $\begin{array}{l}\text { Aplicabilitate în } \\
\text { sectorul } \\
\text { economic }\end{array}$ & $\begin{array}{l}\text { „Vizează găsirea soluţiilor pentru dezvoltarea unui sector } \\
\text { economic important în regiune” } \\
\text { „Rezultatele cercetării ajută la implementarea unei } \\
\text { strategii” } \\
\text { „Aplicabilitate în practica firmelor" }\end{array}$ & 56 & 4 \\
\hline
\end{tabular}

Se observă faptul că argumentele cele mai importante (cu un punctaj net superior următoarelor categorii) în percepţia doctoranzilor ţin de calitatea intrinsecă a cercetării - actualitate, noutate şi de instrumentele metodologice implicate. Aspectele de sustenabilitate a cercetării - potenţiale aplicaţii în domeniile academice şi economico-sociale au obţinut un scor mult mai mic. Aceste rezultate confirmă slaba integrare a temelor doctorale în planuri de cercetare consistente şi coerente, stabilite la nivelul departamentelor, interdisciplinar sau în colaborare cu mediul de afaceri.

Un al doilea chestionar a vizat abilităţile antreprenoriale ale studenţilor doctoranzi, respectiv modul în care aceştia concep un produs educaţional. Respondenţii au fost rugaţi să indice 1-2 aspecte nişate pe care ar putea crea un curs de 2-4 ore, cu ilustrarea elementelor teoretice şi 
aplicative, să identifice un curs / o specializare la care ar putea fi invitaţi cu prelegerea respectivă şi să indice etapele necesare a fi parcurse pentru a putea susţine prelegerea. Doar 3\% dintre respondenţi au avut o abordare integrată, indicând şi etapele de planificare (inclusiv identificare a nevoilor potenţialilor cursanţi) şi cele de relaţionare şi replicare, cu îmbunătăţiri succesive, pentru produsul lor educaţional. Marea majoritate a respondenţilor $(97 \%)$ s-a concentrat strict pe documentare şi realizarea propriu-zisă a prezentării, rezultat care susţine nevoia de formare a competenţelor antreprenoriale pentru doctoranzi.

În sfârşit, un al treilea instrument de învăţare s-a referit la modalitatea de organizare a echipelor de cercetare. Li s-a prezentat un proiect de cercetare în domeniul dezvoltării durabile într-o regiune cu mai multe zone de tip Natura 2000, pentru care se realizează un consorţiu între universităţi din România, Islanda şi Norvegia, cu o echipă în care sunt implicaţi atât cercetători cu experienţă cât şi doctoranzi. Respondenţii trebuiau să identifice modul de organizare a proiectului şi eventualele probleme de coordonare ce ar putea apărea. Rezultatele au arătat o preferinţă netă (a peste $90 \%$ dintre echipele de respondenţi) a organizării pe grupuri specializate de lucru, determinate geografic, evitându-se astfel o abordare interdisciplinară, iar problemele de coordonare potenţiale au fost plasate în sfera tehnică - întârzieri determinate de condiţiile de lucru, deficienţe de comunicare, probleme în realizarea mobilităţilor. Diferenţele culturale ale grupurilor implicate nu au fost luate în considerare, deşi acestea sunt frecvent implicate în problemele de implementare ale proiectelor realizate în parteneriate. Rezultatele arată o nevoie de contextualizare şi de înţelegere a problemelor din mediul academic, fapt ce ar facilita inserţia doctoranzilor în proiectele de cercetare.

Întâlnirile de tip focus-grup au abordat problemele pe care le percep doctoranzii ca fiind determinante pentru slaba lor implicare în proiectele de cercetare (1 singur doctorand dintre respondenţi fusese implicat ca membru al unei echipe de cercetare).

Un prim aspect evidenţiat a fost faptul că noţiunea de proiect este percepută în sens restrâns doctoranzii consideră că putem vorbi de proiecte doar pentru demersurile de cercetare finanţate printr-un contract de finanţare, şi nu îşi setează activităţile specifice cercetării doctorale sub forma unor proiecte personale (participările la conferinţe, lansarea unui produs educaţional, participarea la şcoli de vară sau cursuri de formare pentru dobândirea unor competenţe specifice etc.), abordare care le-ar aduce certe avantaje - obiective clare, scăderea frecvenţei depăşirilor termenelor limită, vizibilitate, CV îmbunătăţit.

Problemele invocate de către respondenţi în derularea activităţilor de cercetare şi, implicit, în creşterea implicării lor în proiecte, sunt multiple:

- lipsa competențelor de bază - chiar dacă a existat o planificare a carierei doctorale, orientările diferite pe parcursul studiilor de licenţă şi masterat şi lipsa ofertei educaţionale pentru dobândirea competenţelor de cercetător induc dificultăţi în prima parte a stagiului doctoral atât la nivelul aspectelor metodologice, cât şi în înţelegerea noţiunilor domeniului specific doctoral; acest fapt conduce la o întârziere a cercetărilor avansate, prima parte a programului doctoral fiind dedicată dobândirii şi îmbunătăţirii competenţelor de bază; o altă consecinţă posibilă este cea a arderii etapelor, din dorinţa de a fi ,la zi” cu parcursul doctoral, însă deficienţele majore cognitive se vor regăsi în etapa finală, de realizare a tezei;

- penalizarea creativităţii - atât în conţinut cât şi în modul de structurare a temei, rapoartelor de progres, propunerilor de prezentare în vederea participării la conferinţe, sunt preferate metodele tradiţionale, modelele acceptate la nivel academic, stilul de comunicare elitist / eclectic, în vederea evitării riscului criticilor sau respingerilor, orice eşec fiind capitalizat extrem de negativ în parcursul doctoral;

- sistemul de evaluare - este perceput ca fiind standardizat, neţinând cont de particularităţile fiecărui domeniu şi teme; apare o percepţie a lipsei aprecierii, cu efecte demotivante;

- lipsa informaţiilor relevante - unii doctoranzi din primul an de studiu nu cunoşteau membrii comisiei de îndrumare, ci doar coordonatorul de doctorat; deşi multe informaţii sunt disponibile pe site-ul şcolii doctorale, al facultăţii sau al universităţii, structurarea lor deficitară determină un 
bombardament de informaţii şi o decelare dificilă a aspectelor relevante pentru doctoranzi (conferinţe accesibile, oportunităţi de finanţare, cursuri necesare etc.);

- procrastinarea - peste $80 \%$ dintre doctoranzi au arătat că manifestă frecvent atitudini tipice procrastinării - realizarea documentărilor şi a materialelor importante exact înainte de termenul limită, nu prioritizează, nu planifică; această atitudine are şi o determinare culturală, dar provine şi din rolurile multiple asumate de doctoranzi (au îndatoriri familiale, au o carieră profesională), din tendinţa de a aştepta o influenţă externă (mesaje de la coordonatori / secretariat), din existenţa hoţilor de timp specifici (discuții nerelevante cel mai adesea, informaţii care trebuie verificate) şi, poate cel mai grav, lipsa încrederii în relevanţa cercetării, fapt care duce la o demotivare accentuată.

Din discuţii au rezultat şi elemente care stimulează implicarea şi performanţa cercetării doctoranzilor. Astfel, au fost apreciate iniţiativele de organizare de către doctoranzi a unor sesiuni de prezentare a cercetărilor proprii, cu o frecvenţă ridicată, evaluarea colegială (peer-to-peer) fiind considerată relevantă şi motivatoare. Posibilitatea formării unor grupuri de cercetare pe teme comune, cu o abordare interdisciplinară, în special pentru difuzarea de informaţii, participarea la conferinţe şi publicarea de articole cu autori multipli a fost stimulată de iniţiative precum modulele SESYR, organizarea unor mese rotunde şi conferinţe dedicate tinerilor cercetători. Comunicarea excelentă cu îndrumătorul ştiinţific, prin continuitate (acelaşi coordonator a fost şi îndrumătorul licenţei şi / sau lucrării de disertaţie), stabilirea unor termene şi condiţii de colaborare clare, frecvente propuneri de implicare în organizarea unor evenimente științifice sau participarea cu o temă comună la conferinţe şi publicarea unor articole în colaborare a fost considerată factorul determinant în progresele obţinute în cadrul programului doctoral.

\section{Concluzii}

Doctoranzii sunt cei mai buni vectori care explică, promovează şi utilizează educaţia doctorală, cercetarea și procesul inovativ. Diploma de doctor ar putea determina recrutări cu foarte bun nivel al competențelor și profundă motivare, ceea ce duce la succese și beneficii.

Capitalizarea rezultatelor cercetării şi sustenabilitatea proiectelor de cercetare doctorală depind de numeroşi factori, atât la nivel instituţional cât şi personal.

Creșterea angajabilității cercetătorilor poate fi obţinută în mod cert prin implicarea companiilor în programul doctoral (în întregime sau în diverse etape).

Problemele diverse apărute în procesul integrării rezultatelor cercetării doctorale pot fi atenuate prin măsuri coerente şi consistente la nivel instituţional, de genul:

- natura neadecvată a pieții muncii - prin dezvoltarea afacerilor inovative;

- cunoașterea limitată şi accesarea dificilă a pieții muncii - prin îmbunătățirea circulației informației și rețelelor;

- $\quad$ slaba reprezentare - prin dezvoltarea relaţiilor

- $\quad$ cererea de noi competențe - prin evaluarea continuă a nevoilor prin studii;

- lipsa proiectelor clare și sustenabile - prin anticipare, creativitate, inovare;

- obișnuințe în recrutare - prin respectarea valorilor și culturii dar și curajul schimbării.

La nivel personal, doctoranzii îşi pot dinamiza cariera prin prioritizarea factorilor principali în dezvoltarea personală şi profesională - networking, implicarea în colaborări şi parteneriate, consolidarea reputației științifice, acumularea de abilități transferabile şi cunoștințe complementare.

Toate aceste măsuri au ca finalitate îmbunătățirea diseminării în societate a competențelor doctorale indiferent de organizații, profesii sau țări.

\section{Referințe}

- Andersen, E. (2016). Do project managers have different perspectives on project management?, International Journal of Project Management 34. 58-65. 
- $\quad$ Baumanna, T., Doyena, M., Swangerb, A., Bayerc, D., Celld, A., Sophie Stepkee, S. (2016). Complexity twice: Multi-project environment in education and shareholders with dynamic agendas - achieving mature decisions and project/ portfolio success, Procedia - Social and Behavioral Sciences 226. 470 - 477.

- Bredillet, C., Tywoniak, S., Dwivedula, R. (2015). What is a good project manager? An Aristotelian perspective, International Journal of Project Management 33. 254-266.

- Bresnen, M. (2016). Institutional development, divergence and change in the discipline of project management, International Journal of Project Management 34. 328-338.

- Conforto, E.C., Capaldo Amaral, D., da Silva, S.L., Di Felippo, A., Kamikawachi, D.S. (2016). The agility construct on project management theory, International Journal of Project Management 34. 660-674.

- Garel, G. (2013). A history of project management models: From pre-models to the standard models, International Journal of Project Management 31. 663-669.

- Guvernul României (2014). Hotărâre nr. 929 din 21 octombrie 2014 privind aprobarea Strategiei naţionale de cercetare, dezvoltare şi inovare 2014- 2020, disponibil la https://uefiscdi.gov.ro/resource-80379, accesat în iunie 2020.

- Klein, L., Biesenthal, C., Dehlin, E. (2015). Improvisation in project management: A praxeology, International Journal of Project Management 33. 267-277.

- Marić, I. (2013). Stakeholder Analisys of Higher Education Institutions, Interdisciplinary Description of Complex Systems 11(2), 217-226, DOI: 10.7906/indecs.11.2.4

- Nelsona, T., Cropper, J. (2016). PMD Pro forward: making the world better one project at a time, Procedia - Social and Behavioral Sciences 226. $20-26$.

- Padalkar, M., Gopinath, S. (2016). Six decades of project management research: Thematic trends and future opportunities, International Journal of Project Management 34. 1305-1321.

- $\quad$ Ramazani, J., Jergeas, G. (2015). Project managers and the journey from good to great: The benefits of investment in project management training and education, International Journal of Project Management 33. 41-52.

- Schjetleina, T., Haavaldsena, T., Lohne, J. (2016). Achieving sustainability? A case analysis of policy-to-project processes, Procedia - Social and Behavioral Sciences 226. 140 - 147.

- Svejvig, P., Andersen, P. (2015). Rethinking project management: A structured literature review with a critical look at the brave new world, International Journal of Project Management 33. 278-290.

- Tamaş, I.C., Abrudan, M.M. (2018). Talent Management - Conceptual Approach and Practical Challenges in the Context of Globalization, Emerging Markets Economics and Business. Contributions of Young Researchers. Proceedings of the 9th International Conference of Doctoral Students and Young Researchers No. 6, December 2018, Oradea University Press, 251-255.

- Too, E., Weaver, P. (2014). The management of project management: A conceptual framework for project governance, International Journal of Project Management 32. 13821394.

- Tsipesa, G., Echkalovaa, N., Sharovaa, E., Tovb, A. (2016). Corporate University as a driver of project culture and competence development, Procedia - Social and Behavioral Sciences 226. $335-342$.

- Uchitpe, M., Uddin, S., Crawford, L. (2016). Predicting the future of project management research, Procedia - Social and Behavioral Sciences 226. 27 - 34.

- UEFISCDI (2018) Raport PNCDI III 2017, disponibil la https://uefiscdi.gov.ro/resource89792, accesat în iunie 2020

- UEFISCDI (2019) Raport PNCDI III 2018, disponibil la https://uefiscdi.gov.ro/resource80181 , accesat în iunie 2020 
- Winter, M., Smith, C., Morris, P., Cicmil, S. (2006). Directions for future research in project management: The main findings of a UK government-funded research network, International Journal of Project Management 24. 638-649.

- http://www.blueoceanstrategy.com

- http://www.nec.ro/

- http://www.uaic.ro/cercetare/competitii-de-finantare/alte-finantari/

- http://www.utrecht-network.org/activities/young-researchers-grant/

- https://uefiscdi.gov.ro/programe-pncdi-iii-coordonate-de-uefiscdi 


\section{Partea a II-a.}

\section{Procese şi fenomene economice}





\title{
Cap. 7. THE DETERRENTS OF THE FOREIGN DIRECT INVESTMENT ATTRACTION IN ROMANIA
}

\author{
Sebastian Tocar \\ Alexandru Ioan Cuza University of Iaşi, Faculty of Economics and Business Administration \\ Iaşi, Romania, seb.tocar@gmail.com
}

\begin{abstract}
The economic results of developing countries are largely determined by the fulfilment of their potential of attracting foreign capital. Similarly to all post-communist countries, it is also the case of Romania. The Romania's volume of foreign direct investments per capita is among the lowest in the region, and identifying the factors that have determined these results could provide a more effective strategic orientation of the policies related to the attraction of foreign investments. The author took the Culture-specific Investment Attractiveness Index (IAI) as a basis for the identification of the factors that impede the attraction of FDI in Romania. This index was elaborated in a previous study and is based on 20 indicators representing six categories of FDI determinants: economic factors, technology, infrastructure, institutional-political factors, the human factor and cultural factors. In the case of this index, considering the impact of cultural factors is very important, because they are often neglected. The analysis of the scores for the elements of this index resulted in the identification of the deterrents that impede the attraction of FDI in Romania, but also of the strengths of Romania in the attraction of foreign capital.
\end{abstract}

Keywords: FDI, Foreign Direct Investment, Investment Attractiveness Index, Romania, deterrents.

\section{Introduction}

In the pursuit of well-being, developing countries consider globalization as a tool to reduce the gap that separates them from the level of economic development, technology and quality of life of developed countries. The cooperation between developing and developed countries brings benefits to both sides of the exchange, and foreign direct investment (FDI) is the means by which the interests of all subjects can be achieved. This aspect encourages researchers to investigate factors that stimulate or discourage the attraction of foreign investment.

With the collapse of the Socialist Bloc, Eastern European countries were integrated into the globalized world, adopting policies for the transition to market economy. Similarly to all postcommunist countries, it is also the case of Romania. The Romania's amount of FDI per capita is among the lowest in the region, and identifying the factors that have determined these results could provide a more efficient strategic orientation of the policies related to the attraction of foreign investments.

The Culture-specific Investment Attractiveness Index (IAI) has its origin in the analysis of the specialty literature, being elaborated on the basis of 20 indicators representing six categories of factors: economic factors, technology, infrastructure, institutional-political factors, human factor and cultural factors. The analysis of the reliability and adequacy of the sampling demonstrated the correctness of the set of selected indicators and the opportunity to develop a composite index (Tocar, 2019).

The index was developed by applying the Principal Components Analysis based on the Handbook on Constructing Composite Indicators (OECD, 2008). The correlation analysis demonstrated a strong and significant link between the Culture-specific Investment Attractiveness Index and the FDI stock per capita, which proved to be the most effective indicator of the transformation of investment attractiveness into investment stock.

The calculation of the IAI and the subsequent ordering of the countries according to the score placed Romania in an unsatisfactory area - that of the countries with a very low level of investment attractiveness. This situation is not surprising, given the amount of FDI attracted and the strong 
correlation between IAI and FDI. However, it is important to identify the factors (including cultural ones) that influence the low investment attractiveness and deter the attraction of FDI in Romania, respectively the factors that facilitate the attraction of FDI in other countries.

This study represents the attempt to identify the factors that deter the attraction of investments in Romania, through the analysis of the elements of the Culture-specific Investment Attractiveness Index (IAI).

This way of approaching the weaknesses in terms of investment attractiveness favors the development of a relevant approach for several reasons. Firstly, the IAI is a composite index, which encompasses 20 quantified determinants of FDI, including factors of cultural origin, which are often neglected in specialty literature, so it provides a comprehensive set of factors. Secondly, this index provides a basis for comparison, due to the presentation of the results of the calculations of the index in the form of a categorization of European countries by investment attractiveness. Thirdly, the IAI demonstrates a very strong correlation with the value of FDI attracted per capita (Tocar, 2019), so it is a relevant indicator.

There are several studies that investigate the factors influencing FDI attraction in Romania (for example, Iammarino and Pitelis, 2000; Kalotay, 2008; Birsan and Buiga, 2009; Goschin, Danciu and Serbu, 2013; Diaconu (Maxim), 2016 etc.), though the sets of factors are usually not very comprehensive, while cultural factors are not even mentioned in most studies. The studies identified from the specialty literature also seem to confirm the originality of the present study in terms of the approach.

The paper proceeds as follows. The second section presents the methodology and data sources, while the further presents the results for each approach. The last section draws conclusions and discusses the limitations and the directions for future research.

\section{Methodology}

\subsection{Data}

As we investigated the elements of the IAI, the sources of data correspond to the sources used for the elaboration of the IAI: online databases of international institutions (World Bank, World Integrated Trade Solution (WITS), UNCTAD), the Heritage Foundation database (for Economic Freedom Index values), and the online database of Hofstede's cultural dimensions (Hofstede Insights).

\subsection{Method}

The author performed a comparative analysis between the values of each factor for Romania on the one hand and the average values for the countries with medium investment attractiveness, and for those with very high investment attractiveness, on the other hand. The ordering of European countries by categories in terms of their investment attractiveness is provided in Figure 1. 


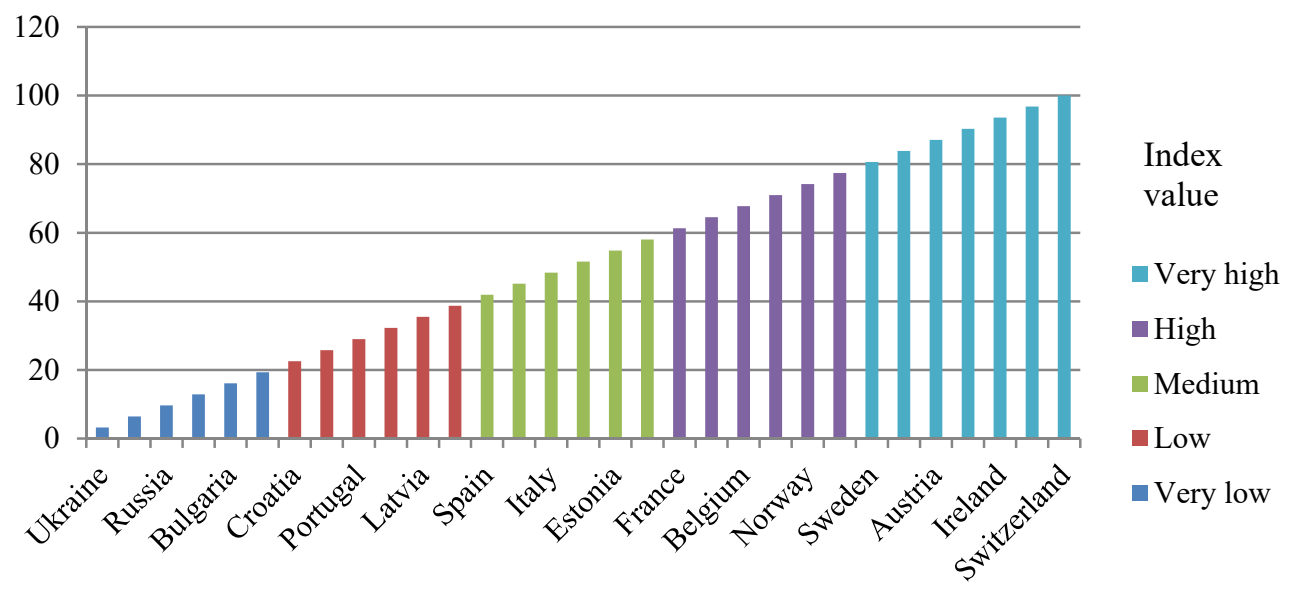

Fig. 1. The categories of European countries according to the value of Culture-specific Investment Attractiveness Index

Source: Tocar (2019)

In determining the intensity of the negative impact of a certain factor on the investment attractiveness of Romania, the author took into account both the difference from the values of the countries with a medium / very high attractiveness and the importance of that factor in the components of the index, given by components' loadings (which are, in fact, the correlations between the initial indicators and the principal components), presented in Table 1.

Table 1. Rotated Component Matrix

\begin{tabular}{|l|l|l|l|l|}
\hline \multirow{2}{*}{ Variable } & \multicolumn{4}{l}{ Component } \\
\cline { 2 - 5 } & 1 & 2 & 3 & 4 \\
\hline Zscor: GDP per capita & 0.871 & 0.088 & -0.099 & -0.126 \\
\hline Zscor: Trade, \% of GDP & -0.047 & 0.777 & 0.182 & 0.199 \\
\hline Zscor: Index of Economic Freedom & 0.717 & 0.426 & 0.339 & -0.232 \\
\hline Zscor: Market Concentration Index HH & 0.127 & 0.83 & -0.35 & 0.165 \\
\hline Zscor: Trade and transport infrastructure & 0.891 & -0.2 & 0.084 & 0.256 \\
\hline Zscor: High technology exports & 0.517 & 0.137 & 0.468 & -0.156 \\
\hline Zscor: Control of Corruption & 0.957 & 0.102 & -0.005 & -0.174 \\
\hline Zscor: Government Effectiveness & 0.952 & 0.083 & -0.001 & -0.082 \\
\hline $\begin{array}{l}\text { Zscor: Political Stability and Absence of } \\
\text { Violence / Terrorism }\end{array}$ & 0.688 & 0.512 & -0.156 & 0.009 \\
\hline Zscor: Regulatory Quality & 0.921 & 0.227 & 0.167 & -0.121 \\
\hline Zscor: Rule of Law & 0.95 & 0.168 & -0.002 & -0.113 \\
\hline Zscor: Voice and Accountability & 0.897 & 0.134 & -0.105 & -0.007 \\
\hline Zscor: Human Capital Index & 0.835 & -0.018 & -0.014 & 0.108 \\
\hline Zscor: Unemployment rate & -0.136 & -0.62 & -0.325 & 0.338 \\
\hline Zscor: Masculinity vs. Femininity & -0.047 & 0.189 & 0.159 & 0.872 \\
\hline Zscor: Uncertainty Avoidance & -0.703 & -0.209 & -0.232 & 0.34 \\
\hline Zscor: Power Distance & -0.849 & -0.088 & -0.035 & 0.157 \\
\hline Zscor: Individualism vs. Collectivism & 0.732 & 0.078 & 0.478 & 0.076 \\
\hline $\begin{array}{l}\text { Zscor: Long-Term Orientation vs. Short-Term } \\
\text { Orientation }\end{array}$ & -0.255 & -0.012 & 0.799 & 0.235 \\
\hline Zscor: Indulgence vs. Restraint & 0.833 & -0.068 & -0.251 & 0.004 \\
\hline
\end{tabular}


As the IAI contains elements (factors) with different units of measurement, in order to ensure the comparability of the differences between the scores for different variables, they have been standardized beforehand. The larger discrepancy reflects the fact that the respective factor represents a weakness and a deterrent of the FDI attraction for Romania, and is also a signal to improve the investment attractiveness in terms of the respective factor. The importance of the deterrents identified in this way was verified in the IAI rotated component matrix, as it was also mentioned above.

\section{Results}

In order to facilitate the demonstrative power of the results, the latter are presented in four separate subsections, accompanied by corresponding figures, as follows: Economic factors; Infrastructure, Technology and Human factor; Institutional-political factors; Cultural factors.

\subsection{Economic factors}

Figure 2 shows the discrepancies between the scores of different countries for economic factors. Among these factors, the GDP per capita amount seems to represent the economic factor that mostly deters the attraction of FDI in Romania. The degree of Openness of the economy, represented by the factor named Trade, is also an issue that needs to be improved in Romania. The other two factors, namely Economic freedom and Market Concentration, do not seem to represent any threat at this point.

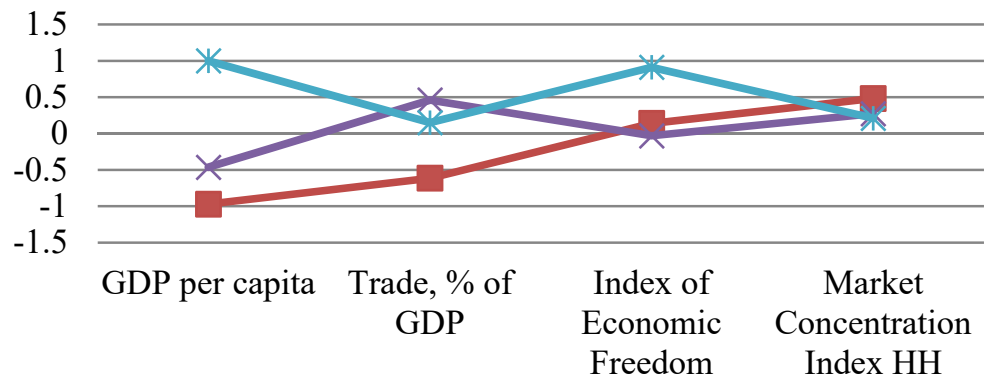

- Romania
$\div$ Average of countries with medium IAI
$\because$ Average of countries with very high IAI

Fig. 2. Romania's standardized scores for economic factors compared to the scores of countries with medium and very high values of IAI Note. IAI - Culture-specific Investment Attractiveness Index.

\subsection{Infrastructure, Technology and Human factor}

As it can be observed from the Figure 3, the human factor is not a weakness of Romania, probably even the opposite. An advantage for Romania is given by the negative relationship between the unemployment rate and the investment attractiveness, but this factor did not prove its high importance following the factor analysis. At the same time, an important factor that deters the attraction of FDI in Romania is the Trade and transport infrastructure. It has to be mentioned that, in this respect, Romania is far below the level of countries with medium investment attractiveness. Another weakness of Romania is the technical progress, represented by High technology exports (but this factor is not very important for the investment attractiveness, according to the results of the factor analysis). 


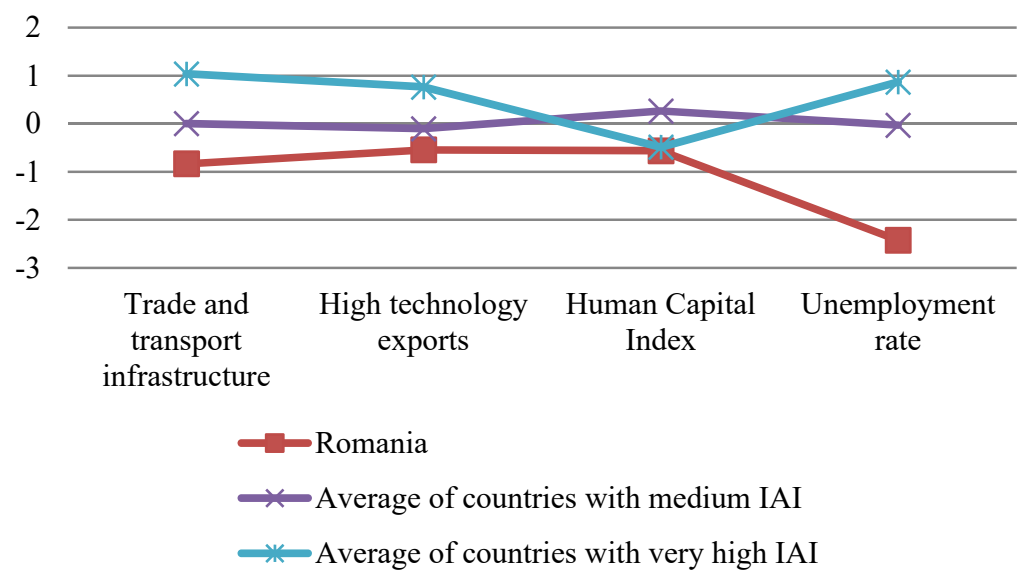

Fig. 3. Romania's standardized scores for the determinants of FDI (infrastructure, technology and the human factor), compared to the scores of countries with medium and very high values of IAI

Note. IAI - Culture-specific Investment Attractiveness Index.

\subsection{Institutional-political factors}

Institutional-political factors are also very important for a country's investment attractiveness. In this context, the factors that mostly deter the attraction of FDI in Romania are: low Government Effectiveness, Political Instability, poor Regulatory Quality and problems related to ensuring Voice and Accountability (among the factors mentioned, Political Instability is slightly less important). In the case of the factors of Control of Corruption and Rule of Law, the discrepancies compared to the countries with medium investment attractiveness are not so large, though the problems persist (Figure 4). Generally speaking, all institutional-political factors reflect problems that Romania has in this sphere, problems that are discouraging foreign investments.

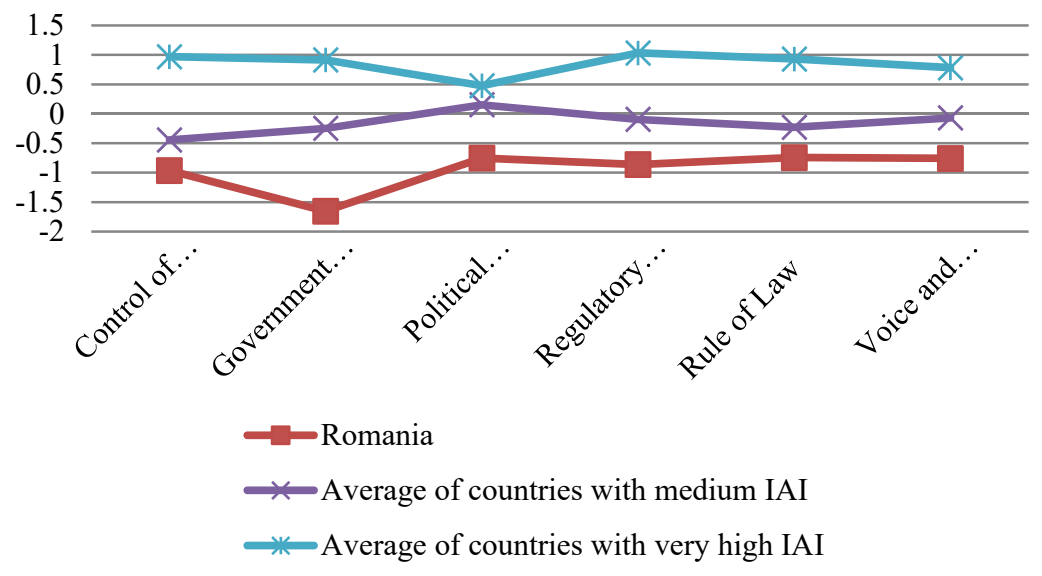

Fig. 4. Romania's standardized scores for the institutional-political factors, compared to the scores of countries with medium and very high values of IAI

Note. IAI - Culture-specific Investment Attractiveness Index.

\subsection{Cultural factors}

The analysis of cultural factors demonstrates that the greatest discrepancies that deter the attraction of FDI refer to the great Power Distance, the Collectivist character, the strong 
Uncertainty Avoidance and the Restraint associated with Romania. Due to the sample size, which included many Masculine countries with a high amount of FDI, Figure 5 suggests that countries with stronger investment attractiveness are, on average, more Masculine than Romania (though countries with a very high IAI score are, on average, more Feminine than those with medium level of investment attractiveness). Regarding the LTO dimension, the situation is similar: on the one hand, the countries with greater investment attractiveness than Romania also have a stronger longterm orientation, while on the other hand the countries with very high investment attractiveness are more short-term oriented than those with medium attractiveness.

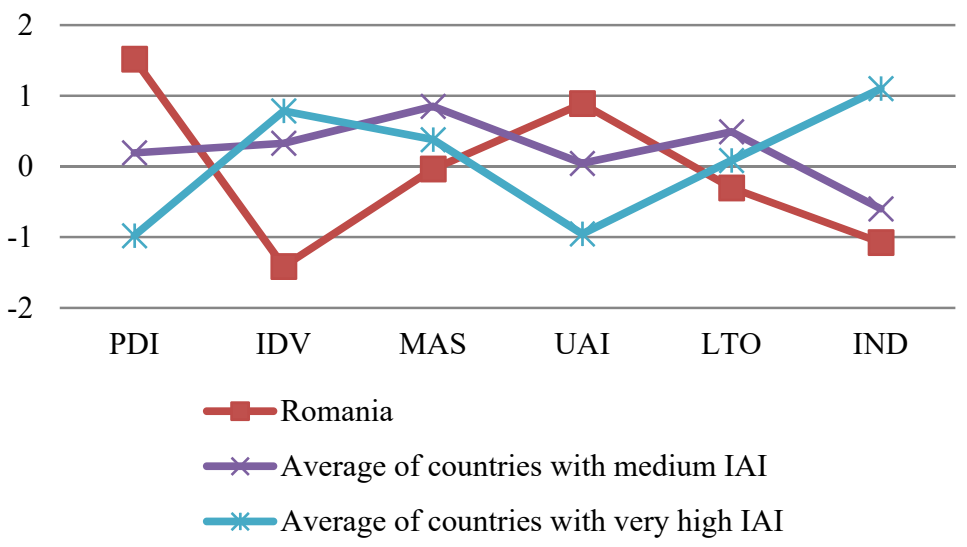

Fig. 5. Romania's standardized scores for the Hofstede's cultural dimensions, compared to the scores of countries with medium and very high IAI values

Note. 1) IAI - Culture-specific Investment Attractiveness Index;

2) PDI - Power Distance; IDV - Individualism vs. Collectivism; MAS - Masculinity vs. Femininity; UAI - Uncertainty Avoidance; LTO - Long-Term orientation vs. Short-Term orientation; IND - Indulgence vs. Restraint.

From the above mentioned, it can be concluded that the scores for four cultural dimensions reflect the cultivation of values that decrease investment attractiveness (or the underestimation of values that are important for increasing investment attractiveness) and represent impediments to the attraction of FDI. These are: Power Distance, Individualism vs. Collectivism, Uncertainty Avoidance, Long-Term orientation vs. Short-Term orientation, Indulgence vs. Restraint.

The analysis shows that the cultural values emphasized in the countries at the other extreme of the cultural dimension create a more favorable cultural environment for the attraction of FDI. Moreover, from previous analyzes we can deduce that these values form a more favorable cultural environment for sustainable economic growth and the transformation of countries into sources of FDI (countries of origin for FDI).

\section{Conclusions}

Romania is a country with very low investment attractiveness, respectively a very low amount of FDI attracted per capita. The most important factors that deter the attraction of FDI in Romania are: low level of GDP per capita, degree of Openness of the economy, Trade and transport infrastructure, low Government Effectiveness, Political Instability, poor Regulatory Quality and problems related to ensuring Voice and Accountability. The level of technology development, Control of Corruption and the Rule of Law are also issues that need to be improved for better investment attractiveness. Simultaneously, Economic Freedom (above the average of countries with medium IAI) and the Human factor (Human Capital Index for Romania is very close to the average of countries with very high investment attractiveness) can be considered Romania's strengths in the context of investment attractiveness. 
In terms of cultural factors, Romania's low investment attractiveness is characterized by great Power Distance, Collectivism, strong Uncertainty Avoidance and Restraint. The cultural specificity of Romania implies the cultivation of values that deter the attraction of FDI, while the cultural values that create a favorable cultural environment for the attraction of FDI do not receive due attention, and their importance is underestimated.

Given the above mentioned, it can be concluded that a public policy aimed at improving the weaknesses in terms of investment attractiveness of Romania (the author refers, in particular, to economic factors, infrastructure and institutional-political environment), along with concrete actions of intercultural awareness and of removal of cultural barriers, can transform Romania into a new pole of attraction for foreign investments, due to the capitalization of its potential.

\section{References}

- Birsan, M., \& Buiga, A. (2009). FDI Determinants: Case of Romania. Transit Stud Rev, 15, 726-736.

- Diaconu (Maxim), L. (2016). Can Romania offer a sustainable environment for the FDI inflows? European Journal of Sustainable Development, 5(4), 443-451.

- Goschin, Z., Danciu, A. -R., \& Serbu, R. R. (2013). Understanding the regional determinants of the FDI in Romania: Evidence from a panel data model. Revista Economica, 65(5), 207-222.

- Iammarino, S., \& Pitelis, C. (2000). Foreign direct investment and 'less favoured regions': Greek FDI in Bulgaria and Romania. Global Business Review, 1(2), 155-171.

- Kalotay, K. (2008). FDI in Bulgaria and Romania in the Wake of EU Accession. Journal of East-West Business, 14(1), 5-40.

- OECD (2008). Handbook on Constructing Composite Indicators: Methodology and UserGuide. Paris, France: OECD Publications.

- Tocar, S. (2019). Culture-specific investment attractiveness index: an original composite indicator. International Journal of Economics and Financial Issues, 9(4), 203-211.

- Hofstede Insights website: https://www.hofstede-insights.com

- UNCTAD - Statistics website: https://unctadstat.unctad.org

- World Bank - World Development Indicators website: http://wdi.worldbank.org

- World Bank - World Integrated Trade Solution website: https://wits.worldbank.org 



\title{
Cap. 8. DOES USING CRYPTOCURRENCY AND BLOCKCHAIN POSE NEW RISK TO GLOBAL ORGANIZATIONS REGARD SENOR MANAGEMENT DECISION MAKING
}

\author{
Levi Guy ${ }^{1}$, Țugui Alexandru² \\ ${ }^{I}$ Alexandru Ioan Cuza University of Iaşi, Faculty of Economics and Business Administration and \\ Informatics, Iași, Romania, guylciso@gmail.com \\ ${ }^{2}$ Alexandru Ioan Cuza University of Iaşi, Faculty of Economics and Business Administration, Iași, \\ Romania,altug@uaic.ro
}

\begin{abstract}
Purpose: The purpose of this paper is to investigate and confront whether information security managers are aware of all the dangers of using blockchain technology and cryptocurrency, what methods of thinking and decision-making they use, regulation issues, and whether these models address the cryptocurrency and blockchain technology threats.

Design: Based on the systematic review of a total of 60 papers that were selected, our paper will discuss the managers decision making in global companies, regard the old and new methodologies confronting the technological progress, regards the blockchain technology and cryptocurrency.

Findings: We found that senior management in global organizations partially aware of the risk that blockchain and cryptocurrency poses to their organizations, and still operate in different and uneven methods supporting decision making regard the blockchain and cryptocurrency technology. Farther and more deeply research need to be performed on management decision making regard the new risks poses from the use of blockchain and cryptocurrency technology.

Originality: Unlike many other systematic reviews we have managed to debate the posed risks that exist by using blockchain and cryptocurrency in global companies identifying the gap in knowledge and therefore the Uneven in decision making facing blockchain and cryptocurrency technology.
\end{abstract}

Keywords: Blockchain, Cryptocurrency, Cybersecurity, Decision Making, Economy, Globalization, Information Security.

\section{Introduction}

Cybersecurity concerns all aspects of life and is a key issue in the protection of resources that ultimately add up to economic issues. They can be day-to-day topics and can be a conversation about Local, Corporate, and Global Economics. Cryptocurrency since the beginning has been a very attractive topic over the past few years now, using vast amount of technological power and pulling great investments that is valued in trillions of dollars on a global scale. Among the very good things that come with cryptocurrency and blockchain technology it brings with it risks to the Cyber and Information Security. There are major risks that is related with cryptocurrency industry such as, cryptocurrency account security, non-regulated and cryptocurrency hackable exchange, the big confusion between blockchain and cryptocurrency, etc. (Onik et al., 2018). Global organizations report that hackers trying on daily basis to get access to the big farms servers to use the power computing in order to mine illegally cryptocurrency abusing company resources. Chief information security officers' reports that the ongoing defending their own premises and getting the right decision making is a very taught task that sometimes cost more money to the organization, and that the regulation are way behind the technology (Swan 2015). Technology and globalization play a big role in our day today life's around the globe (Baldwin 2016) changing completely the game rules when it comes to Economies and managerial decision making. Cryptocurrency and Blockchain changing completely the way global organizations think and react regard global economies in a world without boundary's opening the markets worldwide to a technological 
change such as blockchain and cryptocurrency that help to leverage their business needs (Tapscott et al, 2016). While global economies can prosperity using new technologies such as blockchain and cryptocurrency, New technology also brings with it many dangers (Steen et al., 2020) that information security executives around the world need to deal with another outline of threats that so far have not bothered when they have to make important business-supporting decisions. Hackers from all over the world make extensive use of cryptocurrency such as bitcoins to hide and obscure their illegal footprints, making it difficult for enforcement agencies to try to catch them (Orcutt 2017).

Blockchain is in use today in a vast variety of industries and being utilized in plethora of industries (Bembenik et al., 2019) such as: finance, banking, insurance, hospitals, professional services and governments. The economy, at present, is ready with new and developing types of utilization. These have come about because of a conjunction of new technological, financial, and globalization, which are moving traditional types of business trades in to a digital, agile, global approach. Cryptocurrency attracting different sectors and being in use by global economies worldwide. Cryptocurrency is a decentralized digital currency stored in an online form that does not fall under governments and banks control which from one hand gives more freedom for global economy but in other hand can be pose danger devastate since it is not Supervised making it hard to control (Perkins 2020). Senior executives, especially (CISOs) information security managers who face difficult decisions every day (Kark et al., 2017) need to be updated with new technologies in order to provide the appropriate response in terms of data protection (National Research Council, \& System Security Study Committee, 1990), (Gordon 2015) taking in consideration the Confidentiality, Integrity and Availability (CIA). They need to be familiar with the old and new methods as well as know at all times to put in place all security mechanisms and make it as difficult as possible to compromise and use enterprise resources and steal sensitive information, organization finances and maintaining the companies reputation. They have a constant need to analyze the risk and to assess and measure the business impact in a measurable way, especially with new technologies such as blockchain and cryptocurrency are in use (Casey et al., 2018).

Throughout this paper, we will investigate and confront whether information security managers are aware of all the dangers of using blockchain technology and cryptocurrency, what methods of thinking and decision-making they use, regulation issues, and whether these models address the cryptocurrency and blockchain technology threats. The contributions of this paper provides a literature review that encapsulates the concepts of cryptocurrencies, blockchain technology, and menegerial desicion making regar it while emphasizing the effect on global economy.

\section{Literature Review}

"Blockchain" is the new buzzword nowadays, with each huge money related organization from NASDAQ to Goldman Sachs, investigating various roads with regard to blockchain technology new advancement (Schneider et al., 2016). Many express this astounding progression could transform our cash related structure, clearing out the prices and inefficiencies that plague our present budgetary establishments, as an example: portion, reimbursement, and clearing systems. Financing adventures are filling blockchain new organizations, which are scrambling to agitate the "quadrillion"- dollar markets addressed by existing budgetary market establishments. A conversation fumes about whether open, "permissionless" blockchains (like cryptographic cash) or private, "permissioned" blockchains (like those being organized at various huge banks) are progressively charming blockchain fills in because the development enabling basic cash related market structures the essential essentialness of working cash related market structure to overall budgetary quality, and delineates significant principles that overall money related controllers have gotten to assist continue this sufficiency, focusing particularly on organization, chance organization, and operational risk (Tapscott et al., 2017, June) got to fathom that with incredibly comes danger such operational perils created by the foremost focal features of advanced money its 
status as decentralized, open source programming. Illuminating the unavoidable operational risks of programming, for instance, its shortcoming to bugs and hacking, which will be urgent to a relationship along these lines need to be concider on the administrators experts. The operational dangers created by the foremost essential highlights of blockchain: its status as decentralized, open source programming. Lighting up the inescapable operational dangers of programming, for instance its weakness to bugs and hacking as an example as Bitcoin's exceptional " $51 \%$ Attack" defenselessness. These innovation dangers are exacerbated by the administration dangers created by digital money equivocal administration structure (Mourouzis et al., 2017). The operational dangers generated by decentralized, open source administration, including that no-one is in charge of settling an emergency with the product; no one can really fill in as "the voice" of the product; code upkeep and fix could be deferred or defective in light of the very fact that insufficient time is given to the code by volunteer programming engineers (or, if the coders are paid by privately owned businesses, the code advancement could be impacted by irreconcilable circumstances); agreement on significant changes to the code could be troublesome or difficult to accomplish, prompting parts within the blockchain; and therefore the product designers who "run" the Bitcoin blockchain appear to possess foundations in programming coding as against in strategy making or hazard the executives for budgetary market framework (Walch 2015). Security challenges yet posing risks to executive management using blockchain there is stresses over information assurance and data security, which make genuinely contradicting pressures on management level. In the law and authoritative domain, are concerned that the pseudonymous thought of blockchainbased records mists the character of performers most exceptionally, cash related foundations stress that security protection isn't adequate, since the essential passed on records were organized thinking about straightforwardness, allowing all individuals to see each trade. Information about individuals can be accumulated from structures in the trade outline and balances in the unspent trades outstanding posing risk on data and privet sensitive information (Meiklejohn et al., 2013).

\section{Review}

\subsection{Cybersecurity}

The term "Cybersecurity" is a very young term in the scientific literature. More than $90 \%$ of all papers that explicitly contain Cybersecurity term have been published in the last 13 years (i.e., since 2007). There is furthermore no fully agreed definition of "Cybersecurity". In 2008, the International Telecommunication Union (ITU) characterized Cybersecurity as the " $(. .$. assortment of Tools, Policies, Security Concepts, Security Safeguards, Guidelines, Risk Management Approaches, Actions, Training, Best Practices, Assurance and Technologies that can be utilized to ensure the digital condition, company and client's benefits. In addition, incorporate associated registering gadgets, staff, framework, applications, administrations, broadcast communications frameworks, and the totality of transmitted or potentially put away data in the digital condition (Von et al., 2013). Cybersecurity strives to ensure the attainment and maintenance of the security properties of the organization and user's assets against relevant security risks in the cyber environment. The general security objectives comprise Availability, Integrity and Confidentiality of Systems and Data, which may include authenticity and nonrepudiation (Yaghmaei et al, 2017). Information security is one of the key areas of cyberspace (Zhang et al., 2015) Hackers are maliciously damaging private databases, private and global companies, and government entities. Their purposes include (Sinrod et al., 2000): stealing passwords, Virus distribution, Eavesdropping, Business espionage, obtaining economic information, collecting personal information by impersonation, dropping sites, Takeover of the website home page, inserting a Trojan horse, Misuse of corporate resources for exploitation of virtual money mining Bitcoin resources by exploiting databases and browsing crypto mining through browsers vulnerability abuses and much more. 


\subsection{Information Security Managers}

Our world is completely connected thus, require from the managerial positions in any organization to be able and understand, have the right tools in hand, to be qualified enough to get the right decision in critical moments that the entire organization relaying on his inputs and profession. The CISO (Chief Information Security Officer), Responsible for information security issues in the organization, managing cyber hazards, including the administrative and technical side with the goal of maintaining Confidentiality, Integrity and Availability of information (CIA) from the external and internal cyber threat space, combined with maintaining the business continuity (BCP) of the organization. Part of the CISO role is to be able building an enterprise information security strategy according to the business objectives strategy, building policies and security procedures addressing law and regulatory aspects together with risk management supporting the management and the organization.

In 2004, the United States Department of Defense (DoD) issued Directive 8570.1 on "Information Security Training, Certification and Personnel Management". The provision requires that every technical or administrative professional in information security be trained and certified in accordance with a clear standard to enable effective protection of DoD information, information systems and information infrastructures, and to define groups of professions, and various senior levels. Having saying that there is more to add to the plate, Cybersecurity is about people, it's about the culture of the organization, it's about how we perceive our role in that people /technology interaction. Even with a CISO added to the mix, cybersecurity remains a huge challenge for any organization, at every level. Big gaps can open in any companies strategy. Especially if the end goal falls short of a fully cyber-resilient culture. That means cybersecurity needs to be top of mind for the board, the senior leadership team, and workers at every rank.

The models studied in the various cyber decision-making circles, especially the senior information security managers who are at the forefront of decision -making in various organizations, whether these models serve and can be relied upon at critical moments more than once, many managers make significant and fateful decisions for an organization relaying on old traditional models and do not adapt to the rapidly changing technological world that presents new challenges every day. Managers globally have different backgrounds, different cultures, different education, and make their decisions based on different organizational needs and different methodologies old and new ones, and facing difficulties such as budgets limitations or unclear business goals that are not always goes with the organizational Cybersecurity road map for example: how the organization itself defines its risk management against cryptocurrency and blockchain cyber-attacks, how to implement common cybersecurity methodologies in a world that technologies are much faster than organization can adopt.

\subsection{Managerial Decision Making}

It takes a wide scope of security experts and professional to perform a different data security program data security is best when starting from the top. Senior management is the key part and the imperative power for an effective execution of a data security program. Be that as it may, regulatory help is additionally fundamental to creating and executing explicit security strategies and methodology, and specialized aptitude is obviously basic to actualizing the subtleties of the data security program (Whitman et al., 2011). The chief information security officer (CISO) has essential obligation regarding the appraisal, the board, and execution of data security in the company. The jobs of data security experts are lined up with the objectives and strategic the business. These activity capacities and hierarchical jobs center around securing the companies data frameworks and put away data from potential attacks. Data security is the assurance of data resources that utilization, store, or transmit data from chance through the use of strategy, training, and innovation. The basic qualities of data, among them classification, honesty, and accessibility (the CIA triangle), must be ensured consistently; this insurance is executed by numerous measures (approaches, instruction preparing and mindfulness, and innovation) to do so, executive 
management will drive the top-down security approach to deal with security execution, in contrast with the bottom-up approach, whereby individuals choose security implementation strategies (Hayes 2002). One of the most effective tools being used by decision makers is the risk management process to identifying risk, as represented by vulnerabilities, to an organization information assets and infrastructure, and taking the right steps to reduce this risk to a business acceptable level.

When an organization relay on IT systems to stay viable, information security and the discipline of risk management need to become an integral part of the economic basis for creating business decisions (Avolio 2000). These decisions are supported trade-offs between the prices of applying information systems controls and therefore the benefits realized from the operation of secured, available systems. Risk management include three main objectives: risk identification, assessment and control. the risk identification is the examination and documentation of the safety position of an organization information technology and hence the risks it faces the risk assessment is the determination of the range to which the organization information assets are unprotected or in danger the risk control is the application of controls to come around the risks to an organization data and knowledge information thus, risk management strategy requires that information security professionals to know their organization information assets to identify, classify, and prioritize them and once the organizational assets are identified, a threat assessment process to identifies and quantifies the risks facing each asset need to be complete (Stoneburner et al., 2002). Security managerial positions require to be able use different and broad methods, techniques, security frameworks, policies, procedures, standards, law and regulation along with best practices to be able and get as much knowledge on their information asset to be able and get the right decisions at any point of time (Straub et al., 1998). Security management has "Basket" of concept and principles that can be used according to the process needed to get the right decision outcome (Tipton et al., 2006).

\subsection{Cybersecurity Ethics on Blockchain and Cryptocurrency}

Cyber Ethics gives orientation about right and wrong, good and bad, related to the cyber space. It tries to apply and modify fundamental values and virtues to specific new challenges and situations arising from cyber technologies and cyber society. As cyber space influences all parts of society, cyber ethics includes almost all ethics domains (Christoph et al., 2018). Ethics on cybersecurity has developed in the scientific literature, which ethical issues gained interest, which value conflicts are discussed, and where the "blind spots" in the current ethical discourse on cybersecurity are located. Cybersecurity practices have as their aim the securing-that is the keeping safe-of data, computer systems and networks (software and hardware). While those data, systems, and networks might have some economic or other value in and of themselves, what cybersecurity practices primarily protect are the integrity, functionality, and reliability of human institutions/practices that rely upon such data, systems, and networks (Yaghmaei et al., 2017). Cyber Ethics as Economic Ethics deals with positive and negative impacts of cyberspace on economic growth, job creation or job losses, financial investments in cyber research by sector, military or not, etc. Cyber Ethics therefore means: In today's world, all ethical topics should include the cyber aspect of it. On the other hand, all cyber-related technological, political, economic etc. developments should reflect the ethical aspects of it in terms of ethically positive and negative impacts (Christoph et al., 2018).

Globalization gives a vast complexity for managerial decision making facing hard to past the very intense pressure and competition between large organizations thus enforcing the organizations worldwide to perform all operations types externally outsourcing to countries that the cost of labor is much less expensive to reduce the cost and investment on on-premises costly operations and to reduce the risk by putting it on contractual obligation on third party. Having said that the senior management and the CISO need to adopt and recreate their new strategies to be able to adopt the globalization impact. 
Since the globalization has broken all conventions and opened the market to free boundless markets with the ability to generate new markets and develop the domestic economy and export it aggressively, export manpower and use cheaper manpower in weaker countries, caused the economy to expand and develop and create new opportunities. The Strategic power embrace resources and expertise that a firm uses to compete in its own business domain for that reason, it can form a firm's resilience or weak spot, and can be the source of competitive advantage or disadvantage among others. Globalization does not open only the markets to different opportunities it increased the way information been access and handled thus gave much pressure on managers to adopt and change their habits (Nieminen et al, 2017). Globalization enforced the management leaders to adopt and change their management way of work. When foreign market is open putting challenge on local markets that involved risks on any aspects, it requires management and C-Level decision making approach changes. Leaders according to globalization changes understand that they needed to create and follow new strategies to support the business needs and making it much difficult and complex to formulate and implement the right strategy focus on risk assessment and mitigation plans, risk controlling, risk planning, to be able understand the impact of the business in any move they take. In the past few years now, different researches (Casino et al., 2019) were performed regard blockchain and cryptocurrency since the subject gained vast interest among different researchers in global companies, industry practitioners and developers in varies domains among financial industry's that had focus on the new technologies of cryptocurrency and blockchain, due to its unique trust and security characteristics along with its security issues and much more as its involved cybersecurity management decision making, policy's and methodologies to be in place. Blockchain and cryptocurrency spread worldwide and along with its technological and financial benefits it introduces to the world new security impacts (Kan et al, 2018).

\section{Blockchain and Cryptocurrency}

In august 2008, domain name bitcoin.org was registered online two month later a technical paper was published entitled 'Bitcoin: A Peer-to-Peer Electronic Cash System' was passed around a cryptography mailing list this paper is the first instance of the mysterious figure, "Satoshi Nakamoto's" appearance on the web related to the cryptocurrency S. Nakamoto. This first publication laid the ground bricks for Bitcoin to become the first in a brand-new type of "virtual currency", called cryptocurrency. It is important to understand the implications of this new technology among its benefits much more than the currency itself. Bitcoin and cryptocurrency created A virtual currency to be as a medium of exchange existing entirely in intangible form that is not legal tender, but which can substitute for legal tender (Vigna et al, 2015). Cryptocurrency itself has a broad category in virtual currencies, the definition created as currency held within the internet and verified through the process of cryptography. The technology behind cryptography established the most important part of Bitcoin's creation, the blockchain. The blockchain as it relates to Bitcoin, is a decentralized collection of "blocks" in a public yet anonymous ledger that lists each time a Bitcoin is transferred or used in a purchase. Each "block" is created when one of the aforementioned circumstances is executed. The importance behind the creation of blockchain technology comes from the inability to edit a "block" once it is added to the blockchain. Before any type of transfer is recorded on the blockchain, the process of adding a "block" to the chain must occur (Antonopoulos, 2014). This slang for this process in the case of Bitcoin is defined as "mining" When people talk about "mining" for Bitcoin, they are saying that they are using their computer power and their electricity to solve a complex math problem that encrypts, or secures, the "block" and adds it to the ledger. The solution to the math problem, provides a unique encryption key that is used one time only to add a "block" to the chain. In return for using their resources to solve the equation, they are paid in Bitcoin, introducing more into the Bitcoin economy (Moore, 2015) showing why it is called "mining" The Bitcoin ledger of transactions is decentralized, or not governed by anybody. Therefore, it relies on "miners" to add transactions to 
the chain. Once a transaction is added, it cannot be reversed. It is important in Bitcoin's case to compensate the average person using their resources because just the electricity used is exorbitant and expensive (Lewtan et al., 2018). Moreover, to define this concept, the European Parliament has recently produced a document classifying the definitions provided by various organizations, including the European Central Bank, the International Monetary Fund, the Committee on Payments and Market Infrastructures (a constituent of the Bank for International Settlements), the European Banking Authority, and the World Bank. The common conclusion of these different institutional viewpoints is that there is no generally accepted and regulated definition of cryptocurrency (Ertz et al., 2019). Nevertheless, the majority of these jurisdictions view cryptocurrency as a subset, or a form of virtual currencies, also called digital currencies (Houben et al., 2018).

A blockchain can be custom fitted to suit different kinds of information, and numerous enterprises are investigating blockchain answers for upgrade productivity, smooth out awkward or divided business forms, and create trust between counterparties dependent on the respectability of the innovation (English et al., 2018).

In the financial services industry, blockchain developments generally have focused on more efficient alternatives to resource-intensive processes, such as processes that rely on intermediaries to establish trust and facilitate communication between multiple entities, often across geographies. Potential uses for blockchains in the financial services industry include enhancing the efficiency of trade finance; cross-border payments; compliance and audit functions, including the Bank Secrecy Act, anti-money laundering, and know your customer compliance; and the settlement and clearing of securities and derivatives transactions (English et al., 2018).

Along with Blockchain and Distributed Ledger Technology, many other cryptocurrencies were invented that relay on blockchain technology and businesses in many industries took notice and are actively evaluating and pursuing the possibility of creating their own blockchain to use in their businesses. Blockchain's applicability to use in a business setting stems from it being a type of distributed ledger rather than its use in underpinning cryptocurrencies. A distributed ledger, through algorithms, allows all users within a network to collaboratively create the ledger itself (Moore, 2015).

\subsection{Blockchain and Cryptocurrency Security Threats}

It is goas without saying that Blockchain and Cryptocurrency brings new Attack Vectors that are relevant for the information security managers decision making in global companies and specifically in the financial sector that enforce the decision making much harder to keep track while technologies and Hacking sophistication and much more advanced. The blockchain technology is an open system that need to be public (decentralized) thus making it very hard to secure since it contains varies security flaws and expose all participants to cyber-attacks and threats (Lee 2019).

Blockchain systems security threats can come from different areas such as: It includes the prevention and double-spending security threats, mining or mining pool security threats, blockchain network security threats and smart contract security threats (Mosakheil 2018). These attacks can affect the integrity of the transaction, availability of system and data, confidentiality of system and data, Anonymity of Users' Identity, Unlikability of Transactions. The blockchain is constructed to ensure a number of inherent security attributes, such as consistency, tamperresistant, resistance to a Distributed Denial-of-Service (DDoS) attack, PseudoNymity, and resistance to double-spending attack. However, to use blockchain for secure distributed storage, additional security and privacy properties are required (Mosakheil 2018). The attack can be on the Blockchain infrastructure, Peer-to-Peer systems nor the blockchain application and has various attacks methods that can be used. Attacks can cause chain splitting, revenue loss, partitioning, malicious Mining, system delay, information loss, data and currency thefts, exchanges, the application itself, the users, and among others it can definitely affect the Company Reputation that can cause later on to monitory loss. 


\subsection{Financial Industry Risks}

The finance industry faces on a daily basis cyber threats and attacks that aim to exploit vulnerability's, disrupt systems, steal sensitive data and company funds. Attackers are being much sophisticated against financial sectors such as banks and big firms, trying to steal financial data and customers funds. The majority of the attacks can come in many different methods such as malware distribution, targeted phishing campaigns, malicious URLs to IT personals with fake sources leading to compromise data. They can target web applications to steal credentials and mining personal data, trying to gain access and leverage stolen credentials on costumer's accounts with brute force attacks along with distributed denial of service (DDoS) targeting large scale organizations, using automatic botnets and tools to send heavy stream of traffic and different data's, targeting websites and overloading the systems to cause temporary or permanently operation disruption. Even though the blockchain technology brings good controls for establishing additional layer of security, still there is a risk that needs to take in consideration. Moreover, man in the middle (MITM) attacks can be performed, using unauthorizes access tool by a valid actor that already inside the system, in order to intercept or capture sensitive data. It can be performed on a physical of wi-fi network. A similar attack called man in the browser (MITB) by using a piece of malware injected to user system without the knowledge of the user to collect and record data that later on will be delivered to a bank website. Another vector of attack can be by theft of keys and blockchain is no different than other technologies. These attacks are aiming to compromise and steal cryptographic keys.

The most famous one that relate to blockchain, cryptography and the financial sector in ransomwares attacks, that can be devastative to any small or global large-scale organization. The ransomware attacks aiming directly on financial industry's to be able and gain the maximum possible of funds. Mostly these types of attacks performed anonymously making it much harder to track, making it even harder for the decision makers upon action. Attackers will be demanding their payment in Bitcoin or any other cryptocurrency making it much harder to trace. Most of the attacks of the financial industry can be related to cyber-crimes. According to www.hackmageddon.com site that is monitors the percentage of attacks in the cyberspace, $86.8 \%$ from all cyber-attacks relate to cybercrimes that relate to financial attacks. Cybercrimes are on top of the Motivation Behind Attacks.

Table 1. Cyber-Crime Attack Motivation Statistics

\begin{tabular}{llll}
\hline Motivation & March 2020 & April 2020 & Growth \\
\hline Cyber Crime & $86.6 \%$ & $86.8 \%$ & $0.2 \%$ \\
Cyber Espionage & $11.1 \%$ & $11.7 \%$ & $0.6 \%$ \\
Cyber Warfare & $11.1 \%$ & $11.7 \%$ & $0.6 \%$ \\
Hacktivism & $1.1 \%$ & $1.6 \%$ & $0.5 \%$ \\
\hline
\end{tabular}

Source: Passeri, P. (2020, June 3). April 2020 Cyber Attacks Statistics. Available from https://www.hackmageddon.com/ 2020/06/03/april-2020-cyber-attacks-statistics/

Table 2. Cyber-Crime Attack Techniques Statistics

\begin{tabular}{llll}
\hline Attack Techniques & March 2020 & April 2020 & Comparison \\
\hline Malware & $38.5 \%$ & $35.4 \%$ & $-3.1 \%$ \\
Account Hijacking & $16.8 \%$ & $19.6 \%$ & $2.8 \%$ \\
Targeted Attack & $12.3 \%$ & $6.9 \%$ & $5.4 \%$ \\
Vulnerability & $5.0 \%$ & $4.2 \%$ & $0.8 \%$ \\
SQL Injection & $0.0 \%$ & $2.6 \%$ & $2.6 \%$ \\
Misconfiguration & $1.7 \%$ & $2.1 \%$ & $0.4 \%$ \\
Zoom bombing & $0.0 \%$ & $2.1 \%$ & $2.1 \%$ \\
Business Email Compromise & $1.1 \%$ & $2.1 \%$ & $1 \%$ \\
Malvertising & $0.0 \%$ & $1.6 \%$ & $1.6 \%$ \\
Social Network Groups/Pages & $0.0 \%$ & $1.6 \%$ & $1.6 \%$
\end{tabular}




\begin{tabular}{llll}
\hline Attack Techniques & March 2020 & April 2020 & Comparison \\
\hline Credential Stuffing & $1.1 \%$ & $1.6 \%$ & $0.5 \%$ \\
Brute-Force & $0.0 \%$ & $1.1 \%$ & $1.1 \%$ \\
BGP Hijacking & $0.0 \%$ & $0.5 \%$ & $0.5 \%$ \\
Web Shells & $0.0 \%$ & $0.5 \%$ & $0.5 \%$ \\
Defacement & $0.0 \%$ & $0.5 \%$ & $0.5 \%$ \\
SSAI Hijacking & $0.0 \%$ & $0.5 \%$ & $0.5 \%$ \\
DNS Hijacking & $0.0 \%$ & $0.5 \%$ & $0.5 \%$ \\
Malicious Browser Extension & $0.6 \%$ & $0.5 \%$ & $-0.1 \%$ \\
\hline
\end{tabular}

Source: Passeri, P. (2020, June 3). April 2020 Cyber Attacks Statistics. Available from https://www.hackmageddon.com/ 2020/06/03/april-2020-cyber-attacks-statistics/

Table 3. Cyber-Crime Attack Targets Statistics

\begin{tabular}{llll}
\hline Attack Techniques & March 2020 & April 2020 & Comparison \\
\hline Individuals & $25.1 \%$ & $21.2 \%$ & $-3.9 \%$ \\
Multiple Industries & $21.2 \%$ & $25.4 \%$ & $4.2 \%$ \\
Public administration, defence, social & $11.2 \%$ & $6.9 \%$ & $-4.3 \%$ \\
security & $7.3 \%$ & $10.1 \%$ & $2.8 \%$ \\
Human health, social work & $5.6 \%$ & $7.4 \%$ & $1.8 \%$ \\
Financial, insurance & $4.5 \%$ & $1.1 \%$ & $-3.4 \%$ \\
Wholesale, retail trade & $4.5 \%$ & $1.6 \%$ & $2.9 \%$ \\
Manufacturing & $3.9 \%$ & $2.6 \%$ & $-1.3 \%$ \\
Education & $3.9 \%$ & $3.7 \%$ & $-0.2 \%$ \\
Information and communication & $2.2 \%$ & $1.6 \%$ & $-0.6 \%$ \\
Fintech & $2.2 \%$ & $4.2 \%$ & $2 \%$ \\
Arts, entertainment, recreation & & &
\end{tabular}

Source: Passeri, P. (2020, June 3). April 2020 Cyber Attacks Statistics. Available from https://www.hackmageddon.com/ 2020/06/03/april-2020-cyber-attacks-statistics/

The security of cryptocurrency depends on the algorithm of the blockchain that is being in use, and since there is no centralize authority that responsible for the cryptocurrencies possible cyberattacks can compromise the CIA tried (confidentiality, Integrity and Availability). Such a breach of security represents a form of cyber risk which has been found to be significant in the case of the financial sector (Kopp et al., 2017).

Different research paper on cybercrimes on cryptocurrency was published during the past few years such as, estimating the cyber-attacks from criminal operating in underground dark web communities for the loss of billions of dollars on the global marker (Benjamin et al., 2019), and the value at risk framework to measure cyber risks and losses (Bouveret 2018). Among with different methods that are required for risk management estimation, Platanakis et al. (2019) and Benjamin et al. (2019) gave few evidences on disruptions caused by cyber security breaches on the cryptocurrency markets (Corbet et al., 2019) estimated a DCC-GARCH model that cryptocurrency attacks and hacks increase the volatility of the currencies hacked and their correlations with other cryptocurrencies. Many more related articles and researches was published covering the risk, attack vectors, and the impact of the funds and the global companies' reputation loss, developed different methods and models that is trying to tackle the security aspect and the decision-making process.

\section{Regulatory and Legal Issues on Blockchain and Cryptocurrency -}

Blockchain and cryptocurrency is not Innocent when it comes to Privacy issues and concerns mostly when it relates to personal or pseudonymous data involved in the process. According to the Privacy Regulation EU (Tamburri 2020) In the GDPR the controller is characterized as the regular or legitimate individual, open power, office or other body which, alone or mutually with others, decides the reasons and methods for the preparing of individual information. The processor can be 
characterized as the normal or lawful individual, open position, office or other body which forms individual information for the benefit of the controller, accordingly the preparing of individual information inside a blockchain presumes that there is no progressive connection between the members. Every member is in this way equivalent and ready to contribute and utilize the date as observed fit. In the event that there are different understandings set up, this could end up being the special case (Fabiano 2020). Moreover, from a privacy perspective, permissioned and private blockchain applications are the sheltered decision for companies needing to receive this innovation. These two sorts of blockchain make it simpler to distinguish controllers and processors. Consequently, this makes the administration of legitimate commitments for controllers and processors increasingly sensible, just as dealing with the legally binding commitments among controllers and processors. It is exceptionally hard to recognize all the controllers and processors in an open blockchain, making it flawed on the off chance that it is lawfully conceivable to cling to the GDPR when utilizing an open blockchain (Mondschein 2020).

The GDPR although pointing the right to erasure and the tight to rectification as the first data subject right that is more complicated when approaching blockchain applications, its inherent feature of blockchain applications to ensure that data cannot or should not be deleted. In a way, this undermines the actual purpose of a blockchain solution, making it impossible to adhere to the right of erasure. Furthermore, the right to Rectification and Right to limit processing along with Hashes and Personal Data at the end these issues of privacy need to be taken into consideration when discussing personal data processed on a blockchain application (Lloyd 2020).

Along with GDPR need to take in consideration the Legal aspects on blockchain applications. Naves et al. (2019) ... highlight a few legal considerations, such as how to define the applicable national law for an international blockchain, how to define legally the ownership of a blockchain, legal issues with regard to identity within a blockchain - which especially applies to public blockchains, legal issues with regard to smart contracts, and legal issues concerning the monitoring of blockchains. To meet the security and privacy on blockchain there is a need to meet vast security and privacy requirements. Basically, the level of security and privacy required from the business owners will affect the combination of technologies that will be chose and used and not relating on one technology by itself. Since no technology is bullet proof and perfect when adding different technologies together the risk vector became more complex that can give the attackers more possibilities to fine the way in.Among these two, we can say that there is a trade-off between the privacy, security, and efficiency thus need to use methods that will improve the privacy and security of the blockchain system and at the same time make sure to deploy blockchain applications with the acceptable performance required from the business.

In October 2016, the Digital Currency and Ledger Defense Coalition (DCLDC), an alliance of almost 50 conspicuous U.S. legal advisors and scholastics, was reported (Kastelein 2016, October 3). The DCLDC seeks to protect the right of innovators experimenting with blockchain technology, through pro bono attorney referrals and the filing of amicus briefs (Jamie Oct 4, 2016) Where regulatory sandboxes are not forthcoming; therefore, this can be a powerful fallback for blockchain innovators.

The Jurisdictional point of view regard the Internet itself raised several questions on how to decide when a given jurisdiction's law would govern a given situation. In addition, servers for each blockchain network are decentralized and likely spread throughout the world, making it difficult to pinpoint where a breach or failure occurred. In the case of the Internet generally, several jurisdictions have mandated some form of data localization or border controls, where servers are required to be kept in that jurisdiction (e.g., Russia) or there are restrictions on how data can flow out of the jurisdiction (e.g., the EU and India). For the blockchain, lawmakers will have to consider how their jurisdictions' technology laws apply. A multi stakeholder, global approach appears to be best, to ensure the harmony of international rules (Gabrielle et al., November 2017). The uncertainty of Contract Law, since key feature of blockchains is the "formation and execution of digital contracts." instead of ordinary human language, software code dictates parties' rights and 
responsibilities, and automatically executes when specified conditions are met. This could be for the entirety of the contract or only in certain provisions (Croman et al., 2016, February).

Global world management decision making is a combination of old and new methodology's, along with old and new policies, procedures and does not relate on Absolute solution when it comes to global economy, blockchain technology and cryptocurrency that has completely changed the game rules along with the technology that is way forefront managerial thinking and decision making. Today there is no one method to deal with blockchain and cryptocurrency making managers to adopt and mix methodology's that will fit the organization they are protecting. Information security managers are partially aware of all the dangers of using blockchain and crypto among the very good benefit of using it and the contribution to global economy. Each model being use will face somehow regulatory issues according to the policies and low that relate to the organization and the regen operating. Since the world is borderless when talking about global economie and the use of cryptocurrency, digital monetary and blockchain technology different cybersecurity decision making approaches should be combined to be able having the right tools for each scenario.

The world of CISO and decision-making in dealing with and protecting enterprise resources and decision-making that are sometimes complex and sometimes cost the organization more money and that enforced regulation lags behind the fast-moving technology. This is an ongoing task manager like CISOs are facing on a daily basis.

Security managers are using vas amount of security compensating controls, making sure that the CIA are kept in all times with minimum business impact. Managers will than follow company Regulations upon the business approach supporting the business on any level. Since there is lack of enforcement on blockchain and cryptocurrency, and organizations are being attacked on daily basis by hackers that are trying to exploit and infiltered the security layers of defense in a purpose of funds thefts nor abusing the infrastructure for mining cryptocurrency, thus one method of approach or guidelines is not sufficient to protect the business. Cybersecurity Considerations for Permissioned Blockchains Permissioned blockchains present one of a kind open doors in overseeing cybersecurity dangers. As the budgetary administrations industry investigates the utilization of permissioned blockchains to improve administrations and tasks, industry members ought to perceive and consider various cybersecurity abilities, just as dangers and different contemplations identifying with this innovation (English et al., 2018). Moreover, permissioned blockchains accommodate various abilities in relieving cybersecurity dangers and identifying, forestalling, and fighting the sorts of digital assaults that are frequently aimed at money related foundations. For example, Distributed engineering of a permissioned blockchain is a favorable position that can prevent or limit the impact of cyberattacks. The utilization of agreement systems for approving new squares of information presents another key cybersecurity advantage on a permissioned blockchain organize. Encryption, Permissioned blockchain systems utilize numerous types of encryption at various focuses, giving multilayered assurances against cybersecurity dangers. Straightforwardness, in permissioned blockchain systems gives another level of cybersecurity security.

Manager Risk Controls, Permissioned blockchains frequently are facilitated on cloud stages that have hearty cybersecurity controls across various layers of the innovation stack. Also, major CSPs like Microsoft deliberately submit to intermittent autonomous reviews drove by universally authorize firms, which center around the CSP's adherence to industry-driving principles from the International Standards Organization (ISO), the U.S. National Institute of Standards and Technology (NIST), and others. Distributed computing offers members an effectively available and profoundly deficiency safe stage, bringing about less personal time, less danger of lost exchanges, and less danger of inability to arrive at accord. CSPs likewise can actualize systemwide updates and fixes in a substantially more quick and thorough way, while utilizing most extreme danger knowledge discovery over the system (English et al., 2018). Computer and Internet-based technologies will remain the subject to inherent cybersecurity risks that require thoughtful and 
proactive risk management and good decision making. Perhaps the single most important risk to blockchain security is key management. Maintaining the confidentiality, integrity, and availability of private keys requires thoughtful and robust cybersecurity controls. The majority of the attacks are performed on the outsider's providers that are identified with the blockchain and not focusing on explicitly the blockchain themselves yet focusing on the suppliers (flexibly chain assault) of key administration administrations to take private keys. Managers decision making should be relating on performing concisely Governance and making sure that all security procedures are in place assuring that all business objectives get the right security measurements in place.

In this period there isn't one Business procedure standard for all. Every organization embraces and construct the correct technique to meet all business objectives. Methodologies will ensure that every authoritative resource are shielded from insider and untouchable assaults, consequently every organization choose what resources are increasingly significant for investing all amounts of energy in guarding and securing.

In 2014, the National Institute of Standards and Technology ("NIST") distributed a Framework for Improving Critical Infrastructure Cybersecurity (the "Cybersecurity Framework" or the "Structure"). it is a deliberate structure intended to help companies to all the more likely comprehend, oversee, and lessen their cybersecurity hazard giving a significant level, vital perspective on the lifecycle of an companies cybersecurity hazard the executives and can be custom fitted to explicit business segments and organizations. Numerous organizations especially money related foundations, are creating cybersecurity programs lined up with the Framework that portrays five expansive capacities - distinguish, ensure, identify, react, and recoup - that characterize the elevated level objectives of a cybersecurity hazard the board program (Cybersecurity 2014). The functions and categories represent a helpful way to evaluate and comprehensively think about mitigating the cyber risk of a blockchain solution in the context of an organization's broader technology decisions and overall risk. In many cases, blockchain may facilitate the goals or activities specific in the functions and categories. Framework's emphasis on protective technology solutions that are designed to ensure the security and resilience of IT systems and assets. As part of a review of their cybersecurity capability maturity, companies often will use the Framework to do a regular self-assessment or engage outside auditors or consultants to assess their maturity against the Framework's (Cybersecurity 2014). The Framework explicitly expresses that it is "not a one-size-fits-all way to deal with overseeing cybersecurity chance" since "companies will keep on having exceptional dangers - various dangers, various vulnerabilities, diverse hazard resistances - and how they actualize the practices in the Framework will fluctuate". NIST as of late gave in draft a "Blockchain Technology Overview" that is characteristic of the standard-setting body's enthusiasm for the innovation and likely goal to think about gauges later on (Yaga et al., 2019).

\section{Conclusions}

Information security managers in various organizations worldwide still base their knowledge on the basis of old methodologies taught in the various accreditation courses, without getting down to the depth of the content and are often influenced by an organizational culture based on these old methodologies. This often leads to erroneous decisions since the organization they work for does not necessarily match those methodologies being used. Among the very old methodologies, new ones such as NIST, ISO, SOC, PCI, and many others standards published are being in use according to the business needs, lows and regulations. Bringing new tools for decision making to the table.

Information security managers facing complex challenges that did not exist in previous years, since technologies and progress change frequently, which requires information security managers to try to keep pace with the tools available to them in an organization that often limits their ability to make rational decisions on the one hand and business measurements on the other. Whether these models address the cryptocurrency and blockchain threats? There is still a big debate regard it. The challenges faced by information security managers who are required to make significant decisions that can directly affect the organization can use a mix of different methodologies, policies and 
procedures among new standards to increase the level of maturity and security on the business. The gaps appeared during the systematic literature review addressed the same gaps in all. and draw the fine line between the understanding of blockchain and cryptocurrency, the impact on global economie among the benefit in the blockchain and cryptocurrency technology and the decisionmaking issues adopting and security business while using this technology. In each article reviewed the security approach and decision-making approach was given relate on maturity level of the organization in adopting blockchain technology, defining the Risk level and the right approach to handle it in a way that the resilience of the business will have the less affect as possible. Moreover, it emphasized the necessity of using the blockchain technology and the benefit of the global economy leveraging it along with the lack of proper regulation and legislation to support the business. During the literature review of all the articles that got our attention, one can see that there is a uniform line in reference to blockchain and cryptocurrency technologies and the widespread use in all areas of life and different industries, there is a big focus on the global economy banking and commerce. it is very Noticeable that there is no uniform method of security decision-making on blockchain and cryptocurrency today, and every organization chooses the way to rely on existing methodologies, regulation, and law, and based on the sensitive assets it defines and protects. So far, the studies on the fairly introduced blockchain and cryptocurrency technology have predominantly focused on the good an benefits using blockchain and cryptocurrency technology, the mathematical mechanism behind it and the financial impact on global scale, free markets, etc. There is still a big gap in knowledge regard the information security issues that this new the technology poses while using it and even bigger gap on the approach regard security managers and executive in global companies protecting the company while using blockchain technology and cryptocurrency and from outside attack vectores.

In our opinion since technology moving fast, and global economy relay more than ever on high technology such as blockchain and cryptocurrency, there is much more to do in the way of CISOs decision making adopting agile methods and be more flexible choosing mix Cyber methodologies to leverage the maturity of the business and the organization approaching Cryptocurrency and Blockchain Technology.

\section{Limitations and Further Research}

In spite of the fact that we attempted to evade confinements, it ought to be borne as a primary concern that in this article we included just articles written in English, which means we didn't consider every one of those written in other unknown dialects. Furthermore, the catchphrases utilized were likewise in English, so almost certainly, a few articles were missed that could contain labels and titles in various dialects. Besides, on the grounds that the cyber digital world did not depend exclusively on scholastic articles and is commonly founded on non-scholarly articles, diaries and different online journals, in this article we utilized scholarly databases and in this manner it is essential to consider that much material that isn't scholastic yet proficient and significant has not been tended to. Furthermore, the chose logical articles depend on their perceived writers for the very structure of examination results and results, which might be another wellspring of predisposition. Accordingly, we unquestionably have a vulnerable side around there, and we offer more examination here and a superior strategy for social event data that is better than a deliberate survey. The proposition for additional examination should consider different articles, in various dialects (not simply English) and numerous scholastic databases, including non-scholarly data sources so as to grow and extend the field. 


\section{References}

- Avolio, F. M. (2000). Best practices in network security. Network Computing-Manhasset NY-, 11(5), 60-71.

- Antonopoulos, A. M. (2014). Mastering Bitcoin: unlocking digital cryptocurrencies. O'Reilly Media, Inc.

- Baldwin, R. E. (2016). The great convergence (No. BOOK). The Belknap Press of Harvard University Press.

- Bembenik, R., Skonieczny, L., Protaziuk, G., Kryszkiewicz, M., \& Rybinski, H. (Eds.). (2019). Intelligent methods and big data in industrial applications. Springer International Publishing.

- Bouveret, A. (2018). Cyber risk for the financial sector: a framework for quantitative assessment, IMF Working Paper 18/143.

- $\quad$ Benjamin, V., J.S. Valacich \& Chen, H. (2019). DICE-E: a framework for conducting Darknet identification, collection, evaluation with ethics", MIS Quarterly, 43(1), 1-22.

- Casey, M., Crane, J., Gensler, G., Johnson, S., \& Narula, N. (2018). The impact of blockchain technology on finance: A catalyst for change. Geneva Reports on the World Economy, 21, ICMB and CEPR

- Casino, F., Dasaklis, T. K., \& Patsakis, C. (2019). A systematic literature review of blockchain-based applications: current status, classification and open issues. Telematics and Informatics, 36, 55-81.

- Christoph Stückelberger / Pavan Duggal (2018). Cyber Ethics 4.0: Serving Humanity with Values Geneva: Globethics.net.

- Corbet, S., Cumming, D. J., Lucey, B. M., Peat, M., \& Vigne, S. (2019). Investigating the dynamics between price volatility, price discovery, and criminality in cryptocurrency markets. Price Discovery, and Criminality in Cryptocurrency Markets. https://papers.ssrn.com/sol3/papers.cfm?abstract_id=3384707

- Croman, K., Decker, C., Eyal, I., Gencer, A. E., Juels, A., Kosba, A. \& Song, D. (2016). On scaling decentralized blockchains. International conference on financial cryptography and data security, Springer, Berlin, Heidelberg, 106-125

- $\quad$ Eccles, R. G., Ioannou, I., \& Serafeim, G. (2014). The impact of corporate sustainability on organizational processes and performance. Management Science, 60(11), 2835-2857.

- Ertz, M., \& Boily, É. (2019). The rise of the digital economy: Thoughts on blockchain technology and cryptocurrencies for the collaborative economy. International Journal of Innovation Studies, 3(4), 84-93.

- English, E., Kim, A. D., \& Nonaka, M. (2018). Advancing blockchain cybersecurity: technical and policy considerations for the financial services industry. Cybersecurity policy and resilience, 81 .

- Fabiano, N. (2020). The value of personal data is the Data Protection and Privacy preliminary condition: synthetic human profiles on the web and ethics. Proceedings of the 3rd International Conference on Applications of Intelligent Systems, 1-5.

- $\quad$ Gordon, A. (Ed.). (2015). Official (ISC) 2 guide to the CISSP CBK. CRC Press.

- Gabrielle P., Anurag B. (2017). Rule of Law Versus Rule of Code: A Blockchain-Driven Legal World, IBA Legal Policy \& Research Unit Legal Paper, www.ibanet.org

- Hayes, M. (2002). Where the chief security officer belongs. InformationWeek, 877, 38-38.

- Houben, R., \& Snyers, A. (2018). Cryptocurrencies and blockchain: Legal context and implications for financial crime, money laundering and tax evasion. European Parliament study. PE 619.024. Available from: https://publications.europa.eu/en/publication-detail//publication/631f847c-b4aa-11e8-99ee-01aa75ed71a1. 
- Jamie R. (2016) Jerry Brito Leads Task Force of Lawyers Focusing on Blockchain. Available from: https://news.bitcoin.com/jerry-brito-task-force-blockchain/

- Kastelein, R. (2016). 40 US Law Firms Join Up to Form Blockchain Legal Defense Coalition To Protect Innovation. Available from https://www.the-blockchain.com/2016/10/03/40-uslaw-firms-join-up-to-form-blockchain-legal-defense-coalition/

- Kark, K., Francois, M., \& Aguas, T. (2016). The new CISO: Leading the strategic security organization.(nd). Retrieved August 09, 2017.

- Kopp, E., Kaffenberger, L. and Wilson, C. (2017). Cyber risk, market failures, and financial stability, IMF Working Paper no. 17/185.

- Kan, L., Wei, Y., Muhammad, A. H., Siyuan, W., Linchao, G., \& Kai, H. (2018). A multiple blockchains architecture on inter-blockchain communication. In 2018 IEEE International Conference on Software Quality, Reliability and Security Companion (QRS-C) IEEE, 139-145.

- Lewtan, J., McManus, J., \& Roohani, S. (2018). Blockchain: Opportunity to Improve Financial Reporting and Corporate Governance. http://hdl.handle.net/10125/59363

- Lee, J. H. (2019). Systematic approach to analyzing security and vulnerabilities of blockchain systems (Doctoral dissertation, Massachusetts Institute of Technology).

- Lloyd, I. (2020). Information technology law. Oxford University Press.

- M. Samaniego, R. Deters, Blockchain as a service for IoT (2016). in: 2016 IEEE International Conference on Internet of Things (iThings) and IEEE Green Computing and Communications (GreenCom) and IEEE Cyber, Physical and Social Computing (CPSCom) and IEEE Smart Data (SmartData), 433-436.

- Meiklejohn, S., Pomarole, M., Jordan, G., Levchenko, K., McCoy, D., Voelker, G. M., \& Savage, S. (2013). A fistful of bitcoins: characterizing payments among men with no names. Proceedings of the 2013 conference on Internet measurement conference, 127-140.

- Moore, T., Böhme, R., Christin, N. and Edelman, E. (2015). Bitcoin: Economics, Technology, and Governance. Journal of Economic Perspectives 29(2) (spring), 213-38. Accessed December 6, 2017

- Mosakheil, J. H. (2018). Security threats classification in blockchains. Culminating Projects in Information Assurance. 48. https://repository.stcloudstate.edu/msia_etds/48

- Mourouzis, T., \& Filipou, C. (2017). The Blockchain Revolution: Insights from TopManagement. arXiv preprint arXiv:1712.04649.

- Mondschein, C. F. (2020). Browser-based Crypto Mining and EU Data Protection and Privacy Law: A Critical Assessment and Possible Opportunities for the Monetisation of Web Services. The Journal of The British Blockchain Association, 12585.

- Nakamoto, S. (2008). Bitcoin: a peer-to-peer electronic cash system. Available from https://bitcoin.org/bitcoin.pdf.

- National Research Council, \& System Security Study Committee (1990). Computers at risk: safe computing in the information age. National Academies Press.

- $\quad$ Naves, J., Audia, B., Busstra, M., Hartog, K. L., Yamamoto, Y., Rikken, O., \& van HeukelomVerhage, S. (2019). Legal Aspects of Blockchain. Innovations: Technology, Governance, Globalization, 12(3-4), 88-93.

- Nieminen, R., Puccio, L. and Andre, C. M. (2017) The Added Value of International Trade and Impact of Trade Barriers.

- NIST (2014). Framework for Improving Critical Infrastructure Cybersecurity. https://www.nist.gov/system/files/documents/cyberframework/cybersecurity-framework021214.pdf

- $\quad$ Onik, M. M. H., \& Ahmed, M. (2018). Blockchain in the Era of Industry 4.0. Data Analytics: Concepts, Techniques, and Applications, 259-298. 
- $\quad$ Orcutt, M. (2017). Criminals Thought Bitcoin was the Perfect Hiding Place, but They Thought Wrong. MIT Technology Review. Retrieved from https://www.technologyreview.com/s/ 608763/criminals-thought-bitcoin-was-the-perfect-hiding-place-they-thought-wrong/

- Passeri, P. (2020). April 2020 Cyber Attacks Statistics. Available from https://www.hackmageddon.com/2020/06/03/april-2020-cyber-attacks-statistics/

- Perkins D. W. (2020). Cryptocurrency. The Economics of Money and Selected Policy Issues. Congressional Research Service, https://fas.org/sgp/crs/misc/R45427.pdf

- Platanakis, P., Urquhart A. (2019). Portfolio Management with Cryptocurrencies: The Role of Estimation Risk, Economics Letters, 177, 76-80.

- $\quad$ Schneider, J., Blostein, A., Lee, B., Kent, S., Groer, I., \& Beardsley, E. (2016). Blockchainputting theory into practice. Profiles in Innovation Report.

- Sinrod, E. J., \& Reilly, W. P. (2000). Cyber-crimes: A practical approach to the application of federal computer crime laws. Santa Clara Computer \& High Tech. LJ, 16, 177.

- Steen, C. G., Hamilton, L. L. P., Skadden, A., Slate, M., \& Flom, L. L. P. (2020). Enterprise Ethereum Alliance Glossary the Editor shares key concepts and definitions of blockchain Industry Promoting innovation through education: The blockchain industry, law enforcement and regulators work towards a common goal.

- Stoneburner, G., Goguen, A., \& Feringa, A. (2002). Risk management guide for information technology systems. Nist special publication, 800(30), 800-30.

- $\quad$ Straub, D. W., \& Welke, R. J. (1998). Coping with systems risk: security planning models for management decision making. MIS quarterly, 441-469.

- Swan, M. (2015). Blockchain: Blueprint for a new economy. “O'Reilly Media, Inc.”.

- Tapscott, D., \& Tapscott, A. (2016). Blockchain revolution: how the technology behind bitcoin is changing money, business, and the world. Penguin.

- Tapscott, D., \& Tapscott, A. (2017, June). Realizing the Potential of Blockchain. A Multistakeholder Approach to the Stewardship of Blockchain and Cryptocurrencies. In World Economic Forum.

- Tamburri, D. A. (2020). Design principles for the General Data Protection Regulation (GDPR): A formal concept analysis and its evaluation. Information Systems, 91, 101469.

- Tipton, H. F., \& Krause, M. (Eds.). (2006). Information Security Management Handbook, Volume 3. CRC press.

- Walch, A. (2015). The bitcoin blockchain as financial market infrastructure: A consideration of operational risk. NYUJ Legis. \& Pub. Pol'y, 18, 837.

- Whitman, M. E., \& Mattord, H. J. (2011). Principles of information security. Cengage Learning.

- Vigna, P., \& Casey, M. J. (2015). The Age of Cryptocurrency: How Bitcoin and Digital Money Are Challenging the Global Economic Order.

- Von Solms, R., \& Van Niekerk, J. (2013). From information security to cyber security. Computers \& security, 38, 97-102.

- Yaghmaei, E., van de Poel, I., Christen, M., Gordijn, B., Kleine, N., Loi, M., Morgan, G. and Weber, K. (2017). Canvas White Paper $1-$ Cybersecurity and Ethics. https://ec.europa.eu/research/participants/documents/download

- $\quad$ Yaga, D., Mell, P., Roby, N., \& Scarfone, K. (2019). Blockchain technology overview. arXiv preprint arXiv:1906.11078.

- Zhang, H., Han, W., Lai, X., Lin, D., Ma, J., \& Li, J. (2015). Survey on cyberspace security. Science China Information Sciences, 58(11), 1-43. 


\title{
Cap. 9. THE REPUTATIONAL RISK - A QUALITATIVE RESEARCH OF THE BANKING SECTOR IN ROMANIA
}

\author{
Răzvan-Ionuț Drugă \\ Alexandru Ioan Cuza University of Iasi, Doctoral School of Economics and Business Administration, Iaşi, \\ Romania,drugarazvanionut@gmail.com
}

\begin{abstract}
This paper presents the reputational risk concept, at the level of the first two banks from Romania, according to the value of their assets, in 2018. In the introduction of the paper will be made an analysis of the specialized literature regarding the reputation concept, the reputational risk concept, respectively. Will be presented the factors that influence the level of the reputational risk, as well as the measures that may diminish it. The research technique used is the content analysis. The results of the research show us that the position of the first two banking institutions can be also determined by the level of the reputational risk.
\end{abstract}

Keywords: reputational risk, banking institutions, content analysis.

\section{Introduction}

The economic crisis that started in 2007 represented a delicate period for many economic institutions. Because many companies faced with financial problems in that period, their managers were more cautious in taking their decisions.

One of the consequences of this negative period, in Romania, with a major impact on the banking sector, was represented by the system restructuring. At a short time after the economic crisis, the number of the banks had decreased (Moraru \& Ghita-Mitrescu, 2016). This fact automatically brought to a lower offer on the national market. Also, another important consequence of the reminded economic crisis, manifested in Romania, was represented by "the refining of the banking products and services offered" (Moraru \& Duhnea, 2018, p.4). This fact puts in attention the interest of the banks employees to offer to their customers products and services adjusted to their demands. If the offer does not correspond to the demand of the consumers, they will prefer to reorient to another supplier.

In that period, any wrong, however small it was, could lead to a loss of the consumer's trust in the company. In other words, the level of the reputation of the economic units could decrease. This problem can be identified with the notion of "reputational risk".

According to the specialists (Fombrun et al., 2002, p.88, quoting from March \& Shapira, 1987), the reputational risk represents "the range of possible gains and losses in reputational capital for a given firm". According to the reputation level of the company, to the products and services portfolio, to customer portfolio, the company representatives must to adopt measures which will decrease this indicator. Otherwise, the managers risk that their company to not be recognized on the market.

A consequence of a high level for the reputational risk can be the significant decrease of the demand. Because it is considered a factor that can prevent companies from achieving their goals, it must be eliminated.

Further, will be presented the most important aspects from the specialized literature on the reputational risk. Also, there will be a presentation of the banking sector from Romania, as well as a qualitative analysis of the paper subject.

\section{Literature Review}

According to Zboron (2006, p. 504), the reputation is "one of the most important assets it possesses" a company. If the previous results of the company are more valuable and if the actions 
which will be undertaken follow the same direction, the perception level of the stakeholders will be one to measure.

According to other authors, the reputation can be defined such as: "the global perception or evaluation that constituents hold regarding a company's performance and attributes" (Feldman et al., 2014, p.55). Thus, if an economic unit has lower performance, the level of the reputation, recognized by the public, is lower. Instead, if a company has a higher reputational level, the relations with the stakeholders will be directly proportional (Pérez-Cornejo, 2019).

One of the major risks which the economic units have to overcome them is the reputational risk (Murray, 2004). Because is an important component for the companies, the responsible persons with the management of the company are required to pay it close attention. This fact is necessary because, if the high level of the reputation will be lost, it will be very hard for the company to recover the consumers and contributors trust.

The reputational risk depends on the following factors: "the strategic positioning and execution of the firm", "the conflicts of interest exploitation", "the individual professional conduct", "the compliance and incentive systems", "the leadership and the prevailing corporate culture" (Walter, 2016, p.8). Compare to another risk category, the reputational risk differ regarding on the social structure. This fact is possible, because is considered to be "a purely "manmade' product of social interaction and communication" (Power et al., 2009, p.302).

To be protected against the reputational risk, the economic units can include in their strategies, the following actions: "to address the importance of corporate reputation as a resource at risk"; "to define what is risk and how to assess it"; "to compare reputational risk to other risk categories"; "to identify the main risk sources that can affect reputation" (Gaudenzi et al., 2015, p.249). The managers can create programs and strategies in order to prevent the occurrence of the reputational risk. These will need to contain preventive measures, as well as activities to maintain a low level of reputational risk, as compared to other risk categories.

\section{Research Methodology}

The main objective of the paper is to present the reputational risk concept, on the banking market from Romania, based on the most important notions from the specialized literature, which were previously mentioned. Also, to realize the case study of the research, will choose the first two banks from Romania, according to the value of the assets registered in 2018. The reputational risk for these institutions will be analyzed at a conceptual level.

The second objective of the paper is to identify the level of the reputational risk for the chosen institutions. Will be presented the factors which influenced this score, as well as the measures which can be adopted to reduce the level of this indicator, if applicable.

The purpose question for this research paper, in relation to the objectives, is: Can be the position of the banking institutions, in the speciality rankings, determined by the level of the reputational risk?

To achieve the objectives, the method used will be the qualitative research. The used technique is the content analysis. Will be examined some information relating to the reputational risk, found on the bank's website and in the their reports, between 2016-2018. The two institutions which will be included in the research are Banca Transilvania (BT) and Banca Comerciala Romana (BCR).

\section{The Banking Sector in Romania}

One of the most vulnerable economic sectors, from the point of view of the reputational risk, is the banking sector. The banking sector represents "an industry and a section of the economy devoted to the holding of financial assets for others and investing those financial assets as a leveraged way to create more wealth" (Investopedia, 2020).

In Romania, the banking sector is one of the most important areas, because "finances mainly the Romanian economy, providing about $80 \%$ of total funding granted by the Romanian financial sector" (The Romanian Association of Banks, 2020). 
In 2018, supported by a favourable macroeconomic context, the banking sector had a positive evolution. This trend conducted to a speeding of the lending. Also, in the same year, due to the consumer demand, the GDP value increased by 4.1\% (The European Banking Federation, 2019).

If we refer to the top banking institutions from Romania, after the value of the assets recorded in the end of 2018, on the first two positions were BT and BCR (Ziarul Financiar, 2019).

BT has a customer portfolio "with over 3 million customers". In over 180 cities from Romania, $\mathrm{BT}$ is present. Regarding to the number of employees, no more less 8000 persons are in the company group (Banca Transilvania, 2020a).

In the same time, BCR is "the most important financial group in Romania". From this sentence, the company reputation can be defined such as one strong. Also, the company has "the largest ATM network (over 2,100 ATMs and 13,500 POS terminals)" (Banca Comercială Română, 2020a).

\section{Results and Discussions}

At the managerial level, the activity of central banks can be affected by the many types of risks: "operational risks", "financial risks", "strategic risks". Every type can be a consequence of the negative perception about one of the bank, which will conduct to the appearance of the reputational risk (Vardy, 2015, p. 2). The last-mentioned type represents one of the risks which the banks from Romania had faced in 2018.

In the following table (table 1) are presented some aspects of the reputational risk, found in the reports of the BT and of the BCR:

Table 1. The reputational risk concept at BT and at BCR

\begin{tabular}{|l|l|l|}
\hline The Bank & The reputational risk concept & Keywords terms \\
\hline BT & $\begin{array}{l}\text { "... the risk to incur losses or to fail in achieving } \\
\text { estimated profits due to the lack of public } \\
\text { confidence in the integrity of the Group." }\end{array}$ & $\begin{array}{l}\text { - the risk to incur losses; } \\
- \text { the risk to fail in achieving } \\
\text { estimated profits; } \\
\text { - the lack of public confidence. }\end{array}$ \\
\hline BCR & $\begin{array}{l}\text { "... the current or prospective risk to earnings } \\
\text { and capital arising from adverse perception of } \\
\text { the image of the credit institution on the part of } \\
\text { customers, counterparties, shareholders, } \\
\text { investors or supervisory authorities. }\end{array}$ & $\begin{array}{l}\text { - the current or prospective risk to } \\
\text { earnings and capital; } \\
\text { image adverse perception of the }\end{array}$ \\
\hline
\end{tabular}

Source: Banca Transilvania, (2020b) and Banca Comercială Română, (2020b).

Analyzing the information presented in table 1, it can be observed that there is a difference in content between the two statements, of the two banking institutions. BT representatives chose to provide a personalized definition, referring to the "Group" from which it belongs. BCR representatives decided to use a complex but generalized definition.

Regarding the keywords that could be extracted from the bank definitions, the following phrases were selected for BT: "the risk to incur losses", "the risk to fail in achieving estimated profits", "the lack of public confidence". Therefore, with these variables can be created some causal links of the reputational risk in banking. If the institution will have some possible losses, caused by the level of expenses, the situation will be one negative and the public confidence will decrease.

Regarding the definition presented by BCR in relation to reputational risk, the following keywords could be extracted: "the current or prospective risk to earnings and capital", "the adverse perception of the image". These variables can directly influence the reputational risk of the bank. If the profit level will be lower compared to the previous financial years, BCR consumers will have a negative perception of it, and the reputation level will be affected. 
If we make connections between the two groups of keywords of banking institutions, the following matching can be made:

- the risk to incur losses and the risk to fail in achieving estimated profits can be matched with the current or prospective risk to earnings and capital;

- the lack of public confidence can be matched with the adverse perception of the image.

So, even though there is a difference in form between the two definitions of reputational risk, there are some similarities in content. This may be due to the sector in which the two institutions operate. Depending on the category in which are included, these keywords can be grouped, according to the next table (table 2):

Table 2. Factors that describe the reputational risk

\begin{tabular}{|l|l|l|}
\hline Keywords terms & Keywords groups & Frequency \\
\hline $\begin{array}{l}\text { - the risk to incur losses; } \\
\text { - the risk to fail in achieving estimated profits; } \\
\text { - the current or prospective risk to earnings and capital. }\end{array}$ & Financial aspects & 3 \\
\hline $\begin{array}{l}\text { - the lack of public confidence. } \\
\text { - the adverse perception of the image. }\end{array}$ & Psychological aspects & 2 \\
\hline
\end{tabular}

Source: own processing

Analyzing the keywords groups presented in table 2, it is observed that, in the definitions of reputational risk, the banks referred to both financial and psychological aspects. In both definitions, the financial aspects can be found three times: two times to BT and once to BCR. Instead, the psychological aspects can be found two times, once for each bank.

Regarding the level of reputational risk, during 2016-2018, BT presented a low level. According to company reports, the main factors which influenced the reputational risk level are "maintaining the confidence of the public and of the business partners in the BT's integrity" as well as in "its' economic and financial position". This facts show that this bank has a high level of reputation. If will continue to develop the same policies, BT is not in danger to lose the customers confidence.

During the 2016-2018, the level of reputational risk of BCR has improved. According to company reports, the main reasons for this level are: "the financial education program"; "strengthening corporate culture"; "using the risk-return decision tool"; "new product approval process". These things show us that the economic unit has identified a potential source of threat, which can affect its level of reputational risk. To counteract this source, BCR has found the solution to launch new programs that will support the creation of new products and services. This solution was successful because the reputation level has improved. All the factors presented above can be classified as follows (table 3 ).

Table 3. Factors that influence the reputational risk level

\begin{tabular}{|l|l|l|}
\hline Factors & Group & Frequency \\
\hline - maintaining the confidence of the public and of the business partners & & \\
in the bank's integrity; & - maintaining the confidence of the public and of the business partners \\
in its' economic and financial position; & $\begin{array}{l}\text { Corporate } \\
\text { - the financial education program; }\end{array}$ & 4 \\
- strengthening corporate culture. & & \\
\hline $\begin{array}{l}\text { - using the risk-return decision tool; } \\
\text { - new product approval process. }\end{array}$ & $\begin{array}{l}\text { Managerial } \\
\text { interest }\end{array}$ & 2 \\
\hline
\end{tabular}

Source: own processing

According to the data from the table 3, it is noticed that are two main factors which affected the reputational risk level, for the banks analyzed. One of them refers to the corporate governance, 
which includes four elements. Also, the second factor refers to the managerial aspects, which include two elements.

Analyzing the frequency of each, the following are noticed:

- for BT, two factors from the corporate governance group are assigned;

- for BCR, two factors from the corporate governance group and two from the managerial interest group are assigned.

\section{Limitations and Further Research}

The main limit encountered was represented by the lack of the presented information in the reports of the banks, about the reputational risk subject. Some reports which were analyzed, but not were included in the research, did not contain data about the research subject.

Also, a possible future research direction can be represented by some interviews which can apply to the representatives of banks, to describe in detail this subject.

\section{Conclusions}

The reputational risk represents a sensitive aspect for any institution. Depending on the field in which operates, this risk can present the same characteristics. This fact means that can be adopted general measures to diminish it. If the fields of activity for two institutions differ, the risk can be diminished in different ways. It will be necessary an analysis of all type of risks which can affect the company. The result of this fact can be a hierarchy of their importance, to know which of them are more dangerous.

At the end of this qualitative research was found that the position of the two banking institutions, in the speciality rankings, can be also determined by the level of the reputational risk. Also, the position of one relative to the other is justified by how to attach importance to the reputational risk. In the $\mathrm{BT}$ reports, the presented information about the reputational risk are personalized and more developed. In the BCR reports, the presented information about this subject are more generally. This fact can be a reason for the level of reputational risk registered by the both of banks, during 2016-2018. In conclusion, between the company reputation and the reputational risk, registered by the same company, is an inverse link. If a firm has a low reputational risk, the company reputation is high. Also, being a topic of managerial interest, the boards of the bank institutions must adopt strategies which help these to obtain a lower level of the reputational risk. Thus, the stakeholders perception will be one positive.

\section{Acknowledgements}

The publication of this paper was made with the support of the Erasmus+ Programme of the European Union, through the Jean Monnet Module: Sustainable Education through European Studies for Young Researchers (SESYR), Project Number 587359-EPP-1-2017-1-RO-EPPJMOMODULE.

\section{References}

- Banca Comercială Română (2020a). Our company. Available from: https://www.bcr.ro/en/about-us/our-company, last accessed 2020/01/16.

- Banca Comercială Română (2020b). Banca Comerciala Romana S.A.: The Consolidated and Separate Financial Statements (The Group and the Parent Bank), (2018, 2017, 2016). Available from https://www.bcr.ro/en/investors/financial-reports, last accessed 2020/01/16.

- Banca Transilvania (2020a). Despre noi. Available from: https://www.bancatransilvania.ro/ despre-noi/, last accessed 2020/01/16.

- Banca Transilvania (2020b). Banca Transilvania: The Report of the Board of Directors, (2018, 2017, 2016). Available from https://www.bancatransilvania.ro/en/investor-relations/gms/, last accessed 2020/01/16. 
- Feldman, P.M., Bahamonde, R.A. and Velasquez Bellido, I. (2014). A new approach for measuring corporate reputation. Revista de Administração de Empresas, 54(1), 53-66.

- Fombrun, C.J., Gardberg, N.A. and Barnett, M.L. (2000). Opportunity Platforms and Safety Nets: Corporate Citizenship and Reputational Risk. Business and Society Review, 105(1), 85-106.

- Gaudenzi, B., Confente, I. and Christopher, M. (2015). Managing Reputational Risk: Insights from an European Survey. Corporate Reputation Review, 18(4), 248-260.

- Investopedia (2020). How the Banking Sector Impacts Our Economy. Available from: https://www.investopedia.com/ask/answers/032315/what-banking-sector.asp, last accessed 2020/01/15.

- Moraru, A.D. and Duhnea, C. (2018). E-banking and Customer Satisfaction with Banking Services. Strategic Management, 23(3), 3-9.

- Moraru, A.D. and Ghita-Mitrescu, S. (2016). The Romanian Banking System - Key Dimensions and Visibility of CSR Practices. "Ovidius" University Annals, Economic Sciences Series, 16(2), 559-564.

- Murray, K. (2004). Reputation - Managing the single greatest risk facing business today. Journal of Communication Management, 8(2), 142-149.

- Pérez-Cornejo, C., de Quevedo-Puente, E. and Delgado-García, J.B. (2019). Reporting as a booster of the corporate social performance effect on corporate reputation. Corporate Social Responsibility and Environmental Management, 27(3), 1252-1263.

- $\quad$ Power, M., Scheytt, T., Soin, K. and Sahlin, K. (2009). Reputational Risk as a Logic of Organizing in Late Modernity. Organization Studies, 30(02-03), 301-324.

- The European Banking Federation (2019). Romania's banking sector: Facts \& Figures. Available from: https://www.ebf.eu/romania/, last accessed 2020/01/15.

- The Romanian Association of Banks (2020). About Romanian Association of Banks. Available from: https://www.arb.ro/en/about-rab/, last accessed 2020/01/15.

- Vardy, J. (2015). Reputational Risk Management in Central Banks. Bank of Canada Staff Discussion Paper 2015-16, November, 1-14. Available from: https://www.bankofcanada.ca/ wp-content/uploads/2015/11/dp2015-16.pdf, last accessed 2020/01/16.

- Walter, I. (2016). Reputational risks and large international banks. Financial Markets and Portfolio Management, 30(1), 1-17.

- Zboron, M. (2006). Reputational Risk in the context of A.M. Best's Rating Analysis. The Geneva Papers on Risk and Insurance - Issues and Practice, 31(3), 500-511.

- Ziarul Financiar (2019). Băncile la raport: În ultimul deceniu, Banca Transilvania, ING şi OTP au angajat cei mai mulţi oameni şi au avut cele mai mari creşteri de cheltuieli de personal. La polul opus, BCR, Raiffeisen şi BRD au dat afară cei mai mulţi oameni. Available from: https://www.zf.ro/banci-si-asigurari/bancile-raport-ultimul-deceniu-banca-transilvaniaing-otp-au-angajat-cei-multi-oameni-au-avut-cele-mari-cresteri-cheltuieli-personal-polulopus-bcr-raiffeisen-brd-au-dat-afara-cei-multi-oameni-18540714, last accessed 2020/01/16. 


\title{
Cap. 10. ANALIZA PRACTICILOR SECTORULUI PUBLIC ÎN REPUBLICA MOLDOVA PRIN PRISMA PRINCIPIILOR GUVERNANT,EI CORPORATIVE
}

\author{
Domnița Grițco ${ }^{1}$, Lenuța Cojocariu ${ }^{2}$ \\ ${ }^{I}$ Universitatea ,,Alexandru Ioan Cuza” Iași, Facultatea de Economie și Administrarea Afacerilor Iași, \\ România,gritco95@gmail.com \\ ${ }^{2}$ Universitatea ,Alexandru Ioan Cuza” Iași, Facultatea de Economie și Administrarea Afacerilor Iași, \\ România,lenuta.pauc@yahoo.com
}

\begin{abstract}
The current international situation strongly influences several processes, including both globalization and regionalism, as an effect of left-wing government. Regarding the public sector in Republic of Moldova, there could be remarked a trend toward the development of digitalization and toward the knowledge-based society, in general. Along whith these trends, the main target of the public authorities is the reformation of the legal framework on corporate governance. On this background, where the corporate governance represents a modern and dynamic objective of legal sciences, we analisyed the actions in matter of the public authorities in the Republic of Moldova and their compliance to the Corporate Governance Code. Our paper reveals an analitycal vision of the the achievements and perspectives of the Republic of Moldova government in implementing the principles of good governance and useful landmarks for the public authorities and other specialists in the field.
\end{abstract}

Keywords: Corporate governance, public sector, principles, corporate governance code.

\section{Introducere}

Conjunctura internaţională influenţează puternic mai multe procese, printre care se evidenţiază atât globalizarea, cât şi regionalismul, ca efect al guvernării de stânga. În Republica Moldova existenţa unui studiu fundamental care ar prezenta o abordare științifică de ansamblu lipseşte, fiind investigate separat doar unele aspecte ale fenomenului guvernanței corporative în articole de specialitate, publicate prioritar pe sursele de internet. Acestea prezintă însă o informaţie generalizată și învechită, actualitatea fiind întâlnită doar în comunicatele de presă și sondaje. Există şi cercetări aparținând unor organizații neguvernamentale, instituții de profil, dar care sunt focusate asupra unor componente restrânse ale guvernanței corporatiste. Pe aceste considerente, datele utilizate în prezentul articol sunt cele publicate de instituții publice de profil din Republica Moldova, unele acte legislative şi normative în vigoare, articole din literatura de specialitate și articole de presă.

\section{Stadiul cunoașterii}

Primele accepțiuni ale termenului de conducere corporativă a apărut în limbajul comun începând cu anii 1970 în Statele Unite ale Americii în mijlocul scandalului Watergate când s-a descoperit implicarea companiilor americane în politică, prin contribuții acordate diferitelor partide politice (Buzatu). În Statele Unite ale Americii, conform surselor științifice, termenul de Guvernanță (Corporativă) a fost aplicat în organizații comerciale, instituții naționale, dar și în administrarea coloniilor și a teritoriilor ocupate. Mai târziu, termenul dat sa extins în sectorul privat, ca urmare să fie utilizat în toate industriile. Totuşi, dezvoltarea acestuia a fost în entităţile din sectorul public. Domnul Sir Andrian Cadbury, în Marea Britanie, a avut un șir de cercetări pe subiectul cauzelor comune ale eșecurilor marilor corporații din sectorul privat. Astfel, pe baza crizei din anii 1980, publică Raportul Cadbury în anul 1992 (Adrian, 1992). Conform raportului falimentele corporațiilor au apărut în urma problemelor majore ale organizării și funcționării 
sistemului de control intern, care rezultă din problemele care au fost depistate la nivel de management. Managementul executiv nu a reușit să evite catastrofele produse și mai mult pe unele chiar ei l-au provocat. În scurt timp, au apărut mai multe rapoarte care au confirmat cercetările lordului Sir Adrian Cadbury și au contribuit la dezvoltarea a unor reguli și coduri practice pentru toate domeniile. El a analizat și a definit astfel conceptul de guvernanță corporativă’. Reprezentând acel sistem de coordonare și verificare, menit să dezvolte eficacitatea lucrului prin paza intereselor acționarilor”. De asemenea, o altă accepțiune referitoare la conținutul sistemului, este menționat de autorii francezi (Richard \& Miellet, 2003) în literatura de specialitate:

- Separarea puterilor între Consiliu de Administrație și conducători;

- Raporturile conducători - administratori - acționari și efectele asupra compoziției Consiliului de Administrație;

- Controlul real asupra gestiunii managerilor, care poate fi intern (Administratori) sau extern (Auditori externi);

- Modalitatea în baza căreia se iau deciziile strategice.

Banca Mondială, a venit cu proprie explicație vis-à-vis de conceptul de guvernanță corporativă, conform ei scopul principal al conceptului rezidă prin faptul că e menit să tempereze obiectivele economice cu cele sociale, pe când cele comune sunt în vederea responsabilizării gestiunii resurselor și folosirea lor echilibrat. Aici este de menționat faptul că punctul de vedere a Băncii Mondiale este în concordanță cu concluziile Raportului Cadbury: Scopul guvernanței corporative este de a aduce cât mai aproape interesele indivizilor, corporațiilor și societății (Clarke, 2007). Însuși conceptul de conducere corporativă se referă la transparența tranzacțiilor și la necesitatea monitorizării sistemului de control intern în vederea asigurării capacității acestuia de evaluare a riscurilor posibile elaborate pentru a oferi un plus de siguranță managementului organizațiilor. Conceptul de Guvernanță Corporativă conform doctrinelor, nu este de găsit o definire care să fie plauzibilă și acceptată. De aceea, menționez că, analizând aceste definiții, cea mai concisă definiție se pare a fi cea oferită de către OECD pentru conceptul de Guvernanță Corporativă, - "Guvernanța Corporativă - se exprimă printr-un set de relații între managementul companiei, consiliul acestuia, acționarii ei, alți deținători de titluri. Totodată, conferă structura prin care sunt stabilite mijloacele necesare realizării acelor obiective și monitorizarea performanțelor urmărite.” Astfel, datorită atenției sporite pentru interesele acționarilor, în SUA și Marea Britanie, putem să menționăm faptul că acest conceput de guvernanță corporativă este sistemul creat pentru acționari. Totuși, în Uniunea Europeană, normele judiciare și politicile sunt împărțite în două dimensiuni și anume, interesul acționarilor și interesul angajaților, creditorilor, entităților, societății civile şi organizațiile necomerciale (stakeholders). OECD reprezintă un unic format din guvernele a 34 de democrații, care contribuie la dezvoltare și conlucrează în vederea provocărilor economice, sociale și globalizare. Obiectivele organizației care isși are sediul la Paris, fiind: consolidarea sistemelor de piaţă dezvoltarea economică, şi extinderea comerţului liber. OECD împreună cu Banca Mondială au realizat setul de principii și codurile guvernanței corporative, astfel în anul 1999 au fost elaborate Principiile OECD, cu privire la administrarea corporațiilor, care sunt recunoscute ca parte din cei 12 piloni ai stabilității financiare internaționale (Ghiță, 2009). Aceste principii au fost un pilon de dezvoltare la realizarea codurilor naţionale de guvernanţă corporativă. Care sunt concentrate pe societățile tranzacționate public, dar care este focusat pe problemele ce se referă la societățile cu acționariat mare, dar nu sunt listate pe bursă. De asemenea, principiile elaborate de OECD pentru guvernanța corporativă, pot fi implementate atât pentru firmele în care statul deține acționariat cât și în întreprinderile mici si mijlocii. În Republica Moldova domeniul de studiu privind guvernanța corporativă a căpătat amploare la începutul anilor '90 (odată cu liberalizarea din nou a economiei, implicit a formării pieței de capital și apariției întreprinzătorilor privați), suscitând în numeroase rânduri la reformarea sectorului public în acord cu conţinutul la care aceasta se referă. Astfel, în acest nou context, privatizarea întreprinderilor și realizarea unei infrastructuri instituționale reprezentau precondiții ale manifestării guvernanței corporative, având menirea de garanta siguranța financiară în procesul de tranziție a economiei după anul 1990. 
Ulterior, în anul 2007 Republica Moldova, a realizat Codul de guvernare corporativă fiind aprobat prin Hotărârea Comisiei Naționale a Valorilor Mobiliare (actualmente, Comisia Naţională a Pieței Financiare). Care era aplicabil doar pentru societăţile pe acțiuni, cu norme privind drepturile acționarilor. În data de 04.03.2016 Codul de guvernare corporativă, a fost abrogat, din motiv și a intrat în vigoare noul Cod de guvernanţă corporativă a Republicii Moldova, care a fost aprobat prin Hotărârea Comisiei Naţionale a Pieţei Financiare nr.67/10 din 24.12.2015.

Ca o remarcă finală, literatura de specialitate cuprinde puține cercetări de abordare a analizei principiilor guvernanței corporative în sectorul public din Republica Moldova. În linii mari, legătura dintre principiile OECD și aplicarea lor în practică rămâne un subiect controversat, cu diverse abordări și cercetări metodologii, menținând în continuare atenția multor cercetători.

\section{Metodologia cercetării}

Obiectivul cercetării îl constituie analiza practicilor sectorului public din Republica Moldova prin prisma principiilor guvernanței corporative. Eșantionul analizat este reprezentat de întreprinderile de stat și societățile pe acțiuni cuprinse în registrul patrimoniului public din Republica Moldova:14 Societăţi pe acțiuni în procedură de lichidare; 22 Societăţi pe acțiuni în proces de insolvență; 12 Întreprinderi de stat în proces de lichidare; 13 Întreprinderi de stat în proces de insolvență, cu o valoare totală a patrimoniului de stat 26021835083,00 și cu o valoarea a activelor nete per total de 16602620101,00. Metodele de analiză utilizate în prezentul studiu sunt: metoda logică utilizată la interpretarea normelor juridice pentru descoperirea principiilor care stau la bază şi identificarea conţinutului și a formei fenomenului juridic; metoda comparativă utilizată la realizarea unui studiu comparat a doctrinelor și principiilor guvernanței corporative; metoda de analiză și cercetare utilizată la identificarea lacunelor legislative și de sistem privind practicile din cadrul entităților publice cu privire la guvernanța corporativă și la conturarea situației privind transparența site-urilor web a diferitor entităţi ale statului; metoda cantitativă reprezintă analiza datelor oferite de Registrul Patrimoniului Public a Republicii Moldova prin aplicabilitatea principilor guvernanței corporative în cazul societăților pe acțiuni și întreprinderile de stat.

\section{Analiza practicilor sectorului public din Republica Moldova și aplicabilitatea principiilor guvernanței corporative}

În Republica Moldova există două tipuri de întreprinderi aflate în proprietatea statului, mai exact: întreprinderile de stat (ÎS) și societățile pe acțiuni (SA). Cele mai numeroase sunt întreprinderile de stat, în timp ce societățile pe acțiuni sunt într-un număr mai restrâns și statul este deținătorul a diferite cote de acțiuni, adică poate deține proprietatea parțială sau poate deține proprietatea în întregime. În secțiune de Anexe este prezentat un tabel conținând proprietățile deținute de stat, conform fiecărui minister care le administrează.

Într-o viziune de ansamblu, se remarcă faptul că întreprinderile de stat din Republica Moldova au avut un management slab după procedura de privatizare cu privire la instrumentele de guvernanță corporativă. Atribuțiile de administrare a întreprinderilor de stat le revin miniștrilor, directorului executiv, cât și consiliului de administrație. În ce privește membrii consiliului, aceștia sunt selectați de către minister, pe când directorul executiv este supus alegerii de către minister, după delegarea consiliului de administrație. Observăm că ministerele și managerii de top au putere diferită, dar legislația în vigoare nu o reglementează în conformitate cu modelul de ierarhizare.

Societățile pe acțiuni au un alt sistem de guvernanță corporativă, având ca părți componente adunarea generală a acționarilor și consiliul de administrație, managerul de top și comisia de cenzori. Totuși, legislația privind guvernanța corporativă din Republica Moldova nu legiferează în mod clar aspectele pentru întreprinderile de stat, cum e în cazul societăților pe acțiuni. Societățile pe acțiuni țin cont de exercitarea dreptului cu privire la proprietate, prin instituțiile statului sau chiar fiind entitate fondatoare pentru întreprinderea de stat, Ministerul Finanțelor împreună cu Asociația Proprietății de Stat sunt responsabile și în anumite sarcini de evaluare atribuite de stat. Astfel, regăsim că Agenția Proprietății Publice este o entitate care își gestionează activitatea în 
calitate de instituţie de resort atribuită Ministerului Economiei și Infrastructurii. Conform regulamentului Agenției Proprietății Publice, care a fost supus aprobării prin Hotărâre de Guvern (HG cu privire la Aprobarea structurii, efectivului-limită şi regulamentului Agenţiei Proprietăţii Publice de pe lângă Ministerul Economiei şi Comerţului, nr. 1008 din 10.09.2007), entitatea este responsabilă în vederea gestionării privatizării proprietății publice, cât și îi e atribuit dreptul de proprietate și evidența situațiilor financiare, precum și stabilirea gradului de atingerea a standardelor în cadrul întreprinderilor de stat. Astfel, statul stabilește că Agenția Proprietăţii Publice este obligată să dețină în evidența sa societățile pe acțiuni cu $25 \%$ acțiuni ale statului și cu pachetul majoritar, în timp ce întreprinderile de stat sunt evaluate de Direcția monitorizare și analiză financiară din cadrul Ministerului de Finanțe. Analizând datele din Registrul patrimoniului public al Republicii Moldova, care e administrat de către Agenția Proprietății Publice. Observăm că în gestionarea autorităţilor administrației publice centrale sunt 228 întreprinderi de stat, dar statul mai deține și 106 pachete de acțiuni în cadrul societăţilor pe acțiuni. De asemenea, valoarea patrimoniului de stat, aflat în administrarea întreprinderilor de stat este de 16602,6 mil lei, pe când valoarea patrimoniului de stat, deținut în cadrul societăților pe acțiuni, este în valoare de 94192,1 mil lei.

Ce putem evidenția faptul că în decursul anului 2017 din Registrul patrimoniului public s-au supus radierii există(Anexa 1):

- $\quad 14$ Societăţi pe acțiuni în procedură de lichidare;

- $\quad 22$ Societăți pe acțiuni în proces de insolvență;

- 12 Întreprinderi de stat în proces de lichidare;

- 13 Întreprinderi de stat în proces de insolvență;

Conform OECD, principiile guvernanței corporative sunt: protecția drepturilor acționarilor, tratamentul echitabil pentru toți acționarii; rolul stakeholders, informare și transparență și responsabilitatea Consiliului de Administrație, analiza noastră vizând aplicabilitatea acestora în acord cu recomandările formulate la nivelul organizației menționate.

\section{Protecția drepturilor acționarilor}

Protecția şi drepturile acționarilor reprezintă principiul de bază în guvernanța corporativă și gradul său de performanță se poate evalua prin: modalitatea de implicare a acționarilor în cadrul procesului decizional, drepturile de vot atribuite și modalitatea de lucru, modalitatea prin care se estimează menținerea controlului privind entităţile conform piețelor de capital. Codul de Guvernanță Corporativă al Republicii Moldova cu privire la protecția drepturilor acționarilor stipulează următoarele drepturi care au rolul de protecție a acestora: dreptul de a avea acces la informație, dreptul la vot în cadrul participării la adunările generale a acționarilor, dreptul de a primi dividende, dreptul prin privind înstrăinarea acțiunilor conform legislației în vigoare, dreptul de a avea prioritate la subscrierea acțiunilor noi emise, dreptul de a fi în echipa de management a societății. De asemenea, în legislație prevede și drepturile acționarilor minoritari și anume: dreptul cu privire la protecția contra acțiunilor directe sau indirecte care au un caracter abuziv, dreptul cu privire la protecția contra conduite dubioase a consiliului, dreptul de a fi reparate prejudiciile drepturilor încălcate, dreptul de a cunoaște dacă sunt persoane care pot efectua tranzacții cu existența unui conflict de interese.

În acest sens, identificăm o serie de cazuri prin care se poate analiza măsura implementării acestui principiu nu de jure ci de facto:

SA "Franzeluța" reprezintă principalul combinat de produse de panificație din Republica Moldova. Acesta produce produse cu caracter comercial, dar este obligat să producă și pâine accesibilă ca preț, sub prețul de producție denumită ,pâinea socială”. Costul mediu pentru o pâine, în momentul acestei hotărâri era de $5.70 \mathrm{MDL}$, în timp ce prețul de vânzare stabilit de guvern era stabilit la 1.50 MDL. În anul 2014, în timpul

A.G.A anuale, s-a discutat despre nevoia reorientării doar spre produsele care aduc profit. Acționarii au precizat că producerea de ,pâine socială” ieftină contribuie la rezultatele negative ale activității și este nevoie de o acoperire a costurilor din partea statului, pe lângă furnizarea făinii din 
rezervele statului. Informaţii despre aceste elemente nu sunt disponibile publicului. Sectorul privat a estimat costul de producție a ,pâinii sociale" de trei ori mai mare decât prețul de vânzare. Brutarii acuză că statul afectează piața prin politica prețurilor combinatului de panificație SA „Franzeluța” şi totodată și profitul societăţii în cauză.

\section{Tratamentul echitabil pentru toți acționarii}

Principiul tratamentului echitabil pentru toți acționarii se caracterizează conform structurii prezentate de OECD, drept unul cu menire de echilibrare între acționari, asigurând tratamentul egal vis-a-vis de toți acționarii, fără a îi cataloga după cotele de acțiuni ce le dețin, astfel având ca scop diminuarea conflictelor și prevenirea unor anumite tipuri de riscuri privind ecosistemul unei entităţi. Conform codului de guvernanță a Republicii Moldova, principiul dat este interpretat în vederea asigurării lui potrivit legislației, respectând în egală măsură toți acționarii fără a face discriminări. Astfel, totalitatea de drepturi atribuite acționarilor sunt statutate atât în legislație, cât şi în regulamentele interne ale entităţilor.

Mai jos identificăm cazurile din practică unde am depistat încălcări ale acestui principiu:

Principiul echităţii în societățile pe acțiuni din Republica Moldova nu este respectat la nivelul practicilor internaționale. Legislația prevede că acționarii minoritari dispun de drepturi și tratamente egale, dar în practică le este încălcat și dreptul la dividende. Ca exemplu, "Franzeluța" S.A., o societate cotată la piața reglementată, în care statul deține $52.51 \%$ de acțiuni, având în total 1438 de acționari, unde în 2014, la A.G.A., statul, în calitate de acționar majoritar a votat împotriva alocării retroactive a dividendelor pentru anii financiari 2008 şi 2009. Propunerea investitorilor minoritari ai societății, a fost blocată de stat. În cadrul Adunărilor Generale din 2009 și 2010 s-a luat decizia de reinvestire a profitului în companie. În schimb, Fiscul a considerat această reinvestire drept o încălcare și a oprit suma egală cu cota parte pe care statul ar fi primit-o. În același timp, au aplicat o amendă pentru ,întârzieri la plata dividendelor”. Astfel, autoritățile au obținut 9 milioane de lei, în timp ce acționarii minoritari nu au primit nimic (Sursă pentru informațiile prelucrate, în vederea cazului SA Franzeluța http://www.logos.press.md/node/39358).

\section{Rolul stakeholderilor}

Părțile interesate posedă dreptul de a li se oferi informații despre activitățile și rezultatele companiei, interesele fiindu-le protejate, chiar și în activitatea responsabilităţilor social corporative. În legislație regăsim că natura rolurilor celor interesați este interpretată conform principiilor OECD a guvernanței corporative, implicând un pachet de relaționare dintre consiliu societăților pe acțiuni, managerul de top și părțile interesate, angajați, parteneri, creditori, administrații locale etc. precum și promovarea și respectarea drepturilor părților interesate, cât și misiunea secretarului corporativ de a oferi informația și suportul necesar.

- În cazul apariției unui conflict de interes personal, acesta este soluționat, într-o oarecare măsură, prin norma legală care face referire la conflictul de interese și prin norma privind societățile pe acțiuni (Legea cu privire la conflictul de interes nr. 16. În Monitorul Oficial al Republicii Moldova din 2008 nr. 94-96). Acestea prezintă conflictul de interese și stabilesc un nivel de responsabilizare în cazul încălcării legii. Este dificil de a explica urmărirea intereselor personale în detrimentul companiei, dar este şi mai greu de a cuantifica efectele. Lipsind mecanismele de control, orice investigație publică duce la ideea că Întreprinderile de Stat sunt conduse de administratori ineficienți, care își urmăresc propriile interese, în locul intereselor companiei sau a activelor naționale. Absența acestor elemente de control vor suplimenta mai mult autonomia conducătorilor Întreprinderile de Stat. Deși sunt abordate conflictele de interese în tranzacțiile specifice și restricțiile, legea actuală nu oferă restricții asupra conflictului de interese în cazul membrilor consiliilor de administrație al Întreprinderilor de Stat cu funcții de reglementare a sectorului în care își desfășoară activitatea entitatea supravegheată. Membrii consiliului nu trebuie să ia parte la luarea deciziilor care vizează Întreprinderile de Stat. Mai mult, ei nu trebuie să aibă obligații sau restricții care să le îngrădească posibilitatea să acționeze în interesul societății . Este necesară existența unui cod de etică care ar prezenta modalitatea prin care informația este transmisă 
de la membrii Consiliului de Administrație statului şi modul de soluționare a conflictelor de interese.

- În cadrul Întreprinderilor de Stat din Republica Moldova participarea salariaților din consiliile de administrație este obligatorie conform legislației, pe când în cadrul Societăţilor pe acţiuni participarea salariaților în cadrul consiliilor societăţii este recomandată. Astfel, conform ghidului OECD reprezentarea salariaților în cadrul consiliilor de administrație trebuie să fie obligatorie, ceea ce presupune să fie stipulat în legislație cu titlul de obligatoriu, sau să fie atribuit un instrument prin care să se realizeze într-un mod eficient contribuția la dezvoltarea capacităților consiliului, prin asigurarea de transparență și independența de care au nevoie. În cazul acestor exemple cu privirea asigurării mecanismelor de guvernanță corporativă, reprezentarea se realizează prin sindicate și consiliilor de lucru, care se formează prin opiniile angajaților în anumite decizii ce îi vizează pe ei.

\section{Informare și transparență}

Acest principiu constă în activitatea conducerii entității, care are datoria de a pune la dispoziție informație calitativă pentru cei care sunt interesaţi cât și pentru modalitatea de lucru cu auditorii externi sau interni. Astfel, Banca Mondială a realizat un studiu conform căruia, informația trebuie oferită la timp și să fie realizată cât mai corect astfel de a preveni riscul de a livra informație eronată, prin analiza standardelor de audit și evaluare a informației. Legislaţia Republicii Moldova prevede că principiul de difuzare a informației și asigurare a transparenții atribuindu-i un întreg capitol cu 10 articole. Informațiile trebuie să fie în conformitatea cu legislația, care trebuie să cuprindă și rapoartele financiare și nonfinanciare. Ce ține de asigurarea transparenței, este stipulat că entităţile trebuie să posede pagina web, care trebuie să asigure acest principiu prin plasarea informațiilor. De asemenea, societatea este obligată să realizeze rapoarte anuale despre descrierea activității și analizei financiare cât și a rezultatelor operațiunilor, modificările cu privire la capitalul propriu, totalitatea de riscuri cât și factorii emitenți de risc.

Mai jos e descris cazul prin care nu se respectă acest principiu, conform celor analizate:

- Totuși, dacă analizăm componența Consiliului de Administrație pe un eșantion de societăţi pe acțiuni care nu au ca acționar integral statul, rezidă că acționarii minoritari nu au posibilitatea de a numi membrii consiliilor de administrație (statul deține peste 50\% din societate), iar toți membrii consiliilor de administrație reprezintă doar acționarul de stat sau împart consiliul cu acționarul care deține pachetul de control în cazul SA parțial deținute de stat. $\mathrm{Cu}$ titlu de exemplu ar fi cazul de la S.A. Metalferos, unde cei cinci membri ai consiliului de administrație sunt funcționari publici, statul având o participație de $78.28 \%$ din numărul total de acțiuni, în timp ce acționarii privați, nu sunt reprezentați în consiliu, deși dețin cumulat peste $20 \%$. Având în vedere acestea, statul are acces la informațiile discute de consiliu, informații care sunt indisponibile pentru acționarii minoritari.

- Conform datelor furnizate de Bursa de Valori a Moldovei, de la data de 01 iulie 2016, SA Franzeluța (52\% din acțiuni deținute de stat) este admisă pe piaţa reglementată. Astfel, compania este clasificată ca EIP și este obligată să prezinte raporturi financiare bazate pe IFRS. Totuși, aceasta pregătește în continuare situațiile financiare bazate pe SNC (pe site-ul companiei apar doar o parte din situațiile financiare), (Sursa pentru informațiile prelucrate, în vederea cazului SA Franzeluţa (http://www.franzeluta.info/files/raportul-anual-june-2016.pdf).

- Analizând paginile web al întreprinderilor de stat, lipsesc informații cu privire la consiliu de administrație, precum sunt publicate informații foarte succinte, exemplu este numărul lor. Astfel, în raportul despre politici 2012, publicat de Ministerul Economiei (Sursă cu privire la Raportul Ministerului Economiei (https://mei.gov.md/ro/content/politici-de-administrare-si-deetatizareproprietatii- publice, citat la data de 20.05.2020) pe atunci (Astăzi Ministerul Economiei și Infrastructurii), a fost subliniat că informație cu privire la componența CV-urilor lipsesc al membrilor consiliilor. Şi informații cu privire la numele administratorului lipsește. Pe situ-ul Ministerului Economiei regăsim informații cu privire la membrii consiliului întreprinderilor de 
stat, care sunt în administrarea ministerului, această informație la momentul cercetării nu a fost modificată din 2014 .

\section{Responsabilitatea Consiliului de Administrație}

Consiliul de Administrație este piesa principală a conceptului de guvernare corporativă, rolul sau fiind unul prioritar, în activitatea sa bazându-se pe controlul şi monitorizarea managerilor. Legislația în vigoare definește, în capitolul II a codului de guvernanță corporativă consiliile fiind de două tipuri: consiliul societăţii și adunarea acționarilor. Consiliul societății reprezentă interesele tuturor acționarilor pentru adunările generale și are capacitatea de control şi monitorizare a activității unei societăți. Consiliul este ales de către adunarea generală și îi e subordonat deplin ei. Astfel, regăsim responsabilitățile consiliului și anume: elaborarea strategiei corporative, setarea planului de lucru și monitorizarea riscurilor, promovarea bugetului anual cât şi elaborarea planurilor de afaceri a societăţii, cât și setarea metodologiei de control; tot consiliul are atribuția de a alege directorul executiv și să stabilească renumărarea sa; acceptarea rapoartelor și dărilor de seamă, asigurând comisiei de cenzori la verificare; evaluarea directorului executiv; analiza publicării informației, dacă e conform actelor normative; realizarea unei metodologii privind politica de dividende.

- Serviciului Control Financiar şi Revizie al Ministerului de Finanţe în colaborare cu angajaţii Ministerului Afacerilor de Interne, au realizat împreună un control la S.A. "Franzeluţa”, cu privire la importul de făină în perioada 2008-2010 (Studiu cu privire la „Reflectarea corupţiei în presa scrisă” din anul 2011). S-a identificat că directorul executiv din acel moment, a depăşit limitele atribuţiilor sale de serviciu, a încheiat personal un şir de contracte de procurare a făinii la preţuri majorate şi nefavorabile pentru societate, fără a înștiinţta consiliu societăţii, cu încălcarea legislaţiei în vigoare şi prevederilor statutului societăţii, cauzând astfel daune în proporţii mari intereselor acţionarilor și a prejudiciat întreprinderea cu 24 mil. de lei”. Pe 11 august 2011, Procuratura Generală a abrogat ordonanţa de pornire a cauzei penale pe faptul depăşirii atribuţiilor de serviciu de către directorul general al S.A. „, Franzeluţa” Eugen Baleca, dar a refuzat începerea urmăririi penale, pe motiv că fapta săvârşită nu întruneşte elementele infracţiunii.

\section{Concluzii}

Prezenta lucrare a fost realizată în scopul analizei implementării principiilor Guvernanței Corporative în sectorul public din Republicii Moldova pentru a identifica și abordarea problemelor precum și a oportunităților aferente întreprinderilor de stat precum și a societăților pe acțiuni.

Guvernanța Corporativă prin instrumentele sale oferă publicului larg o mai bună consolidare asupra realității gestionării întreprinderilor și societăţilor. O bună guvernanță poate fi obținută sigur prin utilizarea unor practici corespunzătoare ale consiliilor de administrație, sisteme de control intern eficiente, transparență și dezvăluire de informații financiare și nefinanciare importante, și relații clar definite cu părțile interesate. Asigurarea transparenței în relațiile cu părțile interesate este instrumental esențial în vederea construirea unei întreprinderi sau societăţi eficiente și financiar sustenabile. Urmările unei guvernanțe corporative proaste, se poate vedea printr-o performanță slabă a întreprinderilor și societăţilor, precum și generarea de pierderi, adoptarea de practici necompetitive, poluare a mediului și facilitarea unor practici corupte. Desigur, doar un program bine realizat poate să ajute întreprinderile și societățile tuturor părților interesate (inclusiv investitorilor, consumatorilor, furnizorilor, reglementatorilor, creditorilor, sindicatelor, massmedia, comunității financiare, publicului larg și liderilor politici) că întreprinderile și societățile lucrează într-un mod eficient și sunt efectiv pentru a oferi diferitor interese și obiective pentru care au fost instituite. De altfel, guvernanța corporativă e menită să ajute la gradul de performanță și valoarea adăugată a companiilor.

Conform datelor cu privire la necesitatea şi modul de aplicare a principiilor de guvernare corporativă, dar şi despre impactul lor asupra pieţei, astfel, experţii internaţionali au identificat că situaţia care este pe piaţa de capital din Republica Moldova nu este unică, mai curând ea caracterizează ţările eurasiatice şi de aceea, OECD a focusat atenţia asupra lor. 
Astfel, în urma analizei cu metoda logică, metoda comparativă, metoda de analiză și cercetare, metoda cantitativă cu privire la implementarea principiilor guvernanţei corporative în sectorul public al Republici Moldova, prin principiile OECD, am ajuns la următoarele concluzii:

1) Conceptul de guvernanță corporativă poate să influențeze cel mai mult activitatea companiilor, dar și economia fiecărei țări în parte, astfel toate companiile sunt tentate să adopte cele mai bune măsuri, norme, strategii de guvernanță corporativă pentru a atrage investitori și pentru a fi cele mai eficiente. Analiza guvernanței corporative ne permite să vedem modul de activitate a unei entități în ansamblu, astfel încât să putem analiza minuțios problema care adesea provine de la managementul de vârf și afectează întreaga entitate, atât din punct financiar, cât și din punct ierarhic. De asemenea, guvernanța corporativă este la fel de importantă pentru sectorul privat cât și pentru sectorul public. Așadar, eforturile implicate atât în cercetarea acestui subiect cât și implementarea sa sunt binevenite, mai ales în țările în care corupția este la cote ridicate, sau în țările care se confruntă cu privatizarea sectorului public, în ambele cazuri, oferind mai multă credibilitate și încredere din partea publicului.

2) Principiile elaborate de OECD reprezintă principiile şi practicile pilonului pe care a fost construit și acceptat de toată lumea, pentru conceptul de guvernanță corporativă, care se pot aplica atât la entități publice, private, cât și organizații nonprofit. În esență, majoritatea cercetătorilor în domeniu susțin că aceste principii ar putea aduce mai mult plus valoare în sistemul public decât în sistemul privat, de la care sunt multe aşteptări din partea contribuabililor având în vedere ca oameni contribuie cu resurse financiare în avantajul statului și sunt puse mari așteptări în vederea gestionării acestor bani de către instituţiile publice;

3) Un număr mare dintre întreprinderile de stat înregistrează anual pierderi și datoria lor pe termen lung este în creștere. Astfel, rezultă că activitatea financiară în ansamblu s-a înrăutățit în ultimii ani ca urmare a unui sector public nereformat şi unei guvernări deficitare a întreprinderilor de stat și societăților pe acțiuni. Mai mult, chiar dacă legea cere întreprinderilor de stat să facă publice situațiile financiare, această cerință este rareori îndeplinită de facto;

4) Există probleme mari vis-a-vis de ceea ce privește găsirea precum și numirea membrilor consiliului de administrație și directorilor ai Întreprinderilor de Stat, inclusiv numirea membrilor independenți ai consiliului precum și luarea deciziilor pentru nominalizări specifice este total netransparentă;

5) Protecția insuficientă a acționarilor minoritari ai Societăților pe Acțiuni în care statul dețină cotă parte ridică probleme de aplicare uniformă a bunelor practici și așteptărilor pieței, ceea ce denotă lipsa de implicarea a statului;

6) După procesului de privatizare s-a format situaţia în care avem societăţi pe acţiuni cu o concentrare a pachetelor de acţiuni de $90 \%$ care sunt deţinute de o singură persoană sau un grup afiliat de persoane, iar restul 10\% sunt dispersate la un număr mare de acţionari. Astfel, avem în jur de 170.000 acţionari minoritari. Este dificil să iei decizii la nivel politic, de aceea a devenit necesar adoptarea şi implementarea anumitor măsuri şi principii de guvernare corporativă;

7) Lipsa sistemului de guvernanță este reflectată și în condițiile de concurență și politicile concurențiale slabe, ceea ce duce la un nivel înalt al riscului de afaceri la nivel operațional pentru companiile din Moldova;

Recent Guvernul a elaborat un nou proiect de lege cu privire la întreprinderile de stat care va analiza unele deficiențe în materie de guvernare a întreprinderilor de stat. Totodată, proiectul de lege include soluţii pentru a rezolva unele probleme de management a performanţei pentru managerii seniori și numirea membrilor consiliului de administrație. Echipa, deși e familiarizată cu proiectul de lege, nu a făcut o revizuire în detaliu.

Propunerile bazate pe politici au drept scop să contribuie la consolidarea rolului guvernului în calitate de proprietar al Întreprinderile de Stat care la rândul lor contribuie, la creșterea și dezvoltarea economică generală a țării. Cele trei măsuri de consolidare reciprocă sunt strâns corelate şi au drept scop sporirea gradului de responsabilitate a întregii structuri de proprietate a Întreprinderile de Stat, de la proprietarii în ultima instanță - cetățenii - până la angajații lor. 
Lucrarea de față scoate la lumină principalele domenii care urmează a fi examinate. Cu toate acestea, deși îmbunătățirile în guvernanța Întreprinderilor de Stat sunt importante, acestea nu vor garanta, în sine, sustenabilitate financiară și performanța îmbunătățiă a Întreprinderile de Stat. Unele din cele mai bune practici ale OECD ar putea să nu fie fezabile pentru Republica Moldova în timpul ce urmează.

Astfel, menționăm faptul că recomandările oferite de către OECD cu privire la implementarea şi aplicarea principiilor de guvernare corporativă se referă la consolidarea rolului instituţiilor de reglementare, respectarea drepturilor tuturor acţionarilor, crearea condiţiilor favorabile pentru ca companiile să fie incluse în listarea la Bursa de Valori, atragerea capitalului şi formarea lichidităţilor pentru o mai bună dezvoltare a societăţilor pe acţiuni, dezvoltarea obligaţiunilor corporative şi instruirea participanţilor.

Menţionăm că în Republica Moldova sunt înregistrate circa 3000 societăţi pe acţiuni, mai puţin de jumătate dintre ele fiind active, respectiv aproape 700 ar reprezenta aderenţii potenţiali la actul de guvernare corporativă, aşa cum prevede art. 2 al Legii privind societăţile pe acţiuni. Articolul respectiv desemnează societăţile care dispun de un capital minim de 500 mii lei şi sunt gestionate de 50 şi mai mulţi acţionari, precum şi cele de interes public. Codul de guvernare corporativă, aprobat de către Comisia Naţională a Pieţei Financiare în 2007, este în acest moment, unicul document de acest fel şi se bazează pe principiile OECD. Cele mai importante prevederi definite de această organizaţie se referă la drepturile acţionarilor în materie de guvernare corporativă şi anume - dreptul de a participa, de a vota în cadrul adunării generale a acţionarilor, dreptul de a obţine informaţii relevante şi suficiente cu privire la întreprindere în timp şi în mod regulat, dreptul de a alege şi de a revoca membrii Consiliului de administraţie şi aprobarea tranzacţiilor extraordinare. Implementarea cu succes a principiilor de guvernare corporativă depinde şi de interesul acţionarului minoritar, acesta trebuie să fie cel cointeresat de cunoaşterea, promovarea şi realizarea acestor principii.

\section{Referințe}

- Agle, B. R., Mitchell, R. K., and Sonnenfeld, J. A. (1999). Who matters to CEOs? An investigation of stakeholder attributes and salience, corporate performance, and CEO values. Academy of Management Journal 42, 507-25.

- Andrade, A.; Rossetti, J. P. (2011). Corporate Governance: principles, development and trends, 5th ed., São Paulo, Atlas.

- $\quad$ Bunget, O. (2010). Audit financiar-contabil, Editura Mirton, Timișoara

- Buzatu, L. (2004). Piața de capital din România, identificarea unor căi și oportunități de creștere și deversificare a acesteia - Teză de doctorat, conducător științific prof. univ. dr. Alexandru Puiu, ASE, București.

- Cadbury, A. (1992). Report of the Financial Aspects of Corporate Governance, Burgesss Science Press, London.

- $\quad$ Clarke, T. (2007). International Corporate Governance, Routledge.

- Clarkson,M. B.E. (1999). Principles of Stakeholder Management, Clarkson Center for Business Ethics, Joseph L. Rotman School of Management, University of Toronto.

- Danielson M. G., Heck J. L., Shaffer D. R. (2008). Shareholder Theory - How Opponents and Proponents Both Get it Wrong, Journal of Applied Finance, 18(2), 62-66.

- Ghiță, M., Iațco, C., Brezuleanu C.O., Vorniceanu, M. (2009). Guvernanța Corporativă și Auditul Intern, Editura Tipo Moldova, Iași.

- Ghiţă, M. (2008). Guvernanţa corporativă, Editura Economică, Bucureşti.

- Onofrei, M. (2009). Guvernanța Financiară Corporativă, editura Wolters Kuwer, România. 
- Popa M., Salanță I., Scorțar L., Isopescu A. (2011). Etica în afaceri, Editura Risoprint, ClujNapoca.

- Richard, B; Miellet, D. (2003). La dynamique dunamique du gouvernement d'entreprinse, Editions d'Organisation, Paris.

- $\quad$ Seely, M. (1991). Vision of value-based Guvernance, Directors and Boards, 15, 35-36.

- $\quad$ Shleifer, R.V. (1997). A survey of Corporate Guvernance, Journal of Finance, 52, 737.

- Siems, M. (2011) - Convergence in Shareholder Law, Cambridge University Press, pp. 226-227.;

- Hotărârea Comisiei Naţionale a valorilor mobiliare privind aprobarea Codului de guvernare corporativă, nr.28/6 din 01.06.2007. În: Monitorul Oficial al Republicii Moldova, 2007, nr.86-89.

- Hotărârea Guvernului cu privire la Aprobarea structurii, efectivului-limită şi Regulamentului Agenţiei Proprietăţii Publice de pe lângă Ministerul Economiei şi Comerţului, nr. 1008 din 10.09.2007. În Monitorul Oficial al Republicii Moldova, 2007 nr. 146-148.

- Hotărârea Parlamentului cu privire la Programul d e privatizare pentru anii 1993-1995 din 12 martie 1993, În Monitorul oficial al Republicii Moldova, 05.05.1995. nr. 24.

- Hotărârea Parlamentului privind Privatizarea al altor acte legislative, nr. 1333 din 12.03.1993. În Monitorul oficial al Republicii Moldova, 1993, nr. 3.

- Hotărârii Guvernului cu privire la Registrul patrimonial public. În Monitorul Oficial al Republicii Moldova 2017, nr. 106.

- Legea cu privire la Conflictul de interes, nr. 16. În Monitorul Oficial al Republicii Moldova din 2008 nr. 94-96.

- Legea cu privire la Programul de privatizare pentru anii 1997-1998. În monitorul oficial al Republicii Moldova, 1997 nr. 59-60.

- Legea cu privire la Programul de stat de privatizare pentru anii 1995-1996. În Monitorul oficial al Republicii Moldova, 1995 nr. 24.

- Studiu cu privire la „Reflectarea corupţiei în presa scrisă” din anul 2011.

- https://www.telegraph.co.uk/news/obituaries/11847382/Sir-Adrian-Cadbury- businessmanobituary.html, accesată la data 20.05.2019;

- https://mei.gov.md/ro/content/politici-de-administrare-si-deetatizare- proprietatii-publice, accesată la data de 20.05.2020;

- http://www.ecgi.org/codes/documents/principles_fr.pdf, accesată la data 20.05.2020;

- http://www.franzeluta.info/files/raportul-anual-june-2016.pdf accesată la data de 20.05.2020.

- https://anticoruptie.md/ro/investigatii/economic/metalferos-scheme- firme-fantoma-siimunitate-penala accesată la data 20.05.2020;

- https://dexonline.ro, accesată la data de 19.05.2020;

- http://www.franzeluta.info/files/raportul-anual-june-2016.pdf), citată la data de 19.05.2020;

- $\quad$ http://www.doingbusiness.org/ accesată la data 20.05.2020;

- http://www.logos.press.md/node/39358, accesată la data de 20.05.2020;

- http://www.logos.press.md/node/39358, accesată la data de 19.05.2020;

- https://mei.gov.md/ro/content/politici-de-administrare-si-deetatizare- proprietatii-publice, accesată la data de 20.05.2020.

- $\quad$ http://www.logos.press.md/node/39358" \h http://www.logos.press.md/node/39358, accesată la data de 20.05.2020. 


\section{Anexa nr. I. Date privind întreprinderile de stat și societățile pe acțiuni conform} Registrului Patrimoniului Public la situaţia din 01.01.2018, pag. 42

\begin{tabular}{|c|c|c|c|c|c|c|}
\hline $\begin{array}{l}\text { Denumirea completă a } \\
\text { întreprinderii }\end{array}$ & $\begin{array}{l}\mathrm{Nr} \\
\text { total }\end{array}$ & $\begin{array}{c}\text { Valoarea } \\
\text { patrimoniului } \\
\text { de stat }\end{array}$ & $\mathrm{Nr}$. & \begin{tabular}{|c|} 
Cota statului \\
conform activelor \\
(Societăți pe \\
Acțiuni)
\end{tabular} & $\mathrm{Nr}$. & $\begin{array}{c}\text { Valoarea activelor } \\
\text { nete } \\
\text { (Întreprinderilor } \\
\text { de Stat) }\end{array}$ \\
\hline \begin{tabular}{|c|} 
Ministerul Agriculturii, \\
Dezvoltării \\
Regionale și Mediului
\end{tabular} & 49 & 470360121 & 2 & 0,00 & 47 & 470360121,00 \\
\hline $\begin{array}{l}\text { Ministerul Sănătății, } \\
\text { Muncii și Protecției } \\
\text { Sociale }\end{array}$ & 7 & 98465510 & 2 & 20034520,00 & 5 & 78430990,00 \\
\hline $\begin{array}{l}\text { Ministerul Educației, } \\
\text { Culturii și Cercetării }\end{array}$ & 37 & 712425470 & 3 & 45423950,00 & 34 & 667001520,00 \\
\hline $\begin{array}{l}\text { Ministerul Economiei } \\
\text { și Infrastucturii }\end{array}$ & 90 & 15695080894 & 48 & 3861766584,00 & 42 & 11833314310,00 \\
\hline Ministerul Finanțelor & 4 & 70727300 & 0 & 0,00 & 4 & 70727300,00 \\
\hline $\begin{array}{l}\text { Agenția „Apele } \\
\text { Moldovei” }\end{array}$ & 16 & 416214100 & 0 & 0,00 & 16 & 416214100,00 \\
\hline $\begin{array}{l}\text { Agenția Proprietății } \\
\text { Publice }\end{array}$ & 54 & 6290289548 & 51 & 5491989928,00 & 3 & 798299620,00 \\
\hline Agenția „Moldsilva” & 25 & 1449988350 & 0 & 0,00 & 25 & 1449988350,00 \\
\hline $\begin{array}{c}\text { Agenția Rezerve } \\
\text { Materiale }\end{array}$ & 2 & 728600 & 0 & 0,00 & 2 & 728600,00 \\
\hline $\begin{array}{c}\text { Ministerul Afacerilor } \\
\text { Externe și } \\
\text { Integrării Europene } \\
\end{array}$ & 1 & 10665200 & 0 & 0,00 & 1 & 10665200,00 \\
\hline Ministerul Justiției & 1 & 26800 & 0 & 0,00 & 1 & 26800,00 \\
\hline $\begin{array}{l}\text { Ministerul Afacerilor } \\
\text { Interne }\end{array}$ & 5 & 83863200 & 0 & 0,00 & 5 & 83863200,00 \\
\hline Ministerul Apărării & 2 & 24453000 & 0 & 0,00 & 2 & 24453000,00 \\
\hline $\begin{array}{c}\text { Biroul Național } \\
\text { de Statistică }\end{array}$ & 1 & 11974300 & 0 & 0,00 & 1 & 11974300,00 \\
\hline Academia de Științe & 11 & 18853780 & 0 & 0,00 & 11 & 18853780,00 \\
\hline $\begin{array}{c}\text { Agenția Relații } \\
\text { Funciare și Cadastru }\end{array}$ & 3 & 82387800 & 0 & 0,00 & 3 & 82387800,00 \\
\hline \begin{tabular}{|c|} 
Zona Antreprenoriatului \\
Liber "EXPO- \\
BUSINESS- \\
Chișinău" \\
\end{tabular} & 1 & 11782170 & 0 & 0,00 & 1 & 11782170,00 \\
\hline $\begin{array}{c}\text { Serviciul de Informații și } \\
\text { Securitate }\end{array}$ & 1 & 3269900 & 0 & 0,00 & 1 & 3269900,00 \\
\hline \begin{tabular}{|c|} 
Cancelaria de \\
Stat a Republicii \\
Moldova \\
\end{tabular} & 9 & 555044700 & 0 & 0,00 & 9 & 555044700,00 \\
\hline $\begin{array}{l}\text { Alte instituții şi } \\
\text { organizații }\end{array}$ & 1 & 0 & 0 & 0,00 & 1 & 0,00 \\
\hline \begin{tabular}{|c|} 
Consiliul Coordonator al \\
Audiovizualului
\end{tabular} & 1 & 24300 & 0 & 0,00 & 1 & 24300,00 \\
\hline $\begin{array}{l}\text { Comisia Națională a } \\
\text { Pieței Financiare }\end{array}$ & 1 & 386420 & 0 & 0,00 & 1 & 386420,00 \\
\hline \begin{tabular}{|c|} 
Departamentul \\
Instituțiilor Penitenciare
\end{tabular} & 12 & 14823620 & 0 & 0,00 & 12 & 14823620,00 \\
\hline TOTAL & 334 & 26021835083 & 106 & 9419214982,00 & 228 & 16602620101,00 \\
\hline
\end{tabular}





\title{
Cap. 11. STUDIUL INFLUENȚEI FENOMENULUI SUSTENABILITĂȚII ASUPRA RAPORTĂRII ENTITĂȚILOR ECONOMICE - STUDIUL LITERATURII ȘI ANALIZA COMPARATIVĂ A RAPOARTELOR DE SUSTENABILITATE DIN DOMENIUL BANCAR
}

\author{
Mihai-Florentin Herciu \\ Universitatea „Alexandru Ioan Cuza” din Iași, Facultatea de Economie şi Administrarea Afacerilor, \\ România,herciu_mihai92@yahoo.com
}

\begin{abstract}
Odată cu creșterea eforturilor pentru o dezvoltare sustenabilă, adică preocuparea pentru conservarea resurselor naturale și a desfășurării de diferite acțiuni cu caracter social, s-a remarcat o schimbare a necesităților de informare ale utilizatorilor de informații contabile, în sensul că aceștia doresc să fie la curent cu toate eforturile depuse de o entitate economică în scopul dezvoltării sustenabile. Pentru a răspunde acestei necesități noi de informare, a apărut conceptul de raportare nefinanciară, respectiv conceptul de raportare integrată. Astfel, pe lângă informațiile financiare clasice, prin intermediul raportării nefinanciare, utilizatorii informațiilor publicate sunt informați asupra activităților efectuate în scopul unei dezvoltări durabile. Problema care apare este aceea că nu există un cadru standardizat pentru raportarea nefinanciară, remarcânduse faptul că informațiile nu sunt comparabile între entități economice diferite și sunt ridicate semne de întrebare asupra calității acestor informații, întrucât fiecare entitate economică adoptă un cadru de raportare diferit sau își dezvoltă ele însele un cadru de raportare. Totodată, se ridică întrebarea dacă activitatea nefinanciară are influență asupra performanței financiare, remarcându-se o influență pozitivă a performanței nefinanciare asupra ratei rentabilității economice. Realizând o analiză comparativă a rapoartelor de sustenabilitate publicate de 8 bănci de pe piața românească, se poate observa lipsa de unitate și de normalizare din domeniul raportării nefinanciare, fiind scoasă în evidență necesitatea unei legislații unitare care să reglementeze întocmirea rapoartelor CSR.
\end{abstract}

Cuvinte-cheie: raportare integrată, raportare nefinanciară, rapoarte sustenabilitate, performanță financiară, rapoarte CSR domeniu bancar.

\section{Introducere}

Conceptul de dezvoltare sustenabilă face referire în principal la ansamblul modalităților de dezvoltare economică și socială, ținând seamă de aspectele de natură socială, economică sau ecologică. O altă definiție asupra conceptului de dezvoltare sustenabilă sau durabilă este dată de Comisia Mondială pentru Mediu și Dezvoltare (WCED), care o definește ca fiind "dezvoltarea care urmărește satisfacerea nevoilor prezentului, fără a compromite posibilitatea generațiilor viitoare de a-şi satisface propriile nevoi”.

Procesul complet al dezvoltării sustenabile este compus dintr-o serie de structuri mai mici, ce au drept obiectiv scoaterea în evidență a punctelor tari și îmbunătățirea acelora slabe. Preocuparea pentru dezvoltarea economică sustenabilă a început în jurul anului 1980 și se bazează pe trei piloni principali: economic, social și de mediu.

$\mathrm{Cu}$ referire la influența asupra domeniului economic, în cadrul lucrării de față se va încerca determinarea modului în care dezvoltarea sustenabilă influențează modul de raportare al entităților. Altfel spus, se va încerca scoaterea în evidență a modului în care raportarea financiară se mulează pe cerinţele dezvoltării sustenabile și la modul în care aceasta se adaptează pentru a corespunde acestor cerințe. În vederea răspunderii la aceste cerințe ale dezvoltării sustenabile, a apărut conceptul de raportare non-financiară. 
Raportarea non-financiară reprezintă modalitatea prin care entitățile prezintă impactul pe care activitatea lor îl are din punct de vedere social, economic sau ecologic. De asemenea, prin raportarea non-financiară sunt evidențiate principalele valori la care o entitate economică aderă, evidențiind legătură dintre strategia sa de dezvoltare și grija pentru dezvoltarea sustenabilă, atât la nivel local cât și la nivel global.

Entitățile economice își desfășoară activitatea într-un mediu economic caracterizat printr-o concurență acerbă și incertitudine din punct de vedere fiscal, legislativ sau juridic. Astfel, aceste entităţi trebuie să prezinte anual informații de natură financiară, în raportările financiare anuale, din care să reiasă poziția și performanța financiară a acesteia în vederea atragerii de noi capitaluri. Aceste informații trebuie să fie utile diverșilor utilizatori, în vederea luării deciziei de a investi sau nu capital, trebuind să respecte o anumită structură și să aibă un anumit conținut, conform reglementărilor în vigoare. Totuși, apar situații în care situația din raportările financiare nu este totuna cu situația reală a respectivei entități. Aceste diferențe pot fi puse pe seama influenței factorilor de natură non-financiară.

În contextul noilor cerințe de raportare, rezultate în urma strategiilor de dezvoltare sustenabilă, dar și pentru a prezenta o imagine completă a poziției și performanței financiare a unei entități economice, apare necesară o raportare a informațiilor destinate utilizatorilor care să cuprindă atât informațiile de natură financiară, cât și informațiile de natură non-financiară. Acest tip de raportare poată denumirea de raportare integrată. Astfel, pe lângă datele clasice, de natură financiară, o entitate economică va scoate în evidență și informațiile ce nu au un caracter financiar, respectiv informații referitoare la impactul social al activităților unei companii sau impactul asupra mediului înconjurător.

Raportarea integrată se prezintă ca un instrument menit să sporească gradul de încredere al investitorilor, dar și al consumatorilor, prezentând pe lângă datele clasice, de natură financiară, și informații non-financiare, referitoare la principalele acțiuni cu caracter social ale unei entităţii, în vederea creșterii bunăstării comunității în care aceasta își desfășoară activitatea, dar și al acțiunilor menite să asigure protecția mediului înconjurător.

Se poate observa că preocuparea pentru o dezvoltare durabilă a societății în ansamblul ei a produs modificări în modul în care o entitate economică raportează informațiile sale către utilizatori, apărând conceptul de raportare integrată. Astfel, în prezent nu mai este suficientă doar prezentarea informațiiilor de natură financiară, ci este necesară și prezentarea principalelor acțiuni cu impact social sau de mediu.

Rolul acestor informații de natură non-financiară, prezentate concomitent cu informațiile de natură financiară, a fost acela de responsabilizare al companiilor, în sensul că acestea au fost nevoite să întreprindă acţiuni care nu au fost neapărat generatoare de profit, dar care au avut beneficii de natură socială sau ecologică și au trebuit să-și desfășoare activitățile curente ținând cont de aceste aspecte.

Este cunoscut faptul că procesul de dezvoltare durabilă sau sustenabilă este unul de lungă durată iar preocuparea pentru aceasta este tot mai pregnantă, mai ales în ceea ce privește politicile de protecție a mediului, toate acestea având efecte asupra modului de raportare al entităților economice.

Problema care apare este aceea că nu există un cadru standardizat pentru raportarea nefinanciară, remarcându-se faptul că informațiile nu sunt comparabile între entități economice diferite și sunt ridicate semne de întrebare asupra calității acestor informații, întrucât fiecare entitate economică adoptă un cadru de raportare diferit sau își dezvoltă ele însele un cadru de raportare.

În cadrul acestui studiu se va realiza comparația dintre nouă rapoarte CSR din sectorul bancar din România, scoțând în evidență elemente referitoare la structură, politici avute în vedere, acțiuni specifice dezvoltării sustenabile și modul de prezentare al acestor informații. Se va încerca, astfel, determinarea măsurii în care aceste informații sunt comparabile între entitățile din acelaşi sector de activitate, bancar, pentru a putea determina care dintre entități este mai performantă din punct de vedere nefinanciar. 


\section{Scopul, obiectivele și metodologia utilizată}

Scopul acestei lucrări este acela de a determina măsura în care informațiile prezentate în rapoartele nefinanciare din sectorul bancar, sunt comparabile și omogene de la o entitate la alta, în ceea ce privește conținutul și forma acestor rapoarte. De asemenea, în lucrarea de față se va încerca analiza critică a literaturii de specialitate în vederea relevării aspectelor relevante privitoare la performanța nefinanciară și raportarea integrate.

Obiectivele urmărite, în vederea atingerii scopului propus, sunt:

- Evidențierea elementelor prezentate de fiecare raport în parte;

- Evidențierea măsurii în care acestea sunt standardizate și prezintă calitatea de comparabilitate.

- Analiza critică a literaturii de specialitate.

\section{Raportarea integrată - analiza literaturii}

Un prim articol avut în vedere îl reprezintă Does ESG performance have an impact on financial performance? Evidence from Germany, cercetare realizată de Patrick Velte, în care este analizată influența activității nefinanciare, concretizată în diverse activități ce privesc protejarea mediului sau bunăstarea socială, asupra performanței financiare a unei entități economice în Germania.

Contextul acestei cercetări îl reprezintă faptul că, odată cu criza economică din 2008/2009, a scăzut gradul de încredere al informațiilor de natură financiară, furnizate prin intermediul raportărilor anuale, fiind astfel considerată necesară adăugarea unei noi dimensiuni în ceea ce privește informațiile furnizate utilizatorilor, respectiv raportarea nonfinanciară. Prin intermediul acesteia sunt furnizate utilizate utilizatorilor informații referitoare la guvernanța corporativă, la activităţile de conservare a mediului sau la activitățile cu caracter social întreprinse de o anumită entitate.

În cadrul acestei cercetări, au fost analizate 412 firme listate la bursă, din Germania, datele folosite fiind din perioada 2010-2014. Prin intermediul acestui studiu s-a vrut evidențierea influenței activităţii nefinanciare asupra performanței financiare din două perspective. Pe de o parte, a fost scoasă în evidență măsura în care fiecare element al raportării nefinanciare, respectiv guvernanța, aspectul ecologic și aspectul social, contribuie la legătură dintre performanța nefinanciară și performanța nefinanciară, iar pe de altă parte, au fost incluși în modelul de analiză atât variabile bazate pe criterii contabile (Rata rentabilității economice), dar și variabile ale performanței, care derivă de pe piață (Tobin Q). După cum se poate observa, acest studiu nu s-a concentrat pe o influență globală a performanței nonfinanciare asupra performanței financiare, ci s-a vrut o privire mai analitică asupra acestui fenomen.

Rezultatele acestui studiu relevă faptul că raportarea performanței nonfinanciare, per total și pe fiecare componentă în parte, are un impact pozitiv asupra ratei rentabilitătii economice. De asemenea, studiul a scos în evidență că, din cele trei elemente ale responsabilității corporative, guvernanța are cel mai mare impact, comparativ cu componenta de mediu și componenta socială. Surprinzător, raportarea acestor elemente ale performanței nefinanciare nu prezintă un impact semnificativ asupra performanței de pe piață a unei entități economice (Tobin's Q) (Velte, 2017).

Rezultatele acestui studiu sunt relevante din perspectiva altor cercetători, a organelor de normalizare dar și a practicienilor, deoarece sunt create premisele stabilirii și creșterii unor instrumente pentru managementul activităților ESG de către stakeholderi. În acest context, conexiunea dintre raportarea nonfinanciară și raportarea financiară devine tot mai importantă, în prezent aceasta fiind întărită de obligativitatea raportării integrate, adică publicării pe lângă rapoartele financiare a unor rapoarte ce conțin date nonfinanciare, de către entitățile cotate la bursă şi de implementarea politicilor aferente dezvoltării sustenabile, asumate individual de fiecare entitate economică sau impuse prin legislația în vigoare. Concret, raportarea nonfinanciară va deveni un element complementar marcant al raportării clasice financiare, care va deveni odată cu trecerea timpului tot mai standardizat prin legislația adoptată la nivelul diverselor structuri sociale. 
Raportarea nofinanciară, respectiv raportarea activităților de conservare a mediului sau a activităților menite să asigure bunăstarea socială, nu mai este doar un instrument de marketing, aceasta devenind un adevărat obiectiv pentru entitățile economice, dar și un instrument de informare caracterizat prin grad mare de încredere.

Un al doilea articol supus analizei este Corporate social responsibility and financial performance relationship: a review of measurement approaches, publicat în anul 2017, fiind realizat de Adriana Galant și Simon Cadez.

Această cercetare pleacă de la premisa că relația dintre responsabilitatea socială corporativă (RSC) și performanța financiară clasică a fost subiectul a numeroase studii care de cele mai multe ori au dus la obținerea de rezultate contradictorii. Un motiv pentru acest fapt îl reprezintă percepția diferită avută faţă de aceste două concepte, anterior menţionate. Astfel, prin acest studiu s-a încercat analizarea unor abordări alternative în ceea ce privește operaționalizarea și măsurarea RSC și performanței financiare, abordări existente în diverse articole științifice care studiază relația RSC-performanță financiară. În urma acestui studiu s-a constatat că operaționalizarea RSC variază în literatura de specialitate de la unidimensional la multidimensional. Mai apoi, abordările privind măsurarea RSC includ indici de reputație, analize de conținut, studii bazate pe chestionare, pe când măsurarea performanței financiare includ metode contabile, metode bazate pe piață sau metode combinate între acestea două. În al treilea rând, nicio abordare în ceea ce privește măsurarea RSC nu este fără dezavantaje, cele mai întâlnite probleme fiind subiectivitatea cercetătorului și o atitudine părtinitoare în selecția elementelor care influențează relația RSC-performanță financiară (Galant \& Cadez, 2017). Acest articol încearcă prezentarea unor metode de remediere a acestor dezavantaje.

În urma analizei realizate prin intermediul acestei cercetări, s-a scos în evidență preocuparea tot mai pregnantă a managerilor în ceea ce privește influența RSC asupra performanței financiare, arătându-se faptul în ciuda numeroaselor studii, încă nu există o părere unanim acceptată. Totodată, au fost identificate o serie de avantaje și dezavantaje ale diferitelor modalități de măsurare a RSC și a performanței financiare, prezentate în tabelul 1.

Tabel 1. Avantaje/dezavantaje metode de măsurare

\begin{tabular}{|c|c|c|}
\hline Modalitate de măsurare & Avantaje & Dezvantaje \\
\hline \multicolumn{3}{|c|}{ RSC } \\
\hline 1. Indici & $\begin{array}{l}\text { Existența datelor și comparabilitate; } \\
\text { multidimensionalitate recunoscută }\end{array}$ & $\begin{array}{l}\text { Neștiințifică, cuprindere limitată a } \\
\text { firmelor (geografie, mărime, } \\
\text { industrie) }\end{array}$ \\
\hline 2. Analiză de conținut & Flexibilitate pentru cercetător & $\begin{array}{l}\text { Subiectivitatea cercetătorului, } \\
\text { nepublicarea datelor; }\end{array}$ \\
\hline 3. Chestionare & Flexibilitate pentru cercetător & $\begin{array}{l}\text { Subiectivitatea cercetătorului, erori } \\
\text { de măsurare; }\end{array}$ \\
\hline 4. Măsuri unidimensionale & Existența datelor și comparabilitate & Invaliditate teoretică \\
\hline \multicolumn{3}{|c|}{ Performanța financiară } \\
\hline 1. Metode contabile & Existența datelor și comparabilitate & Date vechi \\
\hline 2. Metode bazate pe piață & Date din prezent & $\begin{array}{l}\text { Date valabile doar pentru companii } \\
\text { citate. }\end{array}$ \\
\hline
\end{tabular}

După cum se poate observa din tabelul 1, nu există o modalitate de măsurare perfectă pentru niciunul din cele două elemente, însă se poate spune că raportarea financiare este mult mai pertinentă, ca urmare a faptului că această este folosită de mult timp și prezintă un grad ridicat de 
standardizare. $\mathrm{Nu}$ același lucru se poate spune despre RSC, care este un concept relativ nou, cu un grad scăzut de standardizare.

Măsurarea pe baza indicilor prezintă avantajul accesibilității datelor și comparabilității acestora între mai multe firme, ca urmare a existenței a unor metode standardizate de compilare a acestora. Totuși, această metodă este departe de a fi o metodă ideală de măsurare relației din RSC și performanța financiară, deși este una din cele mai folosite metode. Marele dezavantaj al acestei metode este acela că acești indici sunt compilați de firme private, care au anumite interese proprii, putând apărea astfel manipulări ale acestora. Un al mare dezavantaj este acela că numărul redus de firme pe care îl iau în considerare acești indici. Entităţile care se ocupă de centralizarea acestor indici analizează doar firme mari, cotate, care au o anumită obligativitatea în ceea ce privește responsabilitatea socială, de aici putând fi constatate anumite anomalii ale rezultatelor obținute.

Analizele de conținut prezintă marele avantaj al faptului că prezintă o mare flexibilitate pentru cercetător, în sensul că acesta își poate alege dimensiunea asociată RSC pe care vrea să o studieze, să culeagă informații privind acea dimensiune și codeze informațiile pentru cercetări cantitative viitoare. Marea problemă asociată acestei metode este aceea că cercetătorul poate prezenta un grad mare de subiectivitate care poate duce la compromiterea studiului. O altă problemă este aceea că datele privind RSC, respectiv raportarea nefinanciară, nu este obligatorie. Astfel, poate fi uşor dedus faptul că firmele mai responsabile din acest punct de vedere vor raporta activitățile de conservare a mediului și activităţile cu caracter social, în timp ce firmele care nu înfăptuiesc astfel de activități nu vor raporta nimic, putând astfel apărea rezultate eronate ale cercetării.

Aplicarea de chestionare prezintă același avantaje ca și analizele de conţinut, prezentând totodată posibilitatea apariției subiectivității din partea cercetătorului dar și a riscului ca chestionarele să fie întocmite necorespunzător, în sensul că acesta nu surprinde elementele care se vor luate în considerare prin cercetarea în cauză.

Un al treilea articol supus analizei este Does Integrated Reporting Matter to the Capital Market?, realizat de Shan Zhou, Roger Simnett, și Wendy Green.

Motivația acestui articol este aceea că sunt necesare dovezi empirice care să dovedească beneficiile raportării integrate, care este considerată a fi "viitorul raportării corporative", fiind o abordare care vizează raportarea financiară împreună cu raportarea nonfinanciară, asigurându-se astfel o raportare transparentă și completă pentru utilizatori. Importanța studiului raportării integrate și a efectelor produse de aceasta derivă din faptul că tot mai multe entităţi economice întocmesc de bunăvoie rapoarte integrate și preocuparea tot mai accentuată la nivel global pentru standardizarea acesteia.

Cei care susțin conceptul de raportare integrată au ilustrat o serie de beneficii pe care raportarea integrată le generează pentru companii în sine, dar și pentru furnizorii de capital și stakeholderi. Totuşi, puține din aceste beneficii au fost testate empiric, acest studiu fiind unul dintre primele care își propune să arate beneficiile raportării integrate, concentrându-se pe două direcții: i) dacă nivelul de aliniere al raportării integrate la cadrul legislativ privind raportarea integrată afectează previziunile analiștilor în ceea ce privește acuratețea și dispersia veniturilor viitoare și ii) dacă companiile care realizează rapoarte integrate cu grad mare de aliniere la normele cadrului internaţional de raportare integrată, prezintă costuri mici de capital.

Acest studiu a fost realizat pe 443 de companii din Africa de Sud, între anii 2009 și 2010 și sa observat că există o relație pozitivă între predicția veniturilor și raportarea integrată, demonstrând că informațiile asociate raportării integrate sunt benefice pentru analiști în predicțiile efectuate, ca urmare a faptului că acestea fac referire la strategia corporativă, model de afaceri sau informații referitoare la strategii viitoare.

De asemenea, s-a constatat că alinierea mai ridicată a raportării integrate la standardele existente la nivel internațional, duce la o scădere a costurilor de capital, ca urmare a faptului că investitorii erau dispuşi să accepte rate mai mici pentru remunerarea capitalului pus la dispoziţia entităților, ca urmare a faptului că informațiile puse la dispoziție îi reduceau riscul investiției respective. 
Un al patrulea articol supus analizei este Corporate and Integrated Reporting: A Functional Perspective, Robert G. Eccles and George Serafeim.

În acest articol sunt aduse în discuție faptul că raportarea integrată îndeplinește 2 funcții majore. Prima este aceea de "funcție informație", care permite investitorilor să ia decizii de a investi sau nu în anumite sectoare/ramuri de activitate. A doua funcție este "funcția de transformare", aceasta fiind o rezultantă a faptului că o companie beneficiază de capitalul adus în aceasta de diverși stakeholderi. Este adus în vedere că, în prezent se remarcă un accentuare a fenomenului de dezvoltare sustenabilă, fiind existente o multitudine de reglementări care să ducă la conservarea resurselor mediului înconjurător și la bunăstarea socială. Astfel, raportarea financiară și cea nefinanciară nu mai pot fi tratate separat, acestea trebuind să complementare uneia celeilalte, oferind un plus de credibilitate informațiilor publicate. Tratarea separată a acestora nu duce la îndeplinirea nici uneia din cele două funcții. În prezent, investitorii au nevoie să știe cum este gestionată relația dintre performanța financiară și cea nefinanciară.

Raportarea financiară este concentrată mai mult pe "funcția de informare", pe când raportarea nefinanciară este concentrată mai mult pe "funcția de transformare". Raportarea integrată reprezintă o tentativă de a le obține pe amândouă.

Cel ce al cincilea articol supus analizei este Integrated reporting: The current state of empirical research, limitations and future research implications, articol publicat de Patrick Velte şi Martin Stawinoga.

În momentul actual, cercetările empirice privind raportarea integrată pot fi sintetizate la 3 nivele, respectiv la nivelul pieței, la nivel organizațional și nivel decizional. O problemă majoră a acestor studii este aceea că acestea sunt validate pe baza principiilor de la nivelul cadrului IIRC pentru raportare financiară. Cadrul IIRC nu descrie indicatori specifici de performanță, modalități de măsurare ori publicare sau sugestii pentru operaţionalizarea raportării integrate. Se poate remarca că studiile privind raportarea integrată la nivel organizaţional și la nivelul pieței au crescut semnificativ, pe când cele la nivel decizional nu sunt tocmai populare. Se anticipează că raportarea integrată va deveni un subiect de sine stătător pentru cercetări empirice datorită interdisciplinarității (contabilitate, finanțe, guvernanță corporativă, management etc.) și datorită grijii tot mai mari la nivel global pentru dezvoltare sustenabilă. Problema majoră a raportării integrate în perioada de față este slaba calitate a acesteia, datorită manipulării informației de către companiei, pentru a fi îndeplinite anumite cerințe ale stakeholderilor. O sinteză a celor prezentate anterior se regăsește în tabelul 2.

Tabel 2. Descoperiri majore la nivelul pieței, decizional și organizației

\begin{tabular}{|l|l|}
\hline Nivelul de analiză & Descoperiri majore \\
\hline 1. Piață & $\begin{array}{l}\text { Implementarea raportării integrate: decizia de } \\
\text { implementare a raportării integrate este } \\
\text { influnețată de caracteristicile acesteia } \\
\text { (profitabilitate și mărime) și factori de natură } \\
\text { internă și externă ai guvernanței corporative } \\
\text { Calitatea raportării integrate: calitatea acesteia } \\
\text { este influențată de calitatea managementului } \\
\text { RSC } \\
\text { Reacția pieței: reacții pozitive din partea pieței } \\
\text { după implementarea raportării integrate } \\
\text { (valoarea firmei în creștere, previziunile } \\
\text { analiștilor) }\end{array}$ \\
\hline 2. Organizațional \\
$\begin{array}{l}\text { Implementarea raportării integrate: motivația } \\
\text { intrinsecă a managementului afectează } \\
\text { implementarea raportării integrate } \\
\text { Calitatea raportării integrate: exist multe } \\
\text { variații în ceea ce privește forma și conținutul } \\
\text { raportării integrate }\end{array}$ \\
\hline $\begin{array}{l}\text { Percepțiile stakeholderilor: } \\
\text { a. raportarea integrată este benefică } \\
\text { investitorilor, companiilor mari și } \\
\text { profesioniștilor contabili } \\
\text { b. raportarea integrată este văzută ca o sursă } \\
\text { de informații adițională } \\
\text { c. Cadrul conceptual IIRC e văzut ca o } \\
\text { imbunățătire majoră. }\end{array}$ \\
\hline
\end{tabular}




\section{Analiza rapoartelor CSR}

Eșantionul de bănci ales este format din:

Raiffeisen Bank;

BRD;

Banca Transilvania;

- Patria Bank;

- Banca Românească;

Alpha Bank;

Unicredit Bank;

- Garanti Bank.

Pentru aceste bănci vor fi prezentate principalele elemente menționate în rapoartele CSR.

\subsection{Analiza raportului Raiffeisen Bank}

Primele rapoarte de responsabilitate socială analizate sunt cele ale Raiffeisen Bank. Această bancă ilustrează prin intermediul acestor rapoarte implicarea acesteia în creșterea comunitătii și impactul pe care acesta îl are prin intermediul proiectelor derulate. Investițiile anuale în comunitate se ridică undeva la 5 milioane de euro, fiind vizate 5 direcții strategice urmărite:

- Educaţie financiară;

- Sport ca stil de viață sănătos;

- Artă și cultură;

- Ecologie urbană;

- Asistență socială;

Raiffensen Bank este o societate a cărei preocupare pentru raportarea financiară există încă din anul 2009, fiind una din primele companii care a acordat importanță raportării elementelor de natură nefinanciară, în vederea oferirii unei imagini mai complete şi transparente asupra propriei activităţi. Ultimul raport disponibil pe site-ul web al băncii este cel din anul 2018. Acesta este împărțit în 4 secțiuni distincte, fiecare prezentând anumite elemente specifice. Aceste secțiuni sunt:

1. „Despre Raiffeisen Bank”;

2. „Modelul nostru de business responsabil”;

3. „Responsabilitatea practicilor noastre”;

4. „Relații pe termen lung”.

În prima secțiune a raportului se face trimitere la experiența pe care o are în domeniul bancar, menționarea experienței în raportarea nefinanciară, rezumatul financiar, guvernanța corporativă și structurile de conducere, codul de conduită, etica în afaceri și conformitate.

Concret, se aduce la cunoștință utilizatorilor acestor informații că această instituție face parte din grupul Raiffeisen, unul din liderii pe piaţa serviciilor financiare și de investiții din Austria și Europa Centrală și de Est. Aceasta este prezentă pe 13 piețe din Europa Centrală și de Est, prin peste 2100 de unităţi bancare și undeva la 47.000 de angajați.

În ceea ce privește rezultatele financiare obținute, este menționat faptul că profitul net al acesteia a crescut în anul 2018, față de anul 2017, cu 79\%, de la 491 milioane lei la 881 milioane lei în anul 2018. Așa cum a fost menționat anterior, grija Raiffeisen Bank pentru raportarea nefinanciară este prezentă de peste 10 ani, ilustrând astfel dorința acestei companii pentru o informare completă a utilizatorilor.

Cu privire la guvernanța corporativă și la structurile de conducere, este menționat faptul că în structura acționariatului este acționar absolut majoritar, respectiv Raiffeisen SEE Region Holding $\mathrm{GmbH}$, care deține 99,925\% din acțiuni, restul de 0,075\% fiind deținute de alte entităţi. De asemenea sunt prezentate informații cu privire la structura organizatorică a băncii, structura de guvernanță corporativă, adunarea generală a acționarilor, structurile de administrare (consiliul de supraveghere și directoratul), fiind prezentate principalele atribuții și sarcini ale fiecăreia.

În vederea respectării unei anumite conduite de etică în afaceri, această societate a adoptat un cod de conduită care să ghideze acțiunile zilnice ale părților interesate, interne sau externe, care să asigure îndeplinirea anumitor standarde și valori etice în conduita de afaceri. Altfel spus, pentru a- 
și desfăşura activitatea în mod legal, etic și responsabil. Principalii piloni ai Codului de etică sunt prezentați în tabelul 3.

Tabel :3. Piloni Cod Conduită Etică Raiffeisen Bank

\begin{tabular}{|l|l|l||}
\hline \multicolumn{2}{|c||}{ Principalii piloni ai Codului nostru de Conduită } \\
\hline $\begin{array}{l}\text { Responsabilitate } \\
\text { socială și de mediu }\end{array}$ & Relațiile cu acționarii & Calitate \\
\hline $\begin{array}{l}\text { Combaterea } \\
\text { infracționalității } \\
\text { economice }\end{array}$ & Relațiile cu angajații & Respect reciproc \\
\hline Relațiile cu clienții & Valorile noastre & Inițiativă \\
\hline $\begin{array}{l}\text { Fundația valorile } \\
\text { noastre }\end{array}$ & Orientarea către client & Lucrul în echipă \\
\hline $\begin{array}{l}\text { Conformitate cu legile } \\
\text { ș reglementările }\end{array}$ & Profesionalism & Integritate \\
\hline
\end{tabular}

În ceea ce privește etica în afaceri, banca acordă o importanţă majoră managementului responsabil și transparent, având ca scop informarea corectă și menţinerea încrederii părţilor cointeresate fiind respectate principiile eticii în afaceri și fiind adoptate anumite politici anticorupție.

În ceea ce privește conformitatea, angajații băncii au responsabilitatea de a-și îndeplini îndatoririle la cele mai înalte standarde de etică și integritate și de a respecta politicile și procedurile băncii, care sunt guvernate de principiile transparenței și responsabilității în afaceri. Sunt menționate utilizatorilor amenzile și principalele litigii avute de bancă în anul de referință.

În cea de a doua secțiune, "Modelul de business responsabil" sunt prezentate Principii, strategie şi afilieri, e Obiectivele de dezvoltare durabilă, Matricea de materialitate, Comunicarea cu stakeholderii și recunoaștere \& premii.

În vederea îndeplinirii Obiectivelor de Dezvoltare Durabilă (ODD-uri), aferente Agendei 2030 pentru dezvoltare durabilă, Raiffeisen Bank prezintă o serie de activități specifice în vederea îndeplinirii unora din cele 17 obiective propuse prin intermediul acestui proiect, prezentate în tabelul 4.

Cea de-a treia secțiune, „Responsabilitatea practicilor noastre”, vizează aspecte referitoare la stabilitate în Relaţiile comerciale, Retail \& Corporate Banking, Susţinerea antreprenoriatului românesc, Principiile finanţării responsabile, Soluţii pentru clienţi, Accesul la servicii şi Digitalizare.

Referitor la principiile finanțării responsabile, Raiffeisen Bank stabilește o serie de activități asupra cărora niciodată nu se va lua în calcul acordarea de finanțări, dar sunt enumerate și o criterii de sustenabilitate pe care trebuie să le îndeplinească anumite proiecte.

Printre finanțările care nu vor fi acordate niciodată, se numără producerea sau comercializarea de produse interzise în țara gazdă, producerea sau comercializarea de arme și muniții, comerț fără licențe de import sau export, transportul petrolului sau al altor elemente similare etc. 
Tabel 4: Obiective dezvoltare durabilă

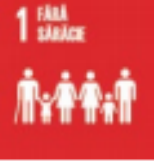

\section{ODD 1: \\ Fără sărăcie}

Componia contribuie indirect la patru $[1 a, 1.1,1.2$ 1.4 | din cele șapte finte stabilite pentru obiectivul de dezvoltare durabilă numărul 1 prin acordurile încheiate cu organizatiii internationale precum fondul European pentru Investitii, pentru mobilizarea de resurse financiare, programele comunitare sustimute si soluțiile oferite pentru dienții care întámpinả dificultăti financiare.

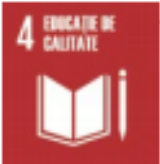

\section{ODD 4: \\ Educatie de calitate}

Banca susfine, dezvoltá și promovează oportunităti de educatie si dezvoltare profesională, fie prin investitiile în educatie financiară pe care le realizeazá alături de partenerii săi comunitari, fie prin programele interne dedicale angajatilor sou finerilor absolvenfi, contribuind astfel la patru din cele 10 finte ale obiectivului $\mid 4.2,4.3,4.4,4.5)$.

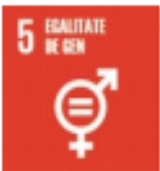

\section{ODD 5: \\ Egalitate de sanse}

Prin polificile pe care le promoveazá, Banca ịsi doreste să contribuie la combaterea futuror formelor de discriminare si sá sprijine parficiparea completá și efectivă a femeilor in procese de manogement (5.1, 5.5).

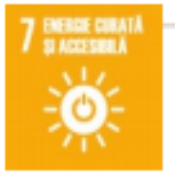

\section{ODD 7: Energie curată și accesibilă}

Prin proiectele pe care Banca le dezvoltă pentru eficientizarea și scöderea consumului de energie, compania contribuie în mod indirect la douá din cele șapte finte ale obiecfivului $(7.2,7.3)$.

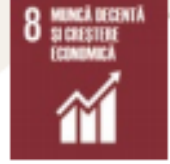

\section{ODD 8: \\ Muncă decentă și creştere economică}

Banca adresează saple din cele douãsprezece finte propuse de obiectivul numărul opt $(8.2,8.3,8.4,8.5$, $8.6,8.8,8.10)$. Imvestiftiile în digitalizarea produselor si serviciilor, eficienfizarea consumului de resurse, programele dervolltate de Bancă pentru spriiinirea imM-urilor și antreprenorilor locali, eforturile companiei pentru încurajarea participárii femeilor în procese de selectie pentru pozitii de conducere, politica de remunerare egalá, investifitile pentru sănătalea, siguranta și bunástarea angajafilor, dar și polifica de credilare responsabilă sunt másuri care genereazá pe termen lung, numeroase efecte pozifive în economia románeascỏ.

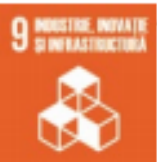

\section{ODD 9}

\section{Industrie, inovatie și infrastructură}

Investiftiile companiei in comunitātilile locale, încurajarea metodelor de fransport alternativ si partenerialele cu institutiile internationale pentru a creste accesul înireprinderilor din România la servicii financiare, contribuie indirect la atingerea a două din cele opt finte ale obiectivului $(9.3,9.4)$.

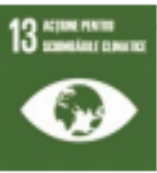

\section{ODD 13:}

\section{Actiune pentru} schimbările climatice

Banca integrează în política sa de mediu mãsuri pentru a contribui la combaterea schimbărilor climatice și în acelaşi fimp promovează în rândurile angajatilor adoptarea unui comportament prietenos cu mediul înconjurălor pentru a contribui la reducerea impactului care cauzeazá schimbări climafice $[13.2,13.3)$.

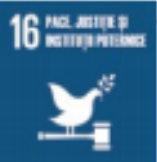

\section{ODD 16:}

\section{Pace, justiție și instituții puternice}

Banca dezvoltã acfiuni pentru a contribui la mobilizarea unor resurse financiare suplimentare pentru fările în curs de dezvoltare, sprijiná parteneriatul global pentru dezvoltare durabilá prin aderarea la Pactul Global al Nafiunilor Unite și încurajazá parteneriatele public-privat și la nivelul sociełátii civile prin numeroasele inifiative pe care le sustine si în care se implica, contribuind astfel la trei din cele douãsprezece finte ale obiectivului.

În ceea ce privește criteriile de sustenabilitate, acestea sunt împărțite în criterii de sustenabilitate și criterii sociale pentru finanțarea responsabilă, așa cum sunt ele prezentate în tabelul 5 . 
Tabel 5: Criterii finanțare sustenabilă

\begin{tabular}{|c|c|}
\hline $\begin{array}{l}\text { Criterii de sustenabilitate } \\
\text { pentru finanţare responsabilă }\end{array}$ & $\begin{array}{l}\text { Criterii sociale } \\
\text { pentru finanţare responsabilă }\end{array}$ \\
\hline $\begin{array}{l}\text { - Energie regenerabilă: producţia și furnizarea } \\
\text { de energie din surse regenerabile (solar, } \\
\text { eolian, hidro, geotermal, biomasă, recuperare } \\
\text { de energie din deșeuri) sau producţia de } \\
\text { echipamente și componente pentru astfel de } \\
\text { proiecte } \\
\text { - Construcţii sustenabile / clădiri eficiente: } \\
\text { construcţii de clădiri eficiente din punct de } \\
\text { vedere energetic, reabilitarea unor clădiri } \\
\text { existente, în direcţia scăderii consumului de } \\
\text { resurse } \\
\text { - Eficienţă energetică: dezvoltarea și } \\
\text { implementarea de tehnologii care contribuie la } \\
\text { reducerea consumului de energie, recuperarea } \\
\text { energiei din deșeuri, cogenerare } \\
\text { • Transport sustenabil: transportul în comun, } \\
\text { vehicule alternative } \\
\text { • Sisteme de apă și canalizare: construcţia } \\
\text { și operarea facilităţilor de furnizare apă și } \\
\text { colectare apă uzată, reciclarea apei, staţii de } \\
\text { epurare, utilizarea eficientă a apei } \\
\text { - Reducerea deșeurilor și a emisiilor: } \\
\text { reducerea cantităţilor de deșeuri produse, } \\
\text { colectarea, managementul și tratarea acestora, } \\
\text { reciclare, reutilizare și depozitare (pentru } \\
\text { captarea metanului), produse și tehnologii și } \\
\text { soluţii pentru reducerea deșeurilor } \\
\text { - Protecţia naturii: proiecte pentru combaterea } \\
\text { schimbărilor climatice, dezmembrarea, } \\
\text { desurselor naturale, concepte cradle-to-cradle } \\
\text { dezafectarea unor zone industriale și } \\
\text { - Agricultură organică, orașe verzi: } \\
\text { promovarea și îmbunătăţirea stării ecosistemului }\end{array}$ & $\begin{array}{l}\text { - Antreprenoriat social/ sustenabil și startup-uri: idei inovatoare } \\
\text { consolidarea climatului economic (Finanţare } \\
\text { pentru micro-intreprinder și IMM-uri) } \\
\text { - Dezvoltare regională și investiţii în } \\
\text { infrastructură în zone slab structurate: } \\
\text { proiecte din statele aflate în curs de dezvoltare } \\
\text { sau pieţe emergente, proiecte din zona } \\
\text { sectorului public } \\
\text { - Sănătate și servicii medicale: spitale, } \\
\text { centre de îngrijire, centre medicale, ambulanţe, } \\
\text { instituţii de reabilitare. centre publice destinate } \\
\text { activităţilor sportive } \\
\text { - Locuinţe sociale: case pentru persoane și } \\
\text { familii care au nevoie de sprijin (cu venituri } \\
\text { mici), orfelinate, azile de bătrâni } \\
\text { • Securitatea hranei: toate măsurile care } \\
\text { asigură hrană adecvată și sănătoasă } \\
\text { • Apă potabilă: staţii de epurare, izvoare de } \\
\text { apă, instalaţii de apă } \\
\text { - Managementul deșeurilor: colectarea și } \\
\text { tratarea deșeurilor, sisteme de canalizare } \\
\text { - Patrimoniu cultural și artă: protecţia } \\
\text { patrimoniului cultural, muzee } \\
\text { • Educaţie și training: școli, universităţi și } \\
\text { centre de instruire } \\
\text { • Știinţă, cercetare și dezvoltare: institute de } \\
\text { cercetare, laboratoare } \\
\text { • Inovaţie în domeniul dezvoltării durabile: } \\
\text { cercetare și dezvoltare în zona corporate } \\
\text { • Alte efecte pozitive asupra societăţii și asupra } \\
\text { unor aspecte sociale }\end{array}$ \\
\hline
\end{tabular}

Sunt menționate o serie de proiecte cu caracter social sau de mediu derulate de aceasta printre care se numără: The Bridge II (27,5 mil. Euro), Unirii View (21,5 mil. Euro), 19,3 proiecte pentru protejarea mediului (19,3 milioane euro pentru achiziția de mijloace de transport moderne în Cluj, Green mortgage - Pentru a încuraja persoanele fizice să-și achiziţioneze locuinţe cu certificare de eficienţă energetică „Green Homes” Raiffeisen Bank a lansat creditul imobiliar „Casa ta Verde”. Alte proiecte sociale mai includ 0,65 mil. euro pentru achiziția de echipamente medicale, 0,5 milioane euro pentru deschiderea de grădinițe noi, diverse echipamente, 2 mil. euro.

Performanța privind protecția mediului este asigurată prin actualizarea politicii de protecție a mediului în conformitate cu prevederile legislative în vigoare. Compania încurajează colectarea selectivă a deșeurilor în rândul angajaţilor și implementează măsuri pentru a-și îmbunătăţi procesele interne de colectare. $\mathrm{Cu}$ toate acestea, pentru anumite categorii de deșeuri, cantităţile 
colectate de la an la an, pot înregistra diferenţe semnificative (ex. baterii, corpuri de iluminat), deoarece procesul de colectare se face la finalul ciclului de viaţă al produsului. Măsurile pentru reducerea impactului asupra mediului sunt prezentate în tabelul 6 .

Tabel 6: Măsuri pentru reducerea impactului asupra mediului

\section{Măsuri pentru reducerea impactului de mediu}

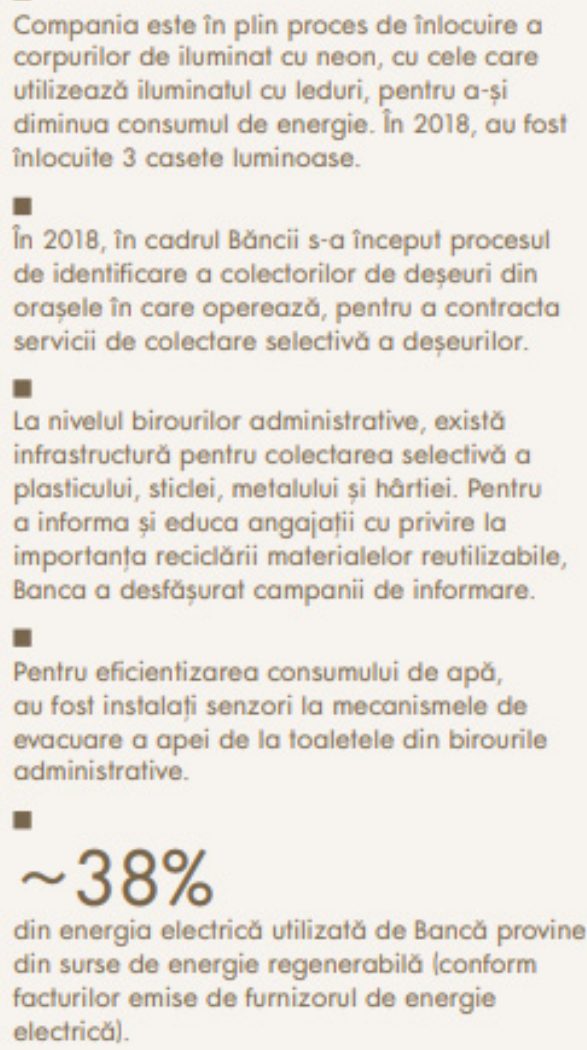

Compania este în plin proces de înlocuire a corpurilor de iluminat cu neon, cu cele care utilizează iluminatul cu leduri, pentru a-și diminua consumul de energie. În 2018, au fost înlocuite 3 casete luminoase.
În 2018, în cadrul Băncii s-a început procesul de identificare a colectorilor de deșeuri din orașele în care operează, pentru a contracta servicii de colectare selectivă a deșeurilor.

$29 \%$

din bugetul de investitii în comunitate a fost alocat proiectelor de ecologie urbană.

\section{În timpul noptii, încalzirea centrală este controlată cu ajutorul unui termostat care regleazŏ temperatura.}

\section{Înlocuirea unei mașini vechi din flota companiei cu o mașină cu emisii scăzute de 98 de grame $\mathrm{CO}_{2} / 100 \mathrm{~km}$. \\ Utilizarea a trei mașini electrice în flota companiei. \\ Informarea angajaţilor prin e-mail, instruiri periodice sau traininguri cu privire la másurile pe care le pot lua pentru a diminua impactul asupra mediului înconjurător.}

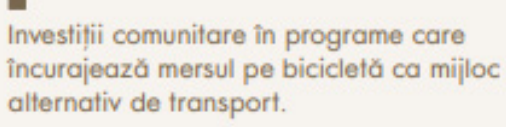

Cea de-a patra secțiune, "Relaţii pe termen lung”, vizează o multitudine de aspecte referitoare la angajați (remunerare și beneficii, echipa existentă, dezvoltare și managementul performanței, sănătate și securitate), la comunitate (voluntariat, contribuții financiare, proiecte pentru comunitate, impactul în comunitate) și la furnizori.

Referitor la comunitate, Raiffeisen Bank se remarcă a fi un actor important în finanţarea proiectelor cu impact social, remarcându-se prin proiecte educaţionale ca "Noi înşine, Familia Mea, Oraşul Meu, Comunitatea Mea, Economia Noastră, ABCdar Bancar, Leaders Experience Leaders Explore Young Leaders Club Finance Raiffeisen Comunităţi Antreprenoria Summit-ul Romanian Business Leaders FinTech Month Reading\&Science Corners Transylvania Beyond Online etc., proiecte ce vizează sportul, ca Sport Arena Streetball (unul din cele mai mari turnee de baschet 3x3 din Europa) Maratonul Internaţional Via Maria Theresia Rowmania Fest Festivalul Internaţional al Bărcilor cu Vâsle Bihor Cycling Tour şi multe altele, artă şi cultură (Festivalul Internaţional de Teatru de la Sibiu), ecologie urbană (i’Velo Urban, i’Velo Relax \& StudentOBike) etc. 
Conform raportului prezentat, Raiffeisen Bank se remarcă printr-o politică caracterizată de responsabilitate faţă de angajații proprii, existând 5.021 de angajaţi (3.805 femei și 1.216 femei), care pot participa la diverse programe existente în cadrul companiei (Vocea Ta, Rstyle) și care au un program de lucru flexibil și posibilități de a avansa în carieră.

Cu privire la Responsabilitatea pentru comunitate, Raiffeisen bank a avut sponsorizări de 2,73 mil. Euro, din care 2,068 mil euro au fost în proiecte comunitare.

$\mathrm{Cu}$ privire la responsabilitatea pentru mediu, 29\% din bugetul de investiții comunitare a fost alocat proiectelor de ecologie urbană iar 38\% din energia utilizată de bancă provine din surse regenerabile.

\subsection{Analiza băncii BRD}

A doua bancă analizată este BRD - Groupe Societe Generale. Această bancă aparține unuia din cele mai importante grupuri bancare din spațiul european, respectiv Groupe Societe Generale..

În ceea ce privește responsabilitatea socială și de mediu, BRD se remarcă prin 2 mari direcții asupra cărora se concentrează, respectiv schimbările climatice, sprijin si implicare in societate

În ceea ce privește investițiile în cultură, BRD se remarcă faptul că susține dezvoltarea culturală, fiind necesară finanțarea proiectelor care să creeze liderii de mâine. BRD susține proiectele culturale inovative, având în acest sens finanţate o serie de proiecte cu caracter cultural.

O primă categorie de proiecte culturale susținute sunt artele performative, fiind parteneri la Festivalul Internaţional de Teatru de la Sibiu (www.sibfest.ro), în Festivalul Naţional de Teatru de la Bucureşti (www.fnt.ro), Festivalul Naţional de Teatru Tânăr de la Alexandria (ideoideis.ro), implicarea în proiecte de producţie cum sunt musicalul «West Side Story» (produs pentru FNT în 2015) sau piesa de teatru «Apa de Mina» (Teatrul Act, 2016) dar şi turnee de teatru cum au fost «Manifest pentru dialog» (Teatrul Radu Stanca - Sibiu, 2015 şi 2016) şi Vanilla Skype (Teatrul Act 2016).

O altă categorie de proiecte culturale este arta contemporană, finanțând evenimentul Noaptea Albă a Galeriilor, în care galerii şi spaţii culturale din 10 oraşe se deschid pentru publicul larg încurajând consumul de artă contemporană şi înţelegerea fenomenului.

Tot în categoria evenimentelor culturale susținute se mai remarcă și muzica clasică, BRD susținând diverse proiecte care să readucă în atenția publicului acest gen de muzică.

În 2016, BRD a creat Scena9, care își propune să facă ordine în actualitatea culturală, să scrie despre ce e relevant, ce e nou sau nedescoperit, ce aduce un plus de valoare în peisajul cultural de la noi, incitând la dialog zone culturale și artistice care, de obicei, nu se intersectează. Stă cu ochii pe noua generație de creatori din domenii cât mai variate, de la artă până la știință, le urmărește proiectele și evoluția.

Mai apoi, BRD și-a manifestat intenția pentru responsabilitatea socială prin diverse proiecte educaționale, având contribuții în programul "Fizica Altfel", în care peste 5.000 de profesori au urmat cursuri de pregătire şi au schimbat modul de a preda această materie elevilor. De asemenea, peste 100 de voluntari BRD au participat la proiectul "Educația îți dă valoare", unde s-a încercat conștientizarea importanței educației pentru elevii de gimnaziu cu un risc crescut de abandon școlar. Mai sunt susținute diverse competiții de robotică, festivaluri șo proiecte tehnologice prin care BRD vrea să deschidă o ușă spre viitor pentru viitoare generație.

În ceea ce privește sportul, BRD finanțează diverse competiții de tenis, diverse programe sportive de interes, dar și programe care încurajează efectuare de activitate fizică.

În fine, a patra categorie de evenimente ce privesc responsabilitatea socială fac referință la societatea civilă. Astfel, prin programele finanțate BRD încearcă să ofere ajutor tinerilor și copiilor aflați în situații dificile, să reducă abandonul școlar, di cauza sărăciei. Se încearcă crearea de mecanisme prin care angajații, clienții şi partenerii să se poată implica în dezvoltarea durabilă.

În acest scop, există programul "Superoameni pentru superşanse", în care angajaţii donează lunar sume care sunt mai apoi dublate de bancă, pentru a finanța programe de educație, reducerea abandonului școlar etc. 
Alt proiect susținut este Hope and Homes for Children Romania, al cărui scop este ca, până în 2020, să nu mai existe nici un copil abandonat în instituţii ale statului de tip vechi, şi să prevină abandonul prin crearea de servicii de suport dedicate copiilor.

BRD mai oferă și numeroase burse în care se încearcă ajutarea copiilor și tinerilor care nu au acces la educație, fiind totodată partener în diverse proiecte cum ar fi Fundaţia Principesa Margareta și Ateliere fără frontiere.

BRD se remarcă prin diverse activități care să conserve resursele mediului înconjurător, aceasta angajându-se în 2017 să ajute la strângerea a 100 de miliarde de euro in finanțări pentru tranziția de energie intre 2016-2020 si sa raporteze periodic asupra progreselor făcute.

\subsection{Analiza Băncii Transilvania}

A treia bancă supusă analizei este banca Transilvania. Această menționează că susține spiritul antreprenorial românesc, afacerile responsabile, creșterea durabilă, calitatea, solidaritatea, responsabilitatea, implicarea și construirea unor relații pozitive cu stakeholderii, altele decât cele de banking. Raportul CSR este împărțit în 6 secțiuni, în care sunt ilustrate activităţile de tip CSR, viziunea firmei în ceea ce înseamnă CSR și modul de evaluarea al activității de CSR, astfel 1 . Domenii în care Banca Transilvania se implică prin activitățile sale; 2. Ca bancă românească, direcțiile Băncii Transilvania din acest punct de vedere sunt următoarele; 3. BT - CSR Landscape; 4. Valorile în jurul cărora este construită politica de implicare socială și de mediu; 5 . Obiectivele activităţilor de implicare și responsabilitate socială BT; 6. Beneficiarii acțiunilor de responsabilitate și implicare socială BT; 7. Monitorizarea activităților de CSR. Domeniile prin care aceasta se implică, prin activităţile sale sunt:

- Antrepronoriat;

- Educație;

- Sport;

- Medical;

- Mediu;

- Social.

Banca Transilvania prezintă în raportul său principalele activităţi prin care acestea se implică în activitatea aferentă sustenabilității. Astfel, Banca Transilvania se remarcă prin implicarea socială (activităţi de sponsorizare, donații, fundații proprii sau voluntariat), responsabilitate socială ( derularea de acțiuni specifice fiecărei categorii de stakeholderi, respectiv clienți, acționari, angajați etc), protejarea mediului ( implicarea în acțiuni de voluntariat pentru împădurirea unor zone din Transilvania; clădiri BT green; distrugerea cardurilor expirate cu respectarea normelor UE de mediu; materialele de comunicare și publicitate tipărite pe hârtie reciclată; respectarea regulilor de amenajare a clădirilor istorice în care se află sedii BT; senzori de amurg la toate firmele luminoase ale clădirilor băncii; finanțarea unor proiecte de eficiență energetică etc.) Politica băncii Transilvania în ceea ce privește politica CSR este ilustrată în figura 1 . 


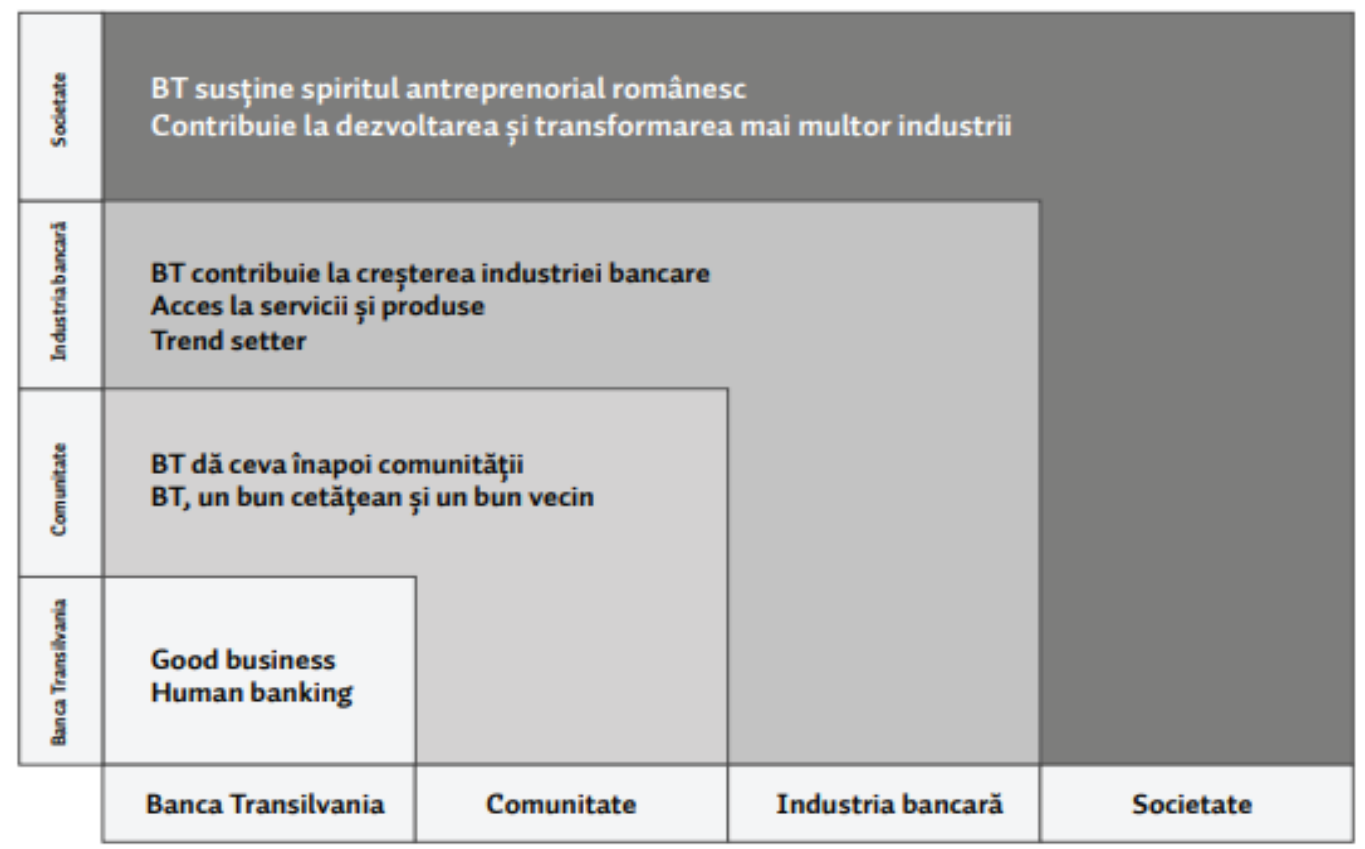

Figura 1. Politica CSR Banca Transilvania

Prin activitățile specifice CSR, Banca Transilvania urmărește îndeplinirea anumitor obiective cu caracter social sau de mediu. Printre acestea se numără:

- Să dovedească responsabilă în ceea ce privește relaţia cu mediul înconjurător;

- Solidaritate și suport;

- Susținerea diverselor proiecte/idei/cazuri sociale;

- Implicarea BT în viaţa comunităţii gazdă.

Beneficiarii acestor activități de responsabilitate socială pot fi persoane fizice, comunități, instituții ori autorități publice, persoane juridice fără scop lucrativ, din anumite domenii specifice.

Activitatea CSR a Băncii Transilvania este monitorizată şi evaluată, fiind determinate rezultate, eficiență după ROI (return of investment) sau ROO (return of objectives), beneficii aduse comunității, gestionarea corespunzătoare a proiectului, analize SWOT, încadrarea în bugetul stabilit etc.

\subsection{Analiza Patria Bank}

Cel de al patrulea raport CSR analizat aparține băncii Patria Bank. Raportul acesteia este împărțit 5 secțiuni: 1. Compania, 2. Materialitate Internă, 3. Clienții 4. Comunitatea și 5. Contextul.

În prima secțiune sunt prezentate, printre altele, istoricul entității, realizările din anul 2018 , informații referitoare la guvernanța corporativă, consiliul de administraţie, echipa managerială etc. Altfel spus, informații referitoare la management, acționari, strategia firmei și partenerii instituționali, creșterea durabilă/sustenabilă fiind unul din obiectivele cele mai importante ale băncii în cauză.

Analizând această secțiune se poate observa că sunt prezentate informaţii complete referitoare la serviciile oferite, la structura acționariatului, la performanțele financiare obținute și multe alte informații menite să asigure o raportare transparentă față de utilizatori. De asemenea sunt aduse la cunoștinţa utilizatorilor valorile, principiile, standardele și normele de conduită adoptate în cadrul companiei, preocuparea pentru eliminarea conflictelor de interese, lupta împotriva comportamentului anticoncurențial și adoptarea unor măsuri anticorupție. 
În secțiunea Clienți, sunt ilustrate anumite date cu privire la aceștia. Astfel, este menționat faptul că $50 \%$ din sucursalele Patria Bank sunt în mediul rural și stipulează grija avută pentru protecția datelor cu caracter personal. $\mathrm{O}$ altă preocupare a acestei bănci este incluziunea financiară, acordând finanțări producătorilor de mici dimensiuni din zone mai defavorizate și lansând diverse promoții pentru pensionari și pentru persoanele cu venituri sub 500 de lei.

Mai este menționată preocuparea pentru inovație și tehnologie, mai precis se pune accentul pe digitalizare, prin lansarea de diverse aplicații de internet banking și mobile banking, lansarea proiectului Cashback, aplicația Lead Generation etc.

Secțiunea a patra face referire la o serie de elemente care vor să ilustreze grija acestei bănci pentru dezvoltarea durabilă.

Sunt menționați numărul de angajați din, respectiv 840 de salariați activi, din care $70 \%$ femei, numărul de angajări şi numărul de concedieri din anul 2018, precum si raportul dintre salariile angajaților de sex masculin și cei de sex feminin. Se remarcă grija pentru diversitate a acestei bănci, asigurându-se că există un echilibru în procesul de selecție a candidaților, atât pe funcțiile de conducere, cât și în cele de execuție, care să asigure o componență suficient de diversificată în ceea ce privește vârsta, genul, educația și experiența profesională. Țintele propuse pentru asigurarea diversității:

- Selectarea de persoane de ambele genuri

- Selectarea unor persoane ale căror studii să acopere diferite domenii

- Selectarea de persoane a căror experiență să acopere diferite niveluri de conducere

Implicarea în comunitate se face simțită prin intermediul unor proiecte culturale, educaționale, sociale și de mediu.

Printre proiectele culturale susținute sunt editarea cărții Un alt cânt al lui Marte. Cântul iubirii, de Paolo Isotta și susținerea concertul extraordinar Iarna Magică.

În ceea ce privește proiectele educaționale, s-a remarcat contribuția la creșterea platformei malltaranesc.ro, sponsorizarea platformei redirectioneaza.ro (a, ce sprijină organizațiile neguvernamentale să strângă $2 \%$ din impozitul de profit) și implicarea în platforma \#patriasanatoasa.

Proiectele sociale și de mediu se realizează prin intermediul platformelor Patria Faptelor Bune și Patria, fiind realizate diverse acțiuni printre care Plantează în România, acțiuni în comunitățile locale (prin programul \#patriaresponsabilă0, campanii de donare de sânge, târguri caritabile.

În total, investițiile Patria Bank SA pentru comunitate s-au ridicat în anul 2019 la circa 30.000 de euro, iar impactul proiectelor în care ne-m implicat sau pe care le-am aproximativ 10.000 de persoane susținute în mod direct.

În secțiunea 5, Contextul, are loc identificarea impactului privind responsabilitatea clienților față de mediul înconjurător, compania clasifică activitățile acestora conform domeniului de activitate, fiindu-le clasificate activitatea astfel:

- Clienți clasa A: cu un impact negative puternic asupra mediului, nu vor fi creditați decât dacă au toate autorizațiile/ licențele pentru funcționarea în condiții legale.

- Clienți clasa B: cu un impact redus asupra mediului, vor fi supuși unui proces de monitorizare anuală.

- Clienți clasa C: impact minim asupra mediului, nu vor fi aplicate măsuri suplimentare.

\subsection{Analiză Banca Românească}

A cincea bancă analizată este Banca Românească. Aceasta prezintă pe site-ul instituției faptul că, în ciuda numelui, aparține de Banca Naţională a Greciei și faptul că aceasta este implicată în anumite proiecte de responsabilitate socială cu impact asupra comunității gazdă.

Este menționat pe site că sunt prezente standarde înalte în ceea ce privește responsabilitatea socială, prin conservarea și promovarea drepturilor omului, precum şi valorilor sociale, culturale și intelectuale ale comunităților aferente. Totodată, este adus în vedere grija pentru alinierea activităților CSR la interesele pe termen lung ale acționarilor. Valorile Băncii Românești sunt aliniate la cele ale grupului din care face parte, desfășurându-și activitatea cu: 
- $\quad$ Respectarea drepturilor omului;

- $\quad$ Grijă față de mediu;

- Contribuție socială;

- Contribuții la nivel cultural, artistic sau educaţional;

- Independență.

Acțiunile de responsabilitate socială vizează anumite direcții. O primă direcție este comunitatea, banca angajându-se să participe la diverse programe de solidaritate pentru grupurile defavorizate, prin donații, premii, burse etc.

O a două direcție este cultura, prin sprijinirea diverselor activități și evenimente culturale.

$\mathrm{O}$ a treia direcție este reprezentată de mediu, concretizată prin conservarea resurselor naturale, managementul efectiv al maculaturii și prin implementare unei politici de evaluarea a riscului de mediu în momentul acordării finanțării.

\subsection{Analiza Alpha Bank}

A șasea bancă studiată este Alpha Bank, care tratează raportul nonfinanciar ca o anexă la situațiile financiare clasice, fiind denumită declarație nefinanciară. Această nu prezintă o anumită structură, fiind înșirate o serie valori și principii de dezvoltare sustenabilă la care banca aderă. Este al doilea an în care aceasta redactează o declarație nefinanciară. Astfel, Alpha Bank își desfășoară activitatea cu grijă pentru protecția resurselor mediului înconjurător, cu gestionarea impactului acțiunilor sale la nivel social și prin susținerea dezvoltării generațiilor viitoare, prin unor metode şi atitudini sociale noi menite sa vină în sprijinul companiei și societăţii.

Eforturile în vederea dezvoltării sustenabile ale Alpha Bank sunt concretizate prin sprijinirea de proiecte în domenii precum educația, societatea, mediul, sportul, cultura. În anul 2018, Alpha Bank a implementat 32 de proiecte de răspundere socială corporativă.

\subsection{Analiza Unicredit Bank}

Pentru cea de a șaptea bancă analizată, Unicredit Bank, raportul de sustenabilitate este o parte componentă a situaţiilor anuale. De peste 11 ani UNicredit se implică în proiecte de educație financiara si antreprenoriala, inițiative comunitare si sociale, precum si evenimente de creativitate, design si cultura din Romania, cum ar Diploma (alături de The Institute, banca promovează absolvenți de facultate din toate disciplinele creative din Romania), Romanian Design Week, cel mai mare eveniment multi-disciplinar dedicat industriilor creative, Festivalul de Teatru de la Sibiu (unde banca se implica in sustinerea locatiei de la Fabrica de Cultura), Creative Mornings (seria de conferinte lunare pentru comunitatea creativa), The Power of Storytelling, Teach for Romania (banca este alaturi de Legiunea Straina a educatiei romanesti sustinand 3 profesori la scoala din Fundeni, Calarasi), a patra editie a Ghidului Antreprenorului Creativ 24/7 (o publicatie despre viata si munca antreprenorului inovator din Romania, realizat impreuna cu Decat o Revista), ZAIN (festivalul de design de la Cluj).

Unicredit Bank a fost implicată într-o multitudine de proiecte educaţionale (The Power of Storytelling, Creative Mornings Bucuresti, DIPLOMA etc.) sociale ((Asociaţia Faborisa, Asociaţia Colorează Viața și Asociația Merci Charity Boutique) și culturale (Festivalul International de Teatru de la Sibiu (FITS)).

\subsection{Analiza Garanti Bank}

A opta bancă analizată este Garanti Bank, care prezintă raportarea nefinanciară la o anexă a situațiilor financiare. În cadrul acesteia sunt ilustrate evaluarea materialităţii, principii pentru o guvernanță transparentă și responsabilă (politică anti-corupție, politică antifraudă, politică pentru combaterea spălării banilor etc.), investiții în angajaţi (egalitate de șanse, diversitatea etc.), grija pentru schimbările climatice și energia (responsabilitate față de mediu, administrarea apei, administrarea deșeurilor, administrarea energiei), politica de mediu și împrumuturile sociale, lanțul de aprovizionare, pionierat în finanțarea sustenabilă și contribuții sociale și de mediu. 
La contribuțiile sociale şi de mediu, Garanti Bank a avut mai multe direcții de acțiune. O primă direcție o reprezintă contribuțiile sociale și de mediu (în cei 20 de ani pe piața locală s-a implicat în proiecte de protejare a mediului și în proiecte care încurajează antreprenoriatul local, susţinerea de proiecte financiare și culturale).

Entitatea a mai fost preocupată de protejarea mediului înconjurător, prin proiecte ca - WWF Bonus Card, Recicleta sau Consiliului Român pentru Clădiri Verzi (RoGBC). Totodată aceasta monitorizează activitățile clienților ei pentru ca aceștia să nu pericliteze prin activitatea lor mediul înconjurător. De asemenea, Garanti Bank a susținut o multitudine de proiecte culturale, antreprenoriale și de educație financiară.

În finalul anexei, este stipulată ideea că activitatea băncii se dorește a fi în concordantă cu obiectivele dezvoltării sustenabile.

\section{Interpretarea datelor}

Principalele aspecte referitoare la rapoartele CSR pentru băncile analizate sunt prezentate în tabelul 7.

Tabelul 7: Sinteza datelor pentru rapoartele analizate

\begin{tabular}{|c|c|c|c|c|c|c|c|c|c|}
\hline & & $\begin{array}{c}\text { Raiffeisen } \\
\text { Bank }\end{array}$ & $\mathrm{BRD}$ & BT & $\begin{array}{l}\text { Patria } \\
\text { Bank }\end{array}$ & \begin{tabular}{|c|} 
Banca \\
Romanească
\end{tabular} & $\begin{array}{l}\text { Alpha } \\
\text { Bank }\end{array}$ & $\begin{array}{c}\text { Unicredit } \\
\text { Bank } \\
\end{array}$ & $\begin{array}{l}\text { Garanti } \\
\text { Bank }\end{array}$ \\
\hline \multirow[b]{3}{*}{ Structura raportului } & Număr pagini raport CSR & 132 & 4 & 3 & 87 & 5 & 7 & 2 & 18 \\
\hline & Număr secțiuni & 4 & 7 & 7 & 5 & 2 & 4 & 3 & 5 \\
\hline & Localizarea raportului & $\begin{array}{l}\text { Separat de } \\
\text { situațiile } \\
\text { financiare }\end{array}$ & $\begin{array}{l}\text { Parte } \\
\text { componentă } \\
\text { a Raportului } \\
\text { Administrat } \\
\text { orului }\end{array}$ & $\begin{array}{l}\text { Separat de } \\
\text { situațiile } \\
\text { financiare }\end{array}$ & $\begin{array}{l}\text { Separat de } \\
\text { situațiile } \\
\text { financiare }\end{array}$ & $\begin{array}{l}\text { Parte } \\
\text { componentă } \\
\text { a situațiilor } \\
\text { anuale }\end{array}$ & $\begin{array}{l}\text { Anexă la } \\
\text { situațiile } \\
\text { financiare }\end{array}$ & $\begin{array}{l}\text { Parte } \\
\text { component } \\
\text { ă a } \\
\text { situațiilor } \\
\text { anuale }\end{array}$ & $\begin{array}{l}\text { Anexă la } \\
\text { situațiile } \\
\text { financiare }\end{array}$ \\
\hline \multirow{3}{*}{ Protecția mediului } & $\begin{array}{c}\text { Proiecte/activități/inițiative/ } \\
\text { parteneriate efectuate în } \\
\text { scopul protecției mediului } \\
\text { inconjurător }\end{array}$ & $\begin{array}{l}\text { Sunt } \\
\text { menționate }\end{array}$ & $\begin{array}{l}\text { Sunt } \\
\text { menționate }\end{array}$ & $\begin{array}{l}\text { Sunt } \\
\text { menționate }\end{array}$ & $\begin{array}{l}\text { Sunt } \\
\text { menționate }\end{array}$ & $\begin{array}{l}\text { Sunt } \\
\text { menționate }\end{array}$ & $\begin{array}{l}\text { Sunt } \\
\text { menționate }\end{array}$ & $\begin{array}{l}\text { Nu este } \\
\text { menționat }\end{array}$ & $\begin{array}{l}\text { Sunt } \\
\text { menționate }\end{array}$ \\
\hline & $\begin{array}{c}\text { Performanţa băncii privind } \\
\text { protecţia mediului }\end{array}$ & $\begin{array}{l}\text { Este } \\
\text { menționat }\end{array}$ & $\begin{array}{l}\text { Este } \\
\text { menționat }\end{array}$ & $\begin{array}{l}\text { Nu este } \\
\text { menționat }\end{array}$ & $\begin{array}{l}\text { Este } \\
\text { menționat }\end{array}$ & $\begin{array}{l}\text { Nu este } \\
\text { mentionat }\end{array}$ & $\begin{array}{l}\text { Nu este } \\
\text { menționat }\end{array}$ & $\begin{array}{l}\text { Nu este } \\
\text { menționat }\end{array}$ & $\begin{array}{l}\text { Nu este } \\
\text { menționat }\end{array}$ \\
\hline & $\begin{array}{l}\text { Criterii de referitoare la } \\
\text { protecția mediului, în } \\
\text { momentul acordării de } \\
\text { finanțări }\end{array}$ & Prezente & Prezente & Absente & Prezente & Absente & Prezente & Absente & Absente \\
\hline \multirow{2}{*}{ Implicare socială } & Activități cu caracter social & $\begin{array}{l}\text { Sunt } \\
\text { menționate }\end{array}$ & $\begin{array}{l}\text { Sunt } \\
\text { menționate }\end{array}$ & $\begin{array}{l}\text { Sunt } \\
\text { menționate }\end{array}$ & $\begin{array}{l}\text { Sunt } \\
\text { menționate }\end{array}$ & $\begin{array}{l}\text { Sunt } \\
\text { menționate }\end{array}$ & $\begin{array}{l}\text { Sunt } \\
\text { menționate }\end{array}$ & $\begin{array}{l}\text { Sunt } \\
\text { menționate }\end{array}$ & $\begin{array}{l}\text { Sunt } \\
\text { menționate }\end{array}$ \\
\hline & Voluntariat & Menționat & Menționat & Menționat & Menționat & $\begin{array}{l}\text { Nu este } \\
\text { mentionat }\end{array}$ & Menționat & Menționat & Menționat \\
\hline \multirow{2}{*}{ Resurse umane } & $\begin{array}{l}\text { Activități de dezvoltare a } \\
\text { resursei umane }\end{array}$ & Menționat & Menționat & $\begin{array}{l}\text { Nu este } \\
\text { menționat }\end{array}$ & Menționat & Menționat & Menționat & $\begin{array}{l}\text { Nu este } \\
\text { menționat }\end{array}$ & Menționat \\
\hline & $\begin{array}{l}\text { Date referitoare la } \\
\text { egalitatea de șanse }\end{array}$ & Prezente & Absente & Absente & Prezente & Prezente & Prezente & Absente & Prezente \\
\hline \multirow[b]{2}{*}{ Conduita în afaceri } & Politici anti-corupție & Menționate & Menționate & $\begin{array}{l}\text { Nu este } \\
\text { mentionat }\end{array}$ & Menționat & Menționat & $\begin{array}{l}\text { Nu este } \\
\text { menționat }\end{array}$ & $\begin{array}{l}\text { Nu este } \\
\text { menționat }\end{array}$ & Menționat \\
\hline & Codul de etică & Existent & Existent & Inexistent & Existent & Existent & Inexistent & Inexistent & Existent \\
\hline
\end{tabular}

După cum se poate observa din tabelul anterior, datele prezentate în rapoartele CSR sunt relativ omogene de la o bancă la alta, dar diferă modul de prezentare și forma prin care acestea sunt prezentate utilizatorilor, ceea ce creează dificultăți în ceea ce privește comparabilitatea acestor date.

Se poate observa că unele bănci întocmesc rapoarte de peste 100 de pagini, în timp ce altele se rezumă la a prezenta informațiile aferente performanței nonfinanciare în 2-3 pagini. De asemenea, unele din aceste bănci prezintă aceste rapoarte separat de raportările financiare, altele le includ efectiv în raportările financiare, în timp ce altele le anexează la situațiile financiare anuale

Toate băncile analizate prezintă date referitoare la mediu și implicarea socială pe care acestea o au. Problema este că modul de prezentare nu este omogen de la o bancă la alta, fiind diferit volumul de informații prezentat, dar și conținutul informațiilor efectiv prezentate. De exemplu, 
Raiffeisen Bank prezintă cu cifre activitățile desfăşurate în scopul protecției mediului, în timp ce Banca Transilvania se rezumă la a prezenta doar anumite programe desfășurate de-a lungul timpul în scopul protecției mediului. Apare astfel problema comparabilității între informațiile prezentate.

Se mai poate menționa că rapoartele nonfinanciare diferă de la o bancă la alta prin faptul că unele bănci aleg să includă în rapoartele nefinanciare date referitoare la resursele umane și conduita de afaceri, în timp ce alte bănci aleg să prezinte aceste informații în alte elemente ale raportării financiare clasice. Apare din nou o eterogenitate la nivelul raportării nefinanciare.

\section{Concluzii}

Performanțele nefinanciare ale băncilor nu pot fi comparate, întrucât fiecare dintre ele aplică un alt standard de raportare nefinanciară, după cum consideră de cuviință. Este lesne de dedus faptul că, în domeniul raportării nonfinanciare, este necesară abordarea unui cadru unitar de raportare pentru toate entitățile din cadrul aceluiași sector de activitate dar și pentru unități aflate în sectoare diferite de activitate. Fiecare entitate alege ce informații să prezinte după cum consideră de cuviință, în funcție de propriile necesități, volumul informațiilor oferite fiind diferit de la unitate bancară la alta.

Spre deosebire de raportarea financiară, unde toate unităţile întocmesc situații anuale unitare, care permit comparabilitatea și calitatea informaţiilor furnizate, în domeniul nefinanciar se remarcă lipsa unui standard unitar, fapt care constituie un impediment în informarea completă și transparentă a utilizatorilor informațiilor furnizate de unitățile economice, astfel încât aceștia să ia decizii în deplină cunoștință de cauză

Conform literaturii actuale, se observă o corelaţie directă între calitatea informațiilor publicate în rapoartele de sustenabilitate și rata rentabilităţii economice, corelație explicată de faptul că toate aceste activități de natură nefinanciară duc la o creștere a brandului unei entități economice, din punctul de vedere al clienților de pe piață.

\section{Bibliografie}

- Abeysekera, I. (2013). A template for integrated reporting, Journal of Intellectual Capital, 14(2), 227-245.

- Cadez, S., Czerny, A. (2016). Climate change mitigation strategies in carbon-intensive firms. Journal of Cleaner Production, 112, 4132-4143.

- Cheng, M., Green, W., Conradie, P., Konishi, N., Romi, A. (2014). The International Integrated Reporting Framework: Key Issues and Future Research Opportunities. Journal of International Financial Management \& Accounting, 25(1), 90-119.

- Churet, C., Eccles, R. (2014). Integrated Reporting, Quality of Management, and Financial Performance. Journal of Applied Corporate Finance, 26(1), 56-64.

- Dumay, J., Bernardi, C., Guthrie, J., Demartini, P. (2016). Integrated reporting: A structured literature review. Accounting Forum. 40(3), 166-185.

- Eccles, R. Serafeim, (2014). Corporate and Integrated Reporting: A Functional Perspective. SSRN Electronic Journal. DOI: 10.2139/ssrn.2388716.

- Galant, A., Cadez, S. (2017). Corporate social responsibility and financial performance relationship: A review of measurement approaches. Economic Research-Ekonomska Istraživanja, 30(1), 676-693.

- García-Sánchez, I.M., Rodríguez-Ariza, L., Frías-Aceituno, J.V. (2013). The cultural systems and integrated reporting. International Business Review, 22(5), 828-838.

- Jensen, J., Berg, N. (2012). Determinants of Traditional Sustainability Reporting Versus Integrated Reporting. An Institutionalist Approach. Business Strategy and the Environment. 21(5), 299-316.

- Pavlpoulos, A., Magnis, C., Iatridis, G.E. (2017). Integrated Reporting: Is it the Last Piece of the Accounting Disclosure Puzzle? .Journal of Multinational Financial Management, 41(C), 23-46 
- Stubbs, W., Higgins, C. (2014). Integrated Reporting and internal mechanisms of change. Accounting, Auditing \& Accountability Journal, 27(7), 1068-1089.

- Velte, P. (2017). Does ESG performance have an impact on financial performance? Evidence from Germany. Journal of Global Responsibility, 8(2), 169-178

- Villiers, C., Rinaldi, L., Unerman, J. (2014). Integrated Reporting: Insights, gaps and an agenda for future research. Accounting, Auditing and Accountability Journal. 27(7), 10421067.

- Weber, M. (2008). The business case for corporate social responsibility: A company-level measurement approach for CSR. European Management Journal, 26, 247-261.

- Zhou, S. Simnett, R., Green, W. (2017). Does Integrated Reporting Matter to the Capital Market? Abacus, 53(1), 94-132.

- https://www.raiffeisen.ro/

- https://www.brd.ro/

- https://www.alphabank.ro/

- https://www.bancatransilvania.ro/

- https://www.banca-romaneasca.ro/

- https://www.unicredit.ro/ro/persoane-fizice.html

- https://www.patriabank.ro/

- https://www.garantibbva.ro/ro/ 



\title{
Cap. 12. SINTEZĂ A LITERATURII DE SPECIALITATE ÎN DOMENIUL FRAUDEI ECONOMICE
}

\author{
Mădălin-Mihai Moțoc \\ Universitatea „Alexandru Ioan Cuza” din Iaşi, Şcoala Doctorală de Economie şi Administrarea Afacerilor, \\ Iaşi,România, madalin.mm995@gmail.com
}

\begin{abstract}
Purpose: The aim of this paper is to make a brief review of the main bibliographical references that refer to economic fraud, which appeared either as an effect of an inefficient managerial policy, or for obtaining undue benefits through tools such as embezzlement, money laundering or illegal contracts.

Design/methodology/approach: This paper uses content analysis to determine, through research or the literature, the scientific references that refers to economic fraud and its effects. The research is based on the review of the literature in the field of fraud by searching for keywords (fraud risk, insolvency, bankrupcty, $z$ score insolvency risk indicator). The number of articles that are the subject of the study is 268 .

Findings: Through the content analysis on the main bibliographical landmarks in the subject of fraud, we found the main causes underlying the need of fraud, with reference to both exogenous and endogenous causes. Originality/value added: This research synthesizes in a constructive way but also criticisez the opinions of the most representative researchers and fraud experts, compressing the essence of the aspects related to economic fraud in the entities aimed to obtain profit.
\end{abstract}

Keywords: economic fraud, embezzlement, money laundering, profit, reasonable opinion (of the audit companies).

\section{Introducere}

Studierea ad litteram a articolelor și referințelor științifice referitoare la frauda economică în perioada 2000-2018 au arătat o creștere exponențială a numărului publicațiilor pe parcursul anilor 2008-2012, anii de regres ai crizei economice.

Criza economică a reprezentat un subiect îndelung dezbătut încă de la începutul anilor 2000, perioadă în care, prin prisma modificărilor de ordin legislativ din zona Statelor Unite ale Americii, pe piaţa economiilor de capital și-au făcut apariția instrumentele financiare derivate ca o nouă metodă de tranzacționare pe bursele de valori. Cu toate că aceste noi instrumente financiare au fost îndelung criticate ca tranzacționând o valoare fictivă, plus-valoarea făcându-se în speță prin transferul dreptului de creanţă a unei datorii deja existente, complicitatea agențiilor de rating, a auditorilor financiari, agenților de pe bursa de valori și a principalelor agenții bancare din Statele Unite ale Americii au creat cea mai mare criză economică globală, după cea din perioada 19291933 (Biscotti, 2012).

Finele anului 2013 aduc și primele semnale de „dezmorțire” a economiei, după o perioadă în care lipsa de capital, scăderea dramatică a pieței de capital, lipsa producției, a cererii sau a ofertei au condus către cele mai răsunătoare insolvențe din ultimii 100 de ani. Un caz reprezentativ este cel al Lehman Brothers, care, cu toate că eșecul economic era iminent, aceștia au continuat să tranzacționeze o serie de instrumente financiare derivate fără acoperire economică, fără niciun suport sau modalitate de asigurare.

Prezentul articol prezintă o analiză de conținut care are în vedere defalcarea numărului de articole publicate în literatura de specialitate în perioade de câte cinci ani calendaristici, ținând seama de perioadele de interes şi de impact ante şi post criză.

Articolul de specialitate continuă cu prezentarea unor implicaţii ale crizei economice globale la nivelul României, urmate de o serie de concluzii asupra implicaţiei crizei economice globale în economiile celor mai dezvoltate state din punct de vedere economic. 


\section{Analiză de conținut}

Analiza principalelor repere bibliografice referitoare la frauda economică prin enumerarea, cercetarea și interpretarea conținutului acestora reprezintă etapa de debut a oricărui tânăr cercetător care dorește aprofundarea și crearea de plus-valoare prin contribuția proprie în domeniul ales spre cercetare. Astfel, stadiul cunoașterii în domeniu este principala cărămidă de temelie în cercetarea științifică.

Baza de date folosită în stabilirea reperelor de urmat în analiza crizei economice globale a fost extrasă din revistele SpringerLink și ProQuest, având ca stabilite ca și criterii de selecție cuvintele cheie fraudă economică, spălare de bani, profit, opinie rezonabilă a companiilor de audit și delapidare, împreună cu un filtru aplicat asupra perioadei de după anii 2000 și o analiză a abstractului, pentru a verifica dacă articolul corespunde tratamentului fraudei economice.

\subsection{Analiză de conținut perioada 2000-2004}

Perioada 2000-2004 nu a reprezentat un ecart temporal semnificativ în studierea fraudelor economice, dat fiind faptul că, în afară de cazul Enron, nu au fost depistate cazuri de fraudă la un nivel atât de înalt, Enron fiind însă doar excepția care confirma regula.

Astfel, analiza de conţinut a perioadei 2000-2004 au fost găsite un număr de 5 articole de specialitate pe tematica fraudei economice.

Interesul scăzut al studierii acestui fenomen s-a datorat unei economii în continuă dezvoltare care nu crea premisele unui eșec economic, creșterea lentă și stabilă a economiei la nivel global și lipsa studiilor de caz reprezentative pentru studiul fraudei. Cu toate că acest fenomen se petrecea zi de zi la nivel individual/local, studiul acestuia rămânea doar la nivel teoretic al unui aspect ,care s-ar putea întâmpla” (Bacon \& Love, 2001).

\subsection{Analiză de conținut 2004-2008}

În perioada 2004-2008, în literatura de specialitate s-au făcut remarcate un număr de 23 de referințe științifice, fapt ce arată un interes nu tocmai crescut în legătură cu fraudele de natură economică. Interesul scăzut poate fi justificat de perioada de boom economic la nivel global, indicatorii economico-financiari care atingeau valori record, o eră în care digitalizarea era în plină expansiune iar tranzacțiile cu instrumente financiare derivate promitea îmbogățirea peste noapte a tuturor participanților la procesul economic (agenți bursieri, bănci, agenții de rating, cumpărători ai acțiunilor).

$\mathrm{Cu}$ toate că părerile economiștilor în legătură cu justețea tranzacțiilor era extrem de rezervată (invocând principiile contabile ca prudența și prevalența economicului asupra juridicului), spusele acestora păreau că nu se adeveresc. Stimulate nu doar de modificările legislative care încurajau tranzacționarea drepturilor de creanță de la o terță parte la alta, cât și de agențiile de rating și membrii Big Four, piețele de capital s-au dezvoltat într-un timp foarte scurt, ajungând coloși economici cu operațiuni de sute de miliarde de dolari, conform Siegfried Utzig, în lucrarea The financial crisis and the Regulation of Credit Rating Agencies: A european Banking perspective (Utzig, 2010).

În lucrarea „The comparative law and economics of pure economic loss” a cercetătorilor Francesco Parisi, Vernon Valentine Palmer și Mauro Bussani publicată în anul 2007 se creează premisele unui eșec economic bazat pe o structură legislativă neconformă cu realitatea economică, în care se oferă sustenabilitate unei piețe de capital fără o valoare reală în bunuri și servicii, fiind un mediu bazat pe consumerism și datorii pe termen scurt respectiv termen lung. Autorii dezbat politica populistă practicată de biroul prezidențial de la momentul actual, numirile politice a unor pseudo-experți și implicaţia pe care o poate avea eșecul economic, în eventualitatea în care acesta apare, neglijența și legiferarea unui fenomen fără înțelegerea pe deplin a modalităților de funcționare și implicațiile pe care acesta le are (Parisi, 2007).

În tratamentul modalităților de detecție a riscului de faliment, în lucrarea „Bankruptcy prediction in banks and firms via statistical and intelligent techniques" (P. Ravi Kumar, 2007) este 
pusă la îndoială modalitatea clasică de depistare a riscului de faliment, cercetarea fiind concepută într-o manieră critică între anii 1968-2005. Cercetarea cuantifică erorile pe care formulele de calcul clasice le redau, fără a lua în calcul un cumul de factori economici, sociali și culturali apăruți ca urmare a globalizării și interconectării economiilor diferitelor state. Cercetarea relevă de asemenea și faptul că modificările legislative de natură constituţională și la nivelul organismelor naționale și internaționale au implicații adânci în jurisprudența entităților creatoare de profit, depistarea riscului de faliment în maniera clasică nemaifiind un indicator clar de corecție, cu atât mai puțin în cazul erorilor/fraudelor.

\subsection{Analiză de conținut 2008-2012}

Cercetarea analizei de conținut cuprinsă între anii 2008 și 2012 a evidențiat 73 de referințe ştiințifice concludente în domeniul fraudei economice. Creșterea exponențială a publicaţiilor în perioada de referință se poate explica prin apariția crizei economice globale și creșterea exponențială a numărului de fraude economice comise în această perioadă, fiind cunoscut faptul că însăși criza economică a apărut ca urmare a unui cumul de factori de natură frauduloasă.

In lucrarea „Cycles in crime and economy: Leading, Lagging and Coincident Behaviors”, Claudio Detotto și Eduardo Otranto tratează corespondența dintre activitățile economice cu caracter ilicit și ciclul de business folosind modelul factorului dinamic (Detotto, 2012). În opinia autorilor, activităţile ilicite din cadrul unei entități economice fac parte dintr-un set de componente ciclice care există și se perpetuează în companiile cu capital privat. Aceștia tratează printr-un studiu de caz legătura dintre insolvența frauduloasă, falimentul și incapacitatea de plată pe de o parte și componentele ciclului de business pe de altă parte, arătând prin modelul econometric al factorului dinamic legătura dintre nevoia de fraudă și ciclul de viață al unei entități economice.

Catalina Frade, în lucrarea acesteia „Bankruptcy, stigma and rehabilitation” pleacă de la premisa falimentului ca „semnal al imoralității și un comportament criminal și păcătos” (Frade, 2012). Cercetătorul tratează insolvența și falimentul încă de la Legile Hinduse până în prezent, arătând slăbiciunile sistemului de insolvență din cele mai vechi timpuri până în prezent. Problema falimentului ajunge în perioada actuală ca o problemă reală nu doar pentru persoana debitorului ci şi pentru familia, comunitatea şi țara/regiunea din care acesta face parte. Se ridică astfel o problemă reală care constă în interesul real al intrării în insolvență și repercusiunile pe care o astfel de decizie le are într-o anumită economie şi într-o anumită regiune.

Criza economică globală din perioada 2008-2012 este considerată de cercetătorii și experţii economici ca Ben Bernanke, economist la Rezerva Federală din America, Jeffrey Shafer, economist la Trezoreria Americană și Jack Rasmus, cercetător în domeniul economic la Universitatea Saint Mary din California) ca fiind cea mai gravă criză economică din timpul omenirii, scoțând la iveală toate acțiunile frauduloase care au ca scop acumularea unui profit întrun timp cât mai scurt, arătând ,de ce sunt în stare oamenii pentru bani, care nu mai sunt un instrument economic ci un etalon social” (Hellwig, 2009).

\subsection{Analiză de conținut perioada 2013 - Prezent}

În perioada de referință 2013 - Prezent, în literatura de specialitate referințele științifice referitoare la operațiunile de fraudă în insolvență și faliment și-au păstrat gradul de creștere exponențială, cercetarea concluzionând un număr de 164 de articole și referințe bibliografice.

Creșterea într-un ritm foarte alert a numărului de publicații editoriale apărute poate fi explicată prin interesul foarte crescut a eșecului care a cauzat criza economică globală pe de o parte, dar și acapararea publicațiilor editoriale cu articole de referință şi interes în acest domeniu, fiind cunoscut faptul că publicarea într-un jurnal ISI cu factor de impact poate dura până la 2 ani. Așadar, există posibilitatea ca o parte din articolele de specialitate incluse în perioada 2013 - prezent să aibă ca perioadă de finalizare propriu-zisă a articolului tot perioada 2008-2012, însă din cauza ciclului procedural pe care trebuie să îl respecte o publicație editorială, acesta să fie publicat în perioada la care se face acum referire. 
În lucrarea „Integrity of financial information as a determinant of the outcome of a bankruptcy procedure", cercetătorii Domenico Campa și Maria Minano tratează legătura cauzală dintre modul de prezentare a situațiilor financiare anuale și procedura de reorganizare/insolvență. Prin studiul empiric efectuat pe 2064 de entități economice spaniole aflate atât în insolvență, cât și în faliment, cercetătorii conchid faptul că în entităţile care se aflau fie în procedura de reorganizare, fie în insolvență ori aveau să își declare insolvența în exercițiul financiar următor, situațiile financiare anuale erau mai mult sau mai puțin manipulate, în scopul fie a creșterii datoriilor, fie a diminuării veniturilor, pentru a crea premisele unei entități aflate în dificultate și a evidenția intrarea acesteia în regres (Campa\& Camacho Miñano, 2014).

Ellen Tobback, Tony Bellotty și Julie Moeyersoms încearcă, în lucrarea „Bankruptcy prediction for SMEs using relational data", să alcătuiască un model al riscului de faliment preluat de la marile corporații industriale, adaptat după cerințele și indicatorii economico-financiari disponibili entităților mici și mijlocii, plecând de la premisa faptului că întreprinderile mici și mijlocii sunt cele mai afectate în perioadele de regres economic, fiind și cele mai predispuse riscului de faliment (Tobback, 2017).

Efectele crizei economice se simt până astăzi, iar importanța tratării obiective și profesioniste a cauzei și a efectelor este imperios necesară pentru a înțelege importanța deciziilor manageriale de bun augur și tratamentul care se impune în cazul unui management deficitar.

\section{Implicații}

Analiza de conținut a perioadei 2000 - prezent a relevat o continuă creștere a interesului pentru domeniul fraudei în operațiunile economice ale întreprinderilor comerciale. Creșterea interesului se poate pune pe seama atât a prevederilor legislative promulgate ante-criză, cât și a crizei economice în sine, perioadă care a scos la iveală toate modalitățile de fraudă, folosite sau nefolosite în trecutul nostru comercial.

La nivelul României, criza economică a avut cel mai ridicat impact nefavorabil din tot blocul estic din pricina consumerismului excesiv promovat de societățile de finanțare bancară și nebancară, marii retaileri locali și dorința unei vieți mai bune, efect al unei mentalităti postcomuniste. Gradul de îndatorare al persoanelor angajate în credite bancare și nebancare ajungând chiar și la $150 \%$, creșterea artificială a veniturilor declarate și excesele de natură monetară achiziții nejustificate (date de lipsa unei educații financiare a românilor) au făcut ca perioada 20082013 să fie una a celei mai ridicate valori a șomajului structural, fricțional și de discontinuitate, cu efecte în scăderea valorilor de piață a bunurilor mobile și imobile, lipsa de lichiditătii în piață și scăderea drastică a nivelului de trai la nivel individual/familial.

La nivel european, cel mai afectat stat (de aparitiia crizei economice) a fost Letonia, din pricina creșterii nejustificate într-un timp foarte scurt a salariului minim pe economie, de la 128 la 227 euro/lună într-un ecart temporal de 36 de luni. Pe de altă parte, cel mai puțin afectat stat de apariția crizei economice a fost Suedia, care, coincidență sau nu, nu are un grad minim de salarizare (Kumar, 2007).

Criza economică globală nu a fost un eveniment petrecut subit, nu a fost neaşteptat sau ireparabil. Aceasta este doar un efect al rezoluțiilor legislative adoptate la începutul anilor 2000, a crearea unor grupuri de interese și a dorinței de acumulare a capitalului financiar într-un timp cât mai scurt, ca parte a definiției generice de fraudă.

\section{Concluzii}

Creșterea exponențială a referințelor bibliografice pe tematica fraudei în perioada analizată a fost în măsură să aducă plus-valoare de cercetare în domeniul fraudei, fiind în măsură să explice atât modalitățile convenționale şi neconvenționale de realizare a fraudelor cât și motivația intrinsecă și extrinsecă din spatele unor astfel de operațiuni ilicite.

În Statele Unite ale Americii şi în blocul vestic al Uniunii Europene măsurile de regresie propuse de cei mai importanți cercetători științifici au avut un impact semnificativ în următoarele 
măsuri de austeritate concretizate în texte de lege, arătând pe deplin impactul studiului academic asupra realității economice actuale. Se dovedește astfel faptul că studiul academic reprezintă un studiu reprezentativ pentru domeniul de business actual, în ciuda criticilor și miturilor legate de faptul că mediul academic promovează o realitate economică ideală, imposibil de atins și că „fabulează” (Tajti, 2017).

Efectele crizei economice globale au fost diminuate în Uniunea Europeană prin existența monedei unice la nivelul blocului comunitar (moneda euro) care a mai redus din constrângerile impuse la nivel global prin diminuarea valorii de piață a bunurilor mobile și imobile și căderea rapidă a sectorului financiar şi bancar însă puterea de cumpărare a cetăţenilor apartenenţi ai monedei euro a fost conservată, efectele fiind din acest punct de vedere limitate, într-o anumită măsură (Francesco, 2007). Interesul în creștere privind frauda economică se poate observa și din Figura numărul 1.

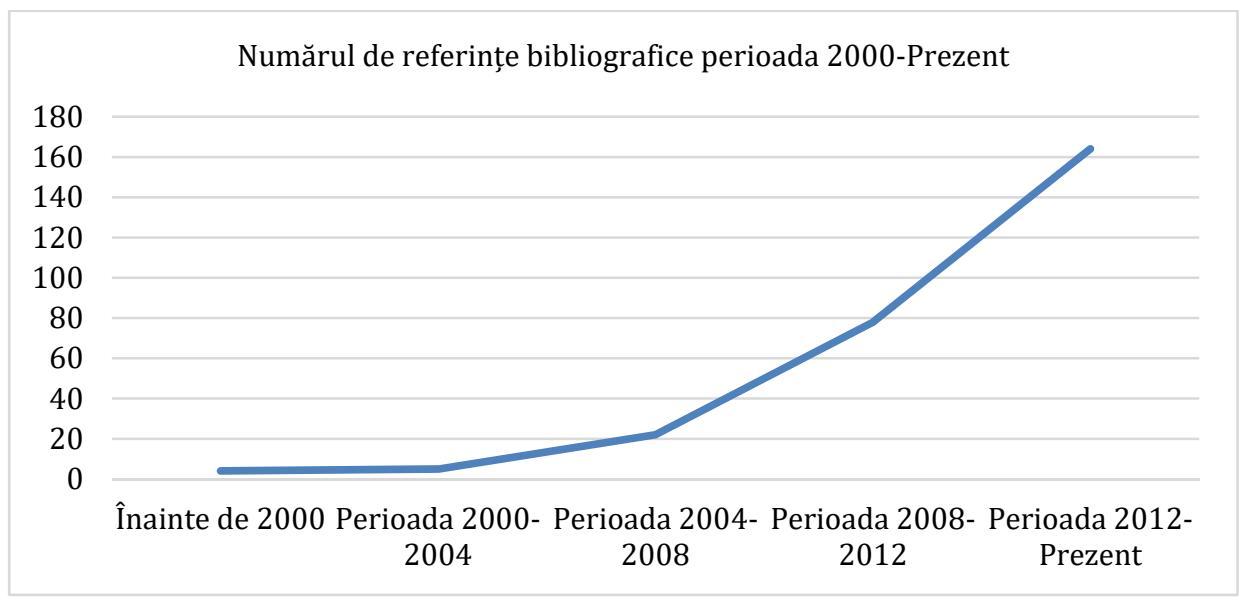

Figura nr. 1: Numărul de referințe bibliografice perioada 2000 - Prezent Sursa: prelucrare proprie

Conform Figurii numărul 1, se poate observa un trend ascendent al numărului de referințe științifice publicate ce au ca subiect frauda economică, evaziunea fiscală, spălarea de bani și delapidarea, acestea apărând ca urmare a modificării normelor legislative cu privire la listarea la bursă a instrumentelor financiare derivate și apariția crizei economice.

Trendul se păstrează crescător și după redresarea economică, referințele apărute ulterior fie detaliind o serie de procedee ilicite petrecute în trecut, fie alcătuind scenarii ale unei viitoare crize economice.

\section{Bibliografie}

- Bacon, D., Love, J. (2001). When good things happen to bad people: Practical aspects of Holding Directors and Managers of Insolvent Corporations Accountable, Journal of Bankruptcy Low \& Practice, 10, 185-186.

- Biscotti, C. (2012). Insolvency? 99\% is a fraud, Fundamina - University of Milan, Italy, 17, $1-13$.

- Campa, D., Camacho Miñano, M. (2014). Integrity of financial information as a determinant of the outcome of a bankruptcy procedure, International Review of Law and Economics, 37, 76-85.

- Detotto, C., Otranto E. (2012). Cycles in crime and economy: Leading, Lagging and coincident Behaviors, Journal of Quantitative Criminology, 28(2), 295-317. 
- Frade, C. (2012). Bankruptcy, stigma and rehabilitation. ERA Forum 13(1), 45-57. SpringerVerlag. DOI 10.1007/s12027-012-0249-9.

- Hellwig, M. (2009). Systemic risk in the financial sector: An analysis of the subprimemortgage financial crisis, De Economist, 157(2), 129-207.

- $\quad$ Parisi, F., Palmer, V. V., \& Bussani, M. (2007). The comparative law and economics of pure economic loss. International Review of Law and Economics, 27(1), 29-48.

- $\quad$ Ravi Kumar, P., Ravi, V. (2007). Bankruptcy prediction in banks and firms via statistical and intelligent techniques, European Journal of Operational Research, 180(1), 1-28.

- Tajti, T. (2017). Bankruptcy stigma and the second chance policy: the impact of bankruptcy stigma on business restructurings in China, Europe and United States, Journal of China-EU Law, 6, 1-31.

- Tobback, E., Bellotti, T., Moeyersoms J., Stankova M., Martens, D. (2017). Bankruptcy prediction for SMEs using relational data, Decision Support System, 102, 69-81.

- Utzig, S. (2010). The financial crisis and the Regulation of Credit Rating Agencies: A european Banking perspective, ADBI Working Paper Series, 188, 1-20. 


\section{Partea a III-a. Piaţa muncii şi managementul resurselor umane}





\title{
Cap. 13. VOLUNTEERISM PRACTICES - A SUSTAINABILITY FACTOR IN COMMUNITY DEVELOPMENT PROGRAMS
}

\author{
Magdalena Cămănaru \\ Alexandru Ioan Cuza University, Doctoral School of Economics and Business Administration, Iasi, \\ Romania,magda.camanaru@gmail.com
}

\begin{abstract}
Our research proposes to evaluate the role of volunteerism as a practice that contributes to the sustainable development of communities, including in the underdeveloped ones. An overview on studies performed on volunteering practices and programs in other countries (USA, Australia, Kenya, Mozambique, Nepal, and Philippines), along with key findings that apply to the European context was made. The premises of the main discussion theme started from The National Strategy regarding Social Inclusion and Reduction of Poverty (2014 - 2020) of the Romanian Government, which talks about the understaffed social services existent at the rural community level. The research focused on the contribution that volunteers from Community Consultative Councils have in the child protection sector and promotion of children's rights, as preventive strategies for social services, by analysing program reports from a community development program, over a 10 years period. These structures are described in Law 272/2004, as having a consultative role nearby the Local Councils and Mayor's Offices, a non-juridical status, being non-governmental, and implementing social activities at the local level, based on volunteerism. Relevant literature review and a case study on the work done by a Romanian NGO in relation with Community Consultative Councils have been the major elements of the research methodology used. The findings of our case study were consistent with others: the dialogue and partnership with local authorities and social work public services, specialized training and increased awareness on the benefits of volunteerism are the main variables involved and constitute the basis of a functional identification, reporting and referring mechanism for child protection cases. On a longer term, this contributes to the development of sustainable community prevention services, which are so important and needed at the level of rural communities in Romania.
\end{abstract}

Keywords: volunteerism, prevention, social services, local authorities, community development.

\section{Introduction}

"Volunteerism is a fundamental element of the spirit and human condition." (Burger et al, 2014, p.10) and, we might add, a topic which could be approached easily or scientifically, for the larger public or for a more knowledgeable one, for whom volunteerism is no longer just an activity for the spare time.

While at the global and European level the preoccupation to increase the number of persons who are involved regularly or occasionally in volunteer-based activities has overcome the stage of declarations, purely theoretical strategies and initiatives, and already has a certain history of intentionality and discussions brought from the civil society area on the public agenda of international bodies and governments, in Romania this topic did not gain the significance which would determine its inclusion, in an active and determined manner, into a well - articulated strategy and action plan in which all actors - public, private and civil society, would play their wellestablished and agreed roles.

The last Global Report on Happiness underlines the connection between happiness and community, stating that volunteerism is a consequence of pro-social behaviour (Helliwell, Layard, Sachs, 2019, p.9). Volunteerism is a predictor for happiness, which is regarded as a wellbeing state, the direct link, in a positive sense, between volunteerism and wellbeing being a universal, transcultural one, in both rich and poor countries (Helliwell, Layard, Sachs, 2019, p.72). In other words, as the report says, adults involved in volunteer activities have a better quality of life than the ones who do not volunteer, registering smaller rates of depression and a better health. The results of surveys applied on a global scale are not validated by experimental proofs, i.e. "the current research 
provides evidence for a powerful association between formal volunteerism and subjective wellbeing, through extended correlational questionnaires, but little evidence is being presented to confirm the existence of causal relation." (Helliwell, Layard, Sachs, 2019, p.74). In a country ranking made based on the percentage of respondents in each country, who have reported they donated for a cause/ charitable organization or did volunteering, over the past month, Romania ranks under the country average. With regards to donations made by a country's population, Romania registered $21.6 \%$, the country average being $29.2 \%$. In terms of $\%$ of population involved in volunteerism, Romania recorded $6.7 \%$, while the country average was $19.7 \%$ (Helliwell, Layard, Sachs, 2019, p.83).

At the European level, the European Commission Eurobarometer 75.2, entitled Volunteerism and Intergenerational Solidarity offered useful, relevant and valid comparative statistics regarding the EU member state and represents, together with the studies regarding volunteerism movement in each country (and the Country Reports) the most important research documents on volunteerism. The Eurobarometer from November 2010 showed that in EU, the involvement average was 30\%, with 13 states ranking over this average. Romania is under the European average, with a population involvement rate of $20 \%$, which places our country among EU states with a low level of involvement in volunteer - based activities (European Commission, 2011).

The data we have available regarding the volunteerism development level in Romania, the management of volunteers and the social and economic effects of volunteerism in our country have been provided by representatives of civil society, through Pro Vobis Association, The Federation of NGOs which work with volunteers, called VOLUM Federation and the Civil Society Development Foundation (CSDF). VOLUM Federation, with 24 founding NGOs and over 80 member NGOs from all over the country (founded in April 2016), has as a mission "the creation of infrastructure for volunteerism in Romania, putting volunteerism on the public agenda and influencing public policies in the area of volunteerism" (VOLUM Federation, 2016). VOLUM Federation, which is involved in advocacy initiatives in order to develop the volunteerism movement in Romania, has published a series of practical guides on volunteer management and measurement of social and economic effects of volunteerism, as a result of research studies and pilot projects, funded by EU or European Economic Space (EES). These have been accompanied by Position Papers useful for all NGOs which have developed the volunteer component (VOLUM Federation, 2016).

In 2010, a report from CSDF stated that active NGOs are the ones which use volunteerism on a large scale, over $90 \%$ out of the 21,000 active NGOs in Romania saying they involve volunteers in their activities and $68 \%$ of them saying they have no working contract based employees and they function only volunteer - based (CSDF, 2010).

An important step in documenting the current article was the legislation study of laws regarding volunteerism in Romania, starting with Law 195/2001, with its subsequent changes and up to Law 78/ 2014, which came into act in October 2016 (with all the subsequent changes).

CSDF provided special chapters on volunteerism study, in their reports from 2010 and 2017, in close connection with the development of NGO sector in Romania. The data from their last report showed that Moldova is before other regions, on the percentage of people who did volunteerism at least once for church or community (38\%), the rural is before the urban (34\% compared to $23 \%$ ) and men are before women (34\% compared to $23 \%$ ) (FDSC, 2017). These data contradict the studies and researches from other countries and the hypothesis according to which the higher the wellbeing level, the higher the percentage of people who get involved in volunteerbased activities, knowing that Moldova Region (North - East Region) is the poorest region of our country.

It is worth mentioning that the study of literature review, so far, shows there are no representative research studies regarding volunteerism in rural Romania, particularly focused on determining (i.e. measuring) the social and economic impact/ effects of rural volunteerism, using the contribution of social and economic capital of volunteer - based activities approach. 
The article is structured in six sections, starting with an Introduction section. It then goes through the research methodology, the discussions and results of the research and then presents the actual case study, ends with the conclusions and points to the scientific articles and studies used as references for the current article.

\section{Research Methodology}

A research study on social and economic impact of volunteerism in rural Romania cannot be made without a proper exploration of data and information from other scientific studies and researches in Romania and in other countries worldwide, which had similar or interrelated objectives. Thus, the current article used literature review addressing mainly the issue of rural volunteerism and the correlation between rural volunteerism and sustainability within the practice of community development programs. The case study includes an analysis of a form of volunteerism (Community Consultative Structures) identified within a community development program in Romania, over a period of more than 10 years, and goes through major aspects, concepts and conclusions regarding volunteerism, used as a practice in rural areas, as part of longterm community development programs, projects or initiatives, carried on by non-governmental organizations (NGOs). NGOs take over the management responsibilities regarding volunteering activities, which have as final goal the provision of services (educational, social, etc.) to vulnerable categories in the community. An analysis of scientific literature revealed that someone needs to take responsibility over the management of volunteer groups when dealing with social, educational or problems of other nature in a rural community, mainly in vulnerable ones, if we want to increase awareness around volunteerism as a practice in development programs, in relation with community members and if the sustainability of our interventions is of major focus. The efforts of measuring the contribution of social and economic capital brought by volunteerism in the community are a substantial part of these attempts.

It is why, following the literature review method we have analysed a case study which has a model of working with volunteers from rural communities in Vaslui County, at the centre. This model belongs to an international NGO, with over 30 years of activity and experience in Romania, in the work of transforming poor communities, through long-term development programs $(10-15$ years).

The study of scientific literature and the case study in particular, emphasized the fact that in the absence of a more intentional approach of sustainable development in rural communities, with the goal of catalysing community members as volunteers, in processes and services targeting vulnerable categories in a community, their transformation and an increased level of well-being can be delayed or prologues the state of poverty, with unwanted effects on a longer term. The current research is mainly about the impact of volunteerism and the management of rural volunteers from Vaslui County on children's well-being.

\section{Discussions and Results}

\subsection{Volunteerism - a vector of social and economic capital in a community}

The global and European context demand on a reconsideration of the added - value of volunteerism in the Romanian context. Since 2001, when the first Law on Volunteerism has been adopted (Law 195/ 2001), last time revised in 2014 (Law 78/2014), and entered into force in July 2014, important steps have been made to recognize the efforts made by thousands of individuals, occasionally or on a constant basis, in order to support communities and other people. The provisions of Law 78/ 2014 bring value because they create a framework for professional employment of volunteers within the organizations, based on a volunteer contract. Voicu\&Raiu (2018, p.2) underlined that, citing the first article from this legislative document, which specifies the fact that volunteers are involved in activities for the benefit of other persons or other companies, organized by legal, non-profit entities (NGOs), governed by private or public laws 
(Law 78/2014, art.1). The professional experience gained through volunteering is a well-known fact, not only in a symbolic way but also on the labour market, if volunteerism is in accordance with the educational history of the volunteer. The provisions of Law 78/2014, recognize the social value of volunteerism, through the moral and educational benefits brought to volunteers (Voicu \& Raiu, 2018, p.2). These authors noticed that "the declared intention of the Law of Volunteerism was to support social solidarity and develop the labour market, if we look at the context from a general perspective" (2018).

The scientific literature approaches the concept of volunteerism as a source of capital, under all its forms: physical, human, social, economic and cultural. Putnam (2000) considers buildings, enterprises, equipment as examples of physical capital, while under the notion of social capital includes social networks, norms of trusts and reciprocity, the human capital being represented by human resource, skills, knowledge and experiences (Bates\&Davies, 2004, p. 195-196). Furthermore, social capital encompasses in its working definition six components: participation in the local community, feelings of reciprocity, of trust and safety, social connections, citizen's power and community perception (Health Development Agency, 1999, apud Bates\&Davies, 2004). Bates $\&$ Davies, the authors of the above-mentioned scientific article correlated these components with the concept of social inclusion, in the sense that social inclusion increases along with the increase in social capital.

Andronic (2014, p.1) mentioned the importance of social capital from the perspective of volunteerism, in one of his articles, as volunteerism is a sum of elements specific to this type of capital (participation, cooperation and trust in people).

Under the aspect of measuring the social and economic impact of volunteerism, UNV underlined in one of their reports (2015) that the existence of complete data, based on thorough scientific researches, which show the diversity of volunteering forms at the global level, is a problem. The size and scale at which volunteer activities take place (through quantitative measurements), as well as the nuances and complexity of volunteer contribution through qualitative case studies, coming from various contexts, remains a challenge which needs to be addressed if we want to raise the level of awareness and highlight the potential of volunteerism as a resource (The Points of Light Institute, 2011). In addition, mentions are being made on the need of the organizations to agree upon a unique measurement methodology of the economic impact of volunteerism, from the perspective of reaching the targets set through the Millennium Sustainable Development Goals (MSDG) (UN Volunteers, 2016). This recommendation does not come as a surprise, considering the data we have from Johns Hopkins Centre for Civil Society Studies, following their initiative to measure the economic impact of volunteerism. They have found out that, within a one year time, almost 1 billion people from all over the world were making their time available to non-profit, profit or public organizations, or directly for friends and neighbours. These people could form a country named Volunteerland, which would be second on the globe as a number of population, after China (Salamon, Sokolowski, Haddock, 2011). Similarly, Bussel \& Forbes mention that in Great Britain the volunteerism sector has become a significant component in the country's economy, with an yearly capital of 40 million pounds and annual expenses of over 11 million pounds, half of the country's population being involved in volunteer activities (Bussel $\&$ Forbes, 2002, p.4). Therefore, if we know the value brought through volunteerism, in terms of social and economic capital, i.e. if we measure it, we can better understand why is it important to encourage volunteerism, stimulate and support, including at the level of rural disadvantaged communities.

The issue of the Law of Volunteerism no. 78/ 2014 was an important step in recognising the economic and social value of volunteerism. The new provisions recognize volunteerism and competencies gained though this kind of activity, by offering national volunteerism certificates and establishing a contract - based relationship between the volunteer and the host - organization, which includes documents like Volunteer Sheet (the equivalent of job description for employees) and a safety and protection sheet. 
Despite all that, so far the economic value of volunteerism is almost entirely ignored, while its social value is more or less formally recognized at the community level. The economic value can be regarded either as a contribution of volunteer hours to the budget of an organization, or as a preparatory stage for a future job and increased employment chances.

NGOs represented by VOLUM Federation, especially NGOs from the social area are planning to adopt and apply measurement instruments (quantitative and qualitative) over the coming period, which will probably provide surprising information about the impact of volunteer activities.

Lack of appropriate information and awareness on the importance of volunteerism is one of the causes for lack of (or absence of) rigorous management of volunteers, at the level of public and private institutions. NGOs are, again, structures which use volunteers on a larger scale. However, in their case also, as one of VOLUM Federation Position Papers stated, the „major barriers which limit the potential of volunteerism" (VOLUM Federation, 2016, p. 3-4) are related to lack of longterm vision, which comprises "support mechanisms for volunteers and for the volunteer activities organizers, like: access to proper funding, training for NGOs carrying on volunteer programs, coherent public policies which reduce the barriers in organizing and implementing volunteer activities, systems to analyse and gather data regarding the impact and social and economic value of volunteerism, as well as measurement systems and recognition of competencies gained through volunteering."

In countries with high percentages of people involved in volunteer activities (UK, Norway, and Holland), volunteer management is essential for their recruitment and retention in the organization, if it's done properly, focused, as a true structured work experience. Obviously, on the other side lies the motivation for volunteering.

The following statement is important and interesting as scientific value and starting point in building the hypothesis for a research aiming at measuring the social and economic value of volunteering, i.e. „economic development tends to produce high levels of volunteerism”, this aspect being correlated with an increase in interest for volunteering activities, over the past years (Andronic, 2014, p.2).

Bates\&Davies (2004) stated that the increase of social capital, through civic participation, facilitates information flow through existing social networks, consolidates local authorities, eventually leading to creation of local cultures in which learning and contribution flourish, relationships improve and the level of trust increases. From the perspective of social capital, volunteerism presents many benefits, cultivating altruism and building a sense of community belonging (Bates\&Davies, 2004, p. 4).

The theory of human resources establishes a direct link between economic, human and social capital and volunteerism. The bigger the economic capital (e.g. income), the richer the human capital (education) and more diversified the social capital (including participation in religious activities), the higher the probability to increase involvement in volunteer activities (Wilson, 2000, apud Fenyes, 2015). Fenyes (2015) quotes a trans-national analysis made by Hodgkinson in 2003, which illustrated the fact that the involvement in religious institutions, as an effect of social capital on volunteerism, increases the probability to do volunteering. By comparison, Voicu \& Voicu (2003), do not identify a specific connection between strong attachments (family and friends related) and volunteerism, the factors in favour for volunteerism trespassing the boundaries of social classes, being, along with trust - based relationships, factors which enable volunteerism. Fenyes (2015) mentions that religiosity can be a predictor of social, human and cultural capital.

\subsection{Volunteerism and sustainable community development}

In all strategic documents of UN, EU and Romanian Government one of the strategic action areas identified to combat poverty is related to the increase of volunteers 'role and volunteer activities in the strategic development of public and private structures and companies. United Nations Volunteers (UNV) (2016) mentioned that in order to achieve the 17 MSDGs by 2030, volunteerism must be "in the centre of development programs" (UNV, 2016). It is, therefore, 
important to become aware and develop forms of volunteerism in the rural area, with one condition: this concept of "volunteerism" is known and correctly understood.

United Nations gives the following definition to the concept of sustainable development: "development which satisfies the needs of the present without compromising the future generations 'ability to satisfy their own needs" (UN, 1987).

Dumitru Sandu defines community development as "volunteer-based changes in, through and for community, based on the practical experience, in post-December Romania” (2001). However, aspects related to volunteerism and its connection with the concept of sustainable community development are, as Andronic (2010) notices, very vaguely approached in the scientific literature. In Romania, characterized by a poor development of civil society, especially in the rural area, and by a low degree of associativity, this could explain various degrees of community development. Despite that, following the logical scheme, the last report of FDSC (2017) contradicts this statement, Moldova being the region with the highest level of volunteerism, although it is recognized as the poorest region of the country.

Given the dynamic context of community development, social services must have a welldefined place in the strategy of achieving the 17 MSDGs, even for the sole reason that the way of achieving this strategy must be an inclusive and people-centred one. How can we increase efficiency and consistency of our efforts? How can we make sure that interventions in the area of development, focused on social services, are reaching the poorest of the poor, in a timely manner and cover the increasingly complex needs and problems of the most vulnerable?

One of the most comprehensive research studies made over the past years regarding volunteerism is the one published in 2015, entitled The Role of Volunteering in Sustainable Development, done within Valuing Volunteering Project by The Institute of Development Studies (IDS) and Volunteering Services Overseas (VSO). The research took place between $2012-2014$ in four countries: Kenya, Mozambique, Nepal and Philippines, and was conducted by a team of volunteer researchers, using participatory research methodologies and included more than 3, 700 people (local groups of volunteers, community leaders, youth, teachers, medical staff, government officials, employees and volunteers from local, national and international NGOs). The research objective was to identify the contribution of volunteerism to sustainable development, to frame volunteerism within the dynamic of power and political context and to establish to what extent organizations working with volunteers reach to the poorest of the poor and most marginalized, by that volunteering becoming a vector of access to these categories of people.

Here are some of the major conclusions of research subthemes, relevant also for the case study presented in the following subsection of the article:

"Needs driven" volunteering programs - a must. If community development is, a process of volunteer changes, "in", "through" and "for" community (Sandu, 2001), the definition leads to the idea that, in order to produce authentic development, active participation must take place, not only citizen consultation. The above - mentioned study makes a distinction between consultation (through this process people are given a voice, but do not have decisional power) and participation (which offers people a framework to analyse circumstances and act accordingly) and the results indicated that failing to understand this distinction can have an unwanted effect on the development process. It was found that through consultation, people directly affected by a certain problem were excluded from the process, and the local leaders were the ones involved in establishing connections, analysis and decision making. In Kenya, for example, both community-based organization $(\mathrm{CBO})$ representatives and health workers involved in volunteer programs which offered services to people affected by HIV or AIDS, have identified this aspect during the research, emphasizing that community leaders did not really know grass - roots problems. As a result, the real, true problems were not being identified and the interventions were, as such, mistakenly articulated, and lacking efficiency in solving the real problems of the marginalized. Also, NGOs using volunteers were being perceived as structures which know what's best for the community, which can affect the development process. This was, in fact, identified through case studies from 
Kenya and Philippines. As a conclusion, volunteering programs must use participatory community approaches, even from the design phase. One of the researchers in Kenya pointed to the importance of establishing relationships (development being, by definition, a relation - based process), of involving stakeholders at all levels, of training offered, to maintain the level of involvement in the research program.

Dependency and sustainability. Intervention in the community development programs must be community - based and on a longer - term, in order to give time to build relationships and trust between local community and the NGO. Volunteers can play a very important role in this sense. In Philippines the research revealed that the time allocated to develop skills and necessary resources so that community volunteers go from dependency to independence is very important in building sustainability. Moreover, each community has its own pace which must be considered and regular context analysis must be an integral part of the exercise of development, in order to increase the chances for sustainable interventions. However, without real ownership, used by the community to identify internal resources (e.g., the creation of a cooperative in the case study from Philippines), sustainability is endangered.

The main conclusion of the research was that ,the role of volunteering can be integrated in development programs as a powerful mechanism by which we can reach to the poorest and most marginalized groups" (Institute of Development Studies \& Volunteering Services Overseas, 2015). Participatory research, organizational, ongoing learning and adjusted programming are needed if we want to have a „bottom-up” approach of the development process.

International organizations like The Points of Light Foundation, The Points of Light Institute and Volunteer Now, played an important role in volunteering studies. They have carried on several researches about the role of volunteerism in the rural area and successful factors, in countries like Northern Ireland, Australia, USA, in the context of community development process and also in relation with social impact of volunteering, signs and measurement of this kind of impact and what does it mean to do volunteering work in poorly developed communities (The Points of Light Foundation, 2004; The Points of Light Institute, 2011; Volunteer Now, 2013; Volunteer Now, 2011; Quirck \& all, 2012). All these themes have a distinct meaning for the objectives of the a future research, if we take into account the place where the research will take place - Vaslui County - and the socio - economic features of this area.

Quirk et al. identified the connection between the lack of volunteers in rural areas and the decrease in services provided, stating that the smaller the communities, the higher the number of essential services offered through volunteers. Usually, in these communities there is a nucleus of people who fulfil various roles as volunteers (Quirck et al, 2012, p.3). The researchers added that demographic factors (population ageing), along with economic crisis and various expectations and interests of the ,boomer” generations (related to volunteering offer), are elements which influence volunteering activity in rural USA.

In building community cohesion, studies have shown that progress and success factors are represented by the key - people in the community, those people who use opportunities and leadership skills to maintain and develop relationships (Johns \& all, 2000, p.1).

In the context of Australian communities, Johns \& all identified the beneficial role played by multi-disciplinary interactions (relationships which transcend role boundaries - e.g. school business environment) in building sustainable community development programs (Johns et al, 2000, p.3-4). These interactions are social capital generators which, in turn, influence social, civic and economic wellbeing of a community (Falk\&Killpatrick, 2000, apud Johns\&all, 2000). Therefore, by correlating these elements, and if community leaders focus intentionally on building social capital, represented also by the level of volunteering development in a community, we can increase chances for sustainable interventions through community development. The same study cited above confirms the fact that development and youth participation in the process of development is another key component (Kenyon, 1999a; Heartland Centre for Leadership Development, 1987, apud Johns et al, 2000]. From this angle, a well -developed volunteering 
sector in a community represents another key component in community development. To illustrate that, the example of inoculating youth with the importance of volunteering by exposing them to working experiences within the emergency volunteer services is given. This, in turn, might be an aspect to consider in a future research, if we take into account Emergency Volunteers Services in rural Romanian communities, formed at the level of each Village Hall.

The major conclusion of Johns et al study was that careful planning is needed to facilitate leadership, along with professional development training which should include above - mentioned elements, if we wish to have sustainable community development, in which volunteering is given a well - deserved role.

With reference to the need of development of the non-profit sector, Kaminski draws attention on the point that in countries with a communist past communities have been destroyed, especially the rural ones, which led to undermining their abilities to "express the need for private, non-profit organizations" (Kaminski, 1992, apud Johnsons \& Young, 1997, p.15).

Cavaye (2001) talks about five challenges of community development workers, one of them being the identification of new forms of community participation, which translates into several dilemmas, volunteering versus professionalization being one of them. If development is "wellbeing creation" (Shaffer, 1989, apud Cavaye, 2001), its sustainability in rural communities depends on less tangible elements: community ownership, local leadership, action, redesign (rethinking) and motivation (Cavaye, 2001, p.3). Rural community development needs participation, which can be made also through volunteering, based on people's motivation and the passion they chose to get involved in the life of the community. These very elements, says Cavaye, are the „fuel” of rural and regional development.

Corduban \& all identified the development of volunteering in rural areas through a community development project, which represents, based on authors 'statement, ,a model to continue education through volunteering” (Corduban \& all, 2014, p.2). CA SA AI Project aimed at offering young people the opportunity to gain new skills demanded on the labour market, through training and by solving one problem of vulnerable families - lack of a proper shelter. Through the benefits and advantages volunteering offers (from the establishment of relationships and social support networks, to the feeling of belonging to a group, developed in young people), Corduban \& all analyse a project carried on by Habitat for Humanity International (HFHI) in the context of the new Law of Volunteering which was freshly issued (the version from 2014), which stipulated that volunteering can be recognized as professional experience. In addition, the need to rebuild the feeling of belonging to the group has also been identified, in the context of a new wave of migration which affected and continues to affect Romanian villages, through the loss in cultural identity. The core of HFHI intervention was the volunteering activity used for the construction of houses for the most vulnerable. In such an initiative, the needs of vulnerable categories happily blend with the reeducation of project volunteers, who gain skills in the construction area that can later on facilitate finding a job on the labour market (Corduban \& all, 2014, p.4).

Davies et al, (2018) mentioned in one of the analysis regarding the state of volunteerism in rural area, that one of the few aspects researchers agreed upon is that "structural ageing of the population represents a major threat for the sustainability of volunteering as a labour force in the rural area" (Davies\&all, 2018, p.1). The study highlights that volunteers played a critical role in building community wellbeing, and this role amplified and diversified over the past decades (Davies\&all, 2018, p.2). Also, the failure of Australian government to provide enough quality services led to an increase in volunteering activities. This is similar to what is happening in the Romanian context. However, although the general picture is very similar (e.g. acute lack of social services in the rural area), the answer offered through volunteering, in the Romanian context is unsatisfactory, to say the least, which is proved by the low percentage of people involved in volunteering, at the national level and in the rural area, in particular.

On the other hand, an increased dependency on volunteers and their participation in providing essential services, might make rural communities more vulnerable, through inadequate services 
offered. Studies made in Great Britain clearly show that while the role and importance of volunteers will be maintained, they will not be able to answer all needs of service provision, due to lack of investment in their training and problems in infrastructure (Moseley and Owen, 2008, apud Davies \& all, 2018).

\section{Community Consultative Structures - a model of working with rural volunteers. Case study.}

The National Strategy regarding Social Inclusion and the Reduction of Poverty (2014 - 2020) shows that we are confronted with understaffed social services in rural communities (Social Work Public Service - SWPS), lack of special training for the people working in public services and with the need to consolidate and improve community social work in these communities. By putting together the need for services and the increased percentage of population living in poverty, we can get a sense of urgency of the need to identify solutions to these problems. The above - mentioned document notices that "the staff deficit in SWPS from rural communities and small towns (the ones with less than 50, 000 inhabitants) is between 2300 to 3600 persons. The highest human resources deficit is being registered in rural communities, especially the smaller communes." The Action Plan which accompanies The National Strategy regarding Social Inclusion and the Reduction of Poverty (2014 - 2020), states in the Social Participation Chapter, that "Stimulation of civic engagement and volunteering for the reduction of poverty and promotion of social inclusion" represents one of the specific objectives.

In Romania, legislation provides a stimulation mechanism for civic engagement and volunteerism, through the Community Consultative Structures (CCS). These civil society structures are mentioned in Law no. 272/2004, regarding the protection and promotion of child rights and appear as such in 2005 (World Vision Romania, 2019).

According to the Law of Social Work no. 292/ 2011, the aim of CCSs is to "support local public authorities and social services providers to find solutions to the need of community social services." CCS are formed of key - people from the community, coming from various activity areas (educational, social, medical, religious, business) and chose to engage, whenever necessary, in finding solutions to vulnerable people's problems, by working as an interdisciplinary team of volunteers, and the provision of primary prevention social services or intervention and even by writing and implementing social work projects. The meetings of this group of people create an environment which encourages the exchange of ideas, opinions and information, with the objective to support vulnerable people from a community, through integrated services, offered by public and private social service providers. The final goal is to prevent situations at risk or to intervene, when appropriate.

Law no. 292/ 2011 (which has various subsequent additions and changes), includes the following attributions of CCSs:

- Consultation among interested parties on the need and manner social and other kind of services (health, education, professional training and occupational, cultural, public order) are being provided;

- Establish cooperation and/ or working relationships among interested persons, which ensure social services provision, like, for example: assistance and support, provide individual, family or community group services to ensure their basic needs (education, personal care services, recovery/ rehabilitation, insertion/ social reinsertion);

- Consultation to elaborate public policies targeting the improvement of social services. At the local level, these public policies are instrumented through: Local Council decisions, Mayor's decisions, programs and/or projects approved through decisions of the Local Council.

The interpretation of the provisions included in this law, in relation with the role of CCS, leads to the following limitations of these civil society structures: 
- $\quad \mathrm{CCS}$ is not a decisional, regulatory, certification or negotiation body;

- $\quad$ CCS is to substituted to the competencies/ functions of the Mayor or of the Local Council;

- Consultation within the CCS does not lead to negotiation, as it happens in social dialogue case;

- The CCS itself is not a service provider and, as such, is not substituted to them (e.g. Social Work Public Service, General Direction of Social Work and Child Protection or to any other accredited social service provider).

In 2008, World Vision Romania was starting an initial assessment process, with the participation of major community stakeholders, with the aim to carry on a community development program, in three communes from Vaslui County, which was back then, and, unfortunately still is one of the poles of poverty in Romania.

The Initial Assessment Report (2008) and the Baseline Research Report that followed (2011), indicated a poor representation of the civil society sector, represented by formal and informal groups of citizens who are involved in the life of their communities, including through volunteering. The results of focus - group methodology and key informant interviews organized with major leaders from each commune (mayors, school principals, priests, medical staff, business men) have been analysed, including information on the status and functionality of CCSs (according to the legislation issued at that time), Parents 'Committees, Students' Councils, which had been indicated as forms of volunteerism manifestations at the local level. At that moment, none of the CCS was functional, in the sense of assuming the responsibilities stipulated in the Decisions given by the Mayor's Office for their functioning. They existed only in formal, official documents (WVR, 2008).

The programmatic decision made was to approach the lack of development of civil society structures by including a civil society sector in the overall intervention and project implementation. This sector aimed at raising the level of awareness on the place and role of these community structures in the life of the community which, eventually, would have lead to an increase of participation in the process of development initiated. CCS were and still are representative for the community, because they consisted of formal and informal leaders of the community, coming from various areas (education, social, local public administration, medical, religious), who work together for the social wellbeing of the community, as an expression of human and social capital, but also as a form of volunteerism specifically mentioned in the Romanian legislation. The initial Assessment Report mentioned that CCS were seldom initiating actions to support children and when this happened, was not done as a civil society group, but only individually, as representatives of their institutions. As a result CCSs were not working and didn't identify themselves as a community group. Overall, all three communes had a low level of association, were characterized by poor communication among its members poor social solidarity, and a general lack of social responsibility (WVR, 2008).

World Vision Romania took over, gradually, the management role in relation with these structures. During the first five years of the program implementation $(2010-2014)$, with WVR's support were organized information and awareness sessions regarding the legislation under which CCS should get organized, their componence, role, and way of working, everything applied on child protection and wellbeing issues, which are at the centre of WVR activity. All the activities were carried on based on a formal partnership between WVR and local public authorities. A specific methodology which encourages dialogue between beneficiaries of services (social, educational, medical), service providers and local public authorities was piloted in one of the communes. The methodology called Citizens' Voice and Action (CVA) aims to improve the quality of services, around service standards. WVR started to work on a specific working methodology with CCSs.

The activity of CCSs was integrated into the broader context of community development programs. Volunteers from these structures become partners in the development process, through 
the manifestation of prosocial behaviour, participation to primary prevention social services carried on in the community and, partially, in intervention services made in support of vulnerable children and families.

At the end of the first five year program cycle (when the number of communities in the program increased to 5), the Evaluation Report showed that the activities implemented with NGO's support activated some of the CCSs and created a nucleus of people who supported program activities. However, from the point of view of sustainability, things were not as perfect, because the CCS were active only when WVR was present in the community, and they were lacking visibility among community members. The general potential of the community to volunteer for the benefit of children was still low and was concentrated around school (information activities on children's rights, citizen rights, role of local institutions and child protection services, parental education sessions), and with increased proactiveness among children, through activities that were contributing to their personal development. CVA methodology succeeded to involve parents in an active manner, increasing awareness around the need for active participation. However, parents were not fully prepared, yet, to manifest social accountability in relation with service providers and local public authorities when minimum standards of service provision were not respected. Although communities were recognising the added - value of having a long-term vision, they still had a limited ability to make projections over time (WVR, 2015).

Durin the next program cycle $(2015$ - 2020), although the program doesn't have a separate civil society sector, this sector becomes a cross-cutting theme and investments are being made in CSS members' training (child protection legislation, the role of each institution in the child protection system, partnerships and participation, volunteering, case management, identification, reporting and monitoring child protection cases, leading to a local reporting and referring mechanism for child protection and school abandonment cases. Experience exchanges among CCS members from different communes are being organized. CCS members write projects to solve some of the cases identified, with funding from WVR, co-funded by local authorities and implement them working as a multi-disciplinary team. CVA methodology is applied in other communes and a new methodology is being presented to the members of CCS. This new methodology, called Child Protection and Advocacy (CPA) is used specifically to solve child protection cases and represents a set of specific interventions aimed to consolidate the child protection system at the community level (at formal and informal level), by empowering local communities. It consists in six working steps during which principals of active participation and empowerment are intentionally used to solve child protection problems identified. These steps are:

Step 1 - How will we work together?

Step 2 - Analysis of the child protection system: the working group analyse the root causes of the child protection problems and the systems in place;

Step 3 - What do we want to do together - members of the working group agree on a common vision, objectives and approach;

Step 4 - Planning - the collaboration structure (group componence) is finalized and a project, with clear objectives, activities, responsible and deadlines, is written;

Step 5 - Project start - baseline data are gathered, action plan is implemented and monitored, reflection meetings are organized and the organizational capacity of the CPA group is built;

Step 6 - Learning and evaluation, adjustment and success celebration.

As a result of CCS activity and increased functionality, children benefited of material donations to support them to go to school, of remedial education sessions to decrease functional illiteracy, home monitoring visits, family and school counselling and parents benefited from parental education sessions. WVR was part of the solutions identified, while at the community level members become more aware of the benefits of participation, especially considering that community services, understaffed and underfunded could not identify and solve the number of cases identified on their own. One proof that benefits of engagement were being recognized is the fact that members of local SPAS and County Social Work and Child Protection Direction became 
members of these structures, contributing to an efficient exchange of information between local and county institutions and implicitly, to the creation and consolidation of the social capital, in the given context.

The relationship between WVR and members of CCS was formalized, as each member of the CCS signed partnership and confidentiality agreements, thus respecting the legislative provisions. The members of CCS and WVR identified one gap in the legislation related to the fact that, although the law provides the Mayor with the possibility to issue a decision on the memberships of the CCS, in order to support the activity of the Social Work Offices within the Mayor's Office, there was no working methodology to accompany the law provisions and no ways to encourage/ reward CCS members participation and involvement, as volunteers. Based on the working experience with CCS, WVR puts together a working methodology (WVR, 2019). By 2022, when the community development program will be phasing out, together with the community, WVR will need to find solutions to increase the sustainability of these kinds of interventions, made through the CCS.

The same manner of working was replicated in other seven communes from a second community development program started in Vaslui County in 2012, which will also end in 2022.

WVR's Practical Guide of Working with CCS mentions that, in 2018 alone, more than 20 prevention and intervention small projects for vulnerable children and adults have been written and implemented by CCS members from 12 communes and one small town from the NW part of Vaslui County, by applying the working methodology described above. The same guide mentions that the number of cases at risk identified and discussed during the meetings of CCS has considerably increased. In 2018, a number of 175 cases were debated, while in 2019 there were 205 cases discussed, for which solutions have been identified. Out of the 13 CCS, 9 are currently functional, a number of 102 community members being actively involved, as volunteers, in these civil society structures.

Although results are promising and impactful, they have been obtained due to a process that has been facilitated and funded by an NGO. The Practical Working Guide published by WVR (2019) is mentioning that one of the challenges, despite all efforts invested, is that not all CCS are naturally active and there still are child protection cases (abuse, neglect, exploitation) which are not being reported or brought to the attention of community social worker, in a timely manner. Moreover, meetings of CCS members, when needed or based on the established working manner, do not always take place at the initiative of CCS members and they still wait for external support and interventions. Writing project proposals to access resources (including from WVR) to solve child protection cases still isn't a priority for all CCS members. Some of them continue to need support and guidance to be able to do that.

\section{Conclusions}

The practical working experience with CCS, along with some data available in the scientific literature, including a qualitative research done by the author of this article in one of the communes from Vaslui County (Cămănaru, 2018), regarding the perceptions on rural volunteerism, lead to the following conclusions:

- Raising the awareness level regarding the importance of volunteerism and Social participation in the life of a community is necessary if we want to increase the number of people who wish to be part of these participatory structures;

- Once people from all levels, from the community leadership to the simple citizens, become more aware of the need to volunteer, somebody needs to take over the responsibility of managing volunteering activities. If this is lacking, the informal, one time forms of volunteering cannot generate a visible, sustainable transformation of the communities. If volunteering development is being left at the hazard's disposal, this means according to UN, to leave the very development of a community, especially its sustainable development at the hazard's disposal; 
- $\quad$ Any strategic planning initiative must include strategies on working with volunteers, including private - public partnerships aiming to develop the existing volunteering structures and the know - how transfer that leads to community ownerships and, implicitly, to the sustainability of interventions that are volunteer - based;

- In order to acknowledge the role and integrate the volunteering component in the development strategy of a community, we need to be able to measure the economic and social capital of volunteering, for is this measurement that can fully offer the dimension of volunteers 'contribution to social participation and the budget of a community and can draw the attention of local public authorities and decision - makers on the importance of and opportunities offered by volunteering, within the algorithm of strategic planning and implementation of sustainable community development;

- The investment made to measure the economic and social impact of volunteering needs to go hand in hand with the motivation that members of an economically underdeveloped community would have to become volunteers. Motivation schemes of citizens must be identified to be able to increase the number of volunteers in a community and the number of formal and informal volunteering structures which initiate impact projects for the community;

- A volunteering culture is not possible in the absence of structured, programmed investments made in activities and projects that are aiming to intentionally increase information, awareness, training and funding of community volunteering projects.

All of the above are reasons for which a future applied doctoral research will aim to identify the real motivation of the CCS members and clear ways and methods to measure the economic and social impact these community structures bring into the community. May be, in this way, local public authorities will become more aware of the added - value of these volunteering structures, within the equation of community development and will come with creative, innovative solutions to motivate volunteers. These elements should also be part of proposals of public policies on how to work with volunteers and/ or, in CCS's case, to improve the existing legislation with clear implementation norms and methodologies, based on NGO's experience in the field.

\section{References}

- Andronic, R. (2010). Volunteer management in Romania - An Emerging Practice, Review of General Management, 11(1), 71-78.

- Andronic, R. (2014). Volunteering: Theoretical Approaches and Personal Characteristics, International Conference of Scientific Paper, AFASES, Brasov, http://www.afahc.ro/

- $\quad$ Bates, P., Davis, F.A. (2004). Social capital, social inclusion and services for people with learning disabilities, Disability\&Society, 19(3), 196-207, Carfax Publishing.

- Burger, E.K., Snyder, B.M. (2014). Volunteering, 1st edition, Sunshine Valley Communication \& bookboon.com.

- Bussell, H., Forbes, D. (2002). Understanding the volunteer market: The what, where, who and why of volunteering, International Journal of Nonprofit and Voluntary Sector Marketing, 7(3), 244-257.

- Cavaye, J. (2001). Rural Community Development - New Challenges and Enduring Dilemmas, Journal of Regional Analysis \& Policy, 31(2), 109-124.

- Cămănaru, M. (2018). Perceptions on Rural Volunteerism and Its Contribution to Sustainable Development in Romania. A Case Study, European Financial Regulation (EUFIRE), Editura Universității „Alexandru Ioan Cuza” Iași, 235-247.

- Civil Society Development Foundation (FDSC). (2010). România 2010. Sectorul neguvernamental: profil, tendinţe, provocări. Bucureşti: FDSC (citat în continuare FDSC).

- Civil Society Development Foundation (FDSC). (2017). România 2017. Sectorul neguvernamental: profil, tendințe, provocări, București. 
- Corduban, C.G., Dumitraşcu, A.I., Nica, R.M., Gafiuc, P.V. (2014). Education through Volunteering: Involvement in a Community Project, Procedia - Social and Behavioral Sciences 142, 285-290.

- Davies, A., Lockstone-Binney, L., Holmes, K. (2018). Who are the future volunteers in rural places? Understanding the demographic and background characteristics of non-retired rural volunteers, why they volunteer and their future migration intentions, Journal of Rural Studies 60, 167-175.

- European Commission (2011). Voluntariat și solidaritate intergenerațională, Eurobarometer 75.2. Brussels: EU, details via Gesis (Leipzig Institute for the Social Sciences). http://www.gesis.org/?id=3421\&tx_eurobaromater_pi1[vol]=3421\&tx_eurobaromater_pi1[p os 1$]=1050$.

- Fenyes, H. (2015). Effects of Religiosity on Volunteering and on the Types of Volunteering among Higher Education Students in a Cross - Border Central and Eastern European Region, ActaUniv. Sapientiae, Social Analysis, 5(2), 181-203.

- Helliwell, J., Layard, R., Sachs, J. (2019). World Happiness Report. New York: Sustainable Development Solutions Network.

- Institute of Development Studies \& Volunteering Service Overseas (2015). The role of volunteering in sustainable development. https://www.vsointernational.org/

- Johns, S., Kilpatrick, S., Falk, I., Mulford, B. (2000). Leadership from Within: Rural Community Revitalisation and the School-Community Partnership, Tasmania Univ. Launceston (Australia). Center for Research and Learning in Regional Australia. https://files.eric.ed.gov/fulltext/ED447992.pdf

- Johnson, K.A., Young R.D. (1997). A profile of the non-profit sector in Romania, Voluntas, $8(3), 303-322$.

- Law no. 272/2004, regarding the protection and promotion of child's rights

- Law no 292/2011 of social work

- Law no. 78/2014, regarding the regulation of volunteering activities in Romania.

- National Strategy on Social Inclusion and the Reduction of Poverty (2014 - 2020). Annex 2.

- Putnam, R.D. (2000). Bowling alone: the collapse and revival of American community. New York: Simon Schuster.

- $\quad$ Quirk, M., Bull, K., Ellis, E., Thormodson, H. (2012). Rural Volunteers: A Vital Force on Fertile Ground, Rural Minnesota Journal, 7, 1-20.

- Salamon, L., Sokolowski, W., Haddock, M. (2011). Measuring the Economic Value of Volunteer Work Globally: Concepts, Estimates, and a Roadmap to the Future, Annals of Public and Cooperative Economics, 82(3), 217-252.

- Sandu, D. (2001). Dezvoltare comunitară și regională, București, https://www.academia.edu/ 14400631/Dezvoltare_comunitara_si_regionala_2011.

- The Points of Light Foundation \& Volunteer Center National Network. (2004). Volunteering in Under-Resourced Rural Communities. Final Report. http://www.resourcesharingproject.org/sites/resourcesharingproject.org/files/files-resourcesruralcommunities.pdf, accessed on 28th of November 2015

- The Points of Light Institute. (2011). Social Impact of Volunteerism. https://www.yumpu.com/en/document/read/51218070/social-impact-of-volunteerism-pointsof-light-foundation, accessed on 28th of November 2015

- UN (1987). Report of the World Commission on Environment and Development: Our Common Future, available at http://www.un-documents.net/wced-ocf.htm, accessed on 28th of November 2015. 
- UN Volunteers. (2015). State of the World's Volunteerism Report. Transforming Governance, https://www.unv.org/swvr/2015-state-worlds-volunteerism-report-swvr-transforminggovernance.

- UN Volunteers. (2016). Annex 4 - UNV Discussion Paper "Volunteering as Essential in achieving Sustainable Development". UNV Responding to the 2030 Agenda, www.undp.org.

- Voicu, M., Voicu, B. (2003). Volunteering in Romania: A Rara Avis. In Dekker, P., Halman, L. (eds), The Values of Volunteering. Cross-Cultural Perspectives. 143-160. New York: Kluver Academic/Plenum Publishers.

- Voicu, C.L., Raiu, L. (2018). Volunteering Advantages and Difficulties in Romania. Postmodern Openings, 9(4), 122-139. https://doi.org/10.18662/po/48.

- VOLUM Federation. (2016). Importanța demersului de măsurare a impactului social şi economic al voluntariatului în România. Document de poziţie. http://federatiavolum.ro/

- VOLUM Federation. (2016). Voluntariat cu efect: Ghid pentru măsurarea efectelor şi impactului voluntariatului asupra organizației gazdă. http://federatiavolum.ro/

- Volunteer Now. (2013). Formal Voluntary Action in Rural Northern Ireland: What does this tell us about the existing and potential impact of volunteering on community wellbeing and capacity?

- Volunteer Now. (2011). The Role of Volunteering as an Integral Part of Community Development in Rural Ireland. https://www.volunteernow.co.uk/

- World Vision Romania. (2019). Practical Guide for Working with Community Consultative Structures in the area of child protection. https://worldvision.ro/

- World Vision Romania (2008). Assessment Report (internal document).

- World Vision România (2011). Baseline Research Report (internal document).

- World Vision România (2015). First Program Cycle Evaluation Report, Vaslui 1 Program (internal document). 



\title{
Cap. 14. DOCTORAL GRADUATES IN THE LABOR MARKET IN THE CONTEXT OF THE KNOWLEDGE ECONOMY
}

\author{
Alexandru Anichiti \\ Ştefan cel Mare University of Suceava, Suceava, alexandru.anichiti@usm.ro
}

\begin{abstract}
The future of jobs is characterized by insecurity. As jobs become more complex, more individuals will not have adequate education and training as required by the labor market. During the last decades, the labor markets around the world have been subject to a perpetual transition from blue-collar jobs to whitecollar jobs. This generated the necessity of more educated and better-trained individuals to face the new technological changes. The key component of this new economy, also called the knowledge economy is a dependence on intellectual capabilities than on physical inputs. This article is a literature review on the employment trends and perspectives of doctoral graduates. The aim of this study is the examination of doctoral employment opportunities. The choice of the topic was given by the insufficient systematization of the specialized literature (lack in the Romanian space, but and in the international research of an approach to such a study). The research methodology consists of statistical indicators regarding the situation of doctoral graduates on the labor market and the qualitative analysis of the results. The results of the literature review were that doctoral graduates are more desirable by employers due to the set of skills that they developed, and therefore have a much lower unemployment rate and higher earnings.
\end{abstract}

Keywords: doctoral graduates; trend analysis; knowledge economy; labor market.

\section{Introduction}

According to a report by the World Bank (2018), the future of jobs is characterized by uncertainty, with more individuals having an education and training inadequate to the jobs market, as jobs become more complex (Lucaci, 2019). Also, in recent years, labor markets around the world have undergone a transition from secondary to tertiary employment. These circumstances have generated the need for more educated and better trained people to cope with technological change and to be able to perform at work.

The doctorate graduates are highly instructed individuals who after completing their Ph.D. can work everywhere in the world and can adapt to a lot of jobs. However, most of them work as researchers or in academia, but more of them are starting to work in the business sector or government institutions. Jarausch (2004) argues that the transition from graduation to career has been a neglected field of research. Therefore, the choice of the topic was given by the insufficient systematization of the specialized literature.

The paper is structured as following: in the first part is presented the scientific literature on career prospects and the importance of doctorates in the labor market, followed by the presentation of advantages and disadvantages of doctoral graduates in the labor market. The research continues with the discussion section and the conclusions that briefly present the main findings of the research, and its limitations. The analysis of the academic literature should improve the general understanding of the concept studied (career prospects and the importance of the doctorate in the labor market), while the conclusions and discussions section should compress the interpretation of the results.

\section{Literature review}

\subsection{The knowledge economy}

Knowledge is a very important strategic resource held by individuals, companies and states (Bolisani and Brătianu, 2017). The knowledge economy is not a new concept, being defined by the 
use of knowledge to create goods and services and refers to the fact that in many jobs in the knowledge economy, the employees require the manipulation of information, as opposed to the manipulation of physical objects (Bell, 1973).

A basic idea of the knowledge economy is the centrality of knowledge as a source of innovation (Bell, 1973). Schumpeter (1934) refers to innovation as a source of economic growth and Romer (1990) emphasizes the importance of knowledge in economic growth and the development of a company. Moreover, the race to innovation has led both high-income and lowincome countries to implement policies to increase the number of doctoral students (Smith, 2010), with a top priority for governments to ensure that there are sufficient highly qualified researchers (Skovgaard-Pedersen, 2014).

Neumann (2002) argues that throughout the literature, the view is that the doctorate is the preparation for an academic career Today, this is not necessarily the case, as the importance and role of doctoral graduates is recognized in various spheres of society, and the need for the transfer of knowledge has made the academic understanding of a doctorate as aimed basic knowledge outdated (Probst and Lepori, 2008, p.477).

In the last decades, more and more doctorate graduates moved from academia to non-academic work and the high level of non-academic employment of can indicate that the doctoral graduates have valuable skills (Mowbray and Halse 2010), but also the fact that the competition in the academia had led many doctoral graduates into non-academic positions (Van der Weijden et al., 2016). This can be seen as a positive fact, that there is more need for highly skilled employees in the private sector. On the other hand, there is the fact that there are more and more doctoral candidates and graduates than ever before and there are simply not enough academic positions, thus being forced to take a job outside of academia.

In the context of the knowledge economy, there are many benefits of holding a doctorate. However, the market value of a doctorate varies with the field of study (Zolas et al., 2015), usually being easier for a graduate in an exact sciences field to find employment in the academia or in the private sector. In a study by the European Science Foundation (ESF, 2017), it was noted that doctorate holders in humanities have a significantly higher level of unemployment than graduated from social sciences.

However, when comparing a doctorate graduate with an undergraduate or high school graduate, there are clear advantages to pursuing a doctorate. It is believed and studied the fact that usually it is easier for a person with higher education to find a job and this is translated in a lower unemployment rate for higher educated persons in comparison to persons with no education or with lower education. Employment statistics show that long-term employment and salary prospects are more favorable for graduates than non-graduates (Neumann, 2002). For example, in the USA, the unemployment rate for doctoral graduates is much lower than college graduates and much lower than high school or primary school graduates. This is shown in figure 1.

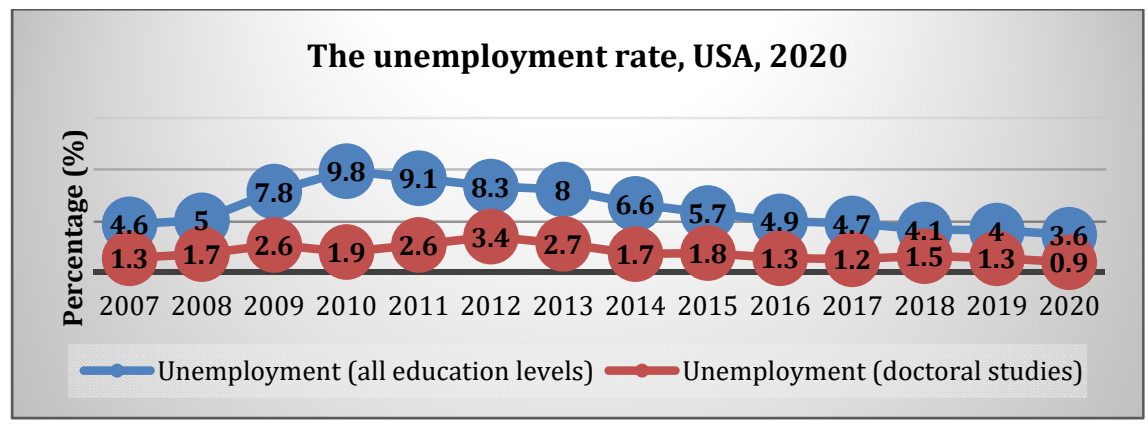

Fig. 1. The unemployment rate, USA

Source: US Bureau of Labor Statistics, 2020 
Moreover, having a higher value as a graduate and having more skills will usually translate into a higher salary. In the USA, the salary for a doctoral graduate is usually much higher than for a person without a doctorate.

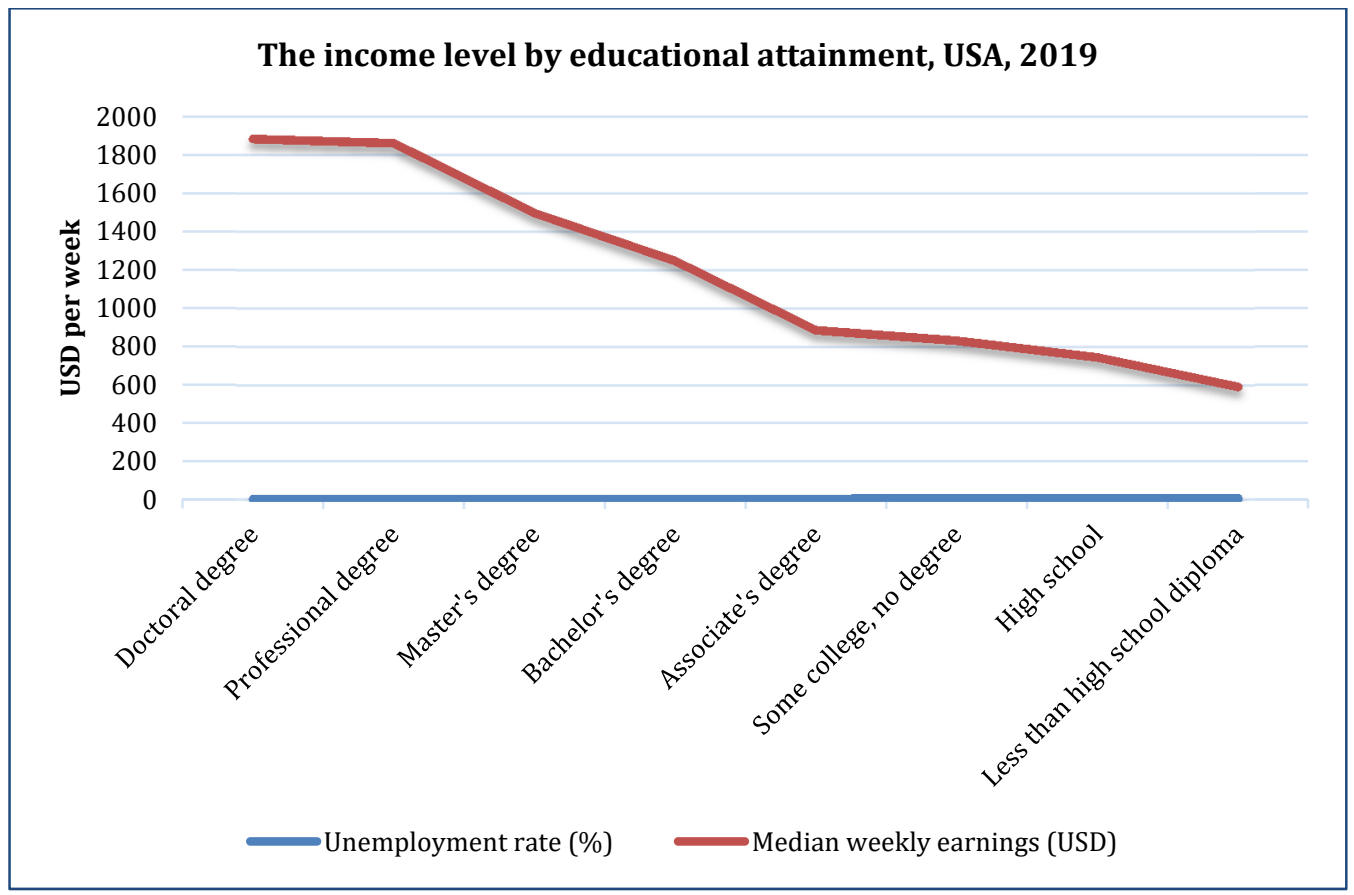

Fig. 2. The income level by educational attainment, USA Source: US Bureau of Labor Statistics, 2020

The situation where doctorate graduates have a lower unemployment rate than non-doctorate graduates is not only applicable to the USA. Although no statistics are showing exactly the situation regarding unemployment in the EU for doctoral graduates, in table 1 there are the statistics of unemployment for people with less than primary and lower secondary education (ISCED levels 02), upper secondary and post-secondary non-tertiary education (ISCED levels 3 and 4) and tertiary education (ISCED levels 5-8). It can be observed that the unemployment rate for people with tertiary education which means undergraduates, graduates and doctoral graduates is less than in the rest of the categories for all the EU member countries, with no exception.

Table 1. The unemployment rate, EU 27 (2019)

\begin{tabular}{|l|c|c|c|}
\hline \multicolumn{1}{|c|}{ Country } & $\begin{array}{c}\text { Less than primary, } \\
\text { primary and lower } \\
\text { secondary education } \\
\text { (ISCED levels 0-2) }\end{array}$ & $\begin{array}{c}\text { Upper secondary and post- } \\
\text { secondary non-tertiary } \\
\text { education (ISCED levels 3 } \\
\text { and 4) }\end{array}$ & $\begin{array}{c}\text { Tertiary education } \\
\text { (ISCED levels 5-8) }\end{array}$ \\
\hline $\begin{array}{l}\text { European Union - 27 } \\
\text { countries (from 2020) }\end{array}$ & 13.3 & 6.0 & 4.2 \\
\hline Belgium & 12.0 & 5.3 & 3.2 \\
\hline Bulgaria & 13.1 & 3.4 & 1.9 \\
\hline Czechia & 10.7 & 1.8 & 1.0 \\
\hline Denmark & 8.4 & 4.1 & 4.0 \\
\hline Germany & 7.9 & 2.7 & 2.8 \\
\hline Estonia & 9.8 & 4.8 & 2.9 \\
\hline
\end{tabular}




\begin{tabular}{|l|c|c|c|}
\hline Country & $\begin{array}{c}\text { Less than primary, } \\
\text { primary and lower } \\
\text { secondary education } \\
\text { (ISCED levels 0-2) }\end{array}$ & $\begin{array}{c}\text { Upper secondary and post- } \\
\text { secondary non-tertiary } \\
\text { education (ISCED levels 3 } \\
\text { and 4) }\end{array}$ & $\begin{array}{c}\text { Tertiary education } \\
\text { (ISCED levels 5-8) }\end{array}$ \\
\hline Ireland & 8.8 & 6.0 & 3.2 \\
\hline Greece & 21.0 & 19.7 & 12.2 \\
\hline Spain & 20.3 & 14.5 & 8.6 \\
\hline France & 15.5 & 9.2 & 5.1 \\
\hline Croatia & 9.3 & 6.9 & 5.3 \\
\hline Italy & 13.8 & 9.4 & 5.7 \\
\hline Cyprus & 7.7 & 8.0 & 6.2 \\
\hline Latvia & 13.7 & 7.1 & 3.6 \\
\hline Lithuania & 18.2 & 8.3 & 2.9 \\
\hline Luxembourg & 8.9 & 6.2 & 3.6 \\
\hline Hungary & 9.7 & 3.0 & 2.5 \\
\hline Malta & 4.6 & 3.2 & 2.2 \\
\hline Netherlands & 5.8 & 3.2 & 3.0 \\
\hline Austria & 10.7 & 4.0 & 2.0 \\
\hline Poland & 8.4 & 3.6 & 5.3 \\
\hline Portugal & 6.9 & 7.2 & 1.6 \\
\hline Romania & 6.3 & 4.0 & 3.0 \\
\hline Slovenia & 9.5 & 4.6 & 2.5 \\
\hline Slovakia & 30.9 & 4.8 & 3.9 \\
\hline Finland & 16.0 & 7.2 & 3.7 \\
\hline Sweden & 20.6 & 5.0 & \\
\hline & & & \\
\hline
\end{tabular}

\subsection{Doctorate graduates in the private labor market}

The demand for doctoral graduates in the labor market was also investigated in numerous studies (Salter and Martin, 2001; Pavitt, 1991, The Rugby Team, 2007).

In a review by Salter and Martin (2001), the training of human resources is presented as one of the most important contributions of academic research to the economy. Doctoral graduates are highly skilled individuals who can bring with them in any company and enterprise the knowledge they acquired directly through their research, but also a network of relationships with other highly skilled individuals (Pavitt, 1991).

A detailed picture of the perceived skills of doctoral graduates has been assembled by the Rugby Team (Rugby Team, 2007), which analyzes more than 50 studies to extract information on the employers' opinion on the doctoral graduates' job-related skills. The most mentioned concerns the difficulty in "making the transition from one working culture to another", lack of adaptability and interpersonal skills. For some employers, doctoral graduates may also be seen as overqualified and overspecialized (Rugby Team, 2007). However, the same study acknowledges that doctoral graduates hold and have developed important skills such as enthusiasm, critical analysis skills, research and presentation skills and public speaking skills. Table 2 presents the perceived skills and the missing skills of doctoral graduates. 
Table 2. Identified skills that employers perceive Ph.D. graduates hold or lack

\begin{tabular}{|l|l|l|}
\hline Skills group & Held skills & Lacking skills \\
\hline $\begin{array}{l}\text { Flexibility and } \\
\text { adaptability }\end{array}$ & $\begin{array}{l}\text { Commercial awareness, initiative, intellectual } \\
\text { ability and capacity to work autonomously }\end{array}$ & $\begin{array}{l}\text { Flexibility and } \\
\text { adaptability }\end{array}$ \\
\hline $\begin{array}{l}\text { Qualifications } \\
\text { and specific } \\
\text { skills }\end{array}$ & $\begin{array}{l}\text { Technical proficiency, specialist knowledge } \\
\text { and problem-solving skills }\end{array}$ & $\begin{array}{l}\text { Over-qualified, } \\
\text { overspecialized, the } \\
\text { narrowness of interest, } \\
\text { lack of self-management }\end{array}$ \\
\hline $\begin{array}{l}\text { Salary and } \\
\text { career path }\end{array}$ & $\begin{array}{l}\text { At the beginning of their career, they do not } \\
\text { require a much higher salary than non-doctorate } \\
\text { graduates }\end{array}$ & $\begin{array}{l}\text { High salary and fast } \\
\text { career achievement } \\
\text { demand }\end{array}$ \\
\hline
\end{tabular}

Source: Employers“ views of researchers skills - A comprehensive review of the existing literature into employers' views of the skills of early career researchers, The Rugby Team, September 2007

In a study by the European Science Foundation (2017), the authors of the study asked a sample of doctoral graduates to self-report their acquired competencies during the doctorate program and compare them with the competencies required by their actual job.

In figures 3, 4, and 5 there are presented the discrepancies between the acquired skills at the doctorate program and the required skills at the job. The required skills are different depending on the sector of work. For example, the respondents employed in service or other business sectors found the following competencies most important in the current job: problem-solving, effective communication, and critical analytical thinking, while the respondents employed in government or other public considered that methodology and languages are the most important skills to be held.

\section{Sector of employment: University}

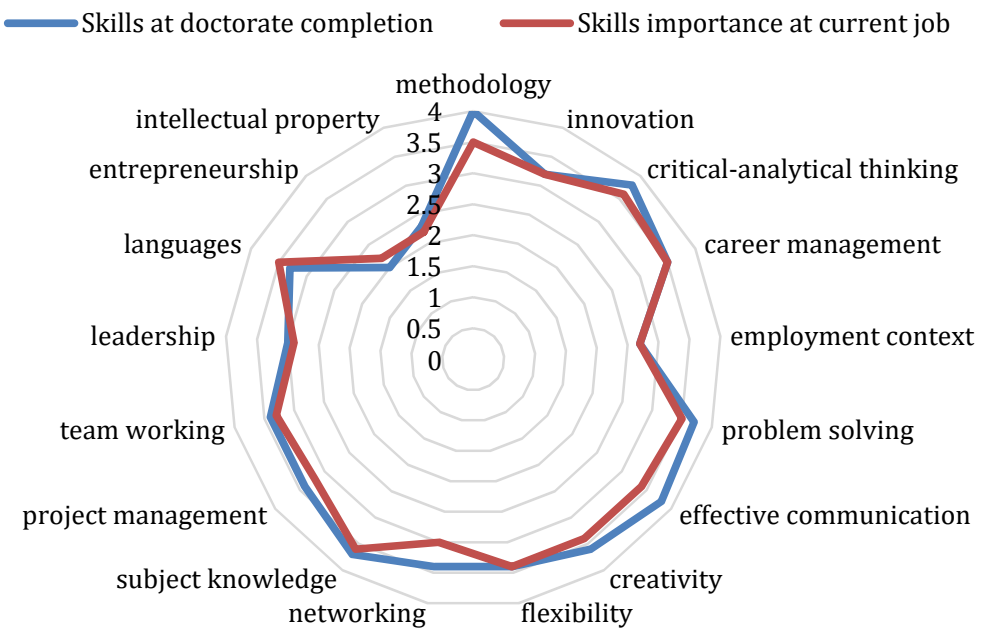

Fig. 3. The competencies of doctoral graduates held and those required by their employer Source: ESF (2017) 


\section{Sector of employment: Government}

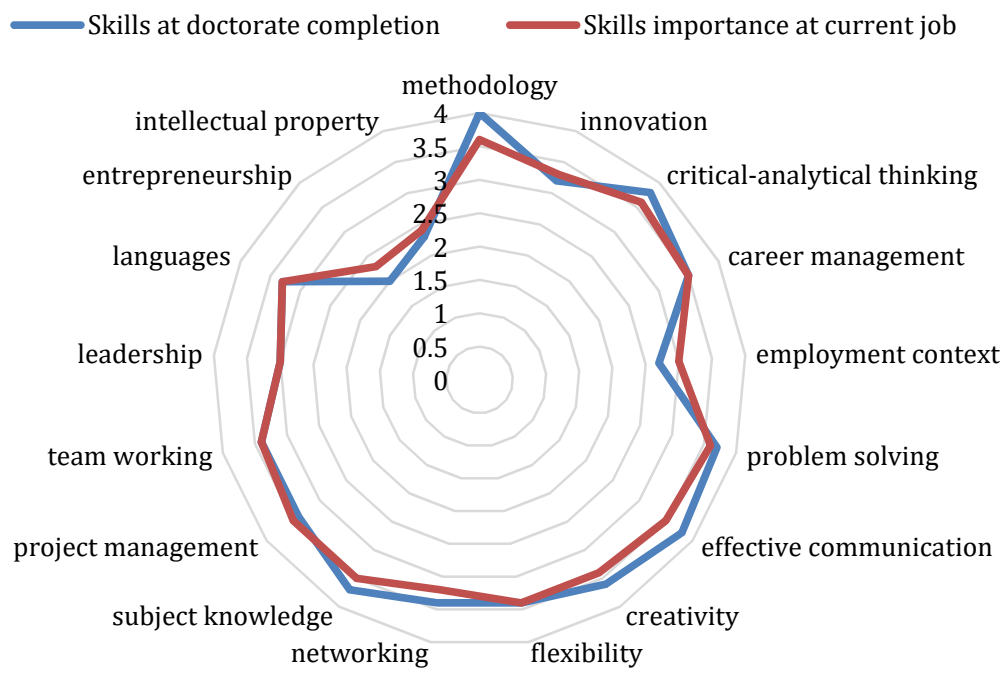

Fig. 4. The competencies of doctoral graduates held and those required by their employer Source: ESF (2017)

\section{Sector of employment: Services or other business sector}

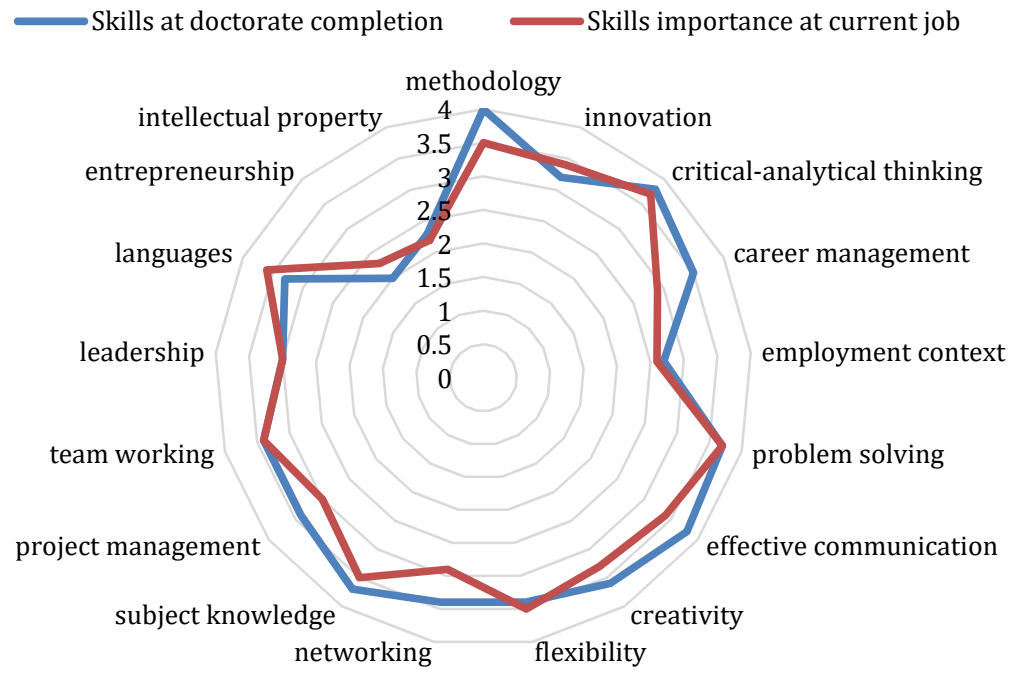

Fig. 5. The competencies of doctoral graduates held and those required by their employer Source: ESF (2017)

The ability to make meaningful connections and build relationships can be more valuable than other job-related skills to gain entry to, and progress within, many professions. Therefore, the networking of doctoral graduates is very important for the prospects of their career, either in the 
academic sector or not. The advantages of a doctoral graduate as found in the specialized literature can be shown in figure 6 .

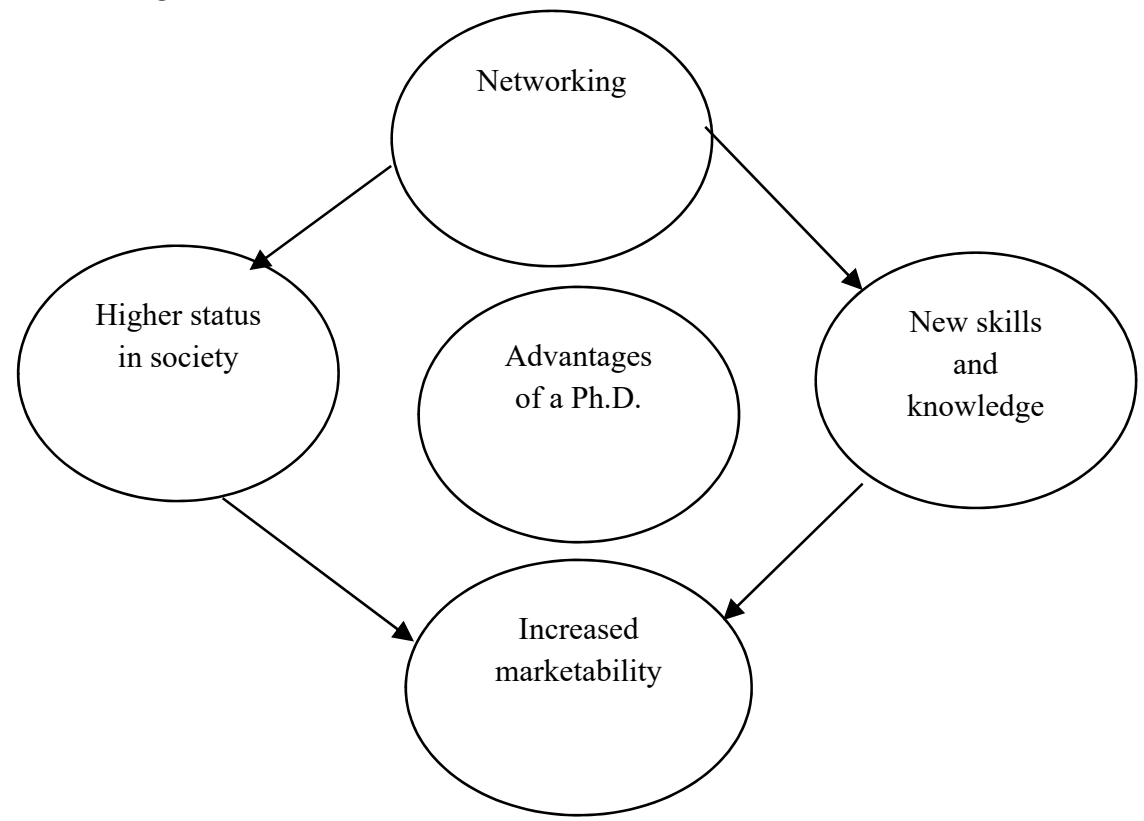

Fig. 6. The advantages of a Ph.D. in the labor market Source: Author's adaptation after Lucaci (2019)

\section{Conclusion}

The knowledge society recognizes to value knowledge a lot and knowledge is believed to increase with the level of education. In this context, the preparation of doctoral students for careers in various sectors of society is a very important task. The role of doctoral studies is changing and adapting to the labor market. Traditionally, doctoral studies were treated as the sign for pursuing an academic career, but nowadays this is not necessarily the case.

Thus, extensive research is needed to better understand the long-term employment patterns and benefits that a doctoral graduate has in the labor market. This research aimed to analyze the career prospects and the importance of the doctorate in the labor market. In the knowledge economy, employees must have the ability to solve complex problems, conduct research, and develop new ideas (Salter et al., 2001). The dominant features of the knowledge economy are innovation, education, creativity and the existence of well-trained and well-educated workers (Fonseca and Domingues, 2017; Hadad, 2017).

In this sense, the knowledge economy brings both opportunities and challenges. Universities need to consider the messages sent to potential and current doctoral students about the value and purpose of a doctorate and the extent to which they promote or criticize the vision of the knowledge economy (Åkerlind and McAlpine, 2017).

The results and findings of this study may indicate that a transition to a job in non-academic sectors may be difficult for doctoral graduates, and could suggest that the doctoral education institutions and the companies should make efforts to improve the training that prepares doctoral students for non-academic positions. A result of the COVID-19 pandemic is the rapid transformation of jobs and it is expected that the transition from blue-collar jobs to white-collar jobs will speed up, therefore increasing the need for more specialized, highly effective and intelligent people in those jobs. 
By capitalizing on concepts associated with and correlated with the notion of the knowledge economy and career opportunities for doctoral graduates, this research represents an approach that can help explain the issues that doctoral graduates encounter when trying to pursue a career. Indeed, such an approach requires several questions and resolutions of a pragmatic nature concerning an interesting and useful topic.

\section{References}

- $\quad$ A kerlind, G., McAlpine, L. (2017). Supervising doctoral students: variation in purpose and pedagogy, Studies in Higher Education, 42(9), 1686-1698, DOI: 10.1080/ 03075079.2015.1118031.

- Bell, D. (1973). The Coming of Post-Industrial Society. New York: Basic Books.

- Bolisani, E., Brătianu, C. (2017). Knowledge strategy planning: an integrated approach to manage uncertainty, turbulence, and dynamics. Journal of Knowledge Management, 21(2), 233-253.

- Eurostat (2020). Unemployment rate by educational attainment level, Retrieved from Eurostat, https://ec.europa.eu/eurostat/databrowser/view/tepsr_wc140/default/table?lang=en.

- European Science Foundation (2017). 2017 Career Tracking Survey of Doctorate Holders. Project Report. Strasbourg: ESF. Retrieved from: https://www.esf.org/ fileadmin/user_upload/esf/F-FINAL-Career_Tracking_Survey_2017_Project_Report.pdf.

- Fonseca, L.M., Domingues, J.P. (2017). Listen to ISO 9001: 2015 for organizational competitiveness: Correlation between change management and improvement. In Proceedings of the International Conference on Business Excellence, De Gruyter Open, 11(1), 916-926.

- Hadad, S. (2017). Strategies for developing knowledge economy in Romania, Management \& Marketing, Challenges for the Knowledge Society, 12(3), 416-430. DOI: 10.1515/mmcks2017-0025.

- Jarausch, K. (2004). Graduation and careers. A history of the university, in Europe. Universities in the nineteenth and early twentieth centuries. ed. W. Ruegg. 363-389. Cambridge: Cambridge University Press.

- Lucaci, A. (2019). Young people on the labour market in the context of the EU contemporary economy. The USV Annals of Economics and Public Administration, 19, 1(29), 58-65.

- Mowbray, S., Halse, C. (2010). The purpose of the Ph.D.: Theorising the skills acquired by students. Higher Education Research \& Development 29(6), 679-690.

- Neumann, R. (2002). Diversity, doctoral education and policy. Higher Education Research and Development 21(2), 167-178.

- OECD/Eurostat/UNESCO Institute for Statistics (2015). ISCED 2011 overview, in ISCED 2011 Operational Manual: Guidelines for Classifying National Education Programmes and Related Qualifications, OECD Publishing, Paris. DOI: https://doi.org/10.1787/ 9789264228368-3-e.

- Pavitt, K. (1991). What Makes Basic Research Economically Useful?, Research Policy, 20, 109-119.

- Probst, C., Lepori, B. (2008). What is a Doctorate? Changing Meanings and Practices in Communication Sciences in Switzerland. European Journal of Education, 43(4), 477-494.

- Romer P.M., (1986). Increasing returns and long-run growth. The Journal of Political Economy, 94(5), 1002-1037, Chicago University Press.

- Rugby Team, (2007). Employers'views of researchers'skills. A comprehensive review of the existing literature into employers' views of the skills of early career researchers, Cambridge, The Careers Research and Advisory Centre (CRAC) Limited.

- Salter, A.J., Martin, B.R. (2001). The Economic Benefits of Publicly Funded Basic Research. A Critical Review, Research Policy, 30, 509-532. 
- Schumpeter, J.A. (1934). The Theory of Economic Growth. Cambridge: Harvard University Press.

- $\quad$ Skovgaard Pedersen, H., (2014). New doctoral graduates in the knowledge economy: trends and key issues, Journal of Higher Education Policy and Management, 36(6), 632-645, DOI:10.1080/1360080X.2014.957891.

- Smith, A. (2010). One step beyond: Making the most of postgraduate education. London: Department for Business Innovation and skills.

- U.S. Bureau of Labor Statistics (2020). Unemployment Rate - College Graduates - Doctoral Degree, 25 years and over [CGDD25O], retrieved from FRED, Federal Reserve Bank of St. Louis; https://fred.stlouisfed.org/series/CGDD25O.

- U.S. Bureau of Labor Statistics (2020). Employed full time: Median usual weekly nominal earnings (second quartile): Wage and salary workers: High School graduates, no college: 25 years and over [LEU0252917300A], retrieved from FRED, Federal Reserve Bank of St. Louis; https://fred.stlouisfed.org/series/LEU0252917300A.

- $\quad$ van der Weijden, I., Teelken, C., de Boer, M. Drost, M. (2016). Career satisfaction of postdoctoral researchers in relation to their expectations for the future. Higher Education 72, 25-40, https://doi.org/10.1007/s10734-015-9936-0.

- World Bank Group (2018). Skills and Europe's Labor Market - How technological change and other drivers of skill demand and supply are shaping Europe's labor market, [Online], Available: https://openknowledge.worldbank.org/handle/10986/29965.

- Zolas, N., Goldschlag, N., Jarmin, R., Stephan, P., Smith, J. O., Rosen, R. F., Allen, B. M., Weinberg, B. A., Lane, J. I. (2015). Wrapping it up in a person: Examining employment and earnings outcomes for Ph.D. recipients. Science (New York, N.Y.), 350(6266), 1367-1371. https://doi.org/10.1126/science.aac5949. 



\title{
Cap. 15. THE INFLUENCE OF FEMALE LEADERSHIP ON ORGANISATIONAL CULTURE
}

\author{
Bogdan Andrei Tiliuță ${ }^{1}$, Ioana Raluca Diaconu² \\ ${ }^{I}$ Alexandru Ioan Cuza University, Faculty of Economics and Business Administration, Iași, Romania, \\ tiliuta.bogdan@yahoo.com \\ ${ }^{2}$ Alexandru Ioan Cuza University, Faculty of Economics and Business Administration, Iași, Romania, \\ ioana.raluca.diaconu@gmail.com
}

\begin{abstract}
As an integrated part of management, leadership carries a lot of weight with how changes are put into effect in the organisational culture spectrum. Given the role of leadership in the organization, we can say that it is the main driver of change, which, in its essence, changes the dynamics when it comes to the intrinsic motivation of personnel. This research analyzes the main types of leadership and their dominant features. It also follows the effects generated by the utilization of different types of leadership within the companies. Consequently, we determined that by introducing women who promote the transformational leadership style into the leadership structure, major and rapid changes are generated in the sphere of organisational culture in order to increase the results obtained.
\end{abstract}

Keywords: leadership, gender, management, organisational culture.

\section{Introduction}

The male-female duality has been existing since ancient times, and differentiation is addressed in most branches starting from sciences such as religion, biology, physics, chemistry to econometric studies. The approach to the perception of gender belongs to the dichotomous one, but there are divisions of science where specialized studies use other types of approaches.

The approach of masculinity and femininity in the field of leadership is not determined by the gender affiliation of the decision-makers of an organization, but by the dominant personal characteristics of the leader.

\section{Feminine characteristics}

Even though the dominant gender-specific characteristics are debated in extensive psychology and sociology studies, they are largely determined by the anatomical features of the characters analyzed.

According to studies, the main differences between male and female brains, from an anatomical point of view, are the following:

Table 1. The main anatomical differences between male and female brains

\begin{tabular}{l}
\hline Masculine \\
\hline - thicker right hemisphere (more spatial, more \\
mathematical) \\
- narrower fusiform gyrus in men than in women \\
(lower degree of femininity) \\
- the orbitofrontal cortex is smaller (lower ability to \\
process emotions) \\
- men use gray matter to think / function \\
- left lower parietal lobe larger than right (ability to \\
understand spatial relationships and connections \\
between elements, perception of time and space, \\
ability to rotate images in 3-D memory)
\end{tabular}
Feminine

- thicker left hemisphere (more communicative)

- women use white matter to think / function (the process is faster)

- deeper limbic system (ability to express emotions, greater ability to get in touch and relate to people)

- lower right parietal lobe larger than the left (ability to focus on specific stimuli - baby crying, etc.)

- frontal lobe and limbic cortex is larger (responsible for problem-solving and decision-making)

- the ratio between the size of the orbitofrontal cortex and the size of the larger amygdala (production of emotional reactions, control of emotional reactions) 
Therefore, we can expect women to be more communicative, emotional, sociable. Their problem-solving and decision-making mechanisms seem to work faster than in the case of men. When it comes to males, we can expect a higher technical ability, an increased rigour, a greater capacity to understand mechanisms, an imaginary projection of the elements, and a better capacity to approximate time and space than in the case of women. Hence, we can conclude that following the anatomical analysis, a number of stereotypes can be generated about the behavior of women and men in general.

According to the general theory of systems, the organization can be perceived as an open system where the entity itself is considered a "black box" and is affected by the exchange of information within the environment in which it operates (Bertalanffy, 1969). However, the internal activity of the organization is considered a closed system in which the entropic effect develops. In line with those presented, the management activity has the role of transforming and reversing this effect through structural and functional methods to prevent Darwinian approaches.

In the case of management, the information encoded and transmitted by the communicators must be as fully captured, understood and capitalized as possible by the receivers in order to make the correct and necessary decisions for a favourable evolution. However, the encoding and later on, the understanding of messages, is directly affected by human qualities.

Bailey (2001) defines entropy as the state of disorder in a system, and negentropy the opposite of it - a general state of order. Zemansky apud Leff \& Rex (1990) argues that information cannot be assimilated to negentropy, but there is a strong correlation between them. Therefore, we can deduce that negentropy is assimilated with the information transmitted and used correctly and completely by an entity, so that it generates added value compared to the entropy used in the internal processing of information.

Accordingly, we can conclude that in order to generate correct management approaches to increase organisational results, it is essential to adapt and develop information communication skills, but also to analyze and understand them correctly. A classic model of not valuing the messages/information on the market is given by the Edsel project of the FORD company launched in 1956 and stopped in 1959 after approximately 400 million dollars were invested. The project is the most famous failure on the car market and the CEO at the time, Henry Ford II, concluded that "The aim was right, but the target moved" (Dicke, 2010). The main cause of this failure was market information and signals indicating a reorientation in consumer behavior being completely ignored.

Moreover, Covrig (2007) concludes that increasing the degree of empathy generates a decrease in information entropy. A lower informational entropy reported at the level of non-entropy generates added value to the activities and implicitly performances of the organization as a whole.

Corroborating the approach of the general theory of systems, as well as the anatomical studies, we deduce the fact that through the organic characteristics, women can generate organisational results if they are introduced in the managerial system.

\section{Feminine leadership and organizational culture}

Leadership as part of management has the role of facilitating the relationship with employees, so that they are motivated, to generate coherence of actions in order to achieve the objectives pursued. The leader has the essential role of being the direct mediator of the organization with its personnel.

Given the need to change and adapt the organisational culture to the specifics of the everchanging market, but also as a result of market signals, the organization must take the necessary measures to remain anchored in everyday reality. These measures cannot be applied without subordinate employees competing to make the changes.

Simple on-the-job training (performing activities/production in a quantity or at a faster pace than another reference period or with a higher quality of products/services) is not enough in the face of change. For this reason, given the roles of leadership, one can draw the idea that this concept is the only viable, fast and effective solution for the change process and its implications. In line 
with the above, there is a growing interest in the concept of leadership, which has lately become much debated. There is a significant relationship between increasing the number of changes in the organization and developed, improved leadership.

Leaders will primarily have to choose the people they work with, they must have a clear vision of the future, they must also convey ideas so that they are understood, and then ultimately they have to ensure that the employees will be involved in making changes in order to achieve the desired objectives.

However, choosing the directions of change for organisational development is not as simple as it seems. If we approach this issue from the deductive point of view, of organizing the activities so that they lead to the achievement of the proposed goal, and not to the activity of change/adaptation, then this attribute will be exclusively the task of the manager. If instead, we analyze the establishment of the direction of change, then this activity is purely inductive. The leader must be informed, find methods, tools, and connections in order to anticipate possible future developments. Consequently, setting the direction by the leader is not done through plans, but by creating strategies and keeping the focus on the bigger picture.

Concluding on the presented facts, we can say that leadership is an activity of leading people, independent of management, which aims to facilitate organized and planned activities to accomplish the strategic objectives of the organization. Leadership is strongly related to characteristics such as the ability to relate, communicate, persuade, and motivate personnel.

Similar to other paradigms with which one works in various sciences and which are not sufficiently known by the general public, leadership has a series of stereotypes associated with it. Stereotypes are connected with prejudice and then with discrimination. Stereotypes are just a general, unconscious opinion of a theory, prejudices are the result of stereotypes regarding emotional action, and discrimination is the factual action generated by emotional states.

Sczesny et al. (2006) found the presence of stereotypes in leadership after conducting two experiments in which they observed that participants gave higher scores for the leadership ability of people according to their gender. Specifically, people with typically masculine characteristics were considered more competent in terms of leadership. These stereotypes are generally related to gender (depending on how men and women are generally perceived). Most stereotypes are generated by a person's experience, culture and knowledge. For this reason, depending on the geographical area and the characteristics of the organisational culture in that area, stereotypes may change in intensity or even disappear.

The characteristic qualities associated with gender-specific leadership styles determined by Park (1996) are presented in the following figure.

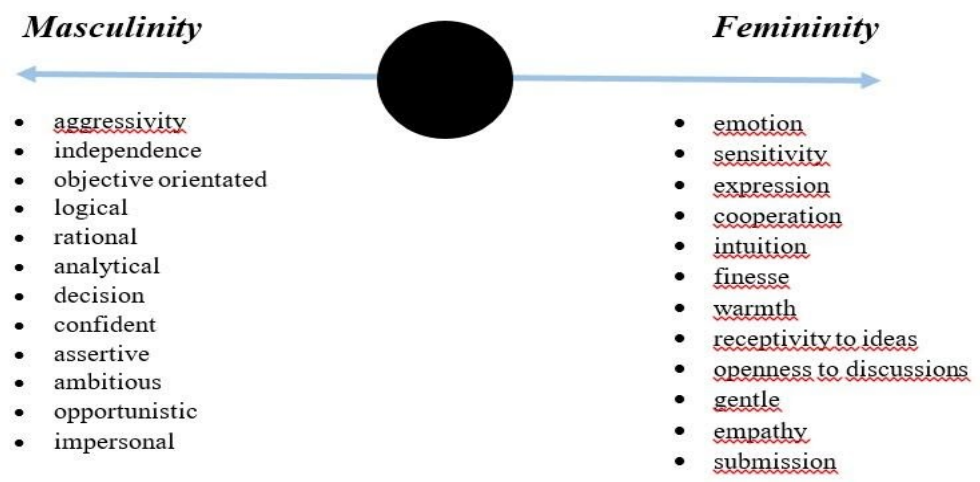

Fig. 1. Characteristics associated with gender type leadership styles Source: processing after Park (1996) 
In specialized studies, it is often noted that there may be differences between managers and leaders in the sense that not all managers have leadership skills and vice versa.

There are five types of leadership as follows: charismatic leadership, transactional leadership, transformational leadership, laissez-faire leadership and cultural leadership.

Charismatic leadership best fits into the approach that leaders are born and cannot be formed. This type of leadership emphasizes the personal qualities of the leader to motivate and influence the personnel around with the help of charisma.

Transactional leadership is based on the leader's ability to negotiate, in which case the qualities such as coaching, development and improvement of the leader can be highlighted, so the approach according to which leaders cannot be trained loses its scientific value. This type of management is largely based on offering rewards, which is why the leaders need to have access to the company's resources or the leaders will cease to fulfil their duties. If the leaders lose credibility, in most cases, they no longer can deliver a good quality of leadership.

People who have a developed sense of perceiving or understanding market messages rely on transformational leadership. They have an increased tendency to bring about beneficial organisational changes and increase the company's results. We can conclude that this type of leadership is needed in drastic times of transition. Given this context, as well as the motivation for the growing interest of leadership today, we can argue that this type of leadership is intended to be applied by interested organizations in order to keep pace with the market and to develop in a suitable way.

What makes the "laissez-faire" leadership style different from the other types of leadership in that it conveys vision and sets goals, but it leaves the transition to subordinates/followers. These leaders have a contribution only to macro activities (in the strategic and/or operational sphere), while the executive or micro sphere is disregarded.

Cultural leadership is special by promoting the elements of organisational culture of the company in order to motivate and carry out specific activities, emphasizing the values, attitudes and norms assumed individually or at a group level.

The theory based on gender-based leadership specifies that men are more task-oriented, more impersonal and have a more autocratic leadership style - adopt a transactional leadership style while women tend to be more collaborative, familiar, prefer more democratic leadership style adopt a transformational or even participatory leadership style. (Pounder \& Coleman, 2002; Eagly \& Johnson, 1990; Trinidad \& Normore, 2005; Eagly et all., 2003). Moreover, the characteristic of transformational leadership highlights the social values of the female personality which includes building human connections, communication, constructive consensus, power used as influence and teamwork for a common goal. (Rosener, 1990; Druskat, 1994; Bass et all, 1996; Kark, 2004).

However, whatever type of leadership is adopted, it requires making decisions about what needs to be done, making human connections and relationships that can lead to achieving the common plan, and ultimately ensuring that employees will do what they need to do. Given this aspect, a model was developed to support the specific decision-making activity at the level of leaders by the consulting firm Ki ThoughtBridge, the model being called IML (Integrated Model of Leadership) (Fig. 2). This involves defining four quadrants determined by the intersection of two axes: the main axis Internal - External and the secondary axis Technical - Adaptive. 


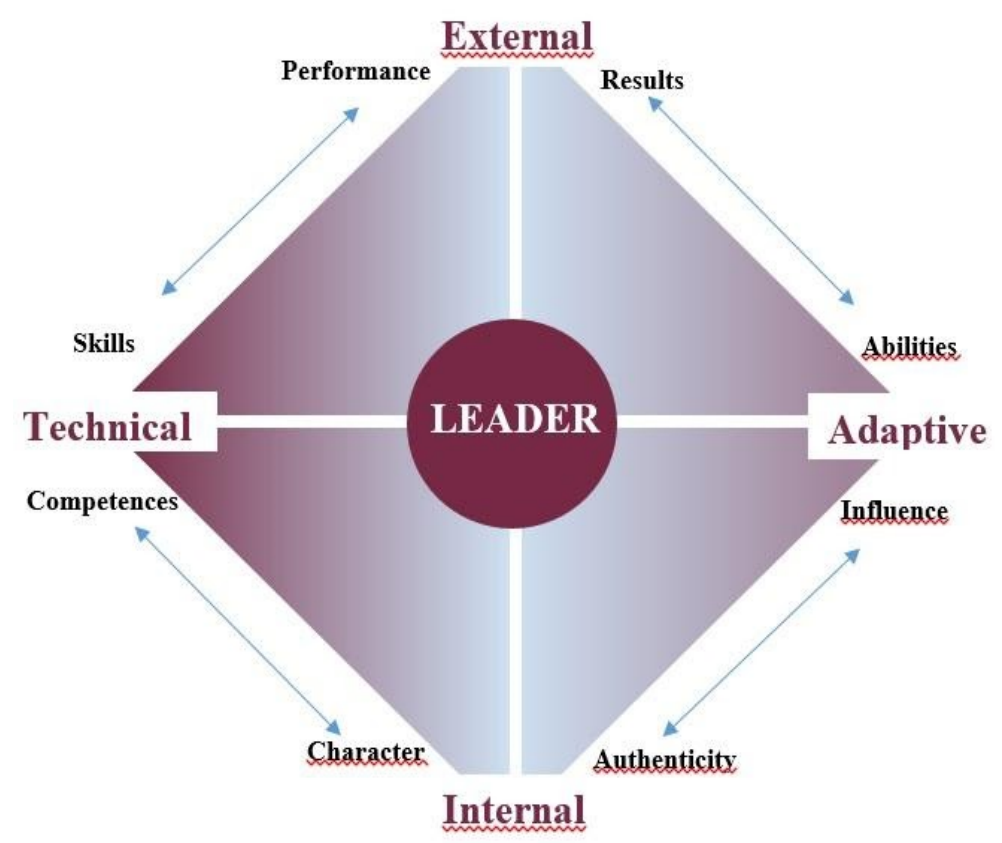

Fig. 2. IML decision - making mode

Source: processing after Ki ThoughtBridge (2016)

Technical skills are determined by the knowledge gained through the classic educational stages, specialization courses or experience. These skills can be assimilated to the concept of Know-How, skills that are applied in clear cases when the context for the problem to be solved is familiar to the leader.

Adaptive skills include specific problem-solving characteristics in areas where the sphere of personal knowledge is exceeded, where the context of the activities is not yet known, having the role of maintaining stability. These skills require patience, critical thinking and the ability to use internal strengths for these situations, such as organisational diversity.

The internal environment refers to the activities that the leader performs personally for the development of ideas, beliefs, perceptions, assumptions, more precisely the activities of internal reflection. These activities develop the leaders' capacity for empathy, adaptability to work styles, self-knowledge which together leads to facilitating the fulfillment of activities in the external sphere.

The external environment refers to the tangible achievements made to meet the expected objectives. It consists of the collaboration between one's interest and the common one for the fulfillment of the organisational goals.

The study determined that leaders who want to achieve goals, but lack the intrinsic characteristic and implicitly adaptive skills, will waste energy and eventually the dedication of their followers. The goal will be achieved, but the leader will lose power and implicitly the number of supporters.

Ki ThoughtBridge defines leaders as compassionate, respectful, attentive to the people around, determined to listen and understand people's needs without forcing their vision on others, without intending to harm people. If harm is done, then the leader defined by Ki ThoughtBridge helps fix the error made. These leaders are consistent, principled, flexible, yet with clearly defined boundaries and are reliable (Scott, 2016). 
We can notice that six out of the ten characteristics defined by Ki ThoughtBridge overlap with the characteristics associated with specific female leadership.

The gender approach has been applied to leadership by many researchers, with main characteristics (such as competitiveness, independence, dominance) being associated with masculinity, while common characteristics (collaboration, helpfulness or charisma) have been associated with femininity. Thus, it is determined that transformational leadership consists of common characteristics.

Evidence in this regard has been provided by studies conducted by Eagly \& JohannesenSchmidt (2001), Rohmann \& Rowold (2009) and many others, but they also highlighted the fact that the reward system for transactional leadership (what is expected of a follower and what is received from him/her) is increasing in the case of women.

Therefore, given the theory of open systems regarding negentropy, information theory, as well as the socio-political and cultural context, we can conclude that the introduction of women in leadership, by addressing the transformational style, leads to major changes in the organisational culture, so that positive results can be generated over time.

\section{Conclusions}

In this paper, we have presented the main types of leadership and highlighted that leaders who adopt a transformational leadership style have an increased tendency to bring about beneficial organisational changes and increase the results of the company. Therefore, we can argue that this type of leadership is intended to be applied by organizations interested in keeping up the pace with the ever-changing market and developing in an adequate fashion.

Moreover, the gender approach has been applied in the case of leadership by many researchers, who have determined that transformational leadership is associated with common characteristics, so specific to female traits.

In the light of what was presented, it was concluded that by introducing women who promote the transformational leadership style in the leadership structure, major and rapid changes are made in the sphere of organisational culture in order to generate positive results.

\section{References}

- $\quad$ Bailey, K. D. (2001). Entropy Systems Theory. Encyclopedia of Life Support Systems.

- $\quad$ Bass, B., Avolio, B., Atwater, L. (1996). The transformational and transactional leadership of men and women. Applied Psychology: An International Review, 5-34.

- Bertalanffy, L.V. (1969). General System Theory - Foundations, Development, Applications. New York: George Braziller.

- Covrig, S. S. (2007). Managementul Resurselor Umane (teză de doctorat). București: Universitatea „Politehnica” București.

- Dicke, Tom (2010). The Edsel: Forty years as a symbol of failure. Journal of Popular Culture. 43 (3), 486-502

- $\quad$ Druskat, V. (1994). Gender and leadership style: transformational and transactional leadership in the Roman Catholic Church. Leadership Quarterly, 99-199.

- Eagly, A. H., \& Johannesen-Schmidt, M. C. (2001). The leadership styles of women and men. Journal of Social Issues, 781-797.

- Eagly, A., \& Johnson, B. (1990). Gender and leadership style: a meta-analysis. Psychological Bulletin, 233-256.

- Eagly, A., Johannesen-Schmidt, M., \& van Engen, M. (2003). Transformational, transactional, and laissez-faire leadership styles: a meta-analysis comparing women and men. Psychological Bulletin, 569-591.

- Kark, R. (2004). The transformational leader: who is (s)he? A feminist perspective. Journal of organisational change management, 160-176. 
- Leff, H. S., \& Rex, A. F. (1990). Maxwell's Demon: Entropy, Information, Computing. CRC Press.

- Park, D. (1996). Gender role, decision style and leadership style. Women in Management Review, 11(8), 13-17.

- Pounder, J., \& Coleman, M. (2002). Women - better leaders than men? In general and educational management it still 'all depends'. Leadership and Organisation Development Journal, 23(3), 122-133.

- Rohmann, A., \& Rowold, J. (2009). Gender and leadership style: A field study in different organisational contexts in Germany. Equal Opportunities International, 1-32.

- $\quad$ Rosener, J. B. (1990). Ways Women Lead. Harvard Business Review, 68, 119-125.

- Scott, K.T. (2016). The Integrated Leader: A Matter of Trust. https://www.kithoughtbridge.com/

- Sczesny, S., Spreemann, S., \& Stahlberg, D. (2006). Masculine=Competent? Physical Appearance and Sex as Sources of Gender-Stereotypic Attributions. Swiss Journal of Pshycology, 15-23.

- $\quad$ Trinidad, C., Normore, A. (2005). Leadership and gender: A dangerous liaison? Leadership \& Organization Development Journal, 26(7), 574-590.

- Zaidi, Z. F. (2020). Gender Differences in Human Brain: A Review. The Open Anatomy Journal, 37-55. 



\title{
Cap. 16. LINK BETWEEN EMPLOYEES EMPOWERMENT AND ORGANIZATIONAL LOYALTY: LITERATURE REVIEW
}

\author{
Simina Nicoleta Bohâlțeanu \\ Alexandru Ioan Cuza University of Iaşi, Doctoral School of Economics and Business Administration, Iași, \\ Romania,bohalteanu_simina@yahoo.ro
}

\begin{abstract}
One of the main issues faced by companies is finding out how to win employee loyalty, because a loyal employee tends to have a greater motivation and implicitly a certain psychological well-being. The aim of the study is to analyze the existing link between employees' empowerment and organizational loyalty, in the light of empirical evidence in the literature. A qualitative, content-based analysis of 23 articles was made, following an inductive approach - grouping the data through an emerging framework, and then looking for the existing relationships between the concepts under consideration. The results indicate that both psychological and structural empowerment have a positive, statistically significant influence on organizational loyalty. The most important aspects of empowerment are meaning, access to information, organizational support. Psychological empowerment is most often associated with affective employee loyalty, but this positive relationship disappears when the organizational context is unfavorable (conflicts occur).
\end{abstract}

Keywords: psychological empowerment; structural empowerment; organizational loyalty.

\section{Introduction}

In a constantly changing competitive environment, organizations have to face the many challenges, but perhaps the most important of them is the human resource with everything it involves. Regardless of the field or sector of activity, any firm targets organizational success, and an essential means to achieve it is to have a competent, motivated, sustained, and ultimately loyal human resource. These rapid changes in technology, as well as the different defining features of employee generations, have made workplaces more complex and demanding in some areas (eg IT, medicine, education, banking, etc.) which is why finding efficient and effective strategies to keep loyal the good employees has become difficult for most business managers.

In order to improve this, the present study finds applicability and, at the same time, the importance for those managers by highlighting specific organizational practices empowering employees, which can be a good strategy for winning employees' loyalty to the company. In this respect, the purpose of this study is to analyze the existing link between employee empowerment and organizational loyalty, in the light of empirical evidence in the literature. The end of this review will consist of tracing future directions that business managers can take into account.

\section{Conceptual aspects}

\subsection{Employees empowerment}

From the etymological point of view, the word empowerment involves a legal side, referring to an "act by which one is empowered to act." (DEX, 2009) It can also be understood as "delegation", "authorization", "right", "power" (Dictionary of synonyms, 2002). This definition emphasizes the traditional approach to empowerment, which involves autonomy in decisionmaking and the delegation of power (responsibility), outlined by Kanter's theory (1993).

Bartunek \& Spreitzer (2006) analyzed the evolution of the "empowerment" concept, emphasizing the difference in meanings of the same word over the years, in six disciplines: religion, psychology, sociology, education, social assistance and management. The conclusion of the two authors is that the meaning of empowerment varied according to the periods and trends of each discipline, but the one that made a major contribution to its alteration was the management 
literature, which claims that an employee is empowered when holding more many responsibilities, thus becoming more accountable for the work place.

In the literature, the concept of empowerment was outlined in management through two approaches: a relational one and a motivational one (Conger \& Kanungo, 1988, p. 473). At a relational or structural level, empowerment involves distributing formal power between managers and subordinates, holding control over the organization's resources. At the motivational level, empowerment is treated from a psychological perspective (the field of human psychology), as it takes into account the human resource, and power and control are considered as internal needs specific to each individual.

Conger and Kanungo (1988, p. 474) define empowerment as a process that "allows the development of a strong sense of efficacy" among employees, and Thomas and Velthouse (1990, p. 666) consider it "a motivation of the intrinsic task increased".

Also, Spreitzer (1995, pp. 1458-1460) considers empowerment as a psychological construct, made up of four dimensions: meaning, competence, self-determination, impact; which is influenced by a number of factors such as: the place of control (internal or external to the employee), self-esteem, access to information and rewards; and which in turn has an influence on managerial efficiency and innovative behaviors. Regarding the four dimensions, we can say that the significance dimension refers to the importance of work for the individual and to the matching of the requirements of the post and its values, beliefs, behaviors. The competence dimension involves an employee's ability to perform tasks in terms of self-efficacy and confidence in their own abilities. The self-determination dimension implies the existence of a sense of autonomy in the decision making of certain activities. The impact dimension refers to the degree of influence an employee has on the results of his / her work at the individual, group, organizational level.

According to Laschinger et al. (2001), structural empowerment involves the following elements: formal power, informal power, perceived access to opportunity structures, information, support and resources. In addition, they believe that structural empowerment is the basis of psychological empowerment, which in turn has a number of consequences, such as increasing employee satisfaction, lowering the sense of exhaustion at work, developing a sense of loyalty to the organization. In this sense, empowerment is perceived as having the purpose of developing the ability to access and control material and non-material resources and to mobilize them effectively to influence the outcome of the decision (Oladipo, 2009). Gaudreau \& Blanchard (2012) claim that in the "era of globalization, employees need a mandate from the organization so that they are able make quick decisions and respond promptly to any change in the environment."

\subsection{Organizational loyalty}

As with the empowerment concept, and in the case of loyalty, there have been many approaches and definitions that have undergone changes due to the context in which they have emerged. In this sense, referring only to the meaning of the word loyalty, according to the Explanatory Dictionary of Romanian Language (2009), we find that it is "the attitude of being loyal, sincerity, leal." Moreover, in the British Encyclopedia (1884) we discover that its meaning implies feelings such as devotion, attachment to an object, an ideal, a duty or a cause. Also, due to the various fields and disciplines, several aspects of this concept have emerged, such as: loyalty to a product/brand - known as consumer loyalty; loyalty to a country; loyalty to the organization.

According to Withey (1992), Hirschman (1970) is the one who began to explain loyalty in an organizational context, thus understanding a form of attachment that involves two aspects: "the voice" (taking active measures to improve the workplace by discussing issues with all those involved) and "going out" (looking for another job).

In terms of the evolution of the significance of loyalty in the organizational context, two perspectives (McGuinness, 1988) have emerged over the years: a traditional one (specific to the second half of the 20th century) and a modern one (specific to today). Thus, according to the first perspective, employees' loyalty to the company was given by the approach of labor contracts 
(stable economic environment, promotion of family value in the company, mentality that once the employee hires the individual will remain permanently in the company). In the new approach (due to the emergence of crises, restructuring, rationalization, staff cuts), loyalty to the organization is less perceptible, and is subject to certain conditions (eg, employee preoccupation for career development - access to development opportunities). Preko \& Adjetey (2013) perceive employee loyalty in terms of behaviors, acting as "lawyers" for the organization to promote products/ services to consumers, as well as a good image in the eyes of the target.

In an attempt to better understand this construct, various authors have come to the conclusion that there are several forms of loyalty that an employee can demonstrate in his organization. According to Allen and Meyer (1990), loyalty can be understood in three forms: affective loyalty, normative loyalty, and economic or continuous loyalty. All these forms are manifested first at the attitudinal level of the individual, and then at the level of behavior, in the light of the decisions made and the actions taken. The first form of loyalty involves an emotional attachment, the employee internalizing the company's values and identifying with its purpose and objectives. The second form of loyalty is based on a sense of duty, a moral attachment, employees considering their work to be important, and being aware that others are counting on their results. The last form, economic loyalty, implies a feeling of loss when leaving the company, as employees are analyzing the cost-benefit relationship, and if costs are greater than benefits, then they will continue their work in the organization in a respectful way.

Other forms of organizational loyalty existing in the literature are similar to those outlined above, but with some semantic differentiation. Thus, there are: unconscious loyal behavior, passive loyalty, reformist loyalty (Graham, 1992); managerial loyalty, continuous or coalition (Fiorito, Summer 2007); moral loyalty, calculated loyalty, forced loyalty (Danguole, 2009).

According to Elegido (2013), being loyal to a single employer brings with it a number of advantages such as: loyal employees tend to have a greater motivation; to be more confident; to improve the performance of the organizations they work for, and in this way also to benefit from professional satisfaction; to contribute to the general good of society; to extend the employee's field of interest to additional objectives.

\section{Methods}

The design of the research is a qualitative one, based on a documentary research of 23 scientific articles on employee empowerment and organizational loyalty, on which a data content analysis was carried out. The types of data used are secondary, being in the form of written papers (structured text) of scientific articles.

The search for articles was done using the Google Academic search engine, and the data sorting was done by relevance to the search topic, in this case the two key concepts: empowerment and organizational loyalty, and the number of citations. The use of the Google-Academic search engine did not negatively influence the retrieval of the data sample as it highlighted the most relevant scientific papers on the proposed subject, papers that are indexed in important journals of management, psychology, human resources.

In terms of data analysis, an inductive approach was chosen because it was first considered to group the data using an emerging framework and then to search for the existing relationships between the concepts under consideration. To begin the analysis of the 23 articles, the following steps were taken:

1. Importing the database into the coding and qualitative data analysis program - Nvivo, through the references added to EndNote.

2. Run a word frequency analysis in order to identify the most used and important for the chosen subject (which facilitated the start of the coding process).

3. Run a cluster analysis based on the similarities between word-level articles to find out which ones have similar themes.

4. Making a first reading in order to trace the main themes. 
5. Initial encoding.

6. Resuming reading and coding after three weeks.

7. Analysis of the coding results and their interpretation.

The qualitative content analysis was used because it is specific to the analysis of the specialized literature, offering the possibility of contouring the conceptual area and then checking/ testing it in certain contexts. In addition, this approach (through the Nvivo program) allows a better structure of the ideas contained in the articles to be analyzed, compared and even revised after a certain period of time, thereby eliminating a certain subjective side of the author. Realizing a parallel in academic research, this approach is particularly present in interviews (Greasley et al., 2005), allowing a deeper analysis, at a semantic, understandable level.

\section{Results and discussions}

Following a word frequency analysis, the central words relating to the variables in question were observed, namely: empowerment and organizational loyalty. But important are the adjacent words that highlight the spectrum of knowledge, respectively the points of interest in the analyzed articles. In this respect, we can realize that the study of the two variables implies the existence of the employees, the working relations between them, the behaviors and, implicitly, a framework for their development.

The cluster analysis (Figure 1) made on articles by word similarity, in order to outline common points, highlighted the fact that the first cluster consisting of 12 articles has central and similar elements, in addition to the proxy variables, loyalty, and the variable related to leadership, context of research (healthcare). The second group, consisting of 13 articles, has as a common point the study of the impact of some variables on others (all articles containing the term "the impact" in the title).

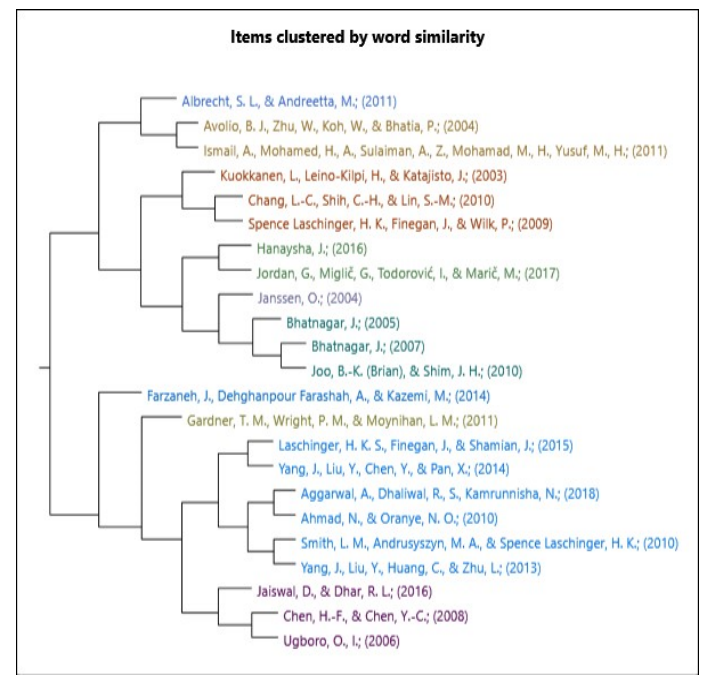

Fig. 1. Cluster analysis based on word similarity (article level) Source: author creation

It seems that psychological empowerment is most often associated with affective loyalty of employees (Aggarwal, 2018; Bhatnagar, 2007; Jaiswal, 2016; Kuokkanen, 2003), which is to a great extent true, because employees who will consider their work important and the values of the company are their values, they will demonstrate a high level of emotional attachment to it. However, Janssen (2004) considers that the positive relationship between employees' psychological empowerment and organizational loyalty disappears when the organizational context is unfavorable by the occurrence of conflicts between them and the superiors. The existence 
of such conflicts leads to a state of stress that prevents the employee from developing feelings of attachment to the organization and implicitly assumes an active role in the accomplishment of the work tasks. In this respect, it is important that managers do not obstruct the work of their employees by supporting and demonstrating that they are important to the organization and that they add value to it.

This perspective is reinforced by Kuokkanen's (2003) according to which employee empowerment has a positive effect on affective loyalty, but also on the level of trust in management. In addition, Joo (2010, p. 437) takes the view that business managers need to develop a learning-centered organizational culture, open communication between employees and superiors, as this will facilitate the process of psychological empowerment and ultimately lead to reduce the intention of individuals to leave the company and implicitly to develop attitudes and behaviors specific to organizational loyalty.

Taking into account the other dimensions of psychological empowerment, respectively forms of organizational loyalty, we can say that between the level of competence perceived by employees and the level of affective loyalty there is a significant negative correlation in the context of a restructuring of the company (Ugboro, 2006). That is, the more employees in this environment will perceive a higher level of their own skills, the more the desire and the need to stay in the organization will decrease. Studies also show that there is a weak link between continued or economic loyalty and employee empowerment (Laschinger, 2002; Bhatnagar, 2005), which emphasizes that individuals do not remain in the organization unless they develop positive cognitive abilities and their stay within it for economic reasons is not influenced by the level of empowerment (so they can leave at any time).

Other results reveal that there is a negative relationship between employee empowerment and loyalty to the company (Chen, 2008, Ahmad, 2010) and no link (Smith, 2010). This may be due either to the existence of other variables influencing loyalty, which makes empowerment mediate that link; or to different socio-cultural contexts and implicitly to the level of development of the countries/regions where the research has been conducted (Ahmad, 2010, p. 590). As for the existence of another variable in the model, psychological empowerment has played a mediation role between work restructuring and organizational loyalty (Chen, 2008), respectively between transformational leadership and loyalty (Ismail, 2011); or empowerment has an influence on employee loyalty only through the mediation effect of work satisfaction (Chang, 2010).

Taking into account the organizational approach to empowerment, the results of Yang's research (2013) show that there is a direct but also indirect link between structural empowerment and organizational loyalty through the presence of the mediation factor - organizational practices. Also, recently graduated employees have a high level of affective loyalty while at the same time perceiving a high level of empowerment at the organization level as well as at the individual level. For these levels to be the highest, employees also need to feel a low level of supervision and lack of politeness among colleagues (Smith, 2010). According to Laschinger et al. (2009), at the unit level, empowerment has a direct positive effect on employees' perceptions of psychological empowerment and organizational loyalty. In this respect, it is important for managers to pay attention to the contextual elements within their companies so that they can determine and eliminate the disturbing factors behind the employees' decision to leave or stay within and alongside them. Thus, they need to create open working environments for communication and collaboration, enabling the empowerment strategies to be implemented.

What is important to underline is the existence of links between these variables (structural, psychological, organizational loyalty) and others, considered to be an integral part of the context of any organization. Thus, psychological empowerment, organizational loyalty are considered to have a significant influence on work satisfaction (Ahmad, 2010; Yang, 2014); aspects specific to professional activity (education level, career consciousness, organizational activities) are correlated with the dimensions of empowerment (Kuokkanen, 2003); psychological empowerment can accelerate civic behavior in the organization (Farzaneh, 2014). Also, Gardner et al. (2011) 
believes that motivating and empowering employees leads them not to leave the organization, trust in management being essential in their perception of practices - access to information and organizational support (Laschinger, 2002). In addition to the two practices of structural empowerment, Yang (2014) concludes that informal power also causes a company's employees to feel a high level of job satisfaction.

\section{Conclusions}

The results of these studies have highlighted important ways to achieve one of the company's goals, the employee's loyalty. In this regard, studies have shown that employees typically experience moderate levels of empowerment and loyalty to the company they work in, and at the same time different from one cultural context to another (Ahmad, 2010); Jordan, 2017). Thus, it is important for business managers in different industries/countries to address employees based on cultural factors at that level and to adopt congruent and context-based management policies (including empowerment practices). From this perspective, it appears, according to the results of the studies, that those who are more likely to demonstrate a positive attitude towards the organization are employees of the health care system who, due to contact with patients, have a higher level of affective state at a psychological level. For this reason, at these employees' level, it is recommended to focus more on the dimensions of psychological empowerment, and less on the issues of structural empowerment, but which should not be absent (Ahmad, 2010).

Another important aspect is that employees should be empowered in both ways due to positive effects on the organizational framework and results, such as: developing a strong culture that reflects the employee's ability to deal with problematic situations and possible future challenges (Hanaysha, 2016); gaining trust and creating opportunities to enable employees to significantly influence the results of their work (Avolio, 2004); acceptance and internalization of organizational goals and values.

The studies analyzed provided real support to both the theoreticians and practitioners in the light of the results obtained, which validated measurement tools and stressed that there is a statistically significant positive link between employee empowerment and organizational loyalty. In addition, these results have strengthened the various empirical theories (Kanter, 1993; Spreitzer, 1995), as well as the effects that these practices have on employees.

By analyzing the link between employee empowerment (with its two essential forms) and organizational loyalty, studies reveal that psychological empowerment mediates the relationship between the dimensions of structural empowerment and the affective loyalty of employees (Aggarwal, 2018). Also, structural empowerment may be a mediating factor between psychological empowerment and other variables considered important to companies, such as employee satisfaction (Chang, 2010). In addition, the latter believes that the two forms of empowerment are predictors of organizational loyalty and work satisfaction.

In conclusion, we can say that managers of companies seeking a loyal human resource must lay the foundations of a process of psychological empowerment through the development of an organizational environment that provides access to information, decision support, growth opportunities, formal and informal power specific to the structural empowerment), ie a working environment with access to structures that allow employees to perform their tasks at the highest level of performance.

In pursuing an analysis of the two variables, it was found that the organizational environment is a complex one, involving a multitude of disruptive or motivating factors, with various connections, which involve the human resource, proven by these articles, and not only, to be difficult to study and at the same time hard to please.

Taking into account the results obtained, but also the fact that most of the studies (12 out of 23) were carried out on employees belonging to the medical system (which can be understood as measuring scales have also been developed in the same field) being followed by those made in 
various organizations in different economic/social/socio-cultural contexts, in services and education, a number of assumptions can be developed to be tested in future research:

H1: Structural empowerment has a positive, statistically significant influence on employees' psychological empowerment.

H2: Psychological empowerment has a positive, statistically significant influence on organizational loyalty.

H3: Work satisfaction is a mediating factor in the relationship between psychological empowerment and organizational loyalty.

\section{Limits and implications}

Regarding the limits of this study, we can say that the volume of the sample (23 articles) was relatively low (from a "large" article on this topic), which is why it is recommended that in future research of this type analyze a larger number of articles that have studied the link between the variables and using a mixed methodology to allow a better understanding of the phenomenon. Also, the subjectivity of the researcher may be taken into account, in the light of the criteria for choosing items to be analyzed, but also through the establishment of the category scheme (empowerment, loyalty, links, etc.), determined according to the purpose of the research. In future research, it is recommended to develop content analysis and theoretical concepts, as well as to study these variables more closely: by carrying out a quantitative (questionnaire) and qualitative analysis (interviews - content analysis); by analyzing the links between empowerment/loyalty and other variables (eg job satisfaction, employee generations).

Understanding the role of empowerment practices on work satisfaction, organizational loyalty, and beyond, is an important step for managers, knowing the levels at which employees are located allows them to manage the human resource effectively and efficiently. The present study also helps practitioners to discover potential and disruptive factors with a direct or indirect influence, respectively positive or negative, on organizational empowerment and loyalty.

At the theoretical level, the study contributes to providing an insight into the links between structural, psychological and organizational loyalty, as well as between them and other variables (such as work satisfaction, trust, management confidence, etc.).

\section{References}

- Academia Română, Institutul de Lingvistică "Iorgu Iordan-Alexandru Rosetti” (2009). DEX, Editura Univers Enciclopedic) Retrieved from Explanatory Dictionary of the Romanian Language, ediția a II-a: https:/dexonline.ro/definitie/imputernicire; https:/dexonline.ro/ definitie/loialitate.

- Aggarwal, A. D. (2018). Impact of Structural Empowerment on Organizational Commitment: The Mediating Role of Women's Psychological Empowerment. SAGE Publications, 22(3), 111. doi: $10.1177 / 0972262918786049$

- Ahmad, N. \&. (2010). Empowerment, job satisfaction and organizational commitment: a comparative analysis of nurses working in Malaysia and England. Journal of Nursing Management, 18, 582-291. doi:10.1111/j.1365-2834.2010.01093.x

- Allen, N. J., \& Meyer, J. P. (1990). The measurement and antecedents of affective, continuance and normative commitment to the organization. Journal of Occupational Psychology, 63, 1-18.

- Avolio, B. J. (2004). Transformational leadership and organizational commitment: mediating role of psychological empowerment and moderating role of structural distance. Journal of Organizational Behavior, 25, 951-968. doi:10.1002/job.283

- Bartunek, J. M., \& Spreitzer, G. (2006). The interdisciplinary career of a popular construct used in Management: Empowerment in the late 20th century. (A. Global, Ed.) Journal of Management Inquiry, 15(3), 255-273. 
- Bhatnagar, J. (2005). The power of psychological empowerment as an antecedent to organizational commitment in Indian managers. Human Resource Development International, 8(4), 419-433. doi:10.1080/13678860500356101

- Bhatnagar, J. (2007). Predictors of organizational commitment in India: strategic HR roles, organizational learning capability and psychological empowerment. The International Journal of Human Resource Management, 18(10), 1782-1811. doi:10.1080/09585190701570965

- Chang, L.-C. S.-H.-M. (2010). The mediating role of psychological empowerment on job satisfaction and organizational commitment for school health nurses: A cross-sectional questionnaire survey. International Journal of Nursing Studies, 47, 427-433. doi:10.1016/j.ijnurstu.2009.09.007

- Chen, H.-F. \&.-C. (2008). The Impact of Work Redesign and Psychological Empowerment on Organizational Commitment in a Changing Environment: An Example From Taiwan's StateOwned Enterprises. Public Personnel Management, 37(3), 279-302. doi:10.1177/ 009102600803700302

- Conger, J. A., \& Kanungo, R. N. (1988, Jul). The Empowerment Process: Integrating Theory and Practice. The Academy of Management Review, 13(3), 471-482. doi:10.2307/258093

- Danguole, S. L. (2009). Forms of expression of employee loyalty. Social Research, 16(2), 8693; Apud. Nyengane, (2007). The relationship between leadership style and employee commitment, Rhodes University.

- Dictionaries, E. O. (1884). English Oxford Dictionary. Retrieved from https://en.oxforddictionaries.com/definition/empowerment.

- Elegido, J. (2013, September). Does It Make Sense to Be a Loyal Employee? Journal of Business Ethics, 116(3), 495-511. doi:10.1007/s10551-012-1482-4

- Farzaneh, J. D. (2014). The impact of person-job fit and person-organization fit on OCB. The mediating and moderating effects of organizational commitment and psychological empowerment. Personnel Review, 43(5), 672-691. doi:10.1108/PR-07-2013-0118

- Fiorito, J. B. (Summer 2007). Organizational Commitment, Human Resource Practices, and Organizational Characteristics. Journal of Managerial Issues, 19(2), 186-207. Retrieved from https://www.jstor.org/stable/40604563

- Gardner, T. M., Wright, P. M., \& Moynihan, L. M. (2011). The impact of motivation, empowerment, and skill-enhancing practices on aggregate voluntary turnover: The mediating effect of collective affective commitment. Personnel Psychology, 315-350.

- Gaudreau, M., \& Blanchard, D. (2012). Effect of Empowerment on Employees Performance. Advanced Research in Economic and Management Sciences (AREMS), 2(40), 40-46.

- Graham, J. W. (1992). Hirschman's Loyalty Construct. Employee Responsibilities and Rights Journal, 5(3), 191-200. doi:https://doi.org/10.1007/BF01385047

- Greasley, K., Bryman, A., Dainty, A., Price, A., Soetanto, R., \& King, N. (2005). Employee perceptions of empowerment. Employee Relations, 27(4), 354-368. doi:10.1108/ 01425450510605697

- Hanaysha, J. (2016). Examining the Effects of Employee Empowerment, Teamwork, and Employee Training on Organizational Commitment. Procedia - Social and Behavioral Sciences, 229, 298-306. doi:https://doi.org/10.1016/j.sbspro.2016.07.140

- Ismail, A. M. (2011). An Empirical Study of the Relationship between Transformational Leadership, Empowerment and Organizational Commitment. Business and Economics Research Journal, 2(1), 89-107.

- Janssen, O. (2004). The barrier effect of conflict with superiors in the relationship between employee empowerment and organizational commitment. Work \& Stress: An International Journal of Work, Health \& Organisations, 18(1), 56-65. doi:10.1080/ 02678370410001690466 
- Joo, B.-K. (. (2010). Psychological empowerment and organizational commitment: the moderating effect of organizational learning culture,. Human Resource Development International, 13(4), 425-441. doi:10.1080/13678868.2010.501963

- Jordan, G. M. (2017). Psychological Empowerment, Job Satisfaction and Organizational Commitment Among Lecturers in Higher Education: Comparison of Six CEE Countries. Organizacija, 50(1), 17-32. doi:10.1515/orga-2017-0004

- $\quad$ Kanter, R.M. (1993). Men and Women of the Corporation. New York: Basic Books, $2^{\text {nd }}$ Ed.

- Kuokkanen, L. Leino-Kilpi, H, Katajisto, J. (2003). Nurse Empowerment, Job-Related Satisfaction, and Organizational Commitment. Journal of Nursing Care Quality, 18(3), 184192. doi:10.1097/00001786-200307000-00004

- Laschinger, H.K. (2002). The impact of workplace empowerment, organizational trust on staff nurses' work satisfaction and organizational commitment. Advances in Health Care Management, 3(3), 59-85. doi:10.1016/S1474-8231(02)03006-9

- McGuinness, B.M. (1988). The change in employee loyalty. Nursing Management, 29(2), $45-$ 46. doi:10.1097/00006247-199802000-00012

- Oladipo, S.E. (2009). Psychological empowerment and development. Edo Journal of Counselling, 2(1), 119-126.

- Preko, A., Adjetey, J. (2013). A Study on the Concept of Employee Loyalty and Engagement on the Performance of Sales Executives of Commercial Banks in Ghana. International Journal of Business Research and Management (IJBRM), 4(2), 51-62.

- Seche, L., Seche, M. (2002). Dictionary of synonyms. (E. L. Internaţional, Editor) Retrieved from https://dexonline.ro/definitie/imputernicire, https://dexonline.ro/definitie/loialitate.

- Smith, L.M. (2010). Effects of workplace incivility and empowerment on newlygraduated nursesÕ organizational commitment. Journal of Nursing Management, 18, 1004-1015. doi:10.1111/j.1365-2834.2010.01165.x

- Spence Laschinger, H.K. (2001). Impact of Structural and Psychological Empowerment on Job Strain in Nursing Work Settings, Expanding Kanter's Model. JONA, 31(5), 260-270. doi:10.1097/00005110-200105000-00006

- Spence Laschinger, H. K. (2009). Context Matters The Impact of Unit Leadership and Empowerment on Nurses' Organizational Commitment. The Journal of Noursing Administration, 39(5), 228-235. doi:10.1097/NNA.0b013e3181a23d2b

- Spreitzer, G.M. (1995). Psychological Empowerment in the Workplace: Dimensions, Measurement, and Validation. Academy of Management Journal, 38(5), 1442-1465. doi:https://doi.org/10.5465/256865

- Thomas, K., Velthouse, B. (1990). Cognitive Elements of Empowerment: An "Interpretive" Model of Intrinsic Task Motivation. The Academy of Management Review, 15(4), 666-681. doi: $10.2307 / 258687$

- Ugboro, O.I. (2006). Organizational Commitment, Job Redesign, Employee Empowerment and Intent to Quit Among Survivors of Restructuring and Downsizing. Institute of Behavioral and Applied Management, 232-257.

- Withey, M.C. (1992). What's Loyalty? Employee Responsibilities and Rights Journal, 5(4), 231-240; Apud. Hirschman, 1970, Exit, Voice, and Loyalty: Responses to Decline in Firms, Organizations, and States, Harvard University Press. doi:10.1007/BF01385050

- Yang, J.L. (2013). Impact ofempowerment on professional practice environments and organizational commitment among nurses: A structural equation approach. International Journal of Nursing Practice, 19(1), 44-55. doi:doi:10.1111/ijn.12016

- Yang, J. L. (2014). The effect of structural empowerment and organizational commitment on Chinese nurses' job satisfaction. Applied Nursing Research, 27, 186-191. 



\title{
Cap. 17. IMPORTANŢA ECHILIBRULUI VIAŢĂ PROFESIONALĂ-VIAŢĂ PERSONALĂ PENTRU ANGAJAŢII ROMÂNI
}

\author{
Elena-Sabina Turnea ${ }^{1}$, Lorena Florentina Dumitrașciuc ${ }^{2}$ and Adriana Prodan ${ }^{3}$ \\ ${ }^{1}$ Universitatea „Alexandru Ioan Cuza” din Iași, Facultatea de Economie şi Administrarea Afacerilor, Iași, \\ Romania,sabina.turnea@yahoo.com,sabina.turnea@uaic.ro \\ ${ }^{2}$ Universitatea ,Alexandru Ioan Cuza” din Iași, Facultatea de Economie și Administrarea Afacerilor, Iași, \\ Romania,lorena.popescul@gmail.com \\ ${ }^{3}$ Universitatea ,Alexandru Ioan Cuza” din Iași, Facultatea de Economie şi Administrarea Afacerilor, Iași, \\ Romania,pada@uaic.ro
}

\begin{abstract}
Leisure is important after intense working, being part of a community can fulfill the employees' safety and security feelings, and through work experience, people become more organized and succeed in more aspects of their lives, developing their professional behavior. Also, studies approve that family supports people, gives them feelings of security, stability, and love. Our research indicates descriptive results about the importance of leisure, of community and family (which are specific variables for work-life balance) for 627 proffesionals, from which 418 are employed. The entire sample is triangulated in: employees from multinational companies, employees from Romanian companies, and young researchers. The results indicate that all these categories of respondents achieved a level of satisfaction higher than $70 \%$ for the importance of work. Also, for all proffesionals, in the case of family, an average of over 4 points out of 5 was obtained, corresponding to a satisfaction level of at least $80 \%$. The same situation was observed in the case of leisure time. If the employees from multinationals do not place much emphasis on the importance of the community, those from the Romanian companies are more enrolled into this aspect at work. Finally, the young researchers are between extremities.
\end{abstract}

Keywords: leisure, community, family, employees, work.

\section{Introducere}

Munca și familia sunt două aspecte importante ce fac parte din viața unei persoane (Saeed și Farooqi, 2014). Astfel, subiectul echilibru viaţa profesională-viaţa personală este unul amplu dezbătut și se va afla multă vreme în tendințe datorită globalizării, presiunilor economice, tehnologice și sociale, din ce în ce mai mari prezente în viața oamenilor (Pasamar și Cabrera, 2013; Saeed și Farooqi, 2014).

La o simplă căutare în Google Academic, am ales anii 2000-2020, ani în care s-a vorbit cel mai mult despre echilibrul viaţa profesională-viaţa personală, și am constat că acest termen a apărut de 2.330 .000 ori, din care doar în 2019 a fost menţionat de 37.700 ori și de 23.000 ori până în martie 2020.

În ceea ce privește sectorul în care echilibrul viaţa profesională-viaţa personală a câștigat cea mai mare atenție este cel corporativ (Varghese și Selvasundaram, 2020), iar acest fapt este din cauza presiunilor destul de mari ce se exercită asupra angajaților legate de a lucra mai mult, chiar și peste orele de program, ceea ce poate deveni un motiv de îngrijorare pentru angajați, pentru că le afectează echilibrul dintre viața personală și carieră (Sturges și Guest, 2004).

\section{Revizuirea literaturii de specialitate}

Este adevărat faptul că locul de muncă ocupă o mare parte din timpul angajaților, astfel că există o presiune tot mai mare de a lucra din ce în ce mai mult şi mai bine, ceea ce duce inevitabil la o sursă de stres și un nivel ridicat de burnout (Rehder et al., 2019; Den-Nagy, 2014). În acest 
sens, este necesară găsirea unui echilibru între carieră şi viaţa privată, pentru ca angajații să se bucure de viaţă personală (familie, prieteni și nevoia de timp liber, mai exact nevoia de a se relaxa).

Echilibrul viaţa profesională-viaţa personală este un concept ce are în vedere prioritizarea în mod echitabil între carieră și viața personală: familie, prieteni, sănătate, timp liber, dezvoltare spirituală (Vijayaraghavan, 2020). Dar și de o bună satisfacție și funcționare a individului atât acasă, cât și la locul de muncă, care să aibă un minim de conflict de rol (Clark, 2000). Însă, pot exista anumiţi factori care ar putea schimba priorităţile fiecărui angajat, pentru că echilibrul viaţa profesională-viaţa personală este diferit de la o persoană la alta. Mai exact, fiecare persoană alocă în proporții diferite timp, efort, energie, implicare, etc. activităților profesionale, respectiv activităților personale. Spre exemplu, am putea crede că unul dintre cei mai importanți factori care schimbă prioritățile este categoria de vârsta, care poate schimba complet viziunea unui angajat. Și asta pentru că, oamenii se schimbă odată cu vârsta atât în ceea ce privește comportamentul lor, aspectul fizic, precum și percepția și evaluarea anumitor fenomene (Kazmierska și Stankiewicz, 2016).

Însă, s-a constat faptul că, indiferent de categoria de vârstă, echilibrul viaţa profesională-viaţa personală este o preocupare pentru angajaţii din toate etapele carierei (vârsta 18-29 ani stadiu de carieră timpurie, vârsta 30-39 ani în curs de dezvoltare a carierei, vârsta 40-49 ani consolidarea carierei, vârsta de 50 de ani reprezintă cariera înainte de pensionare) și nu doar pentru părinții cu copii mici (Darcy et al., 2012). De exemplu, tinerii doresc să-și dezvolte și să își gestioneze cariera în propriile lor condiții, o parte importantă a acestui individualism de carieră fiind realizarea unui echilibru între carieră și viaţa profesională (Loughlin și Barling, 2001).

Dacă este să facem referire la mediul corporativ, absolvenții se simt mai pregătiţi să lucreze peste program, în ciuda propriului interes de a duce o viaţă echilibrată, pentru că, scopul lor este acela de a reuși în mediul corporativ, aceștia dorind să-și demonstreze angajamentul față de orele petrecute la locul de muncă, cu precădere doar în timpul primilor ani de carieră (Coffey, 1994). Însă, acest lucru este mai mult decât dăunător, pentru că îi transformă în workaholici, iar astfel de angajaţi de obicei nu sunt fericiţi, se simt suprasolicitați, și fac mai multe greșeli; se simt furioși faţă de angajatorii și colegii lor care nu muncesc la fel de mult ca ei, au probleme cu somnul şi au probleme cu soțul sau partenerul, copiii și prietenii (Friedman și Lobel, 2003).

Un alt factor important este legat de genul persoanei. De exemplu, în contextul globalizării, femeile au ajuns la conducerea companiilor, astfel că, acestea trebuie să mențină echilibrul dintre munca pe care o prestează și viața de familie (Duong et al., 2020; Kumar și Chaturvedi, 2017). Cu toate acestea, în rolurile și relațiile lor de soții, mame și angajate, femeile de vârsta 46-66 ani prezintă mai mulți factori de stres, cum ar fi cei legați de suportul fizic și emoțional inadecvat din partea soțului sau al partenerului, care conduc la probleme de sănătate (Kenney, 2000).

De exemplu, în cazul femeilor din Generația X (născute între 1965-1980) care lucrează în companii, împlinirea personală este intrinsec legată de succesul profesional prin care își doresc sprijinul companiilor legat de partea de mentori pentru orientare și dezvoltare, oportunități de dezvoltare, recunoașterea meritelor și flexibilitate în ceea ce privește echilibrul muncă-viață personală (Feyerherm și Vick, 2005).

În cazul femeilor tinere (18-29 ani) și celor de vârstă mijlocie (30-45 ani), acestea sunt și ele stresate, însă jonglează cu responsabilitățile și cerințele multiple ale soției, copiilor, părinților în vârstă și a carierei lor, în timp ce încearcă să își păstreze propriul „echilibru interior” (Kenney, 2000). În plus, femeile au reușit să depășească prejudecățile legate de gen pentru a se implica în cariera lor (Duong et al., 2020). Însă, dezechilibrele din viaţa angajaţilor indiferent de vârstă sau gen atrag o serie de consecințe, cum ar fi de pildă forma cea mai ușoară numită stres (Karkoulian, Srour și Sinan, 2016). Iar cea mai periculoasă formă este sindromul burnout, unde un angajat lucrează peste propriile sale limite ajungând la extenuare fizică și emoțională, care duce la o serie de probleme legate de sănătate, cât şi la probleme în viaţa privată (Wright și Cropanzano, 1998). Totodată, apar o serie de probleme cu angajatorul, întrucât acesta va observa doar lipsa de interes şi dificultăţile pe care acesta le întâmpină în vederea îndeplinirii sarcinilor de lucru (Kanwar, Singh 
și Kodwani, 2014). Prin aceste dezechilibre se instalează conflictul între familie și carieră, ceea ce influențează în mod pozitiv nivelul de burnout la locul de muncă şi începe să scadă nivelul de autonomie al angajaților (Haar, 2017).

Angajatorii trebuie să conștientizeze și să înţeleagă care este de fapt problema, să-1 ajute și să1 susţină pe angajat în găsirea echilibrului dintre muncă şi viața personală, prin orientarea angajatului către creșterea satisfacției la locul de muncă, deoarece, în acest fel va crește gradul de retenție a angajaților și va obține o productivitate mai mare din partea acestora, ceea ce se va resimți în cifra de afaceri a companiei (Kanwar, Singh și Kodwani, 2014). Adoptarea de măsuri disciplinare și concedierea reprezintă măsuri care sunt departe de a fi benefice pentru companie, deoarece costurile de recrutare sunt mult mai mari decât dacă angajatorul i-ar oferi posibilitatea angajatului de a avea timp liber (Fallon și Lucas, 1991). În plus, în medie, din 8 ore de lucru pe zi, productive sunt doar 6 , ceea ce iarăși ne conduce la aceeași concluzie: timpul liber oferit, alături de flexibilitatea timpului lucrat la serviciu sunt argumente pentru un echilibru mai bun între carieră și viața personală.

Așadar, inițiative ce țin de echilibrul viaţa profesională-viaţa personală, pe care le pot implementa companiile fac referire la: reducerea numărului de ore de muncă pentru angajați, program flexibil de lucru în care angajații aleg o oră de început și de sfârşit, care să se potrivesc cu nevoile personale, tele-munca / munca la domiciliu / e-working, consilierea angajaților, programe de asistență a angajaţilor, formare în managementul timpului, instruire în managementul stresului; și facilități de îngrijire a copilului, asistență financiară pentru îngrijirea copiilor (Darcy et al., 2012).

\section{Metodologia cercetării}

Prezenta cercetare este una de tip cantitativ. Datele au fost colectate printr-un chestionar completat în format fizic de către respondenți în anul 2016. Scopul principal al cercetării iniţiale a fost analiza recompenselor organizaționale oferite de companii. Chestionarul a avut în vedere și colectarea de date cu privire la echilibrul viață personală-viaţă profesională. Astfel, obiectivul cercetării prezente este de a analiza importanța relativă a echilibrului viață personală-viață profesională pentru angajați.

Din cele 627 de chestionare colectate, 305 au fost din companii multinaționale (corespunzătoare unui procent de 48.6\% de respondenți), 77 din companii românești (12.3\%), 218 chestionare au fost completate de studenții de la mastere (34.8\%), iar 27 de respondenți au avut calitatea de doctoranzi (4.3\%). Detalii se regăsesc în tabelul de mai jos.

Tabel 1. Numărul de respondenți pe tipologii de organizații participante la studiu

\begin{tabular}{|c|c|c|c|c|}
\hline Tipologii organizații & Frecvență & $\begin{array}{l}\text { Procent } \\
(\%)\end{array}$ & $\begin{array}{l}\text { Procent } \\
\text { valid }(\%)\end{array}$ & $\begin{array}{l}\text { Procent } \\
\text { cumulat }(\%)\end{array}$ \\
\hline Companii multinaționale & 305 & 48.6 & 48.6 & 48.6 \\
\hline Companii românești & 77 & 12.3 & 12.3 & 60.9 \\
\hline $\begin{array}{l}\text { Universitatea Alexandru-Ioan } \\
\text { Cuza-studenți master }\end{array}$ & 131 & 20.9 & 20.9 & 81.8 \\
\hline $\begin{array}{l}\text { Universitatea Tehnică Gh. Asachi- } \\
\text { studenți master }\end{array}$ & 87 & 13.9 & 13.9 & 95.7 \\
\hline $\begin{array}{l}\text { Universitatea Alexandru-Ioan } \\
\text { Cuza-doctoranzi }\end{array}$ & 27 & 4.3 & 4.3 & 100.0 \\
\hline Total & 627 & 100.0 & 100.0 & - \\
\hline
\end{tabular}

Grupele de interes asupra cărora ne vom opri pentru analiza separată a datelor, sunt: firme multinaţionale de externalizare, companii românești de servicii (mai exact, cu capital românesc), respectiv studenții de la master și doctoranzii. Cu privire la serviciile de externalizare, precizăm că 
sunt ,,pure”, în sensul că, firmele prestează servicii strict pentru alte organizații (nu și pentru ele, sau doar pentru domeniile de activitate ale propriului grup).

Tabel 2. Genul respondenților

\begin{tabular}{lllll}
\hline Tipologie & & $\begin{array}{l}\text { Gen } \\
\text { Masculin }\end{array}$ & Feminin & Total \\
\hline \multirow{2}{*}{ Companii multinaționale } & Frecvența & 107 & 198 & 305 \\
& $\%$ & 35.1 & 64.9 & 100.0 \\
Companii românești & Frecvența & 44 & 33 & 77 \\
& $\%$ & 57.1 & 42.9 & 100.0 \\
Studenți master & Frecvența & 76 & 142 & 218 \\
& $\%$ & 34.9 & 65.1 & 100.0 \\
Doctoranzi & Frecvența & 8 & 19 & 27 \\
& $\%$ & 29.6 & 70.4 & 100.0 \\
Total & Frecvența & $\mathbf{2 3 5}$ & $\mathbf{3 9 2}$ & $\mathbf{6 2 7}$ \\
& \% & $\mathbf{3 7 . 5}$ & $\mathbf{6 2 . 5}$ & $\mathbf{1 0 0 . 0}$ \\
\hline
\end{tabular}

Sursa: autorii

Numărul de respondenți înregistrează cele mai mari diferențe dintre genuri la doctoranzi, unde 19 persoane sunt de gen feminin (70.4\%), iar 8 sunt de gen masculin (29.6\%). Cea mai echilibrată tipologie o reprezintă firmele românești, unde, 44 de salariați sunt de gen masculin $(57.1 \%)$, iar 33 de angajaţi sunt de gen feminin (42.9\%).

Situația este relativ acceptabilă și în celelalte situații: din companiile multinaţionale, 107 angajați sunt de gen masculin (reprezentând 35.1\% din total), iar 198 sunt de gen feminin (cu un procent de 64.9\%); în cazul studenților de la master, genul feminin (142 de studenți, în proporție de $65.1 \%$ ) prezintă cu 30.2\% mai mulți respondenți decât cel masculin (76 de studenți, cu un procent de $34.9 \%$ ).

Tabel 3. Vârsta respondenților

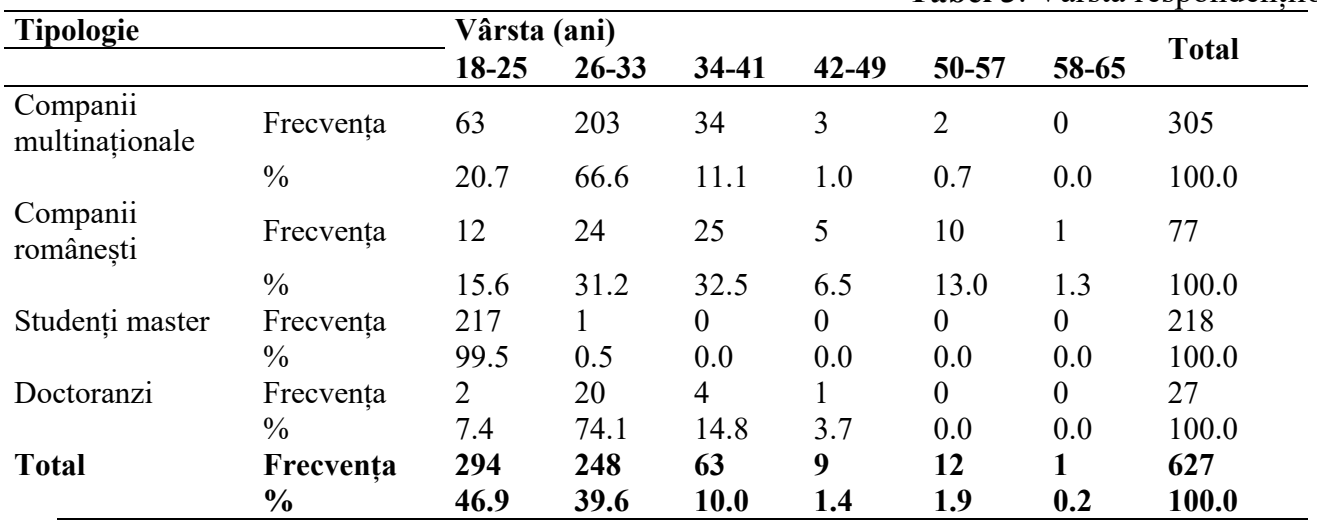

Sursa: autorii

Datele de pe întregul eșantion indică faptul că, 46.9\% dintre persoane au vârsta cuprinsă în intervalul 18-25 ani, 39.6\% au între 26-33 ani, 10\% au între 34 și 41 de ani, 1.9\% între 50-57 ani, $1.4 \%$ au vârsta în intervalul $42-49$ ani, și doar $0.2 \%$ dintre persoane au între 58 și 65 de ani.

În cazul companiilor multinaţionale, cei mai mulți respondenți au vârsta cuprinsă între 26 și 33 de ani (un număr de 203 persoane, corespunzător unui procent de $66.56 \%$ din această categorie de angajați). 63 de persoane se situează între 18 și 25 de ani (cu un procent de $20.66 \%$ din această categorie de salariaţi). 34 de angajaţi au între 34 și 41 de ani ani (cu un procent de 11.15\%), 3 persoane au vârsta cuprinsă între 42 și 49 de ani (cu un procent de $0.98 \%$ ), iar două persoane au între 50 și 57 de ani (cu un procent de $0.66 \%$ ). Nicio persoană nu are peste 58 de ani. 
În firmele cu capital românesc, 25 de persoane au vârsta între 34-41 de ani (cu un procent de $32.47 \%$ din această categorie de salariaţi), 24 de angajaţi au între 26 și 33 de ani (cu un procent de 31.17\%), 12 persoane au vârsta cuprinsă între 18 și 25 de ani (cu un procent de 15.58\%), 10 persoane au vârsta între 50 și 57 de ani (cu un procent de 12.99\%), 5 persoane au vârsta între 4249 de ani (cu un procent de 6.49\%), şi doar o persoană are între 58 şi 65 de ani (1.3\%).

$\mathrm{Cu}$ un număr de 217 persoane cu vârsta cuprinsă între 18 și 25 de ani (99.54\%) și un singur respondent cu vârsta între 26 și 33 de ani (0.46\%), tipologia studenţilor de la master se încadrează cu vârsta în intervalul 18-33 de ani. Doctoranzii din eșantion au vârstele cuprinse între 18 și 49 de ani: 20 au corespunzător intervalul de vârstă 26-33 ani (74.07\%), 4 dintre aceștia au între 34-41 de ani (14.81\%), 2 au între 18-25 de ani (7.41\%), iar o persoană are peste 42 de ani, dar nu mai mult de $49(3.70 \%)$.

Tabel 4. Nivelul de studii al respondenților

\begin{tabular}{llllllll}
\hline \multirow{2}{*}{ Tipologie } & & \multicolumn{2}{c}{ Nivel de studii } \\
& & Liceu & Licență & Master & Doctorat & Altul & Total \\
\hline Companii & Frecvența & 41 & 117 & 141 & 3 & 3 & 305 \\
multinaționale & $\%$ & 13.4 & 38.4 & 46.2 & 1.0 & 1.0 & 100.0 \\
Companii românești & Frecvența & 4 & 20 & 43 & 5 & 5 & 77 \\
& $\%$ & 5.2 & 26.0 & 55.8 & 6.5 & 6.5 & 100.0 \\
\multirow{2}{*}{ Studenți master } & Frecvența & 0 & 218 & 0 & 0 & 0 & 218 \\
& $\%$ & 0.0 & 100.0 & 0.0 & 0.0 & 0.0 & 100.0 \\
Doctoranzi & Frecvența & 0 & 0 & 27 & 0 & 0 & 27 \\
\multirow{3}{*}{ Total } & $\%$ & 0.0 & 0.0 & 100.0 & 0.0 & 0.0 & 100.0 \\
& Frecvența & $\mathbf{4 5}$ & $\mathbf{3 5 5}$ & $\mathbf{2 1 1}$ & $\mathbf{8}$ & $\mathbf{8}$ & $\mathbf{6 2 7}$ \\
& $\mathbf{\%}$ & $\mathbf{7 . 2}$ & $\mathbf{5 6 . 6}$ & $\mathbf{3 3 . 7}$ & $\mathbf{1 . 3}$ & $\mathbf{1 . 3}$ & $\mathbf{1 0 0 . 0}$ \\
\hline
\end{tabular}

Este firesc ca doctoranzii, în proporție de $100 \%$ să aibă cel puțin studii de master, așa cum toți studenții de la master să finalizeze cel puțin studiile de licență. Singura excepție pentru aceste categorii de respondenți era să fi terminat același nivel de studii cu o specializare sau cu o temă diferită (spre exemplu: un doctorand de la management să fi terminat anterior un doctorat, dar în alt domeniu, și analog pentru studenții de la master). Aceste cazuri, posibile, nu au fost însă prezente pe eșantionul de referință.

Majoritatea angajaților din companiile multinaționale au finalizat un master de specialitate (141 de respondenți, cu un procent de 46.2\%), 117 au terminat cursurile de licenţă ale unei universităţi (cu o cotă de 38.4\%), 41 de salariaţi au doar liceul (13.4\%), 3 persoane sunt doctori (1\%), și tot $1 \%$ au alt nivel de specialitate (3 persoane au menționat școala profesională). Salariații din firmele românești au terminat masterul în proporție de 55.8\% (43 de persoane), licența în procent de $26 \%$ (20 de angajați), liceul a fost promovat ca ultim nivel de $5.2 \%$ dintre angajații din această tipologie de respondenți (4 persoane), programele de doctorat au fost finalizate în proporție de $6.5 \%$ (5 persoane), și tot $6.5 \%$ dintre respondenți au bifat alte nivele de educaţie formală (5 persoane au menționat școala postliceală).

Suntem de părere că, nivelul de studii al respondenților poate influența ,pretențiile” respondenților, mai cu seamă în rândul: oportunităților de învățare și a celor de carieră, a metodelor pentru creșterea performanței individuale, a oportunităților de avansare, etc.

Tabel 5. Totalul de respondenți angajați

\begin{tabular}{|c|c|c|c|c|}
\hline \multirow[t]{2}{*}{ Tipologie } & & \multicolumn{2}{|c|}{ Angajați } & \multirow{2}{*}{ Total } \\
\hline & & $\mathrm{Nu}$ & Da & \\
\hline \multirow[t]{2}{*}{ Companii multinaționale } & Frecvența & 0 & 305 & 305 \\
\hline & $\%$ & 0.0 & 100.0 & 100.0 \\
\hline \multirow[t]{2}{*}{ Companii românești } & Frecvența & 0 & 77 & 77 \\
\hline & $\%$ & 0.0 & 100.0 & 100.0 \\
\hline
\end{tabular}




\begin{tabular}{lllll}
\hline Tipologie & & Nu & $\begin{array}{c}\text { Angajați } \\
\text { Da }\end{array}$ & Total \\
\hline Studenți master & Frecvența & 203 & 15 & 218 \\
& $\%$ & 93.1 & 6.9 & 100.0 \\
Doctoranzi & Frecvența & 6 & 21 & 27 \\
& $\%$ & 22.2 & 77.8 & 100.0 \\
Total & Frecvența & $\mathbf{2 0 9}$ & $\mathbf{4 1 8}$ & $\mathbf{6 2 7}$ \\
& \% & $\mathbf{3 3 . 3}$ & $\mathbf{6 6 . 7}$ & $\mathbf{1 0 0 . 0}$ \\
\hline
\end{tabular}

Sursa: autorii

După cum se poate observa, 15 din cei 218 studenți de la master sunt și angajați, cu un procent de $6.9 \%$ din această categorie de respondenți. 21 de doctoranzi din cei 27 sunt și salariați, cu un procent aferent de $77.8 \%$. Privită și ca o întrebare de control, toți angajaţii din companiile multinaţionale și din cele românești au bifat că sunt salariaţi. $\mathrm{Cu}$ siguranță persoanele care au mai multe activităţi, vor fi interesate de o flexibilitate sporită a programului de lucru, pentru a-și putea îndeplini cu succes toate sarcinile pe care le au. Așadar, flexibilitatea programului sau a locului de muncă vor fi urmărite de această categorie de respondenți.

Tabel 6. Domeniile de activitate în care sunt angajați respondenții

\begin{tabular}{|c|c|c|c|c|c|c|c|c|c|}
\hline \multirow{2}{*}{\multicolumn{2}{|c|}{ Tipologie }} & \multicolumn{7}{|c|}{ Domeniile de activitate ale respondenților } & \multirow{2}{*}{ Total } \\
\hline & & Educație & Financiar & Inginerie & IT & Sănă & $\mathbf{T r}$ & t Altul & \\
\hline \multirow{4}{*}{$\begin{array}{l}\text { Companii } \\
\text { multinaționale } \\
\text { Companii } \\
\text { românești }\end{array}$} & Frecvența & 0 & 186 & 79 & 40 & 0 & 0 & 0 & 305 \\
\hline & $\%$ & 0.0 & 61.0 & 25.9 & 13.1 & 0.0 & 0.0 & 0.0 & 100.0 \\
\hline & Frecvența & 0 & 0 & 56 & 0 & 21 & 0 & 0 & 77 \\
\hline & $\%$ & 0.0 & 0.0 & 72.7 & 0.0 & 27.3 & 0.0 & 0.0 & 100.0 \\
\hline \multirow{2}{*}{ Studenți master } & Frecvența & 1 & 2 & 3 & 2 & 0 & 0 & 7 & 15 \\
\hline & $\%$ & 6.7 & 13.3 & 20.0 & 13.3 & 0.0 & 0.0 & 46.7 & 100.0 \\
\hline \multirow{2}{*}{ Doctoranzi } & Frecvența & 6 & 7 & 2 & 4 & 1 & 1 & 0 & 21 \\
\hline & & 28.6 & 33.3 & 9.5 & 19.0 & 4.8 & 4.8 & 0.0 & 100.0 \\
\hline \multirow{2}{*}{ Total } & Frecvența & 7 & 195 & 140 & 46 & 22 & 1 & 7 & 418 \\
\hline & $\%$ & 1.7 & 46.7 & 33.5 & 11.0 & 5.3 & 0.2 & 1.7 & 100.0 \\
\hline
\end{tabular}

Din companiile multinaționale au fost colectate date din următoarele domenii: financiar (186 de respondenți, în procent de 61\%), inginerie (79 de persoane, cu o cotă de $25.9 \%$ ) și IT (40 de angajați, corespunzător unui procent de 13.1\%). Din firmele românești, 56 de respondenți sunt angajați în domeniul ingineriei $(72.7 \%)$, iar 21 de persoane activează în domeniul sănătății $(27.3 \%)$.

Dintre studenții de la master care sunt salariați, 3 sunt în domeniul ingineriei $(20 \%)$, câte 2 respondenți lucrează în domeniul financiar și în IT (cu câte o cotă aferentă de 13.3\%), iar o persoană lucrează în domeniul educaţiei $(6.7 \%)$. 7 persoane activează în alte domenii de activitate decât cele enumerate în chestionar $(46.7 \%)$, trei dintre respondenți menționând următoarele: administrație publică locală, mass-media, nutriţie.

Domeniul de activitate poate avea o mare însemnătate pentru studenții care vor să fie angajaţi pe aceeași specializare pe care o urmează și la programele de master. Însăși congruența studiilor cu domeniul de activitate al postului de lucru poate fi o recompensă distinctă. Fiecare domeniu de activitate are propriile „,cutume” în ceea ce privește echilibrul carieră-viață personală, iar candidații din domenii diferite vor avea așteptări specifice pentru posturile scoase la concurs.

\section{Rezultatele cercetării}

Rezultatele din tabelul următor surprinde, pe o scală de la 1 (minim) la 5 (maxim), cât sunt de importante pentru toți respondenții următoarele aspecte: timpul liber, comunitatea, munca, religia, respectiv familia. Itemul s-a adresat tuturor participanților la studiu (fie aceștia angajaţi sau nu). 
Din totalul de 627 de respondenți, un angajat din companiile multinaționale nu a bifat importanța familiei, și un altul din firmele românești nu a răspuns deloc la această întrebare.

Tabel 7. Importanța timpului liber, a comunității, muncii și familiei,

\begin{tabular}{llllll} 
& & & & \multicolumn{2}{c}{ pe categorii de respondenti } \\
Tipologie & & Timp liber & Comunitate & Munca & Familia \\
\hline \multirow{2}{*}{ Companii } & Media & 4.48 & 2.96 & 3.90 & 4.81 \\
multinaționale & $\mathrm{N}$ & 305 & 305 & 305 & 304 \\
& Abaterea standard & 0.77 & 1.20 & 0.92 & 0.53 \\
Companii românești & Media & 4.49 & 4.13 & 4.50 & 4.53 \\
& $\mathrm{~N}$ & 76 & 76 & 76 & 76 \\
\multirow{2}{*}{ Studenți master } & Abaterea standard & 0.82 & 1.21 & 0.70 & 1.00 \\
doctoranzi & Media & 4.11 & 3.38 & 4.03 & 4.63 \\
& $\mathrm{~N}$ & 245 & 245 & 245 & 245 \\
& Abaterea standard & 1.07 & 1.18 & 0.94 & 0.78 \\
Total & Media & $\mathbf{4 . 3 4}$ & $\mathbf{3 . 2 7}$ & $\mathbf{4 . 0 3}$ & $\mathbf{4 . 7 0}$ \\
& $\mathbf{N}$ & $\mathbf{6 2 6}$ & $\mathbf{6 2 6}$ & $\mathbf{6 2 6}$ & $\mathbf{6 2 5}$ \\
& Abaterea & $\mathbf{0 . 9 2}$ & $\mathbf{1 . 2 5}$ & $\mathbf{0 . 9 2}$ & $\mathbf{0 . 7 1}$ \\
\hline
\end{tabular}

Sursa: autorii

Angajații din companiile multinaționale au obținut următoarele importanțe medii: 4.48 pentru timpul liber, 2.96 pentru comunitate, 3.90 pentru muncă și 4.81 pentru familie. Salariaţii din firmele românești au obținut, în medie, următoarele importanțe: 4.49 pentru timpul liber, 4.13 pentru comunitate, 4.50 pentru muncă și 4.53 pentru familie. Studenții de la master și doctoranzii (angajați sau nu) au obținut următoarele importanțe medii: 4.11 pentru timpul liber, 3.38 pentru comunitate, 4.03 pentru muncă și 4.63 pentru familie. Pentru toate categoriile de respondenți, în cazul familiei, s-a obținut în medie, o importanță de peste 4 puncte din 5, corespunzătoare unui nivel de satisfacție de minim $80 \%$. Aceeași situație s-a observat și în cazul timpului liber. Scorurile acordate sunt bineînțeles, subiective. Pentru ca un angajat să exceleze la locul de muncă, nu trebuie să își neglijeze celelalte aspecte ale vieții, care, ajută la sănătatea și bunăstarea pe termen mediu și lung. Echilibrul viață personală-viață profesională este important pentru rezultate constante în timp.

În cele ce urmează sunt expuse comparativ, pe categorii de respondenți, graficele pentru cele patru aspecte analizate.

$\mathrm{Nu}$ au fost înregistrate diferențe foarte mari între cele trei categorii de participanți la studiu în ceea ce privește importanța timpului liber. Angajații din companiile multinaționale au obținut o medie de 4.48 din 5 pentru importanța timpului liber (cu un nivel de satisfacție aferent de 89.6\%), salariații din firmele românești au obținut o medie de 4.49 (cu un nivel de satisfacție de 89.8\%), iar studenții de la master şi doctoranzii au avut, în medie, o importanță de 4.11 pentru acest aspect (cu un nivel de satisfacție de $82.2 \%$ ). 


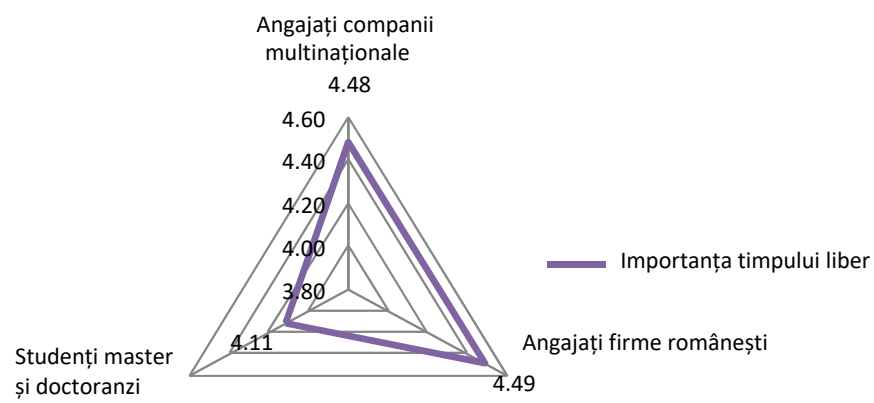

Fig. 1. Importanța timpului liber pe categorii de respondenți Sursa: autorii

Timpul liber este important pentru odihnă, refacerea organismului după muncă intensă, atenție acordată celor dragi, ş.a.m.d. O persoană odihnită suficient va avea o productivitate şi o calitate a muncii superioară comparativ cu o alta care nu s-a bucurat îndeajuns de timp liber.

Angajații din companiile multinaționale au obținut o medie de 2.96 din 5 pentru importanța comunității (cu un nivel de satisfacție aferent de 59.2\%), salariații din firmele românești au obținut o medie de 4.13 (cu un nivel de satisfacție de $82.6 \%$ ), iar studenții de la master şi doctoranzii au avut, în medie, o importanță de 3.38 pentru acest aspect (cu un nivel de satisfacție de 67.6\%).

Dacă salariații din multinaționale nu pun foarte mult accent pe importanţa comunităţii, cei din firmele românești sunt mai ataşaţi de acest aspect. Studenții de la master și doctoranzii au obținut o medie situată între cele două extreme.

Comunitatea din care persoanele fac parte poate fi importantă sau nu pentru respondenţi. Acțiunile prin care se poate observa în mod direct nivelul de importanță pentru aceștia sunt: participarea la programe de împădurire a unei zone, implicarea în acțiuni caritabile pentru oamenii din comunitate, sprijin pentru activități sportive organizate la nivel local, ş.a.m.d. Apartenența la o comunitate poate împlini sentimentele de siguranță și securitate prezente în Piramida lui A. Maslow.

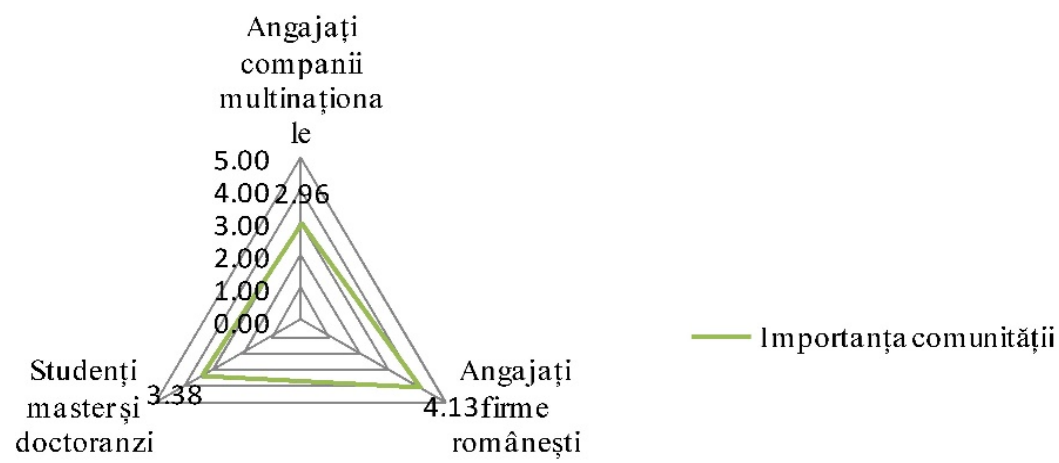

Fig. 2. Importanța comunității pe categorii de respondenți Sursa: autorii 
Firmele, dar și organizațiile non profit (școli, universităţi, fundații) se pot implica activ în susținerea proiectelor organizate la nivelul comunităților din care fac parte, și astfel, să le ofere persoanelor interesate posibilitatea de a implica în domeniile de interes.

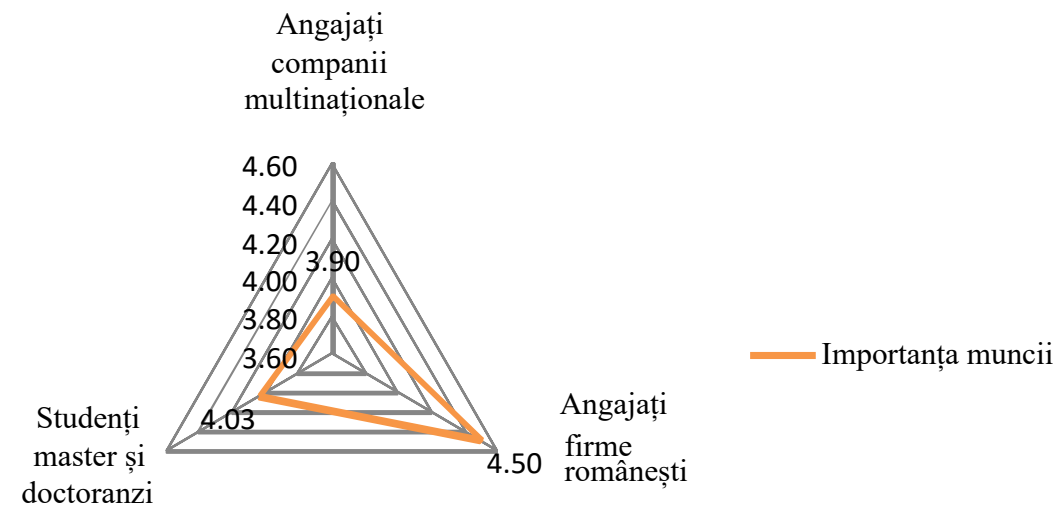

Fig. 3. Importanța muncii pe categorii de respondenți Sursa: autorii

Salariaţii din organizațiile multinaționale au obținut o medie de 3.90 din 5 pentru importanța muncii (cu un nivel de satisfacție aferent de 78\%), angajații din companiile românești au obținut o medie de 4.50 (cu un nivel de satisfacție de 90\%), iar studenții de la master și doctoranzii au avut, în medie, o importanţă de 4.03 pentru acest aspect (cu un nivel de satisfacție de $80.6 \%$ ).

Toate categoriile de respondenți au obținut un nivel de satisfacție superior procentului de $70 \%$ pentru importanța acestui aspect. Munca echilibrată este importantă la balanța carieră-viață personală. Prin muncă, oamenii devin mai organizați, gestionează mai multe aspecte ale vieții lor (atât ceea ce ține de latura profesională, cât și de cea personală), se dezvoltă și încep să adopte un comportament profesionist la locul de muncă.

Deși am fi pornit de la premisa că munca ar fi mai importantă pentru corporatiști, se pare că, din punct de vedere statistic, scorurile înregistrate au avut valori mai mari la angajații din companiile românești. Astfel, este posibil ca motivul pentru această situaţie să fie mobilitatea interorganizațională crescută a angajaților din corporații comparativ cu cea din companiile românești. Salariații din companiile românești, pe lângă faptul că au o vârstă mai înaintată, au în vedere și o menținere pe termen lung în organizații.

Angajații din companiile multinaționale au obținut o medie de 4.81 din 5 pentru importanța familiei (cu un nivel de satisfacție aferent de 96.2\%), salariații din firmele românești au obținut o medie de 4.53 (cu un nivel de satisfacție de 90.6\%), iar studenții de la master și doctoranzii au avut, în medie, o importanță de 4.63 pentru acest aspect (cu un nivel de satisfacție de 92.6\%). Pentru importanța familiei nu s-au înregistrat diferențe semnificative între cele trei categorii de respondenți, în toate cazurile înregistrându-se, în medie, o satisfacție de peste $90 \%$. 


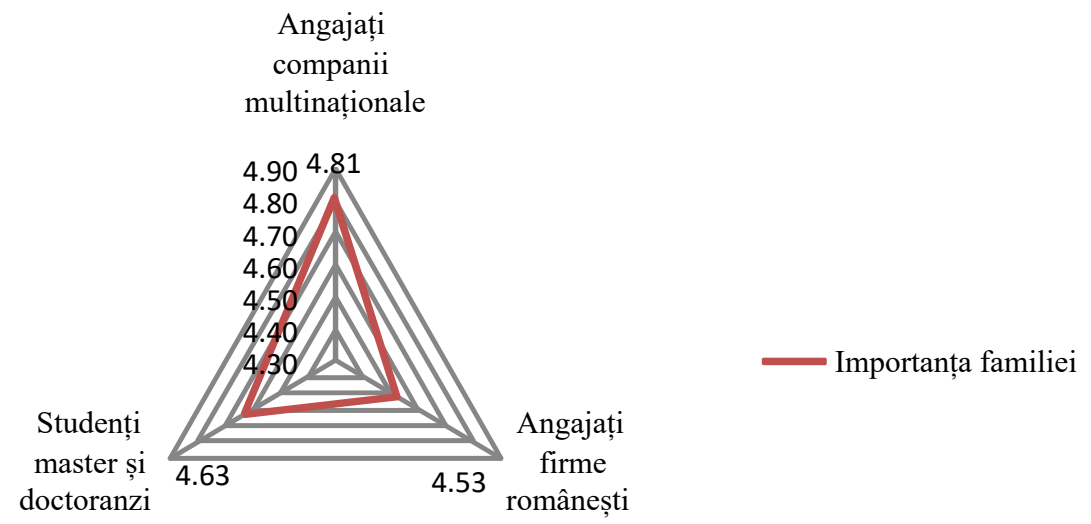

Fig. 4. Importanța familiei pe categorii de respondenți Sursa: autorii

Familia susține persoanele, le oferă sentimente de siguranță, stabilitate, și dragoste, necesare oricărei persoane. Dacă organizația oferă beneficii și flexibilitate în efectuarea muncii, astfel încât, angajații să poată să fie dedicați și vieții personale, cu siguranţă că firma va avea un plus în atragerea și menținerea resurselor umane. Astfel, echilibrul viață personală-viață profesională devine un promotor al bunăstării angajaților și al obținerii de rezultate scontate pentru companii.

\section{Concluzii și discuții}

Munca, familia, sănătatea, timpul liber și dezvoltarea spirituală, conduc la un echilibru viață personală-viață profesională. Acest din urmă concept este urmărit de unele companii pentru angajați, evitându-se cât mai mult apariția burnout-ului, în timp ce, există salariați care, conștient sau nu, urmăresc o astfel de balanță între latura personală și cea profesională.

Prezenta cercetare este de tip cantitativ, iar datele au fost colectate printr-un chestionar completat în format fizic de către respondenţi în anul 2016. Din cele 627 de chestionare colectate, 305 au fost din companii multinaționale (corespunzătoare unui procent de $48.6 \%$ de respondenți), 77 din companii românești (12.3\%), 218 chestionare au fost completate de studenții de la mastere (34.8\%), iar 27 de respondenți au avut calitatea de doctoranzi (4.3\%).

Obiectivul cercetării prezente a fost de a analiza importanța relativă a echilibrului viață personală-viață profesională pentru angajați. Detaliat, s-a avut în vedere analiza importanței timpului liber, comunității, muncii, respectiv a familiei.

Angajații din companiile multinaţionale au obținut o medie de 4.48 din 5 pentru importanţa timpului liber (cu un nivel de satisfacție aferent de $89.6 \%$ ), salariații din firmele românești au obținut o medie de 4.49 (cu un nivel de satisfacție de $89.8 \%$ ), iar studenții de la master şi doctoranzii au avut, în medie, o importanță de 4.11 pentru acest aspect (cu un nivel de satisfacție de $82.2 \%$ ). Practic, cei mai experimentaţi dintre respondenți (angajații) pun accent mult mai mare pe timpul liber pe care îl au la dispoziţie.

Angajații din companiile multinaţionale au obținut o medie de 2.96 din 5 pentru importanţa comunității (cu un nivel de satisfacție aferent de 59.2\%), salariații din firmele românești au obținut o medie de 4.13 (cu un nivel de satisfacție de 82.6\%), iar studenții de la master și doctoranzii au avut, în medie, o importanță de 3.38 pentru acest aspect (cu un nivel de satisfacție de 67.6\%). Dacă salariaţii din multinaţionale nu pun foarte mult accent pe importanţa comunităţii, cei din firmele românești sunt mai atașați de acest aspect. Ori ne-am fi așteptat ca situația să fie tocmai invers, 
întrucât corporațiile sunt cele care se implică vizibil în acțiuni pentru comunitate, pentru a-şi menține salariații în companii.

Salariații din organizațiile multinaționale au obținut o medie de 3.90 din 5 pentru importanța muncii (cu un nivel de satisfacție aferent de 78\%), angajații din companiile românești au obținut o medie de 4.50 (cu un nivel de satisfacție de 90\%), iar studenții de la master şi doctoranzii au avut, în medie, o importanță de 4.03 pentru acest aspect (cu un nivel de satisfacție de 80.6\%). Din nou, potrivit aşteptărilor, angajații din corporații ar fi trebuit să fie pe primul loc. Putem argumenta acest clasament din prisma unei stabilități mai mari a angajaților în companiile românești.

Angajații din companiile multinaționale au obținut o medie de 4.81 din 5 pentru importanța familiei (cu un nivel de satisfacție aferent de 96.2\%), salariații din firmele românești au obținut o medie de 4.53 (cu un nivel de satisfacție de 90.6\%), iar studenții de la master și doctoranzii au avut, în medie, o importanță de 4.63 pentru acest aspect (cu un nivel de satisfacție de 92.6\%).

\section{Bibliografie}

- Clark, S. (2000). Work-family border theory: a new theory of work-life balance, Human Relations, 53(6), 747-770.

- Coffey, A. (1994). Timing is everything: graduate accountants, time and organisational Commitment, Sociology, 28(4), 943-956.

- Darcy, C., McCarthy, A., Hill, J., Grady, G. (2012). Work-life balance: One size fits all? An exploratory analysis of the differential effects of career stage, European Management Journal, 30(2), 111-120.

- Den-Nagy, I. (2014). A double-edged sword?: a critical evaluation of the mobile phone in creating work-life balance, New Technology, Work and Employment, 29(2), 193-211.

- $\quad$ Duong, M.T., Hussain, I.A., Subramaniam, A. (2020). Job Stress, Co-Worker Support, Role Expectation Conflict and Work-Life Balance Among Working Women: A Quantitative study on Multinational Companies in Vietnam, Test Engineering \& Management, 82, 744-749.

- Fallon, P.R., Lucas, R.E.B. (1991). The Impact of Changes in Job Security Regulations in India and Zimbabwe, The World Bank Economic Review, 5(3), 395-413.

- Feyerherm, A., Vick, Y.H. (2005). Generation X women in high technology, Career Development International, 10(3), 216-227.

- Friedman, S.D., Lobel, S. (2003). The Happy Workaholic: A role model for employees, Academy of Management Perspectives, 17(3), 87-98.

- Kanwar, Y.P.S., Singh, A.K., Kodwani, A.D. (2009). Work-life balance and burnout as predictors of job satisfaction in the it-ites industry, The Journal of Business Perspective 13(2), $1-12$.

- Karkoulian, S., Srour, J., Sinan, T. (2016). A gender perspective on work-life balance, perceived stress, and locus of control, Journal of Business Research, 69(11), 4918-4923.

- Kazmierska, A.R., Stankiewicz, K. (2016). Work-life balance: Does age matter? Work, 55(3), 679-688.

- Kenney, J.W. (2000). Women's 'inner balance': a comparison of stressors, personality traits and health problems by age groups, Journal of Advanced Nursing, 31(3), 639-650.

- Kumar, K., Chaturvedi, R. (2017). Work-Life Balance and Job Satisfaction from the Perspective of Multiple Job Holding Women: Comparative Analysis of Generational Cohorts, International Journal of Advances in Management and Economics, 6(5), 32-39.

- Haar, J.M., Roche, M., Brummelhuis, L.T. (2017). A daily diary study of work-life balance in managers: utilizing a daily process model, The International Journal of Human Resource Management, 29(18), 2659-2681. 
- Loughlin, C., Barling, J. (2001). Young workers' work values, attitudes and behaviours, Journal of Occupational and Organisational Psychology, 74, 543-558.

- Pasamar, S., Valle C.R. (2013). Work-life balance under challenging financial and economic conditions, International Journal of Manpower, 34(8), 961-974.

- $\quad$ Rehder, K.J., Adair, K.C., Hadley, A., McKittrick, K., Frankel, A., Leonard, M., Frankel, T.C., Sexton, B. (2020). Associations Between a New Disruptive Behaviors Scale and Teamwork, Patient Safety, Work-Life Balance, Burnout, and Depression, The Joint Commission Journal on Quality and Patient Safety, 46(1), 18-26.

- Saeed, K., Farooqi, Y.A. (2014). Examining the Relationship between Work Life Balance, Job Stress and Job Satisfaction Among University Teachers (A Case of University of Gujrat), International Journal of Multidisciplinary Sciences and Engineering, 5(6), 9-15.

- Sturges, J., Guest, D. (2004). Working to live or living to work? Work/life balance early in the career, Human Resource Management Journal, 14(4), 5-20.

- Varghese, M., Selvasundaram, K. (2020). A empirical on the work and life balance among schools teachers in Chennai city, Our Heritage 68(47), 515-520.

- Vijayaraghavan, T. (2020). A Study on Work Life Balance with Reference to Indian Women, Our Heritage, 68(30), 4771-4775.

- Wright, T.A., Cropanzano, R. (1998). Emotional exhaustion as a predictor of job performance and voluntary turnover, Journal of Applied Psychology, 83, 486-493. 


\title{
Cap. 18. INFLUENŢA SATISFACŢIEI ÎN MUNCĂ ASUPRA FLUCTUAŢIEI RESURSELOR UMANE
}

\author{
Mihaela Denis Gălățanu \\ Universitatea „Alexandru Ioan Cuza” din Iași, Facultatea de Economie și Administrarea Afacerilor Iaşi, \\ Romania,mihaelad.galatanu@yahoo.com
}

\begin{abstract}
Rezumat: Scopul prezentei lucrări este acela de a identifica principalele dimensiuni ce ar trebui urmărite în cercetarea empirică a satisfacției angajaților la locul de muncă. Interesul pentru această temă a apărut ca urmare a necesităţii definirii elementelor comune, a tiparelor ce contribuie la satisfacția angajaților, indiferent de zona de activitate, management privat sau companii publice.

$\mathrm{Cu}$ această ocazie am identificat influența pozitivă ca urmare a autopercepției referitoare la relațiile de muncă bazate pe un contract de muncă pe durată nedeterminată, impactul mediului de lucru asupra satisfacției profesionale, legătura directă dintre stress respectiv epuizarea la muncă și satisfacția în muncă.

Rezultatele demersurilor empirice converg spre o abordare multi-dimensională și multi-disciplinară a studiului satisfacției la locul de muncă.
\end{abstract}

\begin{abstract}
The purpose of this article is to identify the main dimentions which has to be studied during the empirical research for employees job satisfaction. My interest for this subject it appeared as a need for defining the common elements, a typology which contributes to the job satisfaction, in all areas, privat and state company.

I identified with this ocasion the positive impact of the autoperception refearing to the work relations based on permanent labor contract, the impact of the working environment on the job satisfaction, the link beteween the stress - burnout anf job satisfaction.

The empirical research of this study shows us the multi disciplinary dimension of the job satisfaction.
\end{abstract}

\section{Introducere}

Lucrarea are ca punct de plecare ipoteza în general acceptată că satisfacţia în muncă influenţează fluctuația de personal, aceasta din urmă fiind unul dintre riscurile importante în acest mediu volatil și acerbic al pieței muncii din România.

Abilitatea managementului de a gestiona aceste riscuri constituie în prezent un factor cheie de definire a succesului in afaceri a unei companii. $\mathrm{O}$ mare importanța o are existența unui proces sistematic de identificare, evaluare şi control al acestor elemente ce contribuie la satisfacția la locul de muncă. Identificarea și luarea din timp, preventiv, a unor măsuri și acțiuni concrete ce cresc gradul de loialitate, respectiv retenție, a devenit în ultimii zece ani o preocupare majoră în multe sectoare de activitate, în special în companiile cu capital privat străin, dar nu numai. Prin urmare, companiile, indiferent de dimensiune și de piață, se străduiesc să păstreze cei mai buni angajați, recunoscând rolul important și influența resurselor umane asupra eficacității organizaționale.

\section{Metodologia cercetării}

Această cercetare calitativă își propune efectuarea unei analize de conținut a unor articole care abordează tema satisfacției angajaților și legatură acestui concept cu retenția de personal precum și înțelegerea a ceea ce inseamna "satisfacția" în muncă și a altor concepte conexe: " motivaţia". Abordarea este una calitativă, metoda de cercetare fiind analiza de conținut. În acest sens am utilizat softare-ul NVivo, versiunea 12.

Într-o primă etapă au fost selectate 13 articole publicate recent, în perioada anilor 2014-2019. Studiile identificate sunt referitoare la satisfacția în muncă în rândul angajaților, fiind concentrate în jurul unor demersuri empirice realizate anterior. În acest sens, am utilizat instrumentul Google Scholar, cuvintele cheie utilizate fiind job satisfaction și job motivation. 
Printre criteriile care au fost utilizate în selectarea articolelor s-au numărat: citările, indexarea în baze de date internaționale - BDI (Emerald Insight, Taylor and Francis, SagePub, Elsevier ș.a.), aria geografică de răspândire a studiilor (au fost analizate cercetări desfășurate atât în spațiul european - Marea Britanie, Germania, Finlanda, Bulgaria, Lituania ș.a., cât și în afara Europei Statele Unite ale Americii, Malayasia, Australia etc.), respectiv sectoarele de activitate asupra cărora cercetătorii și centrat atenția (satisfacția în muncă în sectorul bancar, non-guvernamental, medical, academic, IT, diverse companii private de mici, medii și mari dimensiuni ș.a.). Prin prestabilirea unor asemenea criterii de selecție, am avut în vedere cuprinderea unei game cât mai variate de studii ce analizează dintr-o perspectivă multi-dimensională satisfacția și motivația în muncă. De altfel, acest fapt transpare și din structura prezentei lucrări.

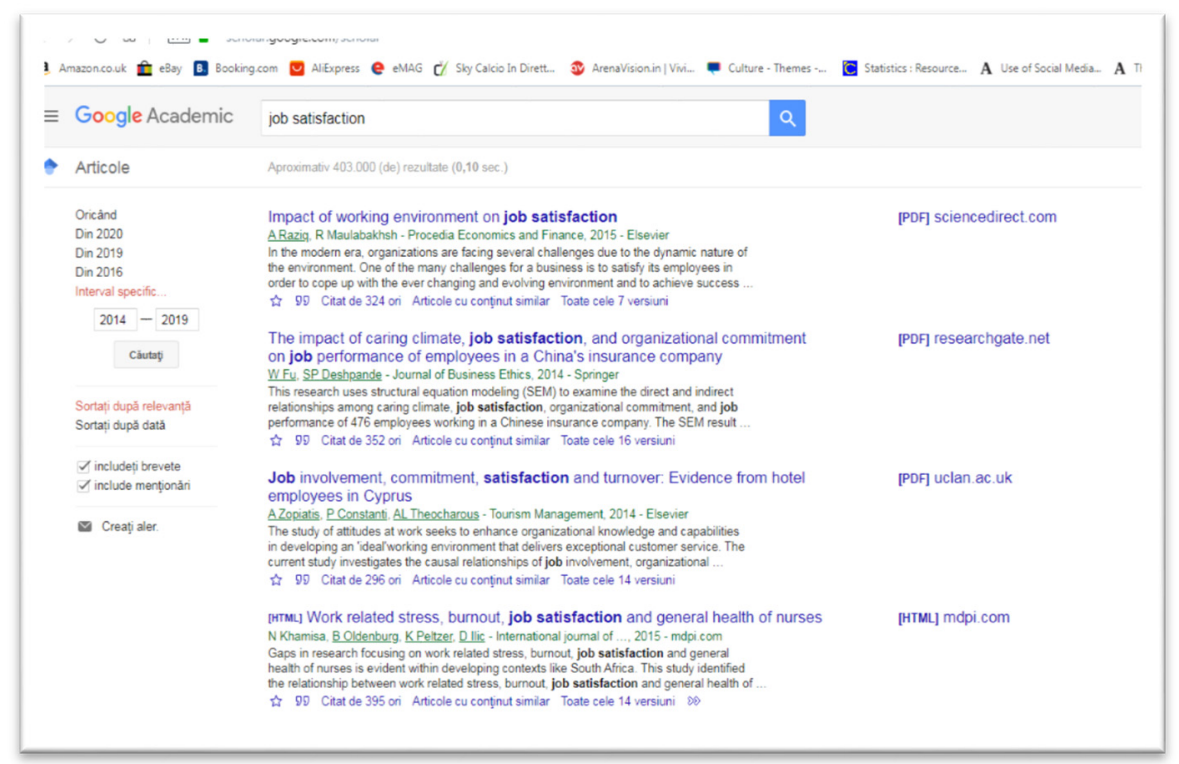

Fig. 1. Ilustrarea modului în care au fost realizată selecția articolelor prin intermediul Google Scholar

În a doua etapă, s-a efectuat o analiză succintă asupra rezultatelor generale prezentate în cadrul fiecărui articol selectat. Pe acest fond, am urmărit să evidențiez cu ce anume este inter-relaţionată satisfacția în muncă, astfel încât să identific principalele dimensiuni ale cercetării unei astfel de tematici.

În a treia etapă, s-a realizat o analiză de conținut sumară asupra frecvenței cu care apar anumiți termeni cheie în cadrul studiilor selectate. Pe parcursul materialului se regăsesc tabele asociate fiecărui articol, însoțite de câte un word cloud, cu scopul de a evidenţia care sunt principalele 20 de concepte/ noțiuni folosite subsecvent unor termeni precum: job, satisfaction sau motivation. Acest demers sprijină procesul de identificare a unor indicatori/ concepte/ termeni/ noțiuni ce sunt necesari a fi măsurați ulterior în vederea analizei satisfacției în muncă în rândul angajaţilor. Pentru a efectua această analiză s-a utilizat soft-ul specializat NVivo12, varianta Trial: 


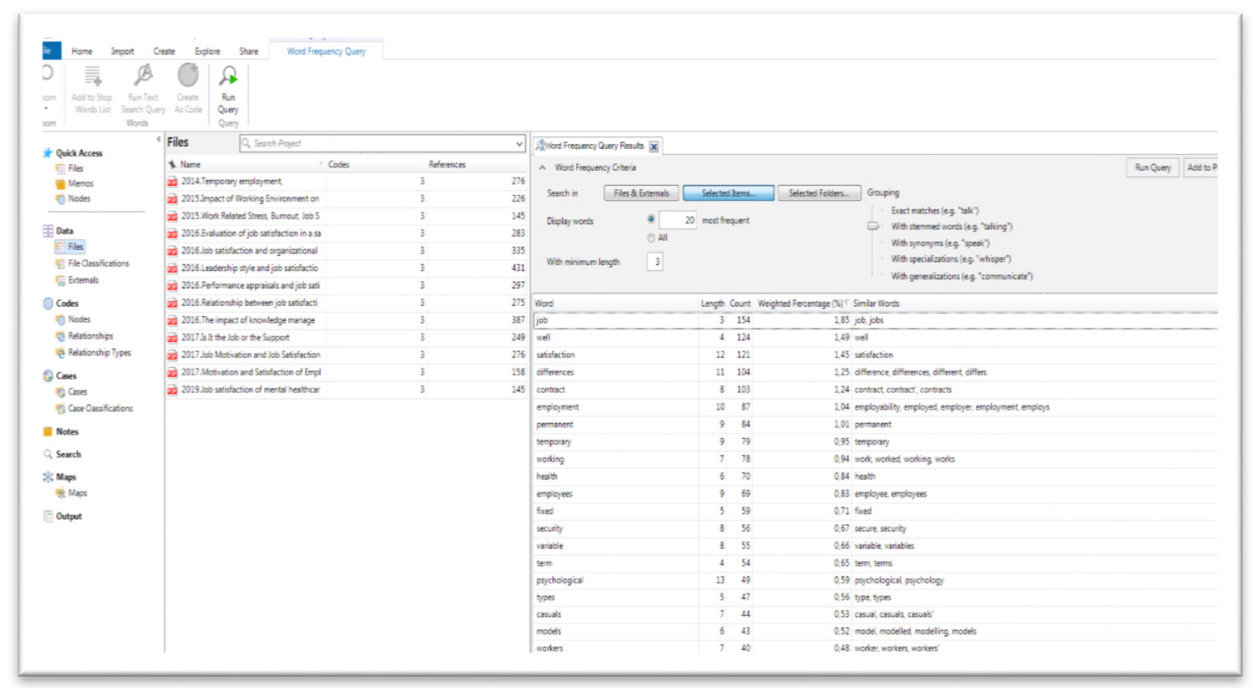

Fig. 2. Ilustrarea manierei în care s-a realizat ierarhizarea cuvintelor/ termenilor dintr-un articol, utilizând NVivo 12

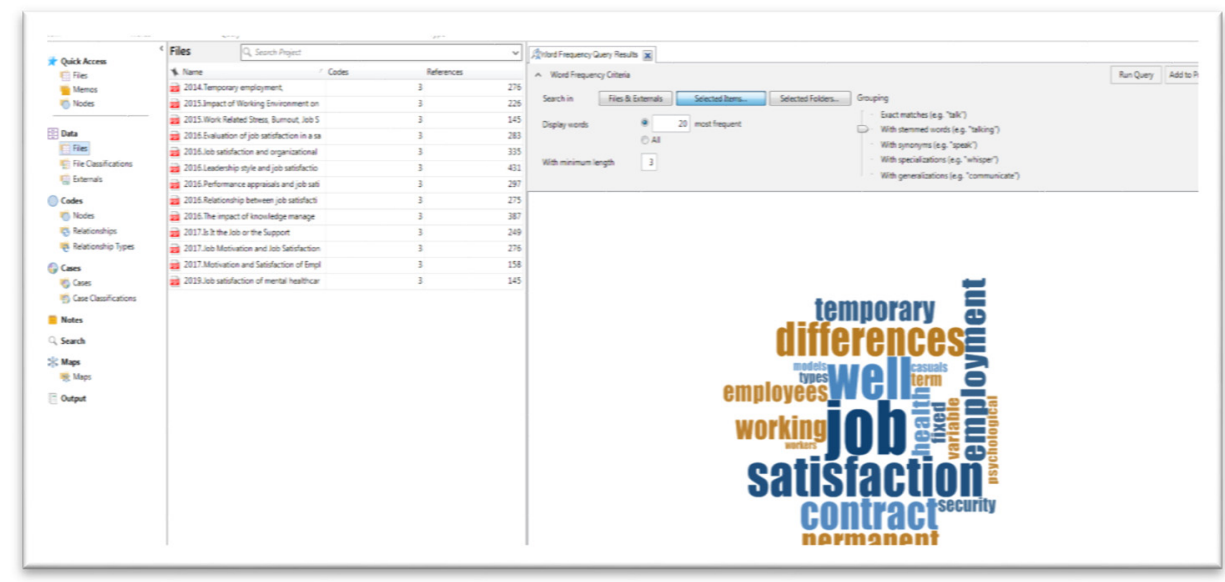

Fig. 3. Ilustrarea modalităţii prin care s-a realizat word cloud-ul, utilizând NVivo 12

Pentru rafinarea rezultatelor și în vederea efectuării unei analize cât mai acurate, în cazul fiecărei ierarhii generate, s-au exclus:

- Indicaţii referitori la ani (2012, 2016 ș.a.);

- Cuvinte de legătură (and, or, between ș.a.);

- Parametri statistici, referitori în speciali la praguri de semnificații $(.00, .05)$;

- Abrevieri (syg, itc ș.a.);

Totodată, în acest proces s-au inclus și cuvintele înrădăcinate (stemmed words).

Tabelele au fost exportate în Microsoft Office Excel 2007, iar reprezentările tabelare sunt proprii.

În a patra etapă, s-au inclus toate articolele într-o analiză de conţinut asupra identificării, la nivel general, a principalelor noțiuni/ termeni/ concepte utilizate în cele 13 studii selectate. 


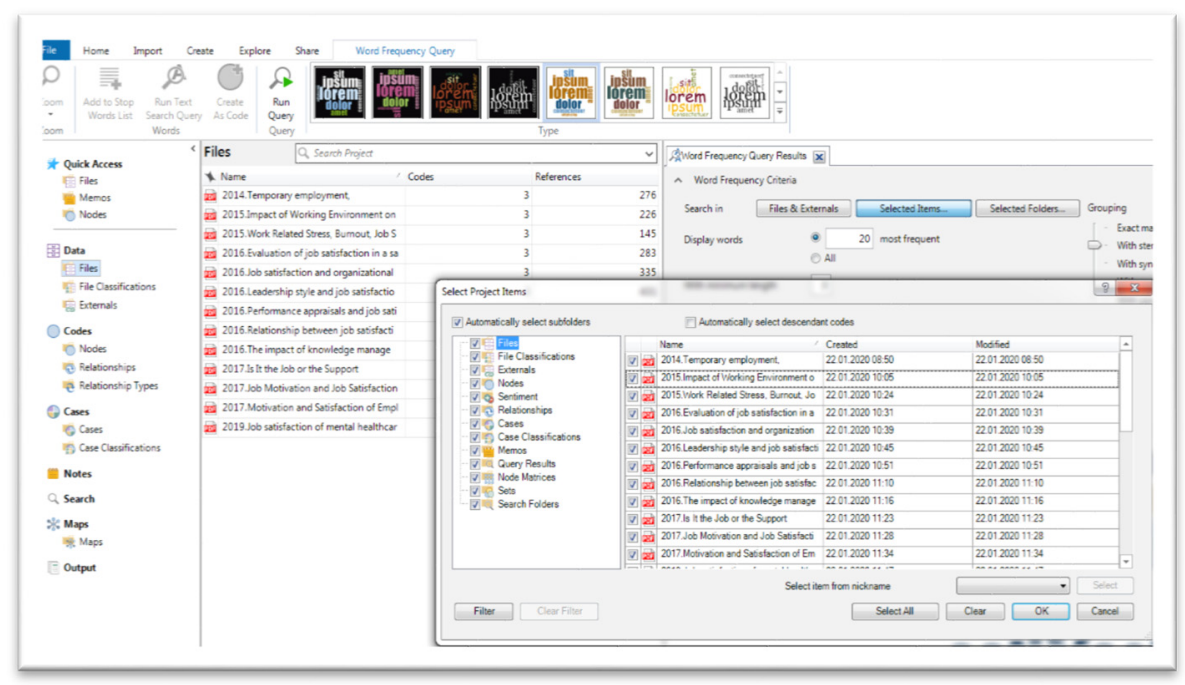

Fig. 4. Ilustrarea modului în care s-a realizat analiza generală pe cele 13 studii selectate, utilizând NVivo 12

În etapa a cincea, s-a efectuat o analiză de tip cluster, pentru a identifica principalele concluzii ale demersului pe care l-am întreprins, în acord cu scopul cercetării precizat.

\section{Literatura existentă}

\subsection{Analiza influenței auto-percepției bunăstării subiective asupra satisfacției profesionale}

În cadrul unui articol apărut în anul 2014, Dawson C., Velizotis M., Hopkins B. (2014). Temporary employment, job satisfaction and subjective well-being. Economic and Industrial Democracy, 1-30, DOI, analizează maniera în care angajaţii din Marea Britanie, beneficiari ai unor contracte de muncă temporare raportează un nivel mai scăzut al bunăstării subiective, comparativ cu angajații pe perioadă nedeterminată. Autorii au subliniat că această relație poate fi marcată de anumite dimensiuni ale satisfacției la locul de muncă. În ampla cercetarea efectuată, se pornește de la premisa că studiile anterioare au identificat diferențe privind auto-perecepția asupra bunăstării între cele două categorii de angajați, însă nu s-au preocupat de identificarea caracteristicilor individuale şi specifice ale contractelor care ar contribui la apariţia acestei discrepanțe. Pe un asemenea fond, Dawson, Velizotis și Hopkins (2014), punctează, că o contribuție majoră la clivajul dintre bunăstarea auto-raportată de angajații temporari și cei pe perioadă nedeterminată este conferită de diferențele de satisfacție referitoare la securitatea locului de muncă. În schimb, alte dimensiuni ale satisfacției par a avea o influență mai puțin semnificativă (spre exemplu, nivelul de satisfacție față de venit, orele de lucru sau cu munca depusă). De altfel, concluzia majoră a studiului indică faptul că deținerea unui contract de muncă pe o perioadă determinată este asociată cu un nivel mai scăzut al bunăstării individuale auto-percepute, legătura fiind puternic afectată de insecuritatea în muncă. Asupra acestui rezultat, o influență mai importantă au avut-o factorii ce țin de bunăstarea psihică (auto-percepția asupra nivelului de stress și a gradului de nemulțumire cu viaţa, în general), comparativ cu indicatorii corelaționați stării subiective de sănătate (anxietate/ depresie sau stare generală de sănătate proastă). 
Tabel 1. Frecvența utilizării cuvintelor în cadrul studiului (reprezentare tabelară proprie, utilizând Microsoft Office Excel 2017) și word cloud (reprezentare grafică transferată din NVivo 12)

\begin{tabular}{|c|c|c|c|}
\hline Termen & $\begin{array}{l}\text { Frecvența } \\
\text { absolută de } \\
\text { apariție }\end{array}$ & $\begin{array}{ll}\text { Frecvența } & \\
\text { relativă } & \text { de } \\
\text { apariție (\%) } & \\
\end{array}$ & Cuvinte incluse \\
\hline job & 154 & $1,82 \%$ & job, jobs \\
\hline well & 124 & $1,46 \%$ & well \\
\hline satisfaction & 121 & $1,43 \%$ & satisfaction \\
\hline differences & 104 & $1,23 \%$ & difference, differences, different, differs \\
\hline contract & 103 & $1,22 \%$ & contract, contract', contracts \\
\hline employment & 87 & $1,03 \%$ & employability, employed, employer, \\
\hline permanent & 84 & $0,99 \%$ & permanent \\
\hline temporary & 79 & $0,93 \%$ & temporary \\
\hline working & 78 & $0,92 \%$ & work, worked, working, works \\
\hline health & 70 & $\mathbf{0 , 8 3} \%$ & health \\
\hline employees & 69 & $\mathbf{0 , 8 1 \%}$ & employee, employees \\
\hline fixed & 59 & $0,70 \%$ & fixed \\
\hline security & 56 & $0,66 \%$ & secure, security \\
\hline variable & 55 & $0,65 \%$ & variable, variables \\
\hline term & 54 & $0,64 \%$ & term, terms \\
\hline psychological & 49 & $\mathbf{0 , 5 8 \%}$ & psychological, psychology \\
\hline types & 47 & $\mathbf{0 , 5 5 \%}$ & type, types \\
\hline casuals & 44 & $\mathbf{0 , 5 5 \%}$ & casual, casuals, casuals' \\
\hline models & 43 & $\mathbf{0 , 5 5 \%}$ & model, modelled, modelling, models \\
\hline Workers & 40 & $0,47 \%$ & worker, workers, workers' \\
\hline
\end{tabular}

Sursa: Dawson C., Velizotis M., Hopkins B. (2014). Temporary employment, job satisfaction and subjective well-being. Economic and Industrial Democracy, 1-30, DOI: 10.1177/0143831X14559781.

În urma procesării datelor, am constatat că termenii de"job" și “satisfaction" apar in cadrul lucrării lui Dawson C., Velizotis M., Hopkins B. (2014). Temporary employment, job satisfaction and subjective well-being. Economic and Industrial Democracy, 1-30, DOI , într-o pondere cumulată de 3,25\%, aceștia fiind alăturați unor cuvinte cheie ce fac referire la bunăstarea angajaților (spre exemplu, well-being). De asemenea, alte concepte sau subtematici de interes fac referire la securitatea locului de muncă, sănătate sau factorii psihologici.

\subsection{Impactul mediului de lucru asupra satisfacției profesionale}

Impactul mediului de lucru asupra satisfacției profesionale este unul deosebit de important, după cum menționează A. Raziq și R. Maulabaksh (2015). Cei doi autori subliniază faptul că pentru creșterea eficienței, eficacităţii, productivității și a angajamentului față de propriul job, este necesar ca managementul să se centreze pe satisfacerea nevoilor angajaților, prin crearea de condiții propice de muncă. Astfel, rezultatele studiului efectuat de Razik și Maulabaksh (2015) în rândul angajaților proveniți din trei sectoare ale economiei (bancar, educațional și telecomunicații), au evidenţiat că există o relație pozitivă între mediul de lucru și nivelul de satisfacție referitor la locul de muncă. Autorii subliniază că angajaţii acordă o atenție sporită asupra manierei în care sunt configurate condițiile de lucru - număr de ore petrecute la job, securitatea locului de muncă, relațiile cu colegii, nevoile de stimă și top managementul. 
Raziq și R. Maulabaksh (2015) propun un model de analiză conceptuală a legăturii dintre mediul de lucru și satisfacția profesională:

\begin{tabular}{|c|c|}
\hline Mediul de lucru & $\begin{array}{l}\text { Satisfacția } \\
\text { profesională }\end{array}$ \\
\hline Număr de ore lucrate & Loialitatea angajaților \\
\hline $\begin{array}{l}\text { Securitatea și } \\
\text { siguranța locului de } \\
\text { muncă }\end{array}$ & Sentimentul proprietății \\
\hline $\begin{array}{l}\text { Relația cu ceilalți } \\
\text { colegi }\end{array}$ & Nivelul de angajament \\
\hline $\begin{array}{l}\text { Nevoile de stimă/ } \\
\text { recunoastere }\end{array}$ & Eficiență şi eficacitate \\
\hline Top management & Productivitate \\
\hline
\end{tabular}

Fig. 5. Modelul Raziq și R. Maulabaksh (2015) de analiză a legăturii dintre mediul de lucru și satisfacția profesională

Tabel 2. Frecvența utilizării cuvintelor în cadrul studiului (reprezentare tabelară proprie, utilizând Microsoft Office Excel 2017) şi word cloud (reprezentare grafică transferată din NVivo 12)

\begin{tabular}{llll}
\hline Termen & $\begin{array}{l}\text { Frecvența } \\
\text { absolută } \\
\text { de apariție }\end{array}$ & $\begin{array}{l}\text { Frecvența } \\
\text { relativă de } \\
\text { apariție } \\
\mathbf{( \% )}\end{array}$ & Cuvinte incluse \\
\hline working & 135 & $\mathbf{4 , 1 3 \%}$ & work, working \\
job & $\mathbf{1 1 2}$ & $\mathbf{3 , 4 2 \%}$ & job, jobs \\
satisfaction & $\mathbf{9 6}$ & $\mathbf{2 , 9 3 \%}$ & satisfaction \\
employees & 92 & $\mathbf{2 , 8 1 \%}$ & employee, employees \\
environment & 65 & $\mathbf{1 , 9 9 \%}$ & environment \\
organizations & 34 & $\mathbf{1 , 0 4 \%}$ & organizations, \\
factors & 28 & $\mathbf{0 , 8 6 \%}$ & factor, factors \\
relationship & 28 & $\mathbf{0 , 8 6 \%}$ & relationship, relationships \\
management & 25 & $\mathbf{0 , 7 6 \%}$ & Management \\
performing & 24 & $\mathbf{0 , 7 3 \%}$ & perform, performance \\
impact & 22 & $\mathbf{0 , 6 7 \%}$ & impact, impacts \\
business & 21 & $\mathbf{0 , 6 4 \%}$ & business, businesses \\
needs & 21 & $\mathbf{0 , 6 4 \%}$ & need, needed, needs \\
conditions & 20 & $\mathbf{0 , 6 1 \%}$ & condition, conditions \\
workers & 20 & $\mathbf{0 , 6 1 \%}$ & worker, workers \\
motivational & $\mathbf{1 8}$ & $\mathbf{0 , 5 5 \%}$ & motivate, motivated \\
hours & 17 & $\mathbf{0 , 5 2 \%}$ & hour, hours \\
supervisor & 16 & $\mathbf{0 , 4 9 \%}$ & supervisor, supervisors, \\
increase & 15 & $\mathbf{0 , 4 6 \%}$ & increase, increased, \\
level & 15 & $\mathbf{0 , 4 6 \%}$ & Level \\
\hline
\end{tabular}

Sursa: Raziq A., Maulabakhsh R. (2015). Impact of Working Environment on Job Satisfaction. Procedia Economics and Finance, 23, 2nd GLOBAL CONFERENCE on BUSINESS, ECONOMICS, MANAGEMENT and TOURISM, 30-31 October 2014, Prague, Czech Republic, 717-725, doi: 10.1016/S2212-5671(15)00524-9

Alăturați termenilor de job și satisfaction, care cumulează o frecvență însumată de apariție de 6,35\%, întâlnim cuvinte precum mediu (environment), management, impact, motivational ş.a. Așadar, o dimensiune de studiu ce rezultă din această analiză este referitoare la impactul pe care îl are mediul de lucru organizațional asupra creșterii satisfacției profesionale în rândul angajaţilor. 


\subsection{Legătura dintre stress, „burnout” și satisfacția profesională}

Într-un studiu axat pe sectorul medical, N. Khamisa, B. Oldenburg, K. Peltzer și D. Ilic (2015) arată că îngrijitoarele și infirmierele din spitale sunt afectate de sindromul de burnout, acest fapt având implicații negative asupra sănătății mentale, dar și asupra satisfacției profesionale. Astfel, au fost evidenţiate o varietate de repercusiuni ale burnoutului, asociate atât cu reducerea productivității și a performanței, cât și cu scăderea calității îngrijirii pacienților. Totodată, problemele referitoare la riscurile securității/ siguranței locului de muncă influențează negativ satisfacția profesională și - la nivel general, sănătatea îngrijitoarelor/ infirmierelor. Așadar, stresul cauzat de problemele specifice personalului (managementul precar, lipsa resurselor și riscurile ce țin de siguranța/ securitatea locului de muncă) determină instalarea burnoutului și alimentează insatisfacția profesională în special în rândul îngrijitoarelor/ infirmierelor, într-o măsură mai ridicată comparativ cu alți specialiști ce activează în domeniul sanitar. De altfel, burnoutul are un impact negativ asupra sănătății mentale și a bunăstării îngrijitoarelor/ infirmierelor, afectând activitatea profesională.

Am prelucrat datele din studiul din sectorul medical amintit mai sus, utilizând soft-ul specializat NVivo12, variant Trial, ceea ce a condus la următoarele frecvențe de apariție:

Tabel 3. Frecvența utilizării cuvintelor în cadrul studiului (reprezentare tabelară proprie, utilizând Microsoft Office Excel 2017) şi word cloud (reprezentare grafică transferată din NVivo 12)

\begin{tabular}{llll}
\hline Termen & $\begin{array}{l}\text { Frecvența } \\
\text { absolută de } \\
\text { apariție }\end{array}$ & $\begin{array}{l}\text { Frecvența } \\
\text { relativa de } \\
\text { apariție (\%) }\end{array}$ & Cuvinte incluse \\
\hline nurses & 99 & $\mathbf{1 , 9 1 \%}$ & nurse, nurses, nurses', nursing \\
health & 95 & $\mathbf{1 , 8 3 \%}$ & health \\
burnout & 76 & $\mathbf{1 , 4 7 \%}$ & burnout \\
satisfaction & $\mathbf{7 4}$ & $\mathbf{1 , 4 3 \%}$ & satisfaction \\
working & 71 & $\mathbf{1 , 3 7 \%}$ & work, worked, working \\
stress & 69 & $\mathbf{1 , 3 3 \%}$ & stress, stresses, stressful \\
job & $\mathbf{6 9}$ & $\mathbf{1 , 3 3 \%}$ & job, jobs \\
staff & 57 & $\mathbf{1 , 1 0 \%}$ & staff \\
associated & 53 & $\mathbf{1 , 0 2 \%}$ & associated, association, associations \\
explaining & 44 & $\mathbf{0 , 8 5 \%}$ & explain, explained, \\
& & $\mathbf{0 , 8 5 \%}$ & explaining, \\
related & 44 & $\mathbf{0 , 8 5 \%}$ & related, relation \\
variance & 44 & $\mathbf{0 , 7 9 \%}$ & variance \\
issues & 41 & $\mathbf{0 , 6 8 \%}$ & issued, issues \\
managers & 35 & & manage, managed, management, \\
& & $\mathbf{0 , 6 2 \%}$ & managers, managers', managing \\
public & 32 & $\mathbf{0 , 6 0 \%}$ & public, publications \\
general & 31 & $\mathbf{0 , 5 8 \%}$ & general \\
patient & 30 & $\mathbf{0 , 5 8 \%}$ & patient, patients \\
poor & 30 & $\mathbf{0 , 5 6 \%}$ & poor, poorly \\
environments & 29 & $\mathbf{0 , 5 2 \%}$ & environ, environment, environments \\
caring & 27 & care, caring \\
\hline
\end{tabular}

Sursa: Khamisa N., Oldenburg B., Peltzer K., Ilic D. (2015). Work Related Stress, Burnout, Job Satisfaction and General Health of Nurses. International Journal of Environmental Research and Public Health, 12, 652-666, doi:10.3390/ijerph120100652.

În jurul termenilor de job (1,33\%) și satisfaction (1,43\%) sunt cuprinși, în ponderi diferite, noțiuni ce fac legătura cu sectorul de activitate analizat - nurse $(1,91 \%)$ sau health $(1,83 \%)$. De asemenea, conceptul de burnout apare cu o frecvență de 1,47\%, în timp ce stress se regăsește în $1,33 \%$ din totalul cuvintelor utilizate în articole. 


\subsection{Influența factorilor motivaționali intrinseci și extrinseci asupra satisfacției la locul de muncă}

Potrivit lui Garcia, Sangregoria și Sanchez (2016), specialiștii din domeniul asistenței sociale se confruntă cu niveluri moderate ale satisfacției profesionale. Natura jobului reprezintă factorul intrinsec cel mai important, acesta generând o influență pozitivă asupra gradului de mulțumire. Pe de altă parte, factorii extrinseci, precum nivelul veniturilor, stimulentele non-salariale și condițiile de muncă sau operare, determină insatisfacția profesională.

Studiul a fost efectuat în Spania, fiind utilizat ca instrument de colectare a datelor scala Job Satisfaction Survey, realizată de Spector (1997). Eșantionul a fost alcătuit din 947 de asistenţi sociali (861 femei și 86 de bărbaţi), proveniți din 35 de Asociaţii Profesionale din Spania.

Tabelul 4. Frecvența utilizării cuvintelor în cadrul studiului (reprezentare tabelară proprie, utilizând Microsoft Office Excel 2017) şi word cloud (reprezentare grafică din NVivo 12)

\begin{tabular}{|c|c|c|c|}
\hline Termen & $\begin{array}{l}\text { Frecvența } \\
\text { absolută de } \\
\text { apariție }\end{array}$ & $\begin{array}{l}\text { Frecvența } \\
\text { relativă de } \\
\text { apariție }(\%)\end{array}$ & Cuvinte incluse \\
\hline social & 186 & $2,97 \%$ & social, sociales \\
\hline satisfaction & 144 & $2,30 \%$ & satisfaction \\
\hline working & 129 & $2,06 \%$ & work, working \\
\hline job & 122 & $1,95 \%$ & job \\
\hline workers' & 76 & $1,21 \%$ & worker, workers, workers' \\
\hline factors & 56 & $0,89 \%$ & factor, factores, factors \\
\hline scale & 39 & $0,62 \%$ & scale, scales \\
\hline retrieved & 31 & $0,49 \%$ & retrieved \\
\hline items & 29 & $0,46 \%$ & item, items \\
\hline dissatisfaction & 26 & $0,42 \%$ & dissatisfaction \\
\hline professionals & 26 & $0,42 \%$ & professional, professionals \\
\hline level & 24 & $0,38 \%$ & level, levels \\
\hline services & 23 & $0,37 \%$ & service, services \\
\hline years & 23 & $0,37 \%$ & years \\
\hline associations & 22 & $0,35 \%$ & $\begin{array}{l}\text { associate, associated, association, } \\
\text { associations }\end{array}$ \\
\hline sample & 21 & $0,34 \%$ & sample, samples \\
\hline different & 20 & $0,32 \%$ & difference, differences, different \\
\hline obtained & 20 & $0,32 \%$ & obtained \\
\hline organisation & 19 & $\mathbf{0 , 3 0 \%}$ & $\begin{array}{l}\text { organisation, } \\
\text { organisations }\end{array}$ \\
\hline internal & 18 & $0,29 \%$ & internal, international \\
\hline
\end{tabular}

Sursa: Garcia R. G., Sangregorio M. A., Llamazares Sanchez M. L. (2016). Evaluation of job satisfaction in a sample of Spanish social workers through the 'Job Satisfaction Survey' scale. European Journal of Social Work, 1-15, http://dx.doi.org/10.1080/13691457.2016.1255929. 


\section{Concluzii}

Concluzionând, din analiza de conținut și analiza cluster care a fost realizată și ale căror rezultate sunt cuprinse în tabelele și graficele de mai sus, reies anumite elemente ce ar trebui să fie luate în considerare pentru studierea comprehensivă a satisfacției angajaţilor.

Astfel, un prim aspect este referitor la auto-percepția angajaților cu privire la bunăstarea profesională. Sunt necesari a fi luați în calcul indicatori precum siguranța locului de muncă sau nivelul de mulțumire față de nivelul de venituri, programul de lucru și munca întreprinsă.

Un al doilea aspect major este legat de gradul de mulțumire al angajaţilor cu privire la condițiile de lucru, printre indicatorii vizați regăsindu-se numărul de ore petrecute la muncă sau gradul de satisfacție referitor la relațiile cu colegii și cu top managementul. De asemenea, ar trebui avută în vedere evaluarea necesarului de resurse de care ar avea nevoie un angajat pentru a oferi randament, astfel încât să își îndeplinească la un nivel optim sarcinile profesionale.

O dimensiune extrem de importantă este legată de alegerea stilului potrivit de leadership. Subsidiar acestui element, ar trebui analizată maniera în care se derulează procesul de comunicare, precum și modalitatea în care este construit sistemul/ mecanismul de promovare/ avansare pe scara ierarhică.

Acest studiu, bazat pe literature review, prezintă legătura directă dintre satisfacția in muncă şi siguranța locului de muncă, mediul de lucru, precum și factorii motivaționali intrinseci ca de exemplu natura jobului. Natura jobului reprezintă factorul intrinsec cel mai important, acesta generând o influență pozitivă asupra gradului de mulțumire. Pe de altă parte, factorii motivaţioali extrinseci, precum nivelul veniturilor, stimulentele non-salariale și condițiile de muncă sau operare, determină insatisfacția profesională.

Pe baza acestor tendințe, etapa următoare a cercetării se va focaliza pe elemente legate de: analiza factorilor structurali, dar şi al celor intrinseci sau extrinseci; angajamentul profesional al angajaților și ataşamentul pe care aceștia îl manifestă faţă de organizație; rolul evaluărilor de performanță și al managementului cunoașterii; influența performanței organizaționale asupra satisfacției profesionale; rolul brandului de angajator asupra satisfacției în muncă, respectiv a fluctuaţiei de personal.

\section{Referințe bibliografice}

- Alonderiene R., Majauskaite M. (2016). Leadership style and job satisfaction in higher education institutions, International Journal of Educational Management, 30(1), 140-164, https://doi.org/10.1108/IJEM-08-2014-0106.

- Bakotić D. (2016). Relationship between job satisfaction and organisational performance, Economic Research-Ekonomska Istraživanja. 29(1), 118-130, DOI: 10.1080/ $1331677 X .2016 .1163946$.

- Dawson C., Velizotis M., Hopkins B. (2014). Temporary employment, job satisfaction and subjective well-being, Economic and Industrial Democracy, 1-30, DOI: 10.1177/0143831X14559781.

- Garcia R. G., Sangregorio M. A., Llamazares Sanchez M. L. (2016). Evaluation of job satisfaction in a sample of Spanish social workers through the 'Job Satisfaction Survey' scale, European Journal of Social Work, 1-15, http://dx.doi.org/10.1080/13691457.2016.1255929.

- Kampkötter P. (2016). Performance appraisals and job Satisfaction, The International Journal of Human Resource Management, 1-15, DOI: 10.1080/09585192.2015.1109538.

- Khamisa N., Oldenburg B., Peltzer K., Ilic D. (2015). Work Related Stress, Burnout, Job Satisfaction and General Health of Nurses, International Journal of Environmental Research and Public Health, 12, 652-666, DOI:10.3390/ijerph120100652.

- Kianto A., Vanhala M., Heilmann P. (2016). The impact of knowledge management on job satisfaction, Journal of Knowledge Management, 20(4), 621-636, https://doi.org/10.1108/JKM-10-2015-0398. 
- Knapp J. R., Smith B. R., Sprinkle T. A. (2017). Is It the Job or the Support? Examining Structural and Relational Predictors of Job Satisfaction and Turnover Intention for Nonprofit Employees, Nonprofit and Voluntary Sector Quarterly, 1-20, DOI: $10.1177 / 0899764016685859$.

- Nica, P., Neștian, A.Ş., Prodan, A. Iftimescu, A., Tiţă, S., Manolescu, I., Corodeanu Aghiorghiesei, D., Bedrule-Grigoruţă, V. (2019). Managementul Organizației. Concepte și practici, Editura Universității „Alexandru Ioan Cuza” Iași.

- Raziq, A., Maulabakhsh, R. (2015). Impact of Working Environment on Job Satisfaction, Procedia Economics and Finance, 23, 717-725, DOI: 10.1016/S2212-5671(15)00524-9

- Rezaei, N.V.S. (2016). Job satisfaction and organizational commitment: an empirical investigation among ICT-SMEs, Management Research Review, 39(12), 1663-1694, http://dx.doi.org/10.1108/MRR-09-2015-0216.

- $\quad$ Rotariu, T., Iluț, P. (2006). Ancheta sociologică și sondajul de opinie, Editura Polirom, Iași

- Rožman, M., Treven, S., Čančer, V. (2017). Motivation and Satisfaction of Employees in the Workplace, Business Systems Research, 8(2), 14-25.

- Scanlan, L.M., Devine, S.G., Watkins, D.L. (2019). Job satisfaction of mental healthcare workers in multidisciplinary teams, Journal of Mental Health, 1-7, DOI:10.1080/09638237.2019.1644489.

- Stankovska, G., Angelkoska, S., Osmani, F., Pandiloska Grncarovska, S. (2017). Job Motivation and Job Satisfaction among Academic Staff in Higher Education, Current Business and Economics Driven Discourse and Education: Perspectives from Around the World BCES Conference Books, 2017, 15, Sofia: Bulgarian Comparative Education Society, 159-166.

- Todiriciu, R. (2017). Particularities of Knowledge Worker's Motivation Strategies in Romanian Organizations, Procedia Economics and Finance, 6, 405-413.

- Zlate, M. (2004). Tratat de psihologie organizațional-managerială, vol.I, Editura Polirom, Iaşi. 


\title{
Cap. 19. CERCETAREA PRACTICII DE COACHING: ÎNTREBĂRI EXPLORATORII
}

\author{
Alina Hurubean \\ Universitatea ,Alexandru Ioan Cuza” din Iaşi, Facultatea de Economie şi Administrarea Afacerilor, \\ SDEAA, Iaşi, România, hurubean.alina@yahoo.fr
}

\begin{abstract}
The purpose of this approach is to outline an overview of the dynamics of coaching research and its relevant components at the moment. After identifying the main trends in current research of coaching practice based on exploratory questions: Who? What? How? Where? Why do coaching research? I chose to exemplify these trends by analyzing some coaching research on career transitions, published in the International Journal of Evidence Based Coaching and Mentoring. In this sense, we propose a content analysis, a literature review on ten articles on the practice of coaching for career transitions that clarifies and opens new research directions.
\end{abstract}

Keywords: coaching research questions; practitioner research; transition process.

\section{Introducere}

Coachingul, ca paradigmă de acţiune şi practică profesională, a început să capete contur acum trei decenii, în contextul apariţiei noilor tehnologii şi a societăţii digitale. Coachingul însoţeşte şi exprimă în bună parte transformările micro- şi macrosociale, produse pe acest parcurs de tranziţie de la era industrială către era postindustrială şi digitală.

Coachingul este despre dezvoltarea potenţialului uman, despre obţinerea unor rezultate concrete, despre creşterea performanţelor atât la nivel individual, cât şi la nivel de grup, echipă şi organizaţie. Coachingul facilitează procesele de schimbare umană, ca procese de învăţaredezvăţare şi reînvăţare pe tot parcursul vieţii. Coachingul este un instrument de dezvoltare personală şi profesională, diferit de metodele clasice de învăţare (training, mentorat, consiliere, predare, acumulare de cunoştinţe ş.a.), care vine în sprijinul omului modern, preocupat să găsească răspunsuri şi soluţii creative la provocările unei societăţi în permanentă schimbare.

Coachingul este o meta-profesie şi, în acelaşi timp, un set de competenţe transferabile în orice profesie şi domeniu de activitate. Coachingul este un mod de a trata oamenii, un mod de gândire, un mod de a fi. Abilităţile de coaching ca şi abilităţi de comunicare, de relaţionare şi leadership sunt utile şi necesare tuturor celor care lucrează cu oamenii: părinţi, profesori, manageri, lideri, antreprenori. Coachingul generează multiple beneficii prin faptul că revitalizează orice domeniu de acţiune sau zonă a vieţii, făcându-le să înflorească.

Termenul englezesc "coach", provenit din sport, și-a făcut loc în vocabularul de afaceri şi management de aproape treizeci de ani. Un "antrenor de oameni" are nevoie - indiferent de domeniu - de abilități diferite de cele cerute de profilul tradiţional al unui bun manager. Multe firme, companii, organizaţii şi lideri de prestigiu din România folosesc serviciile de coaching, conştientizând plusvaloarea acestora. Se configurează, astfel, o nouă formă de leadership şi cultură organizaţională, bazată pe învăţare şi coaching, diferită de vechea paradigmă bazată pe comandă şi control. Liderii de succes ai viitorului vor trebui să conducă pe baza unui stil de tip coaching şi nu recurgând la ordine şi control. (Whitmore, 2008, p.17). Abordarea managerială care integrează valori şi abilităţi de coaching livrează cea mai înaltă performanţă pentru că se bazează pe dezvoltarea oamenilor, pe creşterea gradului lor de conştientizare, de implicare şi responsabilizare.

La nivel mondial, profesia de coach s-a dezvoltat în ritm accelerat în ultimii treizeci de ani, iar în România de aproximativ cincisprezece/douăzeci de ani. Profesia de coach se extinde cu o viteză foarte mare pentru că răspunde cel mai bine nevoilor şi provocărilor omului actual aflat în căutarea sensului şi semnificaţiei vieţii, a profesiei lui, a creşterii organizaţiei în care munceşte sau a 
businessului pe care îl construieşte. Coachingul este o profesie recunoscută şi reglementată la nivel naţional (din 2014, cod COR 242412), de Autoritatea Naţională de Calificări din România (ANC) şi la nivel internaţional, de Federaţia Internaţională de Coaching (ICF). Pentru a deveni coach profesionist este necesară parcurgerea unor programe de formare acreditate de ANC sau ICF sau programe universitare corelate cu profesiile din codul ocupaţiilor (COR), precum şi obţinerea certificărilor emise de aceste foruri profesionale, pe bază de examene.

Există domenii şi profesii care se ocupă de dezvoltarea resurselor umane şi care par a avea puncte comune cu coachingul, însă în realitate sunt diferite. Profesia de coach nu se confundă şi nu se substituie altor roluri sau profesii, precum cea de psiholog, mentor, consilier, consultant, trainer, profesor etc. Într-o accepţiune generală şi cuprinzătoare, coachingul este definit ca o relaţie de parteneriat între coach şi client în care coach-ul acompaniază clientul într-un proces reflexiv, creativ şi dinamic pentru ca acesta să-şi descopere potenţialul personal şi profesional şi pentru a obţine rezultatele pe care şi le propune (ICF).

În sinteză, profesionistul în domeniul coachingului acompaniază procesele de învăţareschimbare la scară individuală şi colectivă (grup, echipă şi organizaţie). Acestea sunt experienţe transformaţionale pentru că nu se rezumă la acumularea de cunoştinţe teoretice (precum învăţarea clasică, de tip şcolar/academic/training), ci schimbă atitudini şi comportamente prin facilitarea conştientizării şi responsabilizării personale. Coachingul este un proces de învăţare experienţială destinat creşterii personale si profesionale prin depăşirea obstacolelor interne ce stau, adesea, în calea succesului precum frica, îndoiala, convingerile limitative, gândirea în ,alb-negru” (Whitmore, 2008, p.24).

Dacă profesia de coach s-a dezvoltat în ritm accelerat în ultimele două decenii, atât în ceea ce priveşte metodele de intervenţie şi eficacitatea practică a acestora, cât şi în privinţa numărului de profesionişti certificaţi de Federaţia Internaţională de Coaching şi de către alte organisme naţionale şi internaţionale de acreditare profesională, cercetarea de coaching nu s-a dezvoltat, însă, în acelaşi ritm cu profesia. Pentru a contura o imagine de ansamblu asupra dinamicii cercetării de coaching şi a componentelor relevante ale acesteia, voi porni de la propria experienţă de coach profesionist folosind câteva întrebări exploratorii, care au potenţialul de a deschide investigări viitoare: cine? ce? cum? unde? de ce face cercetare de coaching? (Linley, 2006). După identificarea principalelor tendinţe în cercetarea actuală a practicii de coaching pe baza acestor întrebări exploratorii, am ales să exemplific aceste tendinţe prin analiza câtorva cercetări de coaching cu privire la tranziţiile în carieră, publicate în International Journal of Evidence Based Coaching and Mentoring.

\section{2. Întrebări exploratorii cu privire la cercetarea practicii de coaching}

\section{Cine?}

La nivel internaţional, există câteva centre universitare de cercetare şi companii private care fac cercetare, cele mai cunoscute fiind: Institute of Coaching, Harvard University; Coaching Psychology Unit, University of Sydney; International Centre for Coaching and Mentoring Studies, Oxford Brookes University; Henley Business School; Sheffield Hallam University; European Mentoring \& Coaching Council (EMCC); International Coach Federation (ICF); INSAID. Cercetarea de coaching este realizată, cel mai frecvent, de profesionişti din zona academică fără ca aceştia să fie şi practicieni în domeniu. Unii coachi publică articole şi cărţi ca demersuri reflexive asupra practicii profesionale sau fac cercetare în contextul programelor de masterat şi doctorat pe care le parcurg. Am putea spune că aceşti coach, relativ puţini la număr, au profilul unor practicieni cercetători prin implicarea lor în cercetarea practicii profesionale, în scrierea de articole şi cărţi. În acelaşi timp, majoritatea coachilor profesionişti folosesc în munca lor concepte şi instrumente de lucru din ştiinţele sociale şi psihologice, pentru diagnoza iniţială, desfăşurarea procesului de coaching şi evaluarea rezultatelor, integrând astfel cercetările existente în aceste domenii.

Între practicienii de coaching şi specialiştii din zona academică se păstrează, încă, o distanţă considerabilă, uneori explicit exprimată, alteori acceptată tacit. Aceasta poate fi datorată unor 
motive ce ţin de orgolii personale sau de sisteme de referinţă diferite. Relaţia dintre cercetarea de tip academic şi practica profesională de coaching este o temă care ar merita să fie cercetată pentru a crea interfeţe productive pentru ambele sisteme. În România, cercetările de coaching se concretizează, în principal, în forma lucrărilor de doctorat, master şi licenţă, care adesea nu sunt publicate pentru a putea fi cunoscute de publicul interesat. De asemenea, coachii români profesionişti au puţine cărţi publicate. Majoritatea cărţilor existente în România despre fundamentele teoretice şi practice ale coachingului (procesul de coaching, beneficii şi rezultate măsurabile, relaţia de coaching, competenţele de coaching etc.) sunt traduceri ale unor coach profesionişti recunoscuţi la nivel mondial: John Whitmore, Alain Cardon, Timothy Gallwey, Marshall Goldsmith, Perry Zeus, Suzanne Skiffington, Manfred Kets de Vries ş.a.

\section{Ce?}

Tematica abordată în cercetările de coaching este diversă, însă temele au pondere diferită, unele fiind frecvent abordate, altele încă necesitând explorare sau aprofundare. În cărţile şi revistele de specialitate (din care am selectat, după criteriile menţionate în paginile următoare, International Journal of Evidence Based Coaching and Mentoring), putem identifica teme care au în atenţie caracteristicile şi competenţele profesionistului; teme care se referă la comportamentul clientului; teme despre relaţia de coaching; despre proces; despre modelele de acompaniere; despre metode, tehnici şi instrumente de învăţare experienţială; despre modelele teoretice folosite în practica de coaching; despre rezultatele obţinute; despre dinamica profesiei; despre etica profesională; despre cele mai frecvente subiecte abordate de către clienţi etc. (Bennett, 2006). Cele mai frecvente cercetări pe care le-am identificat până acum sunt cele referitoare la impactul procesului de coaching asupra clienţilor, fapt explicabil atât prin raţiuni financiare (ROI / return on investment), cât şi prin nevoia de validare şi de vizibilitate a profesiei.

\section{Cum?}

Microcercetările de tip calitativ şi mixte, bazate pe studii de caz, interviuri semi-structurate, focus grup, cercetare acţiune, analiza fenomenologică, analiza tematică sunt demersurile cele mai frecvente pe care le putem identifica în articolele şi publicaţiile academice, de specialitate. Întâlnim şi cercetări de tip experimental şi cercetări care au la bază măsurători pe bază de scale de atitudini/de satisfacţie sau teste psihologice. Cercetări de tip cantitativ, la mivel macro, cu privire la impactul coachingului în organizaţii, realizează anual Federaţia Internaţională de Coaching. Pentru că procesul de coaching este, în esenţa sa, un proces de schimbare şi transformare umană, unde factorul subiectiv/,,invizibil" şi experienţa trăită sunt definitorii, cercetarea cu scop de măsurare, în sensul „,clasic"/'tare” al cuvântului nu este cea mai adecvată abordare. Este adevărat că procesul de schimbare presupune o perspectivă longitudinală în care avem nevoie să comparăm situaţia pre- şi post-intervenţie. Pentru aceasta putem folosi instrumente flexibile, de tip calitativ, care se sincronizează cel mai bine cu spiritul coachingului. Determinarea clientului de a lucra, încrederea lui în proces şi în relaţia de coaching, sistemul de automonitorizare a progreselor şi de autoevaluare a rezultatelor clientului, non-directivitatea acompanierii sunt câteva dintre componentele de bază în evaluarea reuşitei procesului de coaching şi obţinerea rezultatelor dorite/proiectate de către client.

\section{Unde?}

Multe dintre principiile şi regulile care trebuie respectate în cercetarea ştiinţifică şi care ţin de aspectul normativ şi etic al acesteia se regăsesc şi în codul deontologic al profesiei de coach, aspecte care pot genera formularea unor teme de cercetare distincte. În realizarea cercetărilor cu clienţii de coaching, în mediul online sau prin întâlniri în organizaţii este necesar să respectăm atât principiile etice ale cercetării, cât şi codul deontologic al profesiei de coach. 


\section{De ce?}

Principalele argumente pe care le putem dezvolta cu privire la rostul cercetării de coaching sunt cele care ţin de creşterea eficienţei practicii de coaching şi cele care au în vedere profesionalizarea în acest domeniu. Întrebarea de ce este din registrul valorilor, al autenticităţii, al motivaţiei profunde a cercetătorului şi a practicianului (coach) - cercetător. Spaţiul în care spiritul coachingului şi cel al cercetării se întâlnesc, în ciuda barierelor şi separărilor profesionale convenţionale este spaţiul umanismului, al progresului, al curiozităţii descoperirii şi al bucuriei extinderii cunoaşterii şi conştientizării umane.

\section{Cercetări de coaching cu privire la tranziţiile în carieră}

Pentru exemplificarea tendinţelor existente în cercetarea de coaching propunem în continuare o analiză de conţinut, de tip literature review pe zece articole cu privire la practica de coaching pentru tranziţii în carieră.

Obiectivele acestui demers sunt:

- analiza cercetărilor cu privire la practica de coaching, aşa cum sunt acestea reflectate în principala publicaţie a International Centre for Coaching and Mentoring Studies at Oxford Brookes University, UK: International Journal of Evidence Based Coaching and Mentoring, în intervalul 2018 - 2020;

- $\quad$ selectarea cercetărilor cu privire la practica de coaching pentru acompanierea tranziţiilor de carieră-viaţă;

- $\quad$ analiza perspectivelor teoretice utilizate în cercetarea empirică;

- analiza metodologiei de cercetare utilizate;

- $\quad$ identificarea profilului subiecţilor cercetării (număr, profil socio-demografic);

- identificarea temelor cercetării.

Întrebările acestui demers de documentare şi analiză de conţinut, de tip literature review sunt următoarele:

- Cum este realizată cercetarea cu privire la practica de coaching în articolele selectate?

- Cum a fost făcută cercetarea cu privire la practica de coaching pe tema tranziţiilor de carierăviaţă?

- Care este designul cercetării? / Ce metode, tehnici, procedee şi instrumente de cercetare calitativă sunt folosite?

- Ce perspective teoretice sunt alese în fundamentarea cercetării empirice?

- Care sunt temele cercetate?

- Care este profilul subiecţilor cercetării?

- Care sunt definiţiile conceptelor: tranziţie, pasaj de carieră-viaţă ş.a.?

- Ce modele de intervenţie prin coaching se folosesc în practică?

- Care sunt beneficiile coachingului evidenţiate prin cercetare? Beneficii pentru clienţi; beneficii pentru practica de coaching;

- Cine face cercetarea? Cercetătorul sau practicianul (coach) - cercetător?

\section{Metoda analizei de conţinut}

Pentru atingerea obiectivelor pe care le-am ales pentru acest demers, am folosit metoda analizei de conţinut, ca analiză tematică, pe care am aplicat-o pe un set de articole selectate după anumite criterii relevante pentru tema cercetată. În acest sens, am ales zece articole din principala publicaţie ştiinţifică a unui important Centru internaţional de cercetare pe domeniul coachingului şi mentoratului din cadrul facultăţii de business, Universitatea Oxford Brookes.

Principalul criteriu care a stat la baza acestei alegeri a fost faptul că acest centru universitar de cercetare este printre puţinele centre din Europa care are o tradiţie în cercetarea de coaching, are o revistă indexată şi are un program de doctorat pe acest domeniu (singurul din lume la acest moment 
după informaţiile pe care le-am identificat). Revista din care am selectat aceste zece articole este: International Journal of Evidence Based Coaching and Mentoring, revistă indexată în: EBSCO (PsycINFO and Business Source Complete), Scopus, and the Directory of Open Access Journals.

Revista apare din 2003 şi a publicat până în prezent 46 de numere, în medie câte trei numere pe an, având în total 444 de articole publicate în intervalul 2003-2020. Am selectat cele zece articole din numerele apărute în ultimii cinci ani (2015-2020), adică dintr-un total de 165 de articole semnate de cercetători, practicieni şi universitari din întreaga lume, cei mai mulţi fiind din SUA, UK şi Australia.

Selecţia articolelor am realizat-o după cuvinte cheie şi abstract. Cuvintele cheie utilizate au fost: coaching research methodology; research themes; coaching research questions; action research; practitioner research; career coaching; women's career transitions.

Criteriile de includere a articolelor în eşantion au fost:

- Articol apărut în International Journal of Evidence Based Coaching and Mentoring;

- In intervalul 2018-2020;

- Prezintă o cercetare de coaching cu privire la acompanierea unei tranziţii de carieră;

- Prezintă o cercetare de coaching cu un design calitativ;

- Subiecţii practicii şi cercetării de coaching sunt, în principal (dar nu exclusiv), femei;

- Cuvintele cheie menţionate mai sus apar în titlu sau în abstract.

Etapele realizării analizei de conţinut:

1. Stabilirea temei cercetării

2. Formularea obiectivelor cercetării pe baza analizei de conţinut

3. Identificarea literaturii relevante

4. Alegerea bazei de date folosite

4. Criterii de includere şi excludere

5. Selecţia articolelor pentru analiză

6. Analiza tematică (6 etape: Braun \& Clarke, 2006)

7. Interpretarea rezultatelor (Discuţii)

8. Limitele cercetării

9. Direcţii viitoare

10. Concluzii

11. Bibliografie

Am optat pentru o analiză tematică teoretică (diferită de abordarea inductivă), aflată în conexiune cu obiectivele şi întrebările de cercetare care stau la baza demersului propus (Braun, Clarke, 2006, pp. 83-84). Astfel, temele predeterminate pentru această analiză de conţinut sunt în număr de zece:

- T1: Scopul cercetării

- T2: Întrebarea/întrebările de cercetare

- T3: Perspectiva teoretică

- T4: Metodologia cercetării

- T5: Numărul şi profilul subiecţilor din cercetarea de coaching

- T6: Definirea conceptelor utilizate: later career; reinvention; career transitions ş.a.

- T7: Rezultatele/beneficiile procesului de coaching

- T8: Cine face cercetarea: cercetătorul sau practicianul (coach) - cercetător

- T9: Limitele cercetării

- T10: Recomandări pentru cercetări viitoare.

Analiza tematică poate fi vizualizată în tabelele 1, 2 şi 3, unde am utilizat extrase, în traducerea noastră, din articolele analizate. 


\section{Rezultate}

Tabel 1: Elementele strategiei de cercetare

\begin{tabular}{|c|c|c|c|c|}
\hline Articolul & $\begin{array}{l}\text { T1+2 } \\
\text { Scop/întrebările de } \\
\text { cercetare }\end{array}$ & $\begin{array}{l}\text { T3 } \\
\text { Perspectiva teoretică }\end{array}$ & $\begin{array}{l}\text { T4 } \\
\text { Metodologia } \\
\text { cercetării }\end{array}$ & $\begin{array}{l}\text { T5 } \\
\text { Număr şi profil } \\
\text { subiecţi }\end{array}$ \\
\hline $\begin{array}{l}\text { A1: Laura Walker, } \\
\text { Coaching în } \\
\text { perioada de } \\
\text { reinventare a } \\
\text { carierei: modelul } \\
\text { descoperirii, } \\
(2019) \text {. }\end{array}$ & $\begin{array}{l}\text { Scopul studiului } \\
\text { este de a contribui la } \\
\text { extinderea } \\
\text { cunoaşterii necesare } \\
\text { coachi-lor care } \\
\text { lucrează cu oameni } \\
\text { care parcurg un } \\
\text { proces de } \\
\text { reinventare a } \\
\text { carierei lor târzii } \\
\text { (late career). } \\
\text { Studiile arată că cei } \\
\text { mai mulți dintre noi } \\
\text { vom trăi și vom } \\
\text { lucra mai mult timp, } \\
\text { datorită creşterii } \\
\text { speranţei de viaţă, } \\
\text { însă ce se întâmplă } \\
\text { dacă vrem să facem } \\
\text { ceva foarte diferit în } \\
\text { ultimii ani din } \\
\text { cariera noastră } \\
\text { profesională? }\end{array}$ & $\begin{array}{l}\text { Teoria celor opt stadii } \\
\text { de viaţă (Levinson, } \\
\text { 1978). } \\
\text { Literatura cu privire } \\
\text { dezvoltarea carierei, } \\
\text { politicile publice şi } \\
\text { configurarea unor noi } \\
\text { trasee în carieră (Wang } \\
\text { et al., 2013). } \\
\text { Teoriile tradiționale } \\
\text { bazate pe } \\
\text { predictibilitate (locul } \\
\text { de muncă, trăsăturile } \\
\text { personale; etapele } \\
\text { vieții şi ale carierei) au } \\
\text { fost criticate pentru } \\
\text { rigiditatea lor şi } \\
\text { dominanţa modelului } \\
\text { masculin de normare } \\
\text { socială, precum şi a } \\
\text { modelului american de } \\
\text { reuşită profesională. } \\
\text { Modele teoretice } \\
\text { recente: modelul } \\
\text { sistemic cu privire la } \\
\text { muncă şi carieră (Hall, } \\
\text { 2002); modelul } \\
\text { „carierei fără granițe” } \\
\text { (Arthur and Rousseau, } \\
\text { 1996). }\end{array}$ & $\begin{array}{l}\text { Strategie de } \\
\text { cercetare calitativă } \\
\text { ca demers inductiv; } \\
\text { metodologia } \\
\text { generării teoriei din } \\
\text { datele empirice } \\
\text { (Grounded theory). } \\
\text { Utilizarea } \\
\text { interviurilor } \\
\text { individuale, } \\
\text { semistructurate, } \\
\text { realizate prin } \\
\text { telefon. } \\
\text { Codarea și analiza } \\
\text { au început după } \\
\text { primele interviuri și } \\
\text { au continuat pe tot } \\
\text { parcursul acestora. } \\
\text { Analiza datelor a } \\
\text { implicat cele trei } \\
\text { niveluri de codare } \\
\text { tipice teoriei } \\
\text { fundamentate } \\
\text { (Grounded theory): } \\
\text { codarea deschisă, } \\
\text { axială şi selectivă. }\end{array}$ & $\begin{array}{l}\text { Un grup de subiecţi } \\
\text { format din } 7 \text { coachi } \\
\text { cu experienţă în } \\
\text { acompompanierea } \\
\text { persoanelor în } \\
\text { procesele de } \\
\text { reinventare a } \\
\text { carierei târzii. } \\
\text { Un grup de } 7 \\
\text { subiecţi de coaching } \\
\text { care au parcurs } \\
\text { procesul lor de } \\
\text { reinventare a } \\
\text { carierei târzii. } \\
\text { Mai multe femei } \\
\text { decât bărbaţi ( } 5: 2 \\
\text { pentru ambele } \\
\text { grupuri). }\end{array}$ \\
\hline $\begin{array}{l}\text { A2: Mary Louise } \\
\text { Fogg, } \\
\text { Împuternicirea } \\
\text { femeilor în prag de } \\
\text { pensionare prin } \\
\text { coaching orientat } \\
\text { către obiective şi } \\
\text { bunăstare: studiu } \\
\text { de caz multiplu } \\
(2019) \text {. }\end{array}$ & $\begin{array}{l}\text { Cum ajută } \\
\text { abordarea de } \\
\text { coaching bazată pe } \\
\text { dovezi, inclusiv } \\
\text { utilizarea Profilului } \\
\text { PERMA, în } \\
\text { stabilirea } \\
\text { obiectivelor } \\
\text { personale } \\
\text { semnificative și } \\
\text { creşterea bunăstării } \\
\text { femeilor aflate în } \\
\text { etapa profesională } \\
\text { care precede } \\
\text { pensionarea? } \\
\text { Scopul acestui } \\
\text { studiu a fost să } \\
\text { îțeleagă procesul } \\
\text { de coaching pentru } \\
\text { selectarea }\end{array}$ & $\begin{array}{l}\text { Teoria bunăstării } \\
\text { (Seligman, 2011). } \\
\text { Coaching-ul de viaţă, } \\
\text { ca intervenție de } \\
\text { psihologie pozitivă } \\
\text { aplicată. } \\
\text { Literatura privind } \\
\text { stabilirea obiectivelor } \\
\text { care îmbunătățește } \\
\text { bunăstarea şi eficiența } \\
\text { clientului (Clutterbuck } \\
\text { \& Spence, 2016; } \\
\text { Grant, 2012). }\end{array}$ & $\begin{array}{l}\text { Studiul de caz } \\
\text { multiplu folosește } \\
\text { un design integrat } \\
\text { de metode mixte. } \\
\text { Au fost alese mai } \\
\text { multe cazuri pentru } \\
\text { a permite } \\
\text { confirmarea sau } \\
\text { infirmarea } \\
\text { concluziilor dintr-un } \\
\text { caz prin celelalte } \\
\text { cazuri. } \\
\text { Folosirea } \\
\text { chestionarului de } \\
\text { profil PERMA } \\
\text { pentru culegerea } \\
\text { datelor cantitative } \\
\text { (Butler \& Kern, } \\
\text { 2016). }\end{array}$ & $\begin{array}{l}\text { Trei cazuri (trei } \\
\text { femei participante). } \\
\text { Toți subiecţii erau } \\
\text { la începutul vârstei } \\
\text { de şaizeci de ani, } \\
\text { lucrau în locuri de } \\
\text { muncă } \\
\text { guvernamentale şi } \\
\text { aveau în vedere } \\
\text { tranziția de la } \\
\text { profesia cu normă } \\
\text { întreagă la un alt } \\
\text { angajament de } \\
\text { muncă. } \\
\text { Preocuparea } \\
\text { comună era cu } \\
\text { privire la } \\
\text { schimbările } \\
\text { financiare care vin }\end{array}$ \\
\hline
\end{tabular}




\begin{tabular}{|c|c|c|c|c|}
\hline Articolul & $\begin{array}{l}\text { T1+2 } \\
\text { Scop/întrebările de } \\
\text { cercetare }\end{array}$ & $\begin{array}{l}\text { T3 } \\
\text { Perspectiva teoretică }\end{array}$ & $\begin{array}{l}\text { T4 } \\
\text { Metodologia } \\
\text { cercetării }\end{array}$ & $\begin{array}{l}\text { T5 } \\
\text { Număr şi profil } \\
\text { subiecți }\end{array}$ \\
\hline & $\begin{array}{l}\text { obiectivelor } \\
\text { clienților. }\end{array}$ & & $\begin{array}{l}\text { Fiecare participant a } \\
\text { primit cinci sesiuni } \\
\text { de coaching de o } \\
\text { oră, măsuri de } \\
\text { pregătire pre și post } \\
\text { coaching și un } \\
\text { interviu semi- } \\
\text { structurat de } \\
\text { patruzeci de minute } \\
\text { după sesiunea } \\
\text { finală. } \\
\text { Analiza tematică } \\
\text { (TA) a fost utilizată } \\
\text { pentru a identifica, } \\
\text { analiza și raporta } \\
\text { tiparele (teme) în } \\
\text { cadrul datelor } \\
\text { calitative (Braun \& } \\
\text { Clark, 2006). }\end{array}$ & $\begin{array}{l}\text { odată cu } \\
\text { pensionarea. }\end{array}$ \\
\hline $\begin{array}{l}\text { A3: Charlotte } \\
\text { Brown, Julia } \\
\text { Yates, Înțelegerea } \\
\text { experienței } \\
\text { femeilor în etapa } \\
\text { vârstei de mijloc, } \\
\text { beneficiare ale unui } \\
\text { program de } \\
\text { coaching pentru } \\
\text { armonizarea vieţii } \\
\text { personale şi } \\
\text { profesionale: o } \\
\text { analiză } \\
\text { fenomenologico- } \\
\text { interpretativă, } \\
\text { (2018). }\end{array}$ & $\begin{array}{l}\text { Acest studiu are ca } \\
\text { scop clarificarea } \\
\text { modului în care } \\
\text { coachingul de } \\
\text { carieră, ca } \\
\text { intervenție } \\
\text { multidimensională } \\
\text { personalizată, poate } \\
\text { ajuta la susținerea } \\
\text { femeilor de vârsta } \\
\text { mijlocie pentru a } \\
\text { atinge un echilibru } \\
\text { satisfăcător între } \\
\text { viața profesională și } \\
\text { viața personală. }\end{array}$ & $\begin{array}{l}\text { Teoria graniţei muncă- } \\
\text { familie (Clark, 2000). } \\
\text { Teoria } \\
\text { alegerilor/preferinţelor } \\
\text { (Hakim, 2002, 2003, } \\
\text { 2004, 2006). } \\
\text { Coachingul de carieră } \\
\text { are patru funcții pentru } \\
\text { clienți: facilitarea } \\
\text { schimbării, clarificarea } \\
\text { valorilor şi credințelor, } \\
\text { identificarea rolurilor } \\
\text { sociale importante şi } \\
\text { recunoașterea } \\
\text { schimbărilor } \\
\text { emergente de } \\
\text { dezvoltare (Hudson, } \\
\text { 1999). } \\
\text { Cercetări anterioare } \\
\text { care arată beneficiile } \\
\text { coachingului de carieră } \\
\text { ca reducere a stresului, } \\
\text { alinierea între viziunea } \\
\text { personală şi } \\
\text { organizaţională, } \\
\text { creșterea inteligenței } \\
\text { emoționale } \\
\text { (Skiffington and Zeus, } \\
\text { 2002). }\end{array}$ & $\begin{array}{l}\text { Cercetarea-acţiune. } \\
\text { Analiza } \\
\text { interpretativ- } \\
\text { fenomenologică } \\
\text { (IPA). } \\
\text { Un demers de } \\
\text { cercetare-acțiune, } \\
\text { care a implicat ca } \\
\text { intervenție - un } \\
\text { program de } \\
\text { coaching de carieră; } \\
\text { datele au fost } \\
\text { colectate prin } \\
\text { interviuri semi- } \\
\text { structurate şi } \\
\text { analizate folosind } \\
\text { analiza } \\
\text { fenomenologică } \\
\text { interpretativă. } \\
\text { A fost proiectat şi } \\
\text { desfăşurat un } \\
\text { program integrat de } \\
\text { trei sesiuni de } \\
\text { coaching. } \\
\text { Pentru fiecare } \\
\text { participant a fost } \\
\text { realizat un interviu } \\
\text { semi-structurat faţă } \\
\text { în față la o lună } \\
\text { după ultima sesiune } \\
\text { de coaching. }\end{array}$ & $\begin{array}{l}\text { Cinci femei cu } \\
\text { vârste cuprinse între } \\
\text { treizeci și cinci și } \\
\text { cincizeci de ani, din } \\
\text { Londra, au fost } \\
\text { selectate pentru un } \\
\text { program de } \\
\text { coaching de carieră, } \\
\text { conceput pentru a } \\
\text { îmbunătăți } \\
\text { echilibrul muncă- } \\
\text { viață; toate erau } \\
\text { mame de bebeluși } \\
\text { sau copii de școală } \\
\text { primară. }\end{array}$ \\
\hline $\begin{array}{l}\text { A4: Sally Jackson, } \\
\text { Coaching pentru } \\
\text { femei într-un }\end{array}$ & $\begin{array}{l}\text { Subreprezentarea } \\
\text { femeilor senioare în } \\
\text { universități este „un }\end{array}$ & $\begin{array}{l}\text { Literatura de } \\
\text { specialitate relevă } \\
\text { importanța relaţiei ca o }\end{array}$ & $\begin{array}{l}\text { Interviul euristic se } \\
\text { bazează pe o } \\
\text { abordare umanistă, }\end{array}$ & $\begin{array}{l}\text { Nouă femei din } \\
\text { învățământul } \\
\text { universitar englez }\end{array}$ \\
\hline
\end{tabular}




\begin{tabular}{|c|c|c|c|c|}
\hline Articolul & $\begin{array}{l}\text { T1+2 } \\
\text { Scop/întrebările de } \\
\text { cercetare }\end{array}$ & $\begin{array}{l}\text { T3 } \\
\text { Perspectiva teoretică }\end{array}$ & $\begin{array}{l}\text { T4 } \\
\text { Metodologia } \\
\text { cercetării }\end{array}$ & $\begin{array}{l}\text { T5 } \\
\text { Număr şi profil } \\
\text { subiecţi }\end{array}$ \\
\hline $\begin{array}{l}\text { demers de } \\
\text { explorare a } \\
\text { autenticităţii în } \\
\text { profesie, (2019) }\end{array}$ & $\begin{array}{l}\text { fenomen sistemic la } \\
\text { nivel mondial" } \\
\text { (Parker et al, 2018; } \\
\text { Blackmore, 2014). } \\
\text { În încercarea de a } \\
\text { remedia această } \\
\text { disproporție a } \\
\text { personalului dintr-o } \\
\text { universitate, a fost } \\
\text { introdus coaching } \\
\text { pentru unele femei } \\
\text { universitare. } \\
\text { Problema cercetării } \\
\text { a fost identificată la } \\
\text { nivelul experienței } \\
\text { profesionale a } \\
\text { femeilor din } \\
\text { universități care, } \\
\text { muncind într-un } \\
\text { mediu dominant } \\
\text { masculin, își pierd } \\
\text { sentimentul de sine } \\
\text { și de autenticitate. }\end{array}$ & $\begin{array}{l}\text { componentă esențială } \\
\text { atât pentru coaching-ul } \\
\text { productiv, cât și pentru } \\
\text { autenticitate (Sieler, } \\
\text { 2010; de Haan, 2008; } \\
\text { Gyllensten and Palmer, } \\
\text { 2007; Bluckert, 2006; } \\
\text { 2005; Roberts et al, } \\
\text { 2009; Eagly, 2005; } \\
\text { Gardner et al, 2005). } \\
\text { De asemenea, cercetări } \\
\text { anterioare sugerează că } \\
\text { relația este } \\
\text { fundamentală pentru } \\
\text { modul în care femeile } \\
\text { își gestionează viața } \\
\text { profesională (Cabrera, } \\
\text { 2007). }\end{array}$ & $\begin{array}{l}\text { centrată pe } \\
\text { persoană, ca } \\
\text { generatoare a } \\
\text { cunoașterii, ca şi } \\
\text { „cunoaştere tacită” } \\
\text { (Rogers, 1985; } \\
\text { Polanyi, 1966). } \\
\text { Cercetarea euristică } \\
\text { are şase faze: } \\
\text { implicarea inițială, } \\
\text { imersiunea, } \\
\text { incubația, } \\
\text { iluminarea, } \\
\text { explicarea şi sinteza } \\
\text { creatoare } \\
\text { (Moustakas, 1990). } \\
\text { În acest studiu, } \\
\text { datele provin din } \\
\text { experiențele } \\
\text { combinate ale celor } \\
\text { nouă femei care } \\
\text { împărtăşesc } \\
\text { explorarea ca şi ,co- } \\
\text { cercetători”. } \\
\text { Fiecare co- } \\
\text { cercetătoare a fost } \\
\text { intervievată de trei } \\
\text { ori, la un interval de } \\
\text { trei luni între fiecare } \\
\text { interviu. Acest fapt } \\
\text { a permis reflecția şi } \\
\text { auto-observarea } \\
\text { oferind timp pentru } \\
\text { transcriere și analiza } \\
\text { datelor înainte de } \\
\text { începerea } \\
\text { următorului ciclu de } \\
\text { colectare a datelor. } \\
\text { 9 x } 3=27 \text { interviuri. }\end{array}$ & $\begin{array}{l}\text { au colaborat în } \\
\text { calitate de co- } \\
\text { cercetătoare pentru } \\
\text { a explora } \\
\text { autenticitatea, } \\
\text { printr-un demers de } \\
\text { coaching. }\end{array}$ \\
\hline $\begin{array}{l}\text { A5: Maria Smith, } \\
\text { Un nou sens al } \\
\text { sinelui: explorarea } \\
\text { experienței de } \\
\text { coaching în cadrul } \\
\text { unui program de } \\
\text { master în } \\
\text { managementul } \\
\text { afacerii, }(2018)\end{array}$ & $\begin{array}{l}\text { Acest studiu } \\
\text { explorează } \\
\text { experienţa de } \\
\text { coaching a } \\
\text { studenţilor de la } \\
\text { master (FTMBA), } \\
\text { având în atenție trei } \\
\text { întrebări cheie: } \\
\text { • în ce măsură este } \\
\text { evidentă tranziția în } \\
\text { stadiul de viață la } \\
\text { studenții de master } \\
\text { FTMBA? } \\
\text { • cum îi ajută } \\
\text { coachingul pe }\end{array}$ & $\begin{array}{l}\text { Teoriile dezvoltării } \\
\text { adulților care susțin că } \\
\text { oamenii au potențialul } \\
\text { de a învăța, de a se } \\
\text { dezvolta și schimba } \\
\text { de-a lungul vieții lor de } \\
\text { adult (e.g. Levinson } \\
\text { 1986; Kegan and } \\
\text { Lahey, 2009). } \\
\text { Dubouloy susține că } \\
\text { „sinele fals” este } \\
\text { responsabil pentru } \\
\text { deciziile nefericite din } \\
\text { carieră. }\end{array}$ & $\begin{array}{l}\text { Abordarea } \\
\text { interpretativă } \\
\text { fenomenologică } \\
\text { (IPA): modul în } \\
\text { care studenţii au } \\
\text { semnificat } \\
\text { experienţa de } \\
\text { coaching. } \\
\text { Pe parcursul } \\
\text { cercetării, studenții } \\
\text { Cranfield FTMBA } \\
\text { au fost susținuți prin } \\
\text { trei programe de } \\
\text { coaching de carieră, } \\
\text { derulate în timpul } \\
\text { masterului: }\end{array}$ & $\begin{array}{l}\text { Cinci studente de la } \\
\text { Master of Business } \\
\text { Administration } \\
\text { (FTMBA) au } \\
\text { beneficiat de } \\
\text { coaching în timpul } \\
\text { studiilor; } \\
\text { studente cu vârsta } \\
\text { cuprinsă între } 28 \text { şi } \\
33 \text { de ani au fost } \\
\text { acompaniate pentru } \\
\text { tranziţia specifică } \\
\text { vârstei de } 30 \text { de ani } \\
\text { (Levinson, 1986); }\end{array}$ \\
\hline
\end{tabular}




\begin{tabular}{|c|c|c|c|c|}
\hline Articolul & $\begin{array}{l}\text { T1+2 } \\
\text { Scop/întrebările de } \\
\text { cercetare }\end{array}$ & $\begin{array}{l}\text { T3 } \\
\text { Perspectiva teoretică }\end{array}$ & $\begin{array}{l}\text { T4 } \\
\text { Metodologia } \\
\text { cercetării }\end{array}$ & $\begin{array}{l}\text { T5 } \\
\text { Număr şi profil } \\
\text { subiecți }\end{array}$ \\
\hline & $\begin{array}{l}\text { studenții FTMBA } \\
\text { să-și înțeleagă } \\
\text { sentimentul de sine? } \\
\text { • Cum sprijină } \\
\text { coachingul studenții } \\
\text { FTMBA aflaţi într-o } \\
\text { perioadă de } \\
\text { tranziție? }\end{array}$ & $\begin{array}{l}\text { Ibarra se concentrează } \\
\text { pe importanța } \\
\text { identității în cariera } \\
\text { individului și a } \\
\text { „adevăratului sine”. } \\
\text { Dezvoltarea unui simţ } \\
\text { al sinelui are o } \\
\text { semnificație } \\
\text { importantă pentru } \\
\text { etapele cheie ale vieții } \\
\text { și tranzițiile în carieră. } \\
\text { Literatura de } \\
\text { specialitate sugerează } \\
\text { că reevaluarea sinelui } \\
\text { poate fi dureroasă și } \\
\text { dificilă, dar poate } \\
\text { aduce multe beneficii } \\
\text { potențiale (Ibarra and } \\
\text { Obodaru, 2016). }\end{array}$ & $\begin{array}{l}\text { - un atelier de o zi, } \\
\text { care a pus bazele } \\
\text { pentru două sesiuni } \\
\text { de coaching faţă în } \\
\text { faţă de } 90 \text { de minute } \\
\text { cu un coach de } \\
\text { carieră extern } \\
\text { experimentat; } \\
\text { - programul de } \\
\text { coaching executiv a } \\
\text { fost format din șase } \\
\text { sesiuni de o oră } \\
\text { programate pe tot } \\
\text { parcursul anului; } \\
\text { - peer-coaching, } \\
\text { care a constat în } \\
\text { zece sesiuni în } \\
\text { restul programului } \\
\text { MBA. } \\
\text { Pentru cercetare: } \\
\text { - interviuri } \\
\text { aprofundate unu-la- } \\
\text { unu cu cei cinci } \\
\text { participanți. }\end{array}$ & $\begin{array}{l}\text { Tranziția vârstei de } \\
30 \text { de ani se poate } \\
\text { întinde pe intervalul } \\
\text { cuprins între } 28 \text { și } \\
33 \text { de ani și este } \\
\text { înfățișată ca o } \\
\text { oportunitate de a } \\
\text { face un bilanț al } \\
\text { traseului actual de } \\
\text { viață și de a lua } \\
\text { decizii care vor } \\
\text { constitui temelia } \\
\text { următoarei etape a } \\
\text { vieții. }\end{array}$ \\
\hline $\begin{array}{l}\text { A6: Laura G. Lane, } \\
\text { Janet De Wilde, } \\
\text { Impactul } \\
\text { coachingului } \\
\text { pentru studenţii } \\
\text { doctoranzi de la o } \\
\text { universitate din } \\
\text { Londra, (2018) }\end{array}$ & $\begin{array}{l}\text { Acest studiu } \\
\text { explorează două } \\
\text { întrebări cheie: } \\
\text { 1. Care au fost } \\
\text { provocările și } \\
\text { problemele pentru } \\
\text { participanții la } \\
\text { studiu? } \\
\text { 2. Coachingul a avut } \\
\text { un impact pozitiv } \\
\text { asupra acestora? } \\
\text { Problematica } \\
\text { socială care a } \\
\text { generat cercetarea: } \\
\text { Există un număr tot } \\
\text { mai mare de } \\
\text { rapoarte care arată o } \\
\text { scădere a bunăstării } \\
\text { studenților din } \\
\text { Marea Britanie cu } \\
\text { incidente grave de } \\
\text { suicid și tulburări } \\
\text { legate de stres. } \\
\text { (UUK, 2015). } \\
\text { Drept urmare, } \\
\text { instituțiile de } \\
\text { învățământ superior } \\
\text { acordă mai multă } \\
\text { atenție modului în } \\
\text { care sprijină } \\
\text { sănătatea mentală a } \\
\text { studenților lor }\end{array}$ & $\begin{array}{l}\text { Există puţine cercetări } \\
\text { cu privire la impactul } \\
\text { coachingului asupra } \\
\text { studenților doctoranzi } \\
\text { (McCarthy, 2012). } \\
\text { Revizuirea literaturii } \\
\text { pe care o propun } \\
\text { autorii, prezintă cinci } \\
\text { articole cheie relevante } \\
\text { pentru acest studiu: } \\
\text { În } 2003 \text {, Grant a } \\
\text { realizat un studiu cu } 20 \\
\text { de studenți } \\
\text { postuniversitari la o } \\
\text { universitate } \\
\text { australiană. Rezultatele } \\
\text { au identificat că } \\
\text { participanții au asociat } \\
\text { coachingul cu } \\
\text { atingerea obiectivului } \\
\text { și conștientizarea de } \\
\text { sine. } \\
\text { În } 2010 \text {, Geber a } \\
\text { publicat cercetări care } \\
\text { susțineau că, } \\
\text { coachingul accelerează } \\
\text { productivitatea } \\
\text { cercetării în } \\
\text { învățământul superior. } \\
\text { Studiul lui Geber a } \\
\text { examinat impactul }\end{array}$ & $\begin{array}{l}\text { O abordare de } \\
\text { metode mixte: } \\
\text { în primul rând, } \\
\text { datele au fost } \\
\text { colectate prin } \\
\text { interviuri } \\
\text { semistructurate şi, } \\
\text { în al doilea rând, } \\
\text { participanții au fost } \\
\text { invitați să } \\
\text { completeze un } \\
\text { chestionar la } \\
\text { sfârşitul } \\
\text { programului de } \\
\text { coaching. } \\
\text { Interviurile nu au } \\
\text { fost înregistrate. } \\
\text { Cercetătorul şi-a } \\
\text { notat datele, care } \\
\text { apoi au fost apoi } \\
\text { revizuite și } \\
\text { codificate. } \\
\text { Studenților } \\
\text { doctoranzi care } \\
\text { doresc să lucreze cu } \\
\text { un coach calificat li } \\
\text { se oferă până la } \\
\text { patru ședințe de } \\
\text { coaching, pe o } \\
\text { perioadă de } \\
\text { aproximativ șase } \\
\text { luni. }\end{array}$ & $\begin{array}{l}\text { Toți doctoranzii } \\
\text { beneficiari ai } \\
\text { programului de } \\
\text { coaching au primit } \\
\text { un e-mail prin care } \\
\text { au fost invitaţi să } \\
\text { participe la studiu; } \\
\text { cinci au confirmat } \\
\text { că sunt încântaţi să } \\
\text { participe. } \\
\text { Au fost trei femei şi } \\
\text { doi bărbaţi. }\end{array}$ \\
\hline
\end{tabular}




\begin{tabular}{|c|c|c|c|c|}
\hline Articolul & $\begin{array}{l}\text { T1+2 } \\
\text { Scop/întrebările de } \\
\text { cercetare }\end{array}$ & $\begin{array}{l}\text { T3 } \\
\text { Perspectiva teoretică }\end{array}$ & $\begin{array}{l}\text { T4 } \\
\text { Metodologia } \\
\text { cercetării }\end{array}$ & $\begin{array}{l}\text { T5 } \\
\text { Număr şi profil } \\
\text { subiecți }\end{array}$ \\
\hline & $\begin{array}{l}\text { (Stanton, Zanvlier, } \\
\text { Dhaliwal \& Black, } \\
\text { 2016). }\end{array}$ & $\begin{array}{l}\text { coachingului pentru } 8 \\
\text { cercetători la început } \\
\text { de carieră, de la } \\
\text { Universitatea din } \\
\text { Witwatersrand, Africa } \\
\text { de Sud. } \\
\text { În 2012, Richardson, } \\
\text { Abraham \& Bond a } \\
\text { realizat o meta-analiză } \\
\text { a factorilor care } \\
\text { contribuie la succesul } \\
\text { academic. } \\
\text { În 2016, Andreanoff a } \\
\text { examinat impactul } \\
\text { peer-coachingului } \\
\text { pentru studenții dintr-o } \\
\text { universitate din sudul } \\
\text { Angliei. } \\
\text { În 2016, Godskensen } \\
\text { \& Kobayashi, a } \\
\text { efectuat o cercetare } \\
\text { asupra beneficiilor } \\
\text { coachingului pentru } 88 \\
\text { de doctoranzi de la } \\
\text { Universitatea Tehnică } \\
\text { din Danemarca. }\end{array}$ & & \\
\hline $\begin{array}{l}\text { A7: Heather Noon, } \\
\text { Christian van } \\
\text { Nieuwerburgh: } \\
\text { Aștepți cu } \\
\text { nerăbdare să te } \\
\text { întorci? Experiența } \\
\text { luării deciziilor în } \\
\text { carieră pentru } \\
\text { mamele aflate la } \\
\text { primul copil și } \\
\text { implicațiile pentru } \\
\text { coachi, (2020). }\end{array}$ & $\begin{array}{l}\text { Acest studiu îşi } \\
\text { propune să } \\
\text { contribuie la } \\
\text { înțelegerea } \\
\text { experienței femeilor } \\
\text { în luarea deciziilor } \\
\text { în carieră. } \\
\text { Studiul are în } \\
\text { atenţie provocările } \\
\text { psihologice } \\
\text { implicate în } \\
\text { mecanismele luării } \\
\text { deciziilor în carieră } \\
\text { de către femei: } \\
\text { efectele normelor de } \\
\text { grup, a mesajelor } \\
\text { culturale și a } \\
\text { practicilor } \\
\text { angajatorilor asupra } \\
\text { luării deciziilor } \\
\text { femeilor. }\end{array}$ & $\begin{array}{l}\text { Teoria social cognitivă } \\
\text { a carierei (Lent, Brown } \\
\text { \& Hackett, 2002); } \\
\text { Teoria preferinţelor } \\
\text { (Hakim, 2006); } \\
\text { Teorii de carieră şi } \\
\text { cercetări psihologice } \\
\text { (Grether \& Wiese, } \\
\text { 2016); } \\
\text { Coachingul şi teoria } \\
\text { dezvoltării adulţilor } \\
\text { (Bachkirova, T. 2014). }\end{array}$ & $\begin{array}{l}\text { Analiza } \\
\text { interpretativ- } \\
\text { fenomenologică } \\
\text { (Interpretative } \\
\text { Phenomenological } \\
\text { Analysis, IPA); } \\
\text { Această } \\
\text { metodologie } \\
\text { operează o dublă } \\
\text { abordare } \\
\text { hermeneutică a } \\
\text { dezvoltării sensului, } \\
\text { deoarece } \\
\text { participanții reflectă } \\
\text { asupra experienței } \\
\text { lor directe, în timp } \\
\text { ce cercetătorul } \\
\text { reflectă separat } \\
\text { asupra experienței } \\
\text { raportate. } \\
\text { Interviurile semi- } \\
\text { structurate de } 50-60 \\
\text { de minute au fost } \\
\text { realizate în cadrul } \\
\text { unui spirit umanist } \\
\text { de anchetă, pe baza } \\
\text { unui ghid construit } \\
\text { în prealabil. }\end{array}$ & $\begin{array}{l}\text { Şase femei } \\
\text { profesioniste din } \\
\text { Londra cu vârste } \\
\text { cuprinse între } 31 \text { și } \\
41 \text { de ani din } \\
\text { domeniile: } \\
\text { jurnalism, Resurse } \\
\text { Umane, bucătar / } \\
\text { alimentar, pensii, } \\
\text { marketing şi } \\
\text { orientare în carieră } \\
\text { pentru învățământul } \\
\text { superior. } \\
\text { Criterii de } \\
\text { includere: a) femei } \\
\text { profesioniste care se } \\
\text { află într-o perioadă } \\
\text { de concediu de } \\
\text { maternitate (de } \\
\text { început sau final); } \\
\text { b) aflate într-o } \\
\text { familie cu ambii } \\
\text { părinţi; c) aflate } \\
\text { într-un proces } \\
\text { decizional privind } \\
\text { cariera. }\end{array}$ \\
\hline
\end{tabular}




\begin{tabular}{|c|c|c|c|c|}
\hline Articolul & $\begin{array}{l}\text { T1+2 } \\
\text { Scop/întrebările de } \\
\text { cercetare }\end{array}$ & $\begin{array}{l}\text { T3 } \\
\text { Perspectiva teoretică }\end{array}$ & $\begin{array}{l}\text { T4 } \\
\text { Metodologia } \\
\text { cercetării }\end{array}$ & $\begin{array}{l}\text { T5 } \\
\text { Număr şi profil } \\
\text { subiecți }\end{array}$ \\
\hline $\begin{array}{l}\text { A8: Stefanie } \\
\text { Jordan, Simone } \\
\text { Kauffeld, } \\
\text { Studiu cu metode } \\
\text { mixte privind } \\
\text { efectele şi } \\
\text { antecedentele } \\
\text { întrebărilor axate } \\
\text { pe soluții în } \\
\text { procesul de } \\
\text { coaching, (2020). }\end{array}$ & $\begin{array}{l}\text { Rolul întrebărilor în } \\
\text { procesul de } \\
\text { coaching este un } \\
\text { subiect încă } \\
\text { insuficient cercetat. } \\
\text { Acest studiu } \\
\text { investighează } \\
\text { răspunsurile } \\
\text { comportamentale } \\
\text { ale clienților la } \\
\text { întrebările axate pe } \\
\text { soluții (Solution- } \\
\text { focused questions, } \\
\text { SFQ) ale coachilor, } \\
\text { efectele acestora } \\
\text { asupra rezultatelor } \\
\text { obținute prin } \\
\text { coaching. } \\
\text { Scopul acestui } \\
\text { studiu a fost o } \\
\text { investigare a } \\
\text { procesului de } \\
\text { coaching la nivel } \\
\text { micro cu accent pe } \\
\text { efectele și } \\
\text { antecedentele SFQ } \\
\text { ale coachilor. }\end{array}$ & $\begin{array}{l}\text { Modeul procesului cu } \\
\text { intrări-ieşiri (Input- } \\
\text { process-output models: } \\
\text { e.g., Boyce \& Hernez- } \\
\text { Broome, 2011). } \\
\text { Modelul coachingului } \\
\text { care foloseşte întrebări } \\
\text { centrate pe soluții } \\
\text { (Solution-focused } \\
\text { questions: Cavanagh \& } \\
\text { Grant, 2010). }\end{array}$ & $\begin{array}{l}\text { Design cu metode } \\
\text { mixte, care } \\
\text { utilizează date de } \\
\text { auto-raportare } \\
\text { longitudinală și date } \\
\text { comportamentale } \\
\text { pentru } 23 \text { de diade } \\
\text { antrenor-client. } \\
\text { Pentru a acoperi } \\
\text { lacunele de } \\
\text { cercetare bazate pe } \\
\text { modele de intrare- } \\
\text { proces-ieșire, ne } \\
\text { propunem să } \\
\text { analizăm procesul } \\
\text { de coaching la nivel } \\
\text { micro. Mai întâi } \\
\text { investigăm } \\
\text { răspunsurile } \\
\text { comportamentale } \\
\text { ale clienților la SFQ } \\
\text { formulate de către } \\
\text { coachi. În al doilea } \\
\text { rând, avem în } \\
\text { vedere relațiile } \\
\text { dintre } \\
\text { comportamentul } \\
\text { clientului în timpul } \\
\text { conversației și } \\
\text { rezultatele } \\
\text { coachingului. În al } \\
\text { treilea rând, } \\
\text { examinăm efectele } \\
\text { atributelor legate de } \\
\text { cariera coachilor } \\
\text { asupra modelului } \\
\text { SFQ. } \\
\text { Cu acordul informat } \\
\text { al coachilor și } \\
\text { clienților, fiecare } \\
\text { sesiune de coaching } \\
\text { a fost înregistrată } \\
\text { video. }\end{array}$ & 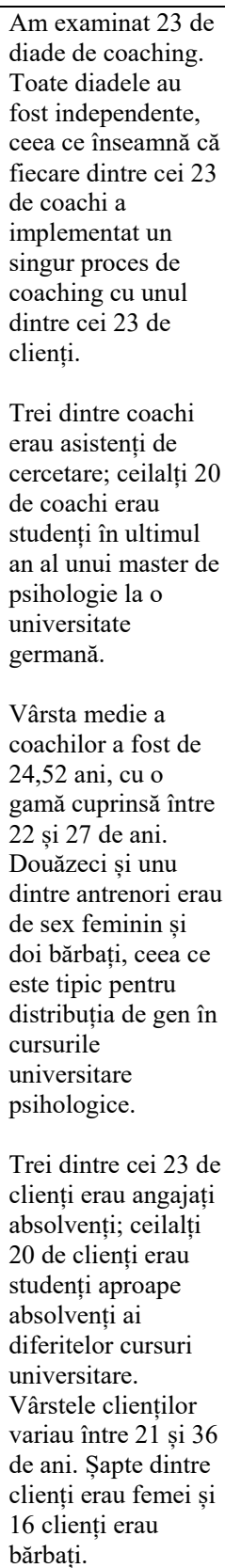 \\
\hline $\begin{array}{l}\text { A9: Shirley } \\
\text { Thompson, Puterea } \\
\text { pragmatismului: } \\
\text { modul în care } \\
\text { managerii de } \\
\text { proiect beneficiază }\end{array}$ & $\begin{array}{l}\text { Scopul studiului a } \\
\text { fost să identifice } \\
\text { beneficiile } \\
\text { coachingului pentru } \\
\text { managerii de } \\
\text { proiect, folosind în }\end{array}$ & $\begin{array}{l}\text { Literatura cu privire la } \\
\text { managementul de } \\
\text { proiect menţionează } \\
\text { nevoia antrenării } \\
\text { abilităților soft și } \\
\text { beneficiile unei }\end{array}$ & $\begin{array}{l}\text { Analiza } \\
\text { interpretativă a } \\
\text { datelor; demers } \\
\text { emergent pragmatic } \\
\text { şi abductiv, } \\
\text { concentrat pe }\end{array}$ & $\begin{array}{l}\text { Şapte coach au } \\
\text { participat la atelier. } \\
\text { De asemenea, au } \\
\text { fost recrutați un } \\
\text { număr echivalent de } \\
\text { participanți ca şi }\end{array}$ \\
\hline
\end{tabular}




\begin{tabular}{|c|c|c|c|c|}
\hline Articolul & $\begin{array}{l}\text { T1+2 } \\
\text { Scop/întrebările de } \\
\text { cercetare }\end{array}$ & $\begin{array}{l}\text { T3 } \\
\text { Perspectiva teoretică }\end{array}$ & $\begin{array}{l}\text { T4 } \\
\text { Metodologia } \\
\text { cercetării }\end{array}$ & $\begin{array}{l}\text { T5 } \\
\text { Număr şi profil } \\
\text { subiecți }\end{array}$ \\
\hline $\begin{array}{l}\text { de coaching pentru } \\
\text { dezvoltarea } \\
\text { abilităților soft și a } \\
\text { încrederii în sine, } \\
(2019) \text {. }\end{array}$ & $\begin{array}{l}\text { acest sens } \\
\text { metodologia de } \\
\text { cercetare- acțiune. }\end{array}$ & $\begin{array}{l}\text { abordări pragmatice, } \\
\text { care poate recunoaşte } \\
\text { procesele sociale } \\
\text { complexe, în ciuda } \\
\text { perspectivei pozitiviste } \\
\text { tradiționale prezente în } \\
\text { domeniul } \\
\text { managementului. } \\
\text { (Cicmil, Williams, } \\
\text { Thomas, and Hodgson, } \\
\text { 2006). } \\
\text { Literatura cu privire la } \\
\text { abilitătile ,soft” (soft- } \\
\text { skills) necesare } \\
\text { managerilor (Hurrell et } \\
\text { al, 2013, Claxton, } \\
\text { Costa and Kallick, } \\
\text { 2016). }\end{array}$ & 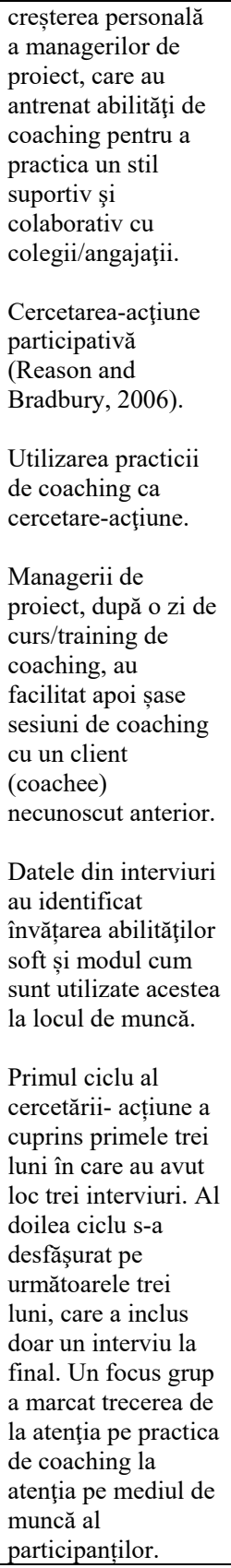 & $\begin{array}{l}\text { clienţi (coachee), } \\
\text { precum şi șapte } \\
\text { manageri de proiect. } \\
\text { Atelierul } \\
\text { experiențial de o zi } \\
\text { și-a propus să ofere } \\
\text { fiecărui manager de } \\
\text { proiect, abilitățile și } \\
\text { încrederea necesare } \\
\text { pentru a antrena un } \\
\text { alt manager de } \\
\text { proiect, ca şi } \\
\text { „participant } \\
\text { coachee”, timp de } \\
\text { șase sesiuni de } \\
\text { coaching pe } \\
\text { parcursul a șase } \\
\text { luni. }\end{array}$ \\
\hline $\begin{array}{l}\text { A10: Sarah } \\
\text { Hughes, Cum } \\
\text { poate un model de } \\
\text { coaching în trei } \\
\text { etape să-i ajute pe } \\
\text { manageri să }\end{array}$ & $\begin{array}{l}\text { Relaţiile } \\
\text { conflictuale de la } \\
\text { locul de muncă sunt } \\
\text { frecvent întâlnite și } \\
\text { au efecte negative } \\
\text { substanțiale asupra }\end{array}$ & $\begin{array}{l}\text { Literatura cu privire la } \\
\text { medierea conflictelor } \\
\text { şi management } \\
\text { organizaţional. }\end{array}$ & $\begin{array}{l}\text { Modelul cercetare- } \\
\text { acţiune (McNiff and } \\
\text { Whitehead, 2011). } \\
\text { Cinci tipuri de date } \\
\text { au fost colectate }\end{array}$ & $\begin{array}{l}\text { Patru directori de la } \\
\text { firme financiare și } \\
\text { servicii tehnologice } \\
\text { de la nivel mondial, } \\
\text { au fost recrutaţi prin } \\
\text { e-mail (din } 15\end{array}$ \\
\hline
\end{tabular}




\begin{tabular}{|c|c|c|c|c|}
\hline Articolul & $\begin{array}{l}\text { T1+2 } \\
\text { Scop/întrebările de } \\
\text { cercetare }\end{array}$ & $\begin{array}{l}\text { T3 } \\
\text { Perspectiva teoretică }\end{array}$ & $\begin{array}{l}\text { T4 } \\
\text { Metodologia } \\
\text { cercetării }\end{array}$ & $\begin{array}{l}\text { T5 } \\
\text { Număr şi profil } \\
\text { subiecți }\end{array}$ \\
\hline $\begin{array}{l}\text { gestioneze } \\
\text { conflictele } \\
\text { existente la locul } \\
\text { de muncă? (2019). }\end{array}$ & $\begin{array}{l}\text { bunăstării } \\
\text { individuale şi a } \\
\text { productivității } \\
\text { organizaționale. O } \\
\text { revizuire a literaturii } \\
\text { a identificat lipsa } \\
\text { unor modele de } \\
\text { coaching, } \\
\text { evidențiate empiric, } \\
\text { care se ocupă de } \\
\text { rezolvarea } \\
\text { conflictelor. } \\
\text { Acest demers de } \\
\text { cercetare- acțiune a } \\
\text { dezvoltat un model } \\
\text { de coaching în trei } \\
\text { etape și a evaluat } \\
\text { utilitatea acestuia } \\
\text { pentru trei directori } \\
\text { din sectorul privat. } \\
\text { Modelul a ajutat } \\
\text { directorii să } \\
\text { dezvolte conștiința } \\
\text { de sine, } \\
\text { conștientizarea altor } \\
\text { persoane, abilități } \\
\text { de comunicare şi } \\
\text { rezolvare a } \\
\text { conflictelor, abilități } \\
\text { de management } \\
\text { emoțional, care s-au } \\
\text { dovedit a fi necesare } \\
\text { pentru a gestiona } \\
\text { eficient conflictele. }\end{array}$ & $\begin{array}{l}\text { Modelul celor cinci } \\
\text { stadii (Brinkert, 2006). } \\
\text { Teoria dezvoltării } \\
\text { constructive (Berger, } \\
\text { 2012). }\end{array}$ & $\begin{array}{l}\text { pentru a permite } \\
\text { validarea } \\
\text { constatărilor } \\
\text { (Bryman, 2012): } \\
\text { transcrieri de } \\
\text { interviuri și } \\
\text { înregistrări audio, } \\
\text { răspunsuri } \\
\text { participanţilor la } \\
\text { chestionar, note de } \\
\text { cercetare și jurnalul } \\
\text { cercetării. } \\
\text { Au fost două faze de } \\
\text { analiză a datelor. } \\
\text { Prima a avut loc pe } \\
\text { parcursul fiecărui } \\
\text { ciclu de cercetare a } \\
\text { acțiunii și s-a } \\
\text { concentrat asupra } \\
\text { modului de } \\
\text { imbunătățire a } \\
\text { fiecărui pas al } \\
\text { modelului. După } \\
\text { terminarea } \\
\text { coachingului, am } \\
\text { efectuat analiza } \\
\text { tematică, deoarece } \\
\text { este compatibilă cu } \\
\text { o paradigmă } \\
\text { interpretivist- } \\
\text { constructivistă și o } \\
\text { metodologie } \\
\text { participativă (Braun } \\
\text { and Clarke, 2006). }\end{array}$ & $\begin{array}{l}\text { contacte iniţiale } \\
\text { avute). Acestora le- } \\
\text { au fost oferite trei } \\
\text { sesiuni gratuite de } \\
\text { coaching în } \\
\text { schimbul feedback- } \\
\text { ului lor; au fost } \\
\text { selectaţi patru } \\
\text { manageri care se } \\
\text { confruntau cu un } \\
\text { conflict la locul de } \\
\text { muncă; trei } \\
\text { participanți au } \\
\text { rămas până la final: } \\
\text { doi directori de } \\
\text { vânzări şi un } \\
\text { consultant de } \\
\text { învățare- dezvoltare. }\end{array}$ \\
\hline
\end{tabular}

Tabel 2: Definirea conceptelor cheie din articolele analizate

\begin{tabular}{|c|c|}
\hline Articolul & $\begin{array}{c}\text { T6 } \\
\text { Definirea conceptelor cheie }\end{array}$ \\
\hline $\begin{array}{l}\text { A1: Laura Walker, Coaching } \hat{\imath} n \\
\text { perioada de reinventare a carierei: } \\
\text { modelul descoperirii, }(2019) \text {. }\end{array}$ & $\begin{array}{l}\text { Cariera târzie (late career) = este considerat a fi punctul în care oamenii înșiși } \\
\text { exprimă faptul că se mută în capitolul (capitolele) final din viața lor } \\
\text { profesională. În practică, există o asociere cu vârsta de peste } 45 \text { de ani. } \\
\text { Tipuri de schimbare a configuraţiei muncii (types of work change) = schimbare } \\
\text { de sarcină, schimbare de poziție și schimbare de ocupație, implicând un rol } \\
\text { complet nou și un alt set de sarcini (Heppner, 1998). } \\
\text { Schimbare sau tranziție semnificativă = scriitorii folosesc termeni diferiți, precum } \\
\text { „reimaginarea” (Burns, 2015), „reinventarea” (Ibarra, 2004), „re-modelare” } \\
\text { (Mintzberg, 1987), „reorientarea”( Bridges, 2004), ,reîncadrare” (Brown, 2015) } \\
\text { sau „,reînnoirea” carierei (Wang, Olsen și Shulz, 2013), dar susțin constant că există } \\
\text { o tranziție psihologică care însoțeşte şi, adesea, depășește schimbările externe, } \\
\text { făcând referire frecventă la modelul de tranziție în trei etape a lui Bridge (Bridges, } \\
\text { 1980). } \\
\text { Reinventarea = implică o schimbare semnificativă a ocupației și o tranziție } \\
\text { psihologică. }\end{array}$ \\
\hline
\end{tabular}




\begin{tabular}{|c|c|}
\hline Articolul & $\begin{array}{c}\text { T6 } \\
\text { Definirea conceptelor cheie }\end{array}$ \\
\hline & $\begin{array}{l}\text { Reinventarea în cariera târzie (late career reinvention) = schimbare în carieră } \\
\text { la vârsta a treia (Ford, 1996); tranziții de carieră pentru persoanele mai în } \\
\text { vârstă (Barham, 2008); schimbarea muncii în perioada târzie a vieții (McNair } \\
\text { și colab., 2004; Johnson, Kawachi și Lewis, 2009); este o călătorie care } \\
\text { durează în timp (între } 3 \text { și } 8 \text { ani), poate implica multe întoarceri și viraje (adică } \\
\text { este neliniară), aduce în atenţie întrebări esenţiale, precum și provocări } \\
\text { practice și este recunoscută doar ca fiind o reinventare abia post-factum. }\end{array}$ \\
\hline $\begin{array}{l}\text { A2: Mary Louise Fogg, Imputernicirea } \\
\text { femeilor in prag de pensionare prin } \\
\text { coaching orientat către obiective și } \\
\text { bunăstare: studiu de caz multiplu } \\
\text { (2019). }\end{array}$ & $\begin{array}{l}\text { Construcția semnificației bunăstării (well-being) constă în dezvoltarea unuia } \\
\text { sau a mai multora dintre cele cinci elemente măsurabile: emoție pozitivă, } \\
\text { implicare, relații, semnificație și realizare/împlinire (PERMA). } \\
\text { Studiul evidențiază rolul obiectivelor și modul în care acestea sunt formulate } \\
\text { şi clarificate în procesul de coaching. De asemenea, se evidențiază modul în } \\
\text { care coachingul ca relație focusată pe obiective (Grant, 2014) poate avea un } \\
\text { impact important asupra bunăstării. }\end{array}$ \\
\hline $\begin{array}{l}\text { A3: Charlotte Brown, Julia Yates, } \\
\text { Ințelegerea experienței femeilor } ̂ \text { in } \\
\text { etapa vârstei de mijloc, beneficiare } \\
\text { ale unui program de coaching pentru } \\
\text { armonizarea vieţii personale şi } \\
\text { profesionale: o analiză } \\
\text { fenomenologico- interpretativă, } \\
\text { (2018). }\end{array}$ & $\begin{array}{l}\text { Echilibrul vieții profesionale şi personale (Work life balance) este definit ca } \\
\text { fiind ,capacitatea unei persoane de a-și îndeplini angajamentele de muncă și } \\
\text { familie, precum și alte responsabilități și activități non-profesionale”, în } \\
\text { conformitate cu definiția folosită de Delecta (2011). } \\
\text { Această cercetare definește vârsta de mijloc (midlife) ca fiind intervalul } \\
\text { cuprins între } 35 \text { şi } 54 \text { de ani. Femeile din mediul întâmpinat se confruntă cu } \\
\text { provocări precum opțiuni limitate de îngrijire a copiilor, îngrijirea părinților } \\
\text { în vârstă, susținerea dezvoltării carierei și găsirea timpului pentru propria lor } \\
\text { îngrijire, ceea ce duce la presiuni generate de solicitări multiple şi concurente } \\
\text { (Burke \& Mattis, 2005; Tajlili, 2014; Hakim, 2004). }\end{array}$ \\
\hline $\begin{array}{l}\text { A4: Sally Jackson, Coaching pentru } \\
\text { femei într-un demers de explorare a } \\
\text { autenticităţii în profesie, (2019) }\end{array}$ & $\begin{array}{l}\text { Esența autenticității este să cunoști, să accepți și să rămâi fidel-ă sinelui tău } \\
\text { advărat, valorilor tale, să fii în adevăr, congruent-ă cu tine însuţi/însăţi (Avolio } \\
\text { et al., 2004). } \\
\text { Cea mai mare parte a literaturii care are în vedere relaţia între coaching şi } \\
\text { autenticitate face referire la autenticitatea coach-ului şi mai puţin la antrenarea } \\
\text { autenticităţii clientului. A fi prezent și a rămâne concetat cu sinele cel mai } \\
\text { interior, profund (the innermost self) sunt atribute ale autenticității coach-ului, } \\
\text { acestea fiind competenţe esenţiale pentru practicarea aceastei profesii } \\
\text { (Bluckert, 2006; Block, 2000). }\end{array}$ \\
\hline $\begin{array}{l}\text { A5: Maria Smith, } \\
\text { Un nou sens al sinelui: explorarea } \\
\text { experienței de coaching în cadrul } \\
\text { unui program de master în } \\
\text { managementul afacerii, }(2018)\end{array}$ & $\begin{array}{l}\text { Sinele (self) nu este o unitate preexistentă care trebuie descoperită, ci mai } \\
\text { degrabă un proiect în curs de desfășurare (Smith, Larkin and Flowers, 2009). } \\
\text { Tranziția de la } 30 \text { de ani (The Age } 30 \text { Transition), este descrisă ca fiind } \\
\text { tranziţia de la vârsta adultă timpurie, moment în care alegerile anterioare de } \\
\text { viață sunt reevaluate în lumina viitorului. Deciziile luate în trecut s-ar putea să } \\
\text { nu se mai potrivească, motiv pentru care oamenii iau în considerare asumarea } \\
\text { unor angajamente mai profunde în ceea ce privește relațiile de muncă și / sau } \\
\text { personale (Levinson, 1986). } \\
\text { Conceptul de carieră fără graniţe (Arthur, 1994) a devenit un concept } \\
\text { proeminent în actualele teorii cu privire la carieră. } \\
\text { Coaching-ul este facilitarea învățării și dezvoltării cu scopul de a îmbunătăți } \\
\text { performanța, de a spori acțiunea eficientă, atingerea obiectivelor și nivelul de } \\
\text { satisfacție personală. Procesul de coaching generează creștere și schimbare în } \\
\text { privinţa perspectivei, atitudinii și/sau comportamentului (Bluckert, 2005). }\end{array}$ \\
\hline
\end{tabular}




\begin{tabular}{|c|c|}
\hline Articolul & $\begin{array}{c}\text { T6 } \\
\text { Definirea conceptelor cheie }\end{array}$ \\
\hline $\begin{array}{l}\text { A6: Laura G. Lane, Janet De Wilde, } \\
\text { Impactul coachingului pentru } \\
\text { studenţii doctoranzi de la o } \\
\text { universitate din Londra, (2018) }\end{array}$ & \\
\hline $\begin{array}{l}\text { A7: Heather Noon, Christian van } \\
\text { Nieuwerburgh: Aștepți cu nerăbdare } \\
\text { să te intorci? Experiența luării } \\
\text { deciziilor în carieră pentru mamele } \\
\text { aflate la primul copil și implicațiile } \\
\text { pentru coachi, }(2020) .\end{array}$ & $\begin{array}{l}\text { Deciziile cu privire la muncă / profesie, luate din perspectiva familiei (family- } \\
\text { related work decisions), deşi frecvent întâlnite, sunt adesea ignorate în } \\
\text { literatura teoretică cu privire la procesul decizional (Greenhaus and Powell, } \\
\text { 2012). } \\
\text { Identitatea este considerată ca fundament în luarea deciziilor, întrucât este } \\
\text { „despre semnificațiile date unei persoane de către ceilalţi şi de către ea însăşi" } \\
\text { (Yates, 2014, p.29). }\end{array}$ \\
\hline $\begin{array}{l}\text { A8: Stefanie Jordan, Simone } \\
\text { Kauffeld, } \\
\text { Studiu cu metode mixte privind } \\
\text { efectele și antecedentele intrebărilor } \\
\text { axate pe soluții în procesul de } \\
\text { coaching, (2020). }\end{array}$ & $\begin{array}{l}\text { Adaptabilitatea în carieră este o construcție psihosocială centrală în psihologia } \\
\text { vocațională și cercetarea în carieră și face trimitere la resurse personale pentru } \\
\text { gestionarea sarcinilor și tranzițiilor curente/anticipate, legate de provocările şi } \\
\text { tranzițiile în carieră. Toate acestea implică deschidere şi preocupare pentru } \\
\text { sarcini potențiale în carieră, pentru dezvoltărea personală şi profesională, } \\
\text { curiozitate pentru oportunitățile de carieră și încredere pentru rezolvarea } \\
\text { problemelor care pot apărea pe acest traseu (Savickas \& Porfeli, 2012). } \\
\text { Orientarea spre obiective, una dintre cele mai importante variabile din teoriile } \\
\text { motivației este definită ca ,dispoziție spre dezvoltarea sau demonstrarea } \\
\text { capacității în situații de realizare, de reuşită” (Vandewalle, 1997). Orientarea } \\
\text { spre obiective este o construcție motivațională importantă și asociată cu } \\
\text { satisfacția și implicarea (Gillet și colab., 2014). Orientarea spre un țel } \\
\text { influențează pozitiv motivația și căutarea îmbunătățirii continue (DeShon \& } \\
\text { Gillespie, 2005). }\end{array}$ \\
\hline $\begin{array}{l}\text { A9: Shirley Thompson, Puterea } \\
\text { pragmatismului: modul în care } \\
\text { managerii de proiect beneficiază de } \\
\text { coaching pentru dezvoltarea } \\
\text { abilităților soft și a încrederii în sine, } \\
\text { (2019). }\end{array}$ & $\begin{array}{l}\text { O definiție pentru abilitățile soft a fost creată prin combinarea perspectivei lui } \\
\text { Hurrell et al (2013) și Yeardley: abilitățile soft se dezvoltă în timp, prin } \\
\text { practică şi implică procese cognitive, aplicarea cunoștințelor dobândite și un } \\
\text { element de discreție, de acordare a spaţiului în interacțiunile sociale. } \\
\text { PMI (2018) oferă această o definiție a managerilor de proiect ca: „agenți de } \\
\text { schimbare care realizează obiectivele proiectului și își folosesc abilitățile și } \\
\text { expertiza pentru a inspira un scop comun în cadrul echipei de proiect”. }\end{array}$ \\
\hline $\begin{array}{l}\text { A10: Sarah Hughes, Cum poate un } \\
\text { model de coaching în trei etape să- } i \\
\text { ajute pe manageri să gestioneze } \\
\text { conflictele existente la locul de } \\
\text { muncă? (2019). }\end{array}$ & $\begin{array}{l}\text { Studiul a definit conflictul ca fiind o stare trăită de una sau mai multe persoane } \\
\text { ca disonanță între ele. Poate fi exprimat verbal, non-verbal sau experimentat } \\
\text { intern. Poate implica: 1) percepții negative, sentimente sau presupuneri despre } \\
\text { celălalt; 2) amenințări anterioare, imaginate sau anticipate cu privire la statutul } \\
\text { socioprofesional. }\end{array}$ \\
\hline
\end{tabular}

Tabel 3: Rezultatele procesului de coaching / rezultatele cercetării

\begin{tabular}{|l|l|l|l|l|}
\hline Articolul & \multicolumn{1}{|c|}{$\begin{array}{c}\text { T7 } \\
\text { Rezultatele/beneficiile } \\
\text { coachingului (pentru } \\
\text { client; pentru practica de } \\
\text { coaching) }\end{array}$} & $\begin{array}{l}\text { T8 } \\
\text { Cine face } \\
\text { cercetarea? } \\
\text { Cercetător/ } \\
\text { Practician } \\
\text { (coach) - } \\
\text { cercetător }\end{array}$ & $\begin{array}{c}\text { T9 } \\
\text { Limitele cercetării }\end{array}$ & $\begin{array}{l}\text { T10 } \\
\text { Recomandări pentru } \\
\text { cercetări viitoare }\end{array}$ \\
\hline $\begin{array}{l}\text { A1: Laura } \\
\begin{array}{l}\text { Walker, } \\
\text { Coaching } \hat{\text { in }} \\
\text { perioada de }\end{array}\end{array}$ & $\begin{array}{l}\text { a) Descoperirea de sine } \\
\text { (self-discovery); b) } \\
\text { antrenarea gândirii } \\
\text { sistemice; c) depăşirea }\end{array}$ & Cercetătorul & $\begin{array}{l}\text { Numărul redus al } \\
\text { subiecților } \\
\text { cercetării. }\end{array}$ & $\begin{array}{l}\text { Există relativ puține studii } \\
\text { despre reinventarea carierei } \\
\text { târzii. }\end{array}$ \\
\hline
\end{tabular}




\begin{tabular}{|c|c|c|c|c|}
\hline Articolul & \begin{tabular}{l}
\multicolumn{1}{c}{ T7 } \\
Rezultatele/beneficiile \\
coachingului (pentru \\
client; pentru practica de \\
coaching)
\end{tabular} & $\begin{array}{l}\quad \text { T8 } \\
\text { Cine face } \\
\text { cercetarea? } \\
\text { Cercetător/ } \\
\text { Practician } \\
\text { (coach) - } \\
\text { cercetător }\end{array}$ & $\begin{array}{c}\text { T9 } \\
\text { Limitele cercetării }\end{array}$ & $\begin{array}{l}\text { T10 } \\
\text { Recomandări pentru } \\
\text { cercetări viitoare }\end{array}$ \\
\hline $\begin{array}{l}\text { reinventare a } \\
\text { carierei: } \\
\text { modelul } \\
\text { descoperirii, } \\
(2019) \text {. }\end{array}$ & $\begin{array}{l}\text { fricilor, creşterea încrederii } \\
\text { în sine. } \\
\text { Integrarea modelului } \\
\text { Discovering în practica de } \\
\text { coaching. }\end{array}$ & & & $\begin{array}{l}\text { În ceea ce privește cercetările } \\
\text { viitoare, revizuirea literaturii } \\
\text { a identificat lacune în } \\
\text { domenii conexe, cum ar fi: } \\
\text { coachingul pentru } \\
\text { acompanierea tranzițiilor de } \\
\text { rol; coachingul de dezvoltare } \\
\text { pentru vârsta de mijloc; } \\
\text { coachingul pentru } \\
\text { reinventarea tardivă a } \\
\text { carierei. } \\
\text { Cercetările explicative } \\
\text { specifice ar fi utile pentru a } \\
\text { susține sau a contesta unele } \\
\text { dintre sugestiile făcute în } \\
\text { special în alte contexte, } \\
\text { culturi sau cu diferite grupuri } \\
\text { decât cele avute în atenţie în } \\
\text { această micro-cercetare. }\end{array}$ \\
\hline $\begin{array}{l}\text { A2: Mary } \\
\text { Louise Fogg, } \\
\text { Imputernicire } \\
\text { a femeilor în } \\
\text { prag de } \\
\text { pensionare } \\
\text { prin } \\
\text { coaching } \\
\text { orientat către } \\
\text { obiective şi } \\
\text { bunăstare: } \\
\text { studiu de caz } \\
\text { multiplu } \\
\text { (2019). }\end{array}$ & $\begin{array}{l}\text { Beneficii pentru client: } \\
\text { 1. Creşterea calităţii } \\
\text { reflecției şi auto- } \\
\text { observarea deciziilor luate; } \\
\text { 1.1. Extinderea } \\
\text { conștientizării şi a stării de } \\
\text { bine a clientului; } \\
\text { 1.2. Spațiu pentru a vorbi } \\
\text { despre sine în contextul } \\
\text { unei ascultări de calitate; } \\
\text { 2. Înaintarea în procesul de } \\
\text { acţiune în vederea atingerii } \\
\text { rezultatelor dorite: focus pe } \\
\text { rezultat, } \\
\text { claritate/clarificare, } \\
\text { explorarea şi descoperirea } \\
\text { resurselor; } \\
\text { 2.1. Extinderea } \\
\text { perspectivei (a privi în } \\
\text { interior şi în exterior); a } \\
\text { gândi ,în afara cutiei”” } \\
\text { (thinking outside the box); } \\
\text { 3. Concordanţă între a } \\
\text { vorbi, a simţi și a face } \\
\text { (congruenţa clientului) - } \\
\text { asumarea responsabilităţii, } \\
\text { implicare; } \\
\text { 3.1. Angajament şi } \\
\text { motivație; } \\
\text { 3.2. Clientul își creează un } \\
\text { mediu de susținere, un } \\
\text { mediu suportiv; }\end{array}$ & $\begin{array}{l}\text { Practicianul- } \\
\text { cercetător } \\
\text { (The } \\
\text { practitioner- } \\
\text { researcher) }\end{array}$ & $\begin{array}{l}\text { Logica de replicare } \\
\text { folosită pentru cele } \\
\text { trei cazuri este un } \\
\text { punct forte. } \\
\text { Cercetarea mai } \\
\text { multor cazuri ar } \\
\text { permite generarea } \\
\text { unor concluzii mai } \\
\text { solide. Cu toate } \\
\text { acestea, mai mult de } \\
\text { trei cazuri într-un } \\
\text { context de coaching } \\
\text { nu sunt întotdeauna } \\
\text { practice. }\end{array}$ & $\begin{array}{l}\text { Studiile viitoare s-ar putea } \\
\text { concentra mai mult pe } \\
\text { schimbările în zona } \\
\text { bunăstării participanţilor, } \\
\text { antrenând prin coaching un } \\
\text { comportament orientat spre } \\
\text { obiective. }\end{array}$ \\
\hline
\end{tabular}




\begin{tabular}{|c|c|c|c|c|}
\hline Articolul & \begin{tabular}{l}
\multicolumn{1}{c}{ T7 } \\
Rezultatele/beneficiile \\
coachingului (pentru \\
client; pentru practica de \\
coaching)
\end{tabular} & $\begin{array}{l}\quad \text { T8 } \\
\text { Cine face } \\
\text { cercetarea? } \\
\text { Cercetător/ } \\
\text { Practician } \\
\text { (coach) - } \\
\text { cercetător }\end{array}$ & $\begin{array}{c}\text { T9 } \\
\text { Limitele cercetării }\end{array}$ & $\begin{array}{l}\text { T10 } \\
\text { Recomandări pentru } \\
\text { cercetări viitoare }\end{array}$ \\
\hline & $\begin{array}{l}\text { 4. Un plan de prioritizare a } \\
\text { obiectivelor corelate, care să } \\
\text { ofere direcție și motivație; } \\
\text { 5. Clientul se simte mai } \\
\text { pozitiv și mai stăpân pe } \\
\text { viața sa. } \\
\text { Beneficii pentru practica } \\
\text { de coaching: studiul } \\
\text { contribuie la dezvoltarea } \\
\text { literaturii de specialitate şi } \\
\text { a fundamentelor teoretice } \\
\text { necesare practicii de } \\
\text { coaching. }\end{array}$ & & & \\
\hline $\begin{array}{l}\text { A3: Charlotte } \\
\text { Brown, Julia } \\
\text { Yates, } \\
\text { Inţelegerea } \\
\text { experienței } \\
\text { femeilor în } \\
\text { etapa vârstei } \\
\text { de mijloc, } \\
\text { beneficiare } \\
\text { ale unui } \\
\text { program de } \\
\text { coaching } \\
\text { pentru } \\
\text { armonizarea } \\
\text { vieții } \\
\text { personale şi } \\
\text { profesionale: } \\
\text { o analiză } \\
\text { fenomenologi } \\
\text { co-interpre- } \\
\text { tativă, (2018). }\end{array}$ & $\begin{array}{l}\text { Trei teme principale } \\
\text { descriu modul în care } \\
\text { participanții au } \\
\text { experimentat programul de } \\
\text { coaching: } \\
\text { 1. Coaching-ul de carieră } \\
\text { ca spațiu sigur; } \\
\text { - subteme: } \\
\text { - libertatea de explorare pe } \\
\text { subiectul ales; } \\
\text { - autenticitate; } \\
\text { - a privi greşelile ca } \\
\text { experienţe de învăţare şi a } \\
\text { îndrăzni să faci lucrurile } \\
\text { diferit. } \\
\text { 2. Transformarea } \\
\text { perspectivei asupra rolului } \\
\text { muncii și al vieții; } \\
\text { - subteme: } \\
\text { - alinierea cu propriile } \\
\text { valorile de bază; } \\
\text { - schimbarea (interioară) } \\
\text { psihologică; } \\
\text { - efectuarea de acţiuni şi } \\
\text { modificări practice. } \\
\text { 3. creşterea pozitivităţii şi } \\
\text { rezilienţei; } \\
\text { - în timpul programului de } \\
\text { coaching; } \\
\text { - dincolo de programul de } \\
\text { coaching } \\
\text { - trecerea clientului de la } \\
\text { „a ști” la ,a face”. }\end{array}$ & $\begin{array}{l}\text { Primul autor a } \\
\text { avut un dublu } \\
\text { rol: cercetător şi } \\
\text { coach de carieră }\end{array}$ & $\begin{array}{l}\text { Mărimea } \\
\text { eșantionului de cinci } \\
\text { participanți este } \\
\text { limitată pentru } \\
\text { generalizarea } \\
\text { acestor rezultate, } \\
\text { însă această } \\
\text { structură este } \\
\text { specifică cercetării } \\
\text { calitative, ca } \\
\text { abordare selectivă. } \\
\text { În timpul culegerii } \\
\text { de date, rolul dublu } \\
\text { al cercetătorului- } \\
\text { coach ar putea } \\
\text { influența } \\
\text { autenticitatea } \\
\text { răspunsurilor } \\
\text { subiecţilor. }\end{array}$ & $\begin{array}{l}\text { Ar putea fi extinsă cercetarea } \\
\text { pe un program cu grupuri de } \\
\text { femei de vârstă mijlocie care } \\
\text { nu sunt mame. } \\
\text { O altă oportunitate de } \\
\text { cercetare pentru dezvoltarea } \\
\text { acestor rezultate ar fi un } \\
\text { studiu realizat la un anumit } \\
\text { interval după terminarea } \\
\text { programului de coaching. }\end{array}$ \\
\hline $\begin{array}{l}\text { A4: Sally } \\
\text { Jackson, } \\
\text { Coaching } \\
\text { pentru femei } \\
\text { intr-un } \\
\text { demers de } \\
\text { explorare a }\end{array}$ & $\begin{array}{l}\text { Studiul porneşte de la } \\
\text { identificarea dificultăților } \\
\text { comportamentului autentic } \\
\text { întâlnite în mediul de } \\
\text { muncă organizaţional. }\end{array}$ & $\begin{array}{l}\text { Cercetător şi co- } \\
\text { cercetător }\end{array}$ & $\begin{array}{l}\text { La fel ca în cazul } \\
\text { tuturor studiilor } \\
\text { calitative care au un } \\
\text { număr mic de } \\
\text { participanți, aceste } \\
\text { constatări nu pot fi } \\
\text { considerate }\end{array}$ & $\begin{array}{l}\text { Limitările acestei cercetări } \\
\text { pot prezenta oportunități } \\
\text { pentru cercetări viitoare, cu } \\
\text { subiecţi bărbați și femei din } \\
\text { mediul academic și servicii } \\
\text { profesionale. De asemenea, } \\
\text { ar putea fi întreprinse }\end{array}$ \\
\hline
\end{tabular}




\begin{tabular}{|c|c|c|c|c|}
\hline Articolul & \begin{tabular}{l}
\multicolumn{1}{c}{ T7 } \\
Rezultatele/beneficiile \\
coachingului (pentru \\
client; pentru practica de \\
coaching)
\end{tabular} & \begin{tabular}{l}
\multicolumn{1}{c}{ T8 } \\
Cine face \\
cercetarea? \\
Cercetător/ \\
Practician \\
(coach) - \\
cercetător
\end{tabular} & $\begin{array}{c}\text { T9 } \\
\text { Limitele cercetării }\end{array}$ & $\begin{array}{l}\text { T10 } \\
\text { Recomandări pentru } \\
\text { cercetări viitoare }\end{array}$ \\
\hline $\begin{array}{l}\text { autenticităţii } \\
\text { in profesie, } \\
(2019)\end{array}$ & $\begin{array}{l}\text { În urma cercetării au } \\
\text { rezultat patru teme şi } \\
\text { corelaţii importante: } \\
\text { 1. Coaching în mediul } \\
\text { profesional; } \\
\text { 2. Coaching și frici; } \\
\text { 3. Coaching și măști/ } \\
\text { comportamente defensive; } \\
\text { 4. Coaching și } \\
\text { autenticitate. } \\
\text { Pentru a fi autentic este } \\
\text { nevoie de congruență și } \\
\text { consecvență între acțiune, } \\
\text { credințe, gândire și relații } \\
\text { productive, bazate pe } \\
\text { spiritualitatea interioară și } \\
\text { codul moral (p.75). } \\
\text { În organizații, frica poate } \\
\text { face parte dintr-un ciclu } \\
\text { comportamental în care } \\
\text { frica creează sau contribuie } \\
\text { la comportamentul } \\
\text { inautentic şi, la rândul ei, } \\
\text { poate fi cauzată de un } \\
\text { comportament inautentic. } \\
\text { Coaching-ul poate } \\
\text { valorifica în mod productiv } \\
\text { energia generată de teamă, } \\
\text { oferind un suport valoros } \\
\text { în transformarea acesteia. }\end{array}$ & & $\begin{array}{l}\text { reprezentative } \\
\text { pentru toate femeile, } \\
\text { universitare sau } \\
\text { antrenoare și nici } \\
\text { exclusiv pentru } \\
\text { experiențele } \\
\text { femeilor, ignorând } \\
\text { experiențele } \\
\text { parcursului } \\
\text { profesional al } \\
\text { bărbaților. }\end{array}$ & $\begin{array}{l}\text { cercetări intersectoriale, } \\
\text { precum şi studii care s-ar } \\
\text { concentra pe relaţia dintre } \\
\text { coachingul în carieră şi } \\
\text { autenticitate. }\end{array}$ \\
\hline $\begin{array}{l}\text { A5: Maria } \\
\text { Smith, } \\
\text { Un nou sens } \\
\text { al sinelui: } \\
\text { explorarea } \\
\text { experienței } \\
\text { de coaching } \\
\text { in cadrul } \\
\text { unui program } \\
\text { de master în } \\
\text { management } \\
\text { ul afacerii, } \\
\text { (2018). }\end{array}$ & $\begin{array}{l}\text { Tranziția specifică acestei } \\
\text { etape de viaţă/vârstă a fost } \\
\text { realizată pentru toți cei } \\
\text { cinci studenți. Coachingul } \\
\text { i-a ajutat, astfel, să-şi } \\
\text { extindă nivelul de } \\
\text { conștientizare și să se } \\
\text { simtă împuterniciţi, } \\
\text { încrezători. } \\
\text { În urma analizei au apărut } \\
\text { trei teme (cu subtemele } \\
\text { lor): } \\
\text { 1. Un nou sens al sinelui; } \\
\text { 2. Gestionarea tranziției } \\
\text { personale; } \\
\text { 3. Crearea spațiului } \\
\text { personal de exprimare de } \\
\text { sine şi creştere. } \\
\text { Coaching-ul i-a ajutat pe } \\
\text { studenţi să-și construiască } \\
\text { încrederea, împreună cu o }\end{array}$ & Cercetătorul & $\begin{array}{l}\text { Doar cinci studenți } \\
\text { au fost intervievați, } \\
\text { extraşi dintr-o } \\
\text { cohortă de } 57 \text { de } \\
\text { studenți. } \\
\text { O altă limitare a } \\
\text { cercetării este în } \\
\text { legătură cu } \\
\text { momentul } \\
\text { interviurilor. } \\
\text { Studenţii erau încă } \\
\text { în plină tranziție în } \\
\text { momentul } \\
\text { interviurilor. }\end{array}$ & $\begin{array}{l}\text { Ar fi interesant de adăugat o } \\
\text { dimensiune longitudinală } \\
\text { acestei cercetări, urmărind } \\
\text { aceiași studenți după ce vor } \\
\text { deveni absolvenți și ișii vor } \\
\text { încheia tranziția în carieră. } \\
\text { Studiile viitoare ar putea } \\
\text { explora experiența de } \\
\text { coaching pentru studenți de } \\
\text { sex masculin, precum și } \\
\text { pentru studenți de diferite } \\
\text { vârste. } \\
\text { Un număr relativ limitat de } \\
\text { studii au explorat impactul } \\
\text { coachingului asupra } \\
\text { persoanelor care doresc să } \\
\text { gestioneze tranziții de viaţă, } \\
\text { de vârstă şi de carieră. } \\
\text { Cercetări cu privire la } \\
\text { coaching, pe de o parte, şi cu } \\
\text { privire la tranziții în carieră, }\end{array}$ \\
\hline
\end{tabular}




\begin{tabular}{|c|c|c|c|c|}
\hline Articolul & \begin{tabular}{l}
\multicolumn{1}{c}{ T7 } \\
Rezultatele/beneficiile \\
coachingului (pentru \\
client; pentru practica de \\
coaching)
\end{tabular} & $\begin{array}{l}\quad \text { T8 } \\
\text { Cine face } \\
\text { cercetarea? } \\
\text { Cercetător/ } \\
\text { Practician } \\
\text { (coach) - } \\
\text { cercetător }\end{array}$ & $\begin{array}{c}\text { T9 } \\
\text { Limitele cercetării }\end{array}$ & $\begin{array}{l}\text { T10 } \\
\text { Recomandări pentru } \\
\text { cercetări viitoare }\end{array}$ \\
\hline & $\begin{array}{l}\text { mai bună înțelegere a } \\
\text { motivației personale, a } \\
\text { punctelor forte și a } \\
\text { modului de a-și folosi } \\
\text { rețeaua de relaţii. Cu alte } \\
\text { cuvinte, sesiunile i-au } \\
\text { ajutat pe participanți să } \\
\text { dezvolte competențele } \\
\text { esențiale necesare } \\
\text { dezvoltării carierei: ,a ști } \\
\text { de ce”, ,,a ști cum” și ,,a ști } \\
\text { cine”. (Arthur, Claman and } \\
\text { DeFillippi, 1995). }\end{array}$ & & & $\begin{array}{l}\text { pe de altă parte, există, dar } \\
\text { aceste fenomene sunt rareori } \\
\text { explorate împreună (Polly } \\
\text { Parker (2017). Ar fi valoros } \\
\text { să fie integrate în cercetare } \\
\text { ambele domenii de studiu } \\
\text { pentru a consolida baza } \\
\text { teoretică a coachingului cu } \\
\text { privire la schimbarea carierei } \\
\text { și tranziția de viaţă şi de rol. }\end{array}$ \\
\hline $\begin{array}{l}\text { A6: Laura G. } \\
\text { Lane, Janet } \\
\text { De Wilde, } \\
\text { Impactul } \\
\text { coachingului } \\
\text { pentru } \\
\text { studenţii } \\
\text { doctoranzi de } \\
\text { la o } \\
\text { universitate } \\
\text { din Londra, } \\
\text { (2018) }\end{array}$ & $\begin{array}{l}\text { Toți subiecţii cercetării au } \\
\text { perceput experienţa de } \\
\text { coaching ca fiind pozitivă } \\
\text { pentru că le-a sporit starea } \\
\text { de bine, le-a facilitat } \\
\text { încrederea de a acţiona şi } \\
\text { le-a îmbunătățit } \\
\text { eficacitatea personală. } \\
\text { Acest studiu arată } \\
\text { modalitățile concrete prin } \\
\text { care coachingul ajută } \\
\text { studenții doctoranzi să } \\
\text { abordeze provocările cu } \\
\text { care se confruntă și } \\
\text { recomandă universităţilor } \\
\text { să integreze acest serviciu } \\
\text { pentru studenţi. } \\
\text { În urma analizei tematice a } \\
\text { interviurilor, care au avut } \\
\text { ca scop cercetarea practicii } \\
\text { de coaching au fost } \\
\text { identificate următoarele } \\
\text { teme lucrate şi ameliorate } \\
\text { prin procesul de coaching: } \\
\text { 1. Dezvoltarea abilităților } \\
\text { profesionale: } \\
\text { - Abilități de gestionare a } \\
\text { timpului; } \\
\text { - Abilități de scriere; } \\
\text { - Depăşirea procrastinării } \\
\text { și a perfecționismului; } \\
\text { 2. Depășirea provocărilor } \\
\text { din relaţia cu } \\
\text { coordonatorul de doctorat: } \\
\text { - Calitatea relației; } \\
\text { - Valorizare şi feed-back; } \\
\text { - Comunicarea cu } \\
\text { coordonatorul; }\end{array}$ & $\begin{array}{l}\text { Coach- } \\
\text { cercetător }\end{array}$ & $\begin{array}{l}\text { Dimensiunea } \\
\text { eșantionului care } \\
\text { este mică. } \\
\text { Cercetătoarea este } \\
\text { ea însăși coach } \\
\text { profesionist și, de } \\
\text { asemenea, } \\
\text { responsabilă pentru } \\
\text { programul de } \\
\text { coaching de la } \\
\text { această universitate. } \\
\text { Acest lucru poate } \\
\text { influența datele } \\
\text { cercetării, deoarece } \\
\text { ea ar dori să } \\
\text { raporteze pozitiv cu } \\
\text { privire la rezultatele } \\
\text { acestei cercetări și la } \\
\text { impactul coaching- } \\
\text { ului. } \\
\text { Datele cu privire la } \\
\text { profilului } \\
\text { subiecţilor, colectate } \\
\text { în timpul } \\
\text { interviurilor nu au } \\
\text { inclus informații } \\
\text { despre factori } \\
\text { precum fundalul } \\
\text { (background) } \\
\text { socioeconomic, } \\
\text { realizările } \\
\text { academice } \\
\text { anterioare, etnia etc. }\end{array}$ & $\begin{array}{l}\text { În prezent există foarte } \\
\text { puține cercetări care privesc } \\
\text { în mod specific bunăstarea } \\
\text { doctoranzilor din Marea } \\
\text { Britanie. } \\
\text { Se recomandă ca } \\
\text { Universitatea să sprijine în } \\
\text { continuare programul de } \\
\text { coaching pentru doctoranzi } \\
\text { având în vedere beneficiile } \\
\text { acestuia. } \\
\text { Pentru viitor, recomandăm } \\
\text { efectuarea unor cercetări } \\
\text { suplimentare asupra unui } \\
\text { eșantion mai mare de } \\
\text { doctoranzi, precum şi studii } \\
\text { comparative care explorează, } \\
\text { de exemplu, impactul } \\
\text { coachingului asupra } \\
\text { doctoranzilor din diferite țări, } \\
\text { discipline și medii socio- } \\
\text { economice. }\end{array}$ \\
\hline
\end{tabular}




\begin{tabular}{|c|c|c|c|c|}
\hline Articolul & \begin{tabular}{l}
\multicolumn{1}{c}{ T7 } \\
Rezultatele/beneficiile \\
coachingului (pentru \\
client; pentru practica de \\
coaching)
\end{tabular} & $\begin{array}{l}\quad \text { T8 } \\
\text { Cine face } \\
\text { cercetarea? } \\
\text { Cercetător/ } \\
\text { Practician } \\
\text { (coach) - } \\
\text { cercetător }\end{array}$ & $\begin{array}{c}\text { T9 } \\
\text { Limitele cercetării }\end{array}$ & $\begin{array}{l}\text { T10 } \\
\text { Recomandări pentru } \\
\text { cercetări viitoare }\end{array}$ \\
\hline & $\begin{array}{l}\text { - Lucrul eficient cu } \\
\text { coordonatorul; } \\
\text { 3. Dezvoltarea } \\
\text { sentimentului de } \\
\text { apartenenţă la comunitatea } \\
\text { academică; } \\
\text { 4. Viața după doctorat: } \\
\text { - timpul personal; } \\
\text { - echilibrul între munca } \\
\text { profesională şi } \\
\text { studiu/cercetare; } \\
\text { - sănătate fizică şi } \\
\text { emoţională; } \\
\text { - dezvoltarea carierei. }\end{array}$ & & & \\
\hline $\begin{array}{l}\text { A7: Heather } \\
\text { Noon, } \\
\text { Christian van } \\
\text { Nieuwerburg } \\
\text { h: Aștepți cu } \\
\text { nerăbdare să } \\
\text { te întorci? } \\
\text { Experiența } \\
\text { luării } \\
\text { deciziilor în } \\
\text { carieră } \\
\text { pentru } \\
\text { mamele } \\
\text { aflate la } \\
\text { primul copil } \\
\text { și implicațiile } \\
\text { pentru } \\
\text { coachi, } \\
\text { (2020). }\end{array}$ & $\begin{array}{l}\text { Cercetarea a identificat } \\
\text { beneficiile obţinute de } \\
\text { participanţi pe următoarele } \\
\text { teme lucrate în procesul de } \\
\text { coaching: obținerea unei } \\
\text { noi perspective asupra } \\
\text { identității profesionale şi a } \\
\text { traseului de carieră; a } \\
\text { învăţa să navighezi în } \\
\text { tranziție; ,negocierea” şi } \\
\text { recadrarea factorilor } \\
\text { contextuali; găsirea } \\
\text { sensului în munca şi în } \\
\text { profesia aleasă; } \\
\text { reformularea şi } \\
\text { resemnificarea naraţiunilor. }\end{array}$ & $\begin{array}{l}\text { Practicianul- } \\
\text { cercetător }\end{array}$ & $\begin{array}{l}\text { Potențialul de } \\
\text { deformare a } \\
\text { rezultatelor de către } \\
\text { cercetător (ca fost } \\
\text { profesionist în } \\
\text { resurse umane, } \\
\text { coach şi mama care } \\
\text { lucrează) a fost } \\
\text { recunoscut ca o } \\
\text { limitare. Acest fapt a } \\
\text { fost atenuat proactiv } \\
\text { prin supervizare și } \\
\text { auto-observare } \\
\text { continuă, utilizând } \\
\text { un jurnal al } \\
\text { cercetării. }\end{array}$ & $\begin{array}{l}\text { Cercetările viitoare ar putea } \\
\text { să se bazeze în mod util pe } \\
\text { acest studiu, ce ar putea fi } \\
\text { continuat printr-o explorare } \\
\text { cu metode mixte a impactului } \\
\text { sprijinului personalizat de } \\
\text { coaching asupra luării } \\
\text { deciziilor în carieră în timpul } \\
\text { concediului de maternitate. } \\
\text { Un studiu experimental ar } \\
\text { putea aduce un plus de } \\
\text { valoare prin comparația între } \\
\text { cei care au primit coaching și } \\
\text { cei care nu. } \\
\text { Cercetări suplimentare ar } \\
\text { putea, de asemenea, să } \\
\text { cerceteze tema încrederii în } \\
\text { sine în luarea deciziilor de } \\
\text { către femei și absența } \\
\text { „convergenței psihologice” } \\
\text { raportată în acest studiu. }\end{array}$ \\
\hline $\begin{array}{l}\text { A8: Stefanie } \\
\text { Jordan, } \\
\text { Simone } \\
\text { Kauffeld, } \\
\text { Studiu cu } \\
\text { metode mixte } \\
\text { privind } \\
\text { efectele și } \\
\text { antecedentele } \\
\text { intrebărilor } \\
\text { axate pe } \\
\text { soluții în } \\
\text { procesul de } \\
\text { coaching, } \\
\text { (2020). }\end{array}$ & $\begin{array}{l}\text { Rezultatele cercetării } \\
\text { contribuie la îmbunătățirea } \\
\text { programelor de training de } \\
\text { coaching, oferind } \\
\text { practicienilor cunoștințe } \\
\text { despre procesele de } \\
\text { coaching la nivel micro. } \\
\text { Studiul a reușit să } \\
\text { investigheze corelațiile } \\
\text { dintre competenţele şi } \\
\text { comportamentul coach- } \\
\text { ului, comportamentul } \\
\text { clientului și rezultatele } \\
\text { obţinute de acesta, folosind } \\
\text { un design de metode mixte }\end{array}$ & Cercetătorul & $\begin{array}{l}\text { Mărimea } \\
\text { eșantionului nu a } \\
\text { permis să testăm } \\
\text { modelul nostru ca } \\
\text { model de referință. } \\
\text { Testul ipotezelor } \\
\text { noastre prin analiza } \\
\text { secvențială și } \\
\text { regresii liniare } \\
\text { multiple a dat } \\
\text { rezultate fiabile. } \\
\text { Atât coachii, cât și } \\
\text { clienții din studiul } \\
\text { nostru au fost } \\
\text { studenți universitari, }\end{array}$ & $\begin{array}{l}\text { Pentru cercetări viitoare, se } \\
\text { recomandă utilizarea unor } \\
\text { eșantioane mai mari, luarea } \\
\text { în considerare a diferitelor } \\
\text { populații de coachi și clienți, } \\
\text { precum și o investigație a } \\
\text { unor atribute suplimentare } \\
\text { legate de cariera și a } \\
\text { comportamentul coach-ului. }\end{array}$ \\
\hline
\end{tabular}




\begin{tabular}{|c|c|c|c|c|}
\hline Articolul & \begin{tabular}{l}
\multicolumn{1}{c}{ T7 } \\
Rezultatele/beneficiile \\
coachingului (pentru \\
client; pentru practica de \\
coaching)
\end{tabular} & $\begin{array}{l}\quad \text { T8 } \\
\text { Cine face } \\
\text { cercetarea? } \\
\text { Cercetător/ } \\
\text { Practician } \\
\text { (coach) - } \\
\text { cercetător }\end{array}$ & $\begin{array}{c}\text { T9 } \\
\text { Limitele cercetării }\end{array}$ & $\begin{array}{l}\text { T10 } \\
\text { Recomandări pentru } \\
\text { cercetări viitoare }\end{array}$ \\
\hline & $\begin{array}{l}\text { care se concentrează pe } \\
\text { date comportamentale și } \\
\text { auto-raportare } \\
\text { longitudinală. }\end{array}$ & & $\begin{array}{l}\text { ceea ce implică o } \\
\text { generalizare ușor } \\
\text { limitată a } \\
\text { rezultatelor noastre, } \\
\text { deoarece studenții ar } \\
\text { putea să nu fie } \\
\text { reprezentativi pentru } \\
\text { alte grupuri } \\
\text { demografice, cum ar } \\
\text { fi angajații sau } \\
\text { directorii. }\end{array}$ & \\
\hline $\begin{array}{l}\text { A9: Shirley } \\
\text { Thompson, } \\
\text { Puterea } \\
\text { pragma- } \\
\text { tismului: } \\
\text { modul în } \\
\text { care } \\
\text { managerii de } \\
\text { proiect } \\
\text { beneficiază } \\
\text { de coaching } \\
\text { pentru } \\
\text { dezvoltarea } \\
\text { abilităților } \\
\text { soft și a } \\
\text { increderii în } \\
\text { sine, (2019). }\end{array}$ & $\begin{array}{l}\text { Studiul arată că pentru } \\
\text { managerii care au } \\
\text { participat la cercetare, } \\
\text { practica de coaching poate } \\
\text { oferi principii, abilități și } \\
\text { instrumente de lucru care } \\
\text { pun mai mult accent pe } \\
\text { oameni decât pe } \\
\text { sarcini/activități; aceasta } \\
\text { este o prioritate esențială } \\
\text { pentru managerii de } \\
\text { proiect. }\end{array}$ & $\begin{array}{l}\text { Cercetătorul ca } \\
\text { facilitator }\end{array}$ & $\begin{array}{l}\text { Abilitățile soft nu } \\
\text { sunt măsurabile, } \\
\text { deși notarea } \\
\text { abilităților soft a fost } \\
\text { o încercare brută de } \\
\text { cuantificare. }\end{array}$ & $\begin{array}{l}\text { Rezultatele cu privire la } \\
\text { schimbarea abilităților soft la } \\
\text { locul de muncă pot oferi } \\
\text { opțiuni măsurabile mai bune } \\
\text { decât abilitățile soft în sine. }\end{array}$ \\
\hline $\begin{array}{l}\text { A10: Sarah } \\
\text { Hughes, Cum } \\
\text { poate un } \\
\text { model de } \\
\text { coaching în } \\
\text { trei etape să-i } \\
\text { ajute pe } \\
\text { manageri să } \\
\text { gestioneze } \\
\text { conflictele } \\
\text { existente la } \\
\text { locul de } \\
\text { muncă? } \\
\text { (2019). }\end{array}$ & $\begin{array}{l}\text { Acest studiu a demonstrat } \\
\text { că procesul de coaching } \\
\text { este un mod eficient de a } \\
\text { ajuta directorii să } \\
\text { gestioneze conflictele la } \\
\text { locul de muncă. În acest } \\
\text { sens, a fost construit un } \\
\text { model în trei etape pentru a } \\
\text { putea fi folosit de către } \\
\text { directorii care se confruntă } \\
\text { cu un conflict la locul de } \\
\text { muncă. } \\
\text { Modelul a fost optimizat ca } \\
\text { urmare a cercetării şi } \\
\text { conţine trei etape. } \\
\text { Gestionarea conflictului } \\
\text { necesită: a) conştientizarea } \\
\text { de sine: pentru a } \\
\text { recunoaște propria } \\
\text { contribuție la conflict; b) } \\
\text { empatie și aprecierea altor } \\
\text { perspective; c) abilități de } \\
\text { comunicare a conflictelor: } \\
\text { pentru a gestiona emoțiile }\end{array}$ & $\begin{array}{l}\text { Practicianul } \\
\text { (coach)- } \\
\text { cercetător }\end{array}$ & $\begin{array}{l}\text { Dublul rol de coach } \\
\text { şi cercetător poate } \\
\text { afecta datele } \\
\text { cercetării. }\end{array}$ & $\begin{array}{l}\text { Cei trei participanți la acest } \\
\text { studiu au fost directori } \\
\text { britanici albi, care ar putea } \\
\text { rezolva conflictele în } \\
\text { conformitate cu propriile lor } \\
\text { norme culturale. } \\
\text { Cercetările viitoare ar putea } \\
\text { explora: } \\
\text { 1. Cum ar putea ajuta } \\
\text { modelul de coaching în } 3 \\
\text { paşi: a) directorii din alte } \\
\text { culturi să rezolve conflictele; } \\
\text { b) persoane fizice care } \\
\text { lucrează în sectorul public } \\
\text { sau sectorul serviciilor; c) în } \\
\text { coordonarea echipelor, atunci } \\
\text { când structura } \\
\text { organizațională a generat } \\
\text { conflicte. } \\
\text { 2. Relația dintre conflict și } \\
\text { stima de sine, care a apărut } \\
\text { ca o concluzie neașteptată a } \\
\text { acestui studiu. }\end{array}$ \\
\hline
\end{tabular}




\begin{tabular}{|l|l|l|l|l|}
\hline Articolul & $\begin{array}{l}|c| \\
\text { T7 } \\
\text { Rezultatele/beneficiile } \\
\text { coachingului (pentru } \\
\text { client; pentru practica de } \\
\text { coaching) }\end{array}$ & $\begin{array}{l}\text { T8 } \\
\text { Cine face } \\
\text { cercetarea? } \\
\text { Cercetător/ } \\
\text { Practician } \\
\text { (coach) - } \\
\text { cercetător }\end{array}$ & $\begin{array}{c}\text { T9 } \\
\text { Limitele cercetării }\end{array}$ & $\begin{array}{l}\text { T10 } \\
\text { Recomandări pentru } \\
\text { cercetări viitoare }\end{array}$ \\
\hline & $\begin{array}{l}\text { fiecăruia și a aborda } \\
\text { constructiv conflictul. } \\
\text { De aceste rezultate pot } \\
\text { beneficia de următoarele } \\
\text { grupuri: manageri; } \\
\text { organizații; coachi } \\
\text { profesionişti; cercetători } \\
\text { interesaţi de demersul } \\
\text { cercetare-de acțiune. }\end{array}$ & & & \\
\hline
\end{tabular}

\section{Interpretarea rezultatelor}

Aplicând întrebările de lucru, care au stat la baza demersului de ceretare concretizat în redactarea acestui articol: cine? ce? cum? unde? de ce face cercetare de coaching? la conţinutul tematic al articolelor analizate, putem realiza câteva conexiuni relvante pentru obiectivele proiectate.

Putem observa că cercetările publicate în aceste articole sunt făcute de către practicieni (coach)-cercetători cu scopul de a eficientiza practica de coaching în sensul generării sau testării unor modele de lucru personalizate pentru profilul clienţilor. Unii dintre aceşti practicienicercetători au făcut cercetarea în contextul programului de master sau doctorat pe care l-au urmat în cadrul Universităţii Oxford.

Cercetările au în vedere, în special, impactul sau rezultatele procesului de coaching asupra subiecţilor (clienţilor). Un singur articol (A8) are în atenţie mai multe dimensiuni ale procesului de coaching, care ţin de atributele şi comportamentului coachiului, ale clientului, ale relaţiei de coaching. Toate cercetările prezentate în aceste articole au un design de tip calitativ, bazat pe interviuri semistructurate, doar articolul opt propune un design mixt.

O componentă relevantă care se conturează pe baza acestei analize tematice şi pentru care ne propunem să extindem cercetarea pe tema coachingului pentru tranziţii de carieră-viaţă este cea referitoare la tranziţiile de carieră ale femeilor. Carierele femeilor sunt, adesea, diferite de cele ale bărbaţilor din cel puţin patru aspecte: a) responsabilităţile familiale; b) dezvoltarea psihologică (aspectul relaţional predilect); c) socializarea specifică (diferenţiată); d) modelul dominant masculin de normare a performanţei profesionale şi organizaţionale (O'Neil, Bilimora, 2005, p.169). Multe dintre femeile active pe piaţa muncii nu se regăsesc în modelul masculin de leadership şi performanţă profesională. În acest sens, studiile vorbesc despre un fenomen de automarginalizare şi autoexcludere a femeilor din poziţiile de top (O’Neil, D. Bilimora, 2005, $\mathrm{p}$. 170) şi, implicit, din istoria făcută, în bună parte, de bărbaţi.

Dintre ipostaze tranziţiilor de carieră-viaţă prezentate în articolele analizate, reţin atenţia acele cazuri de tranziţii ca urmare a schimbării domeniului de activitate şi reinventare pentru motivul că sunt tranziţiile de carieră-viaţă cele mai complexe: a significant occupation change and a psychological transition. Acestea sunt cazuri frecvente care solicită acompaniere prin coaching transformaţional (diferit de coachingul ,tradiţional” sau operaţional). Procesul de acompaniere în aceste cazuri facilitează re-conectarea persoanei cu valorile sale, cu pasiunile, talentele, punctele forte, cu sinele său autentic, cu motivaţia, creativitatea şi bucuria muncii. Este un proces de coaching despre sens, scop, rost şi valori, un proces de re-definire a brand-ului personal şi a identităţii profesionale. Aceste tranziţii se derulează pe parcursul mai multor ani (3-8 ani); sunt asemenea unei călătorii ( journey); au o traiectorie non-liniară; sunt recunoscute doar retrospectiv ca fiind reinventare, transformare (Walker, 2019, p.67). 
O cercetare cu privire la dezvoltarea carierei profesionale a femeilor, respectiv tranziţiile lor de carieră-viaţă ar putea avea ca bază de pornire în selectarea subiecţilor cercetării, principalele tipologii ale tranziţiilor, existente în literatura de specialitate:

- tranziţii în cariera profesională: intrarea într-o profesie (early career: 24-35 ani); mijlocul carierei (mid-career: 36-45 ani); cariera avansată (late career transitions: 46-60 ani) (O’Neil, Bilimora, (2005), pp. 182-184);

- schimbări în carieră (în cadrul aceluiaşi domeniu; schimbare de domeniu/reinventare) (Walker, 2019);

- tranziţii în cariera de leadership: avansarea în funcţii de conducere/poziţii de leadership;

- tranziţii de viaţă: de vârstă, etape de viaţă, roluri (five passages; pass-ages): 18-22 ani; 2832 ani; 40-42 / 35-45 ani; 51-53 ani; 62-65 ani; (Sheehy, 1982);

- tranziţii „,normale”/fireşti, pozitive, previzibile, numite şi „schimbări de tip I” (Cannio, Launer, 2019);

- tranziţii „suferite” (percepute negativ), rupturi, crize, reinventări (Cardon, 2006); pass-ages

(fr.), passages (eng.) (Sheehy, 1982); „,schimbări de tip II” (Cannio, Launer, 2019).

\section{Limitele demersului}

Limitele acestui proiect sunt asumate prin obiectivele stabilite iniţial. Aceste limite constau în următoarele aspecte: numărul redus de articole; selectarea acestora doar dintr-o singură sursă (revistă); articole doar în limba engleză; intervalul de timp redus (2018-2020); majoritatea articolelor sunt pe aceeaşi temă în sensul că prezintă cercetări cu privire la rezultatele şi impactul procesului de coaching, ignorând alte teme specifice domeniului; selectarea cercetărilor care au subiecţi doar femei; nu am utilizat programe computerizate de analiză a frecvenţei temelor/cuvintelor cheie.

\section{Direcţii viitoare}

Toate aceste limite şi limitări ale actualului proiect deschid tot atâtea noi direcţii şi perspective pentru cercetările viitoare în sensul extinderii surselor de documentare (reviste şi cărţi) şi a nuanţării analizei tematice. O altă abordare a cercetării ar putea avea în vedere bazele de date: ProQUEST, EBSCO, PsycINFO, SCOPUS şi alte baze de date. De asemenea, consultarea şi integrarea ideilor din cartea de sinteză pe tema cercetării de coaching la nivel internaţional, apărută în 2018: The SAGE Handbook of Coaching, coordonată de Tatiana Bachkirova - Oxford Brookes University, UK, Gordon Spence - Sydney Business School, David Drake - Centre for Narrative Coaching and Leadership.

O atenţie specială şi un studiu aprofundat, în viitoarele cercetări, necesită metodologia cercetare-acţiune ca fiind un demers pe care mulţi practicieni îl consideră adecvat cercetării practicii de coaching ca proces de învăţare-acţiune-schimbare şi experienţă trăită.

\section{Concluzii}

Articolele selectate şi analizate nu pot fi considerate a fi cele mai reprezentative pentru tema avută în vedere, astfel încât să permită extragerea un concluzii cu caracter de generalitate. Cu toate acestea, prin caracterul de noutate şi actualitate al conţinutului lor oferă un reper important pentru cercetarea de coaching din România, care este încă la început de drum.

\section{Bibliografie}

- Bennett, J.L. (2006). An Agenda for Coaching-Related Research A Challenge for Researchers, Consulting Psychology Journal: Practice and Research, 58(4), 240-249, DOI: 10.1037/10659293.58.4.240.

- Braun, V., Clarke, V. (2006). Using thematic analysis in psychology, Qualitative Research in Psychology, 3(2), 77-101. DOI: 10.1191/1478088706qp063oa 
- $\quad$ Brown, C., Yates, J. (2018). Understanding the experience of midlife women taking part in a work-life balance career coaching programme: An interpretative phenomenological analysis, International Journal of Evidence Based Coaching and Mentoring, 16(1), 110-125, DOI: 10.24384/000472.

- Cannio, S., Launer, V. (2019). Cas de coaching commentés, Editions Eyrolles, Paris.

- Cardon, A. (2012). Adevărata artă a unui master-coach, Editura Codecs, Bucureşti.

- Fogg, M.L. (2019). Empowering female pre-retirees with a goal focused coaching relationship and a direct focus on well-being: A mixed method multiple case study, International Journal of Evidence Based Coaching and Mentoring, 17(2), 79-92. DOI: 10.24384/0z1x-ef06.

- Hughes, S. (2019). How could a 3-step coaching model help executives handle workplace conflict?, International Journal of Evidence Based Coaching and Mentoring, S13, 16-31. DOI: $10.24384 / j z d x-j 617$.

- Jackson, S. (2019). Coaching women towards authenticity: An appropriate workplace environment, International Journal of Evidence Based Coaching and Mentoring, 17(2), 6478. DOI: $10.24384 / \mathrm{c} 2 \mathrm{z3}-\mathrm{qd} 45$.

- Jordan, S. Kauffeld, S. (2020). A mixed methods study of effects and antecedents of solutionfocused questions in coaching, International Journal of Evidence Based Coaching and Mentoring, 18(1), 57-72. DOI: 10.24384/w8ne-fx80.

- $\quad$ Lane, L.G., De Wilde, J. (2018). The impact of coaching doctoral students at a university in London, International Journal of Evidence Based Coaching and Mentoring, 16(2), 55-68. DOI: $10.24384 / 000561$.

- Linley, P.A. (2006). Coaching Research: who? what? where? when? why?, International Journal of Evidence Based Coaching and Mentoring, 4(2), 1-7.

- Noon, H., van Nieuwerburgh, C. (2020). Looking forward to going back? The experience of career decision-making for first-time mothers and the implications for coaches. International Journal of Evidence Based Coaching and Mentoring, 18(1), 88-102. DOI: 10.24384/hqe5-4803.

- O'Connor, J., Lages, A. (2009). Coaching cu NLP. Cum sa fii un coach de succes, Editura Curtea Veche, Bucureşti.

- O’Neil, D.A., Bilimoria, D. (2005). Women's career development phases: Idealism, endurance, and reinvention, Career Development International, 10(3), 168-189, Emerald Group Publishing Limited 1362-0436, DOI 10.1108/13620430510598300.

- Sheehy, G. (1982). Les passages de la vie, Les Editions de Mortagne, Canada.

- Smith, M. (2018). A New Sense of Self: Exploring the Experience of Coaching during a Full Time Master of Business Administration Programme, International Journal of Evidence Based Coaching and Mentoring, S12, 85-97, DOI: 10.24384/000538.

- Sullivan, S.E., Al Ariss, A. (2019). Making sense of different perspectives on career transitions: A review and agenda for future research, Human Resource Management Review, https://doi.org/10.1016/j.hrmr.2019.100727.

- Thompson, S. (2019). The power of pragmatism: how project managers benefit from coaching practice through developing soft skills and selfconfidence, International Journal of Evidence Based Coaching and Mentoring, S13, 4-15. DOI: 10.24384/86ee-ps25.

- Walker, L. (2019). Coaching during late career reinvention: The Discovering Model, International Journal of Evidence Based Coaching and Mentoring, S13, 63-75. DOI: 10.24384/8s09-x110.

- Whitmore, J. (2008). Coaching pentru performanţă. Practica şi principiile coachingului şi ale leadershipului, Editura Publica, Bucureşti. 


\title{
Cap. 20. RETENȚIA VOLUNTARILOR. O DISCUȚIE PRAGMATICĂ DESPRE CULTIVAREA ANGAJAMENTULUI ORGANIZAȚIONAL
}

\author{
Paula-Simona Pădurariu \\ Universitatea „Alexandru Ioan Cuza” din Iași, Școala Doctorală de Economie și Administrarea Afacerilor \\ Iași, România, simonapadurariu2@gmail.com
}

\begin{abstract}
Rezumat: În încercarea de a contura o perspectivă asupra performanței în voluntariat, prin desprinderea de recompensa financiară, un prim pas este reprezentat de identificarea modalităților prin care retenția voluntarilor este realizată în mod eficient. Înainte de a analiza rezultatele activității acestora, va fi analizat un factor determinant al dorinței lor de a dezvolta activităţi și relații, angajamentul organizațional. Acest studiu, printr-o analiză a literaturii de specialitate, pe lângă definirea amănunțită a termenilor, extrage ca principale implicații: diminuarea problemelor de retenție printr-un sistem de planificare eficient, acest rezultat fiind dat și de instruirea atentă și adecvată a voluntarilor; crearea unui contract psihologic prin congruența dintre așteptările voluntarilor și oferta organizației, prin tehnici de recrutare adecvată, care diminuează intențiile ulterioare de părăsire a acesteia, alături de formularea și promovarea unor obiective clare ale organizațiilor, cu care voluntarii să se identifice, înspre dezvoltarea unei forme de angajament.
\end{abstract}

Cuvinte-cheie: angajament organizațional, retenția voluntarilor, managementul voluntarilor.

Abstract: In an attempt to outline a perspective on performance in volunteering, by detaching from the financial reward, a first step is to identify ways in which the retention of volunteers is achieved effectively. The organizational commitment is a determining factor of their desire to develop activities and relationships, therefore it will be analyzed before studying the results of the volunteers activity. This study, through a literature review, in addition to the detailed definition of terms, draws the following main implications: reducing retention problems through an effective planning system, this result being given by attentive and adequate training of volunteers; creating a psychological contract through the congruence between the expectations of the volunteers and the offer of the organization, through appropriate recruitment techniques, which diminish the subsequent intentions to leave it, along with formulating and promoting clear organizational objectives with which volunteers can identify helping them to develop a form of commitment.

Keywords: organizational engagement, volunteer retention, volunteer management.

\section{Definiții ale voluntariatului și implicații aferente}

În vederea conturării unei perspective clare asupra voluntariatului, au fost identificate 4 componente esențiale: răspunderea, definirea organizației, capacitatea de a construi și strategii spațiale/comunicaționale (Roberts, Frohling, \& Jones, 2000). Primul factor, răspunderea, definit ca ansamblul a tot ce se raportează către o autoritate (Edwards \& Hulme, 1996), evidențiază necesitatea unor resurse umane specializate, capabile să gestioneze aceste raportări nu doar către mediul extern, dar și către mediul intern, voluntarii având nevoie de specialiști care să îi îndrume, evalueze, distribuie sarcini de lucruri etc. Despre definirea organizației, autorii subliniază că misiunea şi viziunea sunt elemente-cheie în susținerea și promovarea ulterioară a activității. Totodată, crearea unui brand cu o identitate vizuală în acord cu ceea ce se dorește a transmite poate contribui esențial la consolidarea sustenabilității organizației, pe lângă viabilitatea acesteia din punct de vedere financiar. În ceea ce privește capacitatea de a construi, același articol evidențiază strânsa legătură cu dezvoltarea resurselor umane, ca singur mod de a crește și construi prin strategii adecvate, corespunzătoare unui stil managerial orientat către performanță (Roberts, Frohling, \& Jones, 2000). 
O comparație relevantă privind viziunile asupra voluntariatului este cea dintre Italia, o țară cu o implicare foarte scăzută și Statele Unite ale Americii, care are cel mai performant sistem de voluntariat (Ascoli \& Cnaan, 1997). Autorii sugerează că acesta ar putea deveni complementar serviciilor publice, evidențiind ca punct comun al celor două țări maniera profundă în care se bazează pe voluntari pentru aspecte ale vieții de zi cu zi. Deși frecvența activității este mai redusă în Italia, contrastul evidențiază o diferență culturală ce stă la baza definițiilor atribuite fenomenului. Astfel, în SUA, voluntariatul este o tradiție, bazată pe implicarea activă a tinerilor în cadrul bisericii, în Italia având fațete ale inovației prin redescoperire. Această diferență duce la definirea fenomenului ca pe o normă socială, în SUA, faţă de definiția europeană de alegere individuală. Impactul unei astfel de delimitări este relevat de maniera în care oamenii aderă la fenomen, în Europa fiind nevoie de procese eficiente care să îl ducă la statutul de normă socială, astfel încât să îşi atingă potenţialul maxim politic şi economic. Totodată, autorii subliniază faptul că, în Italia, nu existau programe publice de training a voluntarilor. Acest lucru se perpetuează și la momentul dat, inițiativele provenind de la organizații și foarte puțin de la stat. Astfel, specializarea voluntarilor este un proces dificil. Dacă în America voluntarilor li se dă din ce în ce mai multe responsabilități în domeniul public, care să contribuie la diminuarea taxelor, acest lucru este departe de a deveni comun în spațiul european. Se poate spune că aceste diferențe de percepție sunt cele care determină lipsa instrumentelor necesare consolidării fenomenului, de transformare a acestuia într-un factor determinant al democrației. Având în vedere principiile cultivate prin voluntariat, în special cel al muncii fără recompensă, acesta devine un fenomen al alegerii libere, al implicării necondiționate în comunitate, aducând individul în centrul identificării de soluții. Alegerile orientate către bunul mers al societății reprezintă antene ale democrației, permițând promovarea responsabilității, a libertăţii, a dreptății, a echității sociale, principii definitorii ale acesteia.

La nivel european, conform raportul realizat de Comisia Europeană (GHK, 2016), 22\% dintre tinerii de peste 15 ani sunt implicaţi în activităţi de voluntariat. Statele care ocupă primele locuri în ceea ce privește implicarea sunt: Austria, Olanda, Suedia și Marea Britanie. România se situează în rândul statelor cu o implicare relativ scăzută, între $10 \%$ şi $19 \%$, ultimele locuri revenind Bulgariei și Greciei, în corelație cu PIB-ul acestor țări, dar și cu slaba finanțare a acestora, fondurile provenind în proporție de aproximativ $40 \%$ de la donatori internaționali. Drept caracteristică a fenomenului, studiul relevă directa proporționalitate a nivelelor de educație și a implicării, valoarea economică fiind mai mică de 1\% din PIB în România, ajungând la 5\% în Austria, Olanda și Suedia.

Printre concluziile studiului (GHK, 2016), se remarcă nevoia dezvoltării unui angajament al voluntarilor, prin congruența dintre nevoile acestora și cele ale ONG-urilor, încurajarea specializării prin profesionalism ale organizațiilor, dezvoltarea unui temei legal propice, o finanțare sustenabilă, încurajarea recunoașterii meritelor activităţii, marea provocare fiind retenția voluntarilor.

\section{Managementul motivațiilor, particularitate a voluntariatului}

În încercarea de a determina care sunt factorii motivatori ce îi fac pe indivizi să presteze o activitate fără recompensă financiară, un studiu realizat în anul 2016 subliniază că voluntariatul este potrivit pentru persoanele cu abilități limitate, dar extrem de motivate (Burani \& Palestini, 2016), fapt ce întărește ideea că organizațiile non-profit au o foarte mare responsabilitate în ceea ce privește formarea voluntarilor. De asemenea, un studiu realizat pe un eșantion de 796 de studenți a demonstrat că ideea de a fi agreat este un factor determinant în luarea deciziei de a deveni voluntar, mai ales în cazul persoanelor extrovertite (Carlo, Okun, Knight \& de Guzman, 2005). Totuși, pe lângă această idee de a fi agreat, stă dorința de a fi pregătit și la nivel profesional, pe lista de factori motivatori intrinseci apărând tendința către împuternicire (Finkelstien, 2009). Un alt factor evidențiat într-un studiu realizat în cadrul unui eveniment organizat doar de voluntari este patriotismul (Lee, Reisinger, Ja Kim, \& Yoon, 2014), însă o explicaţie a modului în care acest sentiment poate fi definit și identificat nu este oferită de autori. În aceeași manieră, și cultura unei țări poate deveni factor motivațional (Erdurmazl1, 2019), recomandându-se creare de medii 
culturale atât organizaţionale, dar și prin valorificarea celui extern. Accentuând ideea responsabilității organizațiilor non-profit de a instrui viitori profesioniști, un articol publicat în anul 2016 evidențiază că cei care au experiențe de învățare pozitive sunt mai predispuși către performanță de lungă durată, frecvența participării la activitate fiind mai ridicată (Hu, Jiang, Mo, Chen \& Shi, 2016). Totodată, această frecvență a activității aduce în discuție un alt factor care se poate dovedi a fi demotivator, presiunea timpului. Acest fapt este analizat într-un articol publicat în anul 2020, ce subliniază că percepția asupra implicării în activităţi de voluntariat este influențată de posibila existență a acestei presiuni, fiind invers proporțională cu implicarea viitoare (Ainsworth, 2020). De asemenea, un articol din anul 2011 are ca principală concluzie faptul că instruirea este cel mai puternic factor ce determină satisfacția voluntarilor (Ferreira, Proença \& Proença, 2012), fapt pe care îl reținem pentru următoarele discuții. În aceeași notă, un articol publicat în anul 2016 concluzionează că beneficiile personale și cele legate de carieră contribuie la satisfacția voluntarilor care, deseori, este influențată negativ de costurile fenomenului (Hallmann \& Zehrer, 2016).

Având în vedere discuția despre identitatea organizației, o implicaţie dovedită a acesteia este că gradul de satisfacție al voluntarilor crește odată cu gradul în care aceștia se identifică cu activitatea organizației (Kang, 2016), dar și cu valorile acesteia (do Paço, Agostinho \& Nave, 2013). De asemenea, generarea de emoții pozitive ce poate rezulta din acest ataşament este asociată pozitiv cu intențiile de a rămâne în organizație a acestora (Barraza, 2011), dar și cu încrederea pe care aceștia o au în management și în sine (Bekkers, 2012).

O discuție importantă privind motivaţia voluntarilor este despre altruism, unul dintre principalii factori ce influențează decizia acestora de a întreprinde astfel de activități. Unul dintre cele mai relevante studii parcurse (Burns, Reid, Tonkar, Fawcett \& Anderson, 2006) dovedește că altruismul are un rol în ansamblul activităților de voluntariat, influențând: dezvoltarea carierei, dezvoltarea personală (stima de sine), respectarea și elaborarea de norme la nivel social, îndepărtarea de eventuale sentimente negative (dorința de auto-apărare), deprinderea de noi abilități și exprimarea unor valori și credințe.

Un alt factor determinant al satisfacției în voluntariat este măsura în care indivizii stabilesc relații interpersonale, factor cu un impact puternic și în retenție (Nencini, Romaioli \& Meneghini, 2016). Totodată, având în vedere și relațiile cu managementul organizației, un studiu realizat în anul 2005 demonstrează că liderii carismatici au o influență marcantă în motivația și retenția voluntarilor (De Hoogh și alții, 2005).

Un alt aspect ce subliniază importanța fenomenului, regăsit într-unul dintre articolele studiate, este că voluntarii sunt de părere că autenticitatea lor este confirmată de astfel de activităţi, subliniind chestiunile pozitive pe care aceștia doresc să le transmită și să le demonstreze (von Essen, 2016). Această idee poate fi corelată cu normele etice precizate într-un cod al voluntariatului, norme precum: binele comun, respectul reciproc şi libertatea alegerii, care duc la bunăstarea socială (Fusco-Karmann, Tamburini, Suprani \& Santosuosso, 1998).

La nivel pragmatic, o concluzie pentru această discuție este adusă de un articol ce recomandă ONG-urilor să creeze programe bazate pe nevoile voluntarilor de competențe, aplicabilitate și autonomie, nevoi care cresc satisfacția nu doar față de activitate, ci chiar față de viață (Yan et al., 2013).

\section{Angajamentul organizațional, factor de creștere a retenției în organizațiile non-profit}

Având în vedere că recompensa financiară nu mai există în munca voluntară, procesul de motivare devine o provocare pentru echipa managerială a oricărei organizații non-profit. De aceea, bagajul motivațional al fiecărui voluntar trebuie analizat astfel încât direcțiile de acțiune să contribuie la dezvoltarea angajamentului organizațional. Unul dintre capitolele cărții studiate amintește de următoarele funcții generale ale voluntariatului: exprimarea altruismului și a laturii umanitare prin prisma atenției față de aproape; oferirea de noi experiențe de învățare și a șansei de a exersa și a pune în practică anumite cunoștințe; posibilitatea de a stabili și consolida relații 
interumane; alimentarea propriului ego și protejarea acestuia de caracteristici negative ale sinelui, dar şi reducerea vinovăţiei faţă de faptul de a fi mai norocos decât alții, alături de posibilitatea de a ierarhiza problemele cotidiene (Rochester, Ellis Paine, \& Howlett, 2010). Un studiu realizat în anul 2014, prin analiza acestor funcții și desfăşurarea unei anchete cantitative, concluzionează că principala valoare a voluntarilor este deținerea unui scop clar, urmată de nevoia de ordine și varietate. La nivel interpersonal, cele mai importante valori sunt: ajutorarea datorată generozității, independența și nevoia de leadership (Mihai, 2014). Astfel, pentru a cultiva angajamentul organizațional, se poate deduce că, la nivel managerial aceste valori ar trebui transpuse în acțiuni concrete precum: stabilirea de obiective atât la nivel organizațional, cât și la nivel individual, explicate voluntarilor astfel încât aceștia să se poată identifica cu ele, percepându-le ca pe țeluri proprii; deținerea unui sistem de planificare ce să poată răspunde nevoii de ordine, dar care să dea voluntarilor libertatea de acțiune, una dintre principalele caracteristice ale activității de voluntariat; încurajarea lucrului în echipă, mediat astfel încât să ducă la crearea unor noi relații, dar care să dea ocazia identificării de roluri precum cel de lider. Totodată, managerii trebuie să fie atenți la aceste nevoi ale voluntarilor, echilibrând riscul de a părăsi organizația datorată libertății cu răspunsurile oferite la diversele cerințe ale acestora.

Un alt studiu definește angajamentul ca pe o stare psihologică pozitivă, legată de o serie importantă de beneficii individuale și organizaționale. Voluntarul ataşat de organizație este împlinit, cu o energie orientată către afirmare prin îndeplinirea de sarcini potrivite. Un chestionar aplicat unui număr de 1064 de voluntari demonstrează că angajamentul este determinat de sprijinul organizațional orientat către îndeplinirea de sarcini și consiliere emoțională. La rândul său, angajamentul organizaţional determină fericirea voluntarilor și valoarea socială percepută, factori ce îi împiedică să părăsească organizația. De asemenea, acest studiu subliniază că, prin implementarea unor acțiuni instituţionale care să aibă ca obiective factorii enunțaţi, impactul pozitiv nu va fi doar asupra voluntarilor, ci și asupra comunităţilor din care aceștia fac parte (Alfes, Shantz, \& Bailey, 2016). Practic, angajamentul organizațional stă la baza retenției voluntarilor. Pentru că fericirea este un termen foarte relativ, se poate spune că valoarea socială percepută este în strânsă legătură cu funcția de alimentare a propriului ego, organizațiile non-profit fiind nevoite să investească în promovare și consolidare a unui brand care să asigure această valoare. Totodată, aceasta poate fi determinată şi de feedback-ul constant pe care voluntarii ar trebui să îl primească de la echipa managerială, dar și de la beneficiarii activităților întreprinse. Impactul asupra comunităţii rezultă chiar din consolidarea relațiilor interumane, dar și din latura umanitară pe care aceste activități o pot căpăta. Acesta accentuează importanța activităților de voluntariat, care contribuie la dezvoltarea simțului civic și îi responsabilizează pe participanți. Dincolo de viața personală, societatea nu poate evolua decât prin implicarea tuturor în schimbare.

Pe de altă parte, organizațiile non-profit au o mare responsabilitate în ceea ce privește acordarea acelui sprijin orientat către sarcini și emoții. La nivel practic, acesta este asociat nevoilor de training și de coaching experimentate de către voluntari care, odată îndeplinite, au puterea de a suplini lipsa unor recompense tangibile.

O abordare asemănătoare este susținută și de ASAE Foundation, care susține că succesul organizațiilor stă în obiectivele clare, valorile stabile și medierea oportunităților de a crea relații însemnate oferite voluntarilor (Mason, 2003). De asemenea, acesta amintește de congruența care trebuie să fie creată încă din momentul recrutării, dintre nevoile voluntarilor si ceea ce organizaţia le poate oferi. Această congruență a fost definită într-un articol foarte recent ca fiind un contract psihologic, determinant al unei legături cauzale între recrutare și retenție (Kappelides, Cuskelly \& Hoye, 2019). Practic, cu cât tehnicile de recrutare sunt mai adecvate obiectivelor organizaționale, orientate către găsirea de voluntari potriviți, cu atât riscul ca aceștia să părăsească organizația scade. În acest caz, o sugestie ar fi promovarea unui profil al voluntarului bazat nu pe cerințele organizației, ci prin evidențierea a ceea ce aceasta poate oferi. Acelaşi studiu semnalează dificultățile pe care ONG-urile le întâmpină în procesul de recrutare: lipsa de timp, imposibilitatea de a oferi feedback, de a împărți pe etape desfășurarea, alături de absența unei viziuni pe termen 
lung. Astfel, se recomandă dezvoltarea de tehnici calitative, care să accentueze contactul multiplu cu candidatul, înspre înţelegerea nevoilor sale şi potrivirea acestora cu un cadru organizațional adecvat. Totodată, indiferent de problemele legate de managementul timpului, stabilirea de obiective pe termen lung susținute de nevoia de voluntari, ar trebui să contureze un sistem bazat pe etapă-feedback-etapă, până decizia de integrare în echipă este fundamentată conform contractului psihologic înțeles și acceptat de ambele părți. Deși o soluție actuală este recrutarea sistematică, pentru găsirea periodică de voluntari, acest procedeu semnalează probleme în retenție, dar și imposibilitatea de a forma adecvat oameni.

În ceea ce privește angajamentul organizațional, un alt studiu demonstrează că acesta are o contribuție mai mare la satisfacția voluntarului decât angajamentul față de sarcină (Malinen \& Harju, 2017). Astfel, cu cât un voluntar este mai ataşat de organizație, cu atât este dispus să realizeze sarcini variate, de diferite niveluri de dificultate. Deși dezirabil pentru organizație, acest lucru, în condiții lipsite de mediere, duce la epuizare, urmat de intenții de părăsire. Însă, prin tehnici adecvate de coaching, se poate împiedica această reacție la stres, organizațiile fiind nevoite să administreze extrem de bine sarcinile de lucru, potrivirea acestora cu profilul voluntarilor și timpul de realizare.

Un studiu realizat în rândul unor organizații non-profit cu profil sportiv a raportat că problemele legate de retenția voluntarilor scad odată cu impunerea unui sistem de planificare riguros, alături de răspunsuri adaptate la nevoile de training și sprijin (Cuskelly, Taylor, Hoye, \& Darcy, 2006). Astfel, ideea conform căreia orientarea pe care organizațiile trebuie să o asigure devine factor determinant al retenției, în strânsă legătură cu angajamentul organizațional ce rezultă pe măsura timpului investit. Totodată, conform aceluiaşi studiu, factorul de retenţie dezvoltă voluntari pregătiți să facă faţă provocărilor, uneori prinși în starea de flow, care diminuează intențiile de părăsire a organizației.

O altă discuție despre retenție prezentă într-unul dintre articolele analizate desemnează ca motivaţii principale oportunitatea de a dezvolta prietenii și de a dobândi un sentiment de apartenență la comunitate (Shye, 2010). Deși asemănător cu cele discutate, acest studiu accentuează o altă latură a retenţiei şi a angajamentului. Dacă o organizație, prin obiectivele și valorile sale, răspunde la nevoile voluntarilor, însă oamenii ei nu prezintă potențial relaţional, cauzalitatea dintre cele două se va menține? Un răspuns negativ ar fi mai mult decât probabil, argumentat de un studiu care demonstrează că satisfacția în muncă este mai mare în grupuri închegate, cu o anumită istorie, într-un mediu formalizat, birocratic chiar, cu o ierarhie clară, dar împărțite în grupuri mici (von Schnurbein \& Studer , 2013). Cât despre apartenența la comunitate prin voluntariat, unul dintre articolele studiate (Stebbins, 2009) ridică următoarele întrebări:

1. Suntem capabili de orice fel de interacțiune pentru a implica societatea în rezolvarea unor probleme mai ample?

2. Câți oameni au fost epuizați de activitatea voluntară?

3. Câți oameni ar recomanda proiecte de voluntariat, dar nu o fac de frica de a rămâne singuri cu responsabilitatea?

Aceste întrebări aduc în discuție unele dintre problemele-cheie ale activităţii neplătite, care trebuie să fie clarificate și rezolvate de managementul organizațiilor. Astfel, se poate spune că orice interacțiune presupune un efort, o ieșire din zona de confort. Pentru a putea rezolva o problemă printr-o activitate voluntară este nevoie de resurse umane competente, dispuse să investească foarte mult timp și expertiză. Totodată, cumulul dintre viaţa personală, profesie și activitatea voluntară poate fi copleșitor, interacțiunea permanentă devenind obositoare, stresantă, intențiile de părăsire manifestându-se prioritar în zona voluntariatului.

Starea de epuizare la locul de muncă amintită anterior, dar prezentă și în a doua întrebare, subliniază problemele de management al timpului întâmpinate de un individ implicat care, odată cu experimentarea epuizării, va părăsi organizația, ultima de pe lista de priorități. Pierderea devine cu atât mai mare pentru organizație cu cât voluntarul se numără printre cei performanţi, cu potenţial ridicat de a manifesta frustrări, stres, oboseală etc. De aceea, recomandările privind satisfacerea 
nevoii de coaching devin esențiale în retenția acestora, un angajament crescut neputând garanta disponibilitatea lor continuă.

Atragerea voluntarilor în diferite proiecte presupune un risc imediat al demotivării, responsabilitatea putând fi dată de la unii la alții până la abandon. Cu cât cauzele pentru care se realizează o mobilizare a resurselor sunt vagi, nerealiste, inadecvate pentru competențele actuale, cu atât intențiile de părăsire cresc. Din discuția anterioară, se poate deduce că practicile de management defectuoase reprezintă unul dintre factorii principali care conduc la abandonul organizației. De aceea, asumarea unei responsabilităţi în cadrul comunității ar trebui să se facă prin prisma unei organizații cu un sistem de coordonare bine pus la punct, care să poată lua decizii pertinente privind fezabilitatea unor proiecte.

\section{Limite ale studiului}

Studiul ar putea fi îmbunătătit printr-o abordare psihologică a principalelor motivaţii ale voluntarilor, alături de o analiză a semnificațiilor pe care organizaţia le capătă în viaţa lor. De asemenea, motivațiilor lor pot fi explorate în profunzime prin metode calitative, înspre definirea unor concepte care să devină părți integrante ale procesului de recompensare, dincolo de partea financiară.

\section{Concluzii}

Principalele implicații practice extrase sunt: diminuarea problemelor de retenție printr-un sistem de planificare eficient, acest rezultat fiind dat și de instruirea atentă și adecvată a voluntarilor; crearea unui contract psihologic prin congruența dintre așteptările voluntarilor și oferta organizației, prin tehnici de recrutare adecvată, care diminuează intențiile ulterioare de părăsire a acesteia, alături de formularea și promovarea unor obiective clare ale organizațiilor, cu care voluntarii să se identifice, înspre dezvoltarea unei forme de angajament. Se poate spune că există o relație de cauzalitate între angajamentul organizațional și retenție, cu excepțiile discutate, principala responsabilitate a organizațiilor fiind cea de a evita epuizarea la locul de muncă prin planificare și satisfacerea nevoilor de training și coaching.

\section{Bibliografie}

- Ainsworth, J. (2020). Feelings of ownership and volunteering: Examining psychological ownership as a volunteering motivation for nonprofit service organisations, Journal of Retailing and Consumer Services. doi:10.1016/j.jretconser.2019.101931

- Alfes, K., Shantz, A., \& Bailey, C. (2016). Enhancing Volunteer Engagement to Achieve Desirable Outcomes: What Can Non-profit Employers Do?, Voluntas, 595-617.

- Ascoli, U., Cnaan, R. (1997). Volunteering for human service provisions: lessons from Italy and the U.S.A., Social Indicators Research, 40, 299-327.

- Barraza, J. (2011). Positive emotional expectations predict volunteer outcomes for new volunteers, Motivation and Emotion, 35, 211-219 . doi:10.1007/s11031-011-9210-4

- $\quad$ Bekkers, R. (2012). Trust and Volunteering: Selection or Causation? Evidence From a 4 Year Panel Study, Political Behavior, 34, 225-247. doi:10.1007/s11109-011-9165-x

- Burani, N. Palestini, A. (2016). What determines volunteer work? On the effects of adverse selection and intrinsic motivation, Economics Letters, 144, 29-32. doi:10.1016/j.econlet.2016.04.014

- $\quad$ Burns, D., Reid, J., Tonkar, M., Fawcett, J., Anderson, C. (2006). Motivations to volunteer: the role of altruism. International Review on Public and Non Profit Marketing, 3(2), 79-91.

- Carlo, G., Okun, M., Knight, G., de Guzman, M. (2005). The interplay of traits and motives on volunteering: agreeableness, extraversion and prosocial value motivation, Personality and Individual Differences, 38, 1293-1305. doi:10.1016/j.paid.2004.08.012 
- Cuskelly, G., Taylor, T., Hoye, R., Darcy, S. (2006). Volunteer Management Practices and Volunteer Retention: A Human Resource Management Approach, Sport Management Review, 9(2), 141-163.

- De Hoogh, A., Den Hartog, D., Koopman, P., Thierry, H., Van den Berg, P., Van der Weide, J., Wilderom, C. (2005). Leader motives, charismatic leadership and subordinates' work attitude in the profit and voluntary sector, The Leadership quaterly, 16, 17-38. doi:10.1016/j.leaqua.2004.10.001

- do Paço, A., Agostinho, D., Nave, A. (2013). Corporate versus non-profit volunteering - do the volunteers' motivations significantly differ?, International Review on Public and Nonprofit Marketing, 10, 221-233. doi: 10.1007/s12208-013-0101-0

- Edwards, M., Hulme, D. (1996). Beyond the magic bullet: NGO performance and accountability in a post cold war world, Kumarian Press Books on International Development.

- Erdurmazlı, E. (2019). Satisfaction and Commitment in Voluntary Organizations: A Cultural Analysis Along with Servant Leadership, Voluntas, 30, 129-146. doi:10.1007/s11266-0189992-z

- Ferreira, M.R., Proença, T., Proença, J.F. (2012). Organisational influence on volunteer satisfaction and attitudes towards HRM practices: the case of hospital volunteers, International Review on Public and Nonprofit Marketing, 9, 27-42. doi:10.1007/s12208-0110071-z

- Finkelstien, M.A. (2009). Intrinsic vs. extrinsic motivational orientations and the volunteer process, Personality and Individual Differences, 46, 653-658. doi:10.1016/j.paid.2009.01.010

- Fusco-Karmann, C., Tamburini, M., Suprani, A., Santosuosso, A. (1998). The code of conduct of the volunteer, Support Care Cancer, 6, 120-124.

- GHK. (2016). Volunteering in the European Union, preluat de pe https://ec.europa.eu/citizenship/pdf/doc1018_en.pdf

- Hallmann, K., Zehrer, A. (2016). How do Perceived Benefits and Costs Predict Volunteers' Satisfaction?, Voluntas, 27, 746-767. doi:10.1007/s11266-015-9579-x

- Hu, J., Jiang, K., Mo, S., Chen, H., Shi, J. (2016). The motivational antecedents and performance consequences of corporate volunteering: When do employees volunteer and when does volunteering help versus harm work performance?, Organizational Behavior and Human Decision Processes, 137, 99-111. doi:10.1016/j.obhdp.2016.08.0050749-5978

- Kang, M. (2016). Moderating effects of identification on volunteer engagement. An exploratory study of a faith-based charity organization. Journal of Communication Management, 20(2), 102-117. DOI:10.1108/JCOM-08-2014-0051

- Kappelides, P., Cuskelly, G., Hoye, R. (2019). The Influence of Volunteer Recruitment Practices and Expectations on the Development of Volunteers' Psychological Contracts, Voluntas, 30(1), 259-271.

- Lee, C.K., Reisinger, Y., Ja Kim, M., Yoon, S.M. (2014). The influence of volunteer motivation on satisfaction, attitudes, and support for a mega event, International Journal of Hospitality Management, 40, 37-48. doi:10.1016/j.ijhm.2014.03.0030278-4319

- Malinen, S., Harju, L. (2017). Volunteer Engagement: Exploring the Distinction Between Job and Organizational Engagement. Voluntas, 28, 69-89.

- Mason, M. (2003). Rules of volunteer engagement. Association Management; Washington, 116.

- Mihai, E.C. (2014). The Motivation of Romanian Volunteers: values and implications. Procedia - Social and Behavioral Sciences, 616-620.

- Nencini, A., Romaioli, D., Meneghini, A. M. (2016). Volunteer Motivation and Organizational Climate: Factors that Promote Satisfaction and Sustained Volunteerism in NPOs. Voluntas, 27, 618-639. doi:10.1007/s11266-015-9593-z 
- $\quad$ Roberts, S., Frohling, O., Jones, J. (2000). NGOs and the Globalization of Managerialism: A Research Framework. World Development, 33(11), 1845-1864. doi:10.1016/j.worlddev. 2005.07.004

- Rochester, C., Ellis Paine, A., Howlett, S. (2010). Volunteering and Society in the 21st Century. London: Palgrave Macmillan.

- Shye, S. (2010). The Motivation to Volunteer: A Systemic Quality of Life Theory, Social Indicators Research, 98(2), 183-200.

- Stebbins, R.A. (2009). Would You Volunteer?, Society, 46, 155-159 https://doi.org/10.1007/s12115-008-9186-1.

- $\quad$ von Essen, J. (2016). On the Meaning of Volunteering: A Study of Worldviews in Everyday Life, Foundations of Science, 21, 315-333. doi:10.1007/s10699-014-9392-9

- von Schnurbein, G., Studer, S. (2013). Organizational Factors Affecting Volunteers: A Literature Review on Volunteer Coordination, Voluntas, 24, 403-440.

- $\quad$ Yan, Y.K., Wing, H.C., Lok, P.W. (2013). Need Satisfaction Mechanism Linking Volunteer Motivation and Life Satisfaction: A Mediation Study of Volunteers Subjective Well-Being, Social Indicators Research, 114, 1315-1329. doi:10.1007/s11205-012-0204-8 


\section{Partea a IV-a. Antreprenoriat}





\title{
Cap. 21. TEHNICI CONTEMPORANE DE DEZVOLTARE A BRANDINGULUI DE ANGAJATOR UTILE TINERILOR ANTREPRENORI
}

\author{
Ecaterina Chițu \\ Universitatea „Alexandru Ioan Cuza” din Iaşi, Şcoala Doctorală de Economie şi Adminsitrarea Afacerilor, \\ Iaşi,România, chitu.ecaterina@gmail.com
}

\begin{abstract}
The war for talent is a reality of the business context that companies are currently facing. This competitive environment has led organizations to assume the need to implement strategies to improve quality of human resource management, which is also true for those companies at the beginning of the road. This study aims to analyze the means by which young entrepreneurs can create an employer brand. The research methodology is based on a qualitative approach, based on the analysis of the literature and online documents on the websites of representative companies from America. Thus, in order to create a strong employer brand, it is important first of all, to know the challenges that arose in the process of creating it. After completing this step, an employer brand can be built by defining the vision and purpose of the start-up, defining the core values and the starting culture of the company, completing the EVP (Offer of value to the employee) with the vision, mission and the culture of the organization and the promotion of the employer brand in the online environment.
\end{abstract}

Keywords: Employer Branding, Startup, Strategies.

\section{Introducere}

Creșterea interesului tinerilor pentru dezvoltarea unei afaceri proprii reprezintă o tendință specifică economiei de piață, iar poziționarea în piață constituie un deziderat ce implică tehnici economice interdisciplinare adaptate condițiilor contemporane şi specificului temporal.

Poziționarea în piață, dincolo de cunoașterea acesteia, presupune formarea unei imagini, a unor repere de referință care să permită asocierea noii afaceri, pe de o parte, cu așteptările și regăsirea clientului, pe de altă parte, cu tot ce înseamnă calitate, originalitate și necesitate.

Toate aceste implicări nu se limitează doar la identitatea vizuală şi mesajul extern al organizației, ci am putea spune, în mod just că ele constituie doar o parte din constructul de marketing al acesteia, fundamentul reprezentându-l angajaţii angrenați în procesul comercial, elemente care se circumscriu pe deplin obiectivelor și tehnicilor brandingului de angajator.

Privind din acest unghi, subiectul de față prezintă importanță și originalitate, în condițiile în care acesta se mulează pe situaţia particulară a tinerilor antreprenori, context în care efemeritatea afacerii, lipsa experienței și duritatea condițiilor de acces în piaţă reclamă necesitatea unor tehnici particularizate și contextualizate.

Implicarea laturii umane în formarea imaginii constituie transpunerea afectivă a unor garanții ce sunt percepute pozitiv de client, a căror importanţă transcede mesajului și chiar calităţii serviciului, dat fiind că empatizarea, externalizarea și portretizarea încrederii, calității, seriozității unui furnizor constituie un factor de impact hotărâtor în formarea deciziei și ataşamentului clientului în raport de organizația respectivă.

Eliminarea tradiționalismului și amatorismului în afacerile mici și mijlocii, dar și impregnarea acestora a specificului tânăr, în lumina abordării utilității brandingului de angajator, vizează gândirea unei strategii generale pe termen lung, în care brandul organizației să fie caracterizat de o bipolaritate, unul dintre cei doi poli fiind construirea unui brand de angajator.

Cercetarea de față aduce în prim plan soluțiile proactive necesare a fi adoptate în raport de resursa umană, de potențarea acesteia și de implicarea strategică în construcția imaginii durabile a 
afacerii, aspect care presupune, în primul rând stabilitatea angajaților, confortul lor, aspect ce poate fi obținut doar prin înțelegerea nevoilor și acordarea suportului necesar acestora.

Frecvența programelor de tip startup și accesibilitatea facilă la acestea au generat formarea de afaceri noi de către tineri, de diferite dimensiuni, aspect care atrage în primul rând nevoia de cunoaștere de către inițiatori a modului de abordare a ideii de afacere și a modului de implementare de pe poziția dimensiunii acesteia, a stadiilor de dezvoltare implicate și a rolului resursei umane în toate acestea.

Acest tip de abordare, așa cum vom dezvolta, va permite tinerei companii nu numai îndeplinirea condițiilor minimale ale planului de afaceri, ci chiar atragerea de noi investiții pentru capitaluri proprii, dar și depăşirea provocărilor specifice startup-urilor în crearea propriului brand prin implementarea și menținerea unui brand de angajator personalizat circumstanțelor.

Imaginea externă a organizației capătă o credibilitate și o accesibilitate sporită pentru potențialii clienți dacă este grefată pe satisfacția și calitatea angajaților acesteia, iar o satisfacție reală a acestora, care să reprezinte un mijloc de propagare pe orizontală a brandului, poate fi generată și întreținută prin formarea unei misiuni a companiei comune cu viziunea, cultura și valorile acesteia.

Dacă am numit că publicitatea este sufletul comerțului, în mod just am putea aprecia că satisfacția angajaţilor și aderența lor emoțională și profesională la organizaţia angajatoare reprezintă modul cel mai autentic și util afacerilor pornite de tineri, atât pentru a-și putea spori personalul și nivelul general de pregătire a acestuia, cât și pentru a căpăta o notorietate generală pozitivă.

Pozitivismul și echilibrul - ca atribute a specificului muncii sunt substanța brandingului de angajator extern ce pot să atragă atât potențiali angajați, cât și clienți, iar pe termenul lung să formeze o imagine corporativă esenţială în menținerea şi dezvoltarea produselor ori serviciilor oferite.

Tinerii antreprenori, în orientarea propusă, vor dezvolta capacitatea ca în procesul managerial să adopte o relație interumană internă și externă valorizantă faţă de personalul condus, punând calităţile acestuia şi nevoile multiple ca fundament al activităţii manageriale.

Brandingul de angajator pentru tinerii antreprenori poate reprezenta o provocare care să aducă beneficii pe termen lung, calitative și constante, dat fiind că managementul participativ este circumscris evidențierii factorului uman și stimulării acestuia.

Obiectivele brandingului de angajator răspund fidel nevoilor tânărului antreprenor și prezintă atât accesibilitate, cât și adaptabilitate în privința dimensiunii organizației, pieței și specificului acesteia.

Aplicarea unor trăsături pozitive organizației astfel încât acestea să fie perceptibile intern și extern, reprezintă un răspuns la nevoia de dezvoltare și acces în piața extrem de competitivă, iar stimularea comportamentului productiv al angajaților aduce performanță colectivă și exteriorizare a responsabilităţii angajatorului faţă de bunăstarea şi progresul profesional al indivizilor implicaţi în activitatea de producție ori de prestare a serviciilor.

\section{Brandingul de angajator}

Conceptul de branding de angajator poate fi încadrat în activităţile clasice de marketing intern. Marketingul intern ar putea fi definit ca un proces de dezvoltare prin care o organizație se aliniază, motivează și împuternicește pe angajații săi să ofere o experiență pozitivă pentru clienți, fapt ce ajută la atingerea obiectivelor companiei (Asif \& Sargeant, 2000). Cu alte cuvinte, marketingul intern poate și trebuie utilizat ca instrument strategic care ajută compania să își atingă obiectivele în afaceri.

Brandingul de angajator se bazează pe aplicarea conceptelor de marketing pentru a evidenția poziționarea unei companii ca angajator. Intenția sa este aceeaşi cu cea a unui brand comercial: să atragă clienți noi și să îi păstreze pe cei actuali. Diferența constă în faptul că, în această situație, clientul este reprezentat de angajatul actual și/sau potențial. Totodată, la fel ca un brand de consum, 
brandul de angajator evidențiază beneficiile emoționale și raționale pe care angajatorul le oferă angajaților săi (Barrow \& Mosley, 2005).

Brandingul de angajator prezintă trei elemente cheie și anume:

1. Reflectă valoarea brandului față de consumatori datorită angajamentului personalului.

2. Transmite promisiunea brandului către audiențele interne și externe ale companiei.

3. Prezintă o importanţă multidirecțională: necesită aplicarea strategiilor de branding de angajator la toate nivelurile organizației pentru a realiza alinierea comportamentelor și valorilor conducerii și ale personalului.

Trebuie evidențiat faptul că brandul de angajator trebuie să fie în concordanță cu celelalte branduri ale organizației cu care împărtășesc puncte comune, dar păstrează și două diferențe cheie. În primul rând, brandul de angajator este specific și caracteristic ocupării forței de muncă, subliniind identitatea companiei ca angajator. În al doilea rând, vizează audiențele interne și externe ale companiei, în timp ce eforturile brandurilor corporative și de produse sunt direcționate în principal către audiențe externe (Backhaus \& Tikoo, 2004).

În crearea unui brand de angajator, principalul obiectiv este prezentat de atragerea şi menținerea talentelor, dar și atingerea obiectivelor multiple ale managementului resurselor umane. Având în vedere că organizațiile își doresc să atragă talente este foarte important ca aceste potențiale talente să fie atrase de aceste companii (Chhabra \& Sharma, 2014). De asemenea, brandingul de angajator se focusează atât pe perspective interne, cât și pe perspective externe privind poziționarea unei companii ca fiind cel mai bun angajator (Hubschmid, 2013).

Un brand de angajator de succes poate fi identificat printr-o varietate de caracteristici diferite. Printre principalele caracteristici al un brand de angajator de succes se regăsesc (Figurska \& Matuska, 2013):

- Echilibru între viața profesională și cea personală - această caracteristică este esenţială pentru creșterea loialității angajaților, fapt ce va genera menținerea acestora;

- Beneficii competitive și program de compensare - este necesar ca angajații să se simtă remunerați corect pentru munca pe care o realizează;

- Tratarea angajaților cu respect;

- $\quad$ Mediu de lucru pozitiv;

- $\quad$ Relații de muncă de încredere între angajaţi și manageri

- Comunicare și disponibilitate - angajații ar trebui să simtă că munca lor este recunoscută şi importantă pentru companie;

- $\quad$ Plasarea talentului potrivit pe postul potrivit;

- $\quad$ Flexibilitatea locului de muncă - opțiunea angajaților de a lucra ore flexibile.

\section{Importanța brandingului de angajator}

În prezent, social media face multe companii transparente. Este evident faptul că oamenii tind să se alăture companiilor cu o reputaţie bună şi, de asemenea, să rămână într-o companie mult timp dacă aceasta este considerată un angajator ales (Sivertzen \& Olafsen, 2013). Referindu-ne la definiţia dată de Mosley brandingului de angajator, recrutarea și retenția efectivă a angajaților prezintă o influență puternică asupra rezultatelor afacerii (Mosley, 2014).

Beneficiile pe care le aduce brandingul de angajator pentru organizație sunt clare și evidente. În primul rând, brandingul de angajator reprezintă una dintre puținele soluții pe termen lung la problema deficitului de talent. Având în vedere că majoritatea strategiilor de angajare sunt pe termen scurt, construirea unui brand de angajator este o soluție proactivă pe termen lung concepută să ofere un flux constant solicitanților. Brandul de angajator reprezintă o oportunitate relevantă și distinctivă pentru companie, aceea de a se diferenția de concurență prin crearea factorilor de marcă, cum ar fi USP-ul (propunerea de vânzare unică) în scopul satisfacerii nevoilor angajaţilor. Aceste strategii vor genera retenție, eficiență și productivitate (Ambler \& Barrow, 1996).

Brandingul de angajator oferă companiei un avantaj competitiv greu de imitat deoarece activitățile sale permit atragerea potențialilor angajați și menținerea talentelor existente. De 
asemena, brandingul de angajator contribuie semnificativ la construirea unei companii cu reputație cunoscută în lume. Astfel, cunoscute la nivel mondial, organizațiile au șansa de a atrage talente din întreaga lume, de a promova diversitatea și de a păstra o categorie mai largă de candidați (Chhabra \& Sharma, 2014). Totodată, brandingul de angajator satisface nevoia de recrutare a unei companii pe termen lung. Având în vedere rolul major al mediului social în răspândirea informațiilor, bradingul de angajator prezintă capabilitatea de a modela și consolida vizibilitatea online a unei companii. În cele din urmă, brandingul de angajator determină o influență mai mare a companiilor asupra angajaţilor.

\section{Brandingul de angajator intern și extern}

În general, companiile tind să acorde mai multă atenție activităților externe și nu interne, fapt ce înseamnă că angajatorii pun mai mult accent pe activitățile de marketing pentru atragerea de noi angajaţi și mai puțin pe bunăstarea și satisfacția generală a talentelor deja existente. Este necesar să evidențiem faptul că investițiile atât în brandul intern, cât și în brandul extern sunt la fel de importante. În construirea unui brand de angajator de succes atât intern, cât și extern, companiile ar trebui să acorde prioritate obiectivelor pe care doresc să le atingă prin crearea brandului, menţinând un echilibru între activităţile interne și externe (Chhabra \& Sharma, 2014).

De regulă, organizațiile care pun accent pe satisfacerea nevoilor talentelor actuale determină și creșterea satisfacției clienților externi, deoarece angajații mulțumiți tind să aibă mai multă grijă de clienți. De asemenea, este cunoscut faptul că percepțiile interne sunt transferate în mediul extern prin angajații actuali, dar și prin foștii angajați ai companiei, fapt ce evidențiază interdependența dintre acțiunile interne și externe ale companiei (Chhabra \& Sharma, 2014).

În acord cu Chhabra și Sharma, obiectivul brandingului de angajator intern este reprezentat de determinarea angajaţilor de a se dedica valorilor și obiectivelor organizației. Totodată, brandul intern este privit din ce în ce mai mult ca o doctrină care să asigure livrarea promisiunii brandului prin modelarea atitudinilor și comportamentelor de brand ale angajaţilor (Chhabra \& Sharma, 2014).

Conform lui Suresh, principalele aspecte ale brandului intern sunt legate de (Suresh, 2014):

- Viziunea și misiunea companiei;

- Cultura și valorile companiei;

- Compensare, recompense, beneficii, asistenţă medicală, activităţi de angajare a personalului, oportunități de creștere a personalului, programe de învățare și dezvoltare, sesiuni de feedback;

- Program de sesizare a angajaților;

- Recunoaşterea angajaților;

- Echilibrul vieții profesionale:

- Responsabilitate socială corporativă etc.

În lucrarea lui Backhaus și Tikoo, brandingul de angajator extern își propune să atragă un grup țintă (potențiali angajați), clienți și să creeze o imagine corporativă, sprijinind produsele sau serviciile unei firme (Backhaus \& Tikoo, 2004). Conform lui Suresh, brandingul extern include (Suresh, 2014):

- Performanța pieței - cât de eficientă este o companie în realizarea produselor și serviciilor;

- Performanța produsului - în ce măsură clienții sunt mulțumiți de produsele și serviciile oferite de companie;

- $\quad$ Relații publice și media - care este imaginea corporativă a companiei în mass-media. Este recunoscută public o companie?

- $\quad$ Site-ul web și social media - care este reputaţia unei organizaţii pe social media;

- Clasamentul locurilor de muncă etc. 


\section{Brandingul de angajator pentru startup-uri}

În general, o companie de tip startup poate fi descrisă ca fiind o companie cu fonduri recente, cu o creștere rapidă, unde un antreprenor trece de la stadiul de idei la înființare. O companie de tip startup poate avea diferite dimensiuni și forme (Robegmed, 2013). Un startup prezintă șase stadii de dezvoltare și anume (Ramirez, 2016):

- $\quad$ Etapa de idei - în mod normal, în această primă etapă, un antreprenor are o idee inițială de afaceri despre cum și de ce afacerea lui va crea valoare. Totodată, structura echipei este vagă în această perioadă: ar putea exista o singură persoană responsabilă pentru toate operațiunile;

- $\quad$ Etapa de concepție - sunt deja definite misiunile și viziunile unei companii, precum și strategiile și etapele cheie pentru cel puțin următorii trei ani. În acest moment, echipa se presupune a fi mai structurată și poate fi extinsă pentru roluri suplimentare;

- Etapa de angajament - în mod normal, în această etapă există o echipă de cofinanțare angajată și echilibrată, cu obiective și valori comune.

- Etapa de validare - în această perioadă de dezvoltare, un startup își permite să demonstreze creșterea afacerii, dar și a veniturilor. De asemenea, la acest moment, o companie poate începe să atragă noi investiții pentru capitaluri proprii, cotă de venit etc.;

- Etapa de scalare - în acest moment, o firmă poate și vrea să crească rapid; se concentrează pe o piață țintă mare sau cu creștere rapidă. Totodată, poate atrage deja o finanțare considerabilă. În acest punct, o companie prezintă îmbunătățiri semnificative în ceea ce privește calitatea implementării proceselor interne;

- Stabilirea stadiului - a fi în această etapă, pentru un startup înseamnă că a obținut o creștere considerabilă, care este de aşteptat să fie continuă. De asemenea, o companie este capabilă să atragă cu ușurință finanțare și resurse umane.

\section{Provocări întâlnite de startup-uri în crearea brandului de angajator}

Startup-urile întâmpină dezavantaje competitive în comparație cu organizațiile consacrate, din cauza faptului că acestea funcționează sub un nivel mai ridicat de riscuri și incertitudini. În astfel de circumstanțe, unul dintre cele mai mari obstacole pentru startup-uri este reprezentat de atragerea şi menținerea angajaților talentați (Moser \& Welpe, 2015).

Au fost identificate trei provocări principale cu care se confruntă în mod normal startup-urile. În primul rând, de regulă, companiile de tip startup care abia au început să funcţioneze, nu au încă o reputație consacrată în rândul clienților și nici pe piața muncii (Bresciani \& Eppler, 2010). În al doilea rând, multe structuri interne încă mai sunt construite și dezvoltate în cadrul companiilor startup (Rode \& Vallaster, 2005). Acest lucru cauzează o provocare pentru antreprenori în ceea ce privește axarea pe brandingul de angajator. În al treilea rând, startup-urile au, în mod normal, resurse limitate în ceea ce privește capitalul, calendarul și tehnologiile de know-how. De regulă, antreprenorii tind să se concentreze mai mult pe problemele financiare și de producție ale afacerii decât pe brandingul de angajator, din motivul că nu consideră ca fiind necesară o bună strategie de branding de angajator pentru a conduce afaceri (Boyle, 2003), (Wong \& Merrilees, 2005).

Pe lângă acestea, o provocare întâlnită de startup este și lipsa de consecvență. Un brand de angajator nu este doar un set de cuvinte cheie sau sloganuri care reflectă compania ideală, ci este un proces activ și continuu ce presupune evidențierea companiei în fața unui număr mare de candidați vizați, astfel încât aceștia să fie interesaţi de afacerea companiei. De cele mai multe ori, startup-urile eșuează din perspectiva brandingului de angajator deoarece nu evidențiază suficiente informații. Startup-urile trebuie să se asigure că mesajul pe care îl transmit este în conformitate cu misiunea, cultura și valorile organizației (Lucaci, 2019).

Conform lui Bresciani și Eppler, pentru antreprenori este esențială investirea în brandingul de angajator de la început (Bresciani \& Eppler, 2010). În plus, angajaţii trebuie să fie consideraţi cu precizie de către angajatori mai mult ca o investiţie şi mai puțin ca un cost. Conform lui Boella, nu există motive de ignorare a brandingului de angajator, iar acest lucru este valabil şi pentru companiile startup (Boella \& Goss-Turner, 2013). 


\section{Construirea unui brand de angajator de către startup-uri}

În prezent, a devenit un trend să lucrezi pentru o companie de tip startup. Totuși, o mare parte dintre profesioniști doresc să lucreze pentru o companie consacrată, cu reputație bună. Acest lucru nu este datorat faptului că organizațiile consacrate sunt reprezentate de o categorie largă de locuri de muncă, ci a faptului că un brand de angajator ul unui startup este subdezvoltat, ceea ce îl face neatractiv (Freeman \& Engel, 2007).

În majoritatea situațiilor, startup-urile nu sunt capabile să ofere pachete de plată atractive, un sistem de recompensare bine dezvoltat și nici programe de beneficii comparativ cu marile organizații. Totodată, structura startup-urilor este destul de dezorganizată, motiv pentru care angajații trebuie să depună mai mult efort, lucrând peste program (Bresciani \& Eppler, 2010). Pe de altă parte, startup-urile pot oferi un număr mare de avantaje, precum un mediu de inovație, flexibilitate, dezvoltare personală, oportunități antreprenoriale, ierarhie plană, avansare în carieră etc. (Curtin, 2015). Aceste atribute trebuie luate în considerare de către angajatori atunci când construiesc EVP-ul pentru o strategie de branding de angajator.

De asemenea, startup-urile ar trebui să țină cont de obiectivele de carieră ale potențialilor angajați, indiferent dacă se dorește atragerea tinerilor profesioniști sau a specialiștilor maturi cu experiență solidă. Concret, un angajator ar trebui să se axeze pe valorile și obiectivele de carieră ale grupului țintă de potențiali angajați (Wenngren, 2015). Este de evidențiat faptul că, pentru atragerea potențialelor talente, o organizație trebuie să își construiască strategia de branding de angajator în baza valorilor grupului vizat. Totodată, startup-urile ar trebuie să acorde o mai mare atenție satisfacției angajaților și a implicării acestora în cadrul companiei. Nu este suficient să ne focusăm doar pe angajații pe care dorim să îi atragem în companie, ci trebuie să le acordăm o importanță deosebită și celor existenți.

În prezent, internetul prezintă un rol destul de important în modelarea imaginii companiilor. La început de drum, organizațiile trebuie să ia în considerare rolul rețelelor sociale în crearea reputației companiei. Totodată, acestea joacă un rol crucial în procesul de recrutare. Din aceste considerente, o companie de tip startup ar trebui să privească rețelele sociale în profunzime, acordând o importanță deosebită campaniilor de marketing realizate cu ajutorul acestora. Un conținut potrivit în mediul social este capabil să atragă candidații doriți. Totuși, organizațiile nu trebuie să le promită potențialilor angajați ceea ce nu le pot oferi (Ramkrishnamurthy, 2015).

Astfel, startup-urile, în formarea brandului de angajator, ar trebuie să țină cont de următoarele aspecte (Bresciani \& Eppler, 2010):

- Evidențierea avantajelor companiilor la început de drum: inovații, ierarhii plane etc.;

- $\quad$ Focusarea pe valorile potențialilor angajați;

- Focusarea pe satisfacerea nevoilor angajaților și respectarea promisiunilor făcute acestora;

- Focusarea pe conţinutul publicat în mediul social.

Prin urmare, startup-urile pot construi un brand de angajator de succes prin realizarea următoarelor activități (Lucaci, 2019):

$\sqrt{ }$ Definirea viziunii și a scopului startup-ului - angajații își doresc să lucreze cu ceva cu care sunt pasionați și care le permite totodată și creșterea personală. Trebuie evidențiat modul în care oamenii pot crește în cadrul companiei pentru a putea analiza dacă își asumă riscul de a lucra pentru respectiva companie.

$\sqrt{ }$ Definirea valorilor de bază - valorile de bază ajută angajaţii în prioritizarea eforturilor pentru a reuși să îndeplinească misiunea companiei. De asemenea, acestea îi vor ajuta pe potențialii angajați să identifice dacă valorile lor se aliniază cu cele ale companiei.

$\sqrt{ }$ Definirea culturii de pornire a companiei - cultura prezintă un rol important pentru potențialii angajați, de aceea este necesară comunicarea nuanțelor culturii în strategia de branding de angajator. De asemenea, cultura companiilor de tip startup diferă de cea a marilor companii, iar în crearea acesteia fiecare angajat are un rol. 
$\sqrt{ }$ Crearea EVP-ului (oferta de valoarea către angajat) - orice companie are un EVP, indiferent de dimensiunea acesteia. Startup-urile pot oferi un EVP unic și atrăgător ce nu poate fi aplicat și marilor organizații. Acesta se completează cu viziunea, misiunea şi cultura organizației.

$\sqrt{ }$ Consultarea angajaţilor cu privire la EVP-ul realizat: reflectă acesta spiritul echipei?

$\sqrt{ }$ Promovarea brandului în mediul online și nu numai.

Elementele principale incluse în strategiile de branding de angajator care pot atrage noi candidați sunt reprezentate de scopul și misiunea organizațiilor. Una dintre cele mai mari atracții pentru majoritatea solicitanților de locuri de muncă din lumea startup-urilor este reprezentată de oportunitatea de a lucra la ceva nou și revoltător ce poate determina schimbări reale în domeniul de muncă. Acești candidaţi vor să simtă că pot avea un impact real lucrând pentru un obiectiv în care ei cred, iar brandul de angajator poate ajuta compania să devină un loc în care acest lucru se poate întâmpla. Deseori, candidații companiilor de startup doresc să audă că organizația se angajează să crească rapid, să reprezinte un suport în dezvoltarea personală a angajaţilor și să menţină agilitatea chiar dacă organizația câștigă noi angajați (Lucaci, 2019).

Este evidentă importanța brandingului de angajator atât în companiile de tip startup cât și în companiile consacrate. Un brand de angajator de succes nu presupune investiţii de capital uriașe, ci este necesar ca antreprenorii să pună accent pe principalele aspecte.

\section{Concluzii}

Tratând din diferite perspective postura startup-urilor observăm că dezvoltarea acestora implică un efort managerial sporit care trebuie să fie orientat mai cu seamă spre crearea unui colectiv uman care să răspundă nevoilor de calitate și competitivitate impuse de piață și dependente de nișa vizată.

Atingerea scopurilor organizației, mai cu seamă atunci când acestea au ca iniţiatori tinerii, impun formarea unei imagini, ca angajator, care să surescite interesul potențialilor angajaţi și să le formeze acestora intenția de asumare a unui job în cadrul unui startup sub premisa că acesta răspunde nevoii de confort, calitate a mediului intern şi bunăstare. Așadar, acest sistem de management reprezintă gândirea strategică de construcție a unui brand de angajator de succes, care să promită un moral ridicat angajaților, o recompensare pe măsură și o productivitate ridicată, totul pe baza unui angajament nescris pe termen lung, natural şi reieșit din convingerea intimă a subiectului.

Asumarea, în primul rând a responsabilităților de către potențialul angajat ori de proaspătul angajat, trebuie să aibă ca suport evidențierea strategică a elementelor de natură informală legate de viziunea și scopul startup-ului, astfel încât să se prefigureze dorința de implicare activă în muncă într-un mediu organizațional competitiv în care performanța reprezintă criteriu de apreciere și ascedere.

Observăm din analiza efectuată, că definirea valorilor de bază impulsionează angajații să depună eforturi susținute pentru îndeplinirea misiunii companiei, care devin obiective personale, în climatul de responsabilitate colectivă, neutră ca ierarhie, strategie care pe termen mediu și lung crează interes pentru potențialii angajați.

Definirea unei culturi organizaţionale proprii a companiei constituie un factor important pentru potențialii angajați, stimulând independența și individualitatea, dar și diversitatea culturală, sub dictonul „unitate în diversitate”, confortul unui mediu personalizat, specific, diferă de marile afaceri prin crearea unui rol fiecărui angajat, accentuând astfel securitatea și confortul mediului.

Imaginea externă a noii organizații este strâns legată de angajaţii acesteia, abordare care echivalează constructul de angajator cu un micro sistem social în care evoluția individuală și colectivă, echilibrul dinamic și personalitatea angajaților dau dimensiunea personalizată a unitătii.

Dimensiunea redusă specifică startup-urilor permit o organizare care să reflecte viziunea, misiunea și cultura organizației, creativitatea angajaților, dăruirea și priceperea acestora, elementul special a fiecăruia, iar finalitatea obținută prezentând originalitate și capacitate de atingere a țintelor economice și umane vizate. 
Funcția de marketing a organizației are inclusă, în condiţiile contemporane, ca tehnică de capacitare şi elementele strategice de branding de angajator, dat fiind că dinamica tânărului manager și comportamentul managerial al acestuia poate atrage noi candidați, îndeplinind astfel elementele de scop şi misiune.

Una dintre cele mai mari motivații pentru persoanele aflate în căutarea unui loc de muncă din palierul organizațiilor de tip startup este reprezentată de activitățile economice novative propuse de acestea, flexibilitatea ori specificitatea acestora care generează interes și percepția de oportunitate. Acest tip de motivație poate fi valorificat în formarea brandului de angajator, mai cu seamă dacă sunt dezvoltate modelele netradiționale și rapide de ascensiune în dependență de obținerea performanțelor.

Atingerea optimului motivațional al angajatului poate ajuta compania să devină un loc în care angajații cu pregătire profesională foarte bună ori cu abilităţi deosebite se regăsesc atât ca mediu, cât și ca soluție de dezvoltare personală durabilă.

Problematica actuală a companiilor de orice nivel relevă importanța brandingului de angajator ca soluție și răspuns rapid și ieftin la multe dintre necunoscutele invariabilității conturate de globalizarea pieței muncii și sistematizarea intereselor personale pe termen scurt a forței de muncă calificate.

Un brand de angajator de succes reprezintă impulsul dezvoltării prin poziţionarea justă a factorului uman, dar și prin elaborarea unui model managerial care să permită o relaţie corectă, intuitivă și motivațională dintre tânărul antreprenor și resursa umană a organizației, presupunând adaptarea flexibilă și dedicată a locurilor de muncă în raport de așteptările salariatului, de nevoia sa de recunoaștere și afirmare, de personalitatea acestuia și de capacitatea acestuia de a face față sarcinilor și transformărilor moderne.

Investiția în branding echivalează cu investiția în om, aspect ce dă naştere unui capital uriaș cu care antreprenorii pot să pună accent pe ținte greu de atins în evoluția concurenţială contemporană.

\section{Referințe bibliografice}

- Ambler, T., Barrow, S. (1996). The employer brand, Journal of Brand Management, 4(3), 185-206.

- Asif, S., Sargeant, A. (2000). Modelling internal communications in the financial services secto,. European Journal of Marketing, 34(4/5), 299-317.

- $\quad$ Backhaus, K., Tikoo, S. (2004). Conceptualizing and researching employer branding, Career Development International, 9(4/5), 501-517.

- $\quad$ Barrow, S., Mosley, R. (2005). The employer brand: bringing the bestof brand management to people at work. England: Editorial Chichester.

- Boella, M. J., Goss-Turner, S. (2013). Human resources management in the hospitality industry, Edition Routledge.

- Boyle, E. (2003). A study of entrepreneurial brand building in the manufacturing sector in the UK, Journal of Product \& Brand Management, 12(2), 79-93.

- Bresciani, S., Eppler, M. (2010). Brand New Ventures? Insights on Start-Up's Branding Practices, Journal of Product \& Brand Management, 19(5), 356-366.

- Chhabra, N.L., Sharma, S.K. (2014). Employer branding: strategy for improving employer attractiveness, International Journal of Organizational Analysis, 22(1), 48-55.

- Curtin, M. (2015). 10 Reasons To Work For A Startup. Retrieved 2020, from Linkedin: https://www.linkedin.com/pulse/10-reasons-work-startup-melanie-curtin/

- Figurska, I., Matuska, E. (2013). Employer branding as a human resources management strategy, Human Resources Management \& Ergonomics, 7, 35-45.

- Freeman, J., Engel, J. S. (2007). Models of Innovation: Startups and Mature Corporations, California Management Review, 50(1), 94-119. 
- Hubschmid, E. (2013). Shaping Efficient Employer Branding Strategies to Target Generation Y: A Cross-National Perspective on Recruitment Marketing. Peter Lang AG.

- Lucaci, A. (2019). How to Build Your Employer Brand as a Startup. Retrieved 2020, from SmartDreamers: https://www.smartdreamers.com/blog/employer-brand-startup

- Moser, K.T., Welpe, I. (2017). Small but attractive: Dimensions of new venture employer attractiveness and the moderating role of applicants' entrepreneurial behaviors, Journal of Business Venturing, 32(5), 588-610.

- Mosley, R. (2014). Employer brand management: practical lessons from the world's leading employers. Wiley.

- Ramirez, O. (2016). Startup Development Phases. Retrieved 2020, from Startup Commons: https://www.startupcommons.org/startup-development-phases.html

- $\quad$ Ramkrishnamurthy, S. (2015). Employer Branding: A Key for Startup's to Unlock a Door of Talent Pool. Retrieved 2020, from Linkedin: https:/www.linkedin.com/pulse/employerbranding-key-startups-unlock-door-talent-ramkrishnamurthy/

- Robehmed, N. (2013). What Is A startup? Retrieved 2020, from Forbes: https://www.forbes.com/sites/natalierobehmed/2013/12/16/what-is-a-startup/\#4f8fb3414044

- Rode, V., Vallaster, C. (2005). Corporate Branding for Start-ups: The Crucial Role of Entrepreneurs, Corporate reputation Review, 8(2), 121-135.

- Sivertzen, A.M.N., Olafsen, A.H. (2013). Employer branding: employer attractiveness and the use os social media, Journal of Product \& Brand Management, 22(7), 473-483.

- Suresh, A. (2014). Tips to make employer branding more effective, Retrieved 2020, from Linkedin: https://www.linkedin.com/pulse/20140327015127-43374179-tips-to-makeemployer- branding-more-effective

- Wenngre, A. (2015). What Makes a Start-up an Employer of Choice? Retrieved 2020, from Harvard Business Review: https://hbr.org/2015/12/what-makes-a-start-up-an-employer-ofchoice

- Wong, H.Y., Merrilees, B. (2005). A brand orientation typology for SMEs: A case research approach, Journal of Product \& Brand Management, 14(3), 155-162. 



\title{
Cap. 22. UTILIZAREA SOCIAL MEDIA ÎN ROMÂNIA - EVOLUȚIE ŞI POTENȚIALI FACTORI DE INFLUENŢĂ
}

\author{
Ioana Andreea Bogoslov ${ }^{1}$, Anca Elena Lungu ${ }^{2}$ \\ ${ }^{1}$ Universitatea ,Alexandru Ioan Cuza” din Iaşi, Facultatea de Economie şi Administrarea Afacerilor, Iași, \\ România, andreea.bogoslov@ulbsibiu.ro \\ ${ }^{2}$ Universitatea ,Alexandru Ioan Cuza” din Iaşi, Facultatea de Economie şi Administrarea Afacerilor, Iași, \\ România, ancalungu01@gmail.com
}

\begin{abstract}
Rezumat: Performanța digitală a României din ultimii ani nu poate fi contestată, însă comparativ cu celelalte țări membre, poziţia acesteia este încă una nefavorabilă. Cu scopul monitorizării progresului digital al Europei ne putem raporta la rezultatele oferite de indicele DESI (Digital Economy and Society Index). Conform constatărilor obținute la sfârșitul anului 2019 prin intermediul acestui instrument de măsurare, România ocupa penultimul loc din clasament. Indicele DESI analizează, pe lângă alți factori, aspecte privind utilizarea și integrarea Social Media în diferite contexte. Într-o lume în care instrumentele de tip Social Media sunt adesea caracterizate ca reprezentând preferința dominantă a societății contemporane, contribuția acestui fenomen la sporirea gradului de digitalizare este evidentă. Având în vedere aspectele menționate anterior, scopul prezentului articol este de a oferi, pe baza statisticilor existente, o imagine de ansamblu cu privire la evoluția utilizării instrumentelor de tip Social Media în România. De asemenea, prin lucrarea realizată se intenționează identificarea unor potențiali factori care pot influența progresul României în ceea ce privește utilizarea și integrarea mediilor de socializare online.
\end{abstract}

Cuvinte-cheie: Social Media, România, DESI Index, Evolution.

\section{Introducere}

Indiferent dacă experimentăm sau nu un grad de familiaritate referitor la termeni ce țin de domeniul Tehnologiei Informațiilor și Comunicației, cu siguranță am auzit cel puțin o dată conceptul de digitalizare. În sens restrâns, conform dicționarului de termeni IT Gartner (Gartner Glossary, 2020), noțiunea de digitalizare face referire la utilizarea tehnologiilor digitale cu scopul de a schimba modele de afaceri și de a oferi noi venituri și oportunități de producere a valorilor. În completarea definirii anterioare apare sintagma conform căreia digitalizarea este caracterizată ca fiind procesul prin care are loc trecerea de la o afacere tradițională, la una digitală.

La momentul actual, digitalizarea reprezintă un fenomen global. Prin urmare, conceptul capătă o însemnătate mult mai extinsă, făcând referire la modul în care diverse domenii în care activăm, pe lângă mediul de afaceri, pot fi restructurate prin utilizarea unor mijloace digitale. Adesea asociată cu creșterea eficienței, reducerea costurilor și îmbunătăţirea performanței, digitalizarea reprezintă un avantaj competitiv indiferent de domeniul asupra căruia își exercită influența.

Intenționând să obțină o poziție favorabilă comparativ cu celelalte puteri globale, Uniunea Europeană depune eforturi considerabile întru sporirea gradului de digitalizare aferent țărilor membre. $\mathrm{Cu}$ scopul monitorizării progresului digital al statelor membre UE, a fost dezvoltat și implementat Indicele Societății și Economiei Digitale - DESI (eng. Digital Economy and Society Index). Acest indice vizează, pe lângă multe alte aspecte, analizarea unor indicatori specifici utilizării şi adoptării instrumentelor de tip Social Media în diferite contexte. Observăm astfel consideraţiile globale conform cărora Social Media nu este doar un trend sau o preferință a societății moderne, ci un important factor al digitalizării.

De ce reprezintă Social Media un aspect cheie al digitalizării? Proliferarea acestui tip de mijloace de comunicare online este evidentă, iar actorii pieței, indiferent de sfera în cadrul căreia activează, îi înțeleg tot mai mult potențialul competitiv. Fenomenul Social Media devine, treptat, parte integrată din activitatea de zi cu zi a societății moderne, utilizarea acestor instrumente online 
fiind adoptată în domenii esențiale precum mediul de afaceri, instituții publice, educație ș.a.. Susținând tendințele globale, Social Media reprezintă unul dintre instrumentele strategice a căror utilizare eficientă poate duce la crearea unor avantaje competitive ce nu pot fi trecute cu vederea.

Scopul principal al lucrării de față constă în oferirea unei mai bune înţelegeri asupra evoluției utilizării Social Media în România. Pe lângă constatările generalizatoare reprezentative întru evidențierea fenomenului, accentul va fi pus pe contextele în care utilizarea Social Media poate influența gradul de digitalizare al României comparativ cu celelalte membre UE.

În cele din urmă, prin analiza efectuată se intenționează identificarea unor potențiali factori considerați influenți asupra utilizării Social Media în România. Pornim astfel de la principiul fundamental al gândirii omenești care se traduce prin exprimarea paradigmei conform căreia orice fenomen este determinat de cel puțin un factor cauzal. Aceste cauzalităţi pot fi favorabile sau mai puțin favorabile când vine vorba despre susținerea integrării și utilizării Social Media în România. Totuși, considerăm de bun augur o abordare care să includă atât influențe pozitive, cât și influențe negative. Ca în oricare altă situație, doar prin identificarea capabilităţilor, punctelor forte și oportunităților avem posibilitatea de a determina mijloace de atenuare a punctelor slabe.

Din punct de vedere metodologic, prezenta lucrare are la baza analiza calitativă, fiind predominant axată pe informații din surse secundare precum statistici oficiale, analize și lucrări de specialitate. Totodată, supozițiile autorilor cu privire la factorii de influență asupra utilizării Social Media în România sunt rezultate ale observării directe a realității, în încercarea obținerii unor informații semnificative.

\section{Social Media în România}

Stat membru al Uniunii Europene, România se străduiește să implementeze politici care să susțină progresul digital al țării și să contribuie la transformarea Europei într-o piață unică digitală. Totuși, rezultatele obținute prin intermediul indicelui DESI la finalul anului 2019, poziţionează România pe penultimul loc din clasament în ceea ce privește digitalizarea. Deși eforturile depuse nu pot fi contestate, România a reușit să depășească o singură țară în ceea ce privește performanța digitală obținută în anul precedent, și anume Bulgaria.

Desigur, valorile înregistrate raportat la evoluția digitală a României diferă în funcție de dimensiunea analizată. Există situații în care țara noastră performează mai bine, însă există și domenii pentru care progresul digital al României a fost mai puțin favorabil de-a lungul timpului. În cele ce urmează ne propunem să identificăm şi să analizăm punctele cheie digitalizării României din perspectiva utilizării instrumentelor de tip Social Media.

\subsection{Statistici generale}

Ca prim mijloc de măsurare a utilizării Social Media în România, putem face referire la numărul utilizatorilor care folosesc în mod activ astfel de platforme online. Această rată vizează ponderea populației totale care folosește în mod activ cel puțin o rețea socială, prin orice dispozitiv. În ceea ce privește țara noastră, numărul persoanelor care utilizează activ rețele sociale a înregistrat creșteri anuale, atingând pragul de 56\% din populația totală la sfârşitul anului 2019 (Statista, 2019).

Dintre platformele de socializare folosite, Facebook este lider incontestabil în ceea ce privește numărul de utilizatori, în anul 2019 atingând pragul de 11.000.000 de conturi aparținând unor cetățeni din România. În plus, conform DataReportal (DataReportal, 2019), acest număr reprezentativ utilizatorilor activi de instrumente Social Media a crescut cu aproximativ 10\% comparativ cu anul 2018.

Preferințele românilor se îndreaptă și către utilizarea platformelor Youtube $(\approx 866.720$ care au activitate vizibilă) și Instagram $(\approx 1.137 .063$ utilizatori). Mai puțin populare în rândul cetățenilor români sunt platforme precum Twitter ( $\approx 375.303$ utilizatori) sau Foursquare $(\approx 94981$ utilizatori) (Zelist Research, 2020). 
Cifrele crescute prezentate anterior marchează clar o utilizare mare a platformelor de socializare în cadrul României. În plus, pentru susținerea ideii conform căreia Social Media a devenit un stil de viață pentru mulți dintre cetățeni, iSense Solutions (Romania Insider, 2019) a prezentat rezultatele unui chestionar care releva faptul că peste $53 \%$ dintre românii din zona urbană accesează medii sociale online imediat după ce se trezesc.

\subsection{Social Media în susținerea digitalizării societăţii și economiei europene}

Indicele DESI (eng. Digital Economy and Society Index) reprezintă un indice compus din aproximativ 30 de indicatori considerați relevanți pentru monitorizarea progresului digital al Europei. Prin intermediul acestui instrument de măsurare se urmărește evoluția statelor membre ale UE, fiind analizate aspecte aferente celor cinci dimensiuni principale analizate: Conectivitate (eng. Connectivity), Capital uman (eng. Human Capital), Utilizarea Internetului (eng. Use of Internet), Integrarea tehnologiei digitale (eng. Integration of Digital Technology), Servicii publice digitale (eng. Digital Public Services).

Pentru fiecare dintre cele cinci dimensiuni supuse analizei prin intermediul indicelui DESI au fost definite o serie de sub-dimensiuni specifice, necesare măsurării evoluției digitale din Europa care, la rândul lor, sunt compuse din anumiți indicatori. Referitor la modul de calcul, fiecare subdimensiune reprezintă media ponderată a indicatorilor normalizați. Utilizarea instrumentelor de tip Social Media reprezintă un punct de interes direct, evidențiat prin trei indicatori diferiți, în cadrul a două dimensiuni principale: Utilizarea Internetului și Integrarea tehnologiei digitale. Astfel, indicatorii specifici cu privire la Social Media sunt:

1. Utilizarea Internetului $\rightarrow$ Sub-dimensiunea Activități online (eng. Activities online) $\rightarrow$ Indicatorul Rețele de socializare (eng. Social Networks) - face referire la numărul cetățenilor care folosesc internetul pentru a participa la rețelele de socializare (realizarea profilul utilizatorului, postări sau alte activităţi conexe);

2. Utilizarea Internetului $\rightarrow$ Sub-dimensiunea Activități online (eng. Activities online) $\rightarrow$ Indicatorul Rețele de socializare profesionale (eng. Professional social networks) - face referire la numărul cetățenilor care folosesc internetul pentru a participa la rețelele de socializare profesionale.

3. Integrarea tehnologiei digitale $\rightarrow$ Sub-dimensiunea Digitalizarea afacerilor (eng. Business digitization) $\rightarrow$ Indicatorul Social Media - face referire la numărul întreprinderilor care folosesc două sau mai multe rețele de socializare precum: rețele sociale, blog-uri sau microblog-uri, site-uri web pentru partajarea conținutului multimedia sau instrumente de partajare a cunoștințelor bazate pe wiki-uri. Utilizarea rețelelor de socializare se traduce prin faptul că întreprinderea are un profil de utilizator, un cont sau o licență de utilizator, în funcție de cerințele și tipul de instrument Social Media utilizat.

Observăm cu ușurință interesul crescut în ceea ce privește utilizarea Social Media ca determinant al utilizării Internetului și integrarea acestor mijloace sociale online în cadrul mediului de afaceri. Astfel, marcăm supoziția conform căreia cele menționate anterior reprezintă contextele cheie contributive digitalizării economiei și societății Europei din perspectiva utilizării instrumentelor de tip Social Media.

\subsection{Constatări privind utilizarea Social Media în România pe baza indicelui DESI}

În România, numărul de persoane care au folosit internetul cu scopul de a utiliza rețele de socializare în anul 2019 a atins pragul de aproximativ 86\%, analiza incluzând toți cetățenii cu vârsta cuprinsă între 16 si 74 de ani (European Commission, 2019). Prin comparație, putem observa că progresul României în ceea ce privește utilizarea internetului cu scopul de a desfășura activități online prin intermediul rețelelor de socializare nu a fost unul constant. Conform rezultatelor indicelui DESI pentru perioada 2014 - 2019, în anul 2017 sub-dimensiunea analizată a înregistrat o uşoară scădere, evoluția ulterioară fiind totuși favorabilă (Figura 1). 


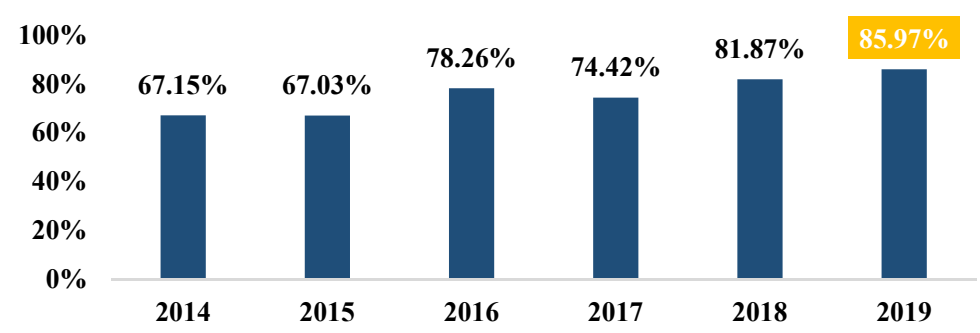

Figura 1. Evoluția utilizării internetului cu scopul desfășurării unor activități prin intermediul rețelelor de socializare (2014-2019) Sursa: Realizat de autori pe baza datelor oferite de Comisia Europeană (European Commission, 2019)

Este important de menționat faptul că procentajul obținut în anul 2019 pentru indicatorul cu privire la numărul cetățenilor care folosesc internetul cu precădere pentru facilitarea utilizării rețelelor de socializare, clasează România pe prima poziție comparativ cu toate celelalte state membre UE și mult peste media UE (Figura 2).

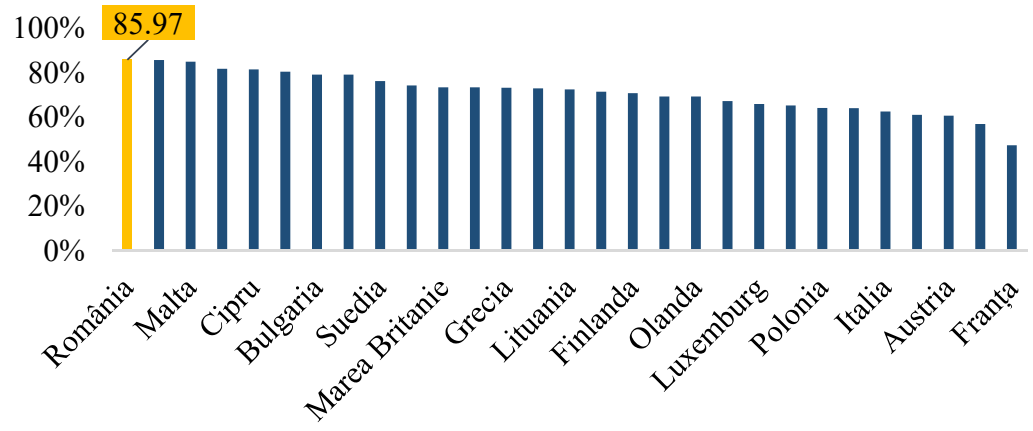

Figura 2. Utilizarea internetului cu scopul desfășurării de activități prin rețele de socializare la nivelul statelor membre ale Uniunii Europene (2019) Sursa: Reprodus după (European Commission, 2019)

Având în vedere aspectele menţionate anterior, putem afirma că evoluția României a fost una favorabilă în ceea ce privește numărul de utilizatori activi și ponderea utilizării instrumentelor de tip Social Media comparativ cu țările membre UE. Datele prezentate relevă astfel preferința cetățenilor țării pentru utilizarea acestor medii de socializare online, cu scopuri diverse.

Totuși, analizând detaliat, există și indicatori pentru care performanța digitală a României raportată la utilizarea Social Media este destul de scăzută. În acest sens, putem face referire la numărul indivizilor care au folosit internetul cu scopul de a utiliza rețelele sociale profesionale, la sfârșitul anului 2019 România ocupând locul 26 în comparaţie cu celelalte membre UE. Constatările cu privire la indicatorul în cauză evidențiază faptul că, în anul 2019, doar 6,24\% dintre indivizi au beneficiat de serviciile oferite de Internet cu scopul utilizării unor rețele sociale profesionale (European Commission, 2019).

O altă situație nefavorabilă vizează întreprinderile din România care folosesc două sau mai multe rețele de socializare, excluzând întreprinderile din sectorul financiar. Rezultatele indicelui DESI pentru anul 2019 clasează țara noastră pe penultimul loc din clasament. Constatările evidențiază faptul că doar 9.23\% dintre întreprinderile din România folosesc instrumente de socializare. Cu toate că România a înregistrat o evoluție favorabilă în perioada 2014 - 2019 în ceea 
ce privește indicatorul în cauză, ritmul de creștere este unul foarte redus. Comparativ cu anul 2014, numărul acestor întreprinderi aproape s-a dublat în anul 2019. Totuşi, diferența dintre anul 2019 și anul precedent este de doar $0.01 \%$.

\section{Potențiali factori de influență}

Observând situația actuală şi evoluția din ultimii ani cu privire la utilizarea instrumentelor de tip Social Media din România, considerăm că un interes crescut trebuie atribuit identificării potențialilor factori care influențează acest progres. Prin urmare, următoarele supoziții reflectă rezultatele analizei autorilor cu privire la diverse circumstanțe, situații și stări de fapt care pot sau chiar afectează, favorabil sau nefavorabil, proliferarea și utilizarea instrumentelor de tip Social Media în România. Aceste influențe identificate reprezintă, de fapt, principali indicatori luați în considerare în statistici oficiale precum cele oferite de Eurostat sau pura supoziție a autorilor.

Pe lângă latura tehnologică, Social Media există cu și prin factorul uman. Numeroase influențe ale utilizării acestor instrumente sunt, astfel, ghidate de caracteristicile comportamentale umane în anumite contexte. Totuşi, aspectele culturale, sociologice, psihologice și demografice care pot determina, într-o oarecare măsură, gradul de integrare al instrumentelor Social Media în diverse activități sunt, cu siguranță, completate de factori ce țin de infrastructura digitală, mediul politic, fiscal și legal al României.

\subsection{Influențe culturale}

De-a lungul timpului, cu scopul explorării culturii românești au fost efectuate numeroase studii, evaluările fiind realizate atât la nivel regional, cât şi comparativ cu alte state. Pentru a putea obține o imagine de ansamblu asupra factorilor motori specifici culturii române în raport cu alte culturi, ne putem raporta la metoda propusă de Geert Hofstede. Deși aceasta implică evaluarea a șase dimensiuni cheie, vom face referire doar la una dintre acestea, și anume Individualism (versus Colectivism).

Caracterul Social Media este predominant axat pe colaborare ceea ce, în consecință, impune existența mai multor utilizatori dispuși să desfăşoare activităţi online împreună. Conform dicționarului Cambridge (Cambridge University Press, 2020), termenul Social în sine face referire la activități în care mai multe persoane se întâlnesc și petrec timp împreună. Aceste afirmații corelează, într-o oarecare măsură, utilizarea Social Media cu o cultură în cadrul căreia predomină colectivismul. Desigur, veridicitatea acestei afirmații poate fi contestată întrucât putem utiliza Social Media și în mod individual, din postura de "observator". Dacă ne referim totuși la scopul de bază Social Media, afirmația se confirmă.

Pe baza modelului Hofstede, individualismul se regăsește în cadrul culturilor în care oamenii nu construiesc legături, acționând predominant pe cont propriu sau împreună cu membrii familiei (Hofstede, Hofstede, \& Michael, 2010). Obținând un scor de 30 în ceea ce privește gradul de individualism (Hofstede Insights, 2019), România este majoritar formată dintr-o societate colectivistă. Astfel, putem afirma că gradul de interdependență pe care o întreține societatea românească în rândul membrilor săi este unul crescut. O societate colectivistă impune un angajament pe termen lung față de grupul aparținător. Prin urmare, preferința cetățenilor români tinde spre apartenența la un grup şi asumarea unor angajamente comune. Acest lucru se manifestă pozitiv și susține utilizarea instrumentelor de Social Media.

\subsection{Influențe demografice}

Referitor la potențialele influențe demografice asupra utilizării Social Media, ne vom raporta la genul și vârsta populației din România, diferențele fiind evidențiate prin intermediul datelor furnizate de biroul de statistică al UE, Eurostat (European Commission, 2020). România se situează peste media UE în ceea ce privește utilizarea instrumentelor Social Media de către persoanele cu vârste cuprinse între 16 și 24 de ani, cu un scor de 85\%. Generația mai înaintată în vârstă (65-74 ani) din România folosește mediile sociale online într-un procent sub media UE (18\%). 
Diferența dintre persoanele de gen feminin și cele de gen masculin, cu vârsta cuprinsă între 16 şi 74 de ani, care utilizează rețele de socializare nu este foarte mare pe teritoriul României. În ambele cazuri procentele obținute depășesc media UE. Astfel, la începutul anului 2020,61\% dintre cetățenii de gen masculin și 59\% dintre persoanele de gen feminin foloseau medii de socializare online (European Commission, 2020).

Pe baza informațiilor demografice prezentate, putem afirma că diferența de gen nu influențează utilizarea Social Media. Diferențele majore constatate sunt date de vârsta persoanelor implicate în activități prin intermediul instrumentelor Social Media. În acest sens, se poate face referire clară la caracteristicile diferitelor generații analizate. Cel mai mare număr de utilizatori Social Media din România este înregistrat pentru tinerii din Generaţia Z. Această generaţie este bine-cunoscută și sub denumirea de Net Generation/iGeneration şi cuprinde cohorta de indivizi născuți în perioada 1995-2010, în conformitate cu Seemiller și Grace (Seemiller \& Grace, 2016).

Generația Z s-a născut, a crescut și s-a dezvoltat într-un mediu în care tehnologia a ghidat treptat aproape toate aspectele vieții. În plus, timpul atribuit apariției acestei generații s-a suprapus dezvoltării celei de-a doua generații Web, cunoscută sub numele de Web 2.0 sau Read-Write Web, fiind considerată o rețea dinamică în cadrul căreia a apărut fenomenul Social Media. Astfel, este de așteptat ca modul în care aceste persoane comunică, creează și partajează conținut reprezintă forme de interacţiune interdependente de mediile sociale online (Bogoslov \& Georgescu, 2019).

\subsection{Infrastructură}

Infrastructura digitală a României susține utilizarea Social Media prin oferirea unor mijloace care sporesc conectivitatea și accesul la Internet. Conform informațiilor furnizate de Institutul Naţional de Statistică, în anul 2019 mai mult de trei sferturi dintre gospodăriile din România, cu un procent de 75,7\%, aveau acces la Internet de acasă (Institutul Național de Statistică, 2019).

În realitate, conform indicelui DESI România a înregistrat cele mai bune performanțe pentru dimensiunea Conectivitate. Progresul se datorează disponibilității largi a rețelelor de bandă largă fixe rapide și ultrarapide, în special în zonele urbane. Scorul obținut pentru țara noastră în anul 2019 raportat la această dimensiune (53,5 este puțin sub media EU de 59,3). Aceste aspecte evidențiază influența pozitivă a infrastructurii asupra adoptării și utilizării Social Media.

\subsection{Influențe politice, legale și fiscale}

În ciuda tuturor eforturilor depuse, România se confruntă cu un mediu politic, legal şi fiscal turbulent, dominat de corupție și foarte instabil. Această situație se resimte cu precădere asupra digitalizării mediului de afaceri, investițiile pentru atingerea obiectivului în cauză fiind încă destul de reduse. În plus, birocrația impusă de autoritățile statului îngreunează toate procesele prin care se intenționează integrarea tehnologiei în activitățile desfășurate în cadrul întreprinderilor din România.

În anul 2019, România s-a situat pe locul 27, comparativ cu celelalte state membre, în ceea ce privește integrarea tehnologiei digitale de către întreprinderi. Rezultatele obținute per ansamblu de țara noastră pentru dimensiunea Integrarea Tehnologiei Digitale din cadrul indicelui DESI $(20,5)$ au fost cu mult sub media UE $(41,1)$, ceea ce evidențiază decalajul cu care se confruntă România în această privință (European Commission, 2019) .

Desigur, ca parte a digitalizării, utilizarea Social Media este influențată negativ din perspectiva menționată anterior. Limitarea utilizării instrumentelor de acest tip în cadrul mediului de afaceri se reflectă și prin scorul slab obținut în această privință comparativ cu media europeană.

În acest context, putem presupune că utilizarea scăzută a Social Media în mediul de afaceri influențează, la rândul său, ponderea persoanelor care utilizează rețele sociale profesionale. $\mathrm{Cu}$ toate că această supoziție necesită o analiză detaliată cu scopul sporirii credibilității, principala premisă de la care pornim în afirmația exprimată poate fi descrisă astfel: într-un context în care mediul de afaceri nu beneficiază de avantajele oferite prin utilizarea Social Media, situație marcată și printr-o prezență sau vizibilitate scăzută a întreprinderilor în rândul platformelor de acest gen, 
utilizatorii (în speță actorii pieței) nu sunt motivați sau susținuți să utilizeze platforme de socializare profesionale.

\section{Concluzii}

Oferind o privire de ansamblu, fenomenul supus analizei în lucrarea de față a fost examinat din perspectiva unui context competitiv, având în vedere situația curentă în care țara noastră încearcă să progreseze întru obținerea unei poziții digitale cât mai bune. Astfel, prezenta cercetare, deși având ca punct de plecare date extrase majoritar din surse externe, evidențiază câteva aspecte notabile în ceea ce privește utilizarea instrumentelor de tip Social Media în România și potențialele influențe asupra fenomenului:

- Per total, România a înregistrat o evoluție predominant favorabilă în ceea ce privește utilizarea Social Media, ocupând prima poziție din clasament comparativ cu toate celelalte țări membre ale UE în anul 2019, raportat la ponderea cetățenilor care folosesc internetul cu precădere pentru facilitarea utilizării rețelelor de socializare.

- Deși popularitatea platformelor de socializare în rândul utilizatorilor români nu poate fi contestată, aceasta diferă în funcție de mai mulți factori, inclusiv tipul instrumentului folosit.

- La nivelul României se observă o tendinţă scăzută către utilizarea platformelor Social Media profesionale, fapt care poate fi considerat, într-o oarecare măsură, consecință a neintegrării sau slabei integrări Social Media în mediul de afaceri.

- Principalele influențe care își exercită forța în mod mai puțin favorabil asupra digitalizării și, în consecință, asupra utilizării platformelor de Social Media, fac referire la mediul politic, fiscal și legal al României.

Astfel, prin constatările aferente cercetării efectuate considerăm fenomenul Social Media ca fiind, într-o mare măsură, o forță cheie în digitalizarea României. Cu toate că, raportat la nivelul integrării Social Media în mediul de afaceri, există un decalaj considerabil între țara noastră și celelalte state din Uniunea Europeană, programele coordonate la nivelul UE dau speranța unei treptate redresări.

În ceea ce privește direcțiile viitoare ale cercetării, se intenționează efectuarea unor cercetări de tip cantitativ cu privire la situația analizată, scopul fiind pe de o parte de a confirma sau infirma supozițiile prezentei lucrări, iar pe de altă parte de a oferi rezultate de o mai mare relevanță.

\section{Bibliografie}

- Bogoslov, I.A., Georgescu, R.M. (2019). Studying the Learning Particularities of New Students Generations - Guidance for Developing Future E-Learning Systems for Higher Education. Educația Plus, 24, 107-115.

- Cambridge University Press. (2020). Dictionary. Retrieved 01.18.2020, from Cambridge Dictionary: https://dictionary.cambridge.org/dictionary/english/social

- DataReportal (2019). DIGITAL 2019: ROMANIA. DataReportal. Retrieved from https://datareportal.com/reports/digital-2019-romania

- European Commission. (2019). DESI by Components. Retrieved February 12, 2020, from European Commission: https://digital-agenda-data.eu/charts/desi-components\#chart= $\{\% 22$ indicator $\% 22: \% 22$ desi_3b5_socnet $\% 22, \% 22$ breakdown-group $\% 22: \% 22$ total $\% 22$, $\% 22$ unit-measure\%22:\%22pc ind_iu3\%22,\%22time-period $\% 22: \% 222019 \% 22\}$

- European Commission. (2019). DESI by Components. Retrieved 14 January, 2020, from European Commission: https://digital-agenda-data.eu/charts/desi-components\#chart= $\{\% 22$ indicator $\% 22: \% 22$ desi_3b6_profsocnet $\% 22, \% 22$ breakdowngroup $\% 22: \% 22$ total $\% 22, \% 22$ unit-measure $\% 22: \% 22$ pc_ind_iu3\%22,\%22timeperiod $\% 22: \% 222019 \% 22$ \}

- European Commission. (2019). Indicele economiei și societății digitale (DESI) - Raport de țară. European Commission. 
- $\quad$ European Commission. (2020, January 31). Individuals - internet activities. Retrieved 11 February, 2020, from Eurostat: http://appsso.eurostat.ec.europa.eu/nui/show.do?query= BOOKMARK_DS-053730_QID_7FAF3D14_UID_-

3F171EB0\&layout=IND_TYPE,L,X,X;GEO,L,Y,0;TIME,C,Z,0;UNIT,L,Z,1;INDIC_IS,L,Z,

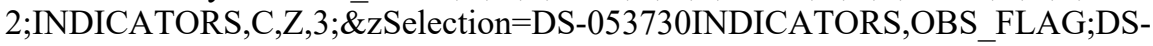

053730TIME,2018;DS-053730

- European Commission. (2020, January 31). Individuals - internet activities. Retrieved from Eurostat: http://appsso.eurostat.ec.europa.eu/nui/submitViewTableAction.do

- Gartner Glossary. (2020). Digitalization. Retrieved 02 10, 2020, from Gartner Glossary: https://www.gartner.com/en/information-technology/glossary/digitalization

- Hofstede Insights. (2019). COUNTRY COMPARISON - Romania. Retrieved 11 February, 2020, from Hofstede Insights: https:/www.hofstede-insights.com/country-comparison/ romania/

- Hofstede, G., Hofstede, G.J., Minkov, M. (2010). Cultures and Organizations, Cultures and Organizations. McGraw-Hill Education.

- Institutul Naţional de Statistică. (2019). Accesul populației la Tehnologia Informaţiilor şi Comunicațiilor. București: Institutul Naţional de Statistică.

- Romania Insider. (2019). Half of urban Romanians check social media first thing in the morning. Retrieved from Romania Insider: https://www.romania-insider.com/urbanromanians-social-media-morning

- Seemiller, C., Grace, M. (2016). Generation Z Goes to College. San Francisco: John Wiley \& Sons.

- Statista. (2019). Active social media penetration in selected European countries in January 2019. Retrieved February 10, 2020, from Statista - The Statistics Portal: https://www.statista.com/statistics/295660/active-social-media-penetration-in-europeancountries/

- Zelist Research. (2020). Overview Social Media in .ro - ianuarie 2020. https://www.zelist.ro/blog/overview-social-media-in-ro-ianuarie-2020/: Zelist. 


\title{
Cap. 23. EVOLUȚIA ROMÂNIEI ANTREPRENORIALE - O ANALIZĂ ASUPRA MEDIULUI DE AFACERI
}

\author{
Anca Elena Lungu ${ }^{1}$, Andreea Ioana Bogoslov ${ }^{2}$ \\ ${ }^{1}$ Universitatea ,Alexandru Ioan Cuza” din Iaşi, Facultatea de Economie şi Administrarea Afacerilor, Iași, \\ România, ancalungu01@gmail.com \\ ${ }^{2}$ Universitatea ,Alexandru Ioan Cuza” din Iaşi, Facultatea de Economie şi Administrarea Afacerilor, Iași, \\ România, andreea.bogoslov@ulbsibiu.ro
}

\begin{abstract}
Rezumat: Activitatea antreprenorială este inerentă acțiunii umane, iar această afirmație este demonstrată de realitatea pieței. Articolul își propune să identifice situația reală a dimensiunii antreprenoriale și să contureze o imagine de sinteză a acesteia în România, având ca suport atât informațiile furnizate atât de literatura de specialitate, cât și datele statistice disponibile. Numărul mare de start-up-uri și finanțarea guvernamentală, realizată sub egida diferitor programe naționale, conduc (aparent) la concluzia că spațiul românesc este unul propice activității antreprenoriale. Informațiile furnizate de World Bank prin intermediul Rapoartelor Doing Business contribuie la conturarea unei poziții cu privire la evoluția activității antreprenoriale românești din ultimii ani. Scopul cercetării noastre îl reprezintă găsirea unui răspuns la întrebarea: este sau nu România o țară antreprenorială? Din perspectivă metodologică, prezentul demers de cercetare utilizează atât analiză calitativă, cât și analiză cantitativă în scopul realizării unui portret clar al României antreprenoriale.
\end{abstract}

Keywords: entrepreneurship, Romania, transformation.

JEL classification: L26, O47, D20

\section{Introducere}

Complexitatea activităţii umane aduce în prim-plan o serie de provocări cu care se confruntă indivizii în fiecare clipă. Activitatea antreprenorială este inerentă acțiunii umane, iar de aici rezultă faptul că deciziile antreprenorilor au ca principal scop obținerea profitului antreprenorial. Orientarea activității antreprenoriale spre profit influențează comportamentul antreprenorului și, implicit, asumarea unor decizii către această direcție. Pornind de la premisa menționată, pe care o considerăm validată de realitate, întrebarea firească pe care ne-am adresat-o este legată de modul în care antreprenorul alege să investească într-o anumită țară.

$\mathrm{Cu}$ toate că rareori putem găsi o justificare standard pentru atitudinea și comportamentul unui antreprenor, considerăm că modificările survenite în cadrul legislativ ale unei țări le pot influența. Acționând într-un cadru concurențial în care trebuie respectate regulile jocului, antreprenorului îi revine atât misiunea de a se informa, cât și de a se adapta noilor schimbări survenite pe piață. Reglementarea sau birocratizarea procesului antreprenorial poate fi considerată determinant al antreprenoriatului.

Problema României antreprenoriale lansează o serie de întrebări fiecăruia dintre noi și, în acest context, ne propunem să identificăm o serie de potențiali factori care influențează situația prezentă. În acest sens, a fost realizată o recenzie a literaturii de specialitate, structurată pe două dimensiuni: într-o primă instanță, riscul și incertitudinea și, ulterior, determinanții generici ai antreprenoriatului. În plus, s-a realizat o analiză a mediului de business din România, având ca punct de plecare rapoartele Doing Business, care supun dezbaterii latura legislativă și reglementările care au apărut în decursul perioadei studiate.

\section{Recenzia literaturii}

Fiecare decizie a antreprenorilor este mai mult sau mai puţin fundamentată și, de cele mai multe ori, comportamentul lor nu poate fi justificat prin standarde general acceptate. Actorul principal al pieței poate fi cu ușurință deosebit de ceilalți, iar acest lucru poate fi realizat prin 
identificarea preferinței pentru asumarea riscului și a incertitudinii. În acest sens, am considerat oportună prezentarea succintă a două direcții studiate în literatură: (1) pe de o parte, principalele opinii cu privire la risc și incertitudine și, (2) pe de altă parte, identificarea factorilor care influențează decizia antreprenorilor de a acționa într-o direcție sau alta.

\subsection{Riscul și incertitudinea}

Piața este un proces dinamic, incompatibilă cu fotografia statică a stării de echilibru. Gradul de incertitudine existent la nivelul oricărei piețe influențează actul antreprenorial și, mai mult decât atât, poate reprezenta sursa profitului sau, dimpotrivă, a pierderii înregistrate de către actorul principal al pieței (McCaffrey, Salerno, 2014, p.436). În aceste condiții, suntem în total acord cu afirmațiile lui Mises, care atribuie incertitudinii un rol vital în procesul unei piețe funcționale, identificând că principal determinant al acesteia este cunoașterea limitată a indivizilor (Mises, 2018 [1949], p.16). Singurii indivizi care sunt capabili de asumarea riscului sunt antreprenorii, care primesc o recompensă pentru atitudinea și comportamentul lor, în contextul concurenței și, nicidecum, managerii (Hawley, 1907, p.111) (Knight, 1921, p.43).

Ludwig von Mises subliniază în repetate rânduri că fiecare acțiune este, iminent, însoțită de incertitudine. Prin intermediul procesului competiţional se realizează o triere între antreprenorii eficienți și cei mai puțin eficienți. Cei din prima categorie vor obținere o remunerare a activității asumate prin profit, pe când ceilalţi vor înregistra pierderi și, în cele din urmă, vor fi eliminaţi de pe piaţă (Mises, 2018 [1949]). Rothbard afirmă că între principalele implicații ale acțiunii umane se regăsește incertitudinea viitorului, dar și a acțiunilor potențiale pe care indivizii sunt dispuși să le realizeze (Rothbard, 2001, p.7). Tot incertitudinea este cea care generează erori în asumarea deciziilor (Rothbard, 2001, p.637).

Una dintre clarificările majore cu privire la diferența dintre risc și incertitudine îi aparţine lui Frank Knight (Knight, 1921). Printre precizările acestuia regăsim importantă a fi subliniată ideea conform căreia antreprenorii sunt, în realitate, acei indivizi care decid să investească în condițiile în care își asumă riscuri ce nu pot fi estimate (Foss, Klein, 2012). Astfel, putem conchide că incertitudinea nu poate cuantificată și, implicit, antreprenorii nu se pot asigura împotriva acesteia, chiar dacă ar fi dispuși să achite contravaloarea unei prime, lucru care este posibil în cazul riscului (Knight, 1921, p.20). În contextul analizei sale, Knight a sesizat că antreprenorul și firma sunt mecanismele utile în gestionarea incertitudinii; antreprenorul este o forță care închide pockets of ignorance pe piață, tinzând mereu spre un anume echilibru. Având ca punct de plecare argumentele fundamentate de Knight, Geoffrey Brooke admite că distincția între risc și incertitudine este, de fapt, diferența între condițiile în care profitul nu poate exista (viitorul este un subiect supus riscului) şi condițiile în care profitul poate exista (viitorul este incert) (Brooke, 2010, p.222). Sub o altă formă, distincția între cele două concepte este dată de convingerile obiective sau subiective despre viitor.

\subsection{Factori determinanți ai activității antreprenoriale}

Identificarea unor factori care să explice şi să justifice procesul antreprenorial este, din punctul nostru de vedere, improprie și, înainte de toate, limitativă. Nu putem identifica în totalitate influențele asupra antreprenoriatului, pornind de la același considerent care vizează individualismul sau subiectivismul. Fiecare individ este unic prin însăși natura sa și, implicit, deciziile sale, asumate nu fac altceva decât să reflecte acest fapt. Astfel, în cele ce urmează ne propunem să identificăm câteva tendințe majore pe care literatura de specialitate le-a catalogat ca fiind importante în activitatea antreprenorilor. Pornind de la viziunea relativ integratoare a lui Audretsch et al., identificăm șase principali determinanți ai activităţii antreprenoriale (Audretsch, Thurik, Verheul, Wennekers, (Ed.), 2002):

(1) cererea, care contribuie la crearea unor oportunități pentru noi idei de afaceri, bazată pe dorințele și preferințele consumatorilor; 
(2) oferta, care oferă potențialilor antreprenori posibilitatea de a acționa în direcția valorificării unor oportunități neexploatate de concurenți;

(3) decizia individuală, asumată, care înglobează abilitățile personale și, implicit, tendința de a se implica în activități antreprenoriale;

(4) ratele actuale și de echilibru, care se referă la dinamismul natural (optim) şi la noul business în contextul dat;

(5) cultura, bazată pe comportamente și atitudini existente la nivelul unei societăți, dar care pot influența decizia de acționa antreprenorial sau nu;

(6) instituțiile. Instituțiile și politicile guvernamentale pot influența atât în sens pozitiv, cât și în sens negativ deciziile indivizilor de a-și orienta activitatea spre antreprenoriat sau nu.

În studiile mai recente, Barreneche Garcia reia analiza celor șase factori pentru a realiza o analiză aspra unor orașe europene și concluzionează că unul dintre cei mai semnificativi determinanți ai antreprenoriatului are legătură cu instituțiile și politicile guvernamentale (Barreneche García, 2013).

Având ca punct de sprijin opiniile regăsite în literatura de specialitate care identifică legislația unei țări ca determinant al activităţii antreprenoriale, considerăm oportună analiza situaţiei României din această perspectivă, utilizând, în această direcție, rapoartele Doing Business.

\section{Metodologie}

Din perspectivă metodologică, prezentul articol utilizează analiză mixtă, pornind de la premisa complementarități, în scopul oferirii unei imagini clare și nealterate a subiectului abordat.

Realizarea unei recenzii a literaturii de specialitate contribuie la identificarea unor direcții teoretice care pot facilita înțelegerea realității economice. În elaborarea recenziei literaturii de specialitate, s-a avut în vedere identificarea opiniilor cu privire la antreprenor și activitatea pe care acesta o desfăşoară, pornind de la principiile individualismului metodologic, aspect care este regăsit cu preponderență în scrierile adepților Școlii Austriece de Economie. În plus, s-a dorit o identificare a principalilor factori sau a principalelor tendinţe care influențează decizia de a acționa antreprenorial sau nu.

Pentru partea cantitativă, au fost utilizate datele furnizate de rapoartele Doing Business, aferente perioadei 2006-2020. După selectarea principalelor informații relevante, acestea au fost prelucrate în vederea sintetizării evoluției contextului antreprenorial din România în perioada menționată. Prin intermediul acestor rapoarte, Banca Mondială (World Bank) își propune să cuantifice și să ierarhizeze situația de la nivel internațional a statelor, din perspectiva reglementărilor care facilitează sau, dimpotrivă, îngreunează procesul antreprenorial. Rapoartele ierarhizează situația a 190 de state de pe glob, ținând cont de o serie de aspecte precum: deschiderea unei afaceri, obținerea unei locații și a finanțării, rezolvarea problemelor zilnice și operarea într-un mediu de business stabil. Principalul obiectiv este reprezentat identificarea modului în care economiile naţionale pot încuraja investițiile antreprenoriale sau le pot diminua prin reglementări. Scara ierarhică înregistrează valori în intervalul 1-190, unde 1 este echivalentul celui mai prielnic mediu pentru activităţi antreprenoriale, iar 190 este asimilat unui stat în care procesul antreprenorial este realizat cu dificultăți majore.

\section{Rezultate \& discuții}

În urma prelucrării datelor, pot fi evidențiate o serie de aspecte cu privire la evoluția activității antreprenoriale din România (figura 1). 


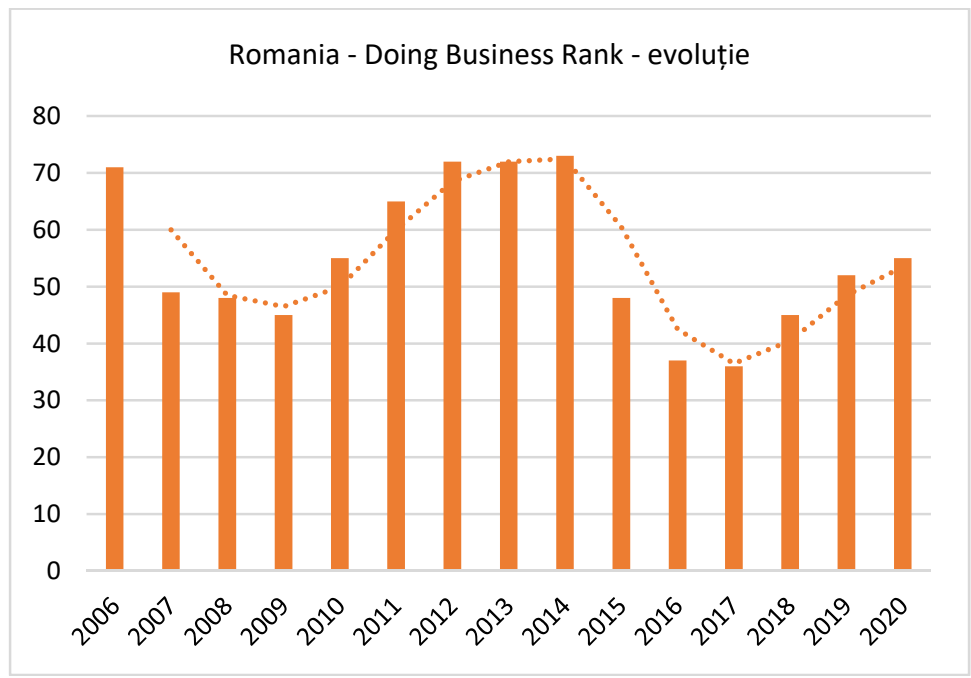

Figura 1. Evoluția României în ierarhia Doing Business în perioada 2006-2020 Sursă: prelucrare proprie a datelor disponibile în Doing Business Report 2006-2020: https://www.doingbusiness.org/en/reports/global-reports/

Într-o primă etapă, poate fi identificată poziția sinusoidală a României la nivelul ierarhiei mondiale, într-un context ce își propune să sintetizeze o analiză a mediului de afaceri. În anul 2006, punctul de referință al analizei, statul român ocupa locul 71 din 190 la nivel internaţional ca destinație pentru potențialele activități antreprenoriale. Un an mai târziu, după aderarea la Uniunea Europeană, se constată o îmbunătăţire a reglementărilor în domeniu, aceasta urcând în clasament până pe poziția 49 din 190 . Noul statut s-a datorat, în bună măsură, adoptării unor reforme în procedurile care fac referire la aspecte precum: tranzacționarea în afara granițelor naționale (mai ales în comerțul cu statele membre ale Uniunii Europene), reducerea numărului de documente necesare pentru export la doar patru (la fel ca în Uniunea Europeană), timpul necesar pentru obținerea unei autorizații de construire a scăzut cu 49 de zile etc. Adoptarea unor contracte mai flexibile, dar și utilizarea sistemului electronic pentru obținerea unor documente a redus birocrația și timpul necesar obținerii documentelor necesare pentru desfăşurarea activității antreprenoriale. Furnizarea de informații în mediul on-line despre accesarea creditelor pentru investiții, dar și diminuarea corupției de o manieră semnificativă reprezintă aspecte care au contribuit la obținerea unei poziții importante în ierarhia internațională (WorldBank, 2006).

Un alt punct important în cadrul analizei îl reprezintă perioada 2010 - 2014. În intervalul menționat, situaţia României în oferirea unui climat favorabil pentru oamenii de afaceri se degradează, retrogradând cu 28 de poziții, față de anul 2009, an considerat unul propice pentru activitatea antreprenorială (WorldBank, 2009). În 2010, apar primele majorări în zone precum: taxe şi impozite pe salarii, taxele aferente construirii unor noi spații/clădiri. Îngreunarea procedurilor de insolvență a avut la bază creșterea costurilor (WorldBank, 2010). În noiembrie 2008, antreprenorii se confruntă cu o modificare a legii insolvenței care prevede ca $1.5 \%$ din suma recuperată prin procedura aferentă trebuie să fie direcționată pentru rambursarea cheltuielilor pricinuite de noua situație a firmei (insolvență). Această decizie a condus la reducerea sumelor pe care creditorii le puteau recupera. $\mathrm{Cu}$ toate acestea, au existat și elemente care au încurajat investițiile antreprenorilor, spre exemplu: reducerea timpului pentru înregistrarea unei proprietăți cu aproximativ 35 de zile (WorldBank, 2008).

În anul 2013, valoarea taxelor pe care un antreprenor trebuia să le achite către statul român reprezenta aproximativ $44.2 \%$ din totalul profitului obținut. Taxele excesive au plasat țara noastră pe locul 136 din 190 la nivel internațional din perspectiva contribuțiilor către stat. De cealaltă parte, 
în zona obținerii unui credit care să finanțeze o afacere, aceasta s-a clasat pe locul 12 la nivel mondial. Comercializarea de bunuri și servicii în afara granițelor se putea realiza, în medie, în aproximativ 13 zile și erau necesare doar 5 documente pentru export, aspecte care i-au adus poziția 72 la nivel international (WorldBank, 2013).

În perioada 2013-2014, țara noastră a reușit să îmbunătățească sistemul de colectare a taxelor prin dezvoltarea şi implementarea unui sistem electronic care să viza taxe precum: impozitul pe profit, taxa pe valoarea adăugată etc. Deși fusese lansat în anul 2010, acesta permitea doar depunerea declarațiilor fiscale on-line.

Ultimii ani au fost marcați de o serie de schimbări care au afectat mediul de business, precum introducerea unor criterii de evaluare a riscurilor fiscale, fapt ce determină, în primă instanță, o creștere a timpilor alocați înregistrării unei afaceri.

\section{Concluzii}

Realizarea unei imagini care să sintetizeze situația României ca urmare a unei analize Doing Business scoate în evidență o serie de aspecte care pot explica atractivitatea sau lipsa de atractivitate a acesteia pentru antreprenori. Între acestea, admitem importanța reglementărilor din domeniul afacerilor. Putem sublinia că, în realitatea pieței, măsurile legislative pot determina potențialii antreprenori să renunțe la ideea de business sau să o orienteze spre o altă piaţă a cărei legislație este mai stabilă și mai orientată spre antreprenor.

Fluctuațiile înregistrate de România în clasamentele realizate la nivel internațional care vizează Doing Business ne atrag atenția asupra modificărilor succesive survenite în reglementările naționale, unele cu un caracter stimulativ asupra antreprenoriatului, iar altele, dimpotrivă, determinând o inhibare a activității antreprenoriale (potențiale).

În concluzie, putem afirma că situația României antreprenoriale este destul de dificil de precizat, ținând cont de seriile de modificări apărute la nivel legislativ. În aceste circumstanțe, poziția și atractivitatea țării noastre pentru desfășurarea activităților antreprenoriale nu poate fi clar susținută, fapt determinat de instabilitatea legislativă și politică. Pe de o parte, suntem tentaţi să spunem că România nu încurajează, în anumite momente, inițiativa antreprenorială, luând în calcul birocrația și taxarea excesivă. Pe de altă parte, observăm situaţia favorabilă şi orientată spre investitori, prin raportare la situația unor alte state de la nivel internațional. În prezent, locul deținut în ierarhia Doing Business de la nivel mondial poate fi considerată favorabilă antreprenoriatului şi, implicit, unei Românii antreprenoriale.

\section{Referinte bibliografice}

- Audretsch, D. (2004). Sustaining Innovation and Growth: Public Policy Support for Entrepreneurship. Industry \& Innovation, 11(3), 167-191.

- Audretsch, D.B., Thurik, R., Verheul, I., Wennekers, S. (Ed.). (2002). Entrepreneurship: Determinants and Policy in a European-US Comparison. New York, Boston, Dordrecht, London, Moscow: Kluwer Academic Publishers.

- Barreneche García, A. (2013). Analyzing the Determinants of Entrepreneurship in European Cities. Small Business Economics, 42(1), 77-98.

- Brooke, G. (2010). Uncertainty, Profit and Entrepreneurial Action: Frank Knight's Contribution Reconsidered. Journal of History of Economic Thought, 32(2), 221-235.

- Foss, N.; Klein, P. J. (2012). Organizing Entrepreneurial Judgment a New Approach of the Firm. New York: Cambridge University Press.

- Hawley, F. (1907). Enterprise and the productive process: a theory of economic productivity. New York, London: G.P. Putnam's sons.

- Knight, F. (1921). Risk, Uncertainty and Profit. New York: Augustus M. Kelly Bookseller.

- Knight, F. (1942). Profit and Entrepreneurial Functions . The Journal of Economic History, Vol. 2, Supplement: The Tasks of Economic History, 126-132. 
- $\quad$ McCaffrey, M., Salerno, J.T. (2014). Böhm-Bawerk's Approach to Entrepreneurship. Journal of the History of Economic Thought, (36), 435-454.

- Mises, L. (2018 [1949]). Acțiunea Umană. București: Editura Institutului Ludwig von Mises România, Traducere: Dan Cristian Comănescu.

- Mises, L. (2018 [1949]). Acțiunea Umană. București: Editura Institutului Ludwig von Mises România, Traducere: Dan Cristian Comănescu.

- Rothbard, M. (2001). Man, Economy and State. Alabama: Ludwig von Mises Institute.

- Sternberg, R. W. (2005). Determinants and Effects of New Business Creation Using Global Entrepreneurship Monitor Data. Small Business Economics, (24), 193-203.

- WorldBank. (2006). Doing Business 2006: Creating Jobs. Washington: World Bank Group.

- WorldBank. (2007). Doing Business 2007: How to Reform. 2007: World Bank Group.

- WorldBank. (2008). Doing Business 2008. Washington: World Bank Group.

- WorldBank. (2009). Doing Business 2009. Washington: World Bank Group.

- WorldBank. (2010). Doing Business 2010: Reforming through Difficult Times. Washington: World Bank Group.

- WorldBank. (2011). Doing Business 2011: Making a Difference for Entrepreneurs. Washington: World Bank Group.

- WorldBank. (2012). Doing Business 2012: Doing Business in a More Transparent World. Washington: World Bank Group.

- WorldBank. (2013). Doing Business 2013: Smarter Regulations for Small and Medium-Size Enterprises. Washington: World Bank Group.

- WorldBank. (2014). Doing Business 2014: Understanding Regulations for Small and Medium-Size Enterprises. Washington: World Bank Group.

- WorldBank. (2015). Doing Business 2015: Going Beyond Efficiency. 2015: World Bank Group.

- WorldBank. (2016). Doing Business 2016: Measuring Regulatory Quality and Efficiency. Washington: World Bank Group.

- WorldBank. (2017). Doing Business 2017: Equal Opportunity for All. Washington: World Bank Group.

- WorldBank. (2018). Doing Business 2018: Reforming to Create Jobs. Washington: World Bank Group.

- WorldBank. (2019). Doing Business 2019: Training for Reform. Washington: World Bank Group.

- WorldBank. (2020). Doing Business 2020. Washington: World Bank Group. 


\title{
Cap. 24. CARACTERISTICILE SPIRITULUI ANTREPRENORIAL DIN ROMÂNIA
}

\author{
Lorena Florentina Dumitrașciuc \\ Universitatea ,Alexandru Ioan Cuza” din Iași, Şcoala Doctorală de Economie şi Administrarea Afacerilor, \\ Iaşi,România, lorena.popescul@gmail.com
}

\begin{abstract}
Purpose: The purpose of this research is to analyze the characteristics of entrepreneurship in influential people in Romania, given that entrepreneurship is what guarantees the success of any business. Methodology: There are five indicators that show that a certain person has the entrepreneurial spirit: passion, optimism, continuous improvement, take calculated risks and achieve their goals.

Results: Entrepreneurship is not learned, but is formed over time and is formed from within the person. So entrepreneurship becomes part of what people really are. Entrepreneurship develops in people, when they feel motivated, empowered, take risks, show passion and are willing to achieve great goals. In other words, to exceed their own limits. Also, the entrepreneurial spirit is always looking for change, because here it is a mentality that is constantly looking for innovation, in seeing the big picture, always looking for constructive feedback, always looking for new opportunities and in to always have a critical spirit. In addition, due to the entrepreneurial spirit that a person manifests, their employees will embrace this entrepreneurial mentality and will come up with new ideas, solutions and opportunities to problems, and this makes organizations grow and develop.
\end{abstract}

Keywords: entrepreneurship, entrepreneurship spirit, passion, achieving goals.

\section{Introducere}

În ziua de astăzi, afacerile trebuie să țină pasul cu schimbările, astfel că este nevoie de creativitate atât la nivel strategic, cât și la nivelul schimbărilor impuse de către concurență (Gries, 2011).

În ceea ce-i privește pe antreprenori, aceștia trebuie să lideri autentici și să nu se teamă să fie altfel în fața celorlalți. Liderii trebuie în primul rând să învețe să fie membri ai echipei și să înțeleagă faptul că echipa lor are idei valoroase (Kiyosaki, 2011).

De asemenea, aceștia trebuie să fie agili (flexibili), să aibă capacitatea de a se schimba, de a inova, de a renunța la propriile programe și scopuri, având în vedere împrejurările incerte și viteza cu care survine schimbarea în lumea de astăzi (Whitmore, 2014).

Spiritul antreprenorial este necesar în vederea creșterii productivității afacerilor pe termen lung, ceea ce îi determină pe antreprenori să caute noi modalități de a produce bunuri şi de a identifica resurse pentru a satisface nevoile piețelor (Shepherd și Douglas, 1997).

Este necesar ca spiritul antreprenorial să se dezvolte mai mult în România, pentru că antreprenorii sunt cei care contribuie la schimbarea lumii, prin afacerile lor și prin impactul lor social și economic (Davis, 2002).

Astfel că spiritul antreprenorial este cel care îi motivează pe oameni să intre în afaceri, să persiste și să aibă succes (Bird, 1989).

În plus, antreprenoriatul reprezintă o atitudine și nu este un loc de muncă (Nobre, 2002).

\section{Spiritul antreprenorial - Literature Review}

Antreprenoriatul este cel care arată calea de urmat către gestionarea organizațională și dezvoltarea personală în noua economie și oferă totodată un impuls în vederea dezvoltării economice (Matlay și Mitra, 2002). 
Spiritul antreprenorial se referă la capacitatea indivizilor de a vedea oportunități acolo unde alții văd probleme și de a acționa în vederea rezolvării problemelor, cu scopul realizării de profit (Eckhardt și Shane, 2003, Mueller, 2007).

Totodată, spiritul antreprenorial este marcat de perseverență, iniţiativă, determinare, imaginație, disponibilitatea de a dezvolta noi proiecte, asumarea de riscuri (Tan et al., 1995), curaj, onestitate, integritate și încredere, deoarece acesta are un rol semnificativ în ceea ce privește învăţarea de noi abilități (Molden, 2013).

Persoanele cu spirit antreprenorial au dorința de a valorifica oportunitățile, prin realizarea de activități care conduc către crearea averii și la valoare adăugată (Ang și Hong, 2000).

Antreprenorii sunt lideri, ceea ce înseamnă că echipa îl determină pe antreprenor să devină mai puternic, să își întărească punctele tari și să își compenseze punctele slabe (Kiyosaki, 2011).

Indivizii cu spirit antreprenorial sunt cei care învață mai mult spre deosebire de cei din propriul anturaj, deoarece cu cât aceștia învață mai mult și mai repede, cu atât mai ușor se pot adapta și evolua. În plus, astfel de persoane au abilitatea de a testa mai multe lucruri, spre deosebire de oamenii din jurul lor pentru a atinge succesul (Parra, 2013).

De asemenea, în contextul antreprenoriatului se pot aborda în mod eficient inovarea, învățarea, precum şi gestionarea de cunoștințe (Matlay și Mitra, 2002).

Referitor la persoanele ce dețin spiritul antreprenorial, acestea au obiceiul de a persevera în vederea atingerii scopului dorit, spre deosebire de alți oameni din jurul lor (Vuong, 2016). În momentul în care oamenii perseverează, fără să mai țină cont de obstacolele temporare, aceștia se diferenţiază destul de mult de majoritatea oamenilor. Ceea ce înseamnă că nivelurile ridicate de perseverență și autoeficiență îi ajută pe antreprenori să depășească neplăcerile și obstacolele (Markman, Baron și Balkin, 2004).

Indivizii cu spirit antreprenorial și-au ales mediul în care să acționeze, și-au găsit identitatea, şi-au stabilit setul de valori și convingeri, au încredere în cunoştinţele și abilităţile lor, au un anumit comportament ce le permite să gândească la nivel înalt, ceea ce contribuie la crearea nivelurilor de învățare, comunicare și transformare a antreprenorilor (Molden, 2013).

În plus, antreprenorii care își înțeleg propriile valori și pe cele ale altor persoane, ar putea înțelege mai bine schimbările pieței către sustenabilitate (Parra, 2013).

Şi nu în cele din urmă, persoanele cu spirit antreprenorial sunt motivate să caute diferite soluţii la probleme și să își asume riscuri (Markman, Baron și Balkin, 2004, Van Gelderen, 2012).

În ceea ce privește riscul, acesta este periculos numai în cazul oamenilor care se complac în propriile lor situaţii și în condițiile în care nu caută alternative la propriile probleme.

În schimb, antreprenorii care își asumă riscuri au și o atitudine corespunzătoare, față de cei care nu își asumă riscuri. Și anume aceea de a căuta mereu noi soluții. (Kiyosaki, 2014).

Pornind de la aceste considerente, vrem să aflăm care sunt caracteristicile spiritului antreprenorial din România.

\section{Metodologie}

Scopul acestei cercetări este de a analiza care sunt caracteristicile spiritului antreprenorial la oamenii cu influență din România, având în vedere faptul că spiritul antreprenorial este cel care garantează succesul oricărei afaceri.

Există cinci indicatori sugerați de literatura de specialitate, care demonstrează că o anumită persoană deține spiritul antreprenorial, printre care avem: pasiune (Biraglia, et al., 2016, Cardon et al. 2017, Cardon, 2013, Cardon, 2005 și Warnick, et. Al, 2018), optimism (Bernoster, et al., 2018, Popescul, 2017, Dawson, et al. 2014, Hyytinen, et al., 2012 și Storey, 2011, Crane și Crane, 2007), îmbunătățire continuă (Winkler, et al. 2018 și Popescul, 2017), asumarea riscurilor calculate (Cardon et al. 2017 și Maxwell, 2008) și atingerea obiectivelor propuse (Popescul, 2017 și Samwel, 2010). 
Indicatorii sunt măsurați astfel:

(1) pasiune - antreprenorilor le place ceea ce fac, vocație;

(2) optimism - utilizarea cuvintelor cu conotații pozitive, dezvoltare pe plan personal și profesional;

(3) îmbunătățire continuă - dobândirea de abilități noi, creativitate;

(4) antreprenorii îşi asumă riscuri calculate - antreprenorii cunosc momentul oportun când să facă noi investiţii sau schimbări strategice

(5) antreprenorii își ating obiectivele propuse - dacă antreprenorii au reuşit să ducă la îndeplinire ceea ce și-au propus.

\section{Rezultate și discuții}

Scopul acestei cercetări este de a analiza care sunt caracteristicile spiritului antreprenorial.

Am observat că un rol important îl au atitudinea și factorii înconjurători, cum ar fí de exemplu, ideea că aceștia au crescut într-un mediu în care s-a discutat și s-au făcut afaceri sau au căutat ca aceștia să facă parte dintr-un astfel de mediu, dorind să iasă din mulțime și să vadă și să facă lucrurile în mod diferit, spre deosebire de cei din jurul lor.

De exemplu, în studiul realizat de Kirkwood (2007), s-a constatat faptul că cei care îi pot ajuta pe tineri în primă fază sunt părinţii, care ar trebui să fie mult mai atenţi la ce îşi doreşte cu adevărat copilul lor, să îi descopere înclinaţiile și să îi dezvolte punctele forte. Iar cei care joacă rolul principal în decizia de creare a riscului sunt tații.

În cazul părinților cu afaceri, femeile antreprenoare au primit sfaturi, sprijin şi încurajare din partea părinţilor, în timp ce bărbații antreprenori au dorit să fie independenţi precum părinţii lor (orientându-se după tați în special) sau au încercat să concureze cu ei (Kirkwood, 2007).

În urma analizei, am observat faptul că au existat și oameni care nu au avut parte de un mediu de afaceri familial, însă au avut atitudinea de învingători, s-au pregătit pentru ceea ce urmau să devină, și-au stabilit obiective, și-au asumat riscuri, au depus un efort semnificativ de învățare și adaptare, astfel că aceștia au demonstrat că se poate să devii antreprenor și fără să fii crescut întrun mediu de afaceri familial.

În ceea ce privește succesul antreprenorilor, acesta depinde foarte mult de calitatea echipei pe care aceștia și-o formează (Kiyosaki, 2011).

Însă, pentru a-și putea proiecta succesul, antreprenorii trebuie să-și stabilească obiective (Popescul, 2017). Ideea este să persevereze, să testeze ideile și să aibă modele și mentorii potriviți de la care să învețe (Molden, 2013).

De asemenea, am constatat în urma analizei că spiritul antreprenorial se dezvoltă la oameni în momentul în care aceștia se simt motivați, împuterniciți, își asumă riscuri, își manifestă pasiunea şi sunt dispuși să îşi atingă obiective mari. Cu alte cuvinte, să își depășească propriile limite.

Pentru că există antreprenori care identifică o problemă şi găsesc imediat o oportunitate de afacere. Astfel că optimismul este o caracteristică dominantă a antreprenorilor (Cassar, 2010). De asemenea, s-a constatat că optimismul este mai ridicat, atunci când un individ lucrează pe cont propriu (Dawson, 2014). Astfel că munca independentă atrage optimismul intrinsec (Dawson, 2014). Așadar, antreprenorii își transformă problemele în oportunităţi (Keller, 2012).

Din analiza poveștilor de viaţă ale acestora, am remarcat faptul că toate aceste persoane care şi-au deschis afaceri şi au devenit antreprenori de succes, au dezvoltat anumite pasiuni pentru ideile lor. Astfel că succesul antreprenorial se datorează combinaţiei între viziune (Whitmore, 2014), pasiune, planificare, perseverență, muncă, investiţii, viteza cu care înaintează, învingerea obstacolelor și contextul favorabil.

O altă observație pe care am remarcat-o în timpul studiului antreprenorilor, este aceea că persoanele cu spirit antreprenorial își asumă riscuri și gândesc la scară mare. Aceștia învaţă în mod continuu şi caută noi modalităţi de a-şi îmbunătăţi abilităţile existente pentru a progresa.

În plus, antreprenorii și-au folosit pasiunea pentru crearea și creșterea de noi riscuri (Cardon, 2005), care să îi ajute să se dezvolte la scară largă. 
În analiză am identificat antreprenori care au dezvoltat succesul din eșecuri. Pentru a ajunge la succes, de cele mai multe ori antreprenorii sunt descurajați și au de înfruntat eșecul. Însă, antreprenorii au privit fiecare provocare ca pe o oportunitate.

Totodată, aceștia au avut curaj și au fost capabili să înfrunte eșecul și să învețe din el, pentru a atinge culmile succesului. Mai ales că mereu oamenii au admirat curajul, indiferent de mediul din care aparțin (Carnegie, 2008).

Pornind de la analiza literaturii de specialitate am creat un model al spiritului antreprenorial (ESM - entrepreneurial spirit model), care cuprinde:

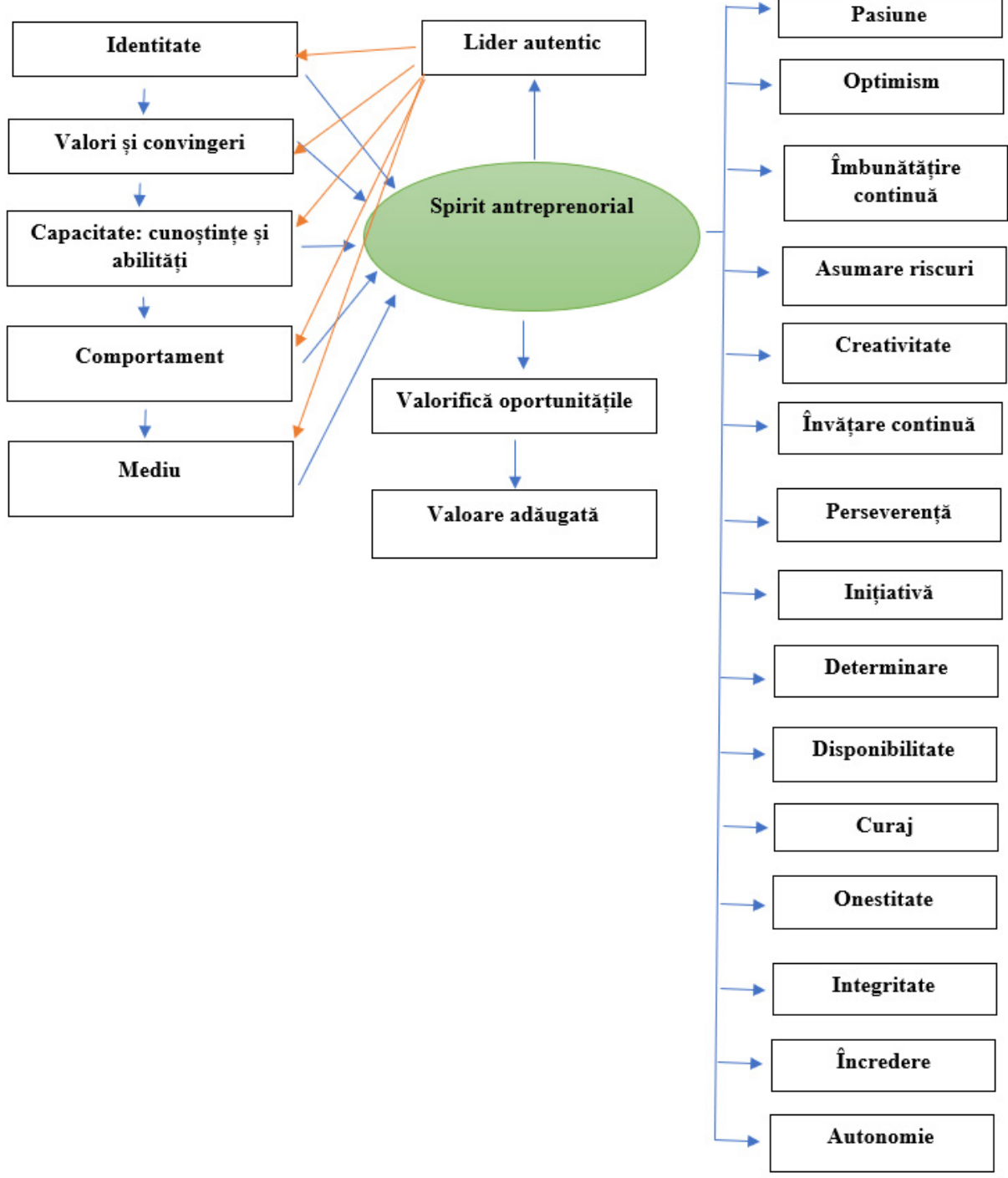

Fig. 1. Modelul ESM - entrepreneurial spirit model Sursa: autorul.

Afacerile de succes sunt cele care au luat naștere din pasiuni. De exemplu, în studiul realizat de Cardon (2005), s-a constatat faptul că pasiunea antreprenorială este o metaexperiență 
emoțională, care influențează trei factori cheie ai eficienței antreprenoriale, cum ar fi de pildă: perseverența, rezolvarea problemelor și concentrarea. Astfel că atât experiențele emoționale subconștiente, cât și cele cognitive sunt influențate de către acești factori cheie.

Referitor la optimism, acesta se dobândește prin învățare socială, astfel că antreprenorii de succes trebuie să devină modele extrem de vizibile, învățând și încurajând pe alții să intre în domeniul antreprenorial (Crane și Crane, 2007).

În studiul lui Dawson (2014) s-a constatat că cei care vor deveni proprii angajaţi sunt mai optimiști, spre deosebire de angajații care nu vor lucra niciodată pentru ei înșiși. Angajații care aspiră la activități independente, își supraestimează randamentul mai mult decât cei care nu au astfel de aspirații.

În momentul în care antreprenorii se gândesc încontinuu la scopul pe care și-1 doresc să și-1 atingă, îşi vor îndrepta paşii către atingerea scopului (Keller, 2012).

Referitor la partea de îmbunătățire continuă, antreprenorii de succes sunt cei care iau inițiative și care au un nivel ridicat de creativitate. Totodată, antreprenorii își pot folosi creativitatea, pentru a căuta soluții la problemele sociale și de mediu, legate de viitoarea lor organizație (Parra, 2013).

În studiul realizat de Ang și Hong (2000), intitulat "Entrepreneurial spirit among East Asian Chinese", a reieșit faptul că spiritul antreprenorial în rândul tinerilor chinezi din Asia de Est este prezis de caracteristicile personalității, cum ar fi propensiunea asumării riscurilor, persistența și locusul intern al controlului, precum și de factori motivaționali, bani și dorința de securitate.

Spiritul antreprenorial se află mereu în căutarea schimbării, pentru că aici este vorba despre o mentalitate care se află în permanență în căutarea inovării, în a vedea imaginea de ansamblu, a căuta mereu feedback constructiv, în a căuta mereu noi oportunități și în a avea mereu spiritul critic. De asemenea, aceștia ar trebui să își schimbe obiectivele, pentru a obține noi comportamente și rezultate noi sustenabile (Parra, 2013).

În plus, datorită spiritului antreprenorial pe care o persoană îl manifestă, angajații acestora vor îmbrățișa această mentalitate antreprenorială și vor ajunge să vină cu noi idei, soluții și oportunități la probleme, iar acest lucru face ca organizațiile să crească și să se dezvolte.

\section{Concluzii}

Pasiunea trebuie să pornească de la vocaţie, de la a-și defini ceea le face plăcere să facă, întrucât pasiunea este inima antreprenoriatului (Cardon, et al., 2013).

Această lucrare a arătat faptul că optimismul este o trăsătură care predispune indivizii la angajarea pe cont propriu sau reprezintă o creație a entuziasmului și a intensității care este de obicei implicat în aventura unei afaceri (Dawson, 2014).

Ideea este ca doza de optimism să fie în limitele normale, pentru că atunci când este exagerat poate afecta rentabilitatea profesională, ceea ce îi poate determina pe lucrătorii independenţi să revină la angajarea remunerată (Dawson, 2014). Iar o doză prea mare de optimism poate duce la așteptări financiare greșite (Dawson, 2014).

În ceea ce privește partea de îmbunătățire continuă, este imperios necesară educaţia în domeniul antreprenorial în rândul tinerilor încă din școli, pentru că odată ajunși la maturitate, mentalitatea acestora se va schimba.

În felul acesta, tinerii vor învăța cum să își rezolve problemele, cum să-i conducă pe alții, cum să pună întrebări, să facă bani, cum să vândă, să vorbească în public, să învețe din greșeli, să știe să ceară ajutorul, să fie creativi, să aleagă soluțiile cele mai bune și să învețe să economisească.

Într-un final, tinerii ajunși la maturitate vor căuta să fie independenți și să aibă propriile lor afaceri de succes.

Practic, spiritul antreprenorial îi va putea ajuta pe tineri să ia viaţa în propriile mâini şi să contribuie la schimbarea lumii.

În România este nevoie de o generaţie de lideri care să-şi asume riscuri, să dea dovadă de creativitate, energie, să fie optimiști, orientați către atingerea obiectivelor și spre rezultate. 
În momentul în care antreprenorii își asumă riscuri, aceștia ies din zona de confort, pentru că riscurile presupun de regulă anumite neplăceri sau neajunsuri pentru antreprenori. Fiecare antreprenor are anumite temeri în materie de riscuri, însă tocmai aceste temeri îi determină pe aceștia să conștientizeze ce s-ar putea întâmpla în viitor și s-ar putea să nu întâmpine neplăceri, în condițiile în care vor învăța să se asculte (Semenik, 2016).

Antreprenorii ajung să își atingă obiectivele, în momentul în care aceștia au o echipă de experți din fiecare domeniu de activitate (Kiyosaki, 2011).

Apoi, am arătat faptul că nimeni nu se naște cu spiritul antreprenorial, ci acesta se cultivă. Iar un rol important îl au atitudinea și factorii înconjurători, cum ar fi de exemplu ideea că aceștia au crescut într-un mediu în care s-a discutat și s-au făcut afaceri.

Antreprenorii pot apela la sesiuni de life coaching, pentru că acestea contribuie la îmbunătăţirea relațiilor cu ceilalți, îi ajută pe antreprenori să își stabilească obiectivele SMART și să își crească performanța.

În acest studiu, am arătat că există situații în care oamenii nu au avut parte de un mediu de afaceri familial şi cu toate acestea au demonstrat că se poate şi fără.

La final, am creat un model al spiritului antreprenorial (ESM - entrepreneurial spirit model), care poate fi utilizat de antreprenori, pentru a-și îmbunătăti abilitățile și competențele, cât și pentru coach-ii care doresc să faciliteze creșterea și dezvoltarea anumitor aspecte ale afacerii.

De asemenea, remarcăm faptul că în cazul antreprenorilor este foarte important mediul în care trăiesc, pentru că mediul determină informația pe care oamenii o primesc, cu ajutorul celor cinci simţuri: vizual, auditiv, tactil, olfactiv și gustativ (Molden, 2013).

\section{Acknowledgement}

This work was co-funded by the European Social Fund, through Operational Programme Human Capital 2014-2020, project number POCU/380/6/13/123623, project title $<<$ PhD Students and Postdoctoral Researchers Prepared for the Labour Market! $>>$.

\section{Bibliografie}

- Ang, S.H., Hong, D.G.P. (2000). Entrepreneurial spirit among East Asian Chinese. Thunderbird International Business Review, 42(3), 285-309.

- Bernoster, I., Rietveld, C., Thurik, A., Torrès, O. (2018). Overconfidence, Optimism and Entrepreneurship. Sustainability, 10(7), 2233.

- Biraglia, A., Kadile, V., 2016. The Role of Entrepreneurial Passion and Creativity in Developing Entrepreneurial Intentions: Insights from American Homebrewers. Journal of Small Business Management, 55(1), 1-19.

- $\quad$ Bird, B.J. (1989). Entrepreneurial behavior. London, U.K.: Scott, Foresman, and Co.

- Cardon, M.S., Glauserb, M., Murnieksc, C.Y. (2017). Passion for what? Expanding the domains of entrepreneurial passion. Journal of Business Venturing Insights, 8, 24-32.

- Cardon, M.S., Post, C., Forster, W., 2017. Team entrepreneurial passion: its emergence and influence in new venture teams. Academy of Management Review, 42(2), 283-305.

- Cardon, M.S., Gregoire, D.A., Stevens, C.E., Patel, P.C. (2013). Measuring entrepreneurial passion: Conceptual foundations and scale validation. Journal of Business Venturing, 28(3), 373-396.

- $\quad$ Cardon, M.S., Wincent, J., Singh, J., Drnovsek, M. (2005). Entrepreneurial passion: the nature of emotions in entrepreneurship. Academy of Management Proceedings, (1), G1-G6.

- Carnegie, D. (2008). Cum să vorbim în public. Editura Curtea Veche, București.

- Cassar G. (2010). Are individuals entering self-employment overly optimistic? An empirical test of plans and projections on nascent entrepreneur expectations. Strategic Management Journal, 31(8), 822-840. 
- Crane, F.G., Crane, E.C. (2007). Dispositional optimism and entrepreneurial success. The Psychologist-Manager Journal, 10(1), 13-25.

- Davis, S.M. (2002). Social Entrepreneurship: Towards an Entrepreneurial Culture for Social and Economic Development. SSRN Electronic Journal. https://ssrn.com/abstract=978868, http://dx.doi.org/10.2139/ssrn.978868

- Dawson, C., de Meza, D., Henley, A., Arabsheibani, G.R. (2014). Entrepreneurship: Cause and Consequence of Financial Optimism. Journal of Economics \& Management Strategy, 23(4), 717-742.

- Eckhardt, J.T., Shane, S.A. (2003). Opportunities and Entrepreneurship. Journal of Management, 29(3), 333-349.

- Flaherty, J. (1999). Coaching: Evoking excellence in others. Burlington, MA: Elsevier.

- Galor, O., Michalopoulos, S. (2006). The Evolution of Entrepreneurial Spirit and the Process of Development. CEPR Discussion Paper, 6022, http://www.cepr.org/active/ publications/discussion_papers/dp.php?dpno $=6022$

- Gries, T., Naude, W. (2011). Entrepreneurship, Structural Change and a Global Economic Crisis. Entrepreneurship Research Journal, 1(3), 1-43.

- Hyytinen, A., Lahtonen, J., Pajarinen, M. (2012). Entrepreneurial Optimism and Survival, Bank of Finland Research Discussion Paper, 20.

- Keller, J. (2012). Atitudinea este totul. Schimbă-ți atitudinea... și îți vei schimba viața!. Editura Curtea Veche, București.

- Kirkwood, J. (2007). Igniting the entrepreneurial spirit: is the role parents play gendered? International Journal of Entrepreneurial Behavior \& Research, 13(1), 39-59.

- Kiyosaki, R. (2014). Avantajul inechitabil: puterea educației financiare. Editura Curtea Veche, București.

- Markman, Baron, R.A., Balkin, D.B. (2004). Are perseverance and self-efficacy costless? Assessing entrepreneurs' regretful thinking. Journal of Organizational Behavior, 26(1), 1-19.

- Matlay, H., Mitra, J. (2002). Entrepreneurship and Learning: The Double Act in the Triple Helix. The International Journal of Entrepreneurship and Innovation, 3(1), 7-16.

- $\quad$ Maxwell, J., 2008. Talentul nu este suficient. București, Editura Amaltea.

- Molden, D. (2013). Management cu NLP. Editura Curtea Veche, București.

- Mueller, P. (2007). Exploiting Entrepreneurial Opportunities: The Impact of Entrepreneurship on Growth. Small Business Economics, 28(4), 355-362.

- Nobre, A.L. (2002). Entrepreneurship as an Attitude. The International Journal of Entrepreneurship and Innovation, 3(1), 17-25.

- Parra, S. (2013). Exploring the Incorporation of Values for Sustainable Entrepreneurship Teaching/Learning. Journal of Technology Management \& Innovation, 8(1), 11-20.

- Popescul, L.F. (2017). The Impact of Life Coaching Sessions on the Behavior of Future Romanian Entrepreneurs - Pilot Study. "Ovidius" University Annals, Economic Sciences Series, 17(2), 449-454.

- Popescul, L.F. (2017). The influence of life coaching sessions on the entrepreneurs' behavior. Journal of Public Administration, Finance and Law, 12, 128-135.

- Samwel Mwasalwiba, E. (2010). Entrepreneurship education: a review of its objectives, teaching methods, and impact indicators. Education + Training, 52(1), 20-47.

- Semenik, D. (2016). Cum să biruim frica. Editura Sophia, București.

- Sexton, D.L., Bowman-Upton, N. (1991). Entrepreneurship: creativity and growth. Macmillan.

- Shepherd, D.A., Douglas, E.J. (1997). Is Management Education Developing, or Killing, the Entrepreneurial Spirit?. USASBE Annual National, Centre for Entrepreneurial Studies, School of Business, Bond University, Gold Coast, Australia 4229. 
- Storey, D.J. (2011). Optimism and chance: The elephants in the entrepreneurship room. International Small Business Journal, 29(4), 303-321.

- $\quad$ Tan, W.L., Siew, L.K., Tan, W.H., Wong, S.C. (1995). Entrepreneurial spirit among tertiary students in Singapore. Journal of Enterprising Culture, 3(2), 211-227.

- Van Gelderen, M. (2012). Perseverance strategies of enterprising individuals. International Journal of Entrepreneurial Behavior \& Research, 18(6), 630-648.

- Vuong, Q.H. (2016). Impacts of geographical locations and sociocultural traits on the Vietnamese entrepreneurship. SpringerPlus, 5, 1189. https://doi. org/10.1186/s40064-0162850-9

- Warnick, B.J., Murnieks, C.Y., McMullen, J.S., Brooks, W.T. (2018). Passion for entrepreneurship or passion for the product? A conjoint analysis of angel and VC decisionmaking. Journal of Business Venturing, 33(3), 315-332.

- Whitmore, S.J. (2014). Coaching pentru performanță. Editura Publica, București.

- Winkler, C., Saltzman, E., Yang, S. (2018). Improvement of Practice in Entrepreneurship Education Through Action Research: The Case of Coworking at a Nonresidential College. Entrepreneurship Education and Pedagogy, 1(2), 139-165. 